Prepared in cooperation with the U.S. Department of Energy under Interagency Agreement DE-Al28-07RW12405

\title{
Analogues to Features and Processes of a High- Level Radioactive Waste Repository Proposed for Yucca Mountain, Nevada
}

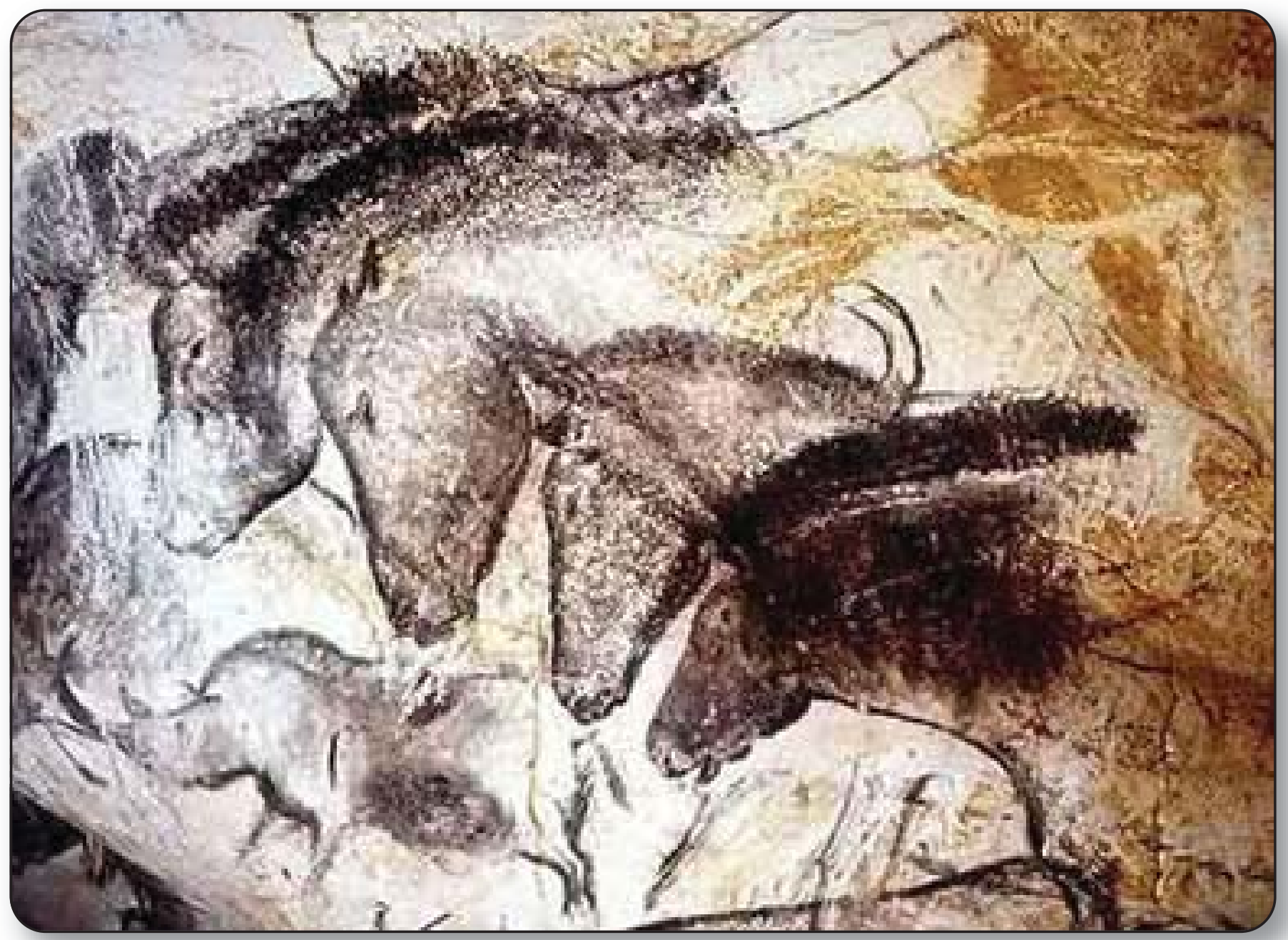

Professional Paper 1779 



\section{Analogues to Features and Processes of a High-Level Radioactive Waste Repository Proposed for Yucca Mountain, Nevada}

By Ardyth M. Simmons, Los Alamos National Laboratory, Los Alamos, New Mexico, and John S. Stuckless, U.S. Geological Survey, Denver, Colorado, with a Foreword by Abraham Van Luik, U.S. Department of Energy

Prepared in cooperation with the U.S. Department of Energy under Interagency Agreement DE-Al28-07RW12405

Professional Paper 1779 


\section{U.S. Department of the Interior \\ KEN SALAZAR, Secretary \\ U.S. Geological Survey \\ Marcia K. McNutt, Director}

\section{U.S. Geological Survey, Reston, Virginia: 2010}

For more information on the USGS - the Federal source for science about the Earth, its natural and living resources, natural hazards, and the environment, visit http://www.usgs.gov or call 1-888-ASK-USGS

For an overview of USGS information products, including maps, imagery, and publications, visit http://www.usgs.gov/pubprod

To order this and other USGS information products, visit http://store.usgs.gov

Any use of trade, product, or firm names is for descriptive purposes only and does not imply endorsement by the U.S. Government.

Although this report is in the public domain, permission must be secured from the individual copyright owners to reproduce any copyrighted materials contained within this report.

Suggested citation:

Simmons, A.M., and Stuckless, J.S., 2010, Analogues to features and processes of a high-level radioactive waste repository proposed for Yucca Mountain, Nevada: U.S. Geological Survey Professional Paper 1779, 195 p.

\section{Library of Congress Cataloging-In-Publication Data}

Simmons, Ardyth M.

Analogues to features and processes of a high-level radioactive waste repository proposed for Yucca Mountain, Nevada / by Ardyth M. Simmons, and John S. Stuckless ; with a foreword by Abraham Van Luik.

p. $\mathrm{cm}$.

Includes bibliographical references.

ISBN 978-1-4113-2945-4 (pbk.)

1. Geological repositories. 2. Radioactive waste disposal in the ground--Nevada--Yucca Mountain. 3. Seepage. 4. Soil chemistry. I. Stuckless, John S. II. Title.

TD1064.S56 2010

621.48'380979334--dc22 


\section{Foreword}

The presentation of analogues in this report is a culmination of years of work by a number of persons who searched for analogues for features, materials, and processes likely to be found in, and determining aspects of the behavior of, a repository for high-level radioactive waste in thick, unsaturated tuffs proposed at Yucca Mountain in Nevada. The analogues discussed provide valuable scientific and technical insight into the functioning of a high-level radioactive waste repository in a semiarid, unsaturated, fractured-rock environment. The analogues presented will have a variety of applications, such as tunnel excavation in fractured unsaturated media, either for transport or storage of materials or energy.

As noted in the Introduction, other repository programs throughout the world have been actively involved in identifying natural and anthropogenic analogues. Most of the international programs are considering a repository site in saturated rock, away from oxidizing groundwater, for which numerous analogues exist in roll-front uranium and other types of ore deposits. For a repository in unsaturated rock with oxidizing groundwater conditions, the search for analogues is more challenging. Therefore, this document is a fitting supplement to the excellent compendia on natural analogues that have been published by several national programs and by international organizations, especially the European Commission.

Beyond the need for the United States' high-level radioactive waste respository, society is likely to require the future disposal of wastes from more advanced nuclear fuel cycles, which are currently undergoing research and development. These differing waste streams will bring new challenges and new opportunities for appropriate analogues. This report provides a useful basis for these future needs. 


\section{Contents}

Abstract

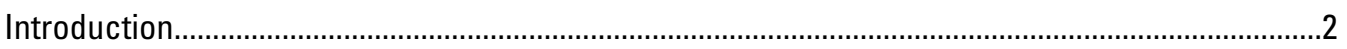

Preservation Within the Unsaturated Zone ............................................................................

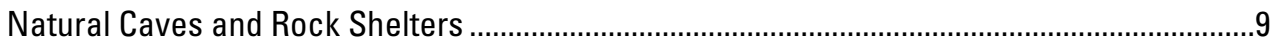

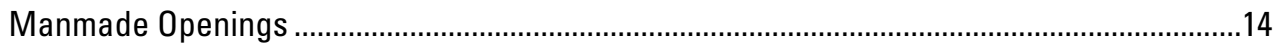

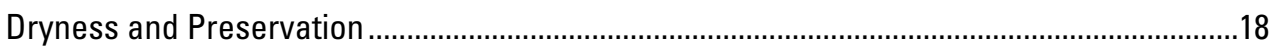

Evaluation of Analogues for Preservation in the Unsaturated Zone......................................18

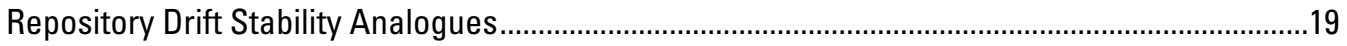

Repository Design Selection and Relation to Applicable Analogues .....................................19

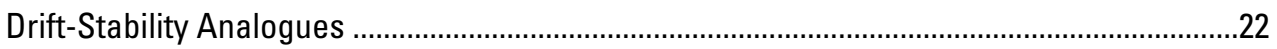

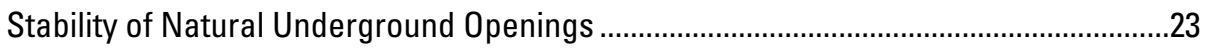

Stability of Manmade Underground Openings ……………………………………......28

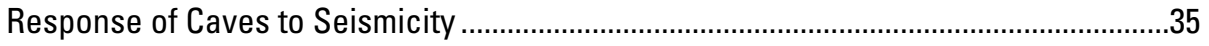

Response of Manmade Underground Openings to Seismicity ...........................................38

Underground Openings Affected by Temperature ........................................................41

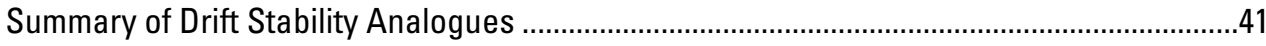

Analogues for the Engineered Barrier System ...........................................................................4

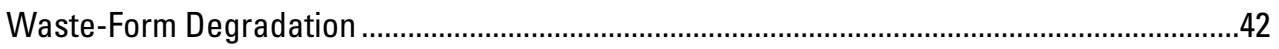

Overview of Conceptual Basis of Waste-Form Degradation.........................................42

Spent-Fuel Dissolution in an Oxidizing Environment .....................................................43

Analogue Studies Related to Waste-Form Dissolution Rates .......................................45

Analogue Studies Related to Immobilization by Secondary Minerals.............................47

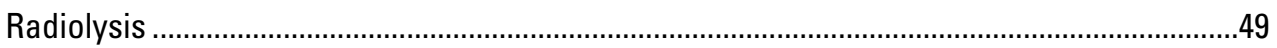

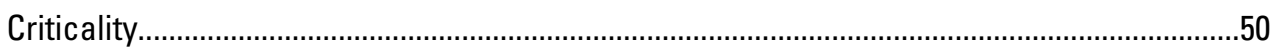

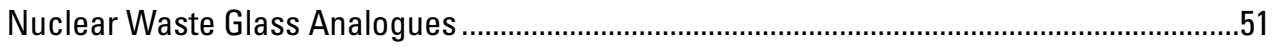

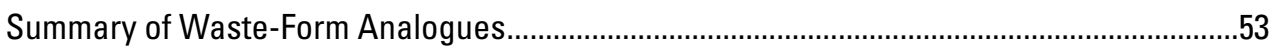

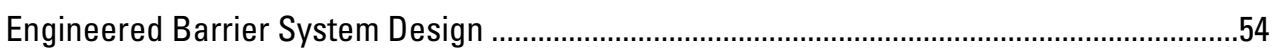

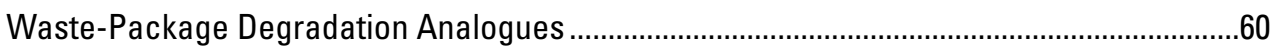

Natural Analogue Studies of Corrosion .......................................................................61

Passive Film Formation .....................................................................................63

Naturally Occurring Metals as Natural Analogues ..............................................63

Summary of Waste-Package Degradation Analogues.....................................................65

Analogues for Other Engineered Barrier System Components and Their Effect on

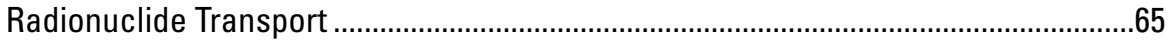

Analogues for the Titanium Drip Shield .......................................................................68

Analogues for the Invert Ballast ..................................................................................68

Natural Analogues for Development of Alkaline Plumes from Cement...................................69

Natural Analogues for Colloidal Transport of Radionuclides in the Near Field.......................70

Summary of Analogues to Engineered Barrier System Materials and Processes...................71

Seepage Analogues ............................................................................................................

Seepage Characteristics of Caves ...................................................................................72

Seepage Characteristics of Underground Openings............................................................ 
Summary of Analogues for Seepage ..................................................................................

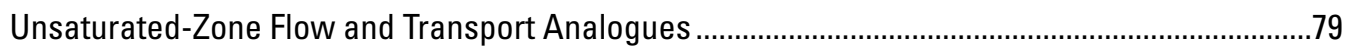

Yucca Mountain Conceptual Unsaturated-Zone Flow and Transport Models .........................79

Unsaturated-Zone Transport Studies ................................................................................

Limited Fracture/Matrix Interaction at Rainier Mesa, Nevada .......................................80

The Subsurface Disposal Area at the Idaho National Laboratory as a Potential Analogue for Radionuclide Transport at Yucca Mountain ...................................81

Geologic and Hydrologic Setting ........................................................................81

Modeling the Large-Scale Aquifer Pumping and Infiltration Test at the Idaho

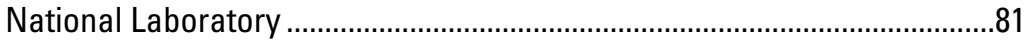

The Subsurface Disposal Area Transport Modeling Study .....................................82

Discussion of the Subsurface Disposal Area Modeling Study ...............................95

Radionuclide Flow and Transport Studies at Nopal I, Peña Blanca,

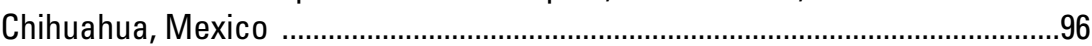

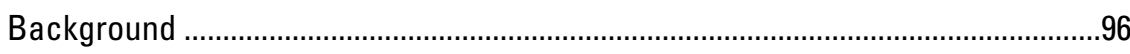

Early Characterization of Radionuclide Transport Using Uranium-Series

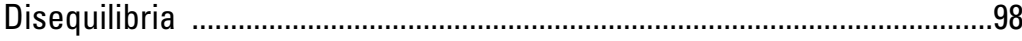

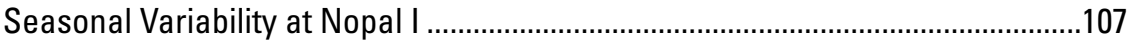

Continued Uranium-Series Analyses ..................................................................108

Conceptual Model of Transport...........................................................................113

Conclusions of Peña Blanca Studies .....................................................................113

Uranium Deposits in Northwestern Nevada/Southeastern Oregon ..............................114

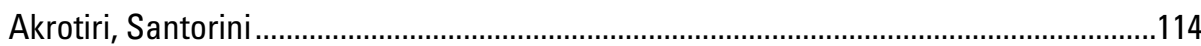

Koongarra Uranium Deposit, Alligator Rivers, Northern Territory, Australia ................115

Busted Butte, Nevada, Tracer Test.........................................................................116

Evidence for Colloidal Transport in the Unsaturated Zone ..........................................116

Conclusions of Unsaturated-Flow and Transport Analogues..............................................117

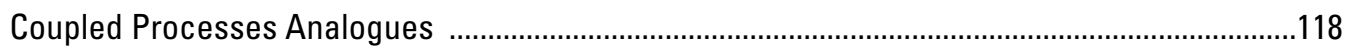

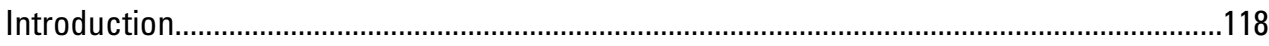

Yellowstone as a Natural Analogue for Thermal-Hydrologic-Chemical Processes .............119

Hydrothermal Sealing ............................................................................................119

Comparison with Yucca Mountain ..................................................................................121

Other Examples of Fossil Hydrothermal Systems.............................................................122

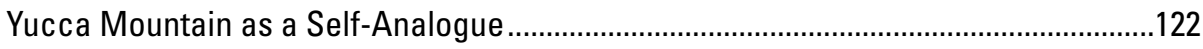

Paiute Ridge, Banco Bonito, and Grants Ridge .........................................................123

Comparison with Yucca Mountain ..............................................................................124

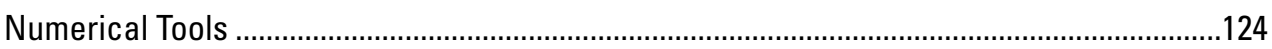

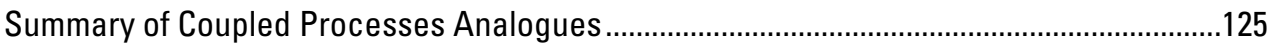

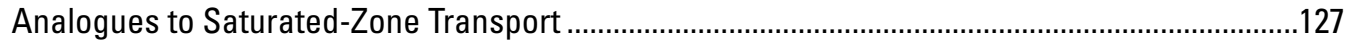

Conceptual Model of Saturated-Zone Flow and Transport ................................................127

Performance Assessment Insights from Poços de Caldas, Brazil .......................................128

Uranium Retardation under Oxidizing Conditions at Coles Hill, Virginia...............................129

Matrix Diffusion Analogues: El Berrocal in Spain, Palmottu in Finland, and Others.............129

Uranium Retention Under Variable Redox Conditions: Bangombé in Gabon, and Olden Granite in Sweden..........................................................................................132

Retention of Uranium Along a Fault: Tono Mine, Japan .....................................................134 
Colloidal Transport in the Saturated Zone .........................................................................136

Anthropogenic Analogues of Saturated-Zone Flow and Transport ....................................137

Saturated-Zone Transport at Uranium Mill Tailings Sites ..............................................137

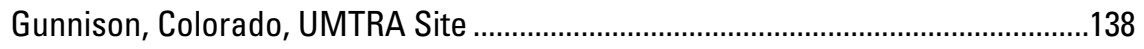

New Rifle UMTRA Site, Rifle, Colorado...............................................................138

Summary and Conclusions of the UMTRA Study ...............................................145

Saturated-Zone Transport at the Idaho National Laboratory .........................................145

Saturated-Zone Transport at the Nevada Test Site .....................................................146

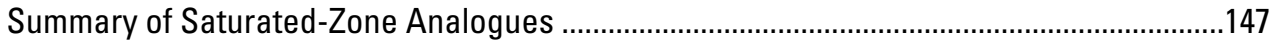

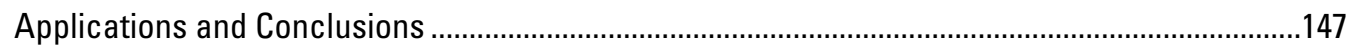

Performance Assessment Applications of Analogues in Geologic Disposal Programs

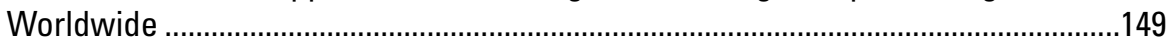

Yucca Mountain Project Incorporation of Natural Analogues .............................................150

Yucca Mountain Project Identified Needs and Applications from this Report ......................151

Remaining Areas for Increased Process Understanding through Analogue Studies ..........151

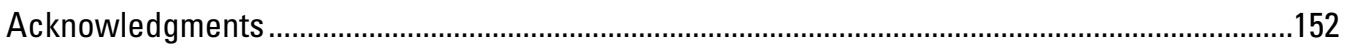

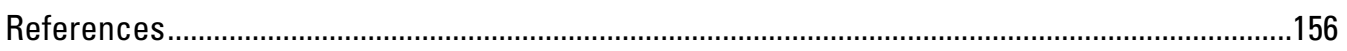

Appendix — Known Caves with Assigned Ages and the Methods of Age Determination.............185

\section{Figures}

1. Location map of Yucca Mountain site in Nevada ...........................................................5

2. Generalized stratigraphic cross section across Yucca Mountain, Nevada .......................6

3. Drawing showing the combination of natural and engineered features that are expected to contribute to waste isolation ...........................................................

4-17. Photographs showing:

4. 9,000-year-old flutes carved from the leg bone of a red-crowned crane ..................8

5. Silver and iron artifacts recovered from Pompeii, Italy, displayed at the Naples Museum ...........................................................................................

6. Materials preserved by burial in volcanic ash at Herculaneum in A.D. 79.............10

7. Packrat midden from the Sheep Range in Nevada................................................11

8. Split-twig figurines made of willow.......................................................................11

9. Fox-skin quiver, atlatl, and darts from Cowbone Cave, northern Nevada................12

10. Footwear recovered from Arnold Research Cave in Missouri ...............................12

11. Painted rhinoceroses, horses, and oryxes from Chauvet Cave, France ..................12

12. The funeral barque of the Pharaoh Cheops (Khufu) ................................................14

13. The painted interiors of many Egyptian tombs show no signs of damage except vandalism.

14. Frescoes from Etruscan tombs of Tarquinia, Italy.................................................16

15. Columns and ceiling of Ajanta Cave \#10, India, painted on a mud plaster in the second century B.C., showing some spallation in lower part of photograph ..17

16. Fresco from Karanlik church, Goreme, Turkey .....................................................18

17. Tomb of Tanwetamani in El Kurru, Sudan, showing the destruction of plaster and painting to the level of a mudflow, which partly filled the tomb after it was left open by grave robbers 
18. Variables affecting thermal performance of a repository .

19. Diagrams illustrating the drift shadow concept under $(A)$ diffusion-dominated, and $(B)$ advection-dominated conditions ....

20. Diagram showing configuration of an intact drift and a drift that has collapsed over a long timeframe.

21-28. Photographs showing:

21. Fairyland in Carlsbad Caverns, New Mexico

22. (A) Lava tube in Undara, Australia. (B) Nahuku lava tube and lava stalactites from Hawaii

23. Tubo Volcánico Corona, Lanzarote, Canary

Islands, with a man shown for scale and a schematic cross sections of the lava tube

24. Megabreccia in Titus Canyon, in the northeast corner of Death Valley National Park, California

25. The Neolithic flint mine at Krzemionki Opatowskie, Poland

26. The Nubian Limestone that hosts the tombs in the Valley of the Kings in Egypt

27. (A) Mined-out cavern in the Laurion mines, Greece, and $(B)$ a temple at Wadi Sikait, Egypt, which was excavated in a talc schist during the first century B.C.

28. (A) The tunnel of Eupalinus, Greece, and $(B)$ the tunnel of Hezekiah, Israel ..........30

29. Location map for the Greek and Roman tunnels discussed in the text and for the Italian caves studied for paleoseismicity

30. Photographs showing $(A)$ large cisterns excavated in tuff 40 meters below Naples, Italy, and $(B)$ part of the 400-kilometer-long aqueduct system ................32

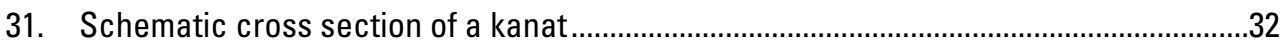

32-35. Photographs showing:

32. Crypt of the Popes (left) and Crypt of Saint Cecilia (right) in the Catacomb of Callixtus, Rome, Italy.

33. A room in the underground city of Kaymakli, Turkey.

34. Mitchell Caverns, California, showing a cracked stalagmite near the entrance and an intact delicate stalactite from deeper in the cave.

35. Soda straws

36. Cross sections through two stalagmites from caves in northeastern Italy .38

37. Index map for the 1964 Good Friday earthquake in Alaska showing location of tunnels near the epicenter and approximate contours for earthquake intensity .......40

38. Illustration of placement of spent nuclear fuel pellets within a fuel assembly and waste packages, and degradation and mobilization of the waste form.

39. Photograph showing reactor zone in a natural fission reactor at the Oklo orebody, Gabon

40. Schematic cross section showing depth of Okélobondo natural fission reactor in relation to other 0 klo reactors.

41. Aggregate of $(\mathrm{U}, \mathrm{Zr})$-silicate, zircon, galena, and illite in the center of the Okélobondo reactor core (RZOKE).

42. Sequence of formation of uranyl minerals by alteration of uraninite . .50

43. Schematic showing components of the engineered barrier system proposed for Yucca Mountain in relation to natural barriers. 
44. Conceptual view of the drip shield assembly designed to serve as a protective barrier to divert water dripping from drift walls.

45. Cross section of emplacement drift with engineered barrier system components.

46. Schematic view of different waste packages in emplacement drift .............................58

47. Processes affecting formation of high-salinity fluids on the waste package surface

48. Photograph of the corrosion-resistant iron pillar at Delhi, India

49. Schematic showing development of rust coating on mild steel, weathering steel, and Delhi iron pillar...

50-52. Photograph showing:

50. Josephinite sample used for surface analysis study

51. Chromite grains in serpentinite before $(A)$ and after $(B)$ acid leachnig

52. Portion of Hadrian's Wall in England, showing strength and stability of Roman mortar after 1,700 years

53. Distribution of ophiolites and hyperalkaline springs in northern Oman

54. Stratigraphic section of drill hole UE-25 UZ\#16, with abundance of zeolites plotted relative to $(A)$ alkaline earth, and $(B)$ alkali constituents

55. Fracture mineralization and wall rock alteration at C353 site, Maqarin, Jordan, showing the presence of hydrated calcium silicate and sulfate phases thaumasite and ettringite

56. Schematic illustration of radionuclide transport in a fractured rock.

57-63. Photographs showing:

57. Entrance to Mitchell Caverns in California, El Pakiva portal, showing fallen blocks that partially occlude the entrance.

58. Fracture in the blackened wall and ceiling of a kitchen in a monastery at Goreme, Turkey, which was probably in use until the 12th century A.D.

59. (A) Building 810 on the Denver Federal Center, Colorado, and $(B)$ a closeup of the underside of the roof over a loading dock

60. Interior of Alcove 1 of the Exploratory Studies Facility, Yucca

Mountain, Nevada

61. The inside of a corbelled ceiling grave at Newgrange, Ireland .............................76

62. Cheomachong tomb in Gyeongju, Korea ...........................................................77

63. Area of large mudcracks formed in the floor of a tomb in the Valley of the Kings in Egypt

64. Plan view of the regional model at the Idaho National Laboratory with shading to illustrate ground surface elevation

65. Map of the Subsurface Disposal Area, Idaho National Laboratory, and deep wells showing location of radionuclide concentrations greater than three times detection for depth intervals to the 9-meter interbed

66. Map of the Subsurface Disposal Area, Idaho National Laboratory, and deep wells showing location of radionuclide concentrations greater than three times detection for depth intervals to the 34-meter interbed

67. Map of the Subsurface Disposal Area, Idaho National Laboratory, and deep wells showing location of radionuclide concentrations greater than three times detection for depth intervals to the 73-meter interbed

68. Depths and elevations of perched water in the vicinity of the Subsurface

Disposal Area, Idaho National Laboratory. 
69. Comparison of FEHM and FLOTRAN for normalized tracer concentration after 50 years for the single-continuum model of the Subsurface

Disposal Area, Idaho National Laboratory, with steady release at the center

of the injection region

70. Liquid saturation for fracture continuum in model of the Subsurface Disposal Area, Idaho National Laboratory...

71. Liquid saturation for matrix continuum in model of the Subsurface Disposal Area, Idaho National Laboratory.

72. Comparison of steady-state saturation profiles for single- and dual-continuum simulations in model of the Subsurface Disposal Area, Idaho National Laboratory

73. Normalized tracer concentration for fracture continuum in dual-continuum transport model of the Subsurface Disposal Area, Idaho National Laboratory.

74. Normalized tracer concentration for matrix continuum in dual-continuum transport model of the Subsurface Disposal Area, Idaho National Laboratory.

75. Normalized tracer concentration after 50 years for the single-continuum model of the Subsurface Disposal Area, Idaho National Laboratory, with constant release

76. Hydrostratigraphy of the Subsurface Disposal Area, Idaho National Laboratory ..........92

77. Steady-state water potentials at the Subsurface Disposal Area, Idaho National Laboratory.

78. Liquid saturation at 50 years in the dipping, continuous layer transport model of the Subsurface Disposal Area, Idaho National Laboratory...

79. Normalized tracer concentration at 50 years in the dipping, continuous layer transport model of the Subsurface Disposal Area, Idaho National Laboratory

80. Comparison of field data to model for sorption of cesium, plutonium, americium, and strontium for a flow velocity of 0.1 meter per year through the surficial sediment at the Subsurface Disposal Area, Idaho National Laboratory.

81. Nopal I uranium deposit in the Peña Blanca Mining District, Chihuahua, Mexico .........97

82. Orthogonal, vertical cross sections through observation well PB 1 of the Nopal I deposit, Chihuahua, Mexico

83. Relative sequence of formation and abundance of uranium minerals at the Nopal I deposit, Chihuahua, Mexico.

84. Plan view of the Nopal I deposit .100

85. Plot of measurements of ${ }^{234} \mathrm{U} / 238 \mathrm{U}$ compared to ${ }^{230} \mathrm{Th} / 238 \mathrm{U}$ for fracture-filling materials, Nopal I area, Chihuahua, Mexico, obtained by the Center for Nuclear Waste Regulatory Analyses

86. ${ }^{234} \mathrm{U} /{ }^{238} \mathrm{U}$ activity ratios at distances from edge of the Nopal I deposit, Chihuahua, Mexico, for the fracture samples .

87. ${ }^{238} \mathrm{U}-{ }^{234} \mathrm{U}-230 \mathrm{Th}$ systematics for fracture-filling materials at Peña Blanca, Chihuahua, Mexico.

88. ${ }^{230}$ Th- ${ }^{226}$ Ra systematics (plotted as activity ratio) for fracture-filling materials at Peña Blanca, Chihuahua, Mexico

89. Schematic of Nopal I Level +00 Adit sampling locations, Chihuahua, Mexico 107

90. Photograph of sampling locations $A, B$, and C in the Nopal I +00 Adit, Chihuahua, Mexico 
91. Plot showing stable isotope ratios for waters collected from the Nopal I adit, Peña Blanca, Chihuahua, Mexico...

92. Portion of topographic map showing locations of Nopal I ore deposit and Peña Blanca wells, Peña Blanca, Chihuahua, Mexico 109

93. Panoramic view of the wells drilled in 2003, Peña Blanca, Chihuahua, Mexico.

94-96. Graphs showing:

94. Uranium isotope systematics and mixing lines for $(A)$ unsaturated-zone and $(B)$ saturated-zone waters, Peña Blanca, Chihuahua, Mexico

95. Decrease in uranium (U) concentrations in 2003-drilled well waters and well development over time, Peña Blanca, Chihuahua, Mexico

96. Strontium $(\mathrm{Sr})$ isotope mixing diagram for unsaturated-zone adit waters and saturated-zone ranch well waters, Peña Blanca, Chihuahua, Mexico

97. Map showing location of the uranium orebodies in the Alligator Rivers region, Northern Territory, Australia

98. Cross section through the Koongarra, Alligator Rivers, Australia, orebody showing the distribution of the major rock types and uranium-bearing minerals

99. Location of Steenkampskraal, South Africa.

100. Comparison of processes in geothermal and anthropogenic thermal systems created by emplacing heat-generating nuclear waste in an unsaturated fractured rock mass

101. Photograph of Porkchop Geyser, Yellowstone National Park, Wyoming

102. Calculated changes in sodium-potassium-calcium (NKC) reservoir temperatures and silica (SiO2) concentrations for waters sampled from Porkchop Geyser, Yellowstone National Park, Wyoming

103. Photomicrograph of altered Rainier Mesa Tuff, Nevada

104. Location map of the Osamu Utsumi Mine and Morro do Ferro study sites at Poços de Caldas, Minas Gerais, Brazil

105. North-south cross section of the El Berrocal, Spain, granite-uranium-quartz vein system and location of selected boreholes

106. Lithology at Palmottu, Finland, with respective uranium and thorium contents

107. Idealized cross section of a fossil reactor zone at $0 \mathrm{klo}$ and

Bangombé, Gabon

108. Schematic representation of groundwater flow paths in the Bangombé area, Gabon

109. Geology of the Tono, Japan, natural analogue study site. $(A)$ Tono mine site, including regional geology. $(B)$ Cross section through the Tsukiyoshi orebody (black) showing its faulted nature.

110. (A) Locations of the Uranium Mill Tailings Recovery Act groundwater project sites. $(B)$ Location map for the Gunnison, Colorado, Uranium Mill Tailings Recovery Act site

111. Plume map of sulfate concentrations, in milligrams per liter, in alluvial groundwater at the Gunnison, Colorado, Uranium Mill Tailings Recovery Act site

112. Plume map of uranium concentrations, in milligrams per liter, in alluvial groundwater at the Gunnison, Colorado, Uranium Mill Tailings Recovery Act site 
113. Location map for the New Rifle, Colorado, Uranium Mill Tailings Recovery

Act site.

114. Aerial photograph of the New Rifle, Colorado, Uranium Mill Tailings

Recovery Act site, showing location of tailings piles in August 1974

115. Map showing locations of wells screened in the alluvial aquifer at the New Rifle, Colorado, Uranium Mill Tailings Recovery Act site

116. Sulfate-chloride $\left(\mathrm{SO}_{4} / \mathrm{Cl}\right)$ ratios in downgradient alluvial groundwater relative to distance in feet from the Colorado River bank on the eastern edge of the New Rifle, Colorado, Uranium Mill Tailings Recovery Act site

117. Uranium concentration in downgradient alluvial groundwater relative to distance in feet from the Colorado River bank on the eastern edge of the New Rifle, Colorado, Uranium Mill Tailings Recovery Act site

118. Decrease in normalized concentrations of selected radionuclides in the Snake River Plain aquifer with distance from the Idaho Chemical Processing Plant, Idaho

119. The function of natural analogues and site characterization in performance assessment

\section{Tables}

1. Items preserved within the unsaturated zone as reported by National Geographic magazine from 1987 to 2001

2. Elemental distribution within uraninite, inclusions, and clays for elements in the reactor zones at Oklo, Gabon

3. Comparison of volcanic glass and nuclear waste glass compositions, in weight percent.

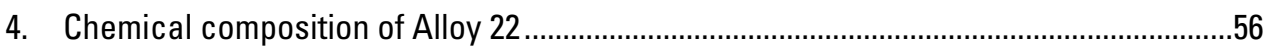

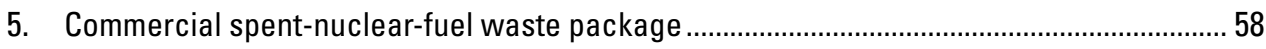

6. Chemical composition of stainless steel type 316NG .....................................................59

7. Composition of synthetic Yucca Mountain waters from unsaturated and saturated zones and their evaporated compositions

8. Typical Salton Sea geothermal well brine composition ...................................................63

9. Chemical characteristics of selected samples of pore water, perched water, and groundwater from Yucca Mountain and the Subsurface Disposal Area of the Idaho National Laboratory

10. Additional water inputs to the Idaho National Laboratory Subsurface Disposal Area due to flooding

11. Composition of injected fluid used in model of Subsurface Disposal Area transport

12. Measurements of concentration and isotopic composition in water samples collected near the Nopal I uranium deposit, Peña Blanca, Mexico................102

13. Comparison of Peña Blanca and Yucca Mountain water samples.................................112

14. Application of geothermal field information as analogues to coupled processes anticipated at the proposed Yucca Mountain, Nevada, repository

15. Natural analogues discussed in this report and their potential application to Yucca Mountain performance assessment.

Appendix Table. Known caves with assigned ages and the methods of age determination. 


\section{Conversion Factors}

\begin{tabular}{|c|c|c|}
\hline Multiply & By & To obtain \\
\hline \multicolumn{3}{|c|}{ Length } \\
\hline centimeter $(\mathrm{cm})$ & 0.3937 & inch (in.) \\
\hline millimeter (mm) & 0.03937 & inch (in.) \\
\hline meter $(\mathrm{m})$ & 3.281 & foot (ft) \\
\hline kilometer $(\mathrm{km})$ & 0.6214 & mile (mi) \\
\hline \multicolumn{3}{|c|}{ Area } \\
\hline square meter $\left(\mathrm{m}^{2}\right)$ & 10.76 & square foot $\left(\mathrm{ft}^{2}\right)$ \\
\hline square centimeter $\left(\mathrm{cm}^{2}\right)$ & 0.1550 & square inch $\left(\mathrm{ft}^{2}\right)$ \\
\hline square kilometer $\left(\mathrm{km}^{2}\right)$ & 0.3861 & square mile $\left(\mathrm{mi}^{2}\right)$ \\
\hline \multicolumn{3}{|c|}{ Volume } \\
\hline liter (L) & 0.2642 & gallon (gal) \\
\hline liter (L) & 61.02 & cubic inch $\left(\mathrm{in}^{3}\right)$ \\
\hline cubic meter $\left(\mathrm{m}^{3}\right)$ & 35.31 & cubic foot $\left(\mathrm{ft}^{3}\right)$ \\
\hline \multicolumn{3}{|c|}{ Flow rate } \\
\hline meter per second $(\mathrm{m} / \mathrm{s})$ & 3.281 & foot per second (ft/s) \\
\hline meter per day $(\mathrm{m} / \mathrm{d})$ & 3.281 & foot per day (ft/d) \\
\hline meter per year (m/yr) & 3.281 & foot per year ft/yr) \\
\hline cubic meter per second $\left(\mathrm{m}^{3} / \mathrm{s}\right)$ & 35.31 & cubic foot per second $\left(\mathrm{ft}^{3} / \mathrm{s}\right)$ \\
\hline cubic meter per day $\left(\mathrm{m}^{3} / \mathrm{d}\right)$ & 35.31 & cubic foot per day $\left(\mathrm{ft}^{3} / \mathrm{d}\right)$ \\
\hline liter per second $(\mathrm{L} / \mathrm{s})$ & 15.85 & gallon per minute (gal/min) \\
\hline cubic meter per day $\left(\mathrm{m}^{3} / \mathrm{d}\right)$ & 264.2 & gallon per day $(\mathrm{gal} / \mathrm{d})$ \\
\hline millimeter per year $(\mathrm{mm} / \mathrm{yr})$ & 0.03937 & inch per year (in/yr) \\
\hline \multicolumn{3}{|c|}{ Mass } \\
\hline gram (g) & 0.03527 & ounce, avoirdupois (oz) \\
\hline kilogram $(\mathrm{kg})$ & 2.205 & pound avoirdupois (lb) \\
\hline \multicolumn{3}{|c|}{ Pressure } \\
\hline kilopascal (kPa) & 0.1450 & pound per square inch (lb/in. $\left.{ }^{2}\right)$ \\
\hline \multicolumn{3}{|c|}{ Density } \\
\hline gram per cubic centimeter $\left(\mathrm{g} / \mathrm{cm}^{3}\right)$ & 62.4220 & pound per cubic foot $\left(\mathrm{lb} / \mathrm{ft}^{3}\right)$ \\
\hline \multicolumn{3}{|c|}{ Hydraulic conductivity } \\
\hline meter per day $(\mathrm{m} / \mathrm{d})$ & 3.281 & foot per day $(\mathrm{ft} / \mathrm{d})$ \\
\hline \multicolumn{3}{|c|}{ Hydraulic gradient } \\
\hline meter per kilometer $(\mathrm{m} / \mathrm{km})$ & 5.27983 & foot per mile (ft/mi) \\
\hline
\end{tabular}

Temperature in degrees Celsius $\left({ }^{\circ} \mathrm{C}\right)$ may be converted to degrees Fahrenheit $\left({ }^{\circ} \mathrm{F}\right)$ as follows:

$$
{ }^{\circ} \mathrm{F}=\left(1.8 x^{\circ} \mathrm{C}\right)+32
$$

Vertical coordinate information is referenced to the North American Vertical Datum of 1988 (NAVD 88)

Horizontal coordinate information is referenced to North American Datum of 1983 (NAD 83)

Concentrations of chemical constituents in water are given either in milligrams per liter (mg/L) or micrograms per liter $(\mu \mathrm{g} / \mathrm{L})$, or in:

parts per million (ppm)

parts per billion (ppb)

parts per trillion (ppt)

parts per quadrillion (ppq) 


\section{Acronyms, Initialisms, and Abbreviations}

\begin{tabular}{|c|c|}
\hline A.D. & anno Domini \\
\hline ARAP & Alligator Rivers Analogue Project \\
\hline B.C. & before Christ \\
\hline B.P. & before present \\
\hline $\mathrm{C}$ & carbon \\
\hline $\mathrm{CHn}$ & Calico Hills nonwelded (hydrogeologic unit) \\
\hline DOE & United States Department of Energy \\
\hline DST & drift-scale test \\
\hline EBS & engineered barrier system \\
\hline $\mathrm{EC}$ & European Commission \\
\hline FEPs & features, events, and processes \\
\hline g & gravity unit \\
\hline $\mathrm{Ga}$ & giga-annum (billion years ago) \\
\hline GMWL & Global Meteoric Water Line \\
\hline IAEA & International Atomic Energy Agency \\
\hline ICPP & Idaho Chemical Processing Plant \\
\hline INL & Idaho National Laboratory \\
\hline k.y. & thousand years \\
\hline $\mathrm{ka}$ & thousand years ago \\
\hline LPIT & Large-Scale Aquifer Pumping and Infiltration Test \\
\hline $\mathrm{L} / \mathrm{mo}$ & liters per month \\
\hline m.y. & million years \\
\hline $\mathrm{Ma}$ & mega-annum (million years ago) \\
\hline Mpa & megapascal \\
\hline NAWG & Natural Analogue Working Group \\
\hline $\mathrm{NRC}$ & United States Nuclear Regulatory Commission \\
\hline NTS & Nevada Test Site \\
\hline OCRWM & Office of Civilian Radioactive Waste Management \\
\hline PA & performance assessment \\
\hline PGA & peak ground acceleration \\
\hline $\mathrm{ppb}$ & parts per billion \\
\hline ppm & parts per million \\
\hline ppq & parts per quadrillion \\
\hline ppt & parts per trillion \\
\hline psi & pounds per square inch \\
\hline PTn & Paintbrush Tuff nonwelded (hydrogeologic unit) \\
\hline REE & rare earth element \\
\hline RMR & Rock Mass Rating \\
\hline RWMC & Radioactive Waste Management Complex \\
\hline RZOKE & Okelobondo reactor zone \\
\hline SDA & Subsurface Disposal Area \\
\hline $\mathrm{TCw}$ & Tiva Canyon welded (hydrogeologic unit) \\
\hline TDS & total dissolved solids \\
\hline $\mathrm{THC}$ & thermal-hydrologic-chemical \\
\hline TIMS & thermal ionization mass spectrometry \\
\hline TSPA & total system performance assessment \\
\hline TSw & Topopah Spring welded (hydrogeologic unit) \\
\hline U.S. & United States \\
\hline UMTRA & Uranium Mill Tailings Recovery Act \\
\hline $\mathrm{UO}_{2}$ & uranium dioxide \\
\hline $\mathrm{UNE}^{2}$ & underground nuclear explosion \\
\hline URL & Underground Research Laboratory \\
\hline USGS & United States Geological Survey \\
\hline VA & viability assessment \\
\hline
\end{tabular}





\title{
Analogues to Features and Processes of a High-Level Radioactive Waste Repository Proposed for Yucca Mountain, Nevada
}

\author{
By Ardyth M. Simmons, Los Alamos National Laboratory, Los Alamos, New Mexico, and \\ John S. Stuckless, U.S. Geological Survey, Denver, Colorado, with a Foreword by \\ Abraham Van Luik, U.S. Department of Energy
}

\section{Abstract}

Natural analogues are defined for this report as naturally occurring or anthropogenic systems in which processes similar to those expected to occur in a nuclear waste repository are thought to have taken place over time periods of decades to millennia and on spatial scales as much as tens of kilometers. Analogues provide an important temporal and spatial dimension that cannot be tested by laboratory or field-scale experiments.

Analogues can be used in a qualitative mode to provide a means of understanding complex or abstract processes or in a quantitative mode to test models. Analogues provide one of the multiple lines of evidence intended to increase confidence in the safe geologic disposal of high-level radioactive waste. Although the work in this report was completed specifically for Yucca Mountain, Nevada, as the proposed geologic repository for high-level radioactive waste under the U.S. Nuclear Waste Policy Act (and it is referred to as such throughout this report), the U.S. Geological Survey believes that the applicability of the science, analyses, and interpretations is not limited to a specific site. The work is important as a contribution not only to investigations of future waste-disposal options, such as the assessment of alternative sites or solutions, but also as a contribution to scientific investigations unrelated to waste disposal.

Isolation of radioactive waste at a mined geologic repository would be through a combination of natural features and engineered barriers. In this report we examine analogues to many of the various components of the Yucca Mountain system, including the preservation of materials in unsaturated environments, flow of water through unsaturated volcanic tuff, seepage into repository drifts, repository drift stability, stability and alteration of waste forms and components of the engineered barrier system, and transport of radionuclides through unsaturated and saturated rock zones.

Hundreds of delicate and easily destroyed artifacts and biological materials have been well preserved both in natural (for example, caves and rock shelters) and in manmade (for example, tombs and mines) underground openings. The maintenance of a stable microclimate is a critical feature in making caves suitable for long-term preservation. The survival of metal artifacts over prolonged periods of time is related to the corrosion-resistant properties of metals and metal alloys, the development of protective passive film coatings with the onset of corrosion, and sequestering artifacts with water, which is enhanced by the location of artifacts in arid to semiarid environments.

Numerous examples demonstrate that both natural and manmade underground openings can exist for thousands of years in a wide variety of geologic settings, even with minimal or no engineered supports. Examination of these openings also leads to the conclusion that seismic events at or near a mined repository are not likely to cause significant damage to the emplacement tunnels. As a consequence, the tunnels should be expected to be a long-term hydrologic feature.

Analogues add valuable insight to understanding longterm waste-form degradation processes through the record left behind in secondary minerals and groundwater chemistry. In addition, measurement of the concentration of fission products as tracers in rock and groundwater surrounding uraninite provides a satisfactory approach to estimating natural dissolution rates, as was tested at a number of sites that demonstrated a more rapid dissolution rate under oxidizing conditions.

Models predict that much of the water percolating through the unsaturated zone will be held in the wall rock of tunnels by capillary forces rather than entering the tunnels as seepage. Analogues in natural and manmade underground openings demonstrate the tendency for water that does become seepage to run down the walls of underground openings rather than drip from the ceiling; thus, not all seepage would affect stored waste.

In the event of waste mobilization and migration away from the emplacement drifts, the rate of radionuclide transport through the unsaturated zone is determined by the percolation flux and by the hydrologic properties and sorptive properties 
of the tuff units. Fractures act both as transport pathways and as places of retardation at a number of unsaturated analogue sites, including the Idaho National Laboratory, near Idaho Falls; Peña Blanca, Mexico; Akrotiri, Greece; and volcanic tuff-hosted uranium deposits in northern Nevada.

In the saturated zone, advective transport along fractures has been identified as a more significant transport mechanism than matrix diffusion in all the analogue sites studied, although matrix diffusion may account for loss of lead in uraninites at Oklo, in Gabon. The Poços de Caldas site in Brazil highlighted the importance of amorphous phases in suspension or as coatings on rock as the principal sorptive surfaces for many trace elements in solution. Some of the fixing processes appeared to be irreversible over long time scales. Sorption onto fracture coatings, particularly calcite, also efficiently retards uranium transport in fractures at Palmottu, Finland, and El Berrocal, Spain. Matrix diffusion in crystalline rock is generally limited to only a small volume of rock close to fractures, but even a small volume can make a significant difference in radionuclide retardation.

In most studies of natural systems, a proportion of the total uranium, thorium, and rare earth elements (REE) in the groundwater was associated with colloids. Colloid transport appears to be an important factor for migration of thorium in one open unsaturated system, Steenkampskraal, in South Africa, but not in another, Nopal I, in Mexico. Colloidal transport of uranium was shown to be minimal at the analogue site in Koongarra, Australia, where filtration of colloids appears to be effective. Observations from the Nevada Test Site lend support to the concept that radionuclide transport in the saturated zone can be facilitated by colloids; but so far, no natural analogue studies have quantified the importance of this process.

The emplacement of heat-generating waste in a geologic repository located in the unsaturated zone will cause perturbations to the natural environment through heat transfer, as well as by associated geochemical and geomechanical changes taking place in the repository near-field and altered-rock zones. The unsaturated conditions, lower temperatures, and much lower fluid-flow rates predicted for the Yucca Mountain system should result in less extensive water/rock interaction than is observed in geothermal systems. Evidence from fossil hydrothermal systems indicates that mineral alteration resulting from flow of hot fluids through fractures extends only a few centimeters from the fracture wall into the matrix.

Simulations indicate that only small reductions in fracture porosity (4-7 percent) and permeability (less than 1 order of magnitude) will occur in the near field as a result of amorphous silica and calcite precipitation. Changes in permeability, porosity, and sorptive capacity are expected to be relatively minor at the mountain scale, where thermal perturbations will be reduced.

The Yucca Mountain Project has applied analogues for testing and building confidence in conceptual and numerical process models and has less frequently used analogues to provide specific parameters in total system performance assessment (TSPA) models. Analogues have been widely used as model validation of aspects of Yucca Mountain characterization. In conclusion, natural and anthropogenic analogues have provided and can continue to provide value in understanding features and processes of importance across a wide variety of topics in addressing the challenges of geologic isolation of radioactive waste.

\section{Introduction}

In the scientific effort involved in evaluating the safety of a repository for the disposal of high-level radioactive waste, reasoning by analogy is a particularly important part of the scientific method. Processes are mimicked in laboratory studies where influences are controlled or in field studies where experimental conditions are applied to accelerate processes. Being able to observe these same processes in a natural setting, with evidence that they have been operative for long periods of time, gives both insight and confidence in the modeling of such processes. For the purposes of this report, natural analogues refer either to naturally occurring or to anthropogenic (manmade) systems in which processes similar to those expected to occur in a nuclear waste repository are thought to have occurred over long time periods (decades to millennia) and large spatial scales (as much as tens of kilometers). Generally, the more similar the setting, the more useful the analogue (Petit, 1990).

Reasoning by analogy is common in all walks of life. Such reasoning relates the likeness of a process or set of properties to a similar process or set of properties, either in another location or a different timeframe. Analogues used in evaluation of a potential radioactive waste repository do not provide exact duplicates of the process or conditions being examined; rather, they provide an important temporal and spatial dimension to the understanding of processes and events that may take place in or around a repository.

The use of analogy has been endorsed by the international nuclear waste community as a means of demonstrating confidence in the operation of systems, components, and processes related to nuclear waste disposal: for example, IAEA (International Atomic Energy Agency, 1989, 1999); publications of the European Commission's (EC) Natural Analogue Working Group (NAWG); and Miller and others (2006). The initial use of the natural analogue studies in radioactive-waste disposal programs was to (1) collect corroborative evidence from analogues to demonstrate additional understanding of processes expected to occur, (2) collect data for variables that could not be measured readily at a proposed site, and (3) test conceptual models for processes affecting a proposed site. With regard to the latter, the IAEA and the EC's NAWG concluded: "The role of a natural analogue should...be to confirm: (a) that the process is, in fact, something which can or will occur in practice, as well as in theory, and in nature, as well as in the laboratory; (b) where, when, and under what conditions it (the process) can occur; (c) that the effects of the process are 
those envisaged in the model; and (d) that the magnitude of the effects, in terms of scale and time, are similar to those predicted for a similar set of conditions" (Chapman and Smellie, 1986). More recently, the use of analogues in communicating with the public has been viewed as an added application for natural analogues (Stuckless, 2002, 2003, 2006; Lopez and others, 2004).

The use of natural analogues in the repository program also has been widely endorsed by the United States (U.S.) Nuclear Regulatory Commission (NRC). In 10CFR63.101(a)2, the NRC identified natural analogues as a potential component of the basis for demonstrating compliance with the reasonable expectation that postclosure performance objectives will be met. The NRC also specified natural analogues as a method to provide support for the technical basis for models in 10CFR63 (Kovach and Murphy, 1995; U.S. Nuclear Regulatory Commission, 2003).

The use of analogy also has been endorsed by oversight bodies, including the National Research Council (National Research Council, 1990) and the NWTRB (Nuclear Waste Technical Review Board, 1990, 2000), and by review panels such as the Natural Analogue Review Group of the DOE (U.S. Department of Energy, 1995) and the International Review Team that addressed a portion of the DOE's modeling efforts (International Atomic Energy Agency, 2001). The National Research Council's report indicated that natural analogues are essential for validating performance assessment (PA) models of geologic repositories over thousands or millions of years, as well as forming the basis for communicating the safety of a deep geologic repository in terms understandable to the public. To this end, the DOE Yucca Mountain Project (YMP) completed a comprehensive technical description and review of its natural analogue work to date: the "Natural Analogue Synthesis Report" (BSC, 2004), which describes analogues and their application to the processes modeled for a Yucca Mountain repository.

This report describes analogues to features and processes of the high-level radioactive waste repository proposed for Yucca Mountain, Nevada. Although the work in this report was completed specifically for Yucca Mountain, as the proposed geologic repository for high-level radioactive waste under the U.S. Nuclear Waste Policy Act (and it is referred to as such throughout this report), the U.S. Geological Survey believes that the applicability of the science, analyses, and interpretations is not limited to the specific site. The work is important as a contribution not only to investigations of future waste-disposal options, such as the assessment of alternative sites or solutions, but also as a contribution to scientific investigations unrelated to waste disposal. The extensive, unique, and often innovative geoscience investigations conducted at Yucca Mountain for more than 20 years have furthered our scientific understanding and have led to advancement of data collection techniques (especially in the unsaturated zone) in the earth science disciplines, including geology, hydrology, geochemistry, and seismicity. Publications such as this are important to disseminate this information for the use of the global scientific community.

The international community initiated several multinational analogue projects. One of the most important and successful projects was sponsored by the EC's NAWG. The DOE and NRC both contributed to, and benefited from, the work done under the oversight of the NAWG. The DOE Office of Civilian Radioactive Waste Management (OCRWM) and its predecessors supported participants in orebody studies at Oklo, Gabon; Poços de Caldas, Brazil; Alligator Rivers, Australia; and Cigar Lake, Canada. The technical reports resulting from these projects contributed to the overall understanding of repository processes. OCRWM also contributed (along with Sweden, Canada, Switzerland, and the Commission of the EC) to making a video on natural analogues that has been distributed to repository programs throughout the world for public awareness and educational purposes. The video "Traces of the Future" (1994-95, 55-minute and 24-minute versions) explores the uses of natural analogues in waste disposal. The English master was translated into German, French, Japanese, Czech, Chinese, Flemish, Spanish, and Swedish.

Analogues must be used with care so as to represent correctly the process or feature of interest. For example, it is well known that in an oxygenated environment, uranium ions are hexavalent and soluble, therefore mobile. This is true both in saturated and in unsaturated zones. Solid granites have been shown to have lost as much as 90 percent of their uranium in both of these zones and to depths of several hundred meters (Stuckless and Nkomo, 1978; Smellie and Stuckless, 1985; Stuckless and others, 1986). Studies indicate that uranium has been lost from labile sites such as grain boundaries and microfractures or where sorbed onto metallic oxides (Stuckless and Nkomo, 1980; Zielinski and others, 1981). Thus, the source material is markedly different from spent nuclear fuel and not appropriate as an analogue, except to confirm laboratory findings that hexavalent uranium is readily mobilized when in contact with water. Conversely, the peralkaline granites of Saudi Arabia appear to have lost little uranium, but most of the uranium in these granites is associated with zircon (Stuckless and others, 1983), and zircon is extremely refractory.

Likewise, all uranium deposits are not categorically good analogues for stability of nuclear waste. Uranium deposits indicate the long-term stability of some geologic environments, but some of the same uranium deposits in different environments could be used as arguments for massive transport of radioactive materials over long distances by natural processes (Pearcy and Murphy, 1991). It may be prudent to exclude those analogues for which initial and(or) boundary conditions are poorly known or for which important data, such as the source term (that is, the starting materials and amounts), are poorly constrained and may not be obtainable. A given site will generally only be analogous to some features of a repository or to a subset of processes or conditions that will occur in a repository. In addition, processes may have occurred at analogue sites that are not characteristic of those at the proposed repository. The long-term nature of analogues introduces some 
limitations and uncertainties, but they can still be used effectively if appropriate selection criteria are applied and limitations of the chosen analogue are recognized explicitly.

Natural analogues can be used in a qualitative or a quantitative mode. In a qualitative mode, they can provide descriptive information about the occurrence of various processes, or they may provide a test as to whether or not a predicted outcome of a model occurs in nature. In a quantitative mode, they may be able to constrain the bounds of a process or the bounds of a parameter used in model calculations. Natural analogues can be used to evaluate the validity of extrapolating from temporally limited field-scale experiments to longer time scales, or to add confidence when extrapolating from laboratory and intermediate-scale experiments to tests at larger spatial scales. In either mode, they are one of the "multiple lines of evidence" intended to increase confidence in the safe disposal of high-level radioactive waste in the geosphere.

Natural analogues were used in suggesting the use of the unsaturated zone for waste disposal at Yucca Mountain. A letter from the U.S. Geological Survey (USGS) to the DOE alludes to data from other parts of the Nevada Test Site (NTS). In it, Roseboom (1983) specifically referred to experience with tunnels in the unsaturated zone beneath Rainier Mesa on the NTS to point out that such tunnels, in spite of intense fracturing and moderate infiltration, are generally dry except for water-bearing fractures that generally drain quickly once intersected by a tunnel. Note that these features make the tunnels in Rainier Mesa less than ideal as an analogue to Yucca Mountain.

The proposed repository at Yucca Mountain (fig. 1) has several features and processes that can be examined using an analogue approach. These features and processes include (1) preservation of materials in unsaturated environments; (2) flow of water through unsaturated volcanic tuff; (3) seepage into repository drifts; (4) repository drift stability; (5) the waste form, waste package, and other parts of the engineered barrier system (EBS); and (6) transport of radionuclides through unsaturated and saturated rock zones.

Other potential radioactive-waste disposal facilities can benefit from analogue insights as well. For example, in some instances there are intermediate-depth disposal proposals that will experience unsaturated conditions, and in some deep geologic repository concepts it is acknowledged that after closure of the system rewetting will not be rapid and will remain a two-phase system for some time. Finally, there are hazardous, non-radioactive-waste disposal sites, as well as some low-level radioactive-waste disposal sites, that can benefit from a subset of the insights discussed herein.

The geology of the Yucca Mountain site has been described in many publications; for a concise summary, see Keefer and others (2007). Briefly, Yucca Mountain is formed by a sequence of volcanic units (mainly ash-flow tuffs) of Miocene age that are more than 1,800 m thick and dip gently to the east (fig. 2). The mountain is bounded on the east and west by steeply dipping normal faults such that the intervening mountain block is a little more than $3 \mathrm{~km}$ wide. The proposed host horizon for the waste emplacement is the Topopah Spring Tuff, which, at repository depth (approximately $280 \mathrm{~m}$ below the mountain crest), is a densely welded, high-silica rhyolite to quartz latite, ash-flow tuff. The welded tuff generally has a porosity of 5-10 percent and contains zones with lithophysal cavities, which can account for as much as 5 percent by volume of the proposed host horizon (Spengler and Fox, 1989). Detailed studies have shown that fractures longer than $1 \mathrm{~m}$ are generally separated by less than $1 \mathrm{~m}$ within the proposed repository horizon. However, fracture spacing and density are variable, depending on proximity to faults, and fractures longer than $1 \mathrm{~m}$ are more common in the nonlithophysal sections (Anna and Wallman, 1997; Sweetkind and others, 1997). Near the base of the Topopah Spring Tuff the rock is vitrophyric and has low permeability. Beneath this horizon and at the top of the underlying Calico Hills Formation, the volcanic rocks have undergone zeolitic alteration.

The climate at Yucca Mountain is semiarid with an average annual precipitation of $17 \mathrm{~cm} / \mathrm{yr}$ (Sharpe, 2007). Regionally, the mean annual free-water surface evaporation is $125-250 \mathrm{~cm}$ (Stuckless and Dudley, 2002); therefore, the infiltration at Yucca Mountain and subsequent percolation of moisture through the proposed repository horizon are both small. The water table is deep, lying $500-750 \mathrm{~m}$ below land surface (Stuckless and Dudley, 2002). Beneath the proposed repository the water table is nearly flat, with the hydraulic gradient ranging from 0.0001 to 0.0003 (Luckey and others, 1996). Flow is dominantly through fractures, especially in the densely welded units; these are highly transmissive, as would be expected from the small hydraulic gradients. An important hydrologic unit referred to as the Paintbrush Tuff nonwelded (PTn) hydrogeologic unit overlies the proposed repository horizon and combines all of the overlying nonwelded to partly welded ash units. The PTn unit is only weakly fractured, and groundwater flow through it is dominantly through pore spaces.

Isolation of waste at Yucca Mountain is proposed to be through a combination of natural features and engineered barriers (fig. 3). The natural features include (1) the small amount of precipitation and high evaporation that together, under current climatic conditions limit the amount of water available to transport waste to the environment; (2) the nonwelded units above and below the repository horizon, which tend to impede flow, thereby slowing the flow of water to or from waste packages; (3) capillary forces that tend to hold water in the matrix and small fractures in the host horizon, thereby limiting the amount of seepage into tunnels; (4) the zeolitic layer below the repository horizon, which provides an ion-exchange barrier for divalent cations should there be leakage from the waste packages; and (5) the flat potentiometric surface below the proposed repository and consequent low groundwater velocity. The engineered barriers include (1) the preclosure ventilation of the repository, which would have a pronounced early drying effect on the host horizon; (2) the waste heat during the early postclosure, which would help prevent seepage of water into the tunnels; (3) a titanium drip shield above the 


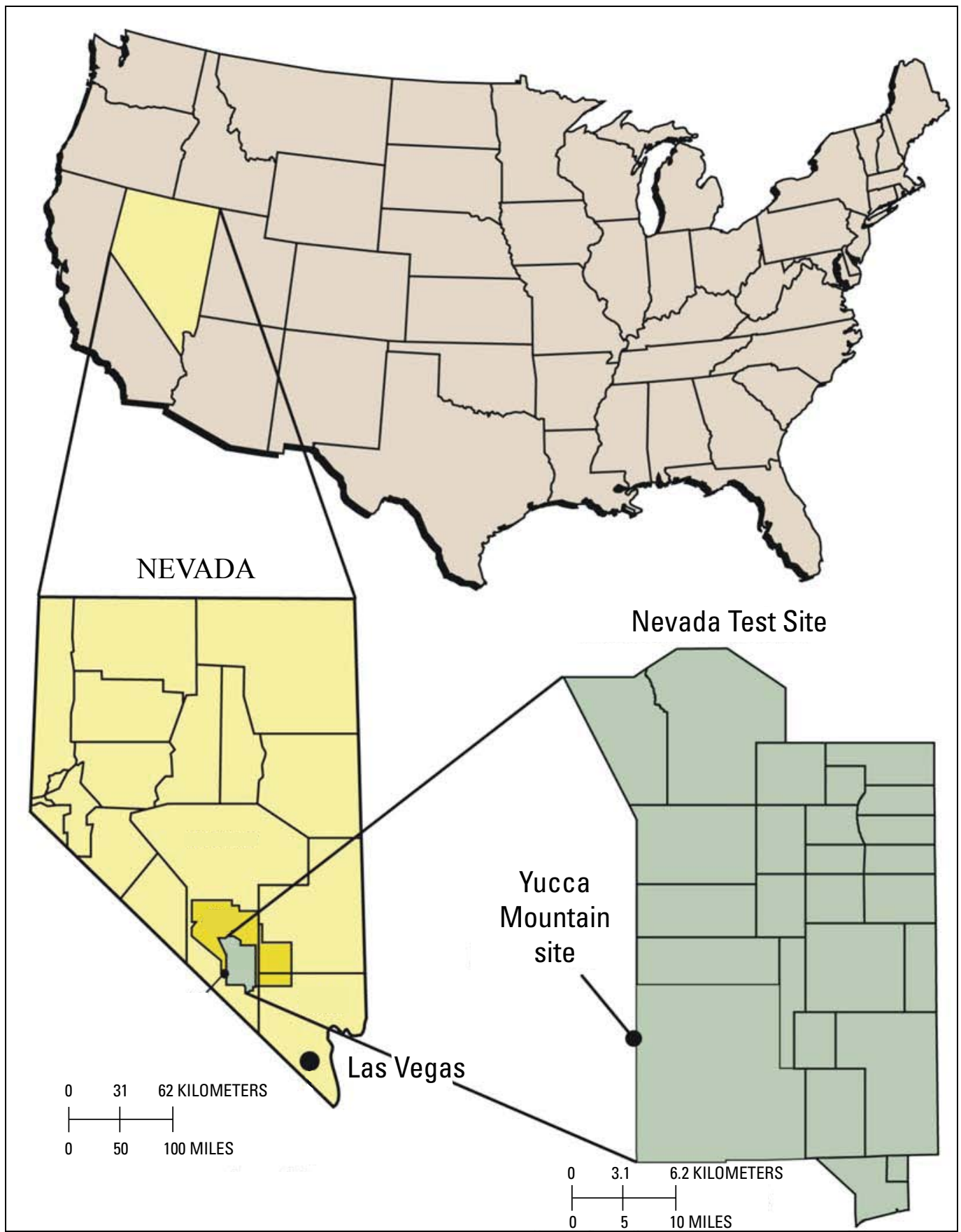

Figure 1. Location map of Yucca Mountain site in Nevada. 


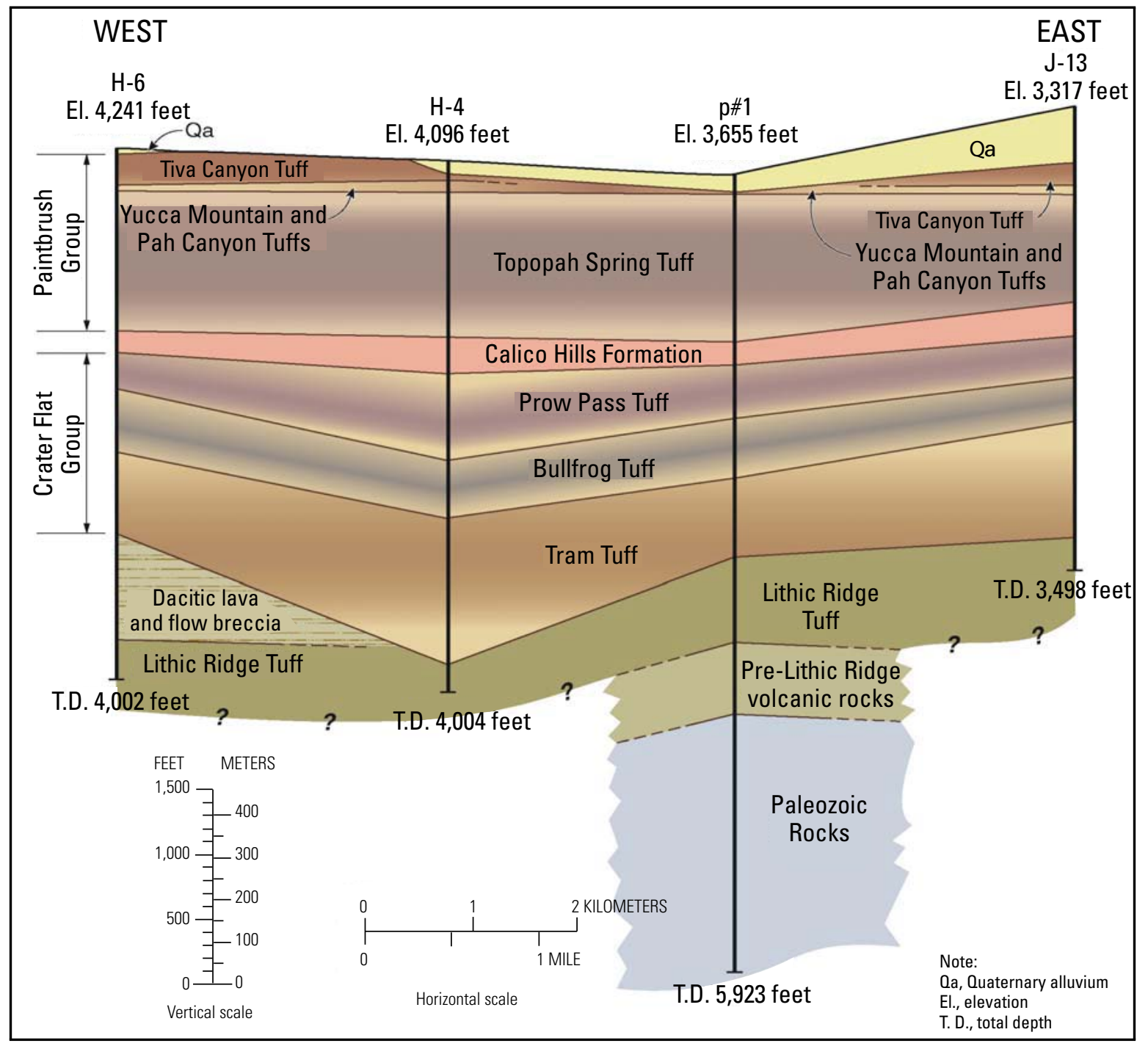

Figure 2. Generalized stratigraphic cross section across Yucca Mountain, Nevada.

waste packages to prevent any seepage that might occur from reaching waste canisters; (4) the waste canister outer shell of the waste packages composed of corrosion-resistant Alloy 22; (5) an inner shell of stainless steel; (6) zircaloy cladded fuel rods; (7) the slow dissolution rate of the fuel pellets; and (8) the use of ballast (partial backfill) below the waste packages to inhibit water movement and also to sorb some radionuclides. The Yucca Mountain Project has searched for analogues for each of these natural and engineered barriers, as well as for analogues that bear on potential future disruptive events such as volcanism and seismicity and their possible effects on repository performance.

The treatment of various components of the Yucca Mountain system is not intended to be uniform in this report. Herein we discuss the preservation of materials in unsaturated environments; the flow of water through unsaturated volcanic tuff; seepage into repository drifts; repository drift stability; stability and alteration of the waste form, waste package, and other parts of the EBS; and transport of radionuclides through unsaturated and saturated rock zones. Some features and processes have numerous examples or are best supported by "weight of evidence" arguments. Some topics, such as uptake of leaked radioactivity within the biosphere or effects of future climate, can only be modeled by use of existing analogue data and therefore cannot be evaluated independently with analogues. Finally, analogues for disruptive events such as ash-fall distributions from volcanic eruptions were directly used in the modeling of this unlikely scenario (U.S. Department of Energy, 2008). The likelihood of volcanic eruptions or igneous intrusions and the likelihood and intensity of seismic ground-motion effects were evaluated using expert elicitations with groups of scientists that brought experience 


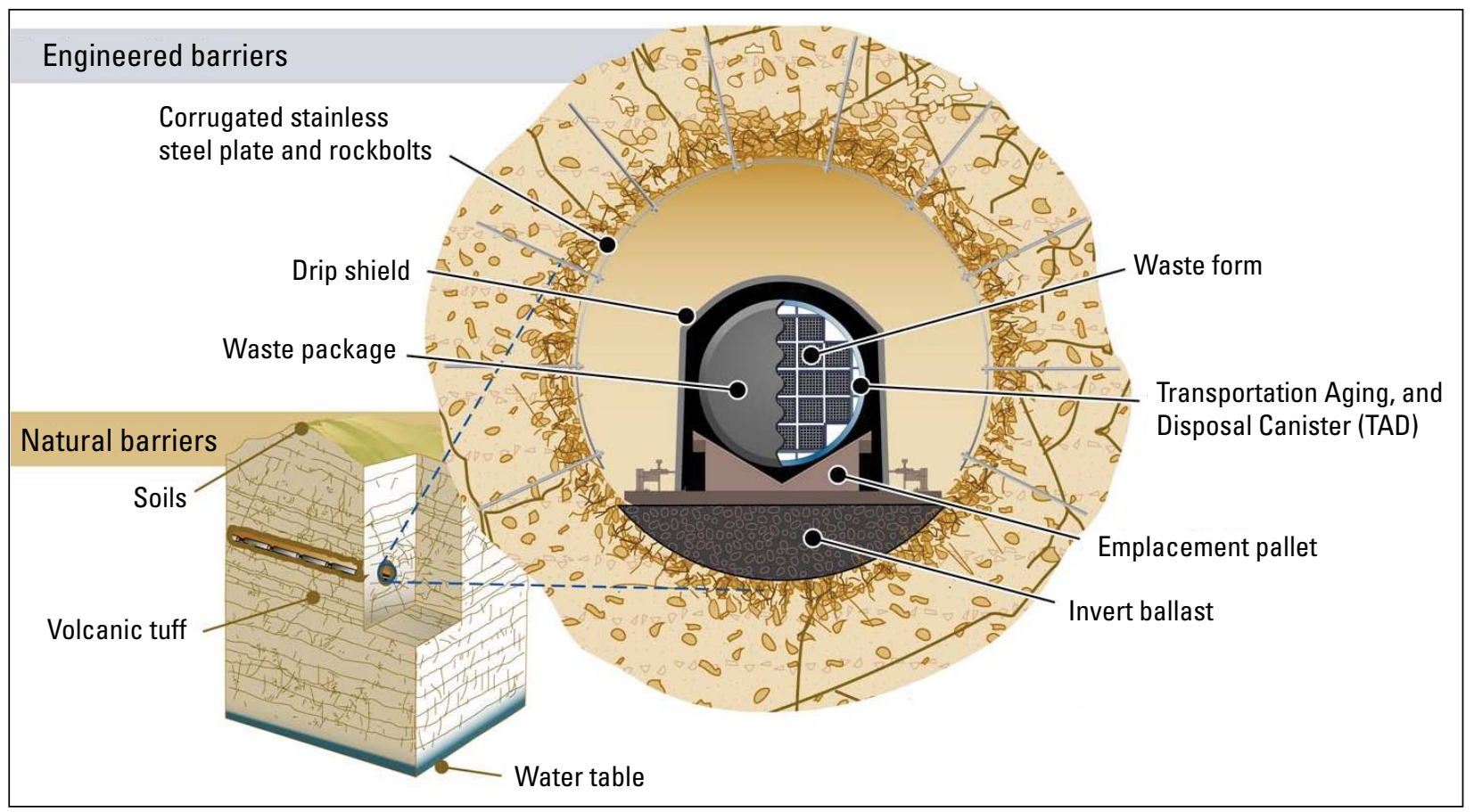

Figure 3. Drawing showing the combination of natural and engineered features that are expected to contribute to waste isolation (U.S. Department of Energy, 2008).

gained at other locations to bear on the determination of these likelihoods. The approach to determining the likelihood and intensity of ground motions at Yucca Mountain is summarized in the License Application (U.S. Department of Energy, 2008). Inasmuch as the analogues used in evaluating these two specific scenarios were discussed in published reports (CRWMS M\&O, 1996; CRWMS M\&O, 1998a; Sandia National Laboratories, 2008), they will not be treated in depth in this report.

\section{Preservation Within the Unsaturated Zone}

An abundance of analogues exists for many processes important to repository performance. Important aspects that can be tested with natural analogues are in the field of hydrology, which is fortunate because water is the principal transport medium for nuclear waste from a potential repository to the accessible environment. Analogues available for studying the long-term behavior of water in the unsaturated zone include caves, archeological sites such as ancient tombs, and tunnels. These sites provide time spans of centuries to tens of millennia, as well as a variety of rock types and hydrologic environments.

The analogues chosen for this section are from a variety of reference materials including examples that are generally available to the public, such as the National Geographic magazine and the Internet. Time terms used are those of the original data sources: (1) B.P. (before present) is used for quantitative ${ }^{14} \mathrm{C}$ ages and is taken as years before 1950, (2) B.C. (before Christ) is years before the birth of Christ, and (3) A.D. (anno Domini) is years since the birth of Christ. Paleolithic, Mesolithic, Neolithic, and Chalcolithic are defined by cultural features at individual sites and therefore are not time-constant from site to site. In general, Paleolithic is roughly 12-40 thousand years ago (ka), Neolithic is $5.5-8 \mathrm{ka}$, and Mesolithic is part or all of the intervening time with considerable overlap with either period depending on location. The timing of the Chalcolithic period is highly variable, starting about the fourth millennium B.C. in Europe but as much as one and a half millennia earlier in the eastern Mediterranean.

Winograd (1986) pointed out that the unsaturated zone served well in preserving a variety of objects. Preservation in the unsaturated zone is most common in underground openings. Delicate and easily destroyed artifacts and biological materials have been well preserved in both natural and manmade underground openings. These environments are not totally dry because air in the unsaturated zone is commonly nearly saturated with water. Furthermore, many archeological artifacts recovered from caves are excavated from thin beds of sediment. For well-preserved and delicate artifacts, these beds 
are eolian with some breakdown from the cave's roof and possibly from bat guano.

One of the oldest artifacts preserved by burial in the unsaturated zone is a 9,000-year-old flute (fig. 4) carved from the leg bone of a red-crowned crane (Zhang and others, 1999). The flute was still playable when recovered from a grave in China. An example nearly as old is a large cache of charred horse bean seeds dating from 6,500 to 6,000 years B.C. that was recovered from an ancient dwelling at Yiftah'el near Nazareth, Israel (Kislev, 1985). Both of these examples are from arid climates.

Other examples from China include the terra cotta armies of Qin Shi Huang (second century B.C.) and Jing Di (first century B.C.). The paint, fabric, and wooden parts of the soldiers are now largely gone, presumably resulting from burial in soil, but the unsaturated conditions have preserved the terra cotta, as well as bronze weapons, iron farming tools, and leather (Mazzatenta, 1992, 1996; Stuckless, 2000). A more recent example discovered near Louang, China, is the numerous underground grain storage bins dating from A.D. 907 to A.D. 581, which were dug in loess above the water table. In one bin, workers found 25,000 metric tons of grain, most of which was still recognizable (Golany, 1989). The bins had been engineered to shield against unsaturated-zone moisture by beating and firing the walls to decrease permeability and adding material to the floors and ceiling to absorb moisture.

One of the more interesting examples of preservation within the unsaturated zone comes from the Atacama Desert in Chile. The Chinchorro Indians mummified their dead before burial (Allison, 1985; Arriaza and others, 1998). As of 1998, 282 prepared mummies had been recovered. In addition, 149 naturally mummified bodies had been found. These had been naturally desiccated by the dry, hot sand. The prepared mummies had been eviscerated, the bones defleshed, and soft tissue replaced with reeds, sea grass, camelid fiber, and sticks. Any missing skin was replaced with sea lion skin. The oldest known mummy is reported as having an age of 5050 B.C. (Arriaza and others, 1998). Several similar dates were given by Allison (1985). The practice of mummification continued for about 3,500 years. Pictures can be found in the National Geographic magazine (Arriaza and Ferorelli, 1995).

Allison (1985) attributed the preservation of the mummies to the dryness and high concentration of nitrate salts in the soils. In addition to hair and skin, the environment has preserved cloth, reed mats, wool, fishing nets, and wooden tools. Allison (1985) reported that, in contrast to the mummies, remains of colonial settlers buried within the last few hundred years in the coastal plains of Peru were nothing but bones. The rapid deterioration of the settlers was apparently due to watering of their grave sites.

Preservation of delicate archeological materials, including metals, appears to be enhanced by their location in an arid or semiarid unsaturated environment. The Dead Sea scrolls were preserved in caves along the shores of the Dead Sea for more than 2,000 years. All of these artifacts have survived millennia, and their preservation is attributed in part to being

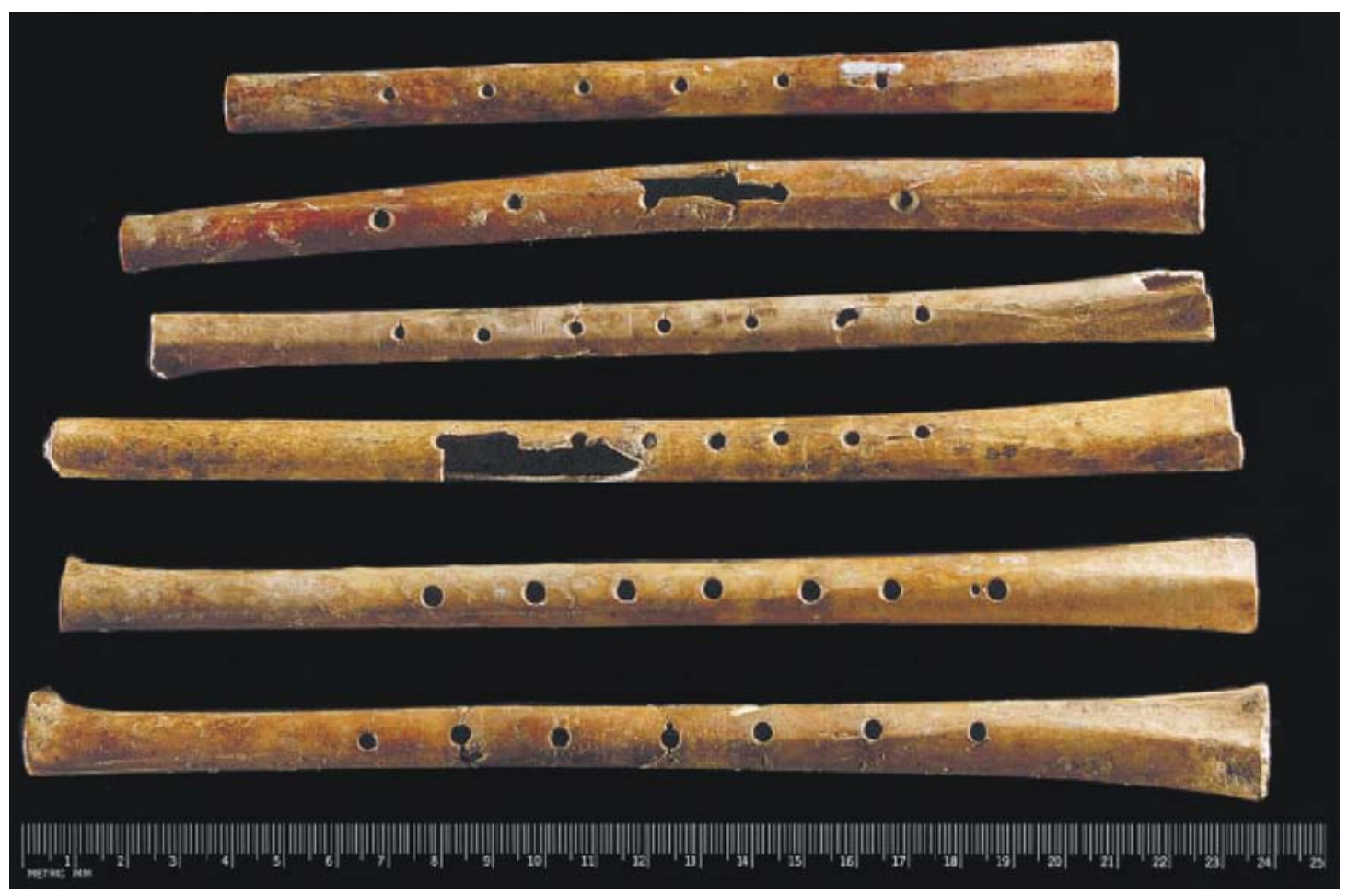

Figure 4. 9,000-year-old flutes carved from the leg bone of a red-crowned crane (Zhang and others, 1999; used with permission of Nature Publishing Group). 
in arid to semiarid unsaturated environments (Winograd, 1986).

The cities of Pompeii and Herculaneum (located near Naples, Italy) were buried in volcanic ash during the eruption of Vesuvius. A large number of metallic objects were recovered from the sites including gold, silver, and bronze jewelry and tools (fig. 5). Some badly rusted tools have survived for nearly 2,000 years. At Herculaneum are many examples of carbonized wood and textiles that have been preserved in the ash deposit (fig. 6). Even 1,800 carbonized scrolls of papyrus have been preserved (Gore and others, 1988). The Philodemus project is currently attempting to salvage hundreds of scrolls, which are still readable in spite of being buried by hot ash and soaked by percolating groundwater for nearly 2 millennia (http://www.humnet.ucla.edu/humnet/classics/philodemus/ philhome.htm, accessed May 4, 2010).

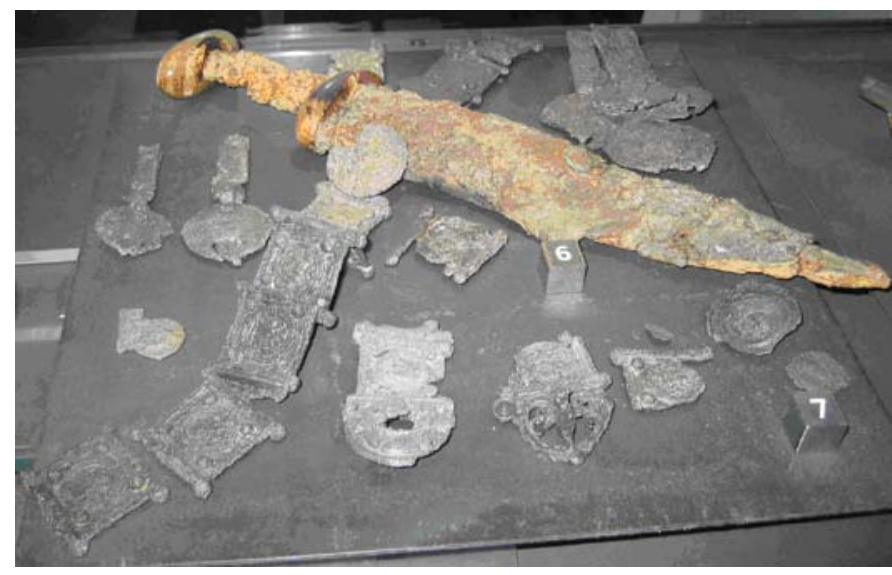

Figure 5. Silver and iron artifacts recovered from Pompeii, Italy, displayed at the Naples Museum (photograph by J.S. Stuckless).

\section{Natural Caves and Rock Shelters}

Some of the better-documented cave examples from Nevada and adjacent areas are representative of the relatively dry caves that are common throughout the Southwestern United States. The dryness in these caves allows and enhances preservation of pollen and other delicate plant and animal materials for tens of thousands to hundreds of thousands of years (Davis, 1990). Even abundant packrat middens (plant and fecal material cemented with dried urine) are preserved (fig. 7). Davis (1990) reported that more than 1,000 packrat middens have been studied throughout arid North America; some of these are older than 40,000 years. Even though the middens dissolve readily in water, there are many older than about 20,000 years, and these apparently survived much wetter past climates.

The Pintwater Cave is a limestone cave located approximately $12 \mathrm{~km}$ east of the NTS (fig. 1). Buck and DuBarton (1994) reported that bones recovered from this cave represent at least 128 species, and Hockett (2000) reported more than 30,000 bones of lizards and small mammals ranging in age from 32000 to 7350 B.P. These reported ages include the last glacial cycle, and in fact, the recovered bones document the change in fauna as a result of the change in climate. Thus, preservation in this cave provides an analogue for the full range of climates predicted for Yucca Mountain during the next 10,000 years. Pintwater Cave is also an archeological site for the Holocene Epoch. Buck and DuBarton (1994) reported recovering 234 wooden darts and arrows, some of which were painted with green, red, white, or reddish brown paint, and one has a fragment of a feather still attached. The wood dates from 9300 to 3000 B.P. and was not buried in sediment.

Stanton Cave in the Grand Canyon National Park, Arizona, provides another example of preservation of fragile artifacts. This is a limestone cave in the same general climatic regime as Yucca Mountain. Although the cave is about $44 \mathrm{~m}$ above the Colorado River (Euler, 1984), driftwood near the mouth of the cave indicates at least one episode of prehistoric flooding near the front of the cave. The main room is about 17 by $44 \mathrm{~m}$ (Euler, 1984). More than 165 split-twig figurines made of willow have been recovered from the cave. These were on the surface, under rockfalls, or under as much as 10 $\mathrm{cm}$ of dust. The figurines measure $8-19 \mathrm{~cm}$ long and $9-15 \mathrm{~cm}$ high, with material from one dated by ${ }^{14} \mathrm{C}$ at $4095 \pm 100$ B.P. (fig. 8). Much biological material has also been recovered from the cave, including sheaths of a Harrington's mountain goat (Oreamus harringtoni) dated at about $21 \mathrm{ka}$. Other archeological artifacts have also been recovered but these may be of Anasazi culture and, therefore, 1,000-2,000 years younger than the split-twig figurines. Several other caves within the Grand Canyon National Park also have some split-twig figurines, but there are no reports of dates for the other locations.

Split-twig figurines have been reported in a cave closer to Yucca Mountain. Wheeler (1973) reported finding 12 split-twig figurines in Etna Cave, about $50 \mathrm{~km}$ northeast of Yucca Mountain. Other artifacts discovered with the figurines included 62 sandals or sandal fragments, many baskets, some human hair wrapped in shredded juniper bark, and an atlatl dart. Correlation with other dated artifacts, as well as assigned ages for associated weapon points, indicate the items recovered by Wheeler ranged in age from 5,000 years B.C. to A.D. 500 .

There are several archeological sites in northern Nevada (Dansie, 1997). Cowbone Cave, in northern Nevada, is formed by tufa draping over a wave-cut cliff on the shore of glacial Lake Lahontan; it is another dry cave with eolian sediment. Figure 9 shows a fox-skin quiver, an atlatl, and 5 darts that were wrapped in a tule matting and buried under a few centimeters of dust. The tule matting, fur, and wood all have an excellent degree of preservation; the feathers have been largely consumed by insects (Amy Dansie, Nevada Museum of Natural History, retired, written commun., 2006).

Horse Cave, in northern Nevada, is also a wave-cut cave sealed with a tufa deposit. It is about $9 \mathrm{~m}$ by $9 \mathrm{~m}$ in size and has about $2 \mathrm{~m}$ of deposits on the floor. The cave is of special interest in that it contained weavings of greatly different ages. The older articles included a complete twined bark bag dated 

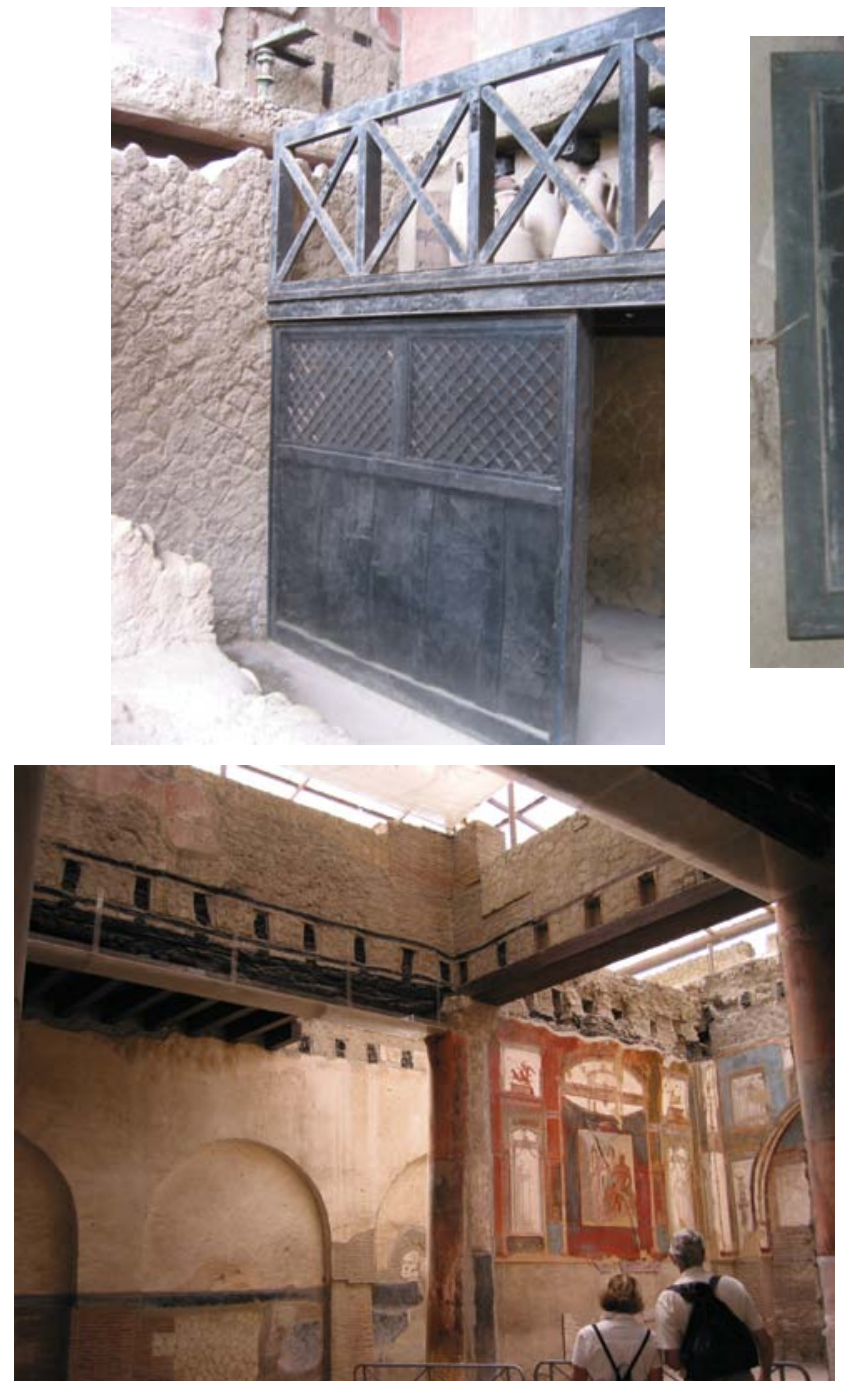
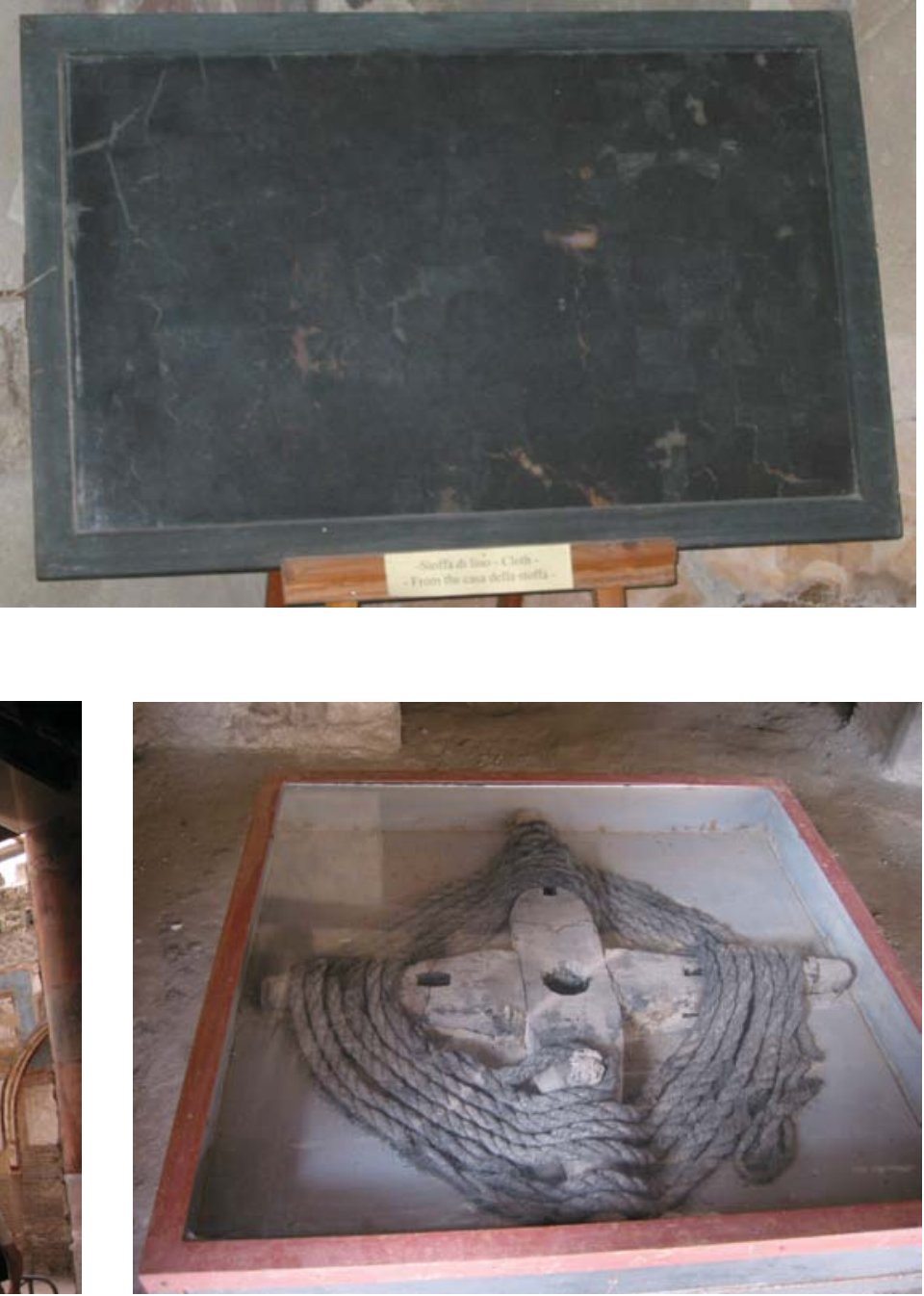

Figure 6. Materials preserved by burial in volcanic ash at Herculaneum in A.D. 79. From upper left clockwise they show carbonized railing and lattice work, carbonized cloth, rope, and carbonized wood and painted walls (photographs by J.S. Stuckless).

at $8400 \pm 40$ B.P. and a fragment of catlow-twined matting (a type of twine named after the Catlow Cave locality) dated at 8,200 \pm 40 B.P. (Fowler and Hattori, 2000). The cave also contained a twined bag that still had moss inside it and four baskets, three of which yielded age dates of 2050, 2030, and 1690 B.P. (Amy Dansie, Nevada Museum of Natural History, retired, written commun., 2006).

Spirit Cave, in northern Nevada, is actually a rock shelter that is located in the unsaturated zone and largely open to the elements. A mummy was recovered from this locality in a pit that was lined with sagebrush and covered with large rocks (Wheeler, 1997). Also preserved were cloth, mats, and a basket. Bone and hair from the mummy and the mat in which it was wrapped yielded ${ }^{14} \mathrm{C}$ dates of about 9400 B.P. (Tuohy and Dansie, 1997). Other artifacts found on or with the mummy include a rabbit-skin robe and leather moccasins, the latter being preserved well enough to permit identification of the source of the leather, although part of each had been eaten by rodents. A basket and a grass mat from Spirit Cave yielded much younger ages of 2200 and 1700 B.P., respectively (Tuohy and Dansie, 1997), but even these younger ages demonstrate long-term preservation in the unsaturated zone. The high degree of preservation of the mummy and artifacts was likely due to the covering of brush and coarse material that allowed air to circulate and prevented prolonged contact with water.

Caves provide the oldest examples of preservation within openings in the unsaturated zone and some have records of preservation much longer than thousands of years. San Antonio Mountain Cave in New Mexico, for example, which is 


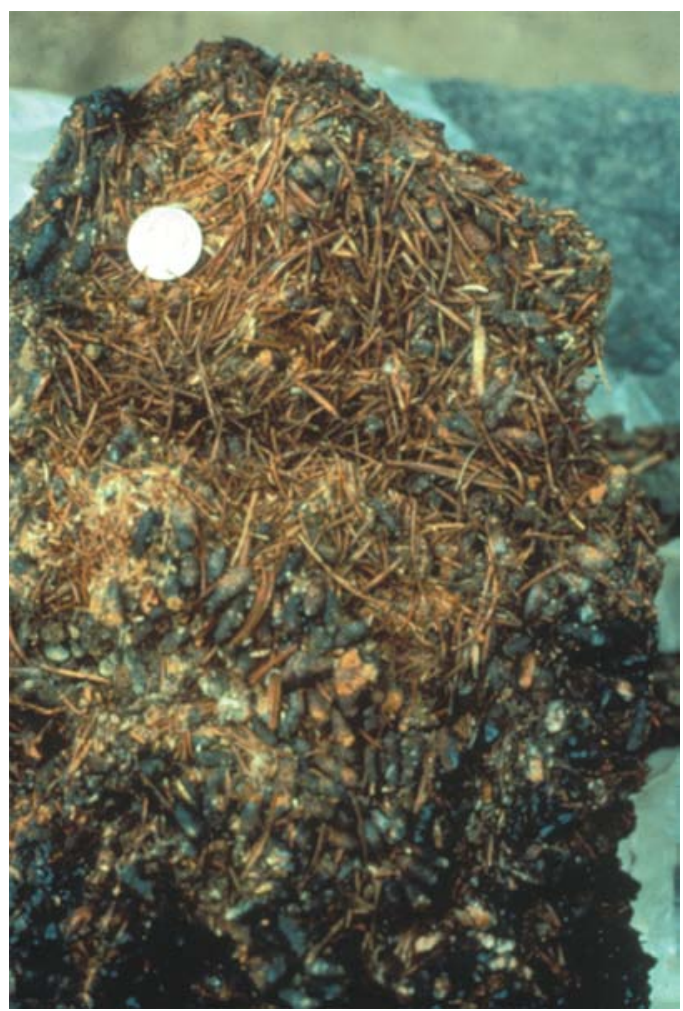

Figure 7. Photograph of a packrat midden from the Sheep Range in Nevada (Stuckless, 2000, fig. 7).

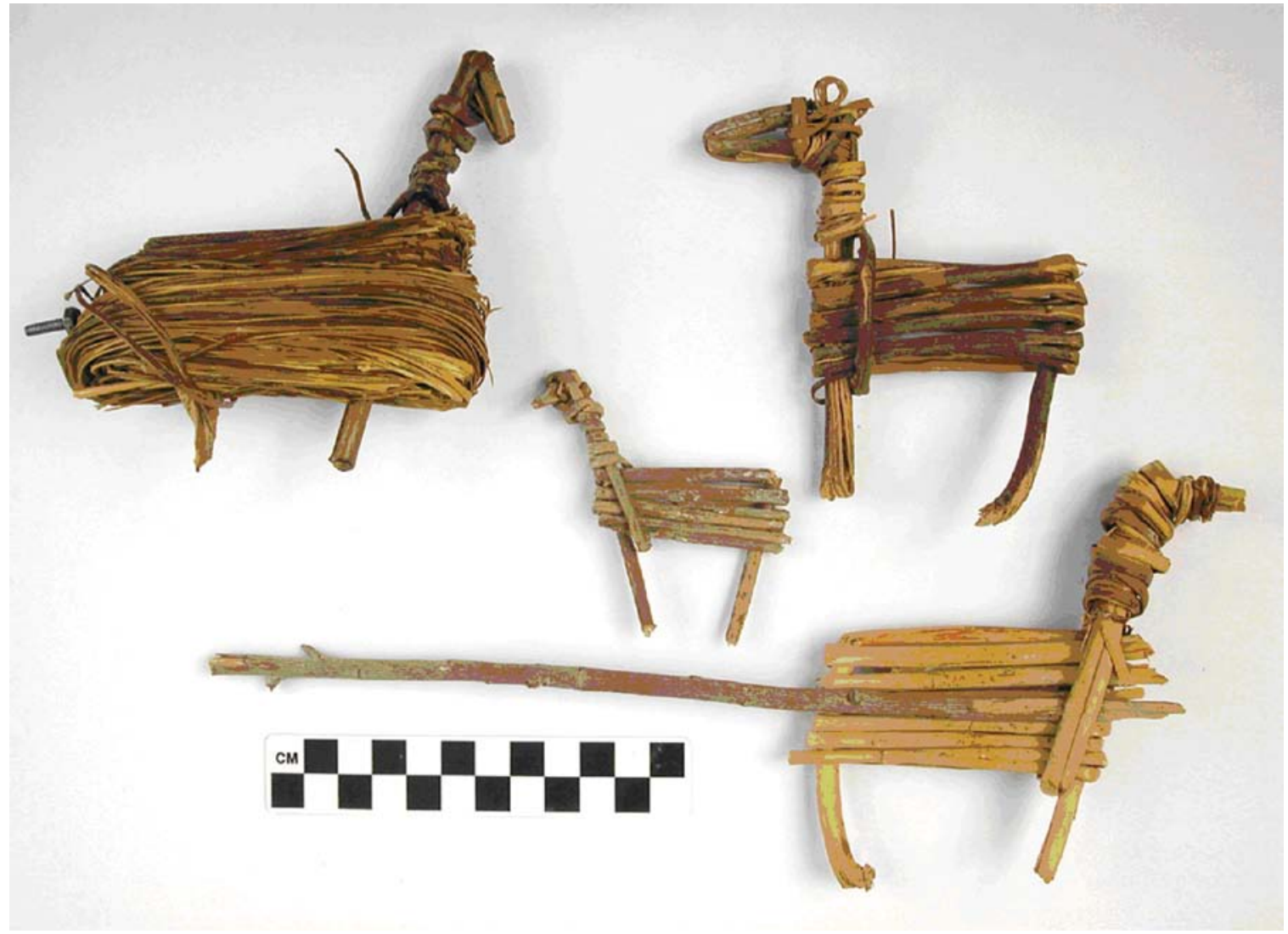

Figure 8. Split-twig figurines made of willow (photograph from Colleen Hyde, National Park Service). See http://www.kaibab.org/tr971/gcr1032m.jpg (last accessed 03/22/2007) for a picture of Stanton Cave, Arizona. 


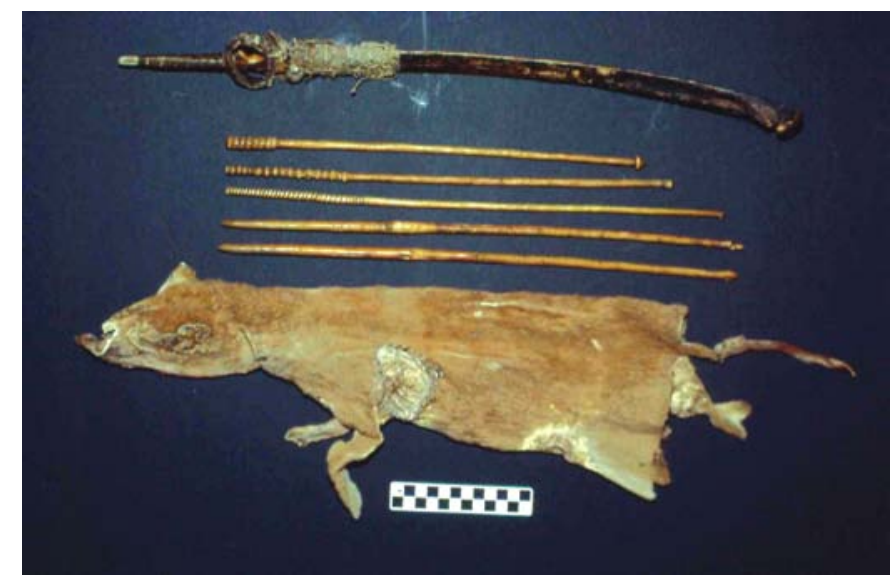

Figure 9. Fox-skin quiver, atlatl (top), and darts from Cowbone Cave, northern Nevada (photograph by Amy Dansie).

formed by a lava tube, has been dated at 3.4-3.9 million years ago (Ma) and contains biological remains that are reported to be about 1-0.74 Ma (Rogers and others, 2000). The remains consist of small, unfossilized bones of amphibians, such as salamanders, and birds, such as wrens and sparrows. Given the antiquity of these biological materials, it can be surmised that the cave has protected these delicate remains through several climate changes.

Arnold Research Cave, in Missouri, is another dry cave that has yielded multiple ages for easily destroyed material. It is a sandstone cave with several layers of windblown material. Footwear (fig. 10) recovered from the cave has yielded ${ }^{14} \mathrm{C}$ ages ranging from 8212 to 945 B.P. (Kuttruff and others, 1998). The oldest preserved footwear is a nearly complete sandal made of twining. All the rest of the shoes are slip-on type footwear, and all but the youngest are also made of twining. The youngest dated shoe is a leather slip-on and contained grass for padding. According to Mike Miller (Saint Louis Community College, oral commun., 2007), no other Missouri caves have yielded footwear, probably because the floors are moist clay and terra rosa, and any organic remains would have decayed in that environment.

In addition to caves in the United States, other caves in the Americas have preserved archeological artifacts. Guitarrero Cave in Peru, for example, produced radiocarbon ages for wooden artifacts, charcoal, and textiles ranging from 9000 to 10000 B.P. (Lynch and others, 1985). Even caves from a jungle environment have preserved artifacts, such as Balankanch Cave near Chichen Itza in Yucatan, Mexico, which had painted pottery dating from about A.D. 860 when it was discovered in 1959 (Andrews, 1970). White was the most common pigment, but several other colors were used as well.

Caves occupied by Paleolithic and Neolithic man provide another set of examples of preservation within openings in the unsaturated zone. Of these, the oldest, and possibly the best known, are the dozens of Paleolithic cave paintings of
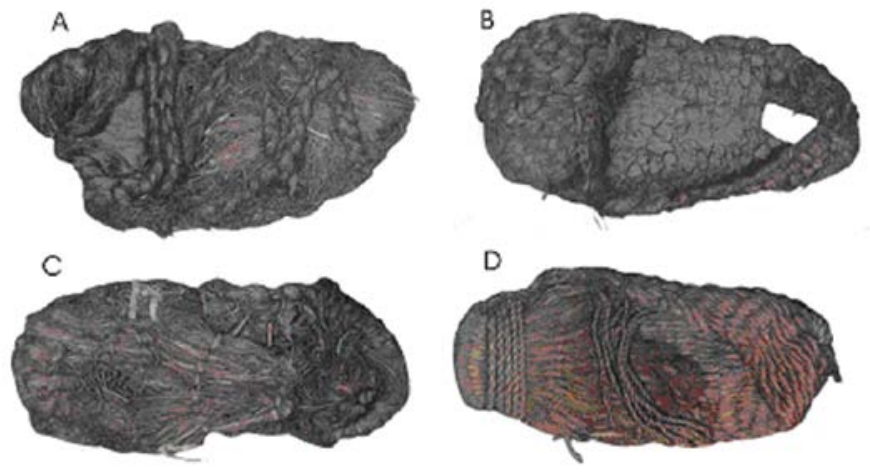

$\mathrm{E}$

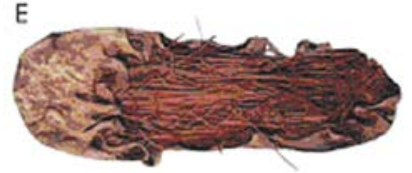

Figure 10. Photographs of footwear recovered from Arnold Research Cave in Missouri. (A) Dated twice with ages of $8212 \pm 112$ and $7785 \pm 110$ years; (B) dated $5437 \pm 137$ years; (C) dated $4912 \pm 72$ years; (D) dated $4905 \pm 70$ years; and (E) dated $925 \pm 145$ years. All ages are calibrated before present (B.P.), and errors are quoted as 2 sigma (Kuttruff and others, 1998).

southern Europe (Stuckless, 2000). The oldest authenticated cave is Chauvet Cave in France (fig. 11), which was discovered in 1992 and has yielded ${ }^{14} \mathrm{C}$ ages as old as $32 \mathrm{ka}$ (Chauvet and others, 1996). The current climate of Chauvet Cave is subhumid, and the average rainfall of approximately $50 \mathrm{~cm} / \mathrm{yr}$ (Stuckless, 2000) is about three times that reported for Yucca Mountain (Sharpe, 2007). The cave paintings depict nowextinct animals, such as mammoths, and species that no longer

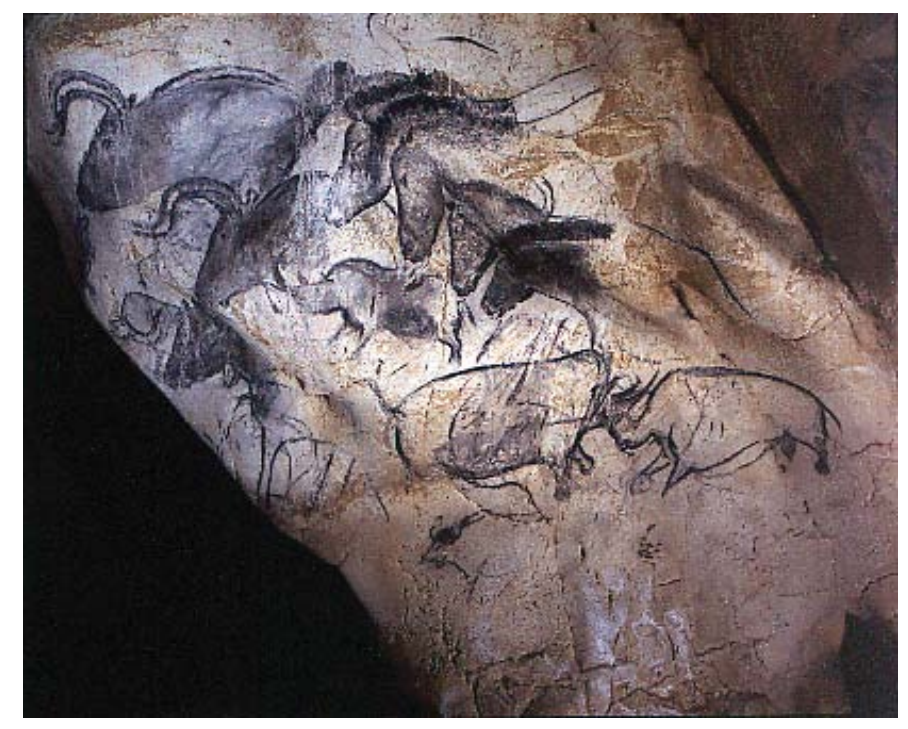

Figure 11. Photograph of painted rhinoceroses, horses, and oryxes from Chauvet Cave, France (Stuckless, 2000, fig. 2). Evidence of water damage is shown by light-colored vertical streaks in the left and prominently in the center of the photograph. 
live in Europe, such as rhinoceroses, which attest to a paleoclimate much different than the present climate; thus, preservation has persisted through major climate changes.

Several other famous caves contain well-preserved Paleolithic paintings. Lascaux Cave in France has more than 600 paintings (Ruspoli, 1986), which are about 13,000-17,000 years old. The cave of Cosquer (Clottes and Courtin, 1996) differs from other known painted caves in that the entrance is currently $37 \mathrm{~m}$ below sea level. Therefore, it must have been occupied before the current interglacial period, which began approximately $10 \mathrm{ka}$. Paintings in this cave yield two greatly different sets of dates (27000 and 18500 B.P.). The cave at Altamira, Spain, also has abundant well-preserved paintings, which date at $14000 \pm 400$ B.P. (Valladas and others, 1992). The paintings in the French caves were largely made with oxides of iron and other minor constituents (Leroi-Gourhan, 1982; Ruspoli, 1986). Charcoal was commonly used for black. Neither the iron nor charcoal would be expected to survive long in the presence of abundant oxidizing water, but there are many well-preserved paintings. Figure 11 appears to show evidence of water that ran down the wall (indicated by streaking), which may be indicative of more seepage during a wetter climate.

Well-preserved Paleolithic art is common only in the caves of western Europe, but examples are known in Africa (Coulson, 1999) and possibly Australia (Breeden and Wright, 1988). Late Paleolithic, or more commonly, Neolithic rock paintings are known throughout the world. In most of the world, painted rock shelters are more common than painted caves, demonstrating that even a few meters of overhang can protect fragile items from infiltration water. Stuckless (2000) provided a summary and references for paintings in Africa, South America, North America, and Asia.

Painted rock shelters had been noted in India since the mid-1800s (Neumayer, 1983) and are common in a variety of climatic zones. Mathpal (1996) lists more than 400 sites. The paintings have not been observed in limestone like the caves of southern Europe but instead are common in shelters formed in a metamorphosed sandstone (Neumayer, 1983). Quantitative age information on the painted rock shelters of India appears to be lacking, but the oldest paintings are thought to be Mesolithic (Neumayer, 1983), which in this region is about 9,000-5,000 years B.P. The paintings were made using hematite for red and glauconite for green pigments. Some of the best-preserved art work is at Bhimbetka (Web site http:// www.mptourism.com/dest/bhimbetka.html, accessed June 13, 2000). These paintings are preserved even though the climate is monsoonal.

Painted rock shelters and caves also are abundant in Baja California, Mexico. Crosby (1997) provided locations and pictures for more than 100 such sites. Many paintings can be viewed on Web site $h t t p: / / w w w$.bajaquest.com/cavepaintings/images (accessed May 4, 2010). Each site described by Crosby (1997) has multiple paintings, and many have multiple layers of paintings. As with the painted rock shelters in India, quantitative age control is limited, but Crosby (1997) reported one radiocarbon age of about 5000 B.P. Inspection of the photographs of the painted rock shelters in India and Mexico suggests that the latter are better preserved. If true, this could be explained by the younger apparent ages or the arid climate of the Baja.

Only one example of cave paintings beyond the interior zone lit by natural light is known in North America, and this is in Arnold/Tainter Cave in Wisconsin. It is a sandstone cave, and the paintings are well preserved (http://www.uwlax. edu/mvac/SpecificSites/Deep\%20Cave.htm; accessed May 4, 2010). The paintings were originally thought to be as old as Late Pleistocene because some seem to depict caribou (antlers curved forwards), a species not known from southern Wisconsin since the end of the Pleistocene (about $10 \mathrm{ka}$ ). However, recent dating of carbon used in the figures yielded an age of $1260 \pm 60$ B.P. (Steelman and others, 2001).

In addition to paintings, caves have preserved fragile Paleolithic to Chalcolithic artifacts. The 14-ka clay bisons in a cave near Tuc d'Audoubert, France (Putman, 1988), provide an example of the former. These are well preserved except for minor desiccation cracks. Putman (1988) noted that the floor of the cave was moist clay and still contained a footprint, presumably that of the sculptor. The current literature search did not reveal any delicate Paleolithic items preserved on the floors of caves, possibly due to prevalent moisture. Breisch (1987) reported a block that fell out of a ceiling painting at Lascaux and landed, painted side down, on the floor of the cave. The block fit perfectly into the painting, but all the paint was gone.

The Cave of the Warrior and the Cave of Treasures in Israel provide Chalcolithic-age examples of preservation. The Cave of the Warrior is in dolomitic limestone on the west side of the rift valley where average rainfall is about $100 \mathrm{~mm} / \mathrm{yr}$ (Tamar Schick, Israel Antiquities Authority, written commun., 1999). The cave is small, measuring $13.5 \mathrm{~m}$ deep, $2 \mathrm{~m}$ wide, and $2 \mathrm{~m}$ high at the mouth. Only the skeleton remained, together with cloth, leather, and wooden items preserved in a nearly perfect state (Schick, 1998) since about 3800 B.C. (Jull and others, 1998). The Cave of Treasures, also on the west side of the rift, contained 429 objects wrapped in a reed mat. Copper and ivory objects were perfectly preserved (Ozment, 1999).

A cave in Lebanon also was used for burial and has yielded a number of well preserved artifacts and mummies, the latter in various states of preservation. The burials are dated at about A.D. 1283 (Hourani, 1997). Eight mummies have been recovered. One, a 4-month-old girl, was wrapped in a burial shroud and clad in three dresses, the outermost of which had elaborate silk embroidery. Nearby were a lock of human hair, bay leaves, almonds, garlic, and onion peels. More information about the mummies can be found at http://www.mummytombs.com/mummylocator/group/maronite.htm, last accessed January 11, 2010.

One of the key attributes of the proposed Yucca Mountain repository is its location within the unsaturated zone, thus limiting the amount of water that can come into contact with waste packages. As mentioned previously, the delicate items 
recovered from Pintwater Cave in southern Nevada were collected from the limestone cave floor and in a test pit excavated within eolian sediments lining the floor of the cave. Their preservation indicates that they were not subjected to prolonged exposure to water. However, as shown in the following example, the maintenance of a stable microclimate is a critical feature in making caves suitable for long-term preservation.

The Altamira Cave, located in northern Spain, is the site of Paleolithic cave paintings (Sánchez-Moral and others, 1999). Since the discovery of the prehistoric cave art in 1879 , significant degradation of the cave paintings has occurred, leading to the cave being closed to the public in 1977. The cave was reopened in 1982 with fixed limits on the number of visitors. Continuous monitoring of the Altamira cave microclimate within Polychromes Hall (a cave chamber with famous polychromatic paintings) during 1997-98 determined that increases in temperature $\left(+0.25^{\circ} \mathrm{C}\right)$ and $\mathrm{CO}_{2}$ concentrations ( +500 ppmv [parts per million vapor]) resulted directly from the presence of visitors in the cave (Sánchez-Moral and others, 1999).

Sánchez-Moral and others (1999) used these data to estimate effective calcite corrosion rates for both the baseline and modified (visitor-related case) cave conditions. They predicted that the visitor-induced temperature increase will greatly increase the amount of water condensation on the cave walls and ceiling. The elevated $P_{\mathrm{CO} 2}$ (partial pressure of carbon dioxide) conditions caused by human respiration, combined with the higher amounts of condensation, were predicted to result in visitor-induced corrosion rates $\left(314 \mathrm{~mm}^{3} / \mathrm{yr}\right)$ in Polychromes Hall that are 78 times higher than the baseline (no visitor) case (Sánchez-Moral and others, 1999). As noted by visual observation and modeling, the relatively minor changes in temperature and $P_{\mathrm{CO} 2}$ at Altamira had a significant effect on deterioration of the cave art. Thus, the corrosion-resistance properties of proposed waste-package materials at Yucca Mountain need to be evaluated for all possible variations in environmental conditions during the postclosure period.

\section{Manmade Openings}

Manmade underground openings in the unsaturated zone do not attain the antiquity of caves, but the examples of preservation in this environment are abundant. One of the oldest examples is the cedar funeral barque of the Pharoah Cheops (Khufu), which was found in a limestone cavern at the base of the pyramid. The barque was disassembled and stored approximately $4.5 \mathrm{ka}$, but it is in excellent condition and has been reassembled for display (fig. 12).

Approximately 3.5-3.0 ka, the Egyptians buried kings, queens, and nobles across the Nile River west of Luxor in tombs excavated in limestone (Weeks, 1998). Most of the painted walls and ceilings in these are still in excellent condition (fig. 13), and artifacts made from a wide variety of materials are well preserved. For example, the tomb of Tutankhamen (King Tut), which dates from about 1331 B.C., contained

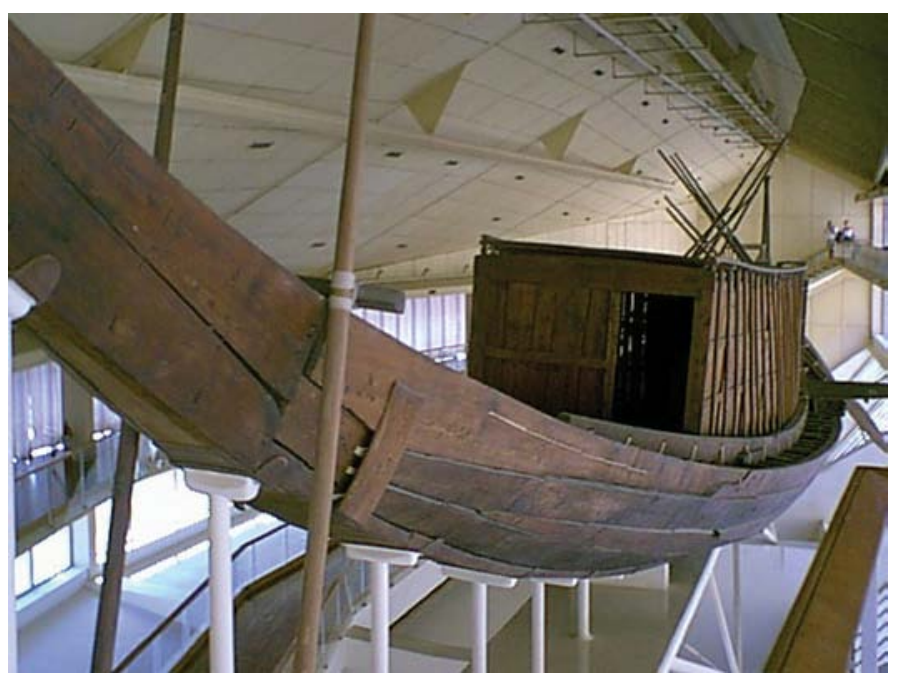

Figure 12. The funeral barque of the Pharaoh Cheops (Khufu), a cedar ceremonial vessel that was buried in a limestone cavern in Egypt and covered with 81 two-meter-thick limestone slabs for nearly 4,500 years. The barque was found disassembled in 1954 but was preserved well enough to permit reassembly (photograph by J.S. Stuckless).

reed baskets of fruit and bread, 30 jugs of wine, linen gloves, a shiny iron knife, and dried cornflowers (Noblecourt and Kenett, 1963; Stuckless, 2000). The fact that the knife has not rusted demonstrates a remarkable degree of preservation.

The tombs of Tuscany, Italy, are located in a temperate climate (approximately $80 \mathrm{~cm} / \mathrm{yr}$ rainfall) and were excavated in volcanic rock from about 600 to 300 B.C. The tombs are decorated with frescoes (that is, the color is soaked into the plaster) that are in various states of preservation (fig. 14). The damage appears to be a result of vandalism and spallation of the plaster. Pottery, bronze, glass artifacts, and even wooden shoes have been found in the tombs (Gore and others, 1988; Chapman and others, 2006). More pictures of murals and other information on Tarquinia can be obtained on the Internet at http://oncampus.richmond.edu/academics/classics/students/ belanger/tarquinia.html (last accessed June 14, 2006).

The previous examples have been from an arid climate (Egypt) and a temperate climate (Italy), but even in the monsoonal climate of Ajanta, India, subterranean paintings are well preserved. Buddhist monks carved 31 temples (referred to as caves) into basalt flows at Ajanta between the second century B.C. and the sixth century A.D. (Behl, 1998). The caves are located along a 550-m-long, horseshoe-shaped gorge of the Waghora River. The paintings were done on a plaster that consisted of mud, rock dust, and vegetable fiber. They are not frescoes and are therefore not imbedded into the plaster. The earliest paintings were made using five basic colors: white from calcite, kaolin, and gypsum; red and yellow, both derived from iron oxide; black from charcoal; and green from glauconite. In addition to the five basic colors, later painters used lapis lazuli for blue. All of the openings are large 


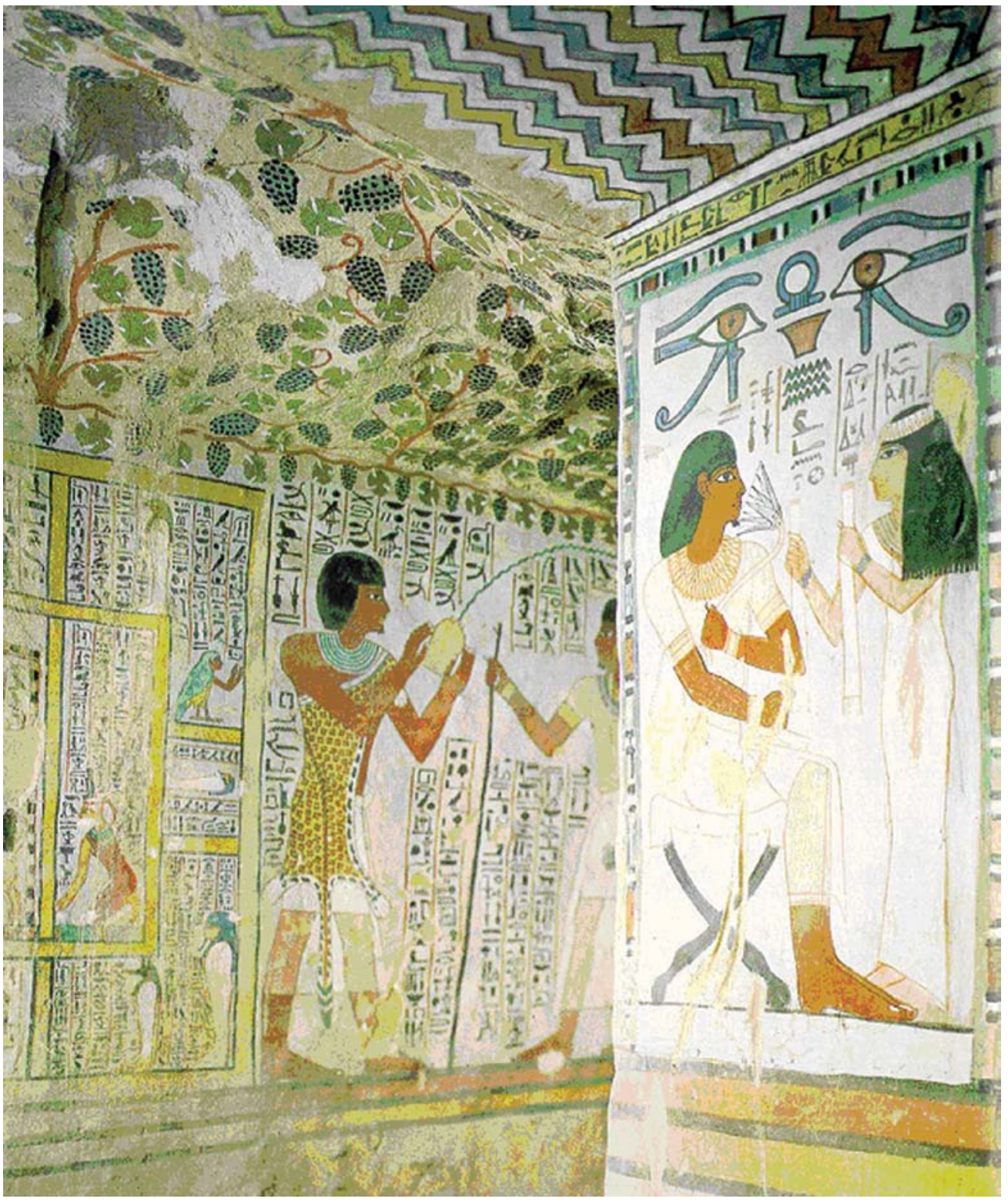

Figure 13. The painted interiors of many Egyptian tombs show no signs of damage except vandalism. The tomb of Sennefer shows some damage to plaster on the wall by moisture (upper left), and some of the paint shows evidence of water running down the wall, but no evidence of dripping from the ceiling. The tomb was excavated in limestone about 1400 B.C. (photograph by J.S. Stuckless).

relative to the proposed size of emplacement drifts at Yucca Mountain, and water flow is dominantly through fractures. The techniques used should have produced paintings that were vulnerable to rapid deterioration; nonetheless, many of the paintings are well preserved (fig. 15), except for small areas of spallation, as can be seen in the lower part of the photograph in figure 15. Similar Buddhist paintings are preserved from the 5th through the 10th centuries A.D. at Ellora and from the 9th century A.D. at the Jain caves at Sittanavasal (Behl, 1998).
Buddhist monks also excavated caves in the sandstone of Dunhuang, China. The excavations range in age from 4th to 14th centuries A.D. (Wenbin, 2000). The caves contained more than 2,000 painted sculptures and about $45,000 \mathrm{~m}^{2}$ of painted walls. Cave \#17 held more than 500 scrolls, which were part of a collection of about 50,000 writings and paintings. The Buddhist murals are better preserved in Dunhuang than in Ajanta, in part because they are younger but also because the climate is more arid than that of India and because water flow 

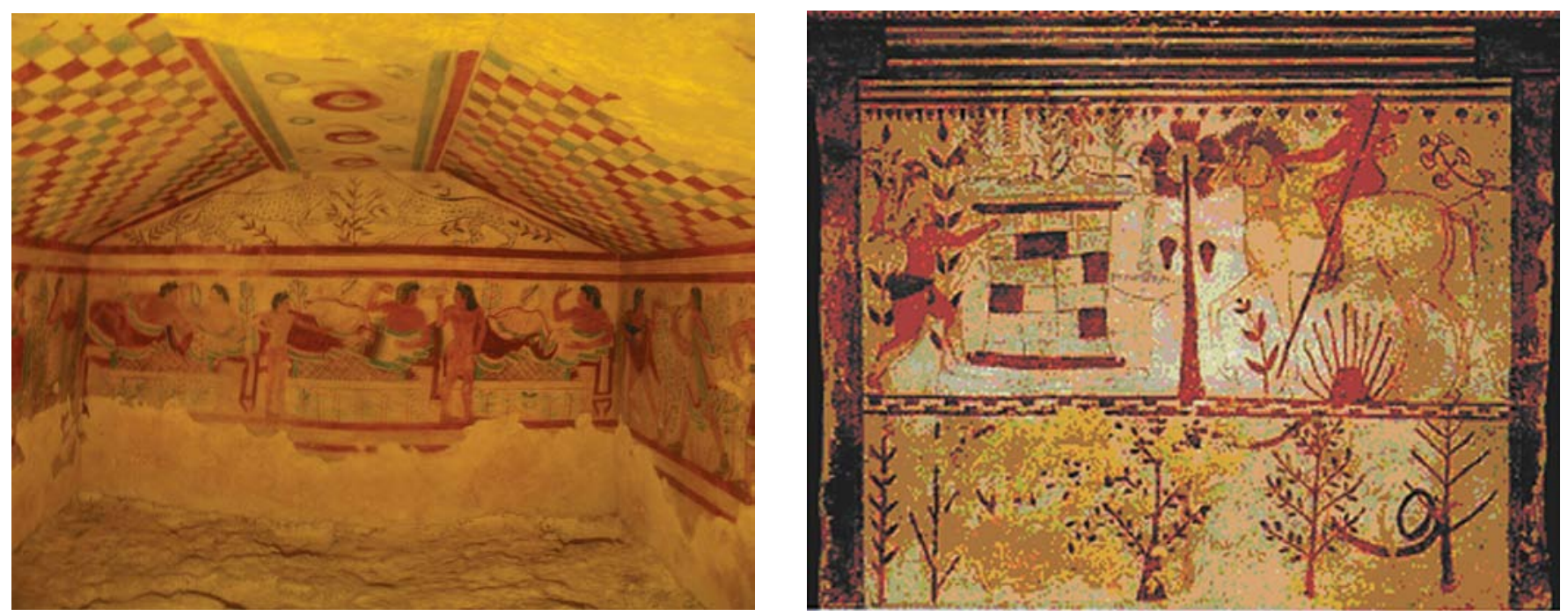

Figure 14. Frescoes from Etruscan tombs of Tarquinia, Italy. The photograph on the left is of the Tomb of the Leopards dated as sixth century B.C. The tomb is 3 by 4 by 2.5 meters. The ceiling appears to be cut by a near-vertical fracture, which bounds a large section of spallation. The photograph on the right is from the Tomb of the Bulls and is the same age, but exhibits much better preservation (photographs by J.S. Stuckless).

is dominantly through the rock matrix rather than through fractures, as in the Ajanta setting.

The Christians of Cappadocia, Turkey, excavated underground cities and churches in ash-flow tuffs from about the $2 \mathrm{~d}$ century A.D. through the 11 th century A.D. The geology of Cappadocia (Toprak and others, 1994) is similar to that of southern Nevada (Sawyer and others, 1994) in that both areas contain a late Tertiary section of thick, silicic volcanic rocks. At Yucca Mountain, the host rock for the proposed repository is a densely welded, quartz latite ash-flow tuff formed about 12.8 Ma, whereas the underground dwellings of Cappadocia are hosted by a partially welded, rhyolite ash-flow tuff formed about 4.5 Ma. Thus, as with the sandstone example from China, water flow is dominantly through matrix, but in Cappadocia, precipitation is much greater, about $38 \mathrm{~cm} / \mathrm{yr}$ (Stuckless, 2000). The paintings in the Karanlik church in Cappadocia are frescoes that are well preserved in most places, but some show evidence of spallation and vandalism (fig. 16). Features that might be associated with dripping water were not observed, and a guide with 40 years of experience in one of the underground cities reported that he had never seen water underground (Stuckless, 2000).

Around A.D. 600 to 800, the Mayans built a number of temples in Mexico and Central America. Many of these were painted and remain preserved today. Two examples considered here are Bonampak in eastern Chiapas, Mexico, and Cacaxtla, located about $150 \mathrm{~km}$ east of Mexico City. The first of these is in the Mexican rain forest and was buried by jungle growth and soil. The original paintings appear dull because water seeped through the limestone blocks from which the temple was built and precipitated calcite as it evaporated. Close examination, however, shows that in many places water must have run down the walls. The reasons for preservation in such an environment are not obvious, but at Cacaxtla, detailed investigation of the murals reveals that the paintings are true frescoes. Furthermore, they were stabilized with a binder extracted from prickly pear cactus, and the blue pigment was created using the zeolite mineral palygorskite that had been impregnated with indigo, thereby creating a less soluble color (Magaloni-Kerpel, 1994). Similar procedures and techniques may have helped preserve the paintings at Bonampak.

Ancient mines provide additional examples for preservation in the unsaturated zone and extend the range of geologic media that can be examined. However, the data for ancient mines are more sparse because when most mines were abandoned, miners took their tools and other artifacts with them. In addition, evidence of preservation within some of the larger mining districts, such as Rio Tinto in Spain, was destroyed by modern open-pit mining.

The Great Orme mine in north Wales is one of the largest mines of the ancient world, with at least $6 \mathrm{~km}$ of workings (http://www.greatorme.freeserve.co.uk/, accessed October 2,2002 ). The mine was excavated in dolomite at least 3,500 years B.P., as determined from dates on charcoal. Dozens of bone tools and thousands of bone fragments have been recovered from the mine as well as small amounts of bronze. Stuckless (2000) reviewed several reports of artifacts recovered from Roman mines, including human skeletons, water wheels, wooden Archimedes' screws, and a few iron tools. The sources cited by Stuckless generally did not state the degree of preservation of these artifacts or the circumstances of preservation. 


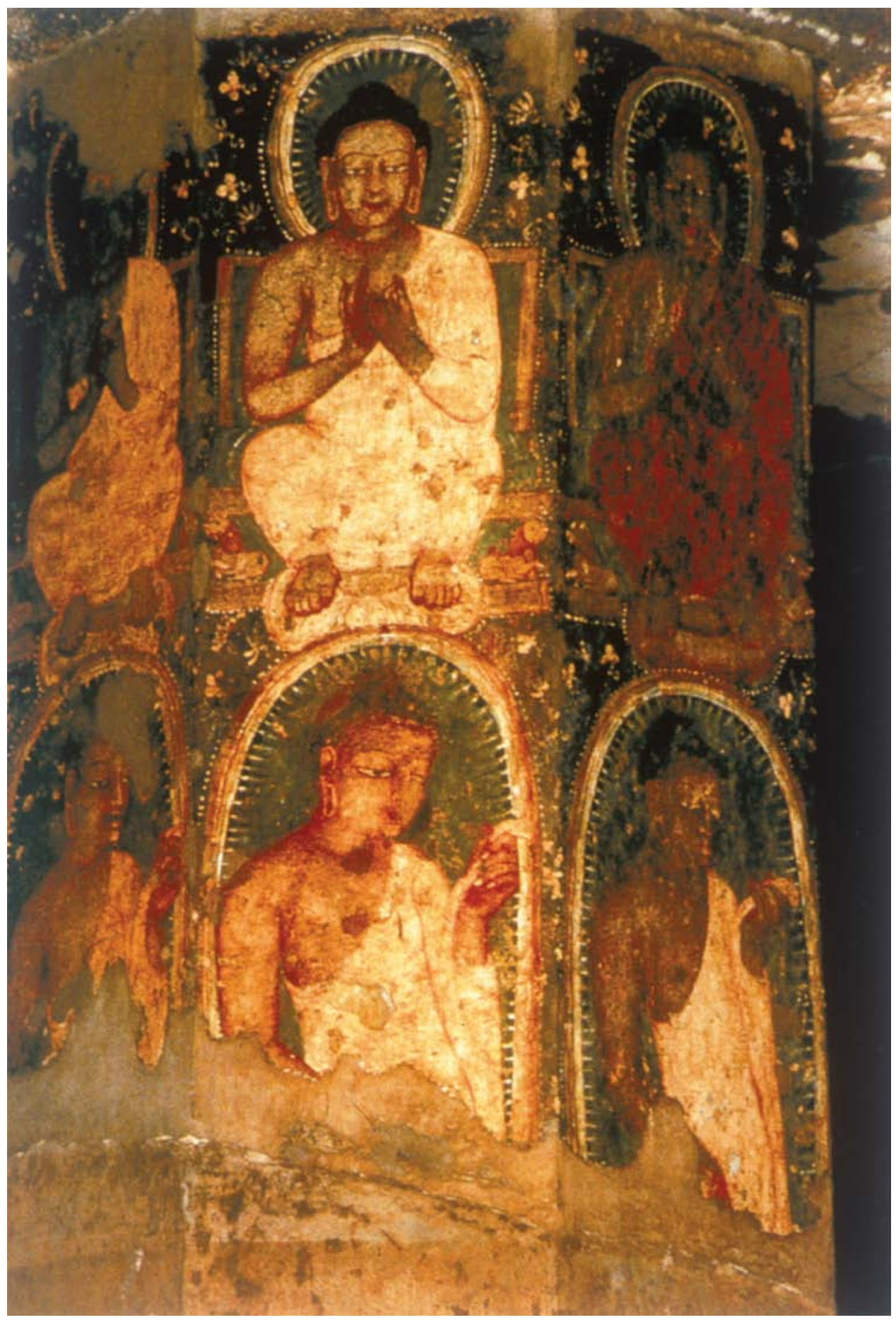

Figure 15. Columns and ceiling of Ajanta Cave \#10, India, painted on a mud plaster in the second century B.C., showing some spallation in lower part of photograph (from Behl, 1998, used with permission of the author). 


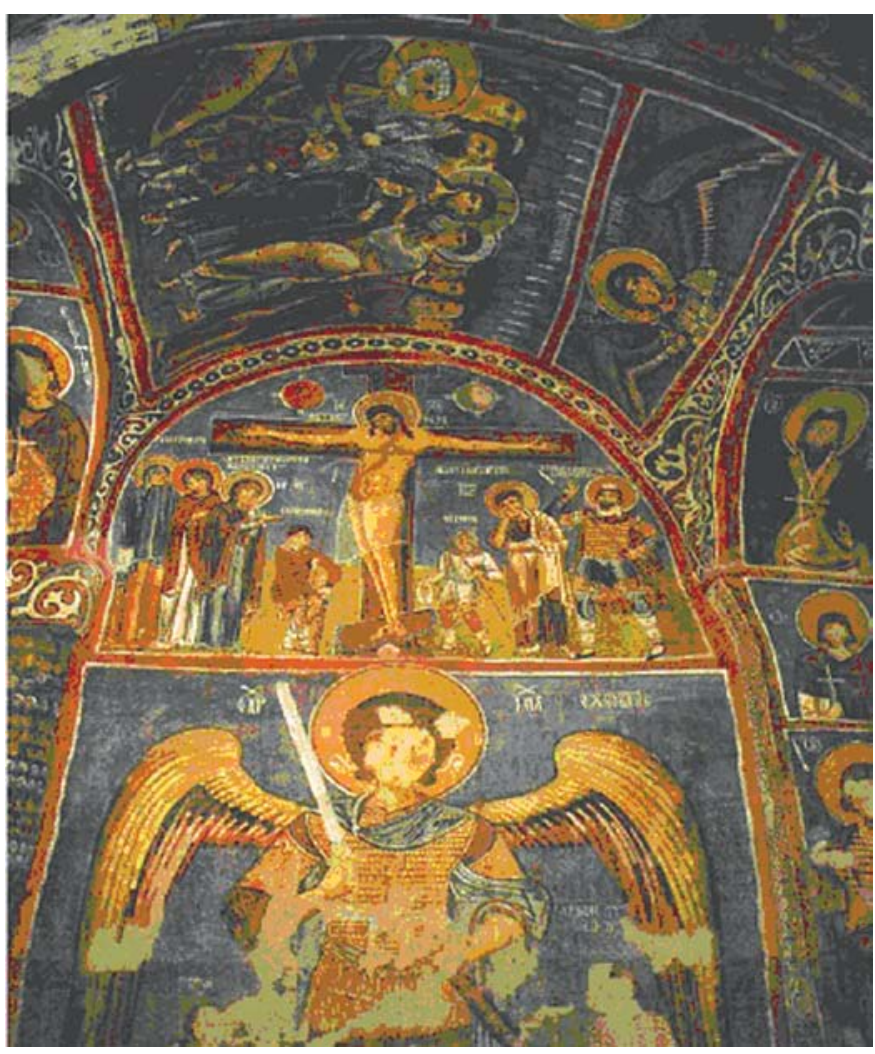

Figure 16. Fresco from Karanlik church, Goreme, Turkey. The fresco was created during the 11th century A.D. in a church excavated in partially welded ash-flow tuff. Some areas of spallation can be seen along the left side of the fresco, but the main damage to the painting is a result of vandalism (Stuckless, 2000).

\section{Dryness and Preservation}

The examples cited thus far indicate that preserved material is common in the unsaturated zone. Furthermore, it seems that the drier the environment, the better degree of preservation of artifacts. Dryness, in turn, can be augmented by local climatic conditions or contact with air. The examples cited earlier (a 9-ka flute carved from the leg bone of a red-crowned crane, the Chilean mummies, and a large cache of charred horsebeans) are all from arid climates. Cave painting, in contact with air, can be preserved for tens of thousands of years, but delicate materials such as pollen or organic artifacts are not known to have survived on the damp cave floors.

The tomb of the last Nubian Pharaoh (Tanwetamani) in El Kurru, Sudan, provides an excellent comparison between preservation in an underground opening and true burial (back-filling) in the unsaturated zone (fig. 17). The tomb was excavated in sandstone about 657 B.C. Shortly after closure, robbers opened the tomb, then sometime later a mudflow half-filled the tomb. Recent removal of the debris revealed that the plaster had been destroyed to the level of the mudflow. The mudflow probably did not remain wet for very long, and even though the climate is very arid, the fine-grained material drew water through the wall by capillary action during the few times when moisture was available. In the air-filled part of the tomb, capillary action in the sandstone kept the water from running into the tomb.

\section{Evaluation of Analogues for Preservation in the Unsaturated Zone}

Although there are many examples of Paleolithic and Neolithic art preserved in caves, questions persist about whether an equal or possibly an even larger number of paintings have been completely destroyed. Null evidence is difficult to evaluate, but a few lines of evidence indicate that paintings have not been totally destroyed in caves where they may have once existed.

First, if paintings had been completely destroyed in some caves, or even parts of caves, one would expect most, if not all, localities to exhibit either a spectrum of preservation from largely destroyed to fully preserved paintings. Alternatively, there should be an explanation for the binary distribution. A variety in the degrees of preservation of cave art was not found in the current literature search, either within individual caves or in the body of literature as a whole. A cave at Palomera in Burgos, Spain, like the cave at Cosquer, has had some paintings removed by water, whereas others are in good condition. This cave, which has paintings dated at $10950 \pm 100$ to $11540 \pm 100$ B.P. (Corchon and others, 1996), has at times had a stream flowing in it that left organic debris plastered to heights of several meters on the walls. The flooding is younger than the paintings and apparently destroyed the paintings to the height of the flooding. Lascaux provides another example where one gallery had over 90 percent of the paintings removed by wind abrasion (Breisch, 1987).

Second, areas where paintings would be least likely to survive, such as drip sites in the ceiling or flow channels on the walls of caves, have probably been the loci of flow for thousands of years. Early man would likely have avoided these areas because they were too wet to paint. Exceptions to this hypothesis are known (for example, one painting on the ceiling at Chauvet is partly covered by stalactitic calcite [Chauvet and others, 1996]). Some paintings have thin coatings of calcite caused by evaporation of thin films of water.

Finally, the sheer number of painted caves and the number of paintings in some of the caves argues for a high degree of preservation. In France and Spain alone, there are more than 150 painted caves (Ruspoli, 1986). Grand (1967) reports more than 2,188 paintings of animals in 110 caves.

In the case of rock shelters, some observational data correlate with preservation or destruction. In sandstone shelters in India, the roots of banyan trees have been noted to provide a preferential path for water across a painting. The part of the 


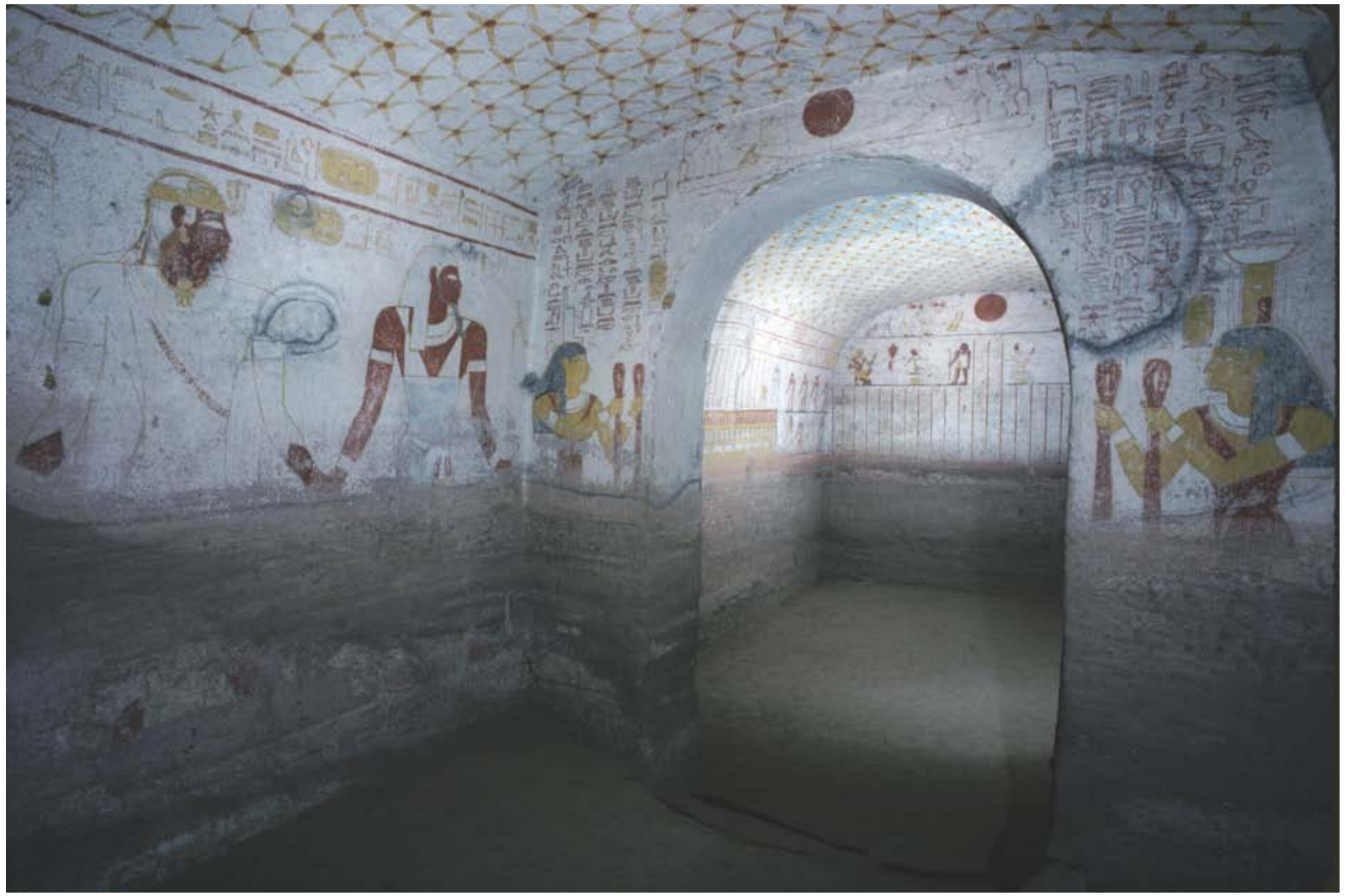

Figure 17. Tomb of Tanwetamani in El Kurru, Sudan, showing the destruction of plaster and painting to the level of a mudflow, which partly filled the tomb after it was left open by grave robbers (photograph by Enrico Ferorelli, used with permission).

painting exposed to water has been encrusted with calcium deposits, “... while leaving another part of the same figureuntouched by water - unscathed" (Neumayer, 1983, p. 6).

The analogues presented here show that the unsaturated zone has a good potential for preserving delicate and fragile materials. This is especially true for items that have been in underground openings. For greatest use and understanding by the general public, the examples of natural analogues should be familiar to them or in reference materials that can be checked easily. Table 1 lists examples of preservation in the unsaturated zone that have been reported in the National Geographic magazine during the period 1987-2001. The degree of preservation in this compilation is not always excellent, but the general tendency for preservation within the unsaturated zone is clearly evident. In fact, were it not for the good preservation of artifacts within the unsaturated zone, the study of archeology would be greatly limited because there would be far less direct evidence of how ancient civilizations lived and functioned.

In summary, there is abundant evidence for preservation in the unsaturated zone of delicate and easily destroyed items. Examples from arid to semiarid climates tend to be the most abundant, which indicates that climate is an important variable. Additionally, materials in open cavities exhibit better preservation than items buried in unsaturated soil.

\section{Repository Drift Stability Analogues}

\section{Repository Design Selection and Relation to Applicable Analogues}

Studies of natural and anthropogenic systems can improve understanding and confidence in the variables affecting the evaluation and operation of a selected repository design. The selection of appropriate analogues to build confidence in repository design parameters needs to focus on the variables affecting operational parameters rather than on a specific design for a proposed Yucca Mountain repository.

Refining the design and operating mode of the proposed geologic repository at Yucca Mountain has been an ongoing process since inception of the Yucca Mountain Project. This iterative design process has been focused on improving the understanding of how design features contribute to the performance of a potential repository and to the uncertainty in that performance.

A primary design aspect has been accommodation of the thermal load that would be generated by radioactive decay of the waste placed in the proposed repository. Early design concepts considered higher-temperature operating modes in 
Table 1. Items preserved within the unsaturated zone as reported by National Geographic magazine from 1987 to 2001.

[B.P., before present; B.C., before Christ]

\begin{tabular}{|c|c|c|c|c|}
\hline Preserved items & Age & Setting and location & Climate & Issue \\
\hline $\begin{array}{l}5,000 \text { paintings in rock } \\
\text { shelters and caves }\end{array}$ & As much as 35,000 B.P. & $\begin{array}{l}\text { Sandstone, Kakadu Park, } \\
\text { Australia }\end{array}$ & Monsoonal & February 1988, p. 266-289 \\
\hline Bone flute and ivory carving & 25,000 B.P. & $\begin{array}{l}\text { Limestone cave (?), } \\
\text { Brassempouy, France }\end{array}$ & Temperate & October 1988, p. 449 \\
\hline Cave paintings & 13,000-17,000 B.P. & $\begin{array}{l}\text { Limestone cave, Lascaux, } \\
\text { France }\end{array}$ & Temperate & October 1988, p. 482-499 \\
\hline $\begin{array}{l}\text { 4,000 paintings in rock } \\
\text { shelters and caves }\end{array}$ & Historic to 12,000 B.P. & Tassili-n-Ajjer, Algeria & Arid & August 1987, p. 180-191 \\
\hline Animal skeletons & 10,000 B.P. & Cebada Cave, Belize & Tropical & April 2000, p. 54-71 \\
\hline Bone tools & 8,300 B.P. & $\begin{array}{l}\text { Tierra del Fuego, } \\
\text { Argentina }\end{array}$ & Arid & December 2000 , p. $40-67$ \\
\hline $\begin{array}{l}282 \text { mummies, fishing gear, } \\
\text { hair, cord }\end{array}$ & 5,050 B.C. & Burial sites, Arica, Chile & Arid & March 1995, p. 68-89 \\
\hline $\begin{array}{l}\text { Mummy, wool, wood, } \\
\text { goatskin }\end{array}$ & 4,000-6,000 B.C. & Luolan, China & Arid & March 1996, p. 44-51 \\
\hline Bronze, cloth, ivory & 3,800 B.C. & Limestone cave, Israel & Arid & April 1999, p. 70-79 \\
\hline Copper ax, skeletal remains & 2,700 B.C. & $\begin{array}{l}124 \text { tombs, Remedello, } \\
\text { Italy }\end{array}$ & Temperate & June 1993 , p. $36-67$ \\
\hline Papyrus & 2,400 B.C. & $\begin{array}{l}\text { Mud-brick tombs, Abusir, } \\
\text { Egypt }\end{array}$ & Arid & $\begin{array}{l}\text { January } 1995 \text {, p. 2-43 } \\
\text { November } 1998 \text {, p. } 102-113\end{array}$ \\
\hline $\begin{array}{l}\text { Silver-coated bronze bull } \\
\text { (Baal) }\end{array}$ & 1,600 B.C. & $\begin{array}{l}\text { Sandstone vault. Ashkel- } \\
\text { ton, Israel }\end{array}$ & Arid & January 2001, p. 66-90 \\
\hline $\begin{array}{l}\text { Painted wooden figures, } \\
\text { carved and painted chairs }\end{array}$ & 1,539-1,078 B.C. & $\begin{array}{l}\text { Tombs of pharaohs in } \\
\text { limestone, Egypt }\end{array}$ & Arid & $\begin{array}{l}\text { September } 1998 \text {, p. 2-33 } \\
\text { April 1991, p. 2-31 }\end{array}$ \\
\hline Dog skeletons, silver coins & 600-400 B.C. & Ashkelton, Israel & Arid & January 2001, p. 66-90 \\
\hline $\begin{array}{l}\text { Frescoes on tomb walls and } \\
\text { ceiling }\end{array}$ & 657 B.C. & $\begin{array}{l}\text { Sandstone tomb, El } \\
\text { Kurru, Sudan }\end{array}$ & Arid & November 1990 , p. 96-125 \\
\hline Mummy & 600 B.C. & $\begin{array}{l}\text { Sandstone tomb, Baha- } \\
\text { riya, Egypt }\end{array}$ & Arid & September 2001, p. 32-41 \\
\hline $\begin{array}{l}\text { Painted tomb walls, painted } \\
\text { pottery, bronze }\end{array}$ & 600-300 B.C. & $\begin{array}{l}\text { Tombs excavated in vol- } \\
\text { canic rock, Tarquinia, } \\
\text { Italy }\end{array}$ & Temperate & June 1988 , p. 696-743 \\
\hline
\end{tabular}


which the temperature of the rock surrounding emplacement drifts would exceed the boiling point of water. To maintain flexibility in design, the design process then evolved to examine the effects of a wider range of thermal conditions on the repository. A flexible approach to design was introduced in the "Yucca Mountain Science and Engineering Report" (S\&ER) (U.S. Department of Energy, 2001a, section 2.1.3). Subsequently, in preparation for a license application, a design was selected. The license application design can be summarily described as having three postclosure thermal regimes (U.S. Department of Energy, 2008):

1. Dryout-Emplacement drift wall temperature greater than the boiling point of water. At the time of permanent closure, the emplacement drift wall rock will already be dried out by 50 years of forced ventilation, and the emplacement drifts will be dry. After closure, emplacement drift wall temperatures will increase to greater than the boiling point of water throughout much of the repository, relative humidity in the emplacement drifts will remain low, and dryout of the near-field host rock will proceed. Waste-package locations will remain dry locally until the dryout zone disappears as a result of declining heat output and rewetting by the percolation flux. During the dryout period, the existence of aqueous conditions on the surfaces of the waste package and drip shield will be limited to the minor effects of deliquescence associated with dust constituents.

2. Transition-Emplacement drift wall temperature at or below the boiling point of water and waste-package temperature at or above the boiling point. Seepage into the emplacement drifts becomes possible as the temperature of the emplacement drift wall drops below the boiling point of water (conservatively at $100^{\circ} \mathrm{C}$ in the thermal-hydrologic seepage model). During this period, the waste package and drip shield surface temperatures will be greater than the emplacement drift wall temperature, so seepage water will tend to evaporate if it contacts drip shields or waste packages, causing evaporative concentration of salts on their surfaces.

3. Low Temperature-Waste-package temperature less than the boiling point of water. As the waste packages cool further, the in-drift relative humidity increases, so evaporated solutions are not as concentrated. After hundreds to thousands of years (depending on local thermal conditions), wastepackage temperatures will become sufficiently cool (and associated chemical conditions become sufficiently benign) that initiation of localized corrosion is unlikely in the repository environment (U.S. Department of Energy, 2008). Figure 18 illustrates the variables affecting the thermal performance of the repository, from waste packages to emplacement drifts.

Analogues need to be considered in terms of repository design variables rather than attempting to match a specific design. The important variables are the temperature of drift walls, presence or absence of a boiling front, dimensions and spacing of drifts, absence of backfill, and ventilation. These variables affect drift stability (addressed in the following section), waste-package and drip-shield corrosion (discussed in the section on "Analogues for the Engineered Barrier System"), processes operative within the EBS (also addressed in

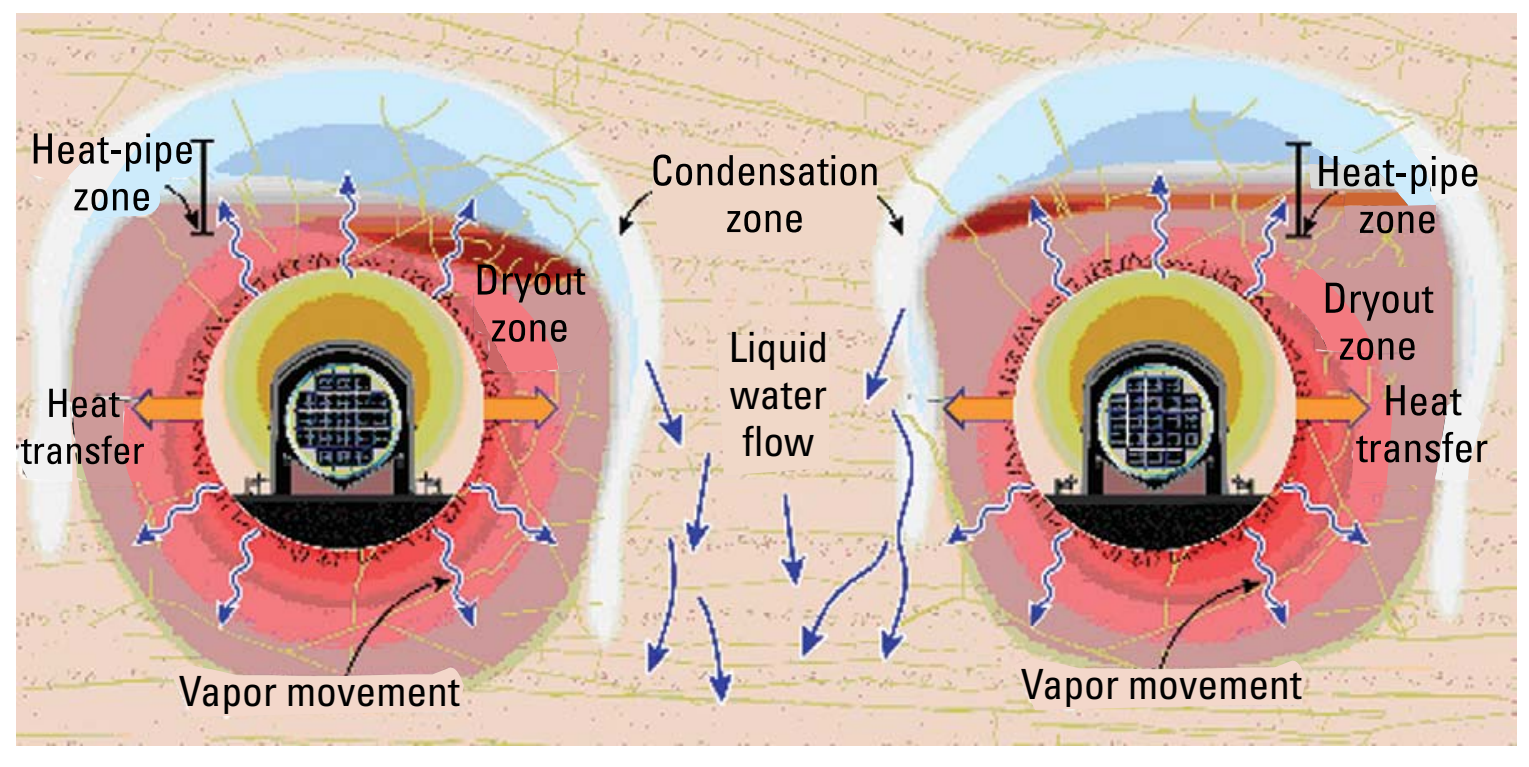

Figure 18. Variables affecting thermal performance of a repository (U.S. Department of Energy, 2001a, fig. 2-8). 
that section), and thermally coupled processes affecting the host rock at the drift and mountain scales (covered in the section on "Coupled Processes Analogues").

\section{Drift-Stability Analogues}

Numerous examples provide evidence of the stability of natural and manmade underground openings for millennia or longer periods under undisturbed conditions. However, an inherent bias is reflected in the studies because of the difficulty of determining the relative percentage of openings that remain compared to those that have collapsed. It is more difficult to evaluate the cause of collapse of such openings, whether by human interference or natural causes.

Calculations made by the Yucca Mountain Project as part of the licensing of a proposed geologic repository for the disposal of high-level radioactive waste predict that emplacement tunnels will exist without much damage long after ground support has disintegrated (BSC, 2001b). This conclusion includes the effects of anticipated seismic events. This section examines analogues that bear upon this conclusion and considers whether stability of subterranean openings is common or uncommon and how long subterranean openings remain open before collapse. It also examines the available records to evaluate the effects of seismic activity on subterranean openings.

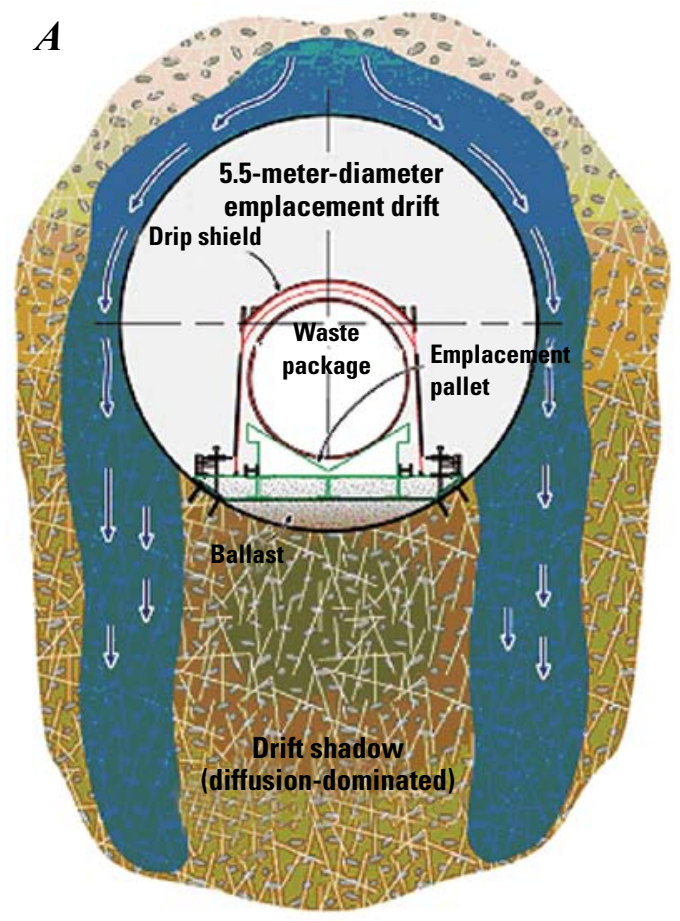

The collapse of underground excavations, or their ability to remain open under ambient conditions, depends on a number of variables, including (1) rock strength; (2) the size, shape, and orientation of the opening; (3) orientation, length, and frequency of fracturing; and (4) effectiveness of ground support. Long-term stability, even after ground support degrades, affects the integrity of the waste packages as well as groundwater flow because the repository tunnels should divert a substantial amount of water moving through the unsaturated zone away from the canisters and create a "drift shadow" or dryout zone beneath the tunnels. Figure 19 illustrates the concept of a drift shadow.

Figure 19 indicates that with flow mainly downward and in the matrix, in other words in a system dominated by diffusive flow, the drift-wall capillarity diverts downward-moving water around a drift, potentially creating a temporary advective flow field around the drift with a substantial reduction in the flux of water directly below the mined opening. If water is moving largely by advection through the matrix, however, the drift-shadow effect is likely to be less effective but still exists.

Studies have addressed the degradation of drifts over very long times, and with a loss of smoothness and asperities developing from rockfalls, the effectiveness of the capillary barrier represented at the opening interface will be lessened. Therefore, the drift shadow effect that may be observable in analogues at a specific moment in time is not likely to be

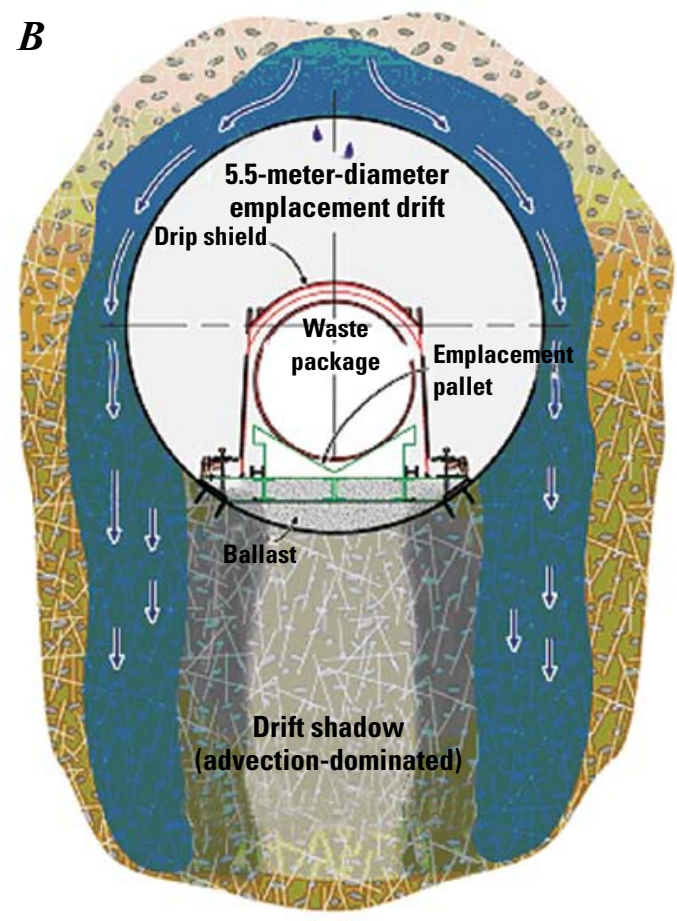

Figure 19. Diagrams illustrating the drift shadow concept under $(A)$ diffusion-dominated, and $(B)$ advection-dominated conditions (U.S. Department of Energy, 2008). 
an effective process over very long times and is not further addressed in this document.

The proposed repository at Yucca Mountain would be excavated in two subunits of the Miocene Topopah Spring Tuff. The welded nonlithophysal unit is brittle and jointed, whereas the lithophysal tuff is less jointed but somewhat more friable. Emplacement tunnels (for the storage of radioactive waste) would be bored with a diameter of $5.5 \mathrm{~m}$ and would be oriented for optimum stability relative to the joint orientations. Access drifts would be bored at a larger diameter (about $8 \mathrm{~m}$ ). Only the portions of the access drifts that are considered the "ramps," coming from outside the mountain into the repository area, would be backfilled to prevent collapse.

There are no exact analogues to the openings that would be created for a proposed repository at Yucca Mountain, but numerous examples demonstrate that both natural and manmade underground openings can exist for thousands of years in a wide variety of geologic settings, even with minimal or no engineered supports. At Yucca Mountain, collapse induced by seismic activity needs to be considered. Once again, exact analogues do not exist, but considerable anecdotal information is available. Examination of these examples leads to a conclusion that seismic events at or near Yucca Mountain are not likely to cause significant damage to the emplacement tunnels. However, the potential for considerable loss of emplacement tunnel integrity from seismic events is built into the modeling of the Yucca Mountain repository (U.S. Department of Energy, 2008). Figure 20 conceptually illustrates the changes in the drift after it has been degraded over a very long time. Capillary diversion around the tunnels becomes less effective as the drifts collapse because of potential asperities, as indicated in this figure, and also because there is a larger area contributing flux to the drift (U.S. Department of Energy, 2008, table 2.3.5-2). The present work suggests that this approach likely is conservative.

\section{Stability of Natural Underground Openings}

Caves are natural subterranean openings. They are abundant worldwide, form in a variety of rock types (although carbonates are the most common host rock), and, in many cases, can be shown to have stood open for long spans of time. Culver and others (1999) had a data base of 44,681 caves in the United States alone as of December of 1999. They reported that 2,774 of these caves were known to host 924 species of animals. Even the small country of Slovakia has about 4,000 caves, according to Web site http://www.slovakiatravels. com/sections/Routes/caves-en.php, last accessed January 8, 2010. The two northeastern provinces of South Korea, which cover about $9,600 \mathrm{~km}^{2}$, have more than 1,000 "extensively developed" caves (Woo and others, 2005). Caves also are abundant in Missouri where more than 5,500 are known, 633

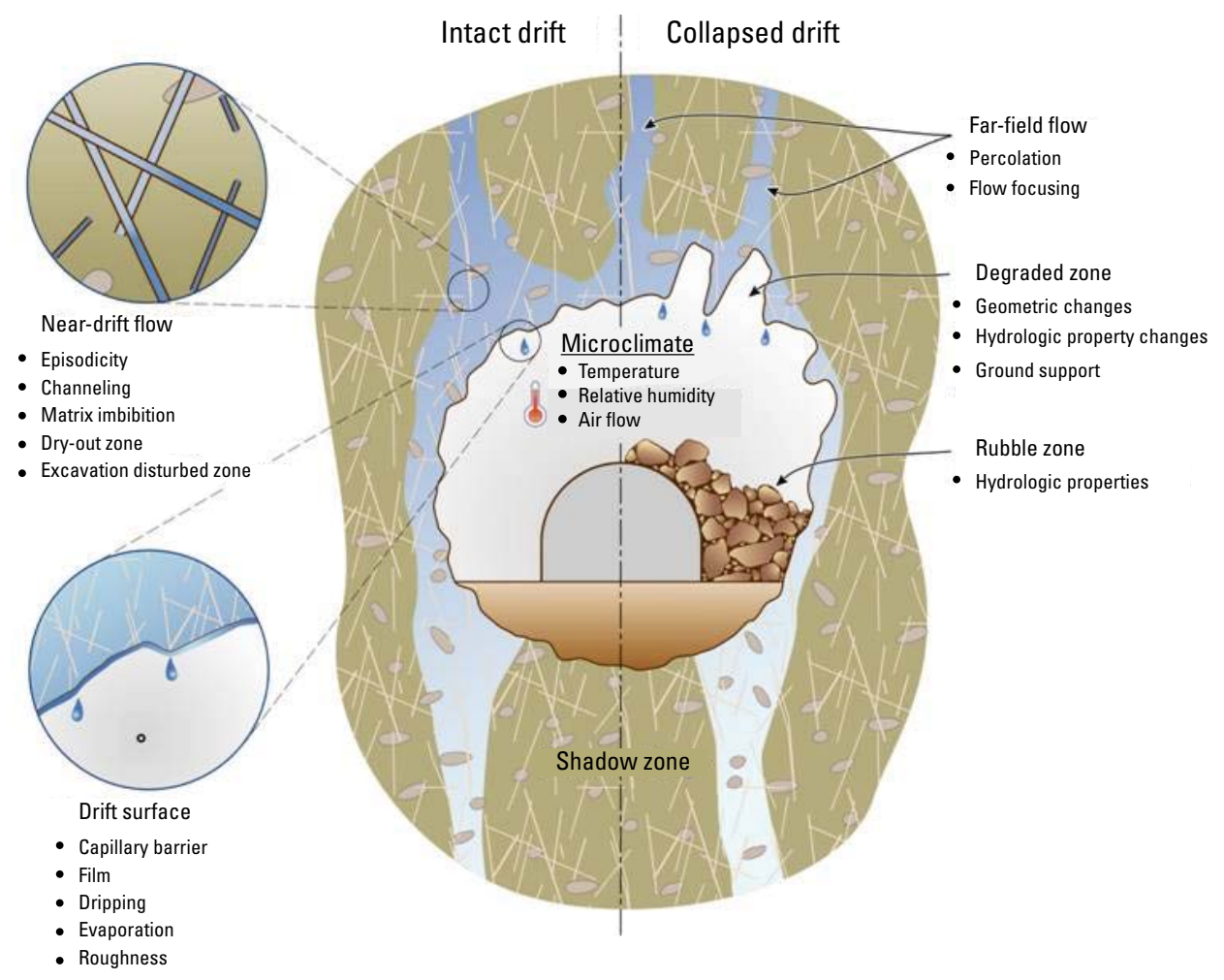

Figure 20. Diagram showing configuration of an intact drift and a drift that has collapsed over a long timeframe (U.S. Department of Energy, 2008). 
of which have been mapped in detail (Dom and Wicks, 2003). Within the United States there are 60 caves longer than $20 \mathrm{~km}$ (Gulden, 2009); worldwide, 45 caves are longer than $44 \mathrm{~km}$ (Gulden, 2009). The Mammoth Cave System is the longest on record at more than $591 \mathrm{~km}$ (Gulden, 2009). Caves also extend to great depth; worldwide, more than 45 caves extend to more than $1 \mathrm{~km}$ in depth (Gulden, 2009).

The large number of existing caves indicates that they must stand open for long periods of time, but for most of the 20th century, landscapes and caves were both thought to be Pleistocene or younger (Osborne, 2005). Although catalogues for length and depth of caves are available, no compilation was found during this study for ages of caves. Furthermore, age information that does exist is largely for material found in caves, which must be younger than the cave itself. In addition, much of what has been dated has been for archeological purposes and done by ${ }^{14} \mathrm{C}$, which is not useful past about $50 \mathrm{ka}$. More recently, speleothems have been studied as a proxy for paleoclimate information. Many of these have been studied by uranium-series dating, which allows determination of ages to about $350 \mathrm{ka}$. A few studies were found that used K-Ar or ${ }^{40} \mathrm{Ar} /{ }^{39} \mathrm{Ar}$ methods and a few that used the cosmogenic isotopes ${ }^{10} \mathrm{Be}$ and ${ }^{26} \mathrm{Al}$. The cosmogenic isotopes date the time when sediments washed into a cave and were sequestered from cosmic radiation. This technique can be used for ages as old as $5 \mathrm{Ma}$ (Stock and others, 2005).

Stock and others (2005) compared dating of caves by paleomagnetics in fine-grained sediments, U-series for speleothems, and cosmogenic dating of sediments. In general, speleothems formed long after the cave was formed; therefore, the age of the cave may be underestimated by as much as an order of magnitude. With this caveat, we compiled ages for caves (or cave contents); the Appendix provides a list of caves and determined ages. The list is meant to be representative of information available and is not intended to be exhaustive.

The oldest documented caves noted in this study, determined by isotope age-dating methods, are within the Upper Silurian Jenolan Caves limestone, New South Wales, Australia. Clays in these caves were dated by K-Ar. Scanning electron microscope (SEM) studies show the clays to be well crystallized with no signs of transport; they were therefore judged to be authigenic. The ages vary widely from $167.12 \pm 3.6 \mathrm{Ma}$ to $394.87 \pm 7.85 \mathrm{Ma}$ (Osborne and others, 2006) with seven ages clustered in the range of 335-342 Ma. Zircons within the clays were also dated using the fission-track technique. These ages also varied widely, but nine grains yielded a pooled age of 345.9 Ma. The zircons and the material from which the clays formed are postulated to have originated as volcanic ash. In any case, neither the zircons nor the clays could have originated as detrital material left after solution of the Silurian limestone; and, because the cave existed before the postulated ash was deposited, the age of about $345 \mathrm{Ma}$ is a minimum age. One of the clay samples was collected in a room that measured about $36 \mathrm{~m}$ long, $36 \mathrm{~m}$ high, and $21 \mathrm{~m}$ wide, which shows that even very large openings can remain open for extended periods of time.
Other very old openings are inferred to exist in the Otis Formation of the Devonian Wapsipinicon Group in eastern Iowa. The Linwood limestone mine is driven on two levels approximately $5 \mathrm{~m}$ apart, and both intersect more than 2,000 cavities greater than $10 \mathrm{~cm}$ in cross section (Garvin, 1995). In places, the upper level has intersected pre-Pennsylvanian karst (the solution areas are infilled with Pennsylvanian sedimentary rocks) (Garvin, 1995). The lower level locally intersects open cavities that likely formed at the same time as the filled cavities in the upper level. Thus, they were formed before about $320 \mathrm{Ma}$ and have stood open since that time. One cavity is described as $4 \times 8 \mathrm{~m}$ and $4.5 \mathrm{~m}$ high (Robert M. McKay, Iowa Geological Survey Bureau, oral commun., 2009).

One other seemingly anomalously old cave date comes from the Big Canyon Cave in the Guadalupe Mountains of New Mexico, which is lined with "dogtooth" spar calcite that (based on fluid inclusion data) formed from hydrothermal solutions (Lundberg and others, 2000). This origin differs considerably from that proposed for other caves in the area. The center of a $40 \times 18-\mathrm{cm}$ crystal was dated by U-Pb, which yielded ages of 87-98 Ma (Lundberg and others, 2000). The room from which the crystal was collected is $12 \mathrm{~m}$ long and $2 \mathrm{~m}$ wide.

Most of the caves in the Guadalupe Mountains are thought to have formed at the level of the water table by the interaction of sulfurous gas, water, and carbonate rock. Alunite that was deposited on the floors of caves during their formation was dated by K-Ar at 4.0-3.9 Ma for the Big Room at Carlsbad Caverns and 6.0-5.7 Ma for the upper level of the nearby Lechuguilla Cave (Polyak and others, 1998). K-Ar ages for alunite from other nearby caves show a trend of increasing age with increasing elevation, with one cave as old as 11.3 Ma (Polyak and Provencio, 2000). Although there are sections of the caves with blocks that appear to have fallen from the ceiling (referred to as breakdown), these may have fallen during cave formation. Regardless of the age of the breakdown, the sections of cave sampled for the dating study were not buried by rock from the ceiling, and the preservation of original floors is complete enough to allow the demonstration of increasing age of formation with elevation. Many of these openings, which have been stable for millions of years, are as large as or larger than those proposed for Yucca Mountain (fig. 21).

Areas such as that shown in figure 21 have no obvious breakdown on the floor of the cavern or holes in the ceiling from which blocks might have fallen. Any breakdown that may have existed from the time of cave formation has since been covered by stalagmites or flowstone. Polyak and Asmerom (2001) and Polyak and others (2004) have dated younger speleothems from three separate caves, including Carlsbad Caverns, as part of their studies of past climates. Their results show continuous growth during the last pluvial (30000-10500 years B.P.); therefore, these areas must have had no collapse for at least the last 30 thousand years (k.y.).

Lava tubes form another common type of cave. The National Park Service has parks and monuments in Hawaii, 


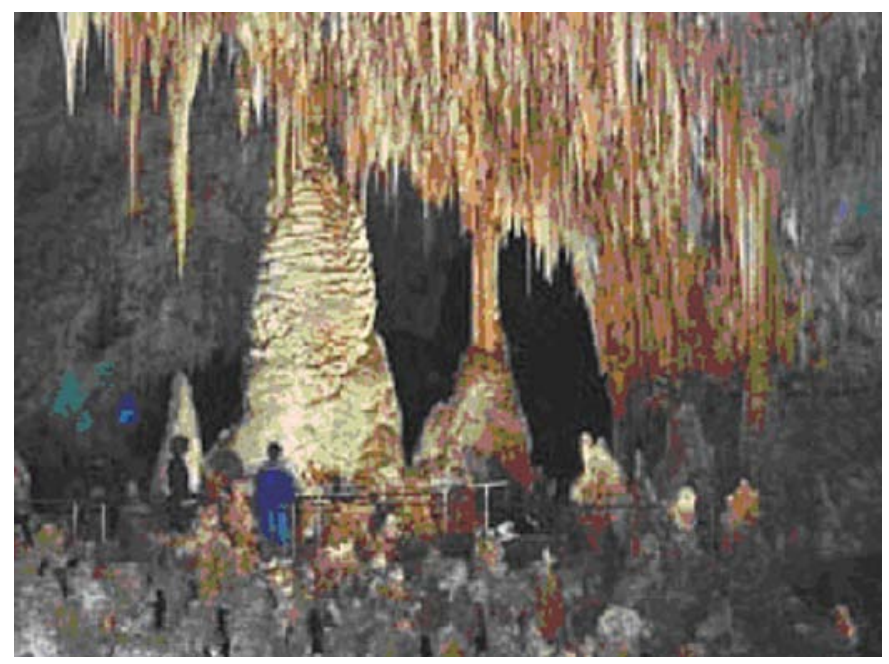

Figure 21. Fairyland in Carlsbad Caverns, New Mexico (photograph courtesy of National Park Service).

Idaho, California, Arizona, and New Mexico with lava tubes. Most lava tubes are a few thousand to a few tens of thousands of years old. They are commonly ellipsoidal to circular in cross section and several meters in diameter (U.S. Geological Survey, 2000b). Some of the most extensive are in the Undara region of Australia (fig. 22A), where 190-ka tubes (Griffin and McDougall, 1975) reach an aggregate length of $30 \mathrm{~km}$ and are as much as 20 m wide (Atkinson and others, 1975; Savannah Guides, 2009). Lava tubes are also common in Hawaii (fig. 22B) where ages are modern to a few thousand years.
Kazumura cave is the longest lava tube known $(65.5 \mathrm{~km})$, and it is as deep as $1.1 \mathrm{~km}$ (Gulden, 2009).

Most lava tubes have areas of collapse where their roof is thin, but large sections persist as open tunnels for long periods of time. Also, not all openings to the surface are a result of posteruption collapse; molten lava is commonly seen in "windows" of active lava tubes. Some areas of roof collapse form during eruption. In Manjang Gul, Jeju, Korea, there are areas of blocky breakdown on the floor of a lava tube and there is no evidence of missing blocks in the ceiling. Further inspection reveals that the blocks are imbedded in the congealed lava, indicating that they fell during eruption and were rafted downstream. Conversely, there are areas where blocks must have fallen from the roof, but there is no breakdown on the floor of the cave. The section of this cave that is open to the public is mostly about $15 \mathrm{~m}$ wide and $10 \mathrm{~m}$ high, but there are sections where the width attains $25 \mathrm{~m}$. A two-lane road was inadvertently built over Sang Gul lava tube (also in Jeju), but traffic has not caused the lava tube to fail, and recently added engineering structures now protect the road from collapse (Waltham and Park, 2002). These authors concluded that a 3:1 width to roof thickness would ensure integrity under normal engineering loads. Woo and others (2007) noted that there are 120 known lava caves on Jeju, which is a relatively small island (about $30 \times 75 \mathrm{~km}$ ).

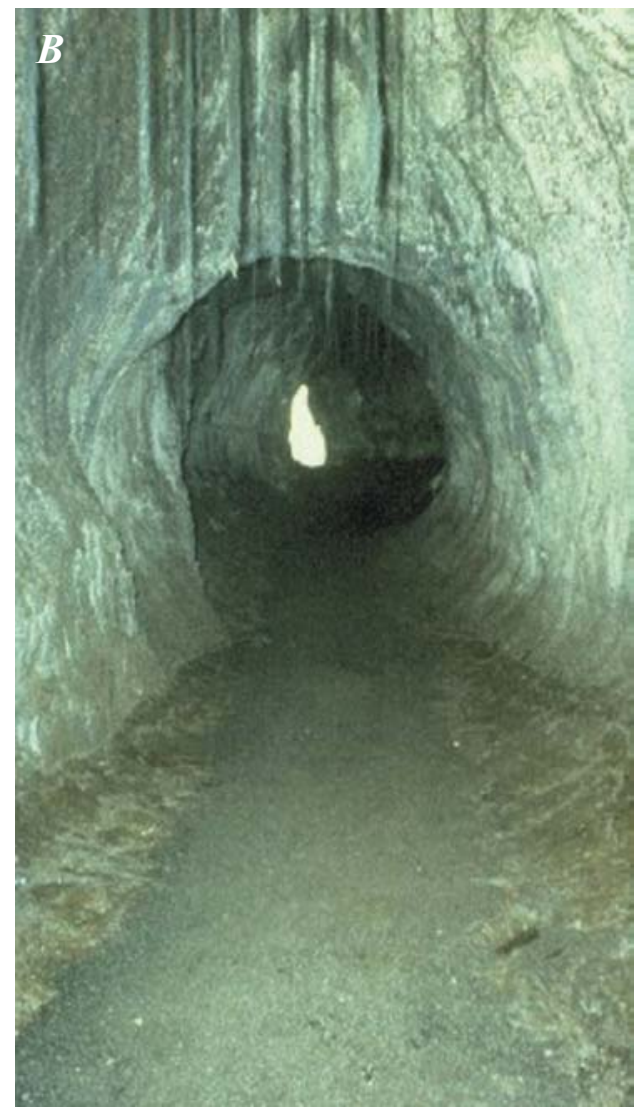

Figure 22. (A) Photograph of a lava tube in Undara, Australia (Atkinson and others, 1975, fig. 7). (B) Photograph of a Nahuku lava tube and lava stalactites from Hawaii (http://volcanoes.usgs.gov/images/pglossary/LavaTube.php, last accessed 10/17/002). 
As described previously, the San Antonio Mountain Cave in northern New Mexico is an example of a lava tube in basalt (dated at 3.4-3.9 Ma; Rogers and others, 2000) that has remained intact over a long period of time. This lava tube is $170 \mathrm{~m}$ long and generally several meters wide. In places, the ceiling is as much as $12 \mathrm{~m}$ high. The large size of the openings, combined with abundant cooling fractures and great antiquity, has resulted in fallen blocks generally less than $0.75 \mathrm{~m}$ in diameter that cover about 30 percent of the cave's floor. Several low areas on the floor of the cave preserve a long record (as much as 1 million years [m.y.] as evidenced by the fossil record) of sediment accumulation (as much as $1 \mathrm{~m}$ thick) with no collapse.

Some of the largest and best-studied lava tubes are in the Canary Islands. Cueva del Viento on Tenerife is one of the longest in the world (over $17 \mathrm{~km}$ ), is as much as $25 \mathrm{~m}$ wide, and has been dated at $17570 \pm 150$ B.P. by ${ }^{14} \mathrm{C}$ analyses of roots carbonized by the erupted volcanic rocks (Carracedo, Paterne and others, 2003). Tubo Volcánico Corona on Lanzarote (fig. 23) is $8 \mathrm{~km}$ long and as much as $35 \mathrm{~m}$ wide (Carracedo and Day, 2002) and large enough to house a theater, restaurant, swimming pool, museum, and a conference room. The host lava has been dated by ${ }^{40} \mathrm{Ar} /{ }^{39} \mathrm{Ar}$ at $21 \pm 6.5 \mathrm{ka}$ (Carracedo, Singer, and others, 2003). The last 1.8-km section of this lava tube is below sea level, by as much as $80 \mathrm{~m}$, owing to the much lower sea level during the last glacial advance. There is no report of collapse of the underwater portion.

Kebara Cave in Mount Carmel, Israel, is a large opening $(20 \times 26 \mathrm{~m})$, and sediments on the floor of the cave yield ages as old as $50 \mathrm{k.y}$. (Bar-Yosef and others, 1996). Although this main portion of the cave shows no sign of collapse, a terrace in front of the cave entrance was formed by collapse sometime after $30 \mathrm{ka}$ (Bar-Yosef and others, 1996). However, even this collapsed section must have stood open for more than $20 \mathrm{k} . \mathrm{y}$. because the section was the entrance from before $50 \mathrm{ka}$ until $30 \mathrm{ka}$.

The maximum length of time that caves have stood open is generally not known. The very old caves in New South Wales, Australia, eastern Iowa, and the Guadalupe Mountains discussed previously may be exceptions, but there is speculation that much paleokarst terrane may have gone unrecognized (Garvin, 1995; Osborne, 2005). Regardless of the maximum amount of time caves can stand open, there are many caves that contain biologic or archeologic materials that have not been buried by collapse for extended periods of time. Davis (1990) cited studies of cave sediments in Europe as old as 1.5 Ma, which indicates that long-term stability of caves is a common feature. As noted earlier, there are several limestone caves that contain Neolithic paintings that have been dated at $12 \mathrm{ka}$ to $32 \mathrm{ka}$. Photographic evidence from several of these caves shows no evidence of roof collapse since the paintings were made (Chauvet and others, 1996; Clottes and Courtin, 1996; Ruspoli, 1986; Saura Ramos, 1998).

Sandstone caves are fairly common, although the ages seem not to be generally reported. Sandstone is the host rock for 30 percent of the 250 recorded caves in Wisconsin (Day, 2001). One of these caves, Arnold/Tainter, has the oldest dated cave art from the dark zone (the portion of a cave beyond
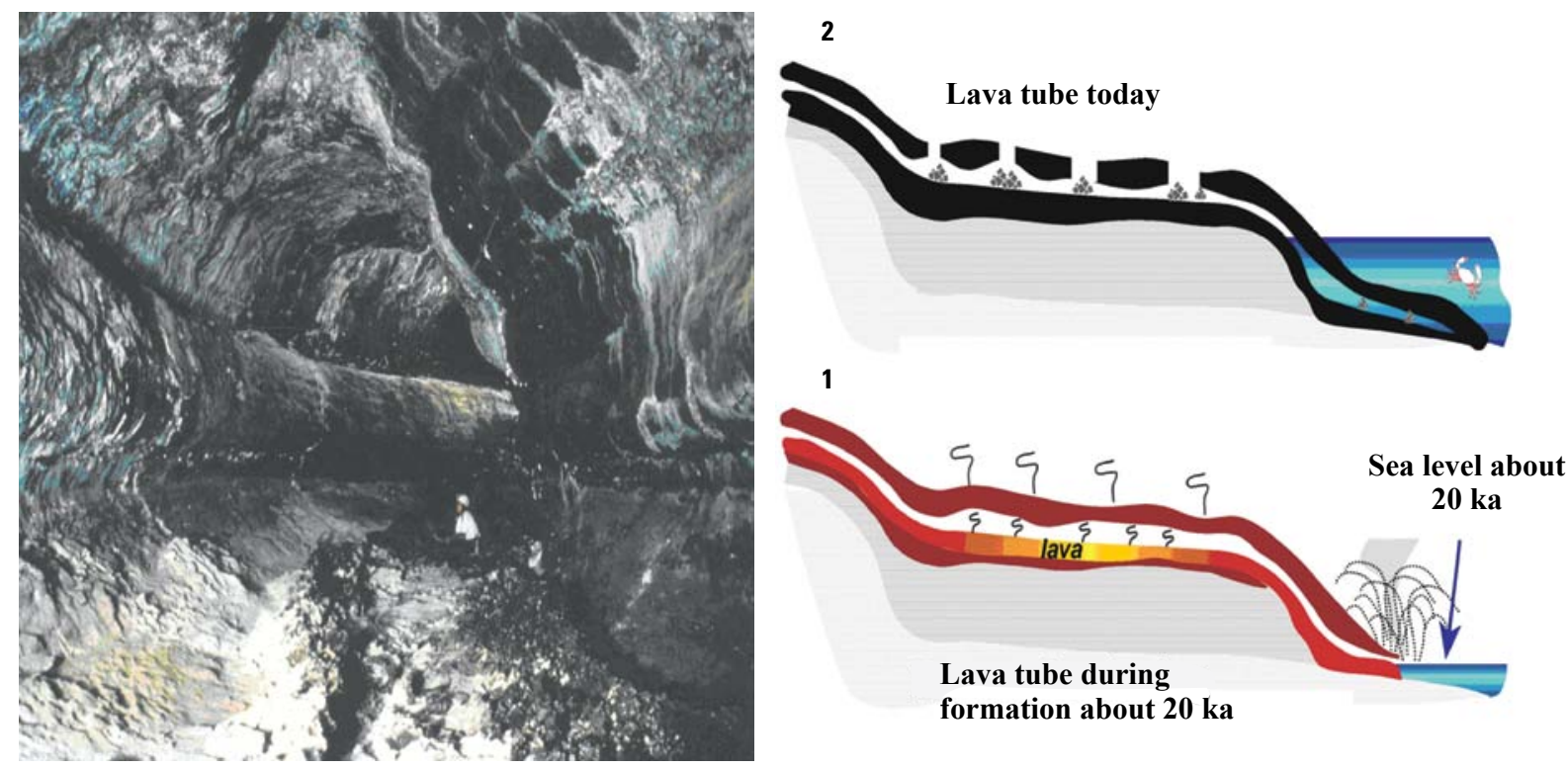

Figure 23. On the left is a photograph of Tubo Volcánico Corona, Lanzarote, Canary Islands, with a man shown for scale. $0 \mathrm{n}$ the right are schematic cross sections of the lava tube: (1) at the time of formation with sea level at least 80 meters lower than at present, and (2) as the lava tube exists today with a few collapse windows and modern sea level (photograph provided by José Mangas Viñuela; schematic after Carracedo and Day, 2002, fig. 4.8). 
which sunlight does not penetrate) in North America (Steelman and others, 2001). The Nangwarry sandstone cave system in southeast Australia is reported to be $407 \mathrm{~m}$ in length, with one section having a floor of $3 \times 7 \mathrm{~m}$ and a height of $8 \times 9 \mathrm{~m}$ (Mannell, 1973). One sandstone cave in southern Egypt gained notoriety because its depiction of people swimming made it unique among Neolithic cave paintings, and the cave became the backdrop of a book and movie of the same name, "The English Patient" (Coulson and Campbell, 2001). It is not likely that the paintings are very old; the paintings in the northern Sahara date from $12 \mathrm{ka}$ to $4 \mathrm{ka}$, and the rate of weathering (presumably by wind ablation) is high (Coulson and Campbell, 2001).

A null hypothesis on cave stability is difficult to evaluate. There may be caves for which collapse has been so complete that they are not recognized as caves. Breakdown is common in many caves, and some may date from the early stages of cave formation, as documented in one lava tube on Jeju, Korea, and noted in limestone caves where fallen material is coated with flowstone. Breccia pipes in northern Arizona and adjacent areas number in the thousands and represent stoping of limestone cavities to the surface, but these are apparently a special case of hydrothermal solutions eroding their way to the surface as nearly circular structures formed at joint intersections (Chenoweth, 1986, 1988).
Heylmun (2001) suggested that there may be breccia pipes that are simply areas of collapse in limestone and are not associated with the hydrothermal systems described by Chenoweth $(1986,1988)$. Figure 24 shows a breccia in Titus Canyon on the east side of Death Valley which could have originated by this mechanism, but such exposures are rare. In addition, sinkholes may represent roof failure for some carbonate-hosted caves; however, more commonly sinkholes represent areas of inflowing water through the unsaturated zone.

Ceiling collapse in caves is also known to have occurred in response to freezing. Bogus Cave in Jones County, Iowa, has a thick accumulation of boulder-sized blocks near its entrance (Josephs, 2002). The blocks lie on top of animal remains that have been dated at 17,206 \pm 120 years and are overlain by a thin veneer of Holocene sediments and a stalagmite dated at $16,900 \pm 4,800$ years. This timing places the collapse during the last glacial maximum when the average temperature in the vicinity of the cave was about $14^{\circ} \mathrm{C}$ colder (Josephs, 2002). Historical collapse of a 40-ton block near the entrance of Mammoth Cave, Kentucky, occurred after walls constructed at the mouth of the cave were removed to return the cave to its precolonial configuration (Olsen, 1996). Removing the walls allowed a much greater influx of cold air in the winter, which in turn caused freezing of water in

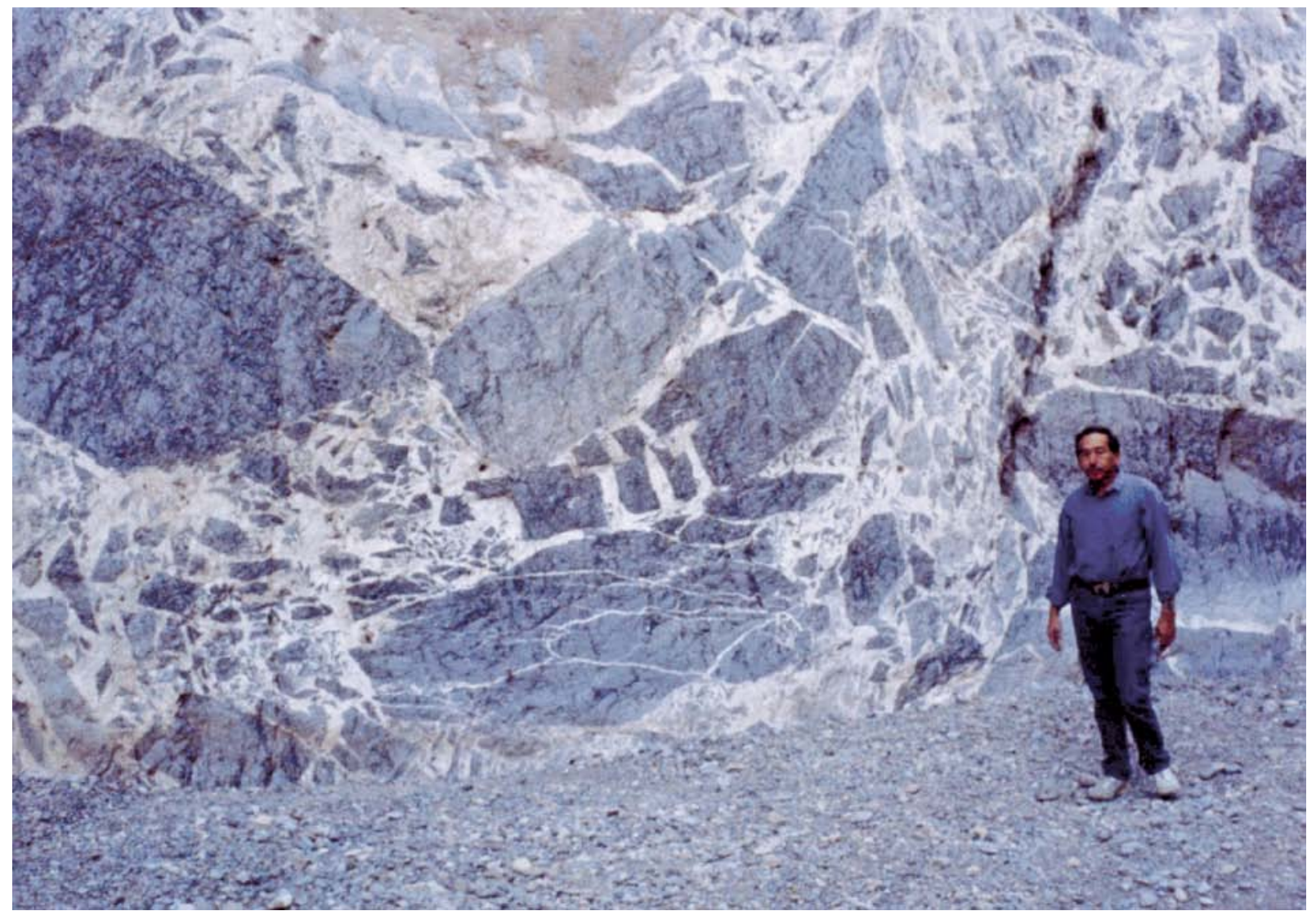

Figure 24. Megabreccia in Titus Canyon, in the northeast corner of Death Valley National Park, California (photograph by J.S. Stuckless). 
the joints and bedding planes and consequent frost wedging (Olsen, 1996). Collapse may also have been accelerated by differential contraction of the relatively warm limestone in contact with the cold air.

\section{Stability of Manmade Underground Openings}

Manmade underground openings do not provide as long a history as the natural ones. They may, however, provide a closer analogy to a mined geologic repository, as there are abundant examples that exhibit considerable stability for hundreds to thousands of years even with minimal engineering. The oldest examples are the Paleolithic flint mines of northern Europe and England. The English deposits were mined into chalk beds $3000-4000$ B.C. These mines have shafts $6-14 \mathrm{~m}$ deep that access galleries 4-24 $\mathrm{m}$ long and $60-150 \mathrm{~cm}$ high (Crawford, 1979). The mines are dated at 3010-3250 B.C. (Crawford, 1979) and are still open today largely because prehistoric man seemed to have utilized the 30 - to 60 - $\mathrm{cm}$ joint spacing so as to leave none of the roof totally unsupported. (Note that ages for the anthropogenic examples are given with respect to B.C. or A.D., as these are the designations given in the data sources.)

Flint mines of Poland are about the same age as those in England. They are assigned to the Funnel Beaker culture that existed from about 4000-2700 B.C. (http://en.wikipedia.org/ wiki/Funnelbeaker_culture, accessed May 4, 2010). The mines were excavated in limestone, with cross sections as large as $4 \times 4 \mathrm{~m}$ and lengths up to $15 \mathrm{~m}$ in areas where jointing was sparse, and by smaller corridors-and-pillar methods where jointing was somewhat more closely spaced (fig. 25).

Around 1500 B.C., the Egyptians began excavating tombs on the west bank of the Nile across from Luxor for pharaohs, queens, nobles, and even workers. The tombs, excavated in massively bedded and jointed limestone (fig. 26), are generally several meters in length and width and about $2 \mathrm{~m}$ in height, with many having entrance corridors tens of meters in length and as much as $3 \times 4 \mathrm{~m}$ in cross section. The total length for the pharaohs' tombs ranges from $25 \mathrm{~m}$ to $200 \mathrm{~m}$ (Siliotti, 1996), and many have pillars left for support in the larger rooms. Today, 62 tombs are known in the Valley of the Kings (Siliotti, 1996), 84 in the Valley of the Queens, and more than 500 tombs for workers and nobles that were excavated between the two famous valleys. Many of the tombs are open to the public; of these, most have incurred some water damage to plaster and paintings on the walls and ceilings, but none seems to have suffered collapse. Siliotti (1996) suggested that some tomb sites were abandoned when the workers encountered "unsuitable rock formation," and thus the apparent lack of collapse may be due to careful selection of host rock.

Mining of metallic ores has produced subterranean openings in a variety of rock types, including badly altered or fractured rock in many cases. Unfortunately, many of the oldest examples have been mined continuously or reopened in more recent times to obtain the lower-grade ore left by the ancient miners. For example, the Great Orme Mine in Wales was thought to be a Roman copper mine, but recent work by archeologists from Liverpool, England, has failed to confirm that the Romans ever worked the deposit (J.J. Taylor, University of Liverpool, written commun., 2001). Charcoal recovered from the early workings yields ${ }^{14} \mathrm{C}$ dates from $900-1800$ B.C., which indicates the workings are of Bronze Age. Part of the reason for the confusion as to the true age is that in 1832 and again in 1849 miners broke into caverns so well preserved that no one thought they could be older than Roman. The cavern discovered in 1832 was nearly $40 \mathrm{~m}$ long and contained stone
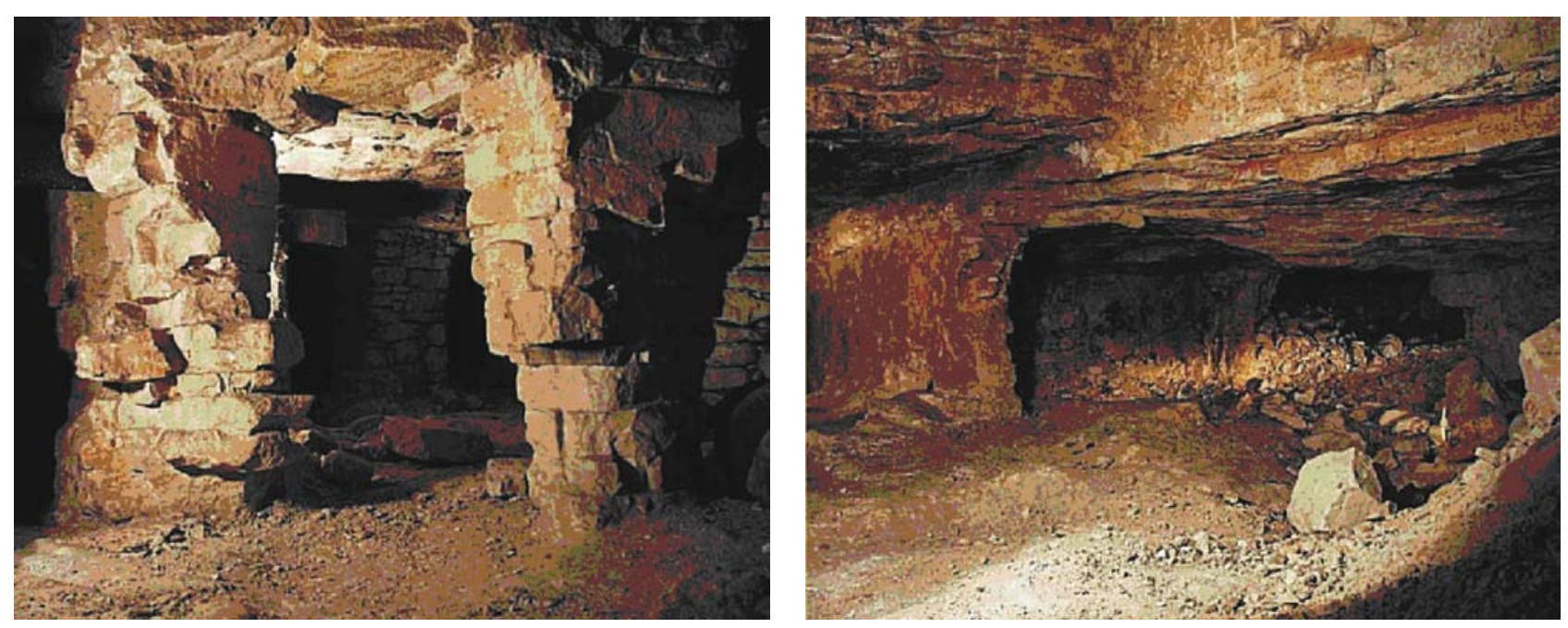

Figure 25. The Neolithic flint mine at Krzemionki Opatowskie, Poland (photographs courtesy of Krzemionki Opatowskie Archaeological Museum and Reserve). 

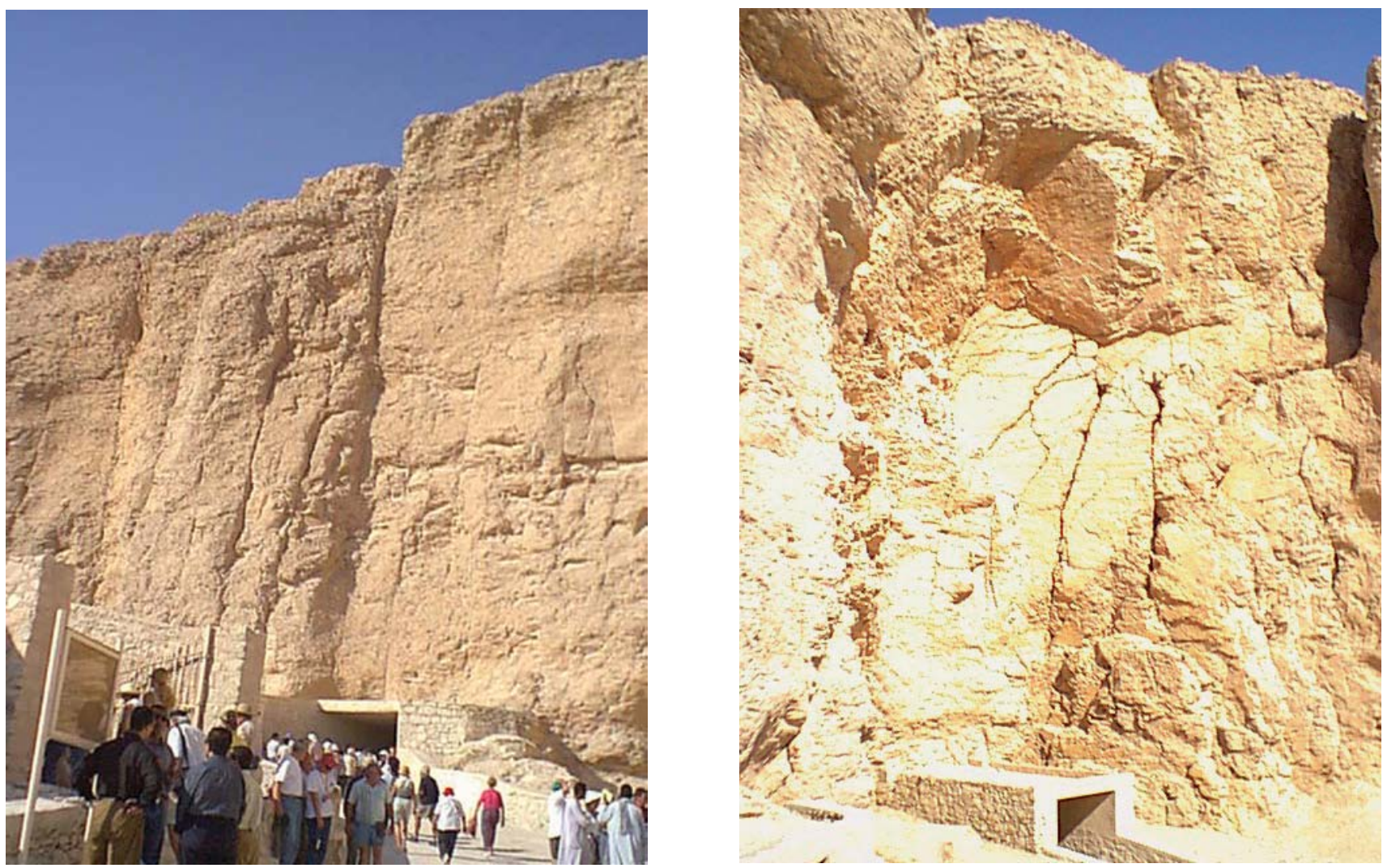

Figure 26. The Nubian Limestone that hosts the tombs in the Valley of the Kings in Egypt (photographs by J.S. Stuckless).

hammers and bones (Shepherd, 1993); it was mined into limestone and had stood open for nearly 2,000 years. As of 2001, more than $7 \mathrm{~km}$ of old workings had been mapped with more than 3 times that much remaining to be mapped (J.J. Taylor, University of Liverpool, written commun., 2001). The old mine has been open for public tours since 1991 (http://www. walesdirectory.co.uk/mines, last accessed August 16, 2005).

The Laurion mines (fig. 27A), about $40 \mathrm{~km}$ south of Athens, Greece, were first mined about 2000-1500 B.C., but were mined most actively from 600 to 300 B.C. (Shepherd, 1993). They are in a gently dipping sequence of mica schists and marble, and sulfides occur along the contacts. Shafts of 1.25$1.4 \mathrm{~m}$ by $1.5-1.9 \mathrm{~m}$ were sunk to depths as much as $111 \mathrm{~m}$ (Shepherd, 1993). Underground workings are $140 \mathrm{~km}$ long; tunnels average $1 \mathrm{~m}$ wide and $1.75 \mathrm{~m}$ high (Shepherd, 1993). Ore zones were mined by underhand stoping that left large cavities a couple of meters high and a few meters in diameter. Pillars of inferior ore-grade rock supported these cavities. Under Athenian mining laws, removal of rock from any pillars was punishable by death (Shepherd, 1993).

Phlogopite schist, in contact with a granite stock, formed the host rock for a low-grade emerald mine at Wadi Sikait in Egypt. The mine was first opened during the first century B.C. and was mined by the Romans until about the sixth century A.D. Tunnels reached as deep as $100 \mathrm{~m}$ (Harrell, 2004).
Also excavated at Wadi Sikait is a first-century B.C. temple (fig. 27B), which was carved into a talc schist. In spite of the poor rock quality, the temple has not collapsed, though roof lintels and support pillars are badly cracked (J.M. Bunbury, Cambridge University, written commun., 2002).

In addition to mines, the Israelis, Greeks, Persians, and Romans constructed a large number of tunnels, largely for the purpose of transporting water. The tunnel of Eupalinus (fig. 28A), on the Greek island of Samos (fig. 29), was constructed around 530 B.C. to transport water beneath Mount Ambelos. The tunnel is $1.8 \times 1.8 \mathrm{~m}$ in cross section, $1,045 \mathrm{~m}$ in length, and as much as $180 \mathrm{~m}$ below land surface. Comparison of the maps of Ring and others (1999) and Apostol (2004) shows that the tunnel was constructed in Neogene sedimentary rocks, and from several pictures, it is likely that the tunnel is within the carbonate portion of that section, which is $400 \mathrm{~m}$ thick. Water was actually transported in ceramic pipes below the level of the tunnel shown in figure $28 \mathrm{~A}$.

One of the oldest of these tunnels is the Hezekiah tunnel that was excavated in the eighth century B.C. (fig. 28B). The tunnel, which is under Jerusalem and was excavated in limestone, is $553 \mathrm{~m}$ long, about $2 \mathrm{~m}$ high, and less than a meter wide; it is mentioned in two books of the Bible.

The Greeks excavated several tunnels in what is now Italy. The Albano tunnel (approximately $20 \mathrm{~km}$ southeast of 

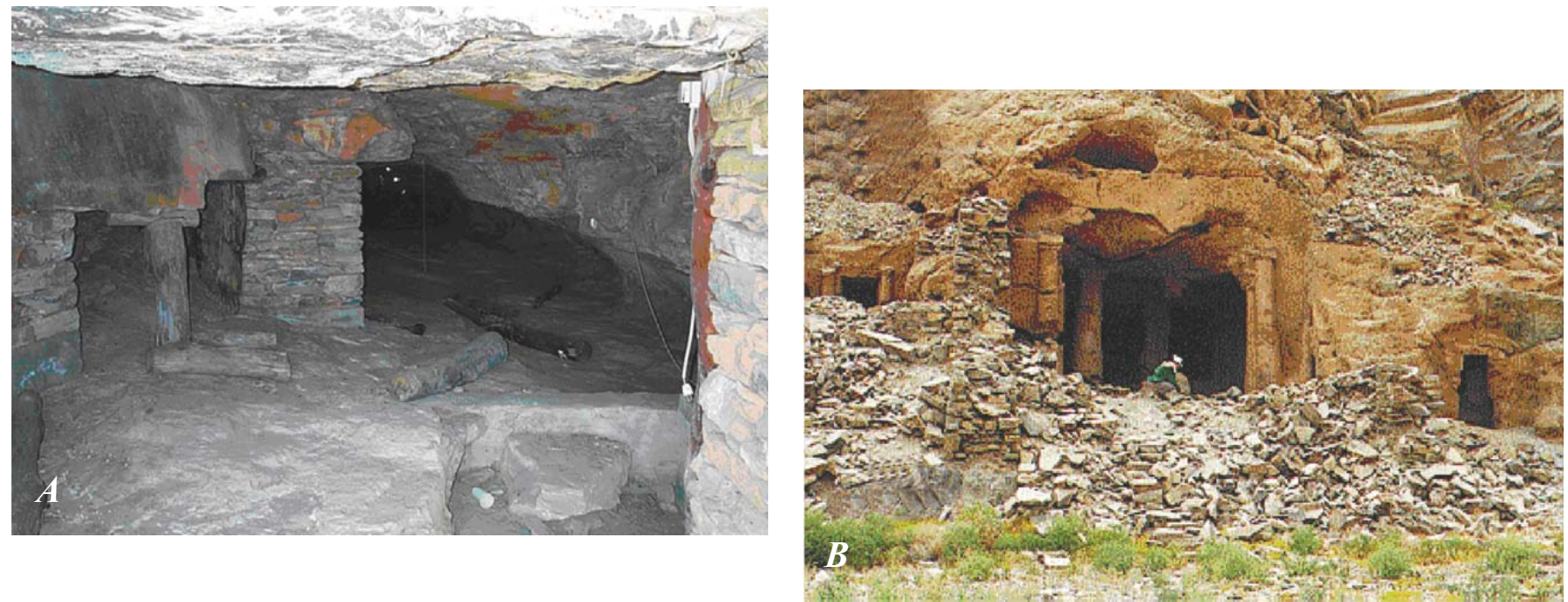

Figure 27. (A) Photograph of a mined-out cavern in the Laurion mines, Greece (Gill, 2001). The roof is formed by mica schist and the floor is marble. Ground support appears to be modern because older reports make no mention of either wood or cement. $(B) \mathrm{A}$ temple at Wadi Sikait, Egypt, which was excavated in a talc schist during the first century B.C. (photograph courtesy of Professor James Harril, University of Toledo). In spite of poor rock quality, the temple has stood open without ground support for about 2,100 years.
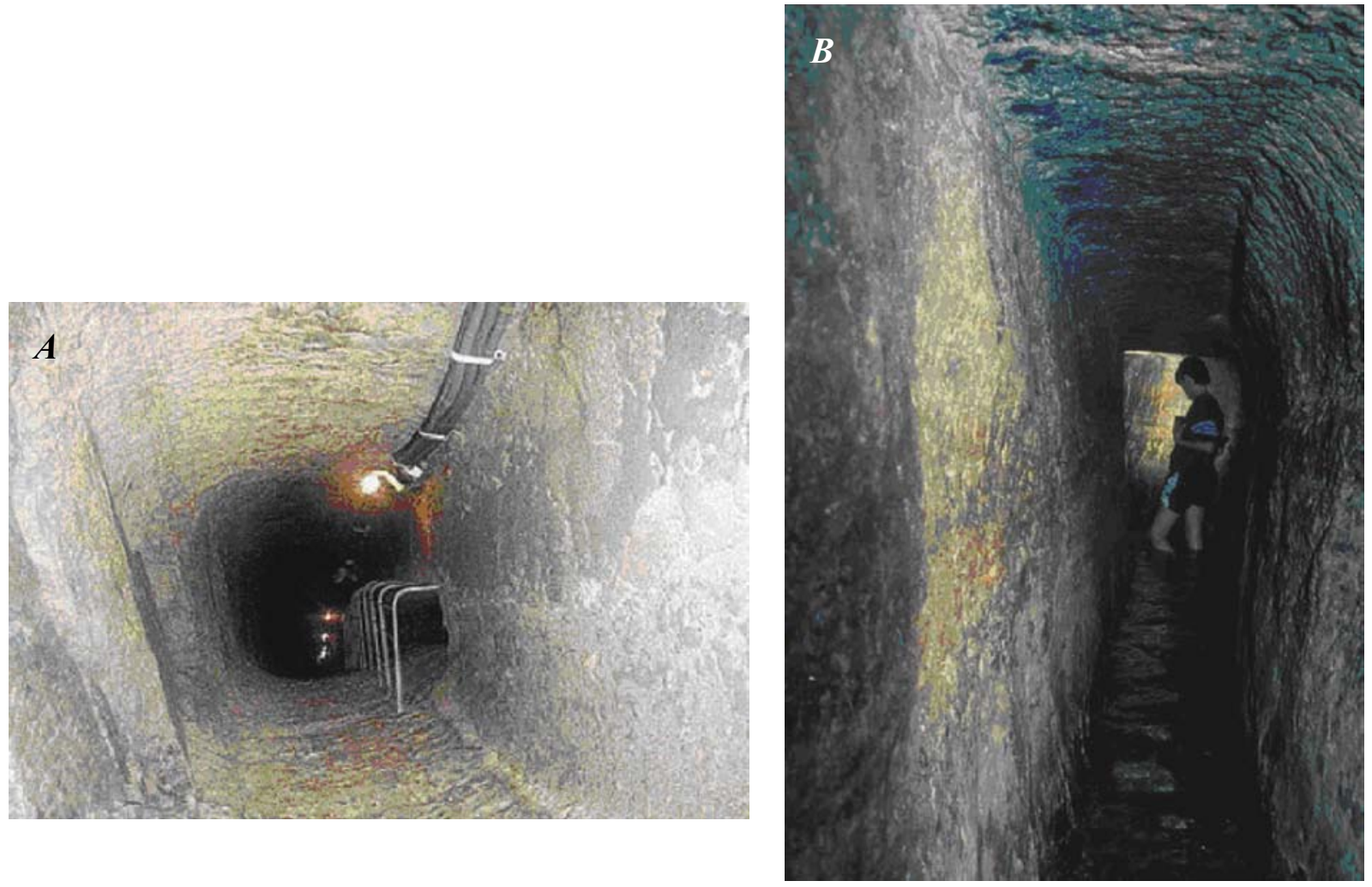

Figure 28. (A) The tunnel of Eupalinus, Greece (from http://www.mlahanas.de/Greeks/Eupalinos.htm, last accessed August 1, 2005). (B) The tunnel of Hezekiah, Israel (http://www.bibleplaces.com/heztunnel.htm, last accessed August 1, 2005). 


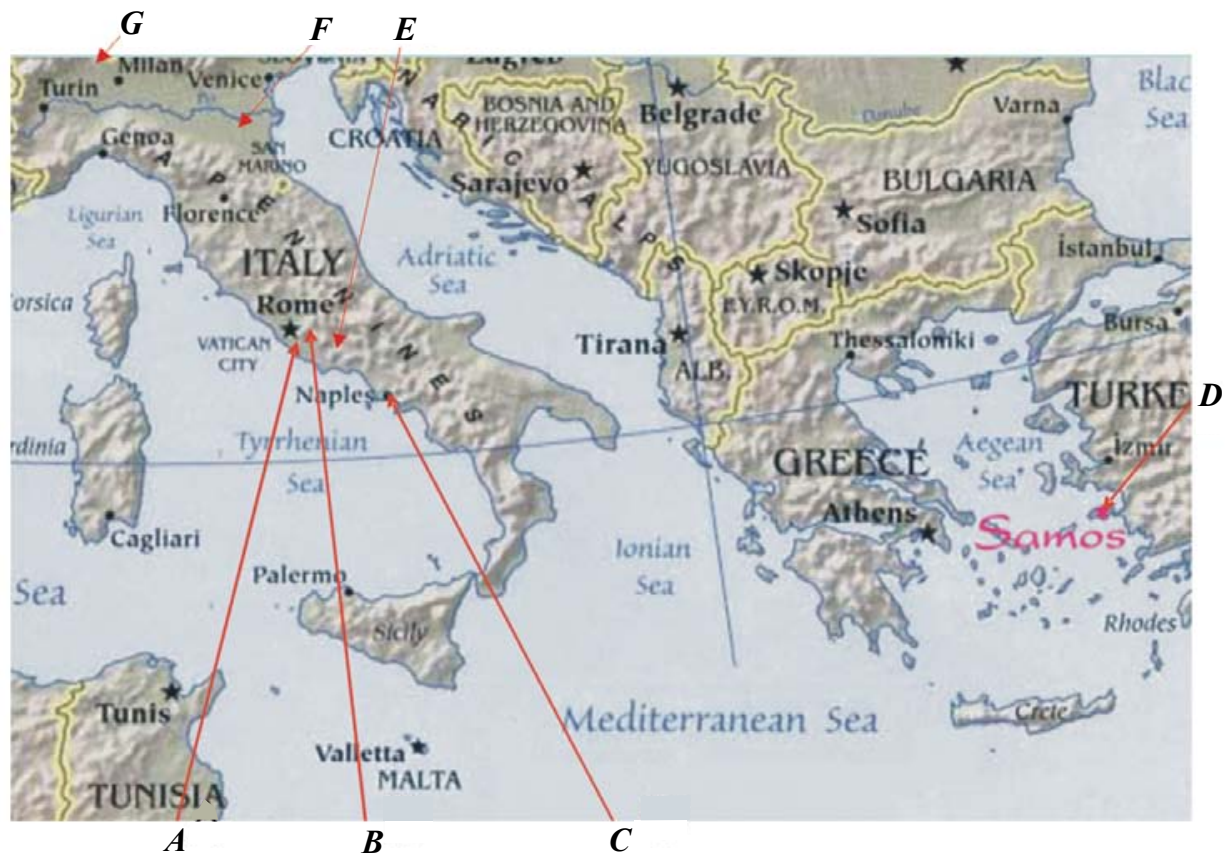

Figure 29. Location map for the Greek and Roman tunnels discussed in the text and for the Italian caves studied for paleoseismicity: $(A)$ Albano tunnel; $(B)$ Nemi tunnel; $(C)$ the aqueduct of Naples; $(D)$ Eupalinus tunnel; $(E)$ Grotta del Cervo and Grotta a Male; $(F)$ Spipola and Buco Dei Buoi caves just south of Bologna; and $(G)$ Frassimo cave of Lombardi.

Rome; fig. 29) is 1,450 m long and was excavated in the fifth century B.C. (Castellani and Dragoni, 1997). The tunnel supplies the Albano Cistern, a large underground opening with an area of about $1,436 \mathrm{~m}^{2}$, a total volume of $10,123 \mathrm{~m}^{3}$, and a roof supported by masonry pillars and brick arches. Two pictures are shown at $h t t p: / / w w w . c o m u n e . a l b a n o l a z i a l e . r o m a$. it/Guida/tour15_eng.htm, last accessed January 8, 2010. The Nemi tunnel (also southeast of Rome; fig. 29) is 1,653 m long and probably was excavated around the end of the sixth or in early fifth century B.C. (Castellani and Dragoni, 1997). The age is assigned on the basis of a lack of written record (making it pre-Roman) and on the age of a temple on the shore of Lake Nemi.

The aqueduct beneath Naples, Italy (fig. 29) differs from the previous examples in that it was modified several times in its history. The Greeks excavated the original aqueduct in tuff during the fifth century B.C. (Hofstadter, 2004). It was about $6.4 \mathrm{~km}$ long and as much as $40 \mathrm{~m}$ below the city. In 326 B.C., the Romans expanded the system (Hofstadter, 2004) to 400 $\mathrm{km}$ in length and lined the bottom with concrete because the porous tuff absorbed much of the water during transport and storage. Some sections of the aqueduct are like the tunnels pictured in figure 28 , and these are probably original openings. However, some sections are large, being several meters in length, width, and height (fig. 30).

The Persians excavated aqueducts, most commonly transliterated as qanats, kanats, ganats, or quanats, but also used other spellings and regional variations, such as kahriz or khettara. As recently as 1935, Tehran, Iran, with a population at that time of 275,000 , was supplied by 36 kanats $13-26 \mathrm{~km}$ long and as deep as $150 \mathrm{~m}$, and these had been in use for at least 200 years (Tolman, 1937). One kanat supplying a suburb of Tehran with water was reportedly $60 \mathrm{~m}$ deep. Kanat building has been going on since at least 800 B.C. Many were excavated in alluvial fans (fig. 31), which are dominantly derived from volcanic tuff and limestone (Tolman, 1937); the limestone supplies enough calcium carbonate to at least partly indurate the fans. About 22,000 kanats are known in Iran, comprising more than $270,000 \mathrm{~km}$ of tunnels, and as recently as 1968, kanats supplied 75 percent of the water used in Iran (Wulff, 1968). Throughout most of their length, kanats have no ground support, and in unstable ground, oval hoops of baked clay are used as ground support. Kanat openings are about $1 \times 1.5 \mathrm{~m}$, and the first 3-5 $\mathrm{m}$ are commonly reinforced with stone, mainly as a protection from stormwater surges (Wulff, 1968).

Based on the current 2009 literature search, it is uncertain whether any of the kanats, dating from several centuries B.C., have been in continuous use from that time to the present. It is likely that some are old because there are reports of the continuous maintenance that is required to remove silt and to repair local areas of collapse. The Bam earthquake (magnitude $[M]=6.6)$ of December 26, 2003, caused serious damage to the kanats used for irrigation in the affected region (United 

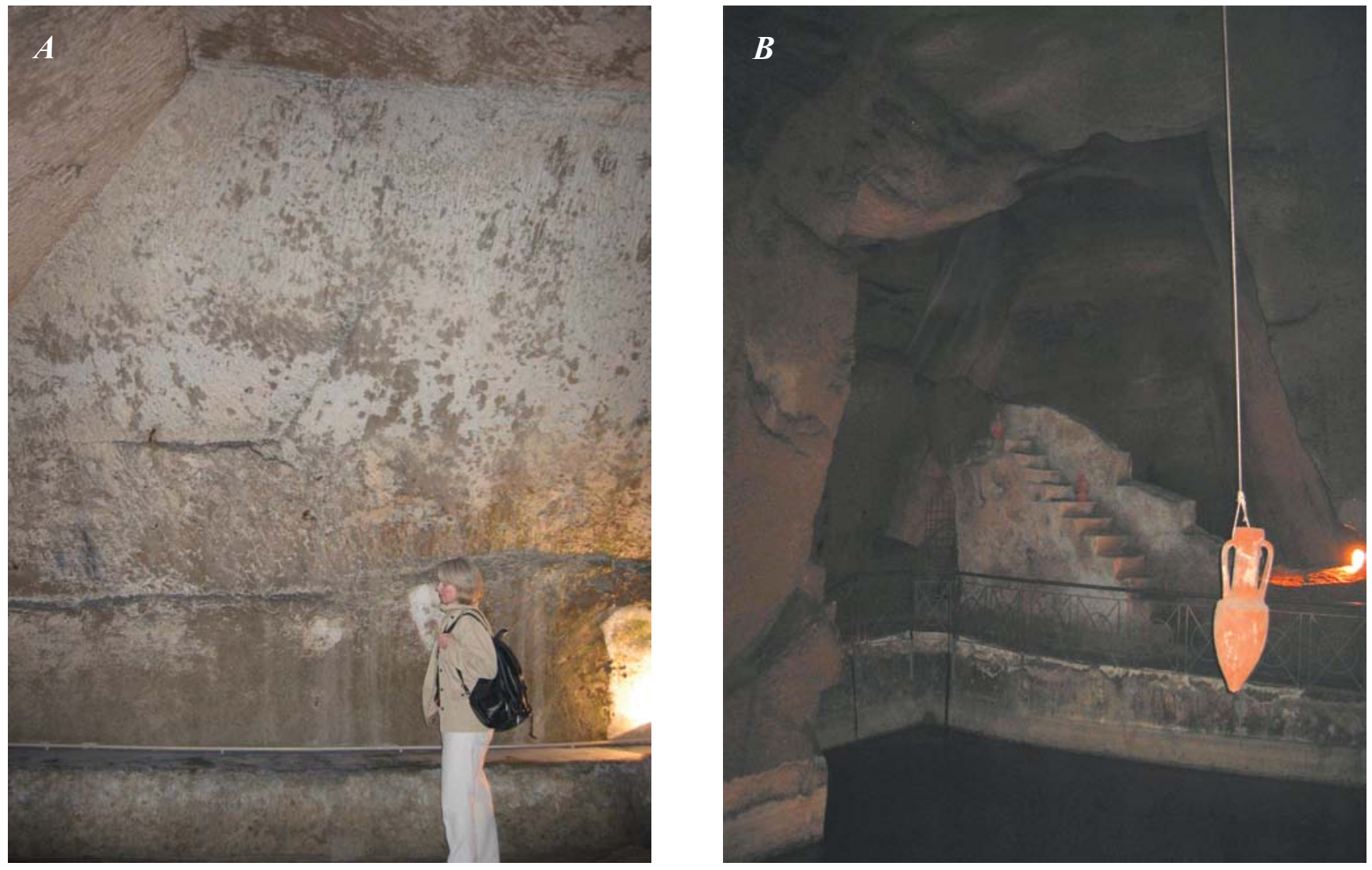

Figure 30. (A) Large cisterns excavated in tuff 40 meters below Naples, Italy. (B) Part of the 400-kilometer-long aqueduct system (photographs by J.S. Stuckless).

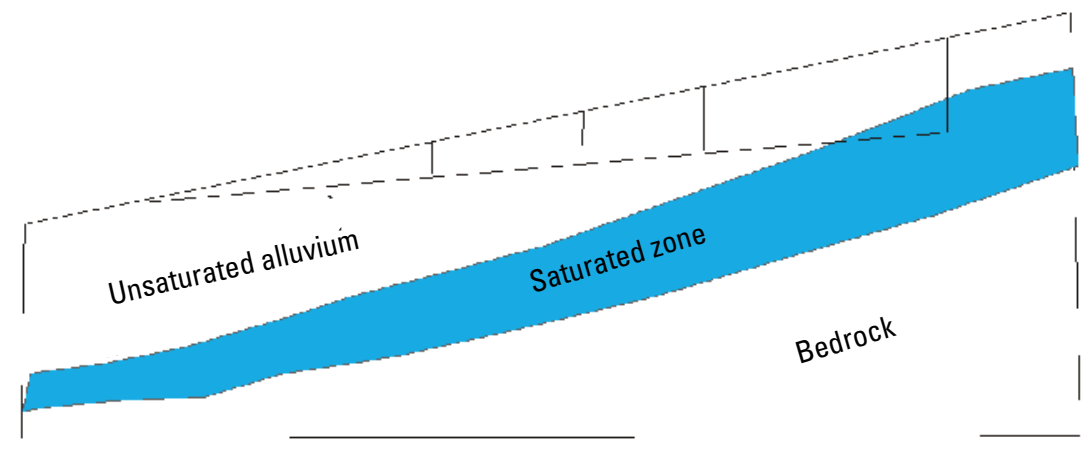

Figure 31. Schematic cross section of a kanat. A well is dug near the top of an alluvial fan deep enough to intersect an aquifer. A series of shafts are dug along a line to define the kanat and provide access for air circulation and removal of muck. Workers connect the shafts and finally cut into the aquifer. 
Nations press release SAG/211). Web site http://www.iraniantrade.org/NNewsUpdates/00000877.htm (last accessed May 4, 2010) provides more information on kanats and notes that they are used in at least 34 countries.

Kanats were introduced to Egypt around 500 B.C. where they irrigated more than $4,600 \mathrm{~km}^{2}$ of land (Tolman, 1937). Although their individual lengths are not known, they likely extend hundreds of kilometers under the desert eastward to intersect seepage from the Nile (Tolman, 1937). Until the early 20th century, some of the Egyptian kanats were still flowing and were thought to be natural springs until ancient documentation and investigation showed that they were indeed kanats.

The Etruscans buried their dead in excavated tombs starting in the mid-seventh century B.C. (Gore and others, 1988). More than 6,000 Etruscan tombs have been discovered, and there may be $2-3$ times that number. The town of Tarquinia, which is about $100 \mathrm{~km}$ north of Rome, is home to some of the more famous tombs. East of the town, there are about 20 tombs, mostly constructed around 500 B.C., but one is as young as 125 B.C.; 12 of the tombs could be visited by tourists in May of 2003. The tombs, excavated in tuff, have openings roughly $4 \mathrm{~m}$ by $5 \mathrm{~m}$ by $2 \mathrm{~m}$, and the ceilings are only about $2 \mathrm{~m}$ below land surface. One of the tombs visited in $2003 \mathrm{had}$ a large spall from the roof, caused by apparent movement on a subvertical joint, but there was no other evidence of collapse.

The following information was taken from $h t t p: / /$ www.catacombe.roma.it/ and http://en.wikipedia.org/wiki/ Catacombs_of_Rome (last accessed August 2, 2005). In the second century A.D., Christians started burying their dead in the excavated catacombs. Five catacombs are known in and around Naples and 60 in the vicinity of Rome; five in the vicinity of Rome are open for public tours. The catacombs of Rome occupy about 600 acres (nearly 250 hectares), are about 1,000 km long, and are 7-19 m deep. Apparently all of the catacombs of Naples and Rome are excavated in tuff. Passageways are generally narrow $(2.5 \mathrm{~m}$ by $1 \mathrm{~m})$, but some of the galleries are several meters in length, width, and height (fig. 32).

Underground mining for metals throughout Europe was common during the reign of the Roman Empire. This era of mining erased evidence of the size and state of preservation of earlier mines, and much of the preservation of Roman mines, in turn, has been destroyed by subsequent mining, especially open-pit mining. For example, the sulfide deposits at Rio Tinto, Spain, were mined by the Tartessans about $5 \mathrm{ka}$, followed by the Phoenicians, Carthaginians, Romans, Visigoths, Moors, and finally by the British (Davis and others, 2000; Shepherd, 1993). The last mining was by open pit, which by 1935 had left only a few galleries exposed in the walls of the pit (Davies, 1935).

Shepherd (1993) and Davies (1935) presented location information and descriptions for most of the ancient mines. Two of the gold mines (Dacia in Romania and Dolaucothi in Wales) were still stable enough to be open for tours in 2009. In addition to mining for metals, the Romans created large tunnels to transport water. The tunnel at Tresmines, Portugal, is $60 \mathrm{~m}$ wide, $80 \mathrm{~m}$ high, and $480 \mathrm{~m}$ long, and the tunnel at Corta das Coras is $100 \mathrm{~m}$ by $100 \mathrm{~m}$ and $350 \mathrm{~m}$ long (Shepherd, 1993). Shepherd makes no mention of roof support, but the large Roman cistern beneath Istanbul has supports on about $5-\mathrm{m}$ centers. This cistern is smaller than those cited by Shepherd $(143 \times 65 \times 9 \mathrm{~m})$.

As described in the previous section, Buddhist monks carved temples into the Deccan basalts of west-central India from approximately the second century B.C. until the 10th century A.D. (Behl, 1998). Although manmade, these
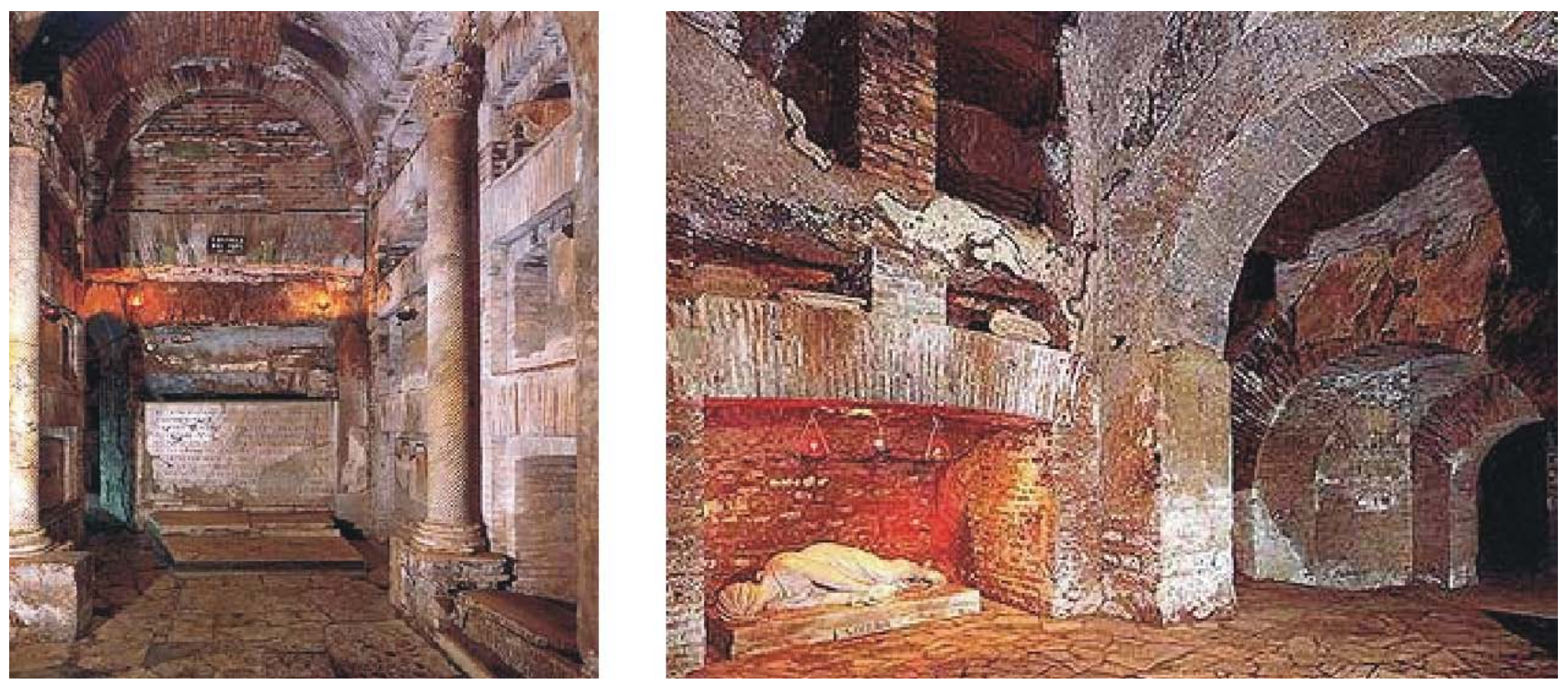

Figure 32. Crypt of the Popes (left) and Crypt of Saint Cecilia (right) in the Catacomb of Callixtus, Rome, Italy. These are among the oldest parts of the Catacomb (photographs by J.S. Stuckless). 
excavations are commonly referred to as Buddhist caves. There are 31 caves at Ajanta, some dating back to the second century B.C., but most were excavated in the late fifth or early sixth century A.D. They are carved along a 550-m-long, horseshoe-shaped gorge of the Waghora River. Each temple originally had steps carved into the rock leading up to it, but only cave \#16 still has a vestige of steps. The monsoonal climate has destroyed the exterior stone structures exposed to the elements, but subterranean openings are well preserved. Similarly preserved are Buddhist caves from the 5th through the 10th centuries A.D. at Ellora and from the 9th century A.D. at the Jain caves at Sittanavasal (Behl, 1998). The Jain monks also excavated caves into sandstone in northeastern India in the second century B.C. The 25 excavated Buddhist caves are currently standing open and are advertised as a tourist attraction (http://www.indyahills.com/orissa/udaygiri.html, last accessed July 21, 2005). Buddhist monks also excavated caves in the sandstone of Dunhuang, China, from the 4th-14th centuries A.D. A total of 812 such caves are known, with rooms large enough to contain paintings that cover more than 45,000 $\mathrm{m}^{2}$ (Whitfield and Otsuka, 1996).

Although the sizes of the Buddhist caves have not been reported for most sites, sizes are given for the Ajanta caves, and each excavation has a larger cross section than that proposed for a mined geologic repository at Yucca Mountain, where excavation drifts would have a 5.5-m diameter. For example, Cave \#10 is $30.5 \mathrm{~m}$ by $12.2 \mathrm{~m}$. Cave \#1 is $2.82 \mathrm{~m}$ by $6.73 \mathrm{~m}$ with a ceiling height of $4.11 \mathrm{~m}$. Cave numbers 4,16 , $17,21,23$, and 24 are of similar size. Cave \#2 has a verandah of $14.10 \mathrm{~m}$ by $2.36 \mathrm{~m}$, a main hall of $14.73 \mathrm{~m}$ by $14.5 \mathrm{~m}$, and a shrine of $4.27 \mathrm{~m}$ by $3.35 \mathrm{~m}$. Cave \#16 has a verandah of $19.8 \mathrm{~m}$ by $3.25 \mathrm{~m}$ and a main hall of $22.25 \mathrm{~m}$ on a side with a height of $4.6 \mathrm{~m}$. Cave \#17 has a verandah of $19.5 \mathrm{~m}$ by $3 \mathrm{~m}$ and a main hall that is $19.5 \mathrm{~m}$ square. In spite of these large sizes, no collapse has been reported. As in the case of the Egyptian tombs, most of the Ajanta paintings appear to have had some water damage and vandalism.

As discussed in the previous section on "Manmade Openings," the Christians of Cappadocia, Turkey, excavated underground cities and churches during the $2 \mathrm{~d}$ through 11 th centuries A.D. One of these cities, Derinkuyu, covered approximately $4 \mathrm{~km}^{2}$ and had an estimated 15,000-20,000 inhabitants (Toprak and others, 1994) during much of the first millennium A.D. As of 1994, eight levels of ancient habitation had been investigated. Access to the underground cities was by way of narrow passageways that could be closed by rolling a 1.5-m-diameter millstone across the opening (fig. 33). The excavated rooms were generally several meters across and more than $10 \mathrm{~m}$ long.

The geology of Cappadocia (Toprak and others, 1994) is similar to that of southern Nevada (Sawyer and others, 1994). In both regions, the upper Tertiary section is composed of a

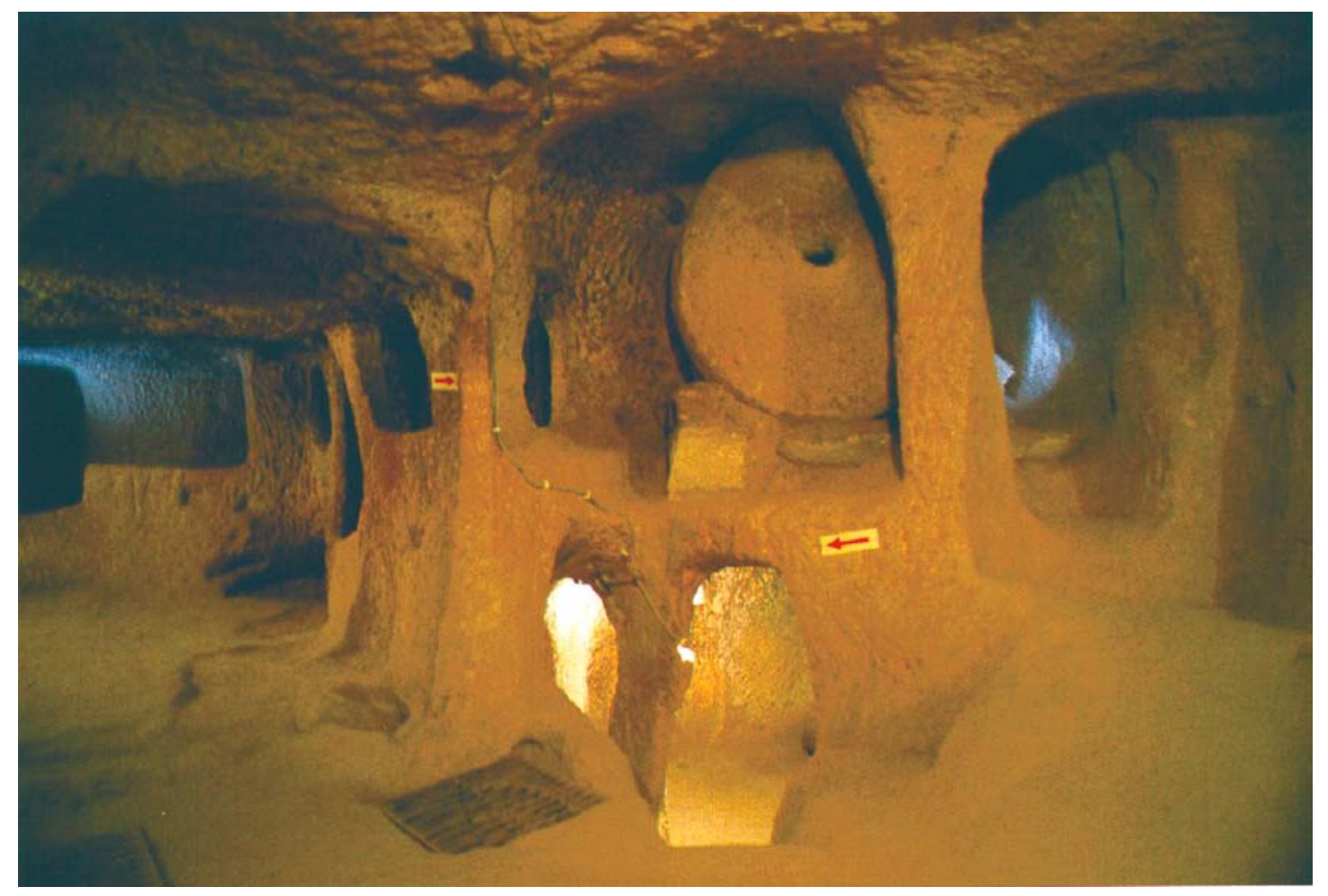

Figure 33. Photograph of a room in the underground city of Kaymakli, Turkey. The millstone is about 1.5 meters in diameter (Stuckless, 2000, fig. 13). Arrows indicate the route of a self-guided tour for visitors. 
thick sequence of silicic volcanic rocks. At Yucca Mountain, the host rock for the proposed repository is a densely welded, quartz latite ash-flow tuff formed about 11.6 Ma, whereas the underground cities of Cappadocia are hosted by a partially welded, rhyolite ash-flow tuff formed about 4.5 Ma. The difference in welding for the proposed repository horizon at Yucca Mountain and the host rock for the underground cities of Cappadocia, however, results in a markedly different fracture density and engineering properties between the two sites. Fracture density, which is a major variable contributing to underground collapse, is much less in the underground cities, and no ground support was used (fig. 33). Thus, the fact that there has been no collapse in the underground cities during the past 1,500-1,800 years indicates that excavations in tuff should be stable for long periods of time. In the case of Yucca Mountain, where fracture density is greater, ground support would need to be carefully engineered, but even after that support degrades, little collapse is predicted for the emplacement tunnels (BSC, 2001a). The Cappadocia example seems to support this prediction.

Churches were excavated into the tuff north of the underground cities at Goreme during the 9th-13th centuries A.D. (Toprak and others, 1994). All but one of these shows no evidence of collapse, the exception being collapse of a cliff face that exposed part of the inside of one church. The interior portions of the church, however, are still in excellent condition, and the painted walls and ceilings are well preserved except for minor water damage and vandalism (Stuckless, 2000).

Some of the underground openings excavated into the tuffs of Cappadocia are still used as dwellings. There are at least two other places where underground excavations also are still used as dwellings. In Tunisia, $20-40 \mathrm{~km}$ south of the city of Gabes, 10 underground villages, some of which date back nine centuries, are excavated in limestone (Golany, 1983). The walls are composed of 2-m-thick layers of poorly indurated limestone, which are easily mined out, as well as better indurated layers of similar thickness forming ceilings. Room sizes are typically $2-2.5 \mathrm{~m}$ on a side with flat ceilings that may have a supporting column in the center. In northern China, there are thick loess deposits that are only slightly indurated and easily excavated. However, the internal structure of the deposits is such that the loess can form vertical cliffs as high as $30 \mathrm{~m}$. The underground dwellings accommodate more than 10 million people who farm the land above their houses (Golany, 1983).

Although all the examples given so far either lack ground support or use only unmined pillars, there are examples of wooden ground support. Around the beginning of the second century A.D., the Roman Emperor Hadrian mandated the use of wooden supports in all mines. Shepherd (1993) provided a discussion of some examples but did not comment on the stability of openings that were shored up. Tombs in China provide a different kind of example. Sixteen emperors from the Ming Dynasty (A.D. 1368 to A.D. 1644) were buried in tombs excavated in rock near Beijing. The earliest of the tombs has
32 sandalwood pillars $1.17 \mathrm{~m}$ in diameter, and all are still intact and sturdy (Golany, 1989).

\section{Response of Caves to Seismicity}

The foregoing discussion shows that both natural and manmade underground openings hold up well in an undisturbed setting. In actual fact, many of the examples given, as well as several others not discussed, have probably been subjected to significant ground shaking. For example, the caves of Ajanta are within a seismically active area of India, and the Laurion mines, as well as the Israeli, Greek, and Roman tunnels, are within seismically active areas around the Mediterranean Sea. Yucca Mountain is also within a moderately seismic region, and some degree of ground shaking likely will occur during the 10,000-year postclosure time, and almost certainly during the next million years.

Natural analogues provide one possible way of assessing ground motion because they can add a dimension of time that is not available with instrumental or even historical records. Archeological examples such as tombs and tunnels, as well as natural features such as caves and balanced rocks, can provide insight into long-term seismic records. For example, pillars at the Byzantine church of Sussita in the Golan Heights of Syria were knocked down by an earthquake January 18, A.D. 749 (Russell, 1982), and apparently they were all tipped in the same direction in response to the first motion; their orientation lying on the ground records the azimuth of that motion.

Seismic damage to caves is well documented in several publications; however, documentation of caves with no damage is probably underreported. Mitchell Caverns in California is about $95 \mathrm{~km}$ from the epicenter of the Hector Mine earthquake (M=7.1) of 1999 and $110 \mathrm{~km}$ from that of the Landers earthquake (M=7.3) of 1992 (U.S. Geological Survey, National Earthquake Information Center for Seismology, Denver, Colorado). The Landers event caused some fracturing of stalagmites near the entrance of the cave, but neither event disturbed delicate formations deeper in the cave (fig. 34). Neither event appears to have caused failure of the roof or walls of the cave.

The Sutherland Peak earthquake of 1887 (centered about $20 \mathrm{~km}$ south-southwest of the New Mexico-Arizona border in Sonora, Mexico) had an estimated magnitude of 7.2 and a Mercalli-scale intensity of XI to XII in the vicinity of the epicenter (Gilli and Serface, 1999). The seismic activity was severe enough at Sutherland Peak Cave to knock over one large stalagmite, although its breakage may have been largely due to failure of the clay beneath it. Soda straws, such as those shown in figure 35, were broken off and stuck in the clay floor. The report by Gilli and Serface (1999), which is specifically about paleoseismic damage to caves, did not mention damage to the roof or walls of the cave. Kartchner Caverns, approximately $50 \mathrm{~km}$ to the north but within the same Mercalli-scale 

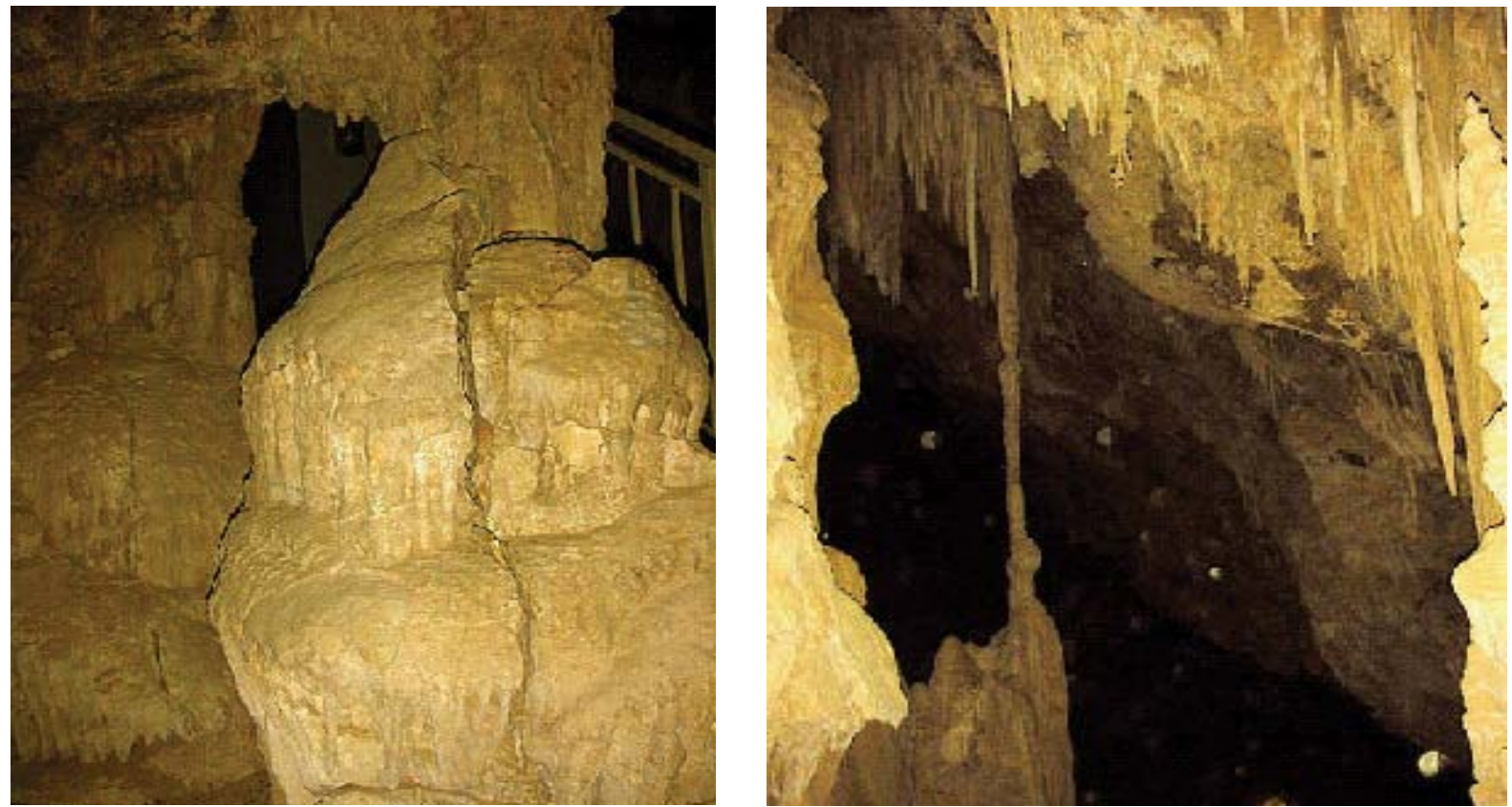

Figure 34. Mitchell Caverns, California, showing a cracked stalagmite near the entrance (left) and an intact delicate stalactite from deeper in the cave (right) (photographs by Abraham Van Luik, U.S. Department of Energy).
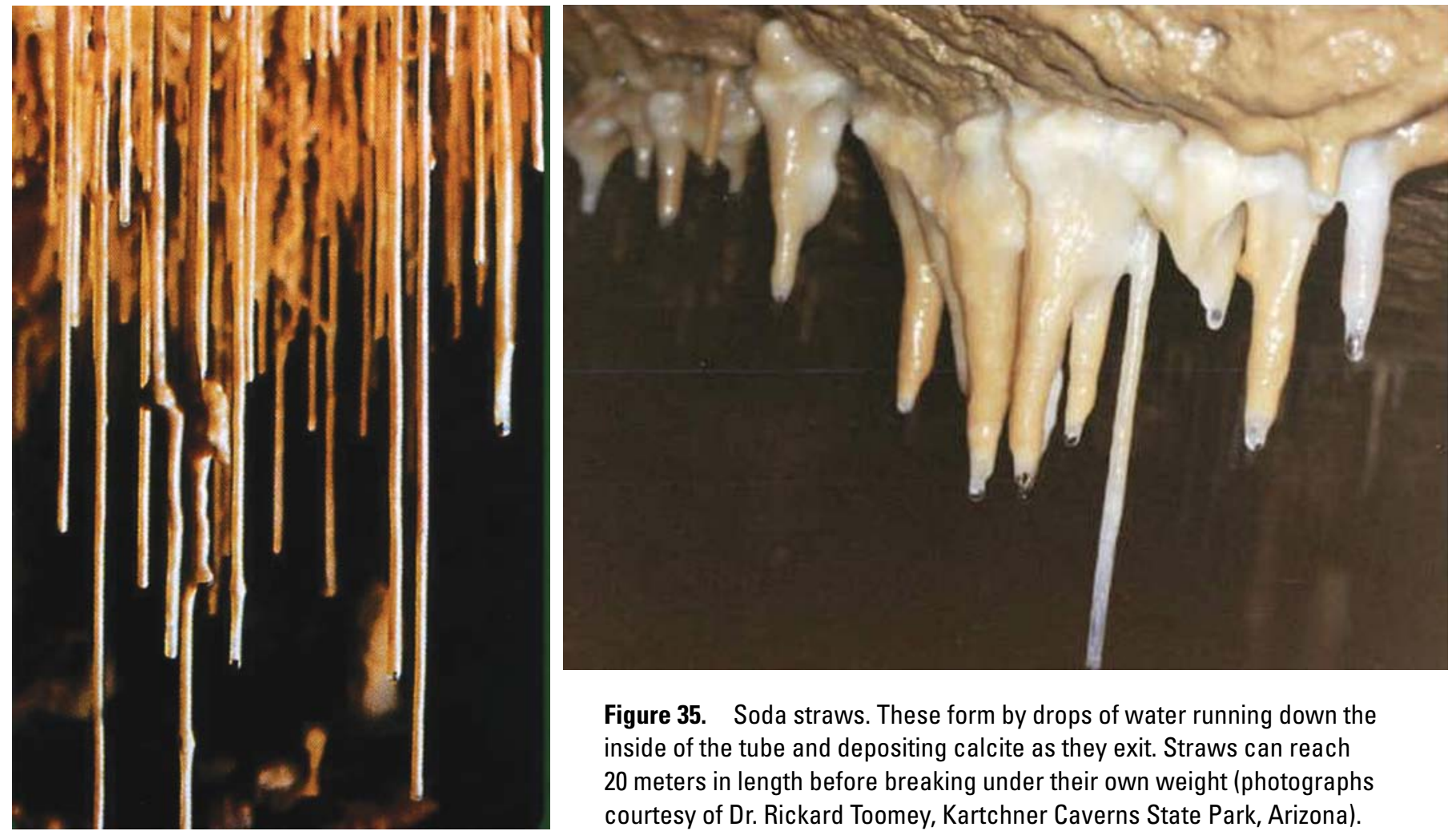

Figure 35. Soda straws. These form by drops of water running down the inside of the tube and depositing calcite as they exit. Straws can reach 20 meters in length before breaking under their own weight (photographs courtesy of Dr. Rickard Toomey, Kartchner Caverns State Park, Arizona). 
intensity zone of IX (Stover and Coffman, 1993), did not incur visible damage.

Damaged soda straws have been used in two separate studies of seismic damage within caves. In the first of these, the orientation of broken soda straws was measured in Paradet Cave, France. These soda straws were broken by a 1996 magnitude-5.2 earthquake with an epicenter $10 \mathrm{~km}$ away and acquired a strong preferential east-west alignment on the floor of the cave (Gilli and others, 1999) in response to the direction of ground motion. The damage was common at the $60-\mathrm{m}$ level. This relatively great depth for damage may relate to the fact that the cave is tectonic in origin, being situated on a $50^{\circ}$-dipping reverse fault. Also, the cave is located on a limestone crest, which may have had an amplifying effect. Soda straws are very fragile, and Gilli and others (1999) estimated that peak ground acceleration (PGA) of $7 \mathrm{~m} / \mathrm{s}^{2}$ or greater is needed to cause homogeneous soda straws to break and fall. This acceleration is 5 times greater than that observed on the spectrum with 5 percent damping, but Gilli and others (1999) asserted that accelerations of 3-4 m/s $\mathrm{s}^{2}$ are commonly observed for magnitude 5 earthquakes at small distances from the epicenter and 5 percent damping, and even higher accelerations are possible with smaller percentages of damping. They noted that other variables must have been involved, in that all the straws were not broken. Again, there was no mention of damage to the roof or walls of the cave.

The second study involving soda straws was in Observatoire Cave, Monaco, where abundant flowstone on the floor of the cave partly covers some broken soda straws and completely buries others, as revealed by drill core taken from the floor of the cave. Gilli (1999) attributed the youngest layer of broken soda straws to an 1887 earthquake, which had a Mercalli-scale intensity of VIII in the vicinity of the cave. A deeper layer, also with broken soda straws, was likely the result of an earthquake in 1564 for which the cave was just outside the intensity VIII contour. The end of the drill core penetrated a broken stalactite in a layer dated as older than $35 \mathrm{ka}$. This oldest event was likely the only one intense enough to cause roof or wall failure, but any such evidence has been buried by flowstone. No failure of the cave due to earthquakes more recent than $35 \mathrm{ka}$ was described.

Spipola and Buco Dei Buoi are two caves just south of Bologna, in northern Italy, (figs. 29, 36) that have experienced considerable tectonic activity. Longitudinal cross sections were cut through two stalagmites, one from each of these caves, and for both stalagmites the axis of growth had changed several times. Inasmuch as growth should be vertical, Postpischl and others (1991) concluded that variations in apparent direction of growth were due to tectonic shifts in the surface upon which the stalagmites were growing. They chose to correlate the largest shift in the growth axes to the largest historical earthquake, which had a Mercalli-scale intensity of X to XI in the vicinity of the caves. They then calculated an average growth rate of $0.12-0.15 \mathrm{~mm} / \mathrm{yr}$, which was used to approximately date each growth band. Each discontinuity correlated with a known earthquake for which the epicenter was within
$15 \mathrm{~km}$ and for which the Mercalli-scale intensity in the vicinity of the caves was greater than VI (fig. 36). The most intense events knocked over some stalagmites and caused some offset of stalagmite-stalactite pairs, but no general collapse of the caves was reported.

The acceleration needed to knock over stalagmites was studied by bending tests on previously failed stalagmites from Hotton Cave in Belgium. The results for 35 tests conducted by Cadorin and others (2001) ranged from $0.3 \mathrm{~m} / \mathrm{s}^{2}$ to $100 \mathrm{~m} / \mathrm{s}^{2}$ for height-to-diameter ratios of about 8 . These authors noted that other factors must be involved to account for the large accelerations being calculated; for example, the stalagmites were already broken, and the breaks may have occurred only on the weak planes.

Farther to the north of Bologna in Lombardi, Frassimo Cave has evidence of major tectonism without collapse (fig. 29). One passageway is offset along a gently dipping joint by more than a meter but with no apparent damage to the roof (Bini and others, 1992). Offset of passageways without reported roof collapse has also been reported in Costa Rica (Gilli, 1996); there, the studied caves are within 50-100 km of seven magnitude-7 or greater earthquakes in the last century alone. Bini and others (1992) reported that speleothems that have been knocked down yield U-Th (uranium-thorium) ages (presumably for the outer surfaces) that are older than $350 \mathrm{ka}$. Thus, the passageways have remained open for at least that long a period of time in spite of repeated seismic events.

Paleoseismic studies also have been conducted in caves of central Italy, about $70 \mathrm{~km}$ east to southeast of Rome. The Grotta del Cervo and Grotta a Male (fig. 29) both have evidence of seismic shaking. The karst area is adjacent to the area affected by the strongest earthquake in Italian history. The December 1456 earthquake caused a rockslide that closed the entrance to Grotta del Cervo. The cave remained closed until uncovered in 1986. Carbon-14 dating of calcite shows that breakage of speleothems, which now lie on the floor for the first $400 \mathrm{~m}$ inside the cave, was a result of the 1456 earthquake (Postpischl and others, 1991). The collapsed stalagmites have a preferred orientation on the floor of the cave, which reflects the effects of ground motion. Beyond $400 \mathrm{~m}$, the stalagmites appear to have remained upright, but some fracturing of the wall was noted. In addition to the ${ }^{14} \mathrm{C}$ dating, speleothems have been dated by $\mathrm{U}-\mathrm{Th}$. These results reveal four older seismic events intense enough to topple stalagmites (30-40 ka, 90-110 ka, 110-150 ka, and older than $350 \mathrm{ka}$ ). In spite of recurring strong seismicity, there are no reports of roof collapse (Postpischl and others, 1991).

The Soreq and Har-Tuv caves in Israel are located approximately $40 \mathrm{~km}$ west of the Dead Sea transform, which is a major strike-slip fault and similar in some ways to the San Andreas fault in the Western United States. It is $1,000 \mathrm{~km}$ long, with a slip rate during the last 1,000-1,500 years of 15-35 mm/yr (Garfunkel and others, 1981) as compared to a length of 1,200 km and a slip rate of $20-35 \mathrm{~mm} / \mathrm{yr}$ for the San Andreas (http://www.data.scec.org/fault_index/sanandre.html, last accessed July 26, 2005). 


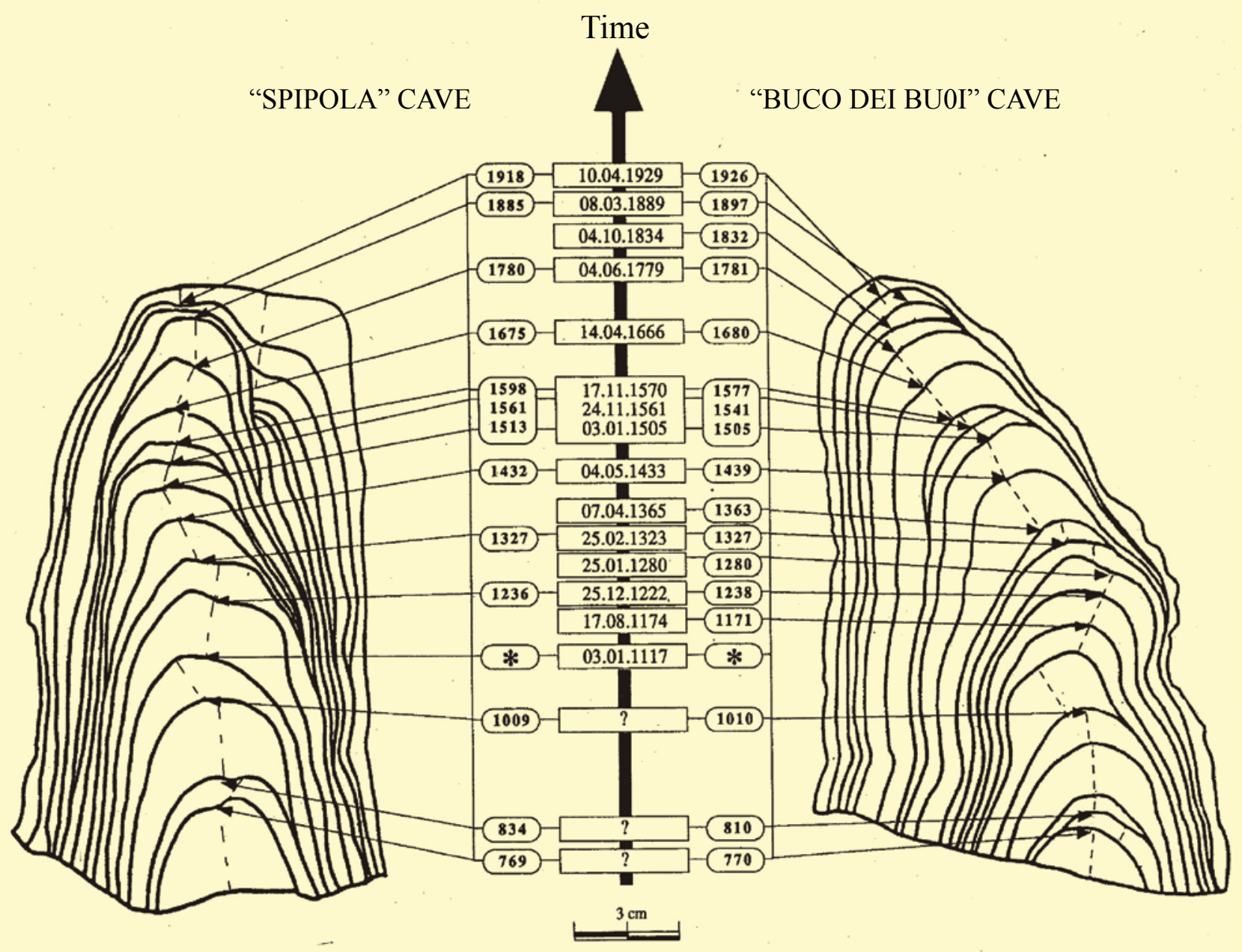

Figure 36. Cross sections through two stalagmites from caves in northeastern Italy. Dates in ovals were calculated from distance between growth bands. Growth rate was calculated by assuming that the earthquake of January 3,1117 (marked with an asterisk) created the large change in axis direction. Intensities for the dated events (shown in boxes) from most recent to oldest were VII, VI-VII, VII, VII, VI, III, VIII, VII, VII, VIII, VIII,VI, VI, VI-VII, and X-VI (Postpischl and others, 1991 [fig. 2 and table 1]).

The caves are small (less than 5,000 $\mathrm{m}^{2}$; Kagan and others, 2005), and had no natural opening before their discovery during excavation in the 20th century. The damaged speleothems have been dated by the uranium-thorium method and correlated with a lacustrine record. The ages extend back 185,000 years, and there is evidence for 13-18 episodes of seismic damage. The authors argue that Mercalli-scale intensities greater than VI to VII are needed to damage speleothems, noting that a 1927 earthquake with a magnitude of 6.2 did not damage the caves. The authors posit that the observed damage could have been caused by a range in magnitudes from 7.6 to 8.2 , with a corresponding range in recurrence intervals of 6,000-10,000 years. Some roof collapse in response to seismicity was noted in the study of Soreq and Har-Tuv caves, but the collapse did not reach land surface.

\section{Response of Manmade Underground Openings to Seismicity}

There have been several compilations on the response of tunnels to seismic disturbances. Considerable information that is largely anecdotal also is available from mines and other subterranean excavations. In both settings, the lack of damage below ground as the result of a seismic event is probably underreported. This section summarizes information from geologic and archeologic sources.

Raney (1988) summarized the effects on Western U.S. mines from 28 historical earthquakes of Mercalli-scale intensity VIII or greater. Most mines that were close to an earthquake (24 in number) reported no damage at depth; three reported minor damage such as cracked timbers, and three 
reported major or unspecified damage. Damage to surface structures was ubiquitous. For example, the Owens Valley, California, earthquake (also referred to as the Lone Pine earthquake) of 1872 , had a Mercalli-scale intensity of X to $\mathrm{XI}$ and may have had a magnitude of 8 . The earthquake was rumored to have caused breakage of a few sets of timbers in some mines in the vicinity of Austin, Nevada, about $320 \mathrm{~km}$ to the north-northeast. The earthquake was distinctly felt in the vicinity of Virginia City, Nevada, about $320 \mathrm{~km}$ to the northnorthwest. The earthquake cracked some timbers in quartz mines in the vicinity of Jackson, California, about $240 \mathrm{~km}$ to the northwest. The mining camp of Cerro Gordo, about $30 \mathrm{~km}$ southwest of the epicenter, was severely damaged, but two separate accounts reported that no damage occurred underground. At Hot Springs (presumably, Benton, California, which is about $130 \mathrm{~km}$ to the northwest), several severe shocks were felt on the surface, but miners at the 60-m level felt nothing. About $50 \mathrm{~km}$ south-southwest of the epicenter, there was heavy damage to railroad tracks, roads, and homes at the Eclipse Mine and damage to the mill of the Kearsarge Mine, but no damage was reported for the underground workings. At the Eclipse Mine, one miner was injured by a minor rock spall. Finally, miners underground in the vicinity of Bakersfield, California (about $130 \mathrm{~km}$ southwest of the epicenter), did not feel the earthquake.

The only documented example by Raney (1988) of major mine damage underground was proximal to the epicenter. The Kennedy Mine was reported to be "near the epicenter" of the Pleasant Valley, Nevada, earthquake. The earthquake, which occurred in 1915, had a Mercalli-scale intensity of X and a magnitude of 7.7. It caused "a considerable portion of mine tunnels" to cave in; however, no damage was reported in the underground at the Golconda Mine (165 km from the Kennedy Mine) or at Elko (70 km from the Kennedy Mine). Brown and others (1981) note that stress changes due to extraction of ore can contribute to the susceptibility of mines to earthquake damage.

Stevens (1977) noted that if the dimensions of mine openings are considerably smaller than the wave length of an incident SH (horizontal shear) wave, ground motion at the surface will be about twice as great as that at depth. Furthermore, solid rock is a good energy transmitter and, as such, waves pass through it without losing velocity. If speed is lost, kinetic energy is maintained by increased amplitude, which in turn causes increased shaking. These factors apparently account for the numerous reports of earthquakes being felt strongly at the surface but not noticed at depth; Stevens (1977) related seven such cases. This is not universally true, and Stevens (1977) related six cases where shaking was felt in mine workings to at least a minor degree. This apparent disparity may be explained by variations in the fundamental period of an earthquake. When the period ( 1 /frequency) is less than 1 second, the above-ground amplitude is at least twice the below-ground amplitude, but when the period is increased to 4 seconds or greater, the amplitudes above and below ground are about the same (Brown and others, 1981).
As with mines, there is considerable anecdotal information on stability of tunnels during seismic events. Many of the tunnels described earlier are located in seismically active areas, although no specific mention was made of their stability in response to seismic shaking in the materials examined during the current literature survey. The tunnel of Hezekiah is only about $30 \mathrm{~km}$ from the Dead Sea transform fault system and has probably been subjected to several moderate to severe earthquakes; however, there has been no apparent damage. The tunnel of Eupalinus is in close proximity to the ancient Greek town of Ephesus, which was destroyed by earthquakes several times. Likewise, the Nemi and Albano tunnels of central Italy are within an area of strong seismicity, similar to that which caused the 1456 earthquake that covered the entrance to Grotto del Cervo with a landslide, but reports of damage are lacking. Eckel (1970) reported that the Good Friday earthquake ( $\mathrm{M}=9.2)$ in Alaska (fig. 37) caused no damage to the Alaskan Railroad tunnel near Whittier nor to the coal mines in the Matanuska Valley. Minor damage was reported to the intake (which is in soft sediment) for the Eklutna hydroelectric tunnel, and the earthquake may have caused a longitudinal crack in a tunnel between Cooper and Kenai Lakes. These tunnels were in the Mercalli-scale intensity zones of VII to X.

The July 28, 1976, earthquake in the heavily industrialized city of Tang-Shan, China, had a magnitude of 7.8. Surface intensities at Tang-Shan were such that in the area where the strongest shaking occurred, 80-90 percent of the surface structures collapsed. However, for important engineered structures immediately below the surface, there was generally no serious damage regardless of the depth or size of the structure (Wang, 1985). In the case of the January 16, 1995, earthquake in Kobe, Japan $(\mathrm{M}=6.9)$, tunnels in the epicentral region experienced no major damage or even partial collapse for PGAs measured at the surface of about 0.6 gravity unit (g) (Savino and others, 1999).

The understanding of the response of underground openings to seismic events has advanced greatly in the last few decades. Sharma and Judd (1991) for example, studied the susceptibility of underground facilities to damage and observed that damage decreases with depth and increases with increasing PGA. The latter variable increases as earthquake magnitude increases and as distance from the epicenter decreases. Sharma and Judd (1991) also noted that openings in a solid medium behaved better than those in unconsolidated material. They also suggested that their dataset is biased toward damage occurring because "there must be literally hundreds of other instances where no damage occurred but observations were not documented" (Sharma and Judd, 1991, p. 275).

Dowding and Rozen (1978) compiled damage reports for tunnels as a function of PGA at the surface. Their data showed that no underground damage occurred at less than 0.2 gravity unit $(\mathrm{g})$ and little to moderate damage between 0.2 and 0.5 gravity unit (g). Commonly, when damage was reported, it was near the portal or in areas of shallow cover. Dowding and Rozen (1978) also noted that tunnels displaced by fault movement usually incur severe damage. 


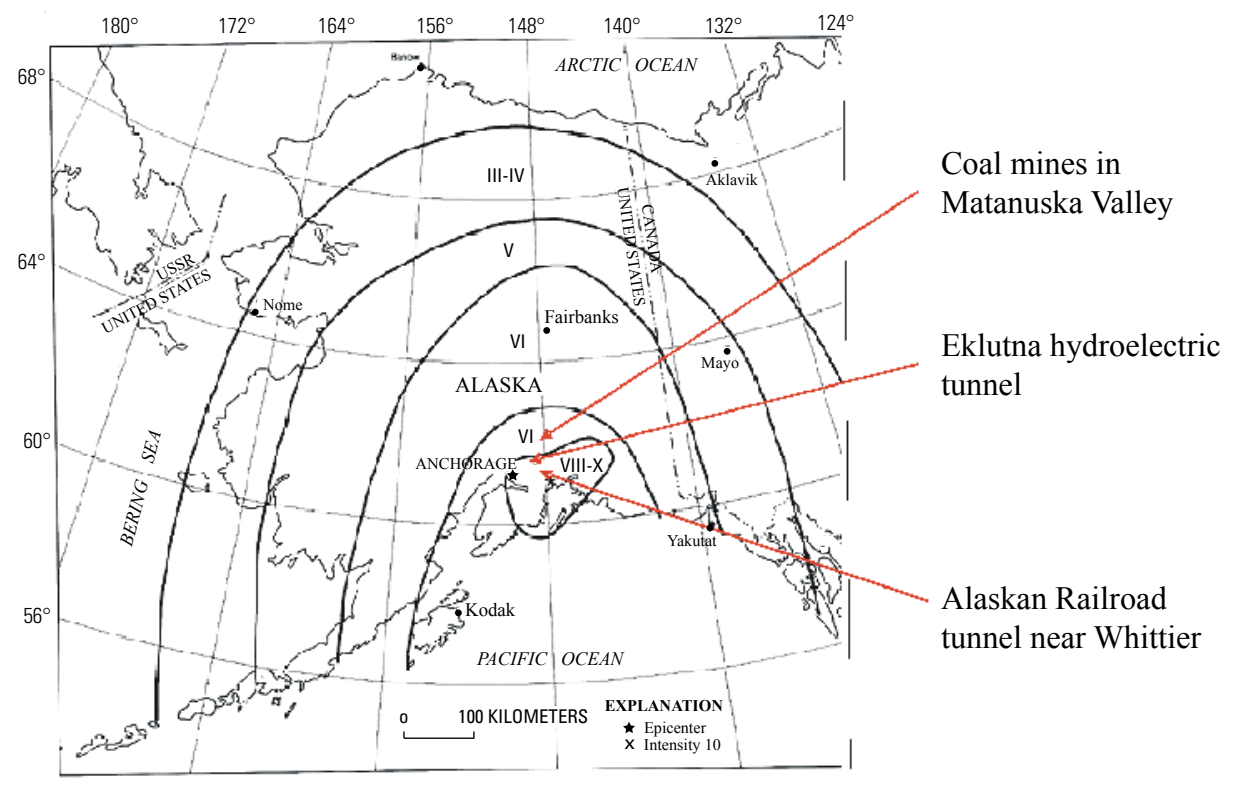

Figure 37. Index map for the 1964 Good Friday earthquake in Alaska showing location of tunnels near the epicenter and approximate contours for earthquake intensity (modified from Stover and Coffman, 1993).

Brown and others (1981) provided six case histories for tunnels with fault movement during earthquakes that document damage and one example for a tunnel displaced by rightlateral creep on the Hayward fault (California). Even when faults move and cut a tunnel, total collapse seems to be rare. A drainage tunnel driven alongside of the Tanna Railroad tunnel (on the main line between Tokyo and Kobe) collapsed during a 1930 earthquake (estimated $\mathrm{M}=7.1$ ), but the main tunnel, estimated to be $0.5 \mathrm{~m}$ east of the active shear zone, incurred only minor cracking in the walls.

Pratt and others (1978) also examined data for subterranean structures and reported few data indicating damage in the subsurface due to earthquakes, which they concluded attested to the decreased effects with depth. They also noted that wells and shafts are not as susceptible to damage from earthquakes as are surface facilities, and that higher frequencies $(50-100 \mathrm{~Hz})$ are more likely to damage subsurface facilities than the lower $(2-10 \mathrm{~Hz})$ frequencies that cause most of the surface damage. (Note that Pratt and others [1978] discuss damage as a function of frequency, whereas Brown and others [1981] express damage as a function of period, the inverse of frequency.)

Power and others (1998) compiled data from 204 tunnels that had experienced seismic shaking, including some data from better-instrumented earthquakes. Their results were similar to those of Dowding and Rosen (1978). They observed that for ground motion with PGAs less than $0.2 \mathrm{~g}$, there was little or no damage in tunnels, and for PGAs of $0.2-0.6 \mathrm{~g}$, damage varied from slight to heavy. All the reports of heavy damage, however, were from a single earthquake in 1923 for which the damage may have resulted from landsliding or collapse of shallow portions of the tunnel. At accelerations greater than $0.6 \mathrm{~g}$, the damage only ranged from slight to moderate, which indicates that the tunnel response to the 1923 earthquake was anomalous. Power and others (1998) also noted that (1) damage was most likely in unlined tunnels and that reinforced concrete prevented heavy damage, (2) some reported damage may be due to causes other than seismic shaking, and (3) wellconstructed tunnels can survive large PGAs without incurring major damage.

Carpenter and Chung (1986) summarized the available literature on damage to underground facilities from earthquakes and underground nuclear explosions (UNEs) for the NRC. They concluded that (1) damage is expected underground if fault displacement occurs, but that damage from shaking alone is limited to the epicentral region with damage to surface facilities more severe than that below ground; (2) amplitude generally decreases with depth; and (3) earthquake damage may be a more serious problem for shafts than for tunnels.

Phillips and Luke (1991) set up an experiment using a UNE as an analogue specific to the proposed geologic repository at Yucca Mountain. They noted that, although the host rocks for the UNE experiment and proposed repository were different (nonwelded airfall tuff compared to welded tuff at Yucca Mountain), the Rock Mass Ratings (RMRs) were similar (57 for nonwelded and 61 for welded). (RMR is an internationally recognized index based on 6 parameters and is used to calculate the stability of discontinuous rock masses.) They noted three differences between earthquakes and UNEs: (1) shear waves dominate over compressional waves in earthquakes, but the opposite is true for UNEs; (2) duration 
of shaking is longer in earthquakes; and (3) frequencies may be different between the two types of seismic sources. Phillips and Luke (1991) analyzed each of these variables and concluded that the UNE was an adequate analogue for an earthquake in terms of seismic effects on a tunnel. Therefore, Phillips and Luke (1991) concluded that a 6.5-magnitude earthquake $16 \mathrm{~km}$ from Yucca Mountain should cause only minor damage to proposed repository emplacement tunnels.

The Little Skull Mountain earthquake of June 29, 1992, had a magnitude of 5.6 and occurred about $20 \mathrm{~km}$ southeast of Yucca Mountain. Examination shortly after the earthquake of the interior of X-tunnel (125 m deep) in the epicentral region indicated no evidence of damage in the tunnel that could be associated with the earthquake (Savino and others, 1999).

\section{Underground Openings Affected by Temperature}

The foregoing descriptions show that both natural and manmade underground openings maintain stability well, both in an undisturbed setting and under seismic conditions. The stability of underground openings also can be affected by temperature. An example of thermal stresses causing rockfall around rock bolts in a heated area occurred at Linwood Mining Company's limestone excavations (A.M. Simmons, Los Alamos National Laboratory, written commun., 2002). Linwood has excavated limestone adjacent to the Mississippi River downstream from Moline, Illinois, since World War I for processing in a kiln. The mine started as a surface quarrying operation, but as excavation progressed, the mine was converted to an underground room and pillar operation. The elevation of the underground workings is lower than the Mississippi River.

The company started venting the kiln exhaust underground in 1971 as part of a solution for controlling dust emissions from the kiln (A.M. Simmons, Los Alamos National Laboratory, written commun., 2002). To do this, a 96-acre portion of the mine was nominally mined with drifts about $10 \mathrm{~m}$ wide and $7 \mathrm{~m}$ high). This portion was walled off from the active workings. Exhaust from the kiln is vented to these workings at $204^{\circ} \mathrm{C}$, leaving the dust behind for later collection.

The mining company adds bolts and mesh when a karstic depression is encountered, but otherwise the mine is essentially unsupported. Possibly for this reason, steel-bar rock bolts were placed near the entry of the exhaust vent. After some period of venting, the rock near the exhaust vent broke out, leaving the bolts that had been emplaced in the rock, with the bottom $5 \mathrm{ft}$ or so of the bolts surrounded by air. It was suggested that the surrounding rock had probably fallen out because heat was transferred up the rock bolt faster than it was transferred through the rock, which resulted in a thermal stress that caused failure for a rock with an unconfined compressive strength of 18,000 pounds per square inch (psi) (about 125 megapascals [MPa]) (A.M. Simmons, Los Alamos National Laboratory, written commun., 2002). This case is not an ideal analogue for conditions that could occur at Yucca Mountain because the repository drift temperatures are expected to remain below $100^{\circ} \mathrm{C}$. However, it is an interesting "bounding" observation and can advise designers of potential unexpected processes.

\section{Summary of Drift Stability Analogues}

The drift degradation analysis report for the proposed geologic repository at Yucca Mountain, Nevada (BSC, 2001b) concluded that (1) even without ground support, there will be little collapse of the emplacement tunnels in either lithophysal or nonlithophysal units of the Miocene volcanic rocks under either static or thermal conditions; and (2) seismic events would cause (a) only minor tunnel damage in the nonlithophysal sections, and (b) only slightly more collapse in the lithophysal units. These conclusions cannot be tested directly with analogues, but their reasonableness can be assessed.

Caves in many rock types, but mostly in carbonates and lava, are known to stand open for tens of thousands to millions of years in regions where no seismic activity has been documented (although there may have been prehistoric activity). Caves also have been investigated in areas where strong ground motion has occurred many times. Damage to speleothems has been widely reported, but roof collapse is rare. If general collapse has occurred in response to seismicity, it is unreported or possibly unrecognizable.

The record for anthropogenic underground openings spans a much shorter period of time than for natural openings, but it also attests to remarkable stability even in areas of strong seismicity. A few prehistoric mines that were not destroyed by subsequent mining are known to have stood open for thousands of years. There are thousands of tombs in limestone and volcanic rock that are older than $2 \mathrm{ka}$. There are several kilometers of tunnels in these same two rock types located within areas of strong seismicity, and these have not collapsed in more than 2,500 years. Even tunnels in partly indurated alluvium have survived with only partial collapse in earthquake-prone areas.

Not only do subterranean openings seem to remain open for extended periods of time, but comparison of the few archeological structures preserved in good condition above ground (such as the pyramids in Egypt or the aqueduct in Segovia, Spain) with the vast number of well-preserved subterranean openings from early recorded history and even older times indicates that tunnels at Yucca Mountain should serve as an effective barrier in the isolation of radioactive waste, as predicted in the drift degradation model (BSC, 2001b).

\section{Analogues for the Engineered Barrier System}

The high-level waste forms to be disposed would be emplaced within an EBS in the proposed repository. In the first part of this section we discuss analogues to processes that 
the waste form could potentially undergo. We then discuss the various components of the EBS.

\section{Waste-Form Degradation}

Whether a geologic repository is sited in an unsaturated environment or a saturated environment, knowing the behavior of spent fuel and vitrified wastes under relevant repository conditions is essential. Many variations of waste-form types may be emplaced within the proposed Yucca Mountain repository. However, most of the waste would be spent fuel in the form of uranium dioxide $\left(\mathrm{UO}_{2}\right)$, with the remaining 10 percent or so being encapsulated in borosilicate glass resulting from vitrification of defense high-level nuclear waste. These waste forms are thermodynamically unstable under wet, oxidizing conditions. For this reason, quantification of the degradation modes and dissolution rates that determine the source term for PA is extremely important. Figure 38 shows how spent nuclear fuel pellets would be placed in a fuel assembly and illustrates their alteration and mobilization processes.

Analogue studies add valuable insight to understanding long-term waste-form degradation processes through the record left behind in secondary minerals and groundwater. Many of the published analogue studies of waste-form degradation focus on dissolution of uranium under reducing groundwater conditions. This is because most of the geologic wastedisposal configurations of other nations involve saturated, reducing conditions. Sketches of the most important and wellstudied of these analogue sites were provided in the "Yucca Mountain Site Description" (CRWMS M\&O, 2000b). As a whole, the sites with reducing groundwater chemistry have limited applicability to conditions that would be expected to occur at the proposed Yucca Mountain repository, or any other site located in an unsaturated oxidizing environment. However, in some cases, information from such analogue studies as these can still provide valuable insights into the processes of waste-form degradation. This discussion relies to the extent possible on information derived from oxidizing environments, but relevant information from examples in reducing environments is included to illustrate general principles of waste-form dissolution, radiolysis, and potential criticality.

\section{Overview of Conceptual Basis of Waste-Form Degradation}

Radionuclide release from the waste forms that would be emplaced at Yucca Mountain is a three-step process requiring (1) degradation of the waste forms, (2) mobilization of the radionuclides from the degraded waste forms, and (3) transport of the radionuclides away from the waste forms. Water strongly influences all three processes. The processes described in the following paragraphs are ones for which we will describe analogues.
As described by the U.S. Department of Energy (2001a), radionuclide release begins after breach of the waste package and the ingress of air. If the breach is early in the lifetime of the proposed repository, the waste may still be highly radioactive and physically hot. The thermal output of hot waste packages, particularly from commercial spent fuel, will limit groundwater access at early times. When water enters the package, the rate of water inflow and evaporation will determine when and if water accumulates. During this period, gamma radiolysis (radiation-induced decomposition) of the humid air within the package may cause production of nitric acid, which could condense into any accumulated water. If the breach is late, radiation levels and heat will be much lower, and evaporation and radiolytic acid production will be less of a factor.

During either earlier or later periods, water may enter the waste package either as water vapor or as liquid. The dissolved constituents in the groundwater entering the package may have a significant effect on in-package chemistry only if evaporation has concentrated them by orders of magnitude. This is unlikely to occur unless the waste package is breached only at the top and large amounts of water enter and evaporate within the package. During the late period, there is no water transport of groundwater species or radionuclides out of the package.

If the package overflows, or if holes in the bottom of the waste package allow flowthrough, freshwater will dilute the groundwater components and water-based radionuclide releases may begin. The release of radionuclides does not begin until after the breach of the cladding (for spent fuel). Chemistry within the package is important because it influences the rate of degradation of the package and waste forms (including cladding) and it determines the mobility of radionuclides as dissolved or colloidal species. Films of stagnant, concentrated, acidified groundwater are considered the worst possible scenario for degradation because they do not inhibit oxygen and carbon dioxide transport and may support localized corrosion of the cladding and waste. Such films, however, do not support substantial mobilization and transport of radionuclides and are only possible at times when there is an exact balance of water inflow and evaporation.

As stated previously in this section, most of the many waste-form types that may be emplaced within a repository are thermodynamically unstable under wet, oxidizing conditions. Uranium dioxide fuels will oxidize and hydrate, and glass waste forms will react with water to form clays, zeolites, and oxides. The rate of these reactions, however, will in most cases be quite slow and may be limited by the rate that reactants such as oxygen and water can be transported to the waste-form surface. Although a few radionuclides such as cesium and iodine may concentrate between the fuel and cladding during reactor operation, most of the radionuclides will be incorporated within the various waste forms and cannot be released from the waste package until the waste forms degrade. 


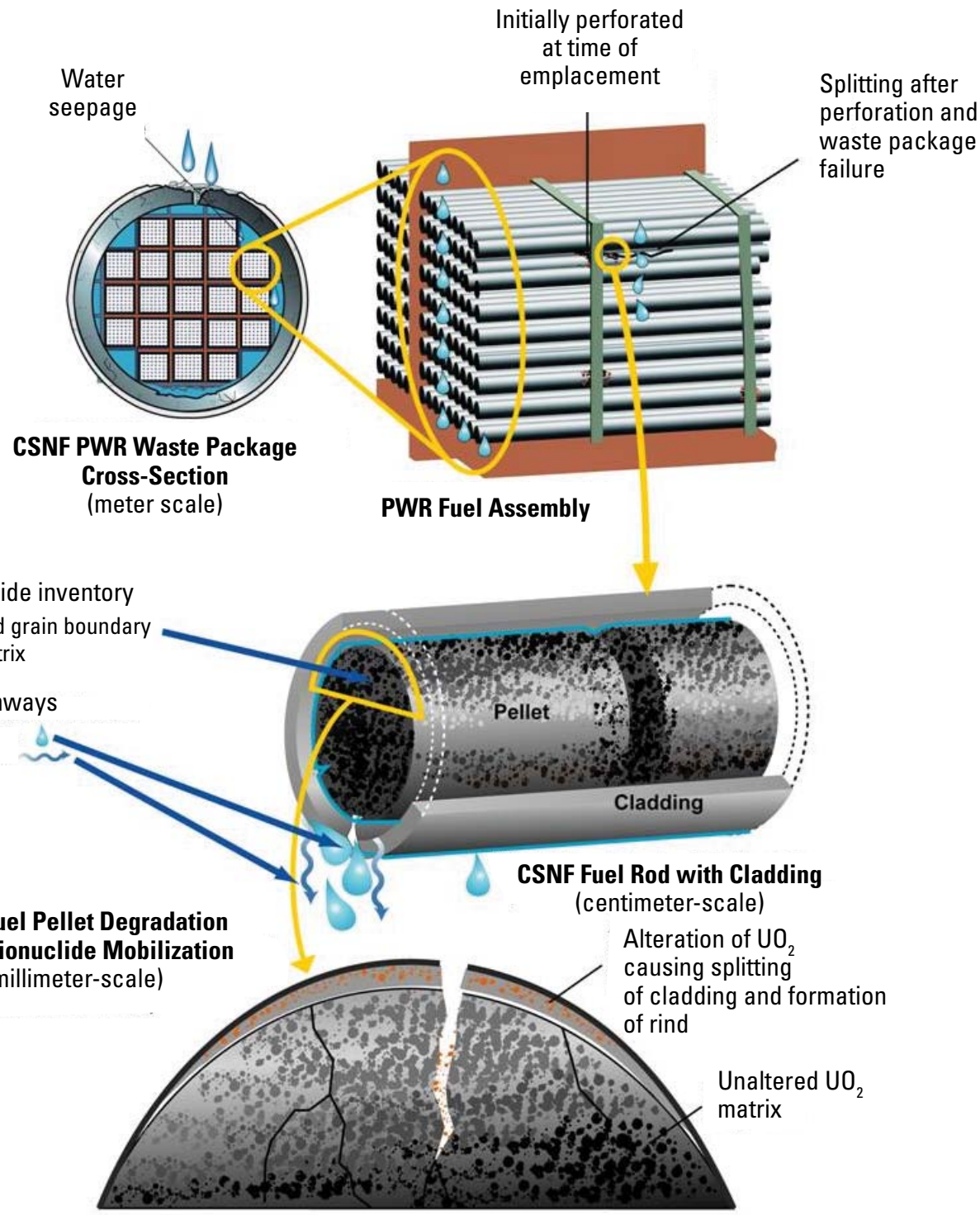

NOTE: CSNF, civilian spent nuclear fuel; PWR, pressurized water reactor; $\mathrm{UO}_{2}$, uranium dioxide

Figure 38. Illustration of placement of spent nuclear fuel pellets within a fuel assembly and waste packages, and degradation and mobilization of the waste form.

Once the waste forms degrade, radionuclides as dissolved species and suspended particles may be mobilized by advection or diffusion. Larger particles settle out of solution or are filtered out by being trapped in small openings. Only after gross failure of the package will these larger particles fall or wash out of the package. Particles in the colloid size range, however, can remain suspended and may travel substantial distances. The concentration of radionuclides associated with colloids is limited by the colloid concentration and radionuclide carrying capacity of the colloids. The concentration of dissolved species is limited by the elemental solubility of the radionuclide within the local environment.

\section{Spent-Fuel Dissolution in an Oxidizing Environment}

Spent nuclear fuel is vital to the proposed disposal concept at Yucca Mountain because it determines the source term of radionuclides that could be released from a repository, whether the radionuclides are solubility-limited, and whether they could be retained in alteration products of spent nuclear fuel. Many laboratory studies attempt to measure parameters that can be used to determine the rate of spent fuel dissolution under repository disposal conditions. These studies use either 
the spent fuel itself, uranium dioxide (as an analogue for spent fuel), or uraninite as a natural analogue.

The dissolution and alteration of uraninite under reducing conditions is quite different from that under oxidizing conditions (Janeczek and Ewing, 1992). Although the uraninite structure can accommodate some degree of oxidation, in highly oxidizing aqueous environments uraninite is unstable and decomposes (Finch and Ewing, 1992a). Secondary uranyl $\left(\mathrm{U}^{+6}\right)$-bearing phases precipitate on the surface of the corroding uraninite, and a rind of corrosion products forms. The impurities commonly contained in uraninite affect its thermodynamic properties, the rate of uraninite alteration, and the composition of the corrosion products (Finch and Ewing, 1991). Studies that have examined the dissolution of uraninite under oxidizing conditions have concluded that the dissolution rate was diminished by the presence of thorium, lead, and rare earth element (REE) impurities in the uraninite (Finch and Ewing, 1992a). Compared to uraninite, spent fuel has a lower content of these impurities (Finch and Ewing, 1992b) and on this basis might be considered to dissolve more rapidly.

Most of the uranium released to solution during the dissolution of uranium dioxide $\left(\mathrm{UO}_{2}\right)$ combines with ions in water to form secondary alteration phases. Both natural and experimental uranium systems display a paragenetic sequence of mineral phase formation that is characterized by the following general trend (Stout and Leider, 1997):

$\mathrm{UO}_{2} \Rightarrow$ uranyl oxide hydrates $\Rightarrow$ alkali- and alkalineearth uranyl oxide hydrates $\Rightarrow$

uranyl silicates $\Rightarrow$ alkali- and alkaline-earth uranyl silicates + palygorskite clay.

Specifically, mineralization in the experimentally determined paragenetic sequence of alteration phases is:

$$
\begin{aligned}
& \mathrm{UO}_{2} \Rightarrow \text { dehydrated schoepite }\left(\mathrm{UO}_{3} \cdot 2 \mathrm{H}_{2} \mathrm{O}\right) \Rightarrow \\
& \text { compreignacite }\left[\mathrm{K}_{2}\left(\mathrm{UO}_{2}\right)_{6} \mathrm{O}_{4}(\mathrm{OH})_{6} \cdot 8 \mathrm{H}_{2} \mathrm{O}\right]+ \\
& \text { becquerelite }\left[\mathrm{Ca}\left(\mathrm{UO}_{2}\right)_{6} \mathrm{O}_{4}(\mathrm{OH})_{6} \cdot 8 \mathrm{H}_{2} \mathrm{O}\right] \Rightarrow \text { sod- } \\
& \text { dyite }\left[\left(\mathrm{UO}_{2}\right)_{2} \mathrm{SiO}_{4} \cdot 2 \mathrm{H}_{2} \mathrm{O}\right] \Rightarrow \text { boltwoodite }\left[\mathrm{K}\left(\mathrm{H}_{3} \mathrm{O}\right)\right. \\
& \left.\left(\mathrm{UO}_{2}\right) \mathrm{SiO}_{4}\right]+ \text { uranophane }\left[\mathrm{Ca}\left(\mathrm{UO}_{2}\right)_{2} \mathrm{Si}_{2} \mathrm{O}_{7} \cdot 6 \mathrm{H}_{2} \mathrm{O}\right]+ \\
& \text { palygorskite clay (Wronkiewicz and others, 1996). }
\end{aligned}
$$

Thus, the uranyl oxide hydrates are common initial corrosion products of uraninite during weathering. In the presence of dissolved silica, these early phases alter to uranyl silicates, most commonly soddyite and uranophane. The phases that form depend on the chemical composition of the waters with which the uraninite is in contact, which in turn depends on the mineralogy of the surrounding host rocks and the oxidation potential of the hydrologic environment.

The experimentally determined mineral sequence appears to be controlled by precipitation kinetics and is nearly identical to secondary uranium phases observed during the weathering of naturally occurring uraninite under oxidizing conditions, such as that at the Nopal I uranium deposit, Peña Blanca, Mexico (Wronkiewicz and others, 1996). In laboratory $\mathrm{UO}_{2}$ tests and in the natural uranium deposits at Nopal I, the alkali- and alkaline-earth uranyl silicates represent the long-term solubility-limiting phases for uranium (Stout and Leider, 1997). Furthermore, at Nopal I, uranium concentrations in groundwater and seepage waters ranged from 170 parts per trillion (ppt) to 6 parts per billion (ppb) (Pickett and Murphy, 1999, their Table 2; table 12 of this report includes some higher values - see section on "Unsaturated Zone Flow and Transport Analogues" for discussion). In general, the upper part of this range is similar to concentrations seen in filtered samples from spent-fuel dissolution experiments (Stout and Leider, 1997). This added similarity increases confidence that the experiments and the natural analogue reactions may simulate the long-term reaction progress of spent $\mathrm{UO}_{2}$ fuel following proposed disposal at Yucca Mountain.

Uraninite typically contains radiogenic lead that has ingrown through time (Finch and Ewing, 1992b). As a result, the early formed lead-poor uranyl oxide hydrates alter incongruently to uranyl silicates plus radiogenic-lead-enriched uranyl oxide hydrates, such as curite $\left(\mathrm{Pb}_{2} \mathrm{U}_{5} \mathrm{O}_{17} \bullet 4 \mathrm{H}_{2} \mathrm{O}\right)$, that may serve to limit the mobility of uranium in nature (Finch and Ewing, 1992b). Curite may also be an important factor in the formation of uranyl phosphates, which are significantly less soluble than the uranyl silicates and control uranium solubility in many groundwaters associated with altered uranium ore (Finch and Ewing, 1992b). In the absence of lead, schoepite and becquerelite are the common initial corrosion products. The reaction path for the alteration of lead-free uraninite results in the formation of uranyl silicates. Thus, the long-term oxidation behavior for ancient, lead-bearing uraninite is different from that of young, lead-free uraninite, which is more similar to spent fuel. Because the presence of lead effectively reduces the mobility of uranium in oxidizing waters, the concentration of uranium in groundwaters associated with oxidized uranium ore deposits will depend in part on the age of the primary uraninite (Finch and Ewing, 1992a).

In summary, the paragenesis of uraninite alteration phases depends on the age of the primary uraninite, the mineralogy of surrounding host rocks, and on groundwater composition, $\mathrm{pH}$, and redox potential. In a general oversimplification, the progression of phases of uraninite alteration, in the absence of radiogenic lead in-growth, will be to uranyl silicates, culminating in uranophane in an oxidizing environment. Numerous compositional variations are caused by trace elements present in the system. The composition of schoepite is commonly used to represent an alteration product in models of spent fuel alteration, but this is an oversimplification, based on observations in nature. As shown by Finch and Ewing (1992a), the formation of intermediate-phase schoepite may be favored early during the corrosion of uraninite. Schoepite is not, however, a long-term solubility-limiting phase for oxidized uranium in natural groundwaters containing dissolved silica or carbonate (for example, the types of groundwater at Yucca Mountain).

Despite the analogy between uraninite and spent fuel, there are important differences between the two. For one thing, spent fuel is artificially enriched in ${ }^{235} \mathrm{U}$ and contains nuclear fission products that are not present, or are present in very small quantities, in uraninite; in contrast, uraninite contains a 
higher proportion of nonradiogenic trace-element impurities. Also, the thermal history of spent fuel, unlike that of natural uraninite, may cause lattice and structural crystallization defects in the spent fuel that are not present in the uraninite. In addition, geologically old uraninite contains in-grown radiogenic lead, which would not be present in younger uraninite or in spent fuel.

\section{Analogue Studies Related to Waste-Form Dissolution Rates}

The remaining issues of most relevance to the behavior of spent fuel in a repository that could be addressed by natural analogues are dissolution and radionuclide release, radionuclide retardation by secondary alteration products, radiolysis, and criticality. These topics are discussed in the following sections, beginning with waste-form dissolution.

Rates of $\mathrm{UO}_{2}$ dissolution can be quantified by measuring the amount of fission product released from the uraninite and using this as a tracer. Concentrations of this tracer in the rock or in the groundwater in the vicinity of the uraninite are proportional to the dissolution rate, assuming that the tracer is released from the uraninite only by dissolution (Curtis, 1996; Curtis and others, 1994, 1999). The tracers used for this method are ${ }^{99} \mathrm{Tc}$ in rock, or its stable daughter ${ }^{99} \mathrm{Ru}$ when technetium has decayed to small amounts, and ${ }^{129} \mathrm{I}$ in groundwater.

There are several uncertainties in the modeling and assumptions made in this approach, but some consistency is apparent in the results obtained from different uranium orebodies when using the same isotopic system. For example, using the ${ }^{99} \mathrm{Tc}$ tracer at Oklo, Gabon, and at Cigar Lake, Canada, average release rates were calculated of $1.5 \times 10^{-6}$ per year and $1.1 \times 10^{-6}$ per year (unitless), respectively (Curtis, 1996). However, different rates are obtained when using ${ }^{129} I$ as a tracer. Applying this tracer at Cigar Lake provided release rates of between $9 \times 10^{-9}$ and $3 \times 10^{-10}$ per year, which are $2-4$ orders of magnitude less than the values obtained using the ${ }^{99} \mathrm{Tc}$ tracer.

Curtis and others (1994) used measurements of ${ }^{99} \mathrm{Tc},{ }^{129} \mathrm{I}$, ${ }^{239} \mathrm{Pu}$, and $\mathrm{U}$ concentrations in rock from uranium deposits at Cigar Lake, Canada, and Koongarra, Australia, to estimate radionuclide release rates from uranium minerals. At Koongarra, release rates appear to have been faster $\left(10^{-7}\right.$ per year $)$ than at Cigar Lake, where model-dependent release constants from the uraninite-bearing rocks were less than $5 \times 10^{-8}$ per year, producing small deficiencies of ${ }^{99} \mathrm{Tc}$ and larger ones of ${ }^{129} \mathrm{I}$. The inferred differences in radionuclide release rates are consistent with expected differences in uranium mineral degradation rates produced by the differing hydrogeochemical environments at the two sites. In the Cigar Lake ore zone, low uraninite solubility in a reducing environment and small water flux through impermeable rock would inhibit the rate of uraninite degradation and, thus, the rate of radionuclide release (Goodwin and others, 1988). At Koongarra, higher mineral solubilities induced by higher oxidation potentials, higher aqueous concentrations of carbonate and phosphate, and greater water fluxes would be expected to produce higher rates of uranium mineral degradation.

Curtis and others (1999) noted that the consistency of ${ }^{239} \mathrm{Pu} / \mathrm{U}$ and ${ }^{99} \mathrm{Tc} / \mathrm{U}$ ratios in bulk rock suggests that the redistribution processes observed at Cigar Lake are highly localized and do not result in large-scale losses or gains of these nuclear products from the deposit as a whole. The fission-product tracer method could be applied to water samples collected at Peña Blanca, Mexico (discussed in the section "Unsaturated Zone Flow and Transport Analogues"). Although this method clearly has potential for quantifying $\mathrm{UO}_{2}$ dissolution under natural conditions, the method has yet to be refined and the differences between results for the two tracers explained. Besides this fission-product tracer method, there is no other technique for directly quantifying long-term uraninite dissolution rates in natural analogue studies.

The Oklo, Gabon, uranium deposit provides a unique record of uranium and fission-product retention (Brookins, 1990; Loss and others, 1989; Chapuis and Blanc, 1993). Parts of the Oklo orebody achieved a natural criticality resulting from high uranium concentration and the higher concentration of ${ }^{235} \mathrm{U}$ in natural uranium that existed then (prior to the preferential decay of ${ }^{235} \mathrm{U}$ to today's natural concentrations). Because of this natural criticality, Oklo uraninite contains significant quantities of fission products or their stable daughters, directly equivalent to those present in spent fuel (Cowan, 1976; IAEA, 1975, 1978; Jakubick and Church, 1986; Gauthier-Lafaye and others, 1989; Holliger, 1993; Jensen and others, 1997). In this regard, Oklo is unlike any other known uranium deposit. A photograph of one of the reactor zones is shown in figure 39. There are, however, some differences between Oklo uraninite and spent fuel. For one thing, Oklo contains lower concentrations of fission products than does spent fuel. Also, the temperature of reaction $\left(400^{\circ}-600^{\circ} \mathrm{C}\right.$; for a discussion of temperatures, see Zetterström, 2000) and power density were somewhat lower than in a reactor, and the duration of criticality at Oklo (on the order of 0.1-0.8 Ma; Louvat and Davies, 1998) was much longer than the lifetime of reactor fuel. Recognizing these differences, several large-scale analogue investigations have taken place at Oklo, and much relevant information has been obtained, including semiquantitative information on the fate of radionuclides contained in the orebody.

The Oklo analogue investigations (for example, Louvat and Davies, 1998; Gauthier-Lafaye and others, 2000) have revealed that when the Oklo reactor zones were cooling after periods of criticality, some dissolution of the uraninite and elemental remobilization occurred. However, the limited extent of this remobilization is indicated by the the fact that more than 90 percent of the uranium "fuel" has remained in the same spatial configuration since criticality (Miller and others, 2000). This implies that uranium has been almost fully retained within the uraninite minerals. The disposition of some PA-relevant elements and other elements in the reactor zones at Oklo is provided in table 2. The transuranic elements neptunium, plutonium, and americium were all formed in situ 


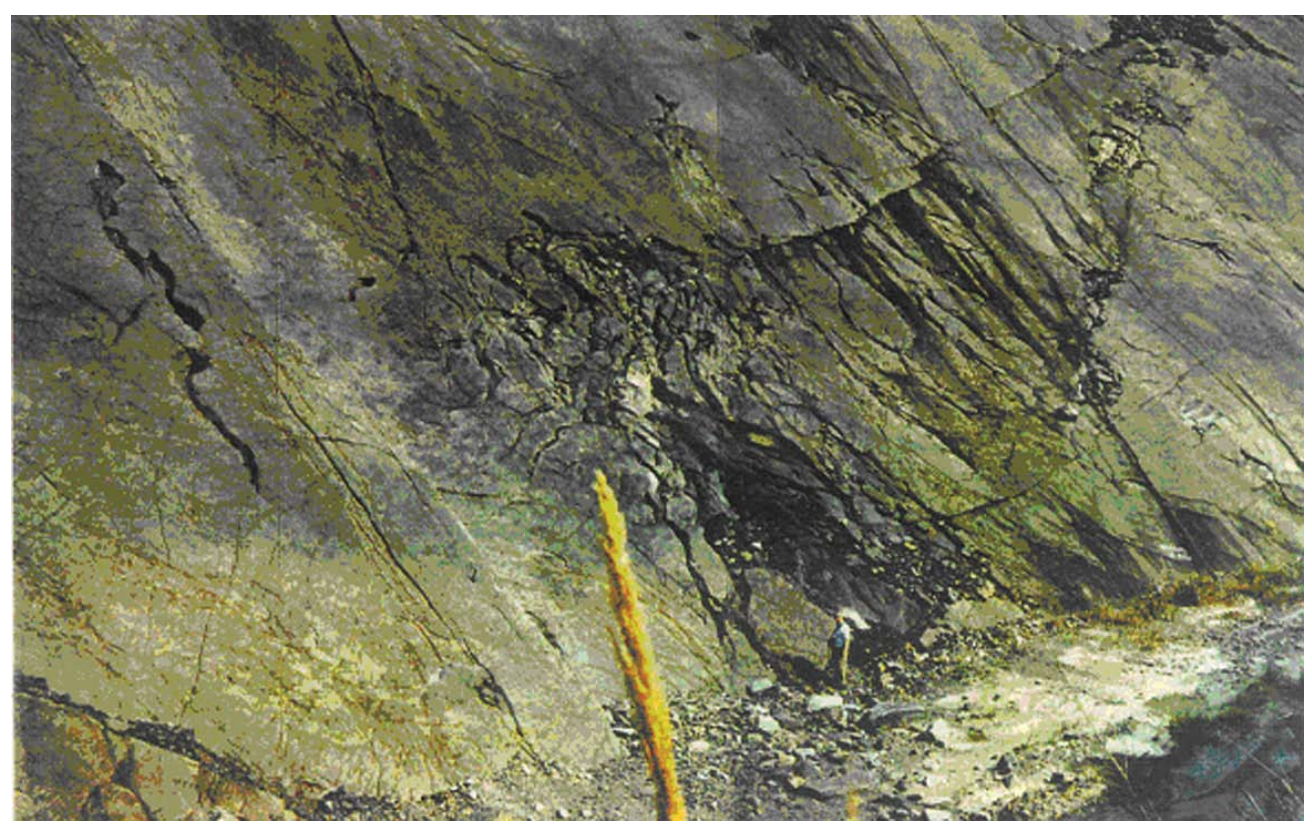

NOTE: Yellow plant matter is in foreground. Man standing in lower right-center for scale.

Figure 39. A reactor zone in a natural fission reactor at the Oklo orebody, Gabon (Blanc, 1966).

Table 2. Elemental distribution within uraninite, inclusions, and clays for elements in the reactor zones at Oklo, Gabon (modified from Miller and others [2000, table 4.2, summarized from Blanc, 1996]).

[REE, rare earth element; X, element present; ?, questionable if element present or migrated]

\begin{tabular}{|c|c|c|c|c|}
\hline Element & Uraninite & Inclusions & Clays & Migration \\
\hline Cesium & & & & $\mathrm{X}$ \\
\hline Rubidium & & & & $\mathrm{X}$ \\
\hline Strontium & & & & $\mathrm{X}$ \\
\hline Barium & & & & $\mathrm{X}$ \\
\hline Molybdenum & & $\mathrm{X}$ & & $\mathrm{X}$ \\
\hline Technetium & & $\mathrm{X}$ & $\mathrm{X}$ & \\
\hline Ruthenium & & $\mathrm{X}$ & $\mathrm{X}$ & $?$ \\
\hline Rhodium & & $\mathrm{X}$ & $\mathrm{X}$ & $?$ \\
\hline Palladium & & $\mathrm{X}$ & $\mathrm{X}$ & $?$ \\
\hline Yttrium & $\mathrm{X}$ & & $\mathrm{X}$ & \\
\hline Niobium & $?$ & $?$ & & \\
\hline Zirconium & $\mathrm{X}$ & $\mathrm{X}$ & $\mathrm{X}$ & \\
\hline Tellurium & & $\mathrm{X}$ & & \\
\hline REE & $\mathrm{X}$ & & $\mathrm{X}$ & \\
\hline Cerium & & $\mathrm{X}$ & & \\
\hline Lead & $\mathrm{X}$ & $\mathrm{X}$ & & $\mathrm{X}$ \\
\hline Bismuth & & $\mathrm{X}$ & & \\
\hline Thallium & $\mathrm{X}$ & & $\mathrm{X}$ & \\
\hline Uranium & $\mathrm{X}$ & & $\mathrm{X}$ & \\
\hline Neptunium & $?$ & $\mathrm{X}$ & & \\
\hline Plutonium & $\mathrm{X}$ & & $\mathrm{X}$ & \\
\hline Americium & $?$ & & & \\
\hline Silver & & & $?$ & $\mathrm{X}$ \\
\hline Tin & & & $?$ & $\mathrm{X}$ \\
\hline Cadmium & & & & $\mathrm{X}$ \\
\hline Neodymium & & $\mathrm{X}$ & $\mathrm{X}$ & \\
\hline
\end{tabular}


within the uraninite during criticality, and their stable daughters have also been retained due to their compatibility with the crystal chemical structure of their host or in inclusions in the uraninite. Other radiogenic elements, which were less compatible with the uraninite host (for example, cesium, rubidium, strontium, barium) have been partially or totally lost by diffusion from the uraninite. Some elements (for example, technetium, ruthenium, rhodium, palladium), however, migrated only short distances and were totally retained within the clay matrix enclosing the reactors. Data for other elements indicate clear deficiencies in the noble gases, halides, and lead (possibly resulting from volatilization) and indicate that some minor loss from the system has occurred for other elements.

Palladium and tellurium appear to have been retained in the reactor zones, whereas silver, tin, and cadmium were lost, but silver and tin may have been retained in the surrounding host rock (De Laeter and others, 1980). According to Gancarz and others (1980) and Curtis and others (1981), ruthenium, technetium, and neodymium were dispersed into rocks surrounding the reactor zones, probably by solid-state diffusion, but appear to have been contained within a few tens of meters of their source. Curtis (1986) postulated that increased temperatures and greater oxidizing conditions in the reactors led to dissolution of technetium in hydrothermal fluids and migration to the surrounding rocks, where the technetium precipitated in response to a drop in temperature and more reducing conditions. Curtis and others (1989) suggested that a portion of the fission-produced $\mathrm{Te}, \mathrm{Ru}, \mathrm{Pd}, \mathrm{Tc}, \mathrm{Cd}$, and Mo was retained, essentially at the site of production, and the portion that escaped the uraninite crystals of origin was completely removed from the reactor zone. They also presented evidence that neodymium and tin were removed from the site of their production but were retained within the reactor zone.

Because the nuclear reactions ended nearly 2 billion years ago at Oklo, the short-lived radionuclides have decayed to more stable daughter nuclides. Analysis of the behavior of these short-lived radionuclides is problematic. According to Brookins (1978), plutonium, neptunium, and americium were likely retained within the reactor, whereas bismuth and lead would have been redistributed locally without substantial migration (Brookins, 1978). Most geochemical observations at Oklo support these predictions to varying degrees. Curtis and others (1989) concluded that the retention of fission products is related to their partitioning into uraninite or secondary mineral assemblages. Those fission products that partitioned into the secondary mineral assemblages were largely lost over time, pointing to the importance of small uraninite grains in controlling the chemical microenvironment. It is unlikely that Oklo is the only place where natural nuclear chain reactions have occurred, but searches have identified no other sites (Cramer, 1986).

It is important to note that most of the observed uraninite alteration at Oklo occurred under hydrothermal conditions. Little uraninite/groundwater interaction has taken place at present-day ambient temperatures, except at the shallow Bangombé reactor zone (Gurban and others, 1998; Smellie and others, 1993). In summary, the Oklo natural analogue investigations indicate that the kinetics of $\mathrm{UO}_{2}$ dissolution, either as uraninite or spent fuel, are exceedingly low under reducing conditions expected in the near field of some repositories. Although dissolution rates cannot be quantified readily from natural analogue data, the abundance of naturally occurring uraninite that is nearly 2 billion years old at Oklo indicates its stability in the natural environment.

\section{Analogue Studies Related to Immobilization by Secondary Minerals}

Laboratory experiments have shown that $\mathrm{UO}_{2}$ dissolution is accompanied by the formation of secondary phases on the fuel surface and that these corrosion products can passivate further dissolution (Wronkiewicz and others, 1996). At the temperature and time scales of laboratory experiments, these phases are amorphous. However, natural sites where uraninite accumulations occur and where dissolution has taken place over long time periods may provide insights into the structure and mineralogy of the secondary passivating phases and indicate whether they have been able to prevent further mobilization of radionuclides.

The 1,800-Ma Shinkolobwe uranium orebody in Zaire (at the time of its study) was the subject of a comprehensive investigation regarding the corrosion products of uraninite (Finch and Ewing, 1991). The Shinkolobwe deposit weathers under oxidizing conditions in a monsoonal-type environment where rainfall exceeds $1 \mathrm{~m} / \mathrm{yr}$, thus providing more aggressive hydrochemical conditions than might be expected at a repository such as at Yucca Mountain. At Shinkolobwe, the uraninite is coarsely crystalline and lacks many of the impurities, such as thorium and REEs, that are in other uranium deposits. This lack of impurities led Finch and Ewing (1991) to suggest that the thermodynamic stability of the Shinkolobwe uraninite might closely approximate spent fuel.

The deposit has been exposed at the surface since the Tertiary period (less than $60 \mathrm{Ma}$ ), and extensive weathering has altered or replaced much of the original uraninite. Uranium (VI) mineralization occurs along fracture zones where meteoric waters have penetrated $80 \mathrm{~m}$ deep or more. Uraninite crystals at Shinkolobwe are commonly surrounded by dense rinds of alteration minerals, mostly uranyl oxyhydroxides, as well as uranyl silicates and rutherfordine, a uranyl carbonate $\left(\mathrm{UO}_{2} \mathrm{CO}_{3}\right)$. Uranyl phosphates also are common within fractures throughout the host rocks but are rare or absent from corrosion rinds.

Uranyl minerals composing the corrosion rinds that surround many uraninite crystals undergo continuous alteration. This alteration occurs through repeated interaction with carbonate- and silica-bearing groundwater combined with periodic dehydration of (especially) schoepite and metaschoepite (Finch and Ewing, 1991). Such alteration occurs along small (about $0.1-1 \mathrm{~mm}$ ) veins within the corrosion rinds. There is a general decrease in grain size as alteration proceeds, most 
commonly along veins. Schoepite, however, is not observed to reprecipitate where in contact with dehydrated schoepite (Finch and Ewing, 1991). Thus, whereas the formation of schoepite early during the corrosion of uraninite may be favored, schoepite is not a long-term solubility-limiting phase for oxidized uranium in natural groundwaters containing dissolved silica or carbonate (for example, the type of groundwaters at Yucca Mountain).

More than 50 secondary uranyl phases were identified from the alteration of the Shinkolobwe uraninite. Finch and Ewing (1991) concluded that uraninite transforms to $\mathrm{Pb}-\mathrm{U}$ oxide hydrates and then to uranyl silicates if sufficient silica is present in the system. Alteration of Proterozoic (approximately 2,400-700 Ma) uranium deposits such as Shinkolobwe introduces the important lead-bearing phases, such as curite, which are a factor in development of other stable phases in the system. Because of the very young age of repository spent fuel, radiogenic lead would not be present at Yucca Mountain for helping to immobilize spent-fuel elements.

In the first detailed study of the Okélobondo natural fission reactor in Gabon, which corresponds to the southern extension of the Oklo deposit (fig. 40), Jensen and Ewing (2001) presented a history of uraninite alteration at that site showing complex mineralogical and textural relations. The Okélobondo reactor, the deepest of the 16 natural reactors (fig. 40), is situated at the base of a 2.5-m-deep synform in the FA sandstone of the Francevillian Series (fig. 40). The Okélobondo reactor zone (RZOKE) developed at the interface between overlying brecciated high-grade uranium-mineralized FA sandstone and underlying bitumen-rich black shale of the FB Formation (fig. 40). RZOKE is relatively small (2.7 m wide and more than $4 \mathrm{~m}$ long) and contains a reactor core about $55-\mathrm{cm}$ thick (Jensen and Ewing, 2001).

Criticality in RZOKE was facilitated by fixation and reduction of oxidized uranium by liquid bitumen and precipitation of uraninite into

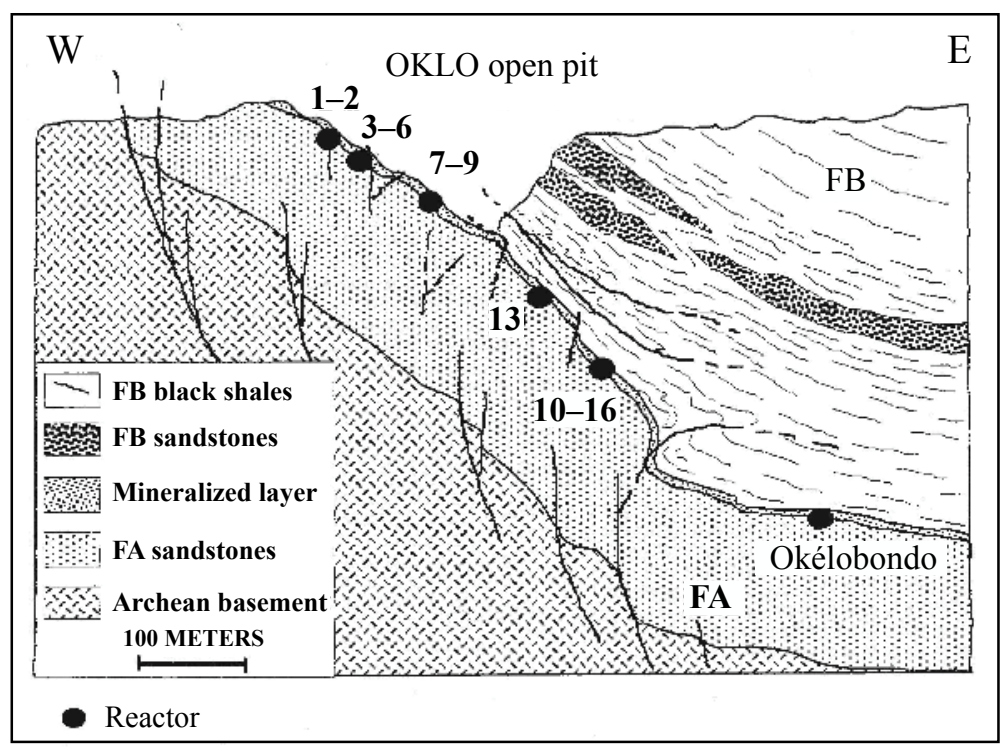

Figure 40. Schematic cross section showing depth of Okélobondo natural fission reactor in relation to other Oklo reactors (Gauthier-Lafaye, 1996, fig. 4). a dense microfracture network in the FA sandstone. The brecciation of the host rock may have been increased by overpressure created by the accumulation of hydrocarbon gases during diagenetic maturation of oil introduced into the FA sandstone. Chemical analyses and model estimates indicate that the ore grade at criticality at RZOKE was on the order of 20 weight percent uranium. Operation of the reactor caused extensive dissolution of the FA sandstone and hydrothermal alteration of the black shale of the FB Formation (fig. 40). The sandstone dissolution was the major process that led to formation of the 2.5-m-deep reactor synform and the high uranium concentrations (less than 90 volume percent uraninite) in the core of RZOKE (Jensen and Ewing, 2001). The mineral assemblage of RZOKE is comparable to that reported in the other Oklo reactor zones, in that uraninite and silica-rich illite are the major phases in the reactor core, whereas chlorite and illite are the major phases in the so-called argile de pile (reactor clays forming a halo around the reactor zone). Galena $(\mathrm{PbS})$ is also a major phase in the reactor zone. Minor coffinite $\left(\mathrm{USiO}_{4}\right)$ and $(\mathrm{U}, \mathrm{Zr})$ silicates also were observed in addition to several accessory phases (for example, titanium oxides, La-bearing monazite, sulfides of $\mathrm{Cu}, \mathrm{Fe}, \mathrm{Co}$, $\mathrm{Ni}$, and $\mathrm{Zn}$, and ruthenium arsenides. The minor and trace elements include $\mathrm{Th}, \mathrm{Zr}, \mathrm{Al}, \mathrm{P}, \mathrm{Ce}$, and $\mathrm{Nd}$ that seldom exceed concentrations of 0.1 oxide weight percent (Jensen and Ewing, 2001). Figure 41 shows galena, illite, and zircon embedded in a matrix of $(\mathrm{U}, \mathrm{Zr})$-silicate in the center of the RZOKE reactor core.

The accessory (U,Zr)-silicate, phosphates, and ruthenium arsenides (plus lead, cobalt, nickel, and sulfur) were of particular importance in secondary retardation of the fissiogenic isotopes at Okélobondo (Jensen and Ewing, 2001). The (U,Zr)-silicate contains elevated concentrations of $\mathrm{ZrO}_{2}, \mathrm{ThO}_{2}, \mathrm{Ce}_{2} \mathrm{O}_{3}$, and $\mathrm{Nd}_{2} \mathrm{O}_{3}$ as compared with the "unaltered" uraninite. This result indicates that the fissiogenic ${ }^{90} \mathrm{Sr}, \mathrm{Zr}$, $\mathrm{Ce}$, and $\mathrm{Nd}$, as well as the Th precursors, were efficiently retarded by the (U,Zr)-silicate during their migration in the reactor zone. Lanthanide element fission products also may have been retained in rare La-bearing monazite observed in the argile de pile of RZOKE. Ruthenium arsenides incorporated fissiogenic ruthenium, probably including ${ }^{99} \mathrm{Ru}$.

The presence of the lead-uranyl sulfate hydroxide hydrate, anglesite, partial dissolution of uraninite and galena, and the rapid oxidation of pyrite are evidence of a later shift toward 


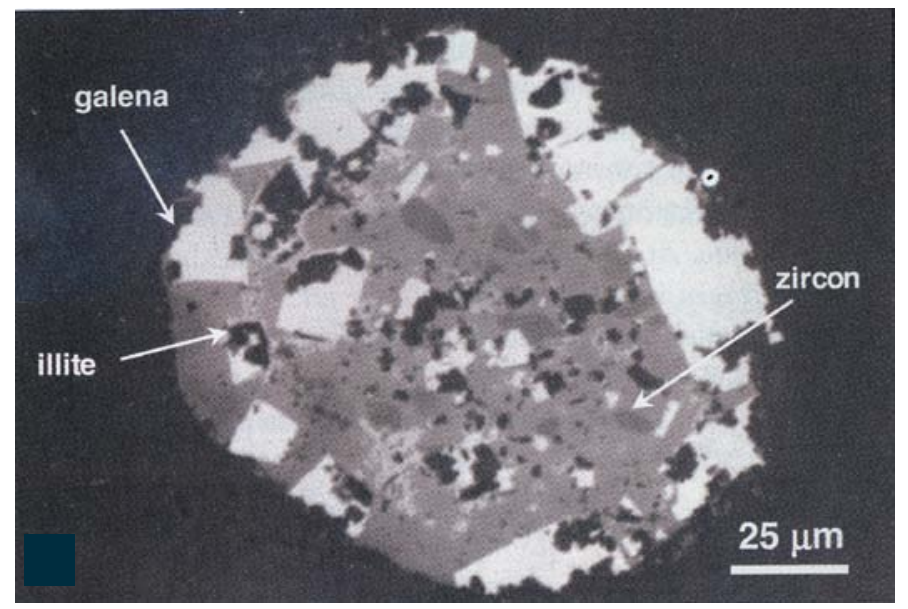

NOTE: The (U,Zr)-silicate is the medium gray colored matrix mineral in which the other minerals are encased.

Figure 41. Aggregate of (U,Zr)-silicate, zircon, galena, and illite in the center of the Okélobondo reactor core (RZOKE) (Jensen and Ewing, 2001, their fig. 11e).

oxidative alteration conditions in and around the reactor zone. Hence, the slightly oxidizing deep groundwaters at Okélobondo may have already reacted with RZOKE.

At Nopal I, Peña Blanca, Mexico, uraninite is in rhyolite tuff in a semiarid environment, where it has been exposed to oxidizing groundwater conditions with nearly neutral pH. (See section on "Unsaturated Zone Flow and Transport Analogues" for a description of the Nopal I site.) Uranium was initially deposited as uraninite at Nopal I approximately $8 \mathrm{Ma}$ (Pearcy and others, 1994). Geologic, petrographic, and geochemical analyses indicate that primary uraninite at Nopal I has been almost entirely altered to hydrated oxides and silicates containing uranium in the oxidized (uranyl) form. The sequence of formation of uranyl minerals by alteration of uraninite at Nopal I is shown in figure 42 and is similar in many geologically young uranium deposits located in oxidizing environments.

Leslie and others (1993) and Pearcy and others (1994) compared the alteration of uraninite at Nopal I to laboratory experiments of degradation of spent nuclear fuel proposed to be disposed at Yucca Mountain, Nevada. They concluded that uraninite from the Nopal I deposit should be a good natural analogue to spent nuclear fuel because long-term experiments on spent fuel show alteration parageneses, intergrowths, and morphologies that are closely similar to those observed at Nopal I (Wronkiewicz and others, 1996). Oxidation of the uraninite at Nopal I has produced an ordered suite of minerals, first forming schoepite, a uranyl oxyhydroxide, followed by hydrated uranyl silicates, such as soddyite (fig. 42). A higher calcium abundance, relative to other cations in Nopal I groundwater, supports the formation of uranophane, a hydrated calcium uranyl silicate, as the dominant secondary uranium phase. Because of the abundance of calcite at Yucca Mountain, uranophane would be a potential secondary phase there as well. Calcite is saturated in unsaturated-zone waters at Yucca Mountain (Marshall and others, 2003). In comparison, laboratory experiments find that the general trend is to form mixed uranium oxides, followed by uranyl oxhydroxides, and finally uranium silicates, mostly uranophane with lesser amounts of soddyite (Wronkiewicz and others, 1996).

In addition, uraninite at Nopal I has a low trace-element component (average of 3 weight percent) that compares well with that of spent nuclear fuel (typically less than 5 weight percent; Pearcy and others, 1994). The young age of the Nopal I deposit is another similarity to Yucca Mountain with respect to the absence of lead-bearing secondary phases.

\section{Radiolysis}

Radiolysis is hydrolysis caused by radiation, resulting in production of charged species (hydrogen and hydroxide ions) that may react to form more mobile species. Radiolysis can affect both the waste form and the waste package. Because the waste canister is thinner than in previous designs (CRWMS M\&O, 1999, table 5-4), it is not self-shielded, so radiation levels at the outside surface of the canister would be higher than in previous designs. However, it is not certain that radiolysis will be a problem.

The effects of radiolysis in the Oklo ore deposit were discussed by Curtis and Gancarz (1983). They calculated the alpha- and beta-particle doses in the critical reaction zones during criticality and the energy provided to the fluid phase by these particles. This energy caused radiolysis of water and the production of reductants $\left(\mathrm{H}_{2}\right)$ and oxidants $\left(\mathrm{O}_{2}\right)$. The effect of these reductants and oxidants on the transport of radionuclides within and outside the reactors has been difficult to quantify. Iron is most reduced in the samples that show the greatest ${ }^{235} \mathrm{U}$ 


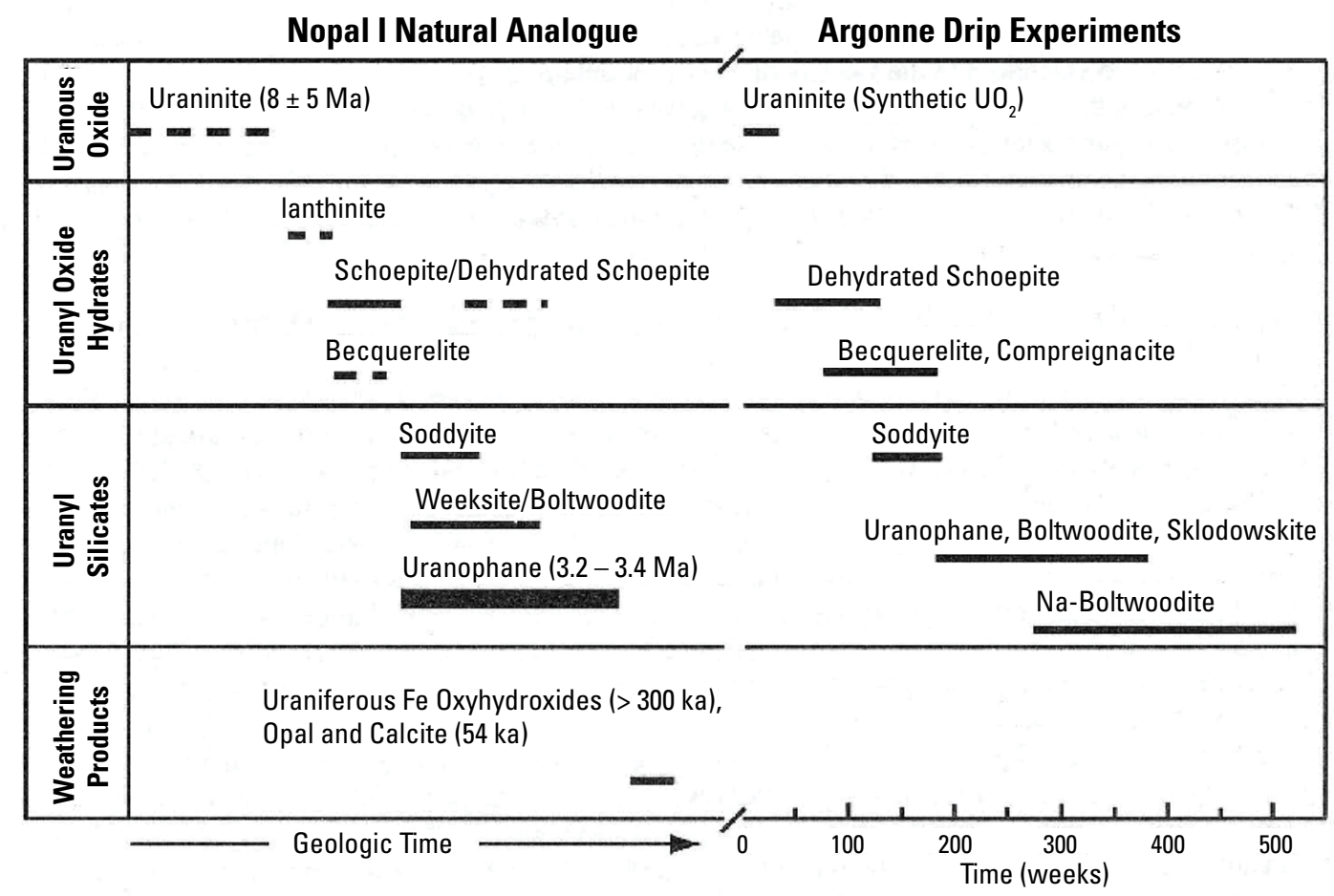

Figure 42. Sequence of formation of uranyl minerals by alteration of uraninite (modified from Murphy, 2000, fig. 1).

depletion. Curtis and Gancarz (1983) suggested that the reduction of iron in the reactor zones and oxidation of U(IV) in uraninite was contemporaneous with the nuclear reactions and not a later supergene phenomenon of secondary enrichment. These authors suggested that radiolysis of water resulted in the reduction of $\mathrm{Fe}$ (III) in the reactor zones and the oxidation of uranium.

Furthermore, Curtis and Gancarz (1983) suggested that the oxidized uranium was transported out of the critical reaction zones and precipitated through reduction processes in the host rocks immediately outside the zones. The reduction processes likely involved organics or sulfides present in the host rocks. However, if the host rocks around the natural reactor cores had not contained species capable of reducing the oxidized uranium transported out of the cores, the uranium could have been transported much farther from the critical reaction zones. The important point is that, even with intensive radiolysis, little (only a few percent) of the uranium in the natural reactors was mobilized (Naudet, 1978).

Jensen and Ewing (2001) noted a migration of cerium from reactor core to rim at Okélobondo and suggested that this resulted from radiolysis taking place during reactor operation. Cerium, particularly, showed indication of redistribution in the reactor zone, when compared with neodymium, in the uraninite rim. Because $\mathrm{Ce}^{3+}$ can be oxidized to $\mathrm{Ce}^{4+}$, the difference in the behavior of cerium as compared with neodymium, results from oxidative alteration. The different concentration of cerium in the uraninite rims, as compared with their cores across the reactor zone, was produced during reactor operation, possibly as a result of radiolysis.

\section{Criticality}

The uranium deposit at Oklo, which was the site of naturally occurring neutron-induced fission reactions over 2 gigaannum (Ga), was used as a basis for reviewing conditions and scenarios that might lead to nuclear criticality within and outside waste packages in the Swedish waste disposal configuration (Oversby, 1996). The Swedish concept involves disposal in deep granite with chemically reducing groundwaters, so the specific conditions are not relevant to those of oxidizing environments. Yet in either oxidizing or reducing conditions, the combination of simultaneous factors and probabilities required for criticality to occur seems unlikely. For criticality to occur, sufficient ${ }^{239} \mathrm{Pu}$ and(or) ${ }^{235} \mathrm{U}$ would need to accumulate together with enough water to allow for moderation of neutron energies. This would achieve a state where neutron-induced fission reactions could be sustained at a rate significantly above the natural rate of spontaneous fission. The chemical and physical conditions required to achieve nuclear criticality at Oklo 
were used by Oversby (1996) to estimate the amounts of spent fuel uranium that would need to be assembled in a favorable geometry in order to produce a similar reactive situation in a geologic repository. The amounts of uranium that must be transported and redeposited to reach a critical configuration are extremely large in relation to those that could be transported under any reasonably achievable conditions, even under oxidizing conditions. In addition, transport and redeposition scenarios typically require opposite chemical characteristics.

Oversby (1996) concluded that the likelihood of achieving a critical condition caused by accumulation of a critical mass of uranium outside the canisters after disposal is nil, provided that space in the canisters is filled by low-solubility materials that prevent entry of sufficient water to mobilize uranium. Criticality caused by plutonium outside the canister could be ruled out because it requires a series of processes, each of which has an increasingly small probability. Criticality caused by uranium outside the canister would require dissolution and transport of uranium under oxidizing conditions and deposition of uranium under reducing conditions. There is no credible mechanism to achieve both oxidizing and reducing conditions in the near-field repository host rock in the long term, after decay of the majority of alpha-active isotopes. Thus, the conditional probabilities required to achieve criticality caused by uranium make the likelihood that criticality would occur exceedingly low.

\section{Nuclear Waste Glass Analogues}

Archeological and industrial analogue studies of materials, such as glasses and cements, have tended to provide qualitative information that can be used to infer long-term stability of these materials. Although these studies may not provide quantitative data themselves, they can be used to support extrapolated values from short-term laboratory experiments. Such studies may also yield important information concerning the nature of the degradation processes (that is, whether radionuclides may be retained by secondary alteration products through sorption or precipitation).

Among the natural volcanic glasses, basalt glasses are compositionally the most similar to nuclear waste glasses (Lutze and others, 1987). Basalt glass and nuclear waste glass are similar in silica content, alteration products, alteration layer morphologies, and alteration rates in laboratory experiments (Grambow and others, 1986; Arai and others, 1989; Cowan and Ewing, 1989). However, there are substantial compositional differences, as shown in table 3 . Basalt glass alteration has been studied in a number of environments, including ocean floor, subglacial, hydrothermal, and surface conditions (Grambow and others, 1986; Jercinovic and others, 1986; Jercinovic and Ewing, 1987; Arai and others, 1989; Cowan and Ewing, 1989). Inferred alteration rates, as calculated from alteration rinds, range from 0.001 micrometer $(\mu \mathrm{m}) / \mathrm{k} . \mathrm{y}$. to $30 \mu \mathrm{m} / \mathrm{k} . \mathrm{y}$. (Arai and others, 1989).

Table 3. Comparison of volcanic glass and nuclear waste glass compositions, in weight percent. (Modified from Petit and others [1990, p. 1942].)

[-, not detected; REE, rare earth element $]$

\begin{tabular}{lccc}
\hline \multirow{2}{*}{ 0xide } & $\begin{array}{c}\text { Basaltic volcanic } \\
\text { glass }\end{array}$ & $\begin{array}{c}\text { Rhyolitic volcanic } \\
\text { glass }\end{array}$ & $\begin{array}{c}\text { Nuclear waste } \\
\text { glass }\end{array}$ \\
\hline $\mathrm{SiO} 2$ & 50.76 & 74.67 & 45.48 \\
$\mathrm{Al2O} 3$ & 13.62 & 12.17 & 4.91 \\
$\mathrm{~B} 2 \mathrm{O} 3$ & - & - & 14.02 \\
$\mathrm{Li2O}$ & - & - & 1.98 \\
$\mathrm{Na} 2 \mathrm{O}$ & 2.48 & 4.25 & 9.86 \\
$\mathrm{MgO}$ & 7.35 & 0.10 & - \\
$\mathrm{K} 2 \mathrm{O}$ & 0.18 & 2.78 & - \\
$\mathrm{CaO}$ & 10.72 & 1.68 & 4.04 \\
$\mathrm{TiO} 2$ & 1.66 & 0.30 & - \\
$\mathrm{MnO} 2$ & 0.16 & - & 0.72 \\
$\mathrm{FeO}$ & 8.18 & 3.21 & - \\
$\mathrm{Fe} 2 \mathrm{O} 3$ & 4.08 & - & 2.91 \\
$\mathrm{ZnO}$ & - & - & 2.50 \\
$\mathrm{ZrO} 2$ & - & - & 2.65 \\
$\mathrm{Cs} 2 \mathrm{O}$ & - & - & 1.42 \\
$\mathrm{Other}$ oxides (of REEs, actinides) & - & - & 8.00 \\
\hline
\end{tabular}


Byers and others (1987) reported results of a study of natural basalt glasses that were collected from a wide range of continental and oceanic environments. Ages of the samples ranged from a few million years to $350 \mathrm{Ma}$. All of the samples had altered to palagonite and exhibited dissolution textures. The alteration products were mainly smectite clays, zeolites, and calcite. The paragenetic sequence of the alteration minerals was largely a function of the altering fluid composition. Byers and others (1987) observed no simple relation between the thickness of the alteration rinds and age or general alteration environments.

Jercinovic and others (1986) reported that basaltic glass from the Wanapum Basalt near Hanford, Washington, is replaced by surface layers of palagonite that are 10-350 $\mu \mathrm{m}$ thick. The palagonite chemically resembles nontronite, an iron-rich smectite. Later alteration causes formation of magnesium-rich clays, such as saponites. In palagonites that formed as alteration rinds in Icelandic basalts, Jercinovic and Ewing (1987) showed that the formed layers were not completely amorphous but contained a high proportion of clays and that channels formed in the leached layer allowed solutions to reach the fresh glass/alteration interface so that it was not protected from further alteration.

Basaltic glass that had weathered for the past 12-28 k.y. at Hanauma Bay in Hawaii had altered partially to palagonite and zeolites (Cowan and Ewing, 1989). Zeolites were formed in the following order: analcime to phillipsite to chabazite. The rate of alteration was less than predicted by experiments, which led the authors to infer that the difference was a result of the episodic presence of the groundwater over the years.

Grambow and others (1986) demonstrated that a glassand-water reaction model could be used to model the longterm reaction of basaltic glass from a variety of aqueous environments. Their study pointed out the important function of metastable phases in controlling solution compositions. Grambow and others (1986) also noted that the reaction rate can vary by five orders of magnitude, depending on the environment, and that the reaction rate is a factor of 100 lower under silica-saturated conditions. They concluded that the long-term stability of glass is related to low temperatures and sealing of the glass against circulating water. According to these authors, basalt glass could be preserved under these conditions for hundreds of millions of years, whereas under more aggressive conditions, the glass could be altered much sooner.

Hydration rates of rhyolitic glass were determined by Ericson (1981) using obsidians from California and Oregon in conjunction with archeological data. He found that laboratory alteration rates were much lower than the rates of natural hydration, in contrast to comparative hydration rates of basaltic glasses reported by Cowan and Ewing (1989). The calculated rate of hydration of high-silica glasses is about $30 \mu \mathrm{m} / \mathrm{m}$.y. at $20^{\circ} \mathrm{C}$ (Zielinski, 1980). It was observed that as the temperature increased, the devitrification rate also increased, and at $120^{\circ} \mathrm{C}$, the process was faster by four orders of magnitude.
Malow and Ewing (1981) compared the thermal and chemical stabilities of two borosilicate glasses and one glass ceramic to those of three natural (volcanic) rhyolitic glasses through a variety of laboratory tests and observations of natural weathering. They concluded that natural glasses are much more stable than waste-form glasses as a result of higher silica contents in the natural glasses ( 74 percent compared to 28-50 percent in waste-form glasses [Malow and Ewing, 1981]). No difference in weathering was observed among the natural samples, which ranged in age from 500 years to 670 k.y. At elevated temperatures, the waste glasses tended to form new phases and to recrystallize, whereas the natural glasses did not display this tendency. They noted that the ages of most volcanic glasses are less than $2 \mathrm{Ma}$, suggesting stability up to a few million years at ambient weathering conditions.

Tektites (nonvolcanic glass of extraterrestrial or impact origin) range in age from approximately $100 \mathrm{ka}$ to $35 \mathrm{Ma}$. They rarely show signs of alteration, dehydration, or devitrification (Lutze and others, 1987). Their great durability may be a result of their high silica and alumina contents (about 30 percent combined) and their low alkali contents (less than 4 percent) (Lutze and others, 1987).

The degradation of archeological glass has also been the subject of study. Core-formed potion bottles are the oldest known glass vessels, the earliest discovered in Mesopotamia and dating from about 3500 B.P. (Chapman and others, 2006). The potion bottles are generally small (a few centimeters long) and are still highly colored.

Glass was first manufactured in approximately 1500 B.C. (Kaplan, 1980). The earliest glass was rich in soda and lime. Later, lead glass was developed, followed by potassium-lime glass. Some of the earliest glass has survived for 3,500 years with little degradation (Kaplan and Mendel, 1982; Miller and Chapman, 1995), even though it has high alkali concentrations that would tend to make it reactive. Kaplan and Mendel (1982) identified five styles of structural decomposition in the ancient glasses: weeping, pitting, crizzling (formation of a tiny network of cracks), layering, and crusting. Some of these types of decomposition could be relevant to decomposition of borosilicate nuclear-waste glass.

A massive, approximately 9 -ton ( 3.4 by 1.95 by $0.45 \mathrm{~m}$ ) glass block about 1,100 years old was found in a cave at Bet She'arim in Israel (Chapman and others, 2006). It was formed in situ in the cave, with about 11 tons of raw materials being heated to $1,100^{\circ} \mathrm{C}$ and held at that temperature for 5-10 days (Freestone and Gorin-Rosen, 1999). The massive block is still intact and is considerably more massive than the vitrified highlevel waste blocks intended for geological disposal at Yucca Mountain (Chapman and others, 2006).

A Japanese study examined the development of alteration products on the surfaces of glasses deposited 280-2,800 years ago that were produced by ancient volcanic eruptions on Mount Fuji and as scorias on Izuoshima Island (Yamato and others, 1992). The glasses had been subjected to weathering by highly oxidizing rainwater, the water on Izuoshima also being enriched in salts. Under conditions that were favorable 
for leaching, the glasses appeared to deteriorate at slow rates, from 0.2 to $3.1 \mu \mathrm{m} / \mathrm{k}$.y. for the Mount Fuji glasses, and 1.7 to $1.8 \mu \mathrm{m} / \mathrm{k}$.y. for the Izuoshima glasses (Yamato and others, 1992).

The compositions of the glasses used in natural analogue studies differ somewhat from borosilicate glasses, and this makes a simple analogy dubious for quantitative purposes. High silica and alumina contents, along with low alkali contents and low water contents, are favorable for longterm preservation. The dissolution rates measured on natural glasses are variable but always very slow. However, natural analogues cannot be used to provide a quantitative estimate for the time at which devitrification will begin, or the rate at which it will proceed in the repository environment. Natural glass studies do indicate that the rate of devitrification is too slow for the process to be significant in the regulatory life of a repository. These studies have not, however, considered the effect of radiation on glass alteration. It might be possible to obtain relevant data on the radiation-induced effects on glass durability by examining glasses that contain uranium oxides as colorants, such as the "vaseline glass" produced in Germany and Bohemia in the 1800s (Miller and others, 2000).

In all cases, the differences in chemistry between borosilicate glass and natural and archeological glasses need to be considered when interpreting analogue data. The qualitative evidence from analogues on natural and archeological glasses has added confidence that the glass degradation processes are well understood and has provided upper bounding limits to the degradation rates.

\section{Summary of Waste-Form Analogues}

The analogue sites located in chemically oxidizing environments are better analogues to conditions expected to occur at Yucca Mountain than the more numerous sites located in reducing environments. However, some examples from reducing environments may be appropriate analogues for processes that would occur under repository conditions in either type of chemical environment. Hence, both types of conditions were considered in studying the processes relevant to waste-form degradation. From the evidence presented in this section, the main points are the following:

1. The reaction path of alteration of spent fuel at Yucca Mountain will be similar to that of geologically young, lead-free uraninite, with schoepite and becquerelite forming as intermediate products followed by uranyl silicates. The uraninite and its alteration products at the Nopal I uranium deposit at Peña Blanca have these characteristics. Therefore, the uranium alteration paragenetic sequence at the Nopal I uranium deposit at Peña Blanca is a good analogue for the alteration of uranium oxide spent fuel.

2. Measurement of the concentration of fission products as tracers in rock and groundwater surrounding uraninite provides a satisfactory approach to estimating natural dissolution rates. This approach was tested at Cigar Lake and Koongarra under reducing and oxidizing conditions, respectively, and the dissolution rate at Koongarra was more rapid. Evidence indicates that dissolution has been slight under reducing conditions at Oklo over the past approximately 2 billion years.

3. Secondary mineral formation was responsible for incorporating uranium in stable mineral phases at Shinkolobwe, Zaire, where 50 secondary uranium-bearing phases could be identified. Because of its great age $(1,800 \mathrm{Ma})$, radiogenic lead-bearing phases were a factor in sequestering uranium. At Okélobondo, Gabon, and Shinkolobwe, other secondary phases, particularly (U,Zr)-silicates, formed stable phases.

4. It is uncertain whether radiolysis will be a potential problem around waste packages in the proposed current design scenario (in which waste packages are not self-shielded). Under radiolysis conditions existing at the time of reactor criticality at Oklo, only a small proportion of uranium was estimated to have been mobilized for transport from its original site, under far more extreme conditions than those anticipated at Yucca Mountain. Likewise at Okélobondo, radiolysis effects at the time of reactor operation appear to have been confined to REE migration from mineral core to rim. Because liquid water in contact with spent fuel is required for radiolysis to occur, the problem seems unlikely under either higher- or lower-temperature operating modes for a repository at Yucca Mountain.

5. Although the deposits at Oklo provide examples of naturally occurring criticality, the circumstances there cannot be reproduced at Yucca Mountain. One very important difference is the fraction of ${ }^{235} \mathrm{U}$ in uranium was substantially greater at Oklo than it would be in the vast majority of spent fuels. Uranium concentration and, hence, potential for criticality can be triggered by changes in $\mathrm{pH}$ as well as by reducing conditions. However, criticality as viewed from the standpoint of redox conditions, either within waste packages or by reconcentration of uranium outside of the package, has a low likelihood because the probability of certain processes required to achieve critical conditions occurring simultaneously or sequentially renders certain conditions mutually exclusive. The processes that occurred at Oklo to regulate the natural criticality and maintain the integrity of the orebody are useful indicators that even in the unlikely case that criticality could be achieved, it likely would be self-limiting and noncatastrophic.

6. Although natural glasses are somewhat different in composition from borosilicate nuclear waste glass, studies of natural glass alteration indicate that glass waste forms would be stable in a repository environment at Yucca Mountain. Higher stability is favored by higher silica and alumina content and by lower alkali and water content of 
the glass. Analogue studies have not considered radiation effects on glass over long time periods to confirm experimental results showing that radiation has little effect on glass waste stability.

\section{Engineered Barrier System Design}

The EBS planned for the proposed Yucca Mountain repository (fig. 43) consists of three main components: (1) drip shield, (2) emplacement drift invert, and (3) waste package. Because they will affect the performance of the EBS, materials included within the waste forms and materials used in the construction of the emplacement drifts also are considered in the evaluation of the EBS. The following summary of the components of the EBS is based upon U.S. Department of Energy (2001a).

The drip shield is designed to serve as a protective barrier for the length of emplacement drifts, which will divert water dripping from the drift walls, thus minimizing direct dripping onto the waste packages. The drip shield has the added function of protecting the waste package from rockfalls from the drift perimeter. These functions require that the drip shield assembly is both highly resistant to corrosion and has the structural strength to withstand rockfalls.

The drip shield consists of three separate elements: the drip shield itself, supporting structural members, and stands (or "feet") upon which the shield assembly rests (fig. 44). The drip shield would be manufactured from 15-mm-thick Titanium Grade 7 plates for long-term corrosion resistance. The structural members would be constructed using Titanium Grade 24, which has greater strength than Titanium Grade 7. Alloy 22, a nickel-chromium-molybdenum alloy (see table 4), would be used for the feet, preventing direct contact between the titanium structural members and the carbon steel beams of the invert.

The drift invert is designed to form a stable, level platform along the base of the emplacement drift on which the waste-package and drip-shield assemblies would be placed. The invert as currently planned consists of two components: a steel invert structure and a crushed-tuff invert ballast. The steel invert structure needs to provide sufficient support for all expected preclosure activities for up to 300 years and must also keep the waste packages in a horizontal position for 10,000 years after closure. The steel structure would consist of transverse and longitudinal support beams that would serve to transfer the weight of the waste package and drip shield (along with any needed emplacement and maintenance equipment during the initial phases of operation) to the bedrock (fig. 3 and fig. 45). Gantry rails, needed to transport the waste packages and drip shields into the tunnel, would be placed along the margins of the support beam structure. Guide beams would be used (if considered necessary to mitigate movement resulting from seismic events) to secure the waste-package emplacement pallets and the drip-shield assembly. The invert support and guide beams would be manufactured of ASTM A 572/A
572M steel, which was chosen to provide sufficient strength for the emplacement drift environment. The gantry rail would be made of ASTM A 759 carbon steel (U.S. Department of Energy, 2001a, Section 2.4.1.1).

The invert ballast is designed so that moisture present in the emplacement drift would drain directly into the surrounding rock without flowing along the base of the drift. Crushed tuff, produced by crushing material obtained during the excavation of the emplacement drifts, would be used as the primary ballast material. The ballast would be placed around the steel invert beams to a level just below the top of the support beams so that the waste-package pallets and drip shields rest on the support beams and not on the ballast. The ballast material would be compacted so that no substantial settling would occur over time. The crushed tuff mineralogy should not be affected by heating related to emplacement of the waste packages. Transport of radionuclides within the crushed tuff is expected to be dominated by diffusive transport, thus serving to retard any potential release of radionuclides into the surrounding host rocks.

The waste-package assembly is designed to securely contain high-level radioactive wastes and serve as the primary element to the EBS. The waste-package system consists of two main components: a waste-package emplacement pallet and a sealed, corrosion-resistant waste-package canister (fig. 46). The waste-package emplacement pallets are designed to support the waste-package canisters in a horizontal position and to facilitate line-loading of the waste packages. The pallets would be manufactured from plates of Alloy 22 (a material highly resistant to corrosion) with support tubes fabricated from stainless steel type 316L. The V-shaped design would allow the pallets to be used for all waste-package canisters.

A number of distinct waste-package designs have been developed to accommodate the different waste forms generated from boiling water and pressurized water reactors, excess weapons material, high-level waste, and DOE and naval spent nuclear fuel (fig. 46). All of these waste-package designs contain a number of important components that are needed to meet performance criteria. The performance criteria (U.S. Department of Energy, 2001a, section 3.4.1) are as follows:

- Strength

- Resistance to corrosion and microbial attack

- Predictable materials behavior

- Compatibility with waste-package and waste-form materials

- Ease of fabrication

- Proven performance record

- Favorable heat transfer properties

- Utility in shielding and preventing criticality.

Table 5 lists the major waste-package components for commercial spent nuclear-fuel waste packages, the 


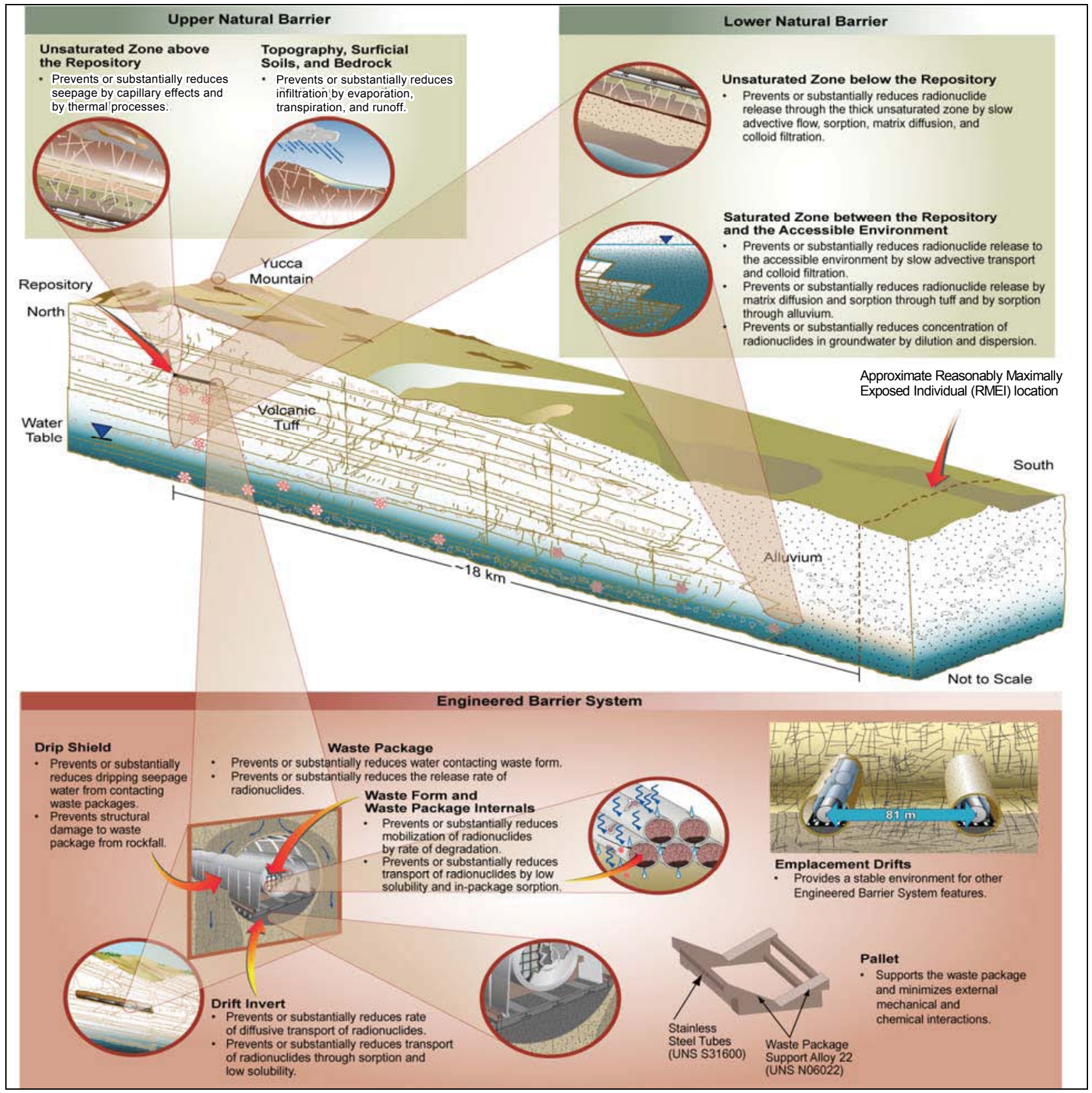

Figure 43. Schematic showing components of the engineered barrier system proposed for Yucca Mountain in relation to natural barriers (U.S. Department of Energy, 2008). See also figure 3. 


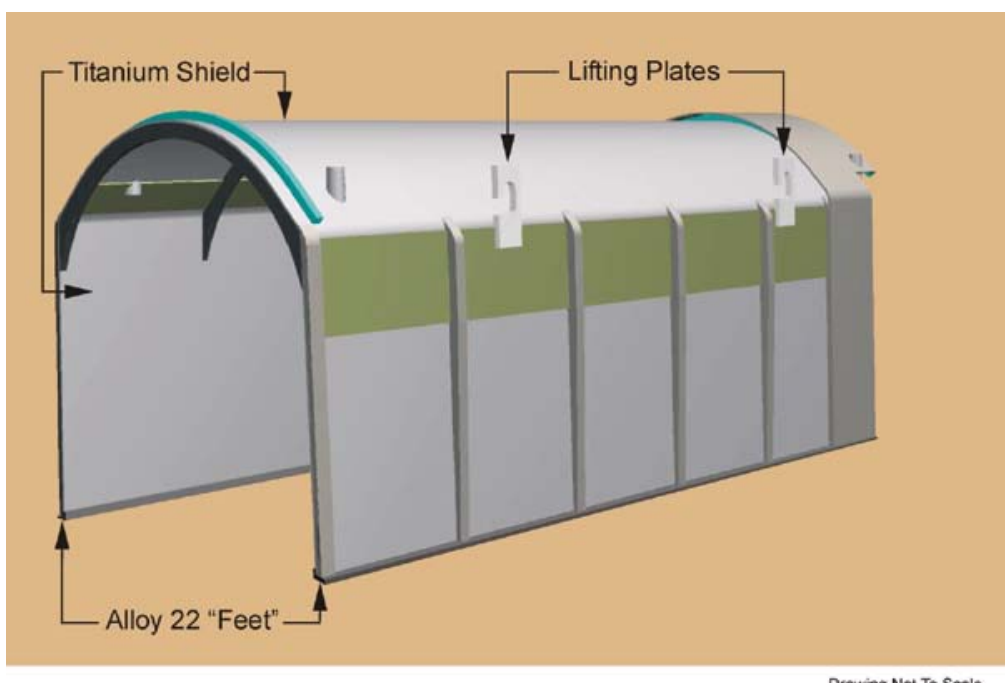

Figure 44. Conceptual view of the drip shield assembly designed to serve as a protective barrier to divert water dripping from drift walls.

Table 4. Chemical composition of Alloy 22.

(Modified from U.S. Department of Energy [2001a, table 3-12].)

[wt. \%, weight percent; max, maximum]

\begin{tabular}{lc}
\hline Element & $\begin{array}{c}\text { Composition } \\
\text { (wt. \%) }\end{array}$ \\
\hline Nickel & $50-63$ \\
Chromium & $20.0-22.5$ \\
Molybdenum & $12.5-14.5$ \\
Iron & $2.0-6.0$ \\
Tungsten & $2.5-3.5$ \\
Cobalt & $2.50(\max )$ \\
Manganese & $0.50(\max )$ \\
Vanadium & $0.35(\max )$ \\
Silicon & $0.08(\max )$ \\
Phosphorus & $0.02(\max )$ \\
Sulfur & $0.02(\max )$ \\
Carbon & $0.015(\max )$ \\
\hline
\end{tabular}




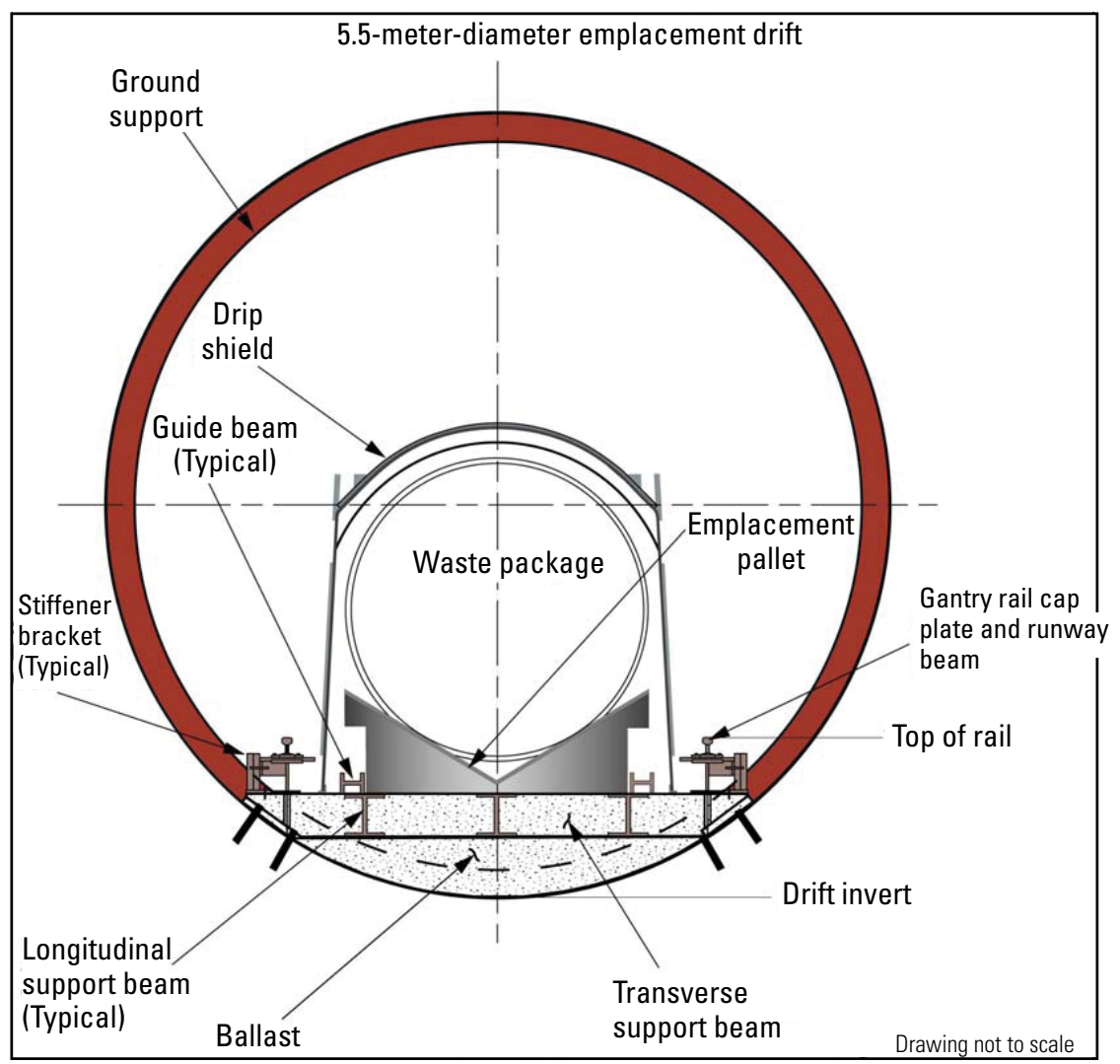

Figure 45. Cross section of emplacement drift with engineered barrier system components (U.S. Department of Energy, 2001a).

composition of each component, and the component function(s).

The different materials that would be chosen for the construction of the waste-package system are based on the functional requirements for each component. Key properties include (1) resistance to corrosion and cracking caused by thermal, mechanical, and chemical processes; (2) preservation of the structural integrity of the waste-package system; (3) conduction of heat away from the waste forms; and (4) the ability to prevent criticality from occurring. A brief description of each of the main types of materials incorporated in the current design (U.S. Department of Energy, 2001a, section 3) is given in the following paragraphs. These materials include corrosion-resistant and structural materials, corrosion-allowance waste-package materials, waste-form components, and materials in the emplacement drifts.

Alloy 22 was selected for the outer barrier of the wastepackage canister because of its resistance to corrosion under conditions of high temperatures and low humidity and under all low-temperature conditions, for its similar thermal expansion coefficient to stainless steel and because it can be welded more easily than can titanium. The chemical composition of Alloy 22 is given in table 4. Stainless Steel Type 316NG was chosen for the inner cylinder of the waste package because of its relative strength, its compatibility with Alloy 22, and its affordability. The chemical composition of Stainless Steel Type $316 \mathrm{NG}$ is given in table 6 .

A variety of other materials would be used in the fabrication of the waste-package assembly. These include Neutronit A 978 (borated 316 stainless steel) or SA 516 Grade 70 carbon steel plates, boron carbide rods with Zircaloy cladding used for control of criticality within the waste-package container, and aluminum shunts (SB-209 6061 T4) to assist in heat transport away from the waste form. The waste package would encompass the waste-form materials.

The waste forms designated for disposal at the proposed Yucca Mountain repository would include spent fuel from commercial power reactors and that owned by the DOE, solidified high-level radioactive waste, and plutonium waste from excess nuclear weapons. All waste must be in solid form and must not contain flammable or chemically reactive materials. The waste forms would contain fuel rods constructed out of Zircaloy and stainless steel as well as a variety of radioactive waste types, including uranium metal, uranium oxide, uranium dioxide, and radioactive borosilicate glass (U.S. Department of Energy, 2001a, section 3). Weapons plutonium immobilized in 


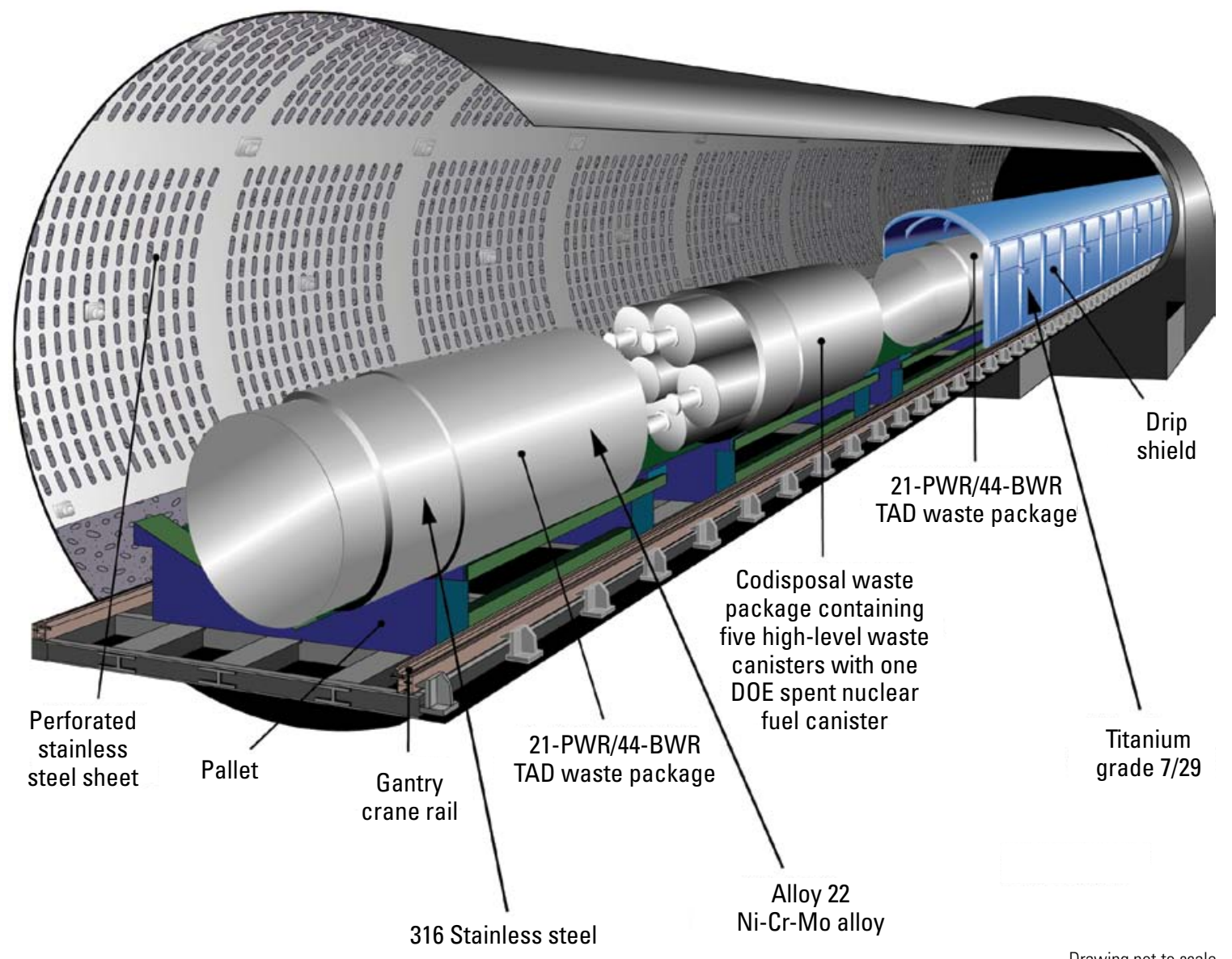

NOTE: PWR = pressurized water reactor; BWR = boil water reactor; $T A D=$ transportation, aging, and disposal.

Figure 46. Schematic view of different waste packages in emplacement drift (U.S. Department of Energy, 2008).

Table 5. Commercial spent-nuclear-fuel waste package (U.S. Department of Energy [2008]).

[TAD, transportation, aging, and disposal]

\begin{tabular}{|c|c|c|}
\hline Component & Composition & Function \\
\hline Outer corrosion barrier and outer lid & Alloy 22 & Protect against corrosion \\
\hline Spread ring & Alloy 22 & $\begin{array}{l}\text { Hold transportation, aging, and disposal (TAD) } \\
\text { canister in place }\end{array}$ \\
\hline Inner vessel and inner lid & Stainless steel type $316 \mathrm{NG}$ & Provide structural integrity \\
\hline $\begin{array}{l}\text { Waste package fill gas for space between TAD } \\
\text { canister and inner vessel }\end{array}$ & Helium & Heat conductor \\
\hline
\end{tabular}


Table 6. Chemical composition of stainless steel type 316NG. (Modified from U.S. Department of Energy [2001a, table 3-13].)

[wt. \%, weight percent; max, maximum]

\begin{tabular}{lc}
\hline Element & $\begin{array}{c}\text { Composition } \\
\text { (wt. \%) }\end{array}$ \\
\hline Iron & $61-71$ \\
Chromium & $16.00-18.00$ \\
Nickel & $11.00-14.00$ \\
Molybdenum & $2.00-3.00$ \\
Manganese & $2.00(\max )$ \\
Silicon & $0.75(\max )$ \\
Copper & $0.50(\max )$ \\
Cobalt & $0.10(\max )$ \\
Vanadium & $0.1(\max )$ \\
Nitrogen & $0.06-0.10$ \\
Titanium & $0.05(\max )$ \\
Tantalum and niobium & $0.05(\max )$ \\
Aluminum & $0.04(\max )$ \\
Phosphorus & $0.030(\max )$ \\
Carbon & $0.020(\max )$ \\
Bismuth + tin + arsenic + lead + & $0.02(\max )$ \\
$\quad$ antimony + selenium & \\
Sulfur & $0.005(\max )$ \\
Boron & $0.002(\max )$ \\
\hline
\end{tabular}

ceramic is no longer an expected waste form at Yucca Mountain; instead, the weapons plutonium would be disposed of as irradiated uranium-plutonium mixed oxide fuel (MOX) (W.G. Halsey, Lawrence Livermore National Laboratory, written commun., 2009). Analogues to waste-form materials and their degradation were discussed earlier in this section.

Although the emplacement drifts are not considered a component of the EBS, the materials used in their construction could substantially affect the EBS performance. The emplacement drifts contain a variety of materials that are used to help maintain the integrity of the drift after excavation. The ground support system, designed to stabilize the emplacement drift, would include W6X20 rolled steel ring beams (steel sets), tie rods, welded wire fabric, rock bolts, and cementitious grout used to secure the rock bolts in place (U.S. Department of Energy, 2001a, section 2.3.4.1.2.1). Analogues relevant to emplacement drift components are discussed later in this section.

Numerous processes and event scenarios have been identified and considered in designing the EBS (U.S. Department of Energy, 2001a, sections 2.4 and 3.1). These processes can be grouped into four major categories: structural, thermal, chemical, and nuclear criticality. The structural events evaluated involve scenarios (such as mishandling of the packages, seismic events, or rockfalls) that would result in the waste package being physically disturbed by an impact that could potentially result in breaching the sealed waste packages. Thermal processes include changes in physical and chemical properties associated with heating caused by radioactive decay of the waste forms, such as thermal expansion and cracking, as well as the effects on heat transfer properties. Chemical processes such as corrosion and chemical reaction of the different materials also could result in breaching of the sealed waste packages and subsequent release of radionuclides into the surrounding environment. Special attention has been placed on the design of the waste packages and composition of the waste forms to prevent the radioactive waste from achieving criticality. The selection of the different materials proposed to be used in construction of the EBS components has been made to ensure the long-term structural, thermal, and chemical integrity of the waste packages and to prevent the waste forms from going critical.

Although failure of a canister would occur most likely in the form of perforations created by localized corrosion of the corrosion-resistant layer, the high-performance, corrosionresistant alloys also might undergo degradation by general corrosion (CRWMS M\&O, 1998b).

Many factors influence the potential corrosion modes of the candidate materials. These include:

- Metallurgical factors (alloy composition and microstructure)

- Physical factors (temperature, relative humidity, and water contact mode)

- Chemical factors ( $\mathrm{pH}$ and concentration of aggressive species, such as chloride, sulfate, nitrate, and carbonate ions)

- Mechanical stress (McCright, 1998)

Under the near-field environmental conditions expected in the unsaturated zone at Yucca Mountain, the majority of waste packages are expected to be exposed to humid air conditions during the emplacement period. In the absence of a drip shield, some fraction of the waste packages that are emplaced in areas where seepage occurs could be dripped on during the emplacement period. Therefore, the important contributors to the degradation mode of the waste package are the temperature and relative humidity in the drift and the water-contact mode. The frequency of the seepage and its chemistry (especially $\mathrm{pH}$ and chloride concentration) also would substantially affect the degradation of the waste packages (CRWMS M\&O, 1998b; McCright, 1998).

Although the properties of all of the materials selected for the proposed EBS design have been extensively tested and determined in the laboratory, the long-term performance of these materials under the predicted temperature, humidity, and chemical environment for the proposed Yucca Mountain repository has not been confirmed experimentally because of the very long timeframe involved. Natural analogues for similar materials in the natural environment can be used to validate long-term performance models for the EBS. The following sections provide descriptions of natural analogues 
for waste-package materials and for processes that might take place within the EBS.

\section{Waste-Package Degradation Analogues}

This section describes the use of natural analogues to evaluate the long-term performance of metals that would be used in the fabrication of waste packages for storage of highlevel radioactive waste. Key concerns for the waste-package materials described earlier include the possible degradation and corrosion of metals caused by mechanical stress, unfavorable physical and chemical environments, and metallurgical factors. The primary degradation and corrosion issues anticipated for the proposed repository at Yucca Mountain include elevated temperature and humidity and contact with seepage water that could have corrosive chemistry.

The long-term stability of the waste-package materials is directly related to repository environmental conditions. Preservation of delicate archeological materials, including metals, appears to be enhanced by their location in an arid or semiarid, unsaturated environment, as discussed in the section "Preservation within the Unsaturated Zone."

An ancient hoard of buried nails has been used in a study of the corrosion of iron. These nails were found on the site of the most northerly fortress of the Roman Empire at Inchtuthil, Scotland. An estimated total of more than 1 million nails had been buried in a 5-m-deep pit and covered with $3 \mathrm{~m}$ of compacted earth in a successful attempt to hide the nails from Pictish tribes when the fortress was abandoned in A.D. 87 (Miller and others, 1994). The fortress was excavated in the 1950s, when the surviving nails (about 850,000) were unearthed. Although composed of iron, the nails were heterogeneous in composition, with regions of high and low carbon content. Their surfaces exhibited some corrosion, but the degree of corrosion was greatly controlled by location within the hoard. The nails toward the inside of the hoard showed minimal corrosion, limited to the formation of a thin corroded layer, whereas those toward the outside of the hoard and especially near the top, were corroded to such an extent that they formed a solid crust. Corrosion of the outermost nails formed a protective rust rind, serving to create a more reducing (and thus more stable) environment for the innermost nails.

It has been suggested that iron meteorites may be good analogues of steel-alloy waste-package canisters. Iron meteorites are essentially nickel-iron alloys (nickel content commonly 5-11 weight percent, with a maximum of 60 weight percent), with minor amounts of cobalt (0.3-1.0 weight percent) and traces of chromium $(5-2,500 \mathrm{ppm})$, chlorine (1-10 ppm), and titanium and vanadium (0.5-5.0 ppm) (Johnson and Francis, 1980). Iron meteorites lack the high chromium concentration of Alloy 22 used in the proposed Yucca Mountain Project design. In addition, iron meteorites generally have poorly constrained exposure histories, but differential corrosion of different mineral phases can be used to estimate relative resistance to corrosion, indicating that nickel-rich phases (taenite and schreibersite) are more stable than ironrich phases (Johnson and Francis, 1980).

The presence or absence of a fusion crust (that is, a magnetite $\left[\mathrm{Fe}_{3} \mathrm{O}_{4}\right]$-wüstite $\left[\mathrm{Fe}_{1-\mathrm{O}} \mathrm{O}\right]$ rind formed by rapid oxidation during atmospheric descent) may be a factor in the range of weathering that occurs at sites where meteorites have fragmented on descent as well as on impact. At Canyon Diablo in Arizona, meteoric material that developed a fusion crust during descent was, with the exception of silica-coated metal particles, more resistant to weathering than masses formed on impact, which developed a thin fusion crust, if any (Johnson and Francis, 1980).

The nickel content of a meteorite appears to affect its resistance to corrosion. Phases with 20-30 percent by weight nickel (ataxites) have commonly shown superior resistance to terrestrial corrosion than phases with less nickel. By measuring potentials between selected phases, Buddhue (in Johnson and Francis, 1980) determined that corrosion over a period of centuries consumed kamacite (iron, 7.5 percent nickel), while preserving phases such as taenite (iron, 25 percent nickel), schreibersite $(\mathrm{Fe}, \mathrm{Ni})_{3} \mathrm{P}$ (identified by Buchwald [in Johnson and Francis, 1980] as the meteorite mineral most resistant to corrosion), and draubreelite $\left(\mathrm{FeCr}_{2} \mathrm{~S}_{4}\right)$. The better preserved phases are higher in chromium and nickel.

The durability of the iron pillar (99.7 percent iron) of Asoka, India, is attributed to its location in a relatively dry environment and to its fabrication with minimal impurities. Johnson and Francis (1980) indicated that the pillar was constructed by forge-welding together many solid disks. They suggested that conditions during welding may have been favorable for formation of corrosion-resistant oxides.

Johnson and Francis (1980) investigated general, as opposed to localized, corrosion of more than 40 iron artifacts and a few meteorites and obtained a rate of uniform corrosion of $0.1-10 \mu \mathrm{m} / \mathrm{yr}$ over a range of environmental conditions, excluding seawater. Chapman and others (1984) used a corrosion rate of $1 \mu \mathrm{m} / \mathrm{yr}$ (in the middle of this range) to obtain a lifetime of 50 k.y. for the mechanical stability of the Swiss waste-package container.

Johnson and Francis (1980) noted that dry and tomblike environments were the most benign to all ancient materials because lack of moisture condensation suppressed corrosion. They further indicated that if temperatures are below the range where rapid oxidation occurs (varying by metal), elevated temperatures (above the dew point) are an advantage to the preservation of metals.

Copper-bearing archeological artifacts, such as sunken and buried bronze cannons, hoards of ancient copper, and bronze ceremonial objects found in caves, can also be used to estimate general corrosion rates over extended (hundreds to thousands of years) periods of time (Tylecote, 1977, 1979; Neretnieks, 1986; Miller and others, 1994; Chapman and others, 2006). These metal analogues, although differing in chemical composition from the waste-package films, provide important insights into the way different metals survive 
corrosion over long time periods and illustrate the importance of passive films.

Most of the metals that were considered for use in the waste packages at the proposed Yucca Mountain repository consist of alloys that do not occur naturally and are not present in the archeological record (see tables 4-6). However, the long-term behavior of metals with similar compositions that are present either as minerals or as manmade objects can be used to build confidence in long-term performance models of the waste-package materials. Analogues to the long-term behavior of metals related to waste-package materials are described in the following section.

\section{Natural Analogue Studies of Corrosion}

Knowledge of the in-drift physical and chemical environment at Yucca Mountain is critical in predicting the long-term performance of waste packages and the EBS. Processes such as the evaporation and condensation of water, precipitation and dissolution of salts, seepage and mass transport of materials into the drift environment, and the abundance, compositions, and reactions between solid, liquid, and gas phases can affect the physical and chemical integrity of waste packages and other EBS components.

One of the key attributes of the proposed Yucca Mountain repository is its location within the unsaturated zone, thus reducing the amount of water that can come into contact with waste packages. The previous discussion of natural analogues of caves within the unsaturated zone demonstrated that ancient archeological artifacts can be preserved in such environments when not subjected to prolonged exposure to water. Also as previously noted, the relatively minor changes in temperature and $P_{\mathrm{CO} 2}$ at Altamira, Spain, had a substantial effect on deterioration of the cave art there. Thus, the corrosion-resistant properties of waste-package materials that may be used at Yucca Mountain are important to evaluate for all possible variations in environmental conditions during the postclosure period.

One critical factor affecting the chemical integrity of the waste packages is the potential development of hypersaline fluids within proposed emplacement drifts at Yucca Mountain. Such fluids could be generated by evaporative concentration of dissolved salts in pore waters in the near-drift environment caused by heating, or by dissolution of previously formed salts in the dryout zone around the drift by downward-percolating condensate waters and(or) surface infiltration. The amount and salinity of water in contact with waste packages depend on a number of factors, including evaporation, condensation, temperature, and fluid flux rates into the emplacement drifts (fig. 47).

Conceptual and numerical models of these processes indicate that fluid compositions within the emplacement drifts may be highly variable over time (Walton, 1994). To constrain models involving the generation of hypersaline fluids at Yucca Mountain, Rosenberg and others (2001) conducted a series of experiments at subboiling temperatures $\left(75-85^{\circ} \mathrm{C}\right)$ to evaluate the evaporative chemical evolution of pore water from the unsaturated zone and of well water from the saturated zone at Yucca Mountain. Synthetic solutions of these two fluid types were evaporated, with samples collected and analyzed after approximately 100 and 1,000 $\times$ evaporative concentration (table 7) and evaporation to dryness. A number of different minerals formed from complete evaporation of these waters, including amorphous silica, aragonite, calcite, halite, niter, smectite, thermonatrite, tachyhydrite, and gypsum. The groundwater (obtained from the J-13 well at Yucca Mountain) composition evolved into a high-pH, sodium carbonate-bicarbonate brine resulting from the precipitation of calcium-magnesium carbonate, whereas the unsaturated zone pore-water composition evolved into a near-neutral $\mathrm{pH}$, sodium-potassium-calcium-magnesium-chloride-nitrate brine resulting from the precipitation of gypsum.

Different fluid chemistry may develop under higher temperature (boiling) conditions as a result of $\mathrm{CO}_{2}$ degassing, which could have an important effect on the $\mathrm{pH}$ of the evolved fluids. These experimental results provide a dataset against which to compare brines from analogue sites that have interacted with metals in a natural environment. Hypersaline fluids, such as those at the Salton Sea geothermal field in California (table 8), have been observed to corrode many steel compositions aggressively (McCright and others, 1980). Carbon steel drill casings initially used in geothermal production wells at the Salton Sea field experienced general corrosion rates as high as $25.4 \mathrm{~mm} / \mathrm{yr}$, with even higher localized corrosion rates observed (Pye and others, 1989). These rates are much higher than the rates of 10-40 $\mu \mathrm{m} / \mathrm{yr}$ obtained by Ahn and Soo (1995) for corrosion tests of A216-Grade WCA low-carbon steel in concentrated synthetic groundwater solutions. The differences in corrosion rates likely result from (1) differences in steel compositions, (2) higher temperatures for the Salton Sea fluids $\left(232-315^{\circ} \mathrm{C}\right)$ than temperatures used for the corrosion experiments $\left(80-150^{\circ} \mathrm{C}\right)$, and $(3)$ much higher salinities for the Salton Sea brines (150,000-300,000 ppm total dissolved solids [TDS]) relative to the synthetic experimental brines (7,455 ppm TDS). Corrosion problems at the Salton Sea were successfully mitigated through the use of a corrosion-resistant titanium alloy (discussed in the "Analogues for the Titanium Drip Shield" section). The current drip shield design for Yucca Mountain calls for the use of titanium because of its corrosionresistant properties.

Another concern for waste-package materials is the possible evaporative concentration of minor dissolved constituents, such as arsenic, lead, and mercury, that could enhance corrosion. The hypersaline Salton Sea brines have substantial concentrations of arsenic (8 ppm) and lead (66 ppm). However, groundwaters in the vicinity of Yucca Mountain have only trace amounts of lead, with a median concentration of 9 ppb (Lee, 2001; Perfect and others, 1995). Two samples of J-13 well water from Yucca Mountain were analyzed for lead, with one sample yielding a value of $3 \mathrm{ppb}$, while the other was below detection (Perfect and others, 1995). Lead concentrations in groundwater at Yucca Mountain may be limited by 


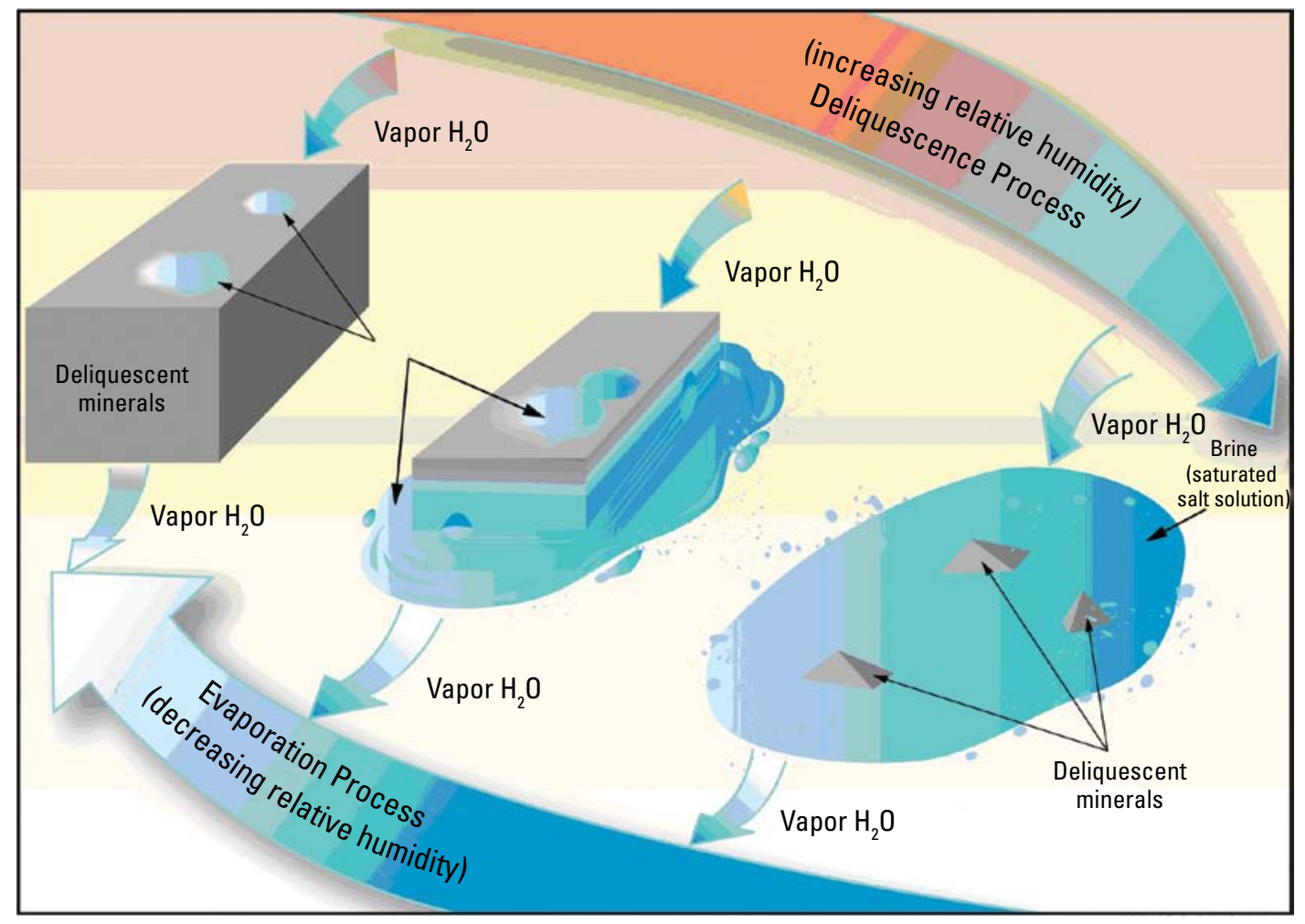

Figure 47. Processes affecting formation of high-salinity fluids on the waste package surface (U.S. Department of Energy, 2008).

Table 7. Composition of synthetic Yucca Mountain waters (in milligrams per liter) from unsaturated and saturated zones and their evaporated compositions (Modified from Rosenberg and others [2001, tables 2 and 4]).

\begin{tabular}{|c|c|c|c|c|c|c|}
\hline $\begin{array}{c}\text { Element or } \\
\text { property }\end{array}$ & $\begin{array}{c}\text { Synthetic J } 13 \\
\text { water }\end{array}$ & $\begin{array}{c}\text { “157 } \times ” \text { J-13 } \\
\text { water }\end{array}$ & $\begin{array}{c}\text { “956 ×” J-13 } \\
\text { water }\end{array}$ & $\begin{array}{c}\text { Synthetic UZ } \\
\text { water }\end{array}$ & $\begin{array}{c}\text { “62 ×” UZ } \\
\text { water }\end{array}$ & $\begin{array}{c}\text { “1,243 } \times ” \text { UZ } \\
\text { water }\end{array}$ \\
\hline $\mathrm{Na}$ & 45.2 & 5,288 & 43,302 & 8.56 & 477 & 6,223 \\
\hline $\mathrm{K}$ & 5.2 & 593 & 4,701 & 4.00 & 268 & 2,644 \\
\hline $\mathrm{Mg}$ & 2.1 & 1.2 & 0.13 & 11.8 & 550 & 5,546 \\
\hline $\mathrm{Ca}$ & 5.8 & 0.06 & 27.3 & 57.3 & 1,713 & 15,643 \\
\hline $\mathrm{HCO}_{3}$ & 105 & 4,410 & 24,255 & 20.3 & 9.9 & $<45$ \\
\hline $\mathrm{SO}_{4}$ & 18.5 & 2,109 & 13,209 & 83.9 & 1,544 & 2,098 \\
\hline $\mathrm{Cl}$ & 7.2 & 814 & 5,047 & 76.6 & 4,259 & 52,165 \\
\hline $\mathrm{NO}_{3}$ & 7.9 & 1,035 & 5,483 & 10.7 & 592 & - \\
\hline
\end{tabular}


Table 8. Typical Salton Sea geothermal well brine composition (from Pye and others [1989, table 1]).

[ppm, parts per million; TDS, total dissolved solids]

\begin{tabular}{lrcr}
\hline Component & $\begin{array}{c}\text { Concentration } \\
\text { (ppm) }\end{array}$ & Component & $\begin{array}{c}\text { Concentration } \\
\text { (ppm) }\end{array}$ \\
\hline $\mathrm{Na}$ & 49,800 & $\mathrm{Ba}$ & 100 \\
$\mathrm{~K}$ & 12,840 & $\mathrm{~B}$ & 301 \\
$\mathrm{Mg}$ & 80 & $\mathrm{Cu}$ & 7 \\
$\mathrm{Ca}$ & 24,000 & $\mathrm{Fe}$ & 708 \\
$\mathrm{SiO}_{2}$ & 658 & $\mathrm{~Pb}$ & 66 \\
$\mathrm{CO}_{2}$ & 125 & $\mathrm{Li}$ & 177 \\
$\mathrm{SO}_{4}$ & 22 & $\mathrm{Mn}$ & 785 \\
$\mathrm{Cl}$ & 126,700 & $\mathrm{Rb}$ & 62 \\
$\mathrm{NH}_{3}$ & 339 & $\mathrm{Sn}$ & 402 \\
$\mathrm{As}$ & 8 & $\mathrm{Zn}$ & 287 \\
$\mathrm{I}$ & 5 & $\mathrm{Br}$ & 68 \\
$\mathrm{pH}$ & 5.8 & $\mathrm{H} 2 \mathrm{~S}$ & 90 \\
& & $\mathrm{TDS}$ & 261,800 \\
\hline
\end{tabular}

precipitation of lead in the form of carbonate, oxide, or sulfide minerals, or by sorption onto mineral surfaces.

Evaporative concentration of water in the near-drift environment at Yucca Mountain could result in higher lead concentrations. However, even a thousandfold increase in lead concentration in $\mathrm{J}-13$ water would still only result in a brine with about 3 ppm lead, more than 20 times lower than the concentrations observed in Salton Sea brines. Thus, the extremely low concentrations of lead in groundwater at Yucca Mountain greatly reduce the risk that lead (and other trace metals) could pose to the chemical integrity of the waste packages.

\section{Passive Film Formation}

The formation of passive films has a substantial effect on the corrosion-resistant properties of metals and metal alloys. Passive films are stratified coatings consisting of an inner oxide layer and an outer layer of hydroxide or oxyhydroxide (Macdonald, 1992; Marcus and Maurice, 2000). The inner layer forms a corrosion barrier, whereas exchange occurs within the outer layer of the passive film. These films act as semiconductors or insulators, thus reducing the rate of metal dissolution triggered by an electrochemical potential between a metal and its surrounding electrolyte solution.

The Delhi iron pillar is a 1,600-year-old metal artifact (fig. 48) that has withstood exposure to the atmosphere with only relatively small amounts of corrosion. Study of the rust layer coating the pillar reveals the presence of crystalline iron-hydrogen-phosphate hydrate and amorphous iron oxyhydroxides and magnetite (Balasubramaniam, 2000). The low-porosity crystalline phosphate phase forms a passive film around the pillar, serving to protect it from further corrosion (fig. 49). Balasubramaniam (2000) interpreted the presence of about 0.25 weight percent phosphorus and fine slag particles in the iron to be critical to the development of the corrosionresistant layer.

\section{Naturally Occurring Metals as Natural Analogues}

A number of naturally occurring metals provide information of an analogous nature regarding the potential durability of metals proposed for the EBS at Yucca Mountain. The following section discusses josephinite and chromite, two naturally occurring metals that have been studied and would comprise some of the waste-package metals.

Josephinite, a naturally occurring nickel-iron-cobalt metal-bearing rock consisting of the minerals $\mathrm{Ni}_{3} \mathrm{Fe}$ (awaruite), andradite garnet, $\mathrm{FeCo}$ (wairuite), and minor to trace amounts of $\mathrm{Ni}_{6} \mathrm{Fe}_{4}$ and $\mathrm{CaO} \cdot 2 \mathrm{FeO}$ (calciowüstite), is a possible natural analogue for nickel-iron alloys (similar to Alloy 22, which is a nickel-chromium-molybdenum alloy) planned for the Yucca Mountain waste packages. The type locality of josephinite is the Josephine Peridotite, a serpentinized ultramafic ophiolite about 150 million years old in Oregon (Dick, 1974), where it occurs within serpentine veins and as coarse metallic nuggets in nearby placer deposits. Relatively unaltered masses of metal that are predominantly $\mathrm{Ni}_{3} \mathrm{Fe}$ (with small inclusions of $\mathrm{Ni}_{3} \mathrm{As}$ ) were discovered in 1999 within harzburgite in the Josephine ophiolite and as eroded blocks weighing up to about $3 \mathrm{~kg}$ (Bird, 2001). Josephinite and awaruite are stable rock and mineral phases, as evidenced by their survival for millions of years with only minor amounts of oxidation. Because of this long-lived stability, these ordered nickel-iron-cobalt metals (Bassett and others, 1980) have been proposed as alloys in constructing containers for the storage of high-level radioactive waste (Bird and Ringwood, 1980, 1982, 1984).

The josephinite nuggets have alteration rims composed of $\mathrm{Fe}_{3} \mathrm{O}_{4}$ (magnetite, with maghemite) and $\mathrm{NiFe}_{2} \mathrm{O}_{4}$ (trevorite). Some samples of josephinite contain the high-temperature phase taenite (a disordered nickel-iron metal) in addition to awaruite. Phase relation studies of the iron-nickel system indicate that taenite is not stable below about $350^{\circ} \mathrm{C}$, and that iron, pure nickel, and awaruite are the stable phases for this system at ambient temperatures (Botto and Morrison, 1976). The persistence of taenite for millions of years indicates that low-temperature phase change rates for taenite are exceedingly slow. X-ray photoelectron spectroscopic analysis of a josephinite placer sample from the Josephine ophiolite (fig. 50) revealed that while both iron and nickel are oxidized on the surface, nickel remains in reduced (metallic) form at depths of 2 nanometers $(\mathrm{nm})$ and greater (analyzed to a depth of $120 \mathrm{~nm}$ ), indicating that the bulk sample has not undergone 


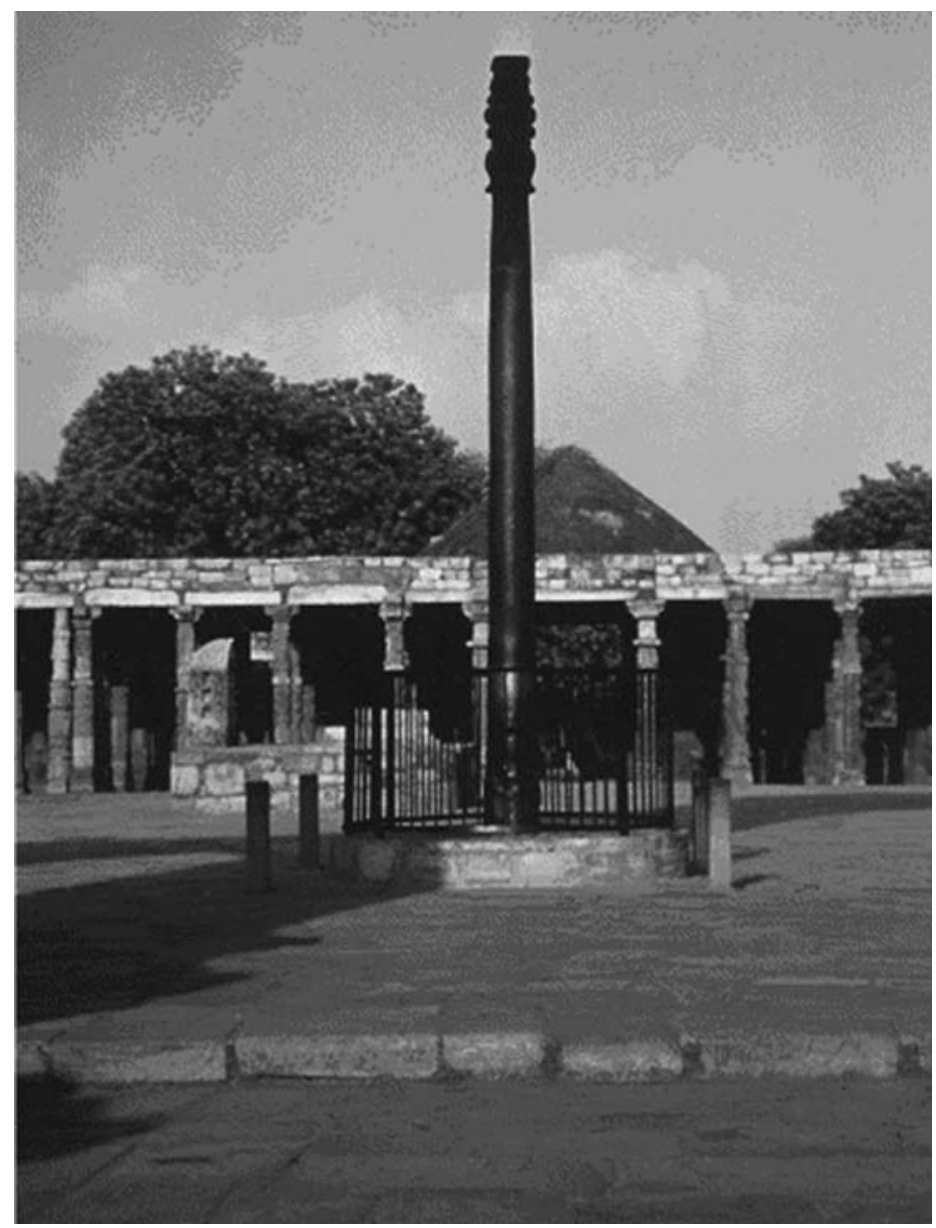

Figure 48. The corrosion-resistant iron pillar at Delhi, India (Balasubramaniam, 2000, fig. 1).
MILD STEEL

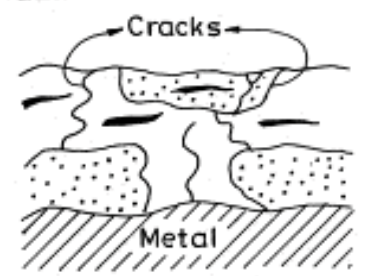

WEATHERING STEEL

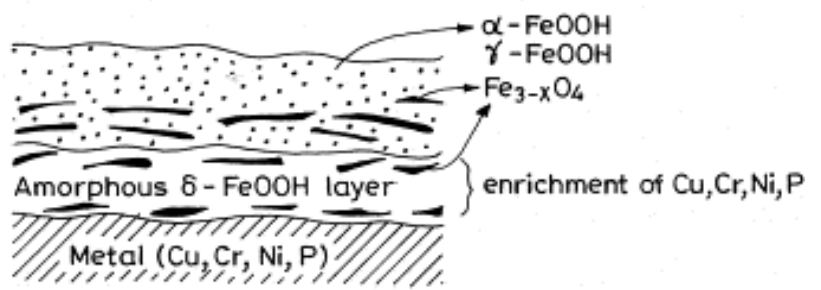

\section{DELHI IRON PILLAR}

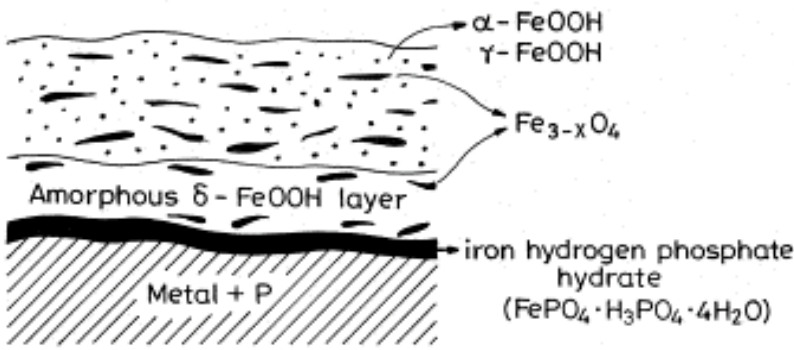

NOTE: Iron hydrogen phosphate hydrate layer on Delhi iron pillar forms a protective, impermeable coating that retards further corrosion.

Figure 49. Schematic showing development of rust coating on mild steel, weathering steel, and Delhi iron pillar (Balasubramaniam, 2000, fig. 7).

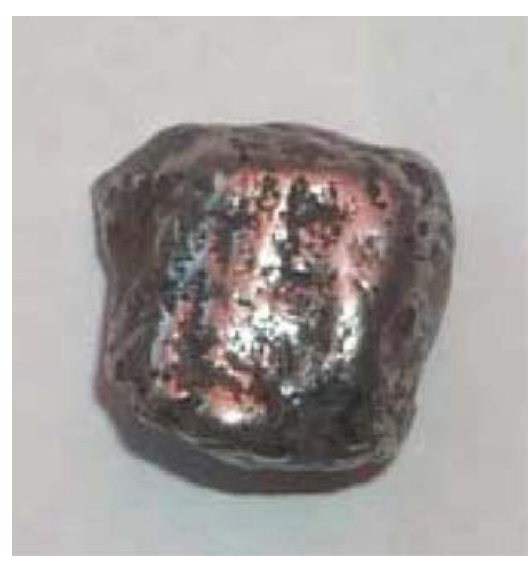

NOTE: Metallic-looking areas were analyzed using $\mathrm{X}$-ray photoelectron spectroscopy.

Figure 50. Josephinite sample used for surface analysis study (BSC, 2001b, Appendix E, fig. 3). 
susceptibility of the rocks to weathering and subsequent release of chromium (Robles-Camacho and Armienta, 2000). The laboratory acid treatment was designed to examine (over a much shorter time scale and under much more acidic conditions than in the field) the effects of weathering resulting from interaction of oxygenated, $\mathrm{CO}_{2}$-rich groundwater with chromium-bearing minerals. The leachate from chromiumrich serpentinite samples yielded the highest concentrations (as much as $274 \mathrm{mg} \mathrm{Cr} / \mathrm{kg}$ rock), indicating that they have the greatest potential to release chromium. Scanning electron microscope analysis of samples examined after leaching indicates that dissolution occurred along magnetite exsolution borders of chromite grains (fig. 51). Total chromium contents of groundwater samples collected from wells, streams, and reservoirs near the ultramafic rocks range up to $0.0149 \mathrm{mg} / \mathrm{L}$. Concentrations at this level may be analogous to the long-term chromium concentrations that may be expected to leave the EBS at Yucca Mountain; the Environmental Impact Statement estimated a value of $0.015 \mathrm{mg} / \mathrm{L}$ for chromium (U.S. Department of Energy, 2002, Appendix I, Table I-31). The calciummagnesium- $\mathrm{HCO}_{3}$ composition of these waters is consistent with interaction with serpentinized ultramafic rocks. The study does not provide information on the rates of chromite weathering, but it does indicate that chromite exsolution borders are susceptible to chemical attack. This observation is analogous to localized corrosion and pitting observed in metals along structural defects.

\section{Summary of Waste-Package Degradation Analogues}

1. The survival of metal archeological artifacts over prolonged periods of time is related to the corrosion-resistant properties of metals and metal alloys, the development of protective passive film coatings with the onset of corrosion, and the location of artifacts in arid to semiarid environments. Such features can be used in the selection of materials and design configuration to enhance the durability of waste packages at the proposed repository at Yucca Mountain.

2. Archeological examples, such as the Altamira cave, illustrate how environmental changes can substantially affect corrosion behavior. A wide variety of environmental conditions is expected in the near-drift environment at Yucca Mountain during the life span of the proposed repository. The introduction of heat-generating waste packages and EBS materials into drifts would perturb the existing physical and chemical system at Yucca Mountain. The materials used for the waste packages (and the rest of the EBS) would need to withstand the predicted adverse changes in environmental conditions.

3. Small volumes of concentrated brines could develop in the near-drift environment as a result of evaporation and later dissolution of precipitated salts in the dryout zone with rewetting. High-salinity fluids pose a substantial corrosion hazard to carbon steel, as seen at the Salton Sea geothermal field, but the use of titanium alloys can effectively minimize this hazard.

4. The survival for millions of years of the naturally occurring ordered nickel-iron alloy in josephinite (with only relatively minor amounts of surface oxidation) indicates that this material is highly resistant to oxidation and other forms of corrosion that occur in its geologic environment. Although the composition of this metal differs from Alloy 22 (in that it does not contain chromium, molybdenum, and tungsten), it does provide evidence that a similar alloy can remain passive over prolonged periods of time.

5. The potential instability of chromium-bearing materials is illustrated by the observed natural release (under ambient conditions) of chromium from chromite in the Sierra de Guanajuato ultramafic rocks. Corrosion appears to be concentrated along exsolution rims, analagous to structural defects on metal surfaces. Although the chromite has undergone some alteration, it has survived for more than 140 m.y. (since Jurassic time). The corrosive qualities of this chromium oxide mineral may differ from those of the chromium-bearing metal alloys that are currently proposed for use in the construction of a waste package.

\section{Analogues for Other Engineered Barrier System Components and Their Effect on Radionuclide Transport}

This section describes the use of natural analogues to evaluate the long-term performance of materials that would be used in the construction of the EBS and how these materials may affect radionuclide transport. The primary functions of the EBS components are to (1) protect the waste package from physical and chemical degradation resulting from processes such as seepage, corrosive fluids, and rockfall; and (2) retard any potential transport of radionuclides from the emplacement drift in the event of waste-package failure. Key concerns for the EBS materials (described in the "Engineered Barrier System Design" section) include the possible degradation and corrosion of metals resulting from mechanical stress, aggressive physical and chemical environments (for example, corrosive fluids, radiation, thermal and physical stresses, and microbial attack), and metallurgical factors. Another important performance parameter is the effect of EBS materials on flow and transport of fluids and dissolved solids into and out of the emplacement drifts, including the effects of sorption and colloids on radionuclide transport.

Degraded cementitious repository materials and their interaction with water can generate high-pH alkaline plumes that may affect the integrity of EBS materials, cause reactions with the surrounding host rock, and ultimately affect radionuclide transport. Under the proposed EBS design, cementitious 

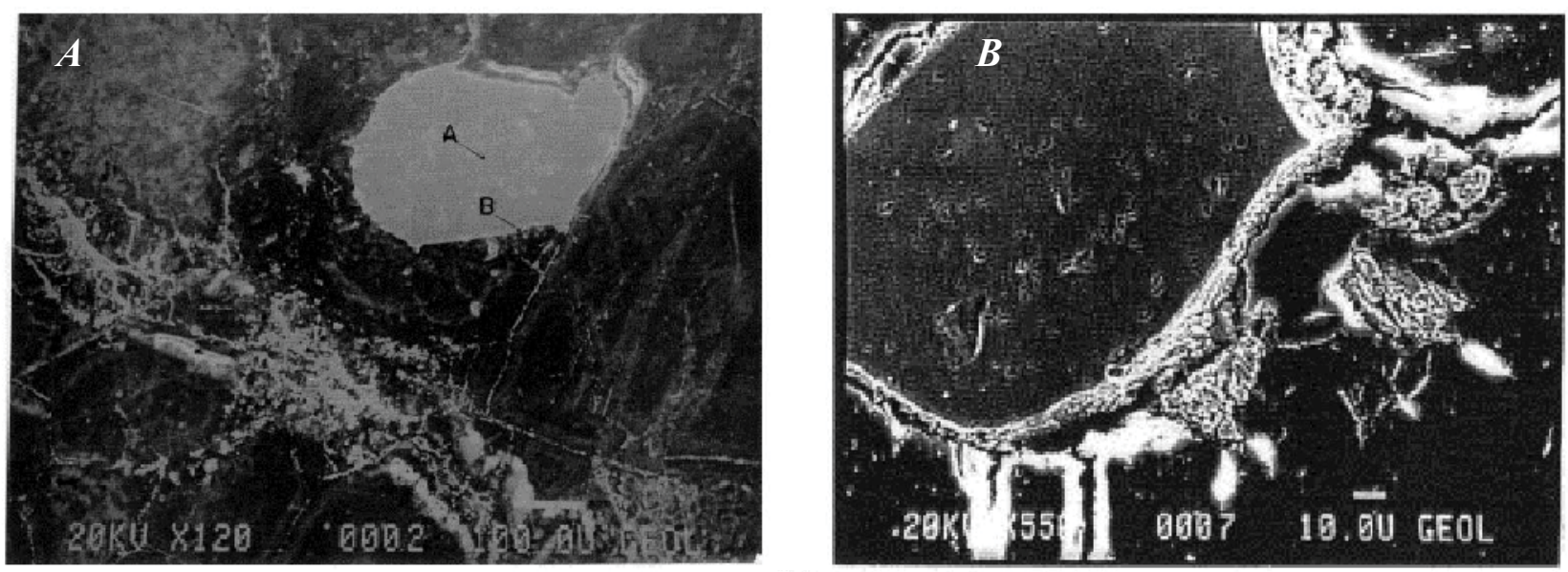

NOTE: White rim around chromite in $B$ reflects dissolution of exsolution border around chromite.

Figure 51. Chromite grains in serpentinite before $(A)$ and after $(B)$ acid leachnig (Robles-Camacho and Armienta, 2000, figs. 5 and 8).

material is expected to be present in only minor amounts (as grout for rock bolts) in the near-drift environment.

The durability of cements over time has been documented by Gallo-Roman cements that are more than 1,500 years old (Thomassin and Rassineux, 1992). Calcium silicate hydrate compounds were formed early in the development of Roman cement, which used crushed vitreous fireclay as a pozzolan in the concrete mixture (Miller and others, 1994, 2000; Miller and Chapman, 1995). The calcium silicate hydrate compounds reduced the porosity and permeability of the concrete and helped to ensure its preservation for more than 2,000 years with no loss of mechanical strength. Cementitious mortar from Hadrian's Wall (about 1,700 years old) in England (fig. 52) has the same calcium silicate hydrate phases that are in modern Portland cement and still possesses excellent strength and stability (Miller and others, 2000). Similar results were obtained from the earliest reinforced concrete structures in Britain and in the earliest Portland cements used in sea defenses 150 years ago (Miller and Chapman, 1995). However, the interaction between cements and materials with which cement is in contact is important to examine. One industrial analogue study examined interaction between cement and rock in a tunnel driven into marls. The concrete was observed to be completely recrystallized at the contact zone, resulting in a significant increase in porosity and loss of mechanical strength (Miller and Chapman, 1995).

The potential development of hyperalkaline fluids resulting from interaction of water with cementitious material could affect radionuclide transport and reduce the stability of EBS materials. Two areas with hyperalkaline fluids are the Semail ophiolite in Oman and the Maqarin area in Jordan. The Oman natural analogue site is located in the Semail Ophiolite Nappe of northern Oman (fig. 53). The Oman investigation was a natural analogue study of hyperalkaline groundwaters concerned with the effect of hyperalkaline conditions on radionuclide transport processes, including solubility and speciation, colloids, and microbial populations. A primary aim of the study was to test the ability of thermodynamic codes to represent and predict hyperalkaline rock/groundwater equilibrium conditions. Details of the investigations are given by Bath and others (1987b) and are summarized in Bath and others (1987a) and McKinley and others (1988). At Oman, serpentinization
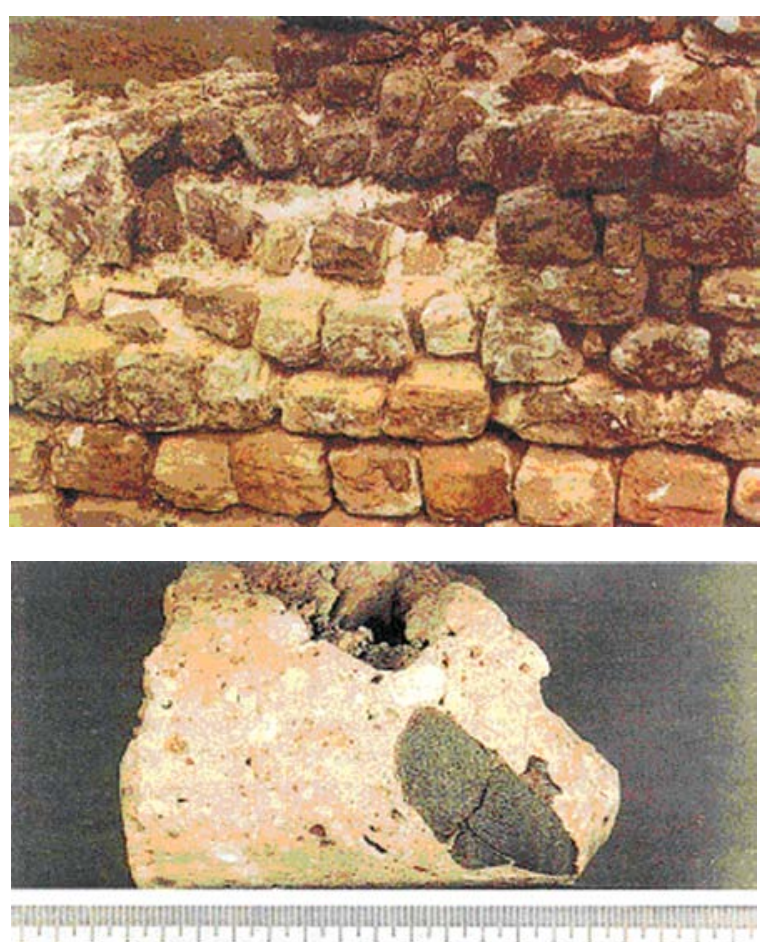

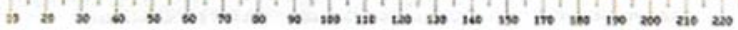

Figure 52. Portion of Hadrian's Wall in England, showing strength and stability of Roman mortar after 1,700 years (Miller and others, 2000, fig. B10.2). 


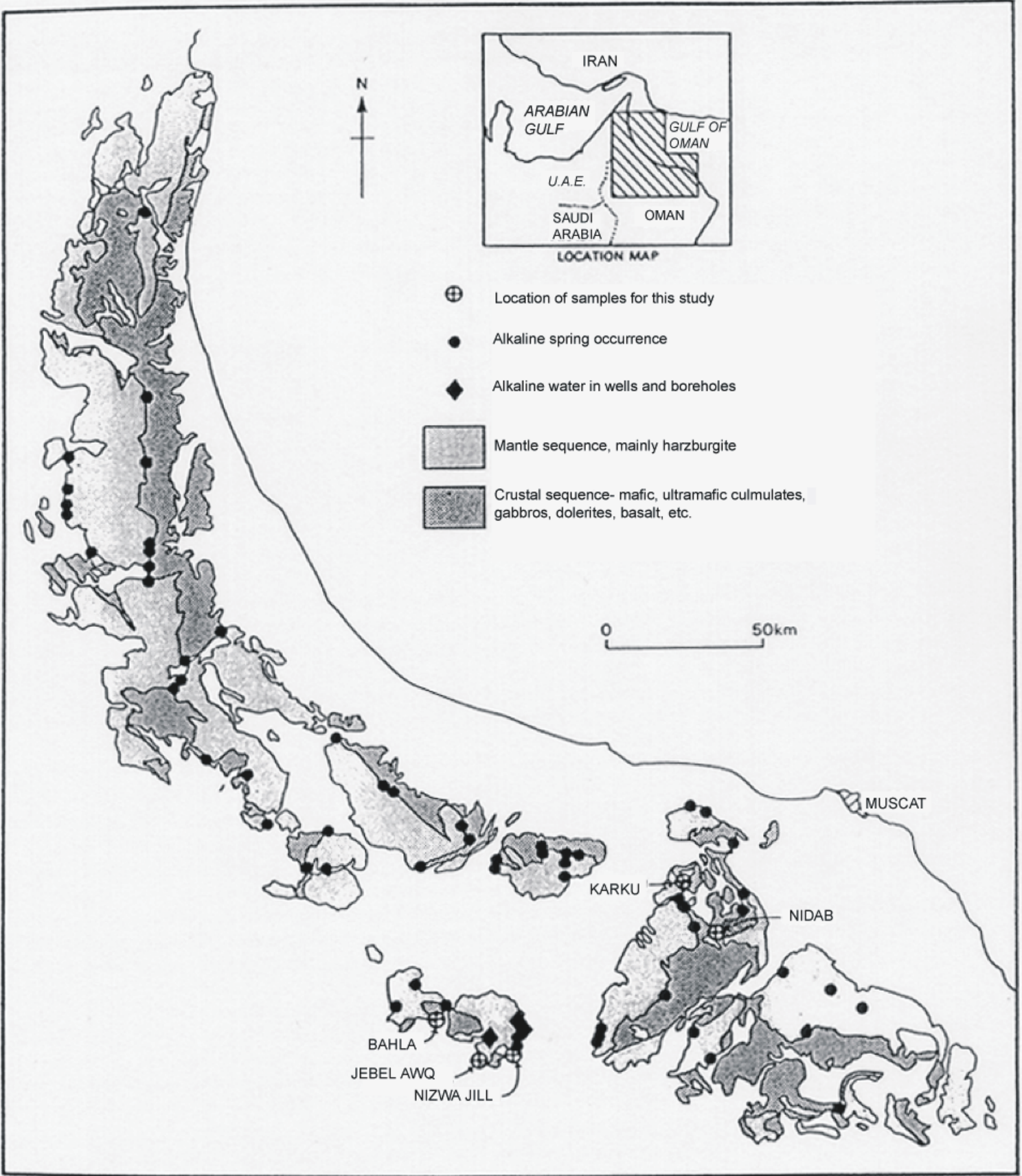

Note: The locations of springs sampled as part of the Oman natural analogue study are shown.

Figure 53. Distribution of ophiolites and hyperalkaline springs in northern Oman (Bath and others, 1987b). 
reactions in the Semail ultramafic rocks have resulted in the generation of reducing, hyperalkaline $(\mathrm{pH}=10-12) \mathrm{Na}-\mathrm{Cl}-$ $\mathrm{Ca}-\mathrm{OH}$ fluids, with associated minerals brucite $\left[\mathrm{Mg}(\mathrm{OH})_{2}\right]$ and portlandite $\left[\mathrm{Ca}(\mathrm{OH})_{2}\right]$.

The Maqarin analogue site contains a suite of naturally formed cement minerals, including portlandite. High-pH (12-13) fluids emanate from these rocks as a result of reaction of groundwater with the cement phases. These analogue sites have been used in the development of numerical models to predict water/rock reactions and resulting fluid compositions under similar conditions (McKinley and others, 1988; Chambers and others, 1998).

Chemical decomposition resulting from radiolysis was studied at the natural reactor site at Oklo, Gabon, where high radiation doses were interpreted to have led to radiolysis of water and redox reactions involving the surrounding rocks (Curtis and Gancarz, 1983). Similar reactions within the waste-package assembly at Yucca Mountain could lead to decomposition of the waste packages and release of radionuclides. However, because the waste loads are configured so that they will not approach criticality and the waste-package design excludes free water, the amount of radiolysis that might occur at the proposed Yucca Mountain repository should be much less than at Oklo (see previous discussion in the "Radiolysis" section).

\section{Analogues for the Titanium Drip Shield}

Corrosion caused by saline fluids has been identified as a potential hazard to the integrity of waste packages, as discussed in the section "Natural Analogue Studies of Corrosion." The drip shield assembly is designed to protect the waste packages from physical and chemical degradation resulting from events such as rockfalls and seepage and from saline fluids. The proposed drip shield design calls for corrosion-resistant titanium. Titanium metal does not occur in nature, nor in the archeological record, so other proxies are needed to assess its long-term resistance to corrosion.

The Salton Sea geothermal field in California is characterized by hypersaline (15-30 weight percent) TDS brines that have caused significant corrosion and scaling problems (Pye and others, 1989). A series of corrosion tests led field operators to select Beta-C titanium (Ti-3Al-8V-6Cr-4Mo-4Zr) for the fabrication of corrosion-resistant production casing. Four tests were conducted over a 256- to 833-day period that involved installation of full-size Beta-C titanium tubulars in geothermal production wells, resulting in no visible pitting corrosion in two of the tests, little or no change in hydrogen content, and no significant degradation in mechanical properties (Pye and others, 1989). During the 833-day test, localized corrosion was observed, at a rate of $178 \mu \mathrm{m} / \mathrm{yr}$; this was interpreted to have occurred in an area where surface contamination had not been completely removed at the start of the test. Local corrosion was observed along 2 of the 48 casing joints in the fourth test; this corrosion was also interpreted to be the result of preexisting surface contamination.
A longer-term evaluation of the corrosion behavior of titanium-bearing materials can be obtained by examining the stability of naturally occurring titanium minerals. Titanium is present as a major constituent in a number of refractory accessory minerals commonly found as a minor phase in igneous rocks and in heavy mineral concentrates in sediments. These minerals include sphene (titanite) $\left[\mathrm{CaTiSiO}_{4}(\mathrm{O}, \mathrm{OH}, \mathrm{F})\right]$, rutile $\left(\mathrm{TiO}_{2}\right)$, ulvöspinel $\left(\mathrm{Fe}_{2} \mathrm{TiO}_{4}\right)$, and ilmenite $\left(\mathrm{FeTiO}_{3}\right)$.

Most of the world's production of titanium is from heavy metal sands containing ilmenite. These are lag deposits of heavy minerals that accumulate on beaches (or to a lesser extent in streams) by virtue of their high density, mechanical stability, and resistance to corrosion. The deposits can be very large; for example, in both 2006 and 2007, Australia produced over 2.5 billion metric tons of mineral concentrate and China produced over 1 billion metric tons (Gambogi, 2009). The resilience of titanium is indicated by the fact that "although numerous technologies are used to produce synthetic rutile $\left(\mathrm{TiO}_{2}\right)$, nearly all are based on selective leaching or thermal reduction of iron and other impurities in ilmenite" (Gambogi, 2009, p. 78.1).

The Canadian nuclear-waste disposal concept includes a metallic titanium container surrounding spent fuel. The corrosion resistance of titanium arises from its passivation in aqueous solutions by the formation of a protective layer containing rutile (Cramer, 1994). At the Cigar Lake uranium deposit in Saskatchewan, Canada, rutile is present within the uranium ore and has persisted unchanged for over a billion years in reducing groundwaters, under hydrothermal conditions, and in a radiation field (Sargent and Cramer, 1986; Cramer and Sargent, 1994; Cramer and Smellie, 1994; Cramer, 1995a, b; Cramer and others, 1987; Cramer, 1989). Although rutile and other titanium-bearing minerals are oxides and thus do not share the same physical properties as metals, their general resistance to alteration reflects the stable nature of titaniumbearing materials.

\section{Analogues for the Invert Ballast}

The nonwelded Calico Hills Formation and portions of the Paintbrush Tuff at Yucca Mountain are possible analogues for processes, such as sorption and ion exchange, which would affect the transport of radionuclides within the crushed tuff invert ballast. The relative lack of fractures in these tuffs results in fluid flow in the tuff matrix, resulting in overall slower fluid flow and transport in these units caused by the lack of fast flow pathways, similar to what is predicted for the crushed tuff invert. Because of the presence of zeolites and(or) smectite in the nonwelded tuffs, extensive ion exchange occurs between pore waters and the tuffs (Vaniman and others, 2001). The zeolitic tuffs are substantially enriched in cations such as $\mathrm{Ca}^{2+}, \mathrm{Mg}^{2+}$, and $\mathrm{Sr}^{2+}$, and depleted in $\mathrm{Na}^{+}$and $\mathrm{K}^{+}$(fig. 54); thus, waters are interpreted to have complementary (opposite) enrichments and depletions (Vaniman and others, 2001). This ion-exchange process would have a major effect on radionuclide transport, with species such as ${ }^{90} \mathrm{Sr}$ being effectively 

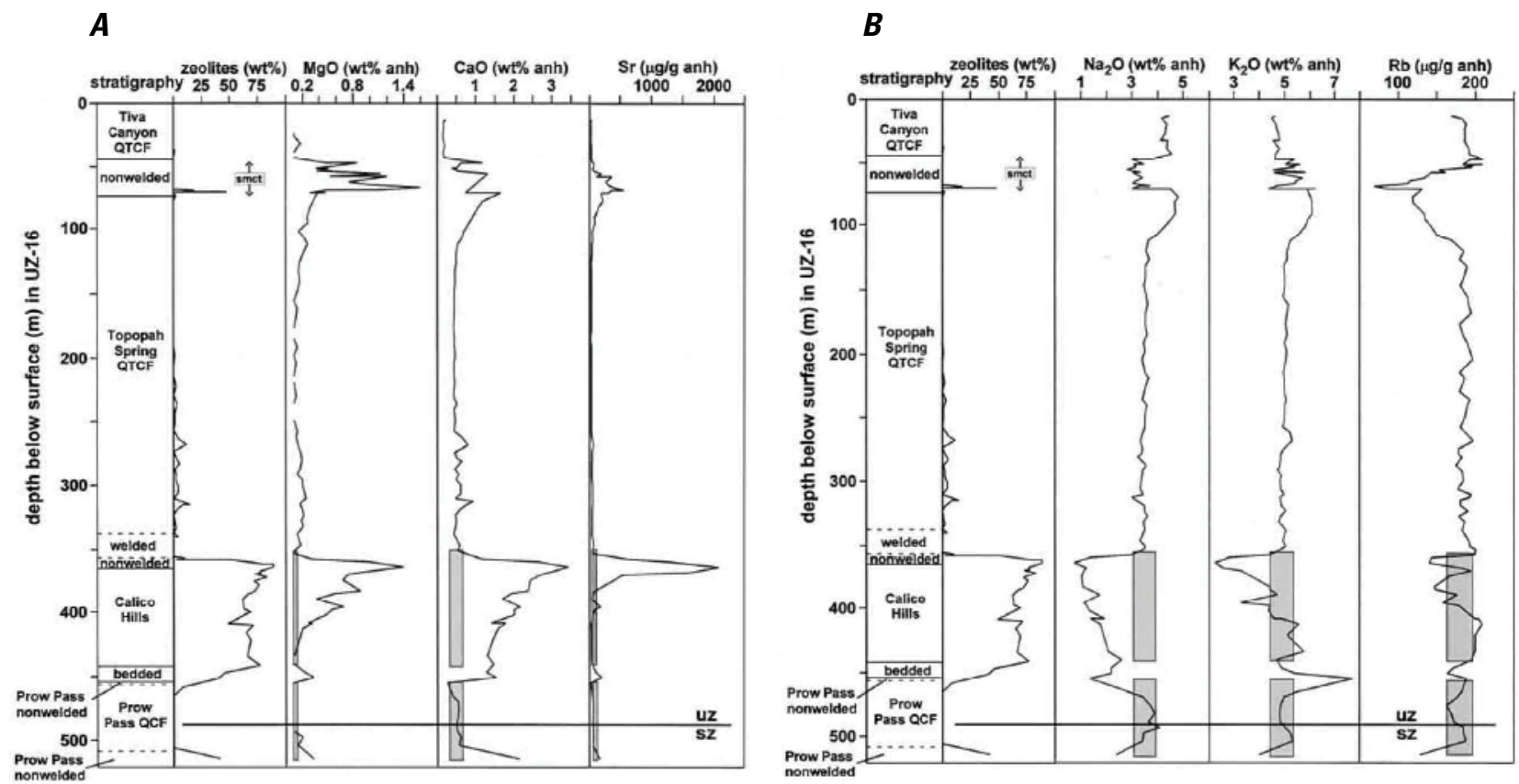

NOTE: Shaded bars represent corresponding compositions of unzeolitized precursor tuffs. Symbols ( $Q$, quartz; T, tridymite; C, cristobalite; $\mathrm{F}$, feldspar) indicate devitrification minerals in welded tuff intervals. US-SZ line marks location of water table. Chemical abundances are normalized to anhydrous (anh) compositions.

Figure 54. Stratigraphic section of drill hole UE-25 UZ\#16, with abundance of zeolites plotted relative to $(A)$ alkaline earth, and (B) alkali constituents (Vaniman and others, 2001, fig. 4)

immobilized by this process. However, the proposed design for the invert ballast (U.S. Department of Energy, 2001a) uses crushed tuff derived from the repository interval (welded, devitrified Topopah Spring Tuff), which has only minor amounts of zeolites and clays (Vaniman and others, 2001). As a result, the ion exchange and sorption capacity of the crushed tuff invert ballast should be substantially lower than that observed in the nonwelded tuffs at Yucca Mountain. The crushed tuff invert would have high effective grain surface areas, which would favor sorption of species onto mineral surfaces, thus serving to retard radionuclide transport. Zeolitized tuffs at depth, however, could have a pronounced effect on retardation of certain radionuclides (as discussed in the section "Unsaturated Zone Flow and Transport Analogues").

\section{Natural Analogues for Development of Alkaline Plumes from Cement}

The presence of naturally occurring cement minerals and associated hyperalkaline groundwaters at Maqarin, Jordan, has been used as a natural analogue for examining the effects of hyperalkaline waters on elements of a nuclear waste repository (for example, Khoury and others, 1992; Smellie, 1998). The
Maqarin site consists of interbedded bituminous limestones and marls that have been thermally metamorphosed locally from spontaneous combustion of the bitumen, resulting in the calcination of limestone and formation of cement minerals, including portlandite. Water interacting with portlandite resulted in the formation of highly alkaline ( $\mathrm{pH}$ about 12.5) groundwaters and the precipitation of minerals such as ettringite and thaumasite at ambient temperatures (fig. 55).

Initial geochemical modeling efforts of Maqarin groundwaters resulted in model predictions of dissolved selenium and uranium concentrations that were several orders of magnitude higher than those observed in the field (Linklater and others, 1996). Thus, a multicomponent reactive transport model that incorporated mixed equilibrium and kinetic reactions was applied to simulate rock alteration mineralogy and fluid chemistry changes for discrete fractures in the Maqarin system (Steefel and Lichtner, 1998). These simulations predict the formation of hydrated calcium sulfate and silicate minerals, such as ettringite and tobermorite, which were observed in the field (Khoury and others, 1992), and also reproduced measured fluid $\mathrm{pH}$ values. The simulations indicate that mineralization caused by interaction of the hyperalkaline plume with surrounding rocks may result in both reduction of matrix porosity and fracture sealing. Fractures at the Maqarin site have 


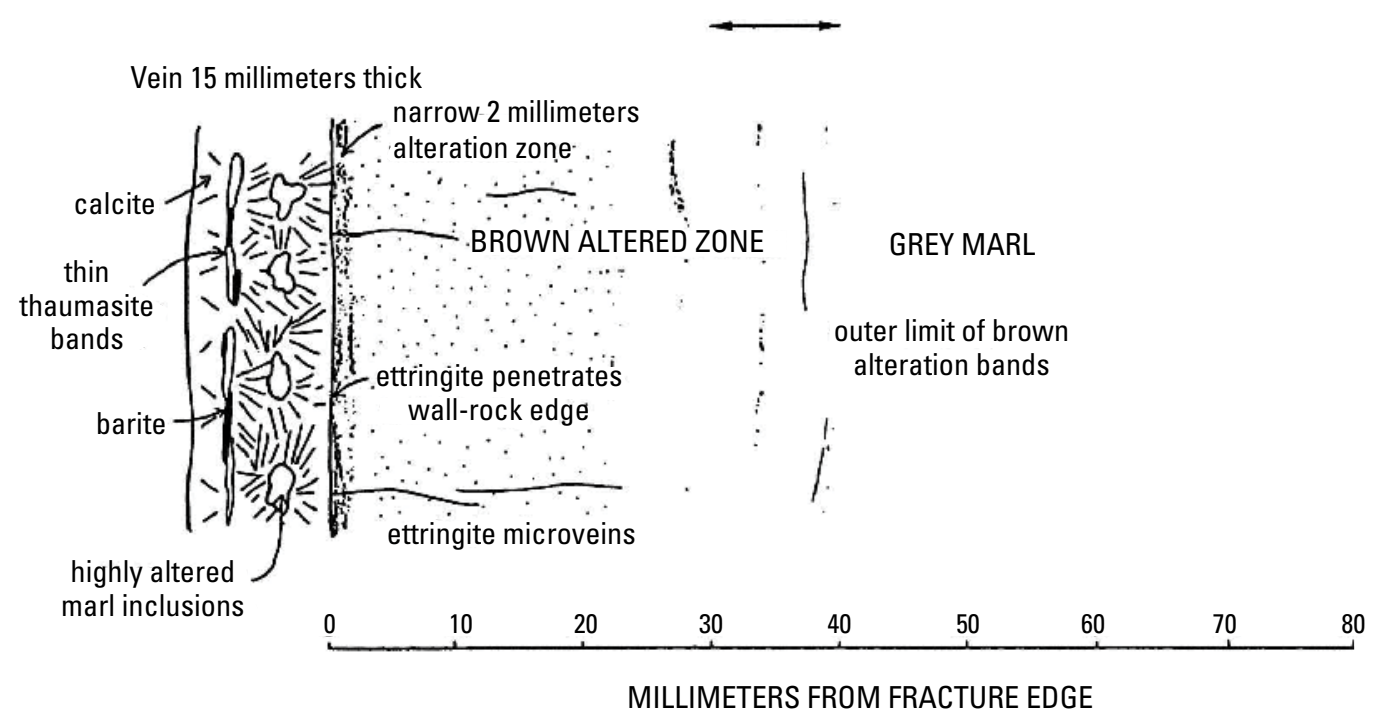

Figure 55. Fracture mineralization and wall rock alteration at C353 site, Maqarin, Jordan, showing the presence of hydrated calcium silicate and sulfate phases thaumasite and ettringite (Steefel and Lichtner, 1998, fig. 6).

complex mineralogy and textures, indicating that they have undergone repeated sealing and reopening over time. The relative rates of matrix and fracture mineralization (and associated reduction in permeability) will significantly affect the mobility of the alkaline plume, and thus the transport of associated radionuclides.

The principal use made of the Maqarin natural analogue has been in blind testing of solubility and speciation thermodynamic databases and, to a lesser extent, thermodynamic codes. Microbiological and colloidal populations have also come under investigation. Full details of these investigations are given in Khoury and others (1992), Maqarin Natural Analogue Site Study Group (1992, Chapter 5), Tweed and Milodowski (1994), and Smellie (1998).

The development of large hyperalkaline plumes and associated alteration and transport would not be expected at Yucca Mountain. The amount of cementitious material expected to be present in the proposed repository (in the form of grout around rock bolts in the emplacement drifts) is much less than what is observed at Maqarin. The fluid $\mathrm{pH}$ of the near-field environment thus will be buffered by tuff rather than by portlandite, resulting in less alkaline $\mathrm{pH}$ conditions. The Maqarin natural analogue is important to consider in illustrating the effects of alkaline fluids on water/rock processes, thus constraining EBS design parameters (through minimization of the use of cement) and coupled process models. The ability of the multicomponent reactive transport simulations to reproduce observed water/rock interactions for the alkaline plumes at Maqarin provides confidence that similar modeling efforts at Yucca Mountain predict reactive chemistry and transport processes that would be expected over time.

\section{Natural Analogues for Colloidal Transport of Radionuclides in the Near Field}

Colloids can facilitate radionuclide transport (fig. 56) if they are present in sufficient quantities, are mobile, and can bind radionuclides (Wieland and Spieler, 2001). Naturally occurring colloids are ubiquitous in groundwaters; those sampled by Kingston and Whitbeck (1991) (mainly from central and southern Nevada) have dilute colloid concentrations ranging from 0.28 to $1.35 \mathrm{mg} / \mathrm{L}$. Ferric oxide and oxyhydroxide colloids also can be generated through degradation of structural steel present in EBS materials.

Filtration of iron-bearing colloids has been documented in some environments. For example, groundwater in the natural-analogue study site at the Poços de Caldas area in Brazil typically has low concentrations (less than $1 \mathrm{mg} / \mathrm{L}$ ) of colloids (Miekeley and others, 1989, 1991b). Most of the colloids there are composed of iron and organic species. Only minor amounts of uranium are associated with colloids, but greater amounts of thorium and REEs are transported in the colloidal fraction. The results of the colloid studies at Poços de Caldas (Miekeley and others, 1989, 1991b) indicate that radionuclide and other trace-element transport by colloids is not a major factor in the geochemical processes of weathering, dissolution, and erosion of these ore deposits. One reason for this could be filtration of material that traps colloids in pore throats and narrow fractures (Smellie and others, 1989). The colloidal material acts as an efficient and largely irreversible sink or trap for many elements (especially if they are immobile) but needs to be taken into account in equilibrium thermodynamic modeling of radionuclide speciation. The point of this example 


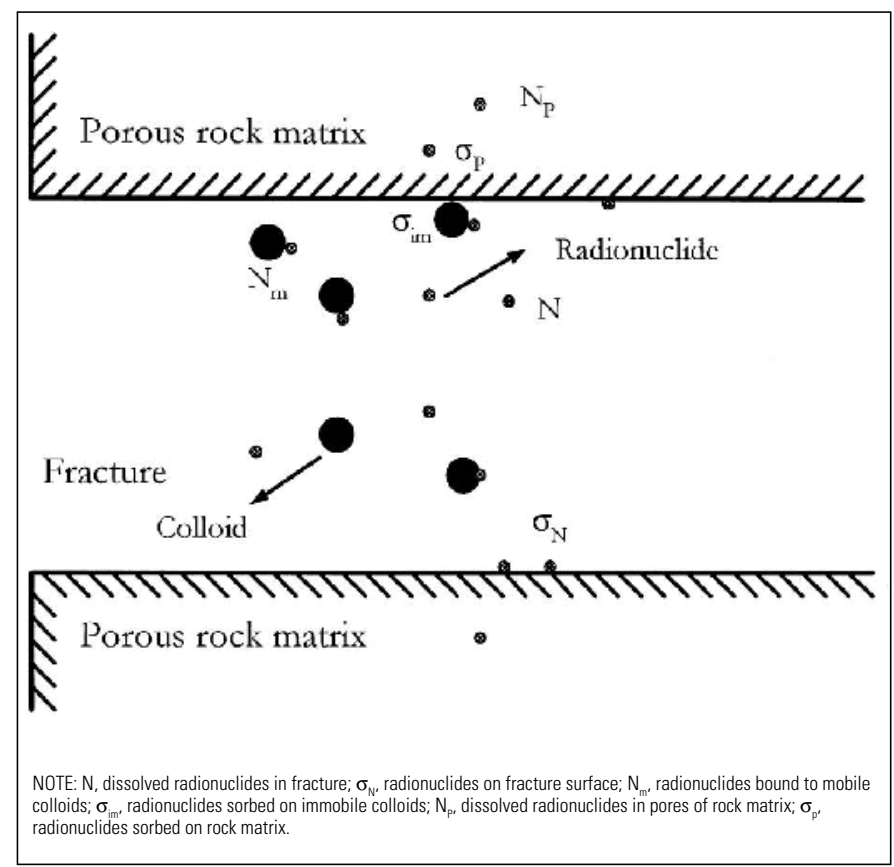

Figure 56. Schematic illustration of radionuclide transport in a fractured rock (modified from Jen and Li, 2001, fig. 1).

is that the iron-bearing colloids that may form from steel structural elements in the EBS could be beneficial in complexing with uranium and could be retained effectively in the EBS by filtration.

\section{Summary of Analogues to Engineered Barrier System Materials and Processes}

The analogues presented in this section serve mainly to demonstrate that under ambient to slightly elevated temperatures, these metals (iron, nickel, chromium, titanium) will be stable for thousands of years, even under oxidizing conditions. Because the historical record is unlikely to offer analogues to titanium stability, titanium-bearing minerals such as sphene, ilmenite, and rutile may offer insights. For cements, important considerations are the effects of elevated temperatures on stability of cement minerals and reactions at the interface between cement and other materials. Radiolysis deserves consideration because it is uncertain if it poses a potential problem around waste packages in the design scenario in which waste packages are not self-shielded. Under criticality conditions at Oklo, a portion of the uranium was estimated to have been mobilized, but the conditions were far more extreme than those that would be anticipated at Yucca Mountain.

The highly corrosion-resistant nature of titanium has been demonstrated by long-term experiments conducted on a range of metal alloys in wells at the Salton Sea geothermal field. The commercial use of titanium alloys in production casings over the past decade at that locality has greatly alleviated previous severe corrosion problems resulting from exposure of conventional steel casing to the hot, hypersaline geothermal brines. This anthropogenic example supports the selection of titanium alloys for the construction of a corrosion-resistant drip shield for the EBS.

The survival of metal archeological artifacts over prolonged periods of time is related to the corrosion-resistant properties of metals and metal alloys, the development of protective passive film coatings with the onset of corrosion, and the location of artifacts in arid to semiarid environments. Such features have been used in the selection of materials and design configuration that would enhance the durability of waste packages at Yucca Mountain. The survival of the naturally occurring ordered nickel-iron alloy in josephinite for millions of years, with only relatively minor surface oxidation, indicates that this material is highly resistant to oxidation and other forms of corrosion that occur in its geologic environment. Although the composition of this metal differs from Alloy 22 (in that it does not contain chromium, molybdenum, or tungsten), it does provide evidence that a similar alloy can remain passive over prolonged periods of time under similar conditions. The potential instability of chromium-bearing materials is illustrated by the observed natural release of chromium from chromite in the Sierra de Guanajuato ultramafic rocks under ambient conditions. Corrosion appears to be concentrated along exsolution rims, analogous to structural defects on metal surfaces. However, although the chromite has undergone some alteration, it has survived for more than 140 m.y.

The presence of cementitious materials can potentially lead to the development of alkaline plumes, resulting in corrosion of waste-package materials, alteration of surrounding host rocks, and possible enhancement of radionuclide transport. Because the use of cementitious material in the EBS and its environs would be restricted to grout for securing rock bolts in the emplacement drifts, hyperalkaline conditions would not be expected to develop at Yucca Mountain. However, through reactive transport modeling of the Maqarin site, it has been demonstrated that a model can reproduce the same suite of cement minerals, hyperalkaline water compositions, and $\mathrm{pH}$ that were observed in the field, thus building confidence in the use of such a model for analogous conditions at other sites.

The Poços de Caldas analogue illustrated that ironbearing colloids may retard the transport of uranium and other spent-fuel components by forming colloids that then are filtered from suspension at short distances. Degradation of steel structural elements in the EBS could conceivably contribute to this process.

\section{Seepage Analogues}

Water moves through the unsaturated zone by matrix flow and by flow along fractures. The proposed repository horizon at Yucca Mountain is the welded part of the Topopah Spring Tuff, a brittle rock in which fractures are common. Because of this and because matrix porosity is low, water flow within 
this unit is postulated to be dominantly by fracture flow (U.S. Department of Energy, 2001a). Although water flow within or from this unit has not been observed, the proposed flow mechanism is supported by water flow that was observed from an identical tuff (Tiva Canyon Tuff) stratigraphically above the Topopah Spring Tuff after a heavy storm in 1995. The best analogues for the welded tuffs are rocks with low porosity and dominantly fracture flow (for example, limestones or basalts). The Paintbrush nonwelded hydrogeologic unit (PTn) lies between the welded parts of the Tiva Canyon and Topopah Spring Tuffs; it has few fractures, and water flow is postulated to be by matrix flow (U.S. Department of Energy, 2001a). Sandstones and other nonwelded tuffs provide the best analogues for this unit.

The potential for dissolution and transport of radionuclides is predicted on the assumptions that water reaches the stored waste by seepage and that the waste package subsequently fails. For purposes of this report, the term infiltration is used for precipitation that is not lost by runoff, evaporation, or transpiration, and the term seepage is used for that portion of the infiltration within the unsaturated zone that enters tunnels or other underground openings. Seepage may drip from the ceiling, flow down walls, or be lost by evaporation.

The physical properties of water and, specifically, its high surface tension led to models that predict that much of the water percolating through the unsaturated zone will be held in the wall rock of tunnels by capillary forces (Birkholzer and others, 1999) or will flow down the walls rather than dripping onto waste packages as seepage. Many natural and manmade underground openings in a wide range of geologic and climatic settings provide analogues that can be used to examine this hypothesis.

Both qualitative and quantitative analogues of seepage into openings exist, but neither type provides an exact match to the geohydrologic situation at Yucca Mountain. The qualitative examples are those that demonstrate the large degree of preservation for material in openings within the unsaturated zone, as described in the "Preservation within the Unsaturated Zone" section. Were it not for the capillary barrier tendency of water to stay in the matrix and fractures and not enter tunnels and caves, this good preservation of delicate artifacts and biologic remains would not be possible. The theoretical models also predict that the percentage of net infiltration that can become seepage decreases as infiltration decreases, such that at low infiltration rates (less than $5 \mathrm{~mm} / \mathrm{yr}$ ) and most permeabilities, there is no seepage (U.S. Department of Energy, 2001a). This prediction is consistent with the observed better preservation in underground openings located in arid, rather than more humid, climates.

\section{Seepage Characteristics of Caves}

All of the following examples are from limestone caves where water flow is dominated by fracture flow as it is in the welded tuffs at Yucca Mountain. Because these caves are located much closer to the surface than the depth of the proposed repository at Yucca Mountain, there is a much greater probability for fractures to communicate directly between the underground opening and the surface, thereby facilitating seepage. In each example, precipitation exceeds current $(170 \mathrm{~mm} / \mathrm{yr}$; Sharpe, 2007) and predicted future (266$321 \mathrm{~mm} / \mathrm{yr}$ ) precipitation at Yucca Mountain (U.S. Department of Energy, 2001a). Thus, each of these examples may overestimate the percentage of infiltration that would become seepage at Yucca Mountain.

The first example is a cave at Altamira, Spain, that was discovered in 1870 and is famous for its painted Hall of the Bulls. The paintings are estimated to be about 14,000 years old (Valladas and others, 1992 ) but are remarkable for their excellent state of preservation. This part of the cave was monitored for 22 months by Villar and others (1985). The volume of water dripping into the cave was measured and an average total seepage of 7 liters per month $(\mathrm{L} / \mathrm{mo})$ was reported. The volume measured was estimated to represent about 80 percent of the total seepage (J.R. Solana, Ministerio de Cultura, Madrid, Spain, written commun., 2000), thereby bringing the seepage to almost $9 \mathrm{~L} / \mathrm{mo}$ (or 108 liters per year). The area of the painted cave studied was reported as $150 \mathrm{~m}^{2}$; thus the seepage rate was $0.72 \mathrm{~mm} / \mathrm{yr}$. Villar and others (1985) also measured the average rainfall and reported an average of approximately $0.095 \mathrm{~L} / \mathrm{mo}(1,140 \mathrm{~mm} / \mathrm{yr})$. The average evapotranspiration was calculated as approximately $0.055 \mathrm{~L} / \mathrm{mo}$, which results in an average net infiltration of about $0.040 \mathrm{~L} /$ mo $(480 \mathrm{~mm} / \mathrm{yr})$. Although the wall and roof rock of the cave are obviously fractured, less than 1 percent of the infiltrating water seeped into the cave. The fact that the paintings have not been bleached or dissolved near the fractures indicates that little water has seeped in along most fractures during the last 14,000 years.

In the second example, Buecher (1999) studied the climate and speleology at Kartchner Caverns in Arizona for 2 years. Precipitation in southern Arizona is highly variable, both monthly and yearly. Annual precipitation during the 2-year study was $288 \mathrm{~mm}$ and $607 \mathrm{~mm}$. The average $(448 \mathrm{~mm} /$ yr) is similar to the long-term average precipitation at two nearby stations and thus is probably representative of longterm conditions. Estimates for net infiltration range from 0 to $127 \mathrm{~mm}$ for any given year, depending mainly on annual precipitation. The long-term average for annual infiltration is 47 mm/yr (Arizona Conservation Projects, Inc., 1992). There are several features at the site that might influence that number locally. The area above the cave has sparse vegetation, so transpiration is minimal. The climate is monsoonal such that most moisture comes during a short period of time, which might decrease the potential for evaporation. The potential for evaporation after short events is greater in southern Arizona than for the European examples. The slope above Kartchner Caverns is moderately steep (about 20 percent), which increases the likelihood of runoff. Finally, the block of ground that hosts the cave, which is only about $5,500 \mathrm{~m}$ by $350 \mathrm{~m}$, is cut by more than 60 mapped faults (Jagnow, 1999). 
Observations of air movement in and out of Kartchner Caverns show that at least some fractures must provide good communication between the cave and the surface (Stuckless and Toomey, 2003), which is reasonable because the cave has only $10-40 \mathrm{~m}$ of overlying rock and little soil. Such fractures could provide a rapid path for water to reach below the zone of evapotransporation and become net infiltration. Although changes in seepage related to precipitation events are implied for the fast pathways, changes in rates of dripping were not reported by Buecher (1999). Seepage into the cave, as estimated by three different methods, ranged from $4.3 \mathrm{~mm} / \mathrm{yr}$ to $12.4 \mathrm{~mm} / \mathrm{yr}$, with an average of $7.9 \mathrm{~mm} / \mathrm{yr}$ (Buecher, 1999). Thus, about 17 percent of the net infiltration became seepage.

The third example is Grotta Gigante near Trieste, Italy. This is reportedly the largest of all caves (in terms of volume of a single opening) and is a well-known tourist site. Covelli and others (1998) reported an average rainfall of $1,350 \mathrm{~mm} /$ yr between 1980 and 1989, based on collections from 12 drip locations, and Cucchi and others (1985) estimated individual drip-point flow rates at 2,600 L/yr. From a map presented by Covelli and others (1998) we estimated an area for the studied portion of the cave at $8,125 \mathrm{~m}^{2}$. If the collected flow is assumed to be only 80 percent of the total (as at Altamira), a seepage rate of $5 \mathrm{~mm} / \mathrm{yr}$ is indicated. The climate conditions at Altamira and Trieste are fairly similar, so we assume that the values for evapotranspiration would be similar. With this assumption, the net infiltration rate would be $800 \mathrm{~mm} / \mathrm{yr}$, and again the seepage is less than 1 percent of the available infiltration.

The fourth example, Mitchell Caverns, which is located on the eastern slope of the Providence Mountains in the East Mojave National Preserve, California, is another locality similar to Kartchner Caverns. The caverns are located at an elevation of 1,341 $\mathrm{m}$ (Pinto, 1989) in a wedge of Permian limestone (approximately $300 \mathrm{Ma}$; Norris, 1999) (fig. 57). The limestone layers are folded and highly fractured by intrusion of younger Jurassic quartz monzonite (approximately $160 \mathrm{Ma}$; Miller and others, 1993, plate 1). Mean annual precipitation measured at the caverns is $18.6 \mathrm{~cm}$ (Stein and Warrick, 1979).

Two separate caves are open to the public at Mitchell Caverns: Tecopa and El Pakiva. The speleothems in both caves are nearly inactive under present climate conditions, and there are no continuous seeps. There is a considerable bedrock catchment basin above the caves, and the fractured limestone in which Mitchell Caverns are situated provides rapid communication with the ground surface. This is shown by a rapid response underground after a rainfall. Dripping can be observed at approximately 10 locations and may last at some of the locations for as long as 28 days after a heavy rainfall. If this same phenomenon is operating at Kartchner Caverns, it could explain the greater percentage of seepage than observed at Altamira or Grotta Gigante. Alternatively, because the rainfall is sporadic, it may be that using long-term averages is not appropriate. That is, if all the rain is in one month, the effective precipitation is more like 12 times the yearly average.

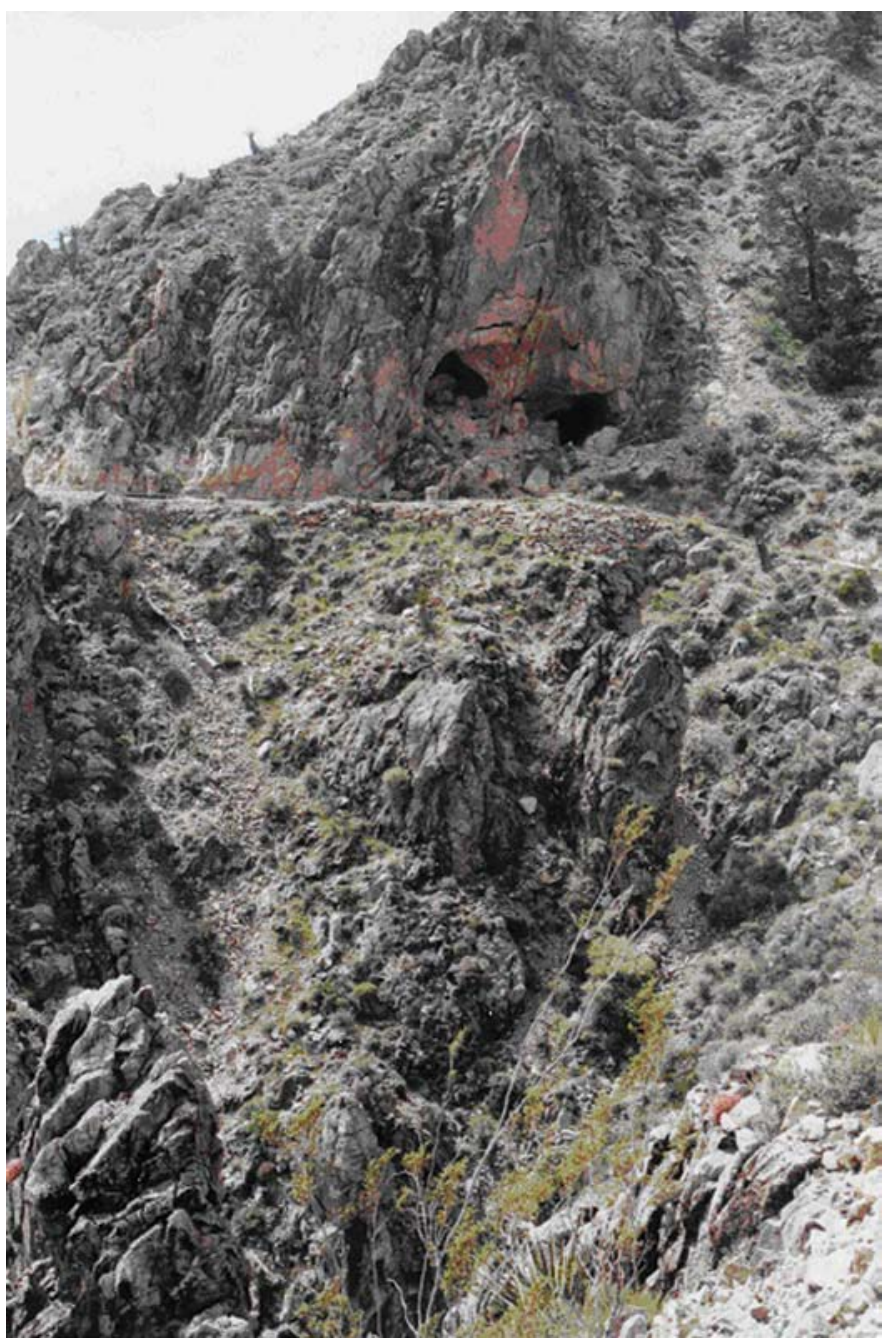

Figure 57. Entrance to Mitchell Caverns in California, El Pakiva portal, showing fallen blocks that partially occlude the entrance (photograph by A.M. Simmons).

This would agree with a higher percentage of seepage with a higher rate of infiltration.

The predicted percentage of infiltration that can become seepage with decreasing infiltration cannot be tested quantitatively with available data, but the concept is consistent with observational data from caves. The caves at Carlsbad Caverns in New Mexico, for example, have stood open for as long as 11 m.y. (Polyak and others, 1998) and therefore have been subjected to a wide variety of climates. There have obviously been times when more seepage occurred, as evidenced by the abundance of inactive stalactites, stalagmites, and flowstone. Today, only a small percentage of the seeps are active in spite of an average precipitation of about $370 \mathrm{~mm} / \mathrm{yr}$ (McLean, 1976). Polyak and Asmerom (2001) documented two periods of increased seepage in the last 4,000 years: one from 3,000 to 
800 years B.P. and one from 440 to 290 years B.P. It is likely that there are many other periods of greater seepage, and these likely indicate times of much greater infiltration, such as during the last pluvial period.

\section{Seepage Characteristics of Underground Openings}

Natural analogues demonstrate the tendency for water that does become seepage to run down the walls of underground openings rather than drip from the ceiling; thus, not all seepage would affect stored waste. Evidence of this tendency is shown by water damage to painted cave walls and by the greater abundance of speleothems on cave walls than ceilings. At Chauvet Cave in France, for example, some paintings show evidence of water damage from water running down the walls (fig. 11). Stuckless (2000) presented evidence of preferential movement of water down the wall of an underground kitchen

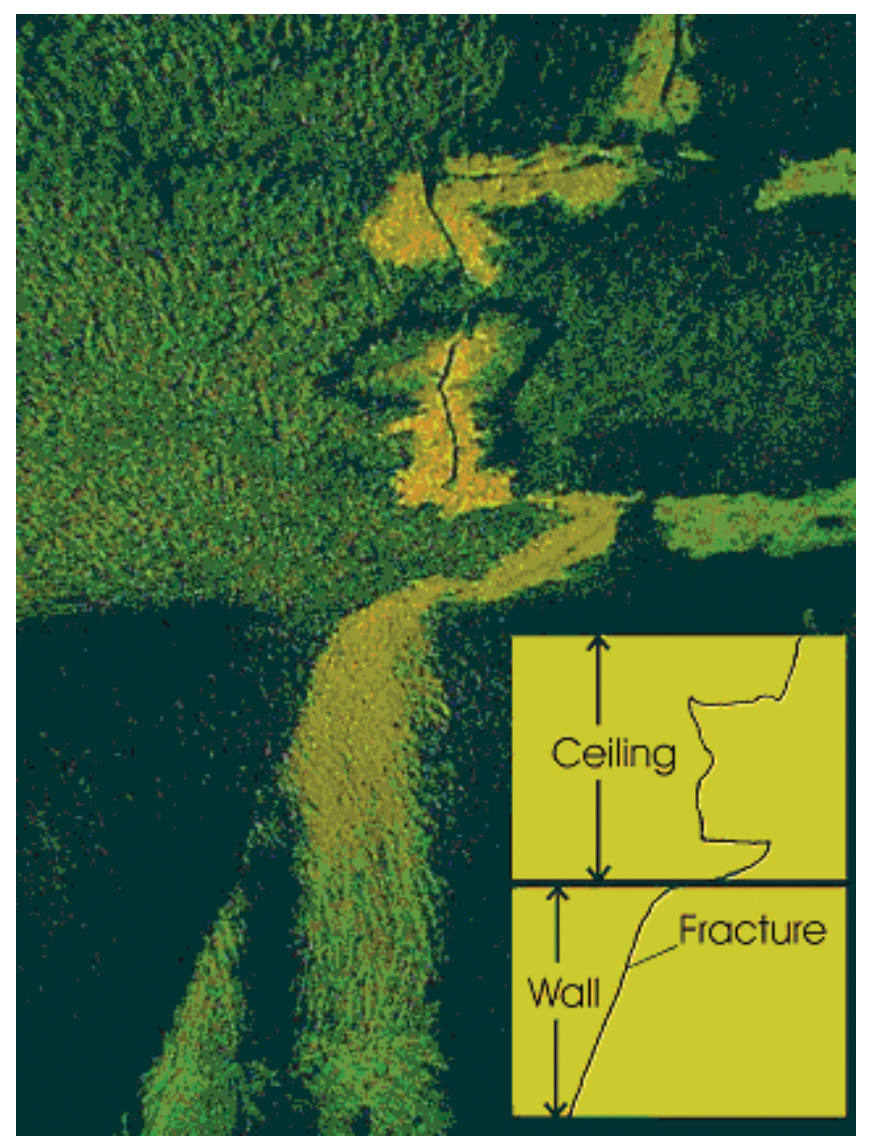

Figure 58. Photograph showing fracture in the blackened wall and ceiling of a kitchen in a monastery at Goreme, Turkey, which was probably in use until the 12th century A.D. The soot has been removed adjacent to the fracture in the ceiling, possibly by oxidation. $0 \mathrm{n}$ the wall, flow has occurred from the fracture removing some of the soot below the intersection of the fracture with the wall (Stuckless, 2000, fig. 15). in a subterranean monastery at Goreme, Turkey. The pattern shows removal of soot along a fracture in the ceiling and removal of soot in streaked patterns below the fracture in the wall (fig. 58). Figure 59 shows that water has seeped through a barrel-vaulted ceiling of Building 810 at the Denver Federal Center and has flowed on the underside of the curved arch, as shown by the white efflorescent salt deposits. Figure 60 shows that this same tendency for water to follow the curve of a tunnel and run down the wall is observable in the Exploratory Studies Facility at Yucca Mountain, and similar evidence is apparent in some subway tunnels (for example, Washington, D.C., and Paris, France). These examples represent end-member cases because tunnels of a repository would be expected to have more asperities, some of which could become a focus for dripping. This is common in limestone caverns where speleothem development and dripping can be correlated with the presence of fractures.

Ancient people apparently were aware of the need to prevent water contact with items buried in tombs. Thus, in order to increase preservation, two different methods of tomb construction were used in widely separated areas. Both methods rely on the principle previously described - that is, the high surface tension of water, which causes preferential flow of water in small spaces relative to larger openings.

The corbelled roof was used in tombs in Ireland (fig. 61) around 3,100-3,200 years B.C. (Stuckless, 2000) and in Korea and adjacent China from about 277 B.C. to A.D. 668 (Lena, 2004). In this method, vaulted tombs were built with overlapping slabs of rock, which were then covered with earth. Tombs of this type do not appear to have been common in Ireland, but the one in Newgrange has apparently remained dry in spite of modern rainfall of more than $65 \mathrm{~cm} / \mathrm{yr}$. This type of tomb is much more common in Asia where more than 13,000 have been reported (Lena, 2004), at least 80 of which still have elaborately painted walls and ceilings that are well preserved.

The second method for diverting water from tombs is referred to as a Richards barrier (Conca and others, 1998). In this method, a fine conductive material is placed over a coarse material. Archeologic examples include a wooden tomb (or merely a wooden coffin) which was covered with a relatively impervious material such as clay. Next, a very coarse layer, such as boulders, covered the tomb. Finally the area was covered with fine material and soil. An example from the Cheomachong tomb in Korea is given in figure 62. This tomb is $12.7 \mathrm{~m}$ high and $40-47 \mathrm{~m}$ in diameter. It is open to the public, and thousands of artifacts have been moved to a nearby museum, including a painting on bark of a flying horse, for which the tomb is named (Heavenly Horse) and a 98-cm-long sword. The tomb is in Tumuli Park, Gyeongju, which contains at least 20 more tombs of similar construction. Views of the park can be seen at http://www.orientalarchitecture.com/kyongju/heavenlyindex.htm, last accessed January 8, 2010.

Watanabe (1989) reported that similar tomb construction was used in Japan 1,300-1,500 years ago and that steel, bronze, wood, and cloth have been preserved in these tombs owing to the low moisture content within the coarse gravel 

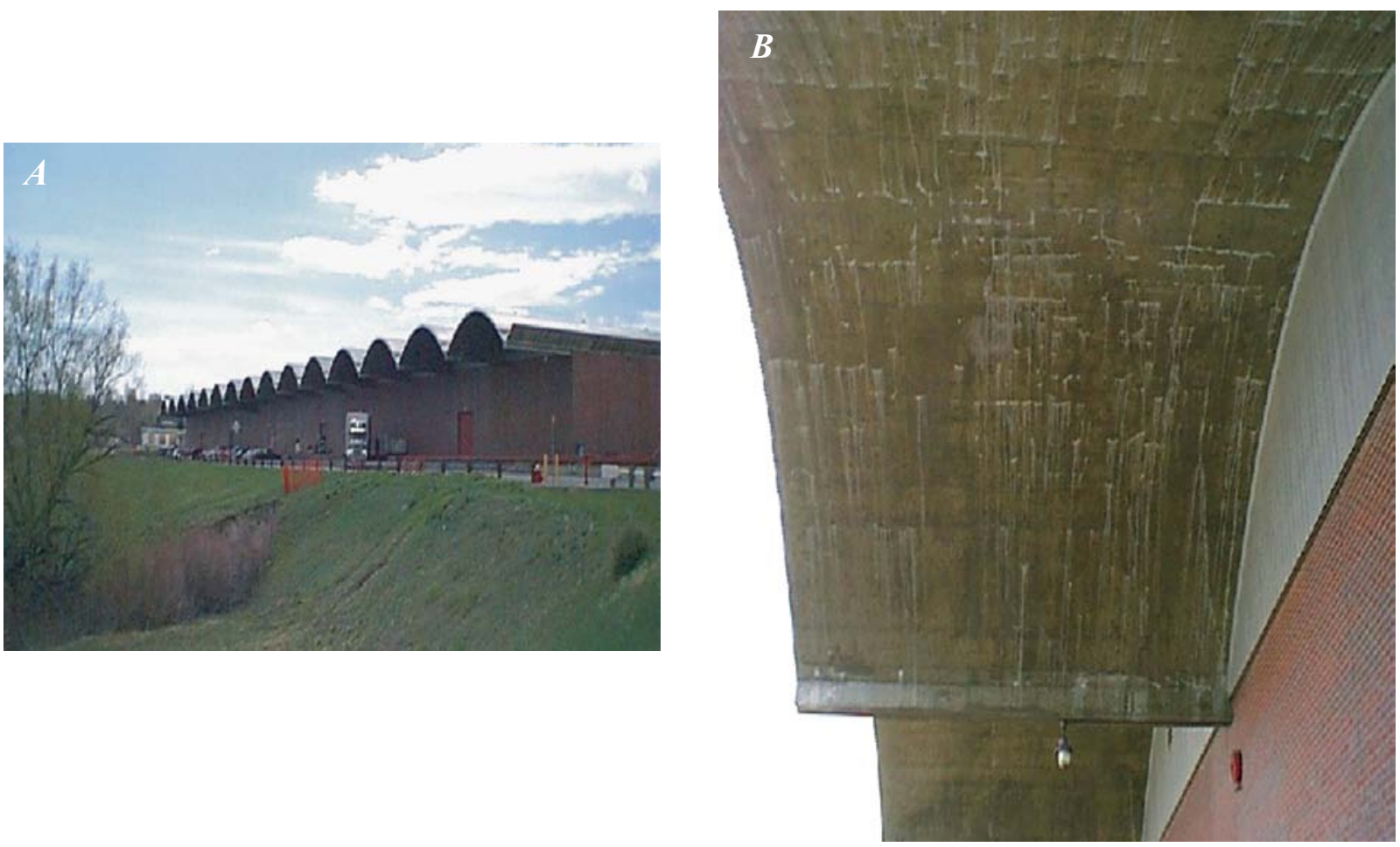

Figure 59. (A) Building 810 on the Denver Federal Center, Colorado, and $(B)$ a closeup of the underside of the roof over a loading dock. Water has seeped through minor fractures in the concrete and flowed along the curvature of the roof rather than dripping (Stuckless, 2002, fig. 7).

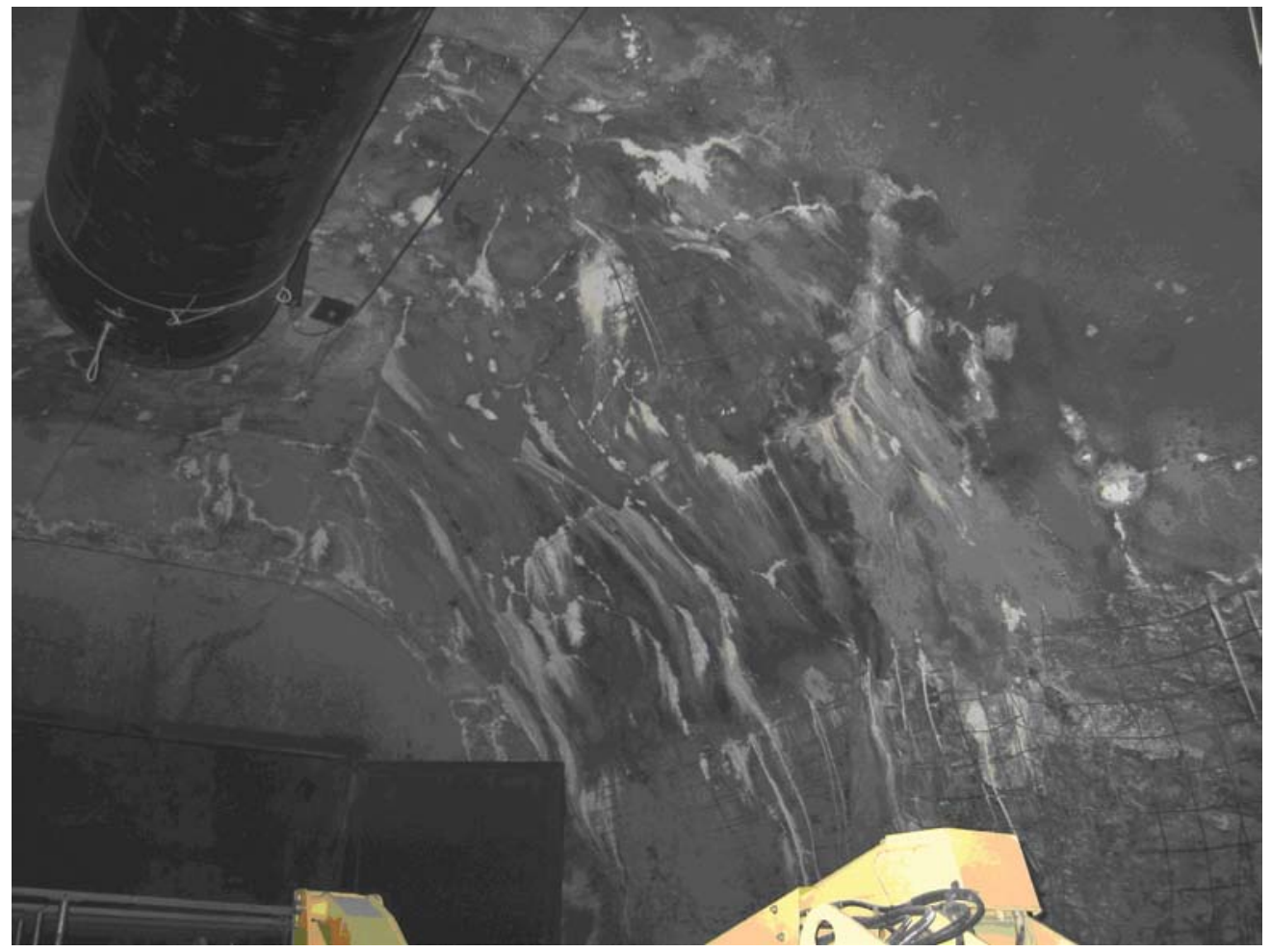

Figure 60. Interior of Alcove 1 of the Exploratory Studies Facility, Yucca Mountain, Nevada. Water (which was applied in large volumes just beyond the area of this photograph as part of an infiltration experiment) has seeped through the shotcrete and followed the curvature on the tunnel rather than dripping (photograph by J.S. Stuckless). 

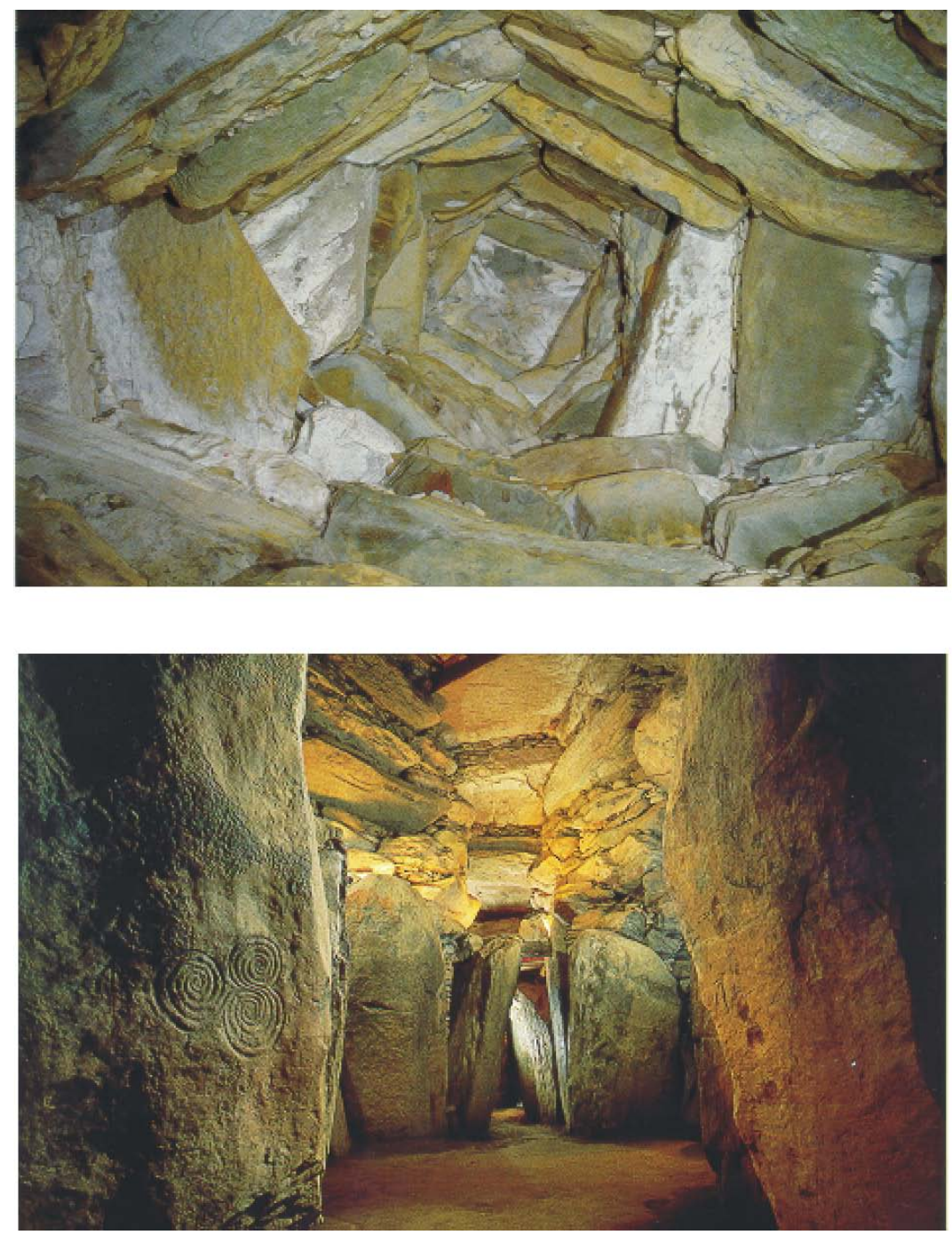

Figure 61. Photographs taken from the inside of a corbelled ceiling grave at Newgrange, Ireland (Stuckless, 2000, fig. 9). Pictures of the restored exterior can be seen at http://www.knowth.com/newgrange-images.htm, accessed August 1, 2005.

layer. He attributes the dryness to the much greater suction force (capillary force) in the fine materials than in the gravels. He further noted that not all graves contained highly preserved articles. By quantifying what artifacts were preserved and how well, Watanabe documented that mounds built on well-drained material (such as river terraces) provided for better preservation, and that mounds with thicker layers of gravel performed better than those with thinner layers. Conca and others (1998) noted further that the Japanese tombs have been subjected to 14 magnitude 7 or greater earthquakes during the last 100 years alone, attesting to their long-term seismic, as well as hydrologic, stability.

A much older example of a Richards barrier is reported in Turkey. King Midas' tomb is about $40 \mathrm{~m}$ high and was constructed about 700 B.C. A description of the wooden structure beneath the mound, as well as identification of beverage and food residues still preserved, can be seen at $h t t p: / / w w w$.
museum.upenn.edu/new/research/Exp_Rese Disc/Mediterranean/Midas/intro.shtml, last accessed June 22, 2006. Fifteen pieces of wooden furniture and nearly 200 bronze vessels have been recovered from the tomb, all in excellent condition. (http://www.archaeology. org/0107/abstracts/midas.html, last accessed June 22, 2006).

Not all underground openings provide appropriate analogues. The previous examples of caves and underground openings were all less than $100 \mathrm{~m}$ from the surface. The Mission Tunnel through the Santa Ynez Mountains near Santa Barbara, California, is closer in depth (200-670 $\mathrm{m}$ from the surface) to the proposed repository (300-m depth) at Yucca Mountain, as compared to the previous examples. The Mission Tunnel exhibits rapid response to precipitation events and large amounts of seepage flux (1.23 million $\mathrm{m}^{3} / \mathrm{yr}$; Boles, 1999). Unfortunately, quantitative measurements have not been made, so the percentage of infiltration that becomes seepage is unknown. However, the apparently large amounts of seepage into the Mission Tunnel are caused by flow paths that are within nearly vertical, highly transmissive, fractured sandstone units (Boles, 1999). Furthermore, at least some part of the flow could be from groundwater seeps below the water table (Boles, 1999). Thus, the hydrogeology for this potential analogue is very different from that for the proposed repository at Yucca Mountain, where the hydrologic units are gently dipping and few through-going fractures have a hydrologic connection with the surface.

Another example that does not fit the predicted diversion of water around underground openings and the concomitant preservation of fragile artifacts is the Valley of the Kings in Egypt. Although tombs available for public tours are generally dry and well preserved, there are a few that have obviously had abundant water (fig. 63). Parizek (2006) reported that these were excavated in fracture zones that allowed rapid contact with surface water. Furthermore, the fracture zones form topographic lows and provide a natural channel for surface water during rare precipitation events.

The benefit gained in the isolation of radioactive waste by only a small percentage of net infiltration becoming seepage exists only as long as the tunnels remain open. As discussed in the "Drift Stability Analogues" section, the ability to remain open under ambient conditions depends on a number of variables, including (1) rock strength; (2) the size, shape, and orientation of the opening; (3) orientation, length, and frequency of fracturing; and (4) effectiveness of ground support. Values for these variables at Yucca Mountain have led to the prediction that only limited failure of the proposed emplacement 

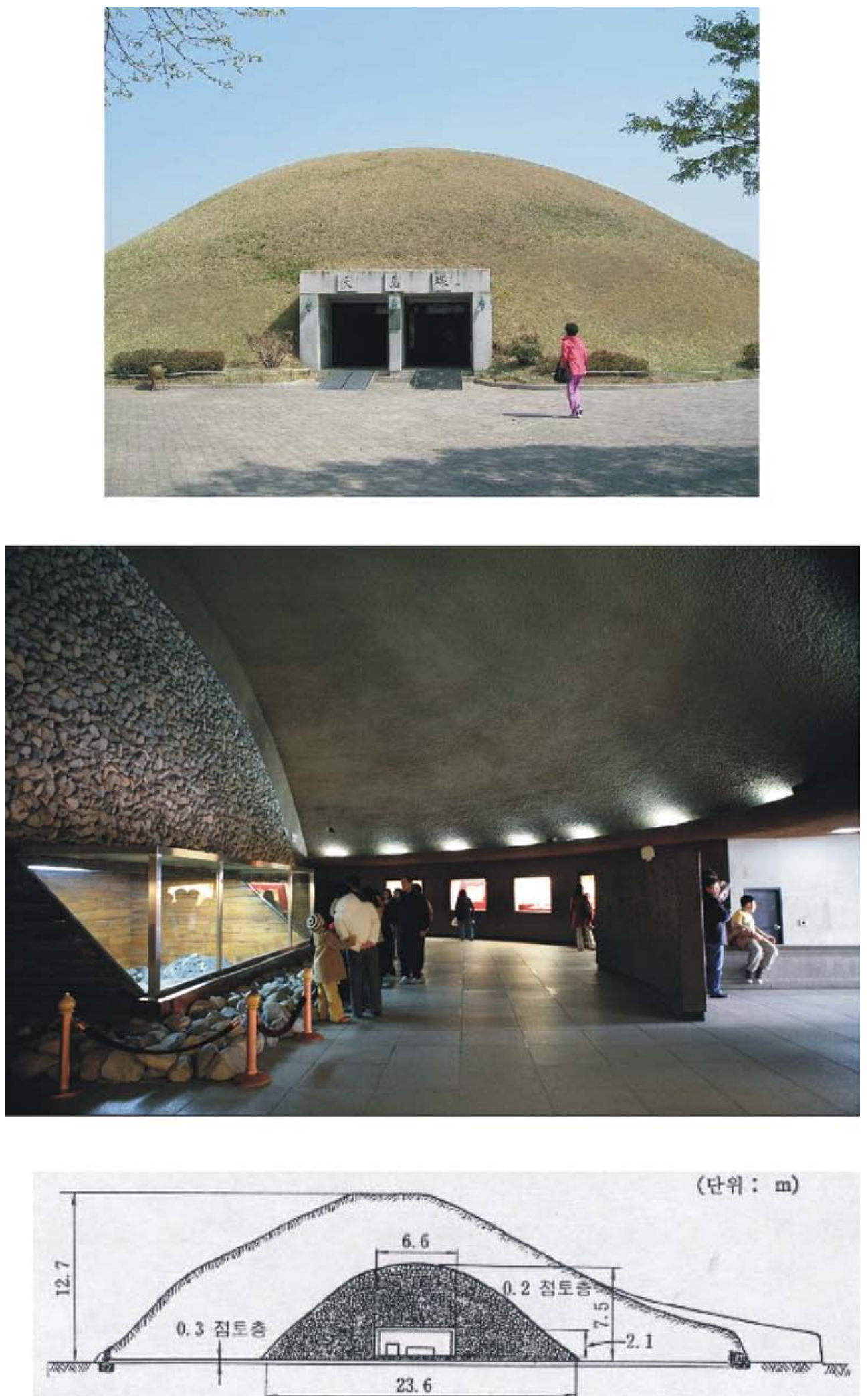

Figure 62. Cheomachong tomb in Gyeongju, Korea (photographs and diagram courtesy of Dr. Seok Yeong-cheol, Korean Industrial Technology Foundation, Seoul, Korea). 


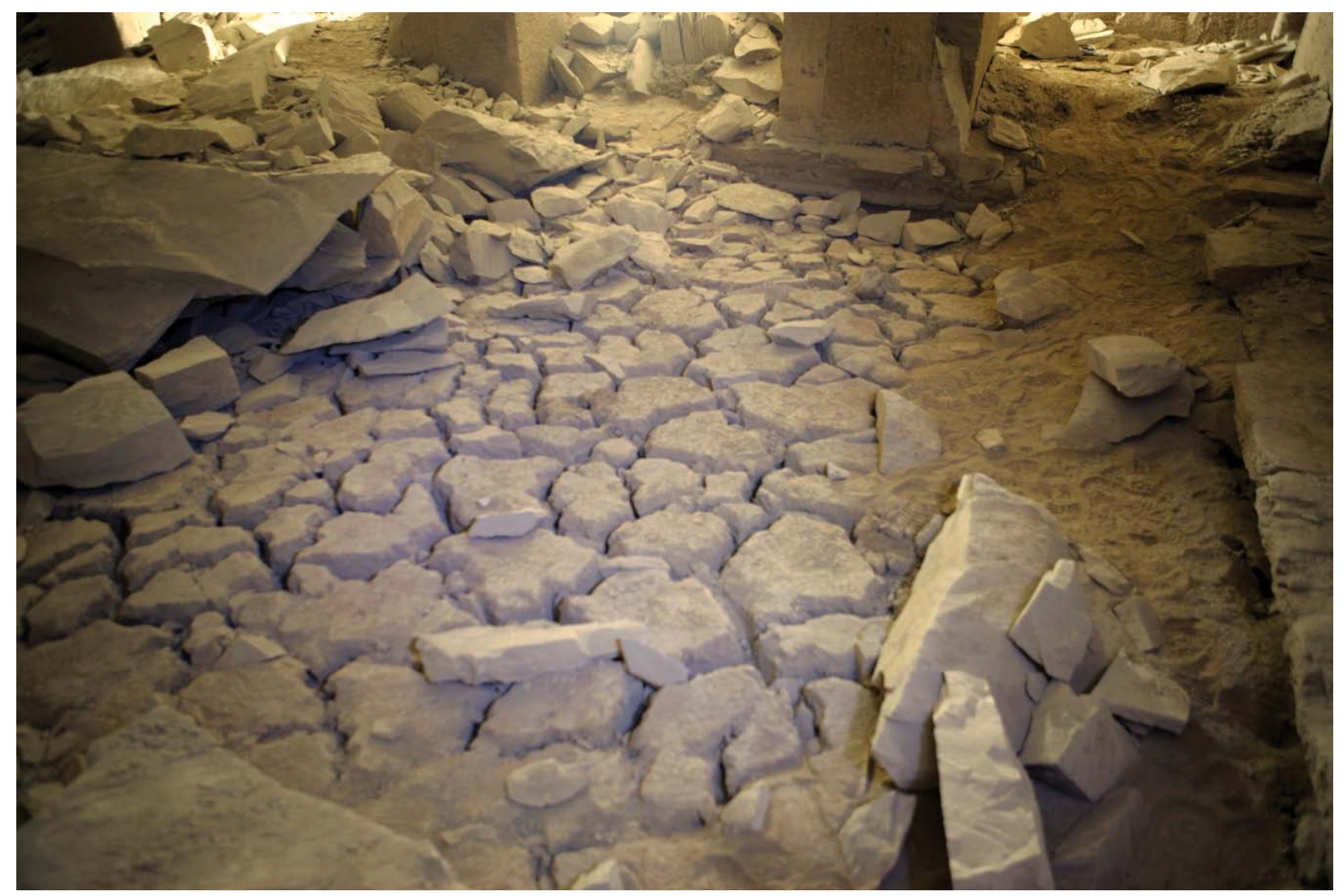

Figure 63. Area of large mudcracks formed in the floor of a tomb in the Valley of the Kings in Egypt. Unlike well-preserved tombs, this one was constructed in a fracture zone with a topographic low above it such that rare precipitation was preferentially funneled into the tomb. (Photograph by Katarine Parizek, Pennsylvania State University; used with permission.)

drifts would occur over the period of thousands of years (BSC, 2001b).

One important variable for preservation in underground openings is relative humidity. It is obvious that if relative humidity (RH) in the drift is kept below 100 percent by ventilation, then seepage of liquid water would be reduced or completely suppressed. Most caves are close to but below 100-percent humidity (for example, Kartchner RH=99.4 percent [Buecher, 1999]; Altimira $\mathrm{RH}=98 \pm 2$ percent [Breisch, 1987; Quindos and others, 1987]). These caves are naturally ventilated; thus, the amount of seepage in these caves would be expected to be low. This would also be true at Yucca Mountain while ventilation is maintained.

\section{Summary of Analogues for Seepage}

The findings support the hypothesis that most of the infiltrating water in the unsaturated zone is diverted around underground openings and does not become seepage. The analogues show that this is true even for areas with much greater precipitation rates than that at Yucca Mountain. Although examples exist where large amounts of seepage can be observed (for example, the Mission Tunnel and some tombs in the Valley of the Kings), the hydrogeologic settings are substantially different from that at Yucca Mountain and are not appropriate analogues. Even caves with fractures that provide fairly direct connections to the surface (Kartchner and Mitchell Caverns) provide diversion for most of the flow around the underground opening.

In addition, all of the analogues that show some seepage also have some evidence that some of the seepage does not drip, but rather flows down the walls. In the few cases where dripping has been noted in settings that are analogous to Yucca Mountain, the drips can be attributed to asperities in the surface of the roof and ceiling of the opening. Whether water flows on walls or drips depends on conditions affecting drop 
formation and drop detachment (for example, surface tension, roughness angle, saturation). Thus, by analogy at Yucca Mountain, although most water would flow around emplacement drifts, the small amount of seepage that would occur would primarily flow down tunnel walls. In the few cases where dripping may occur, it would be expected to be attributable to asperities in the tunnel ceilings.

\section{Unsaturated-Zone Flow and Transport Analogues}

\section{Yucca Mountain Conceptual Unsaturated-Zone Flow and Transport Models}

Conceptual and numerical modeling methodologies for unsaturated-flow conditions at Yucca Mountain are applicable to other semiarid sites in fractured rock, including the Idaho National Laboratory (Idaho) and Rainier Mesa (Nevada). In general, these analogues contribute to providing confidence in the understanding of paleoclimatic conditions, the bounds on various climate and infiltration models, the efficacy of an unsaturated zone in isolating nuclear waste, limited seepage in the unsaturated zone, and limited fracture/matrix interactions.

The unsaturated-zone flow model is described in the "Yucca Mountain Science and Engineering Report" (U.S. Department of Energy, 2001a). Site data are used to provide infiltration and percolation flux distributions and hydrologic properties. The model accounts for the presence of perched water below the proposed repository, the effects of the PTn above the proposed repository, and the effects of fault zones on flow in the unsaturated zone.

Models of infiltration under future semiarid and wetter climate conditions compare favorably with measured estimates at field sites in Nevada located to the north and at higher elevation than Yucca Mountain, where prevailing climatic conditions are thought to be representative of the range of paleoclimatic conditions near Yucca Mountain during Quaternary time and therefore expected in the next 10,000 years. Results of the modeling approaches support the conclusion that reasonable estimates of average annual recharge to groundwater range from about 1 to $3 \mathrm{~cm} / \mathrm{yr}$ for 3-Springs Basin and from about 30 to $32 \mathrm{~cm} / \mathrm{yr}$ for East Stewart Basin (Lichty and McKinley, 1995).

Upper-bound limits on infiltration rates and percolation fluxes at Yucca Mountain are estimated based on multiple approaches, including analyses of chloride mass balance, chlorine isotopic ratios, calcite deposition, and the presence of perched water. The average percolation rate over the model domain at Yucca Mountain is about $4.6 \mathrm{~mm} / \mathrm{yr}$, based on chloride mass-balance data. Analysis of calcite deposition gives infiltration rates of 2-20 mm/yr in the vicinity of borehole USW WT-24 (U.S. Department of Energy, 2001a, section 4.2.1.3.1.5). To match perched water occurrences, three-dimensional model calibrations require that the presentday infiltration rate be greater than $1 \mathrm{~mm} / \mathrm{yr}$, with an upper limit of about $15 \mathrm{~mm} / \mathrm{yr}$.

The net infiltration is episodic, with a substantial amount infiltrating only every few years. Infiltration also is spatially variable, with most water infiltrating on ridgetops and in the upper reaches of washes where there is little alluvial cover. Fracture flow dominates in the Tiva Canyon welded hydrogeologic unit (TCw), transmitting water rapidly through the TCw to the underlying PTn. Flow through the PTn is primarily matrix flow with most of the fast flow along faults, although this represents only a very small fraction of the total flow. Limited lateral flow occurs in the PTn.

Episodic flow into the Topopah Spring welded hydrogeologic unit (TSw) is damped by the PTn to the extent that flow can be considered steady state at the boundary to the TSw (Paces and others, 1998; Bodvarsson and others, 1999). However, at or near major faults episodic flow may still persist through the PTn. Fracture flow dominates in the TSw because it is densely welded and highly fractured; in addition, within some subunits of the TSw, the low-permeability matrix is incapable of transmitting the percolation flux estimated to be moving through the unit. Fracture flow dominates in the proposed repository horizon, which intersects the Topopah Spring middle nonlithophysal, lower lithophysal, and lower nonlithophysal stratigraphic units. Fast flow appears to be restricted to these few horizons, and it is estimated to range from 84 to 94 percent of the total water flow. Observations of calcite and opal in cavities in the unsaturated zone at Yucca Mountain indicate that seeps are not regularly spaced in underground workings, and not all fractures sustain flow. Furthermore, many cavities represent sites of seepage that have remained stable for millions of years (Marshall and others, 2000).

Water drainage in the proposed repository units is expected to be good, owing to the generally high fracture permeability (about $10^{-11}$ to $10^{-12} \mathrm{~m}^{2}$ ) (LeCain, 1997). Average percolation flux in the proposed repository horizon is estimated to be about $5 \mathrm{~mm} / \mathrm{yr}$. Evidence for fast or preferential flow is seen at the proposed repository horizon, primarily near major faults (Yang and others, 1996).

Fracture flow has been shown to be the most likely mode of transport in the TSw unit (U.S. Department of Energy, 2001a), but water continuing downward would encounter different hydrologic conditions and flow properties when it reached the Calico Hills nonwelded ( $\mathrm{CHn}$ ) hydrogeologic unit. It is expected that water percolating through this unit would contact both zeolitic and vitric tuffs, in which case flow in the zeolitic zones would probably retard sorbing radionuclides, such as neptunium, cesium, and strontium. In other areas, perched-water zones resulting from low matrix permeabilities or hydrologic discontinuities may result in lateral diversion. Depending on the extent of the perched zone, water either may be laterally diverted for short distances before returning to the unsaturated zone or flowing vertically down faults or may continue laterally to the water table, bypassing the lower unsaturated zone. 
The evaluation of possible radionuclide transport from the proposed repository to groundwater in the saturated zone is key to assessing the performance of the proposed repository. In the event of waste mobilization and migration away from the proposed emplacement drifts at Yucca Mountain, the rate of radionuclide transport through the unsaturated zone would be determined by the percolation flux and by the hydrologic properties and sorptive properties of the tuff units (U.S. Department of Energy, 2001a). Water carrying radionuclides may percolate vertically through fractured tuff units, or it may be diverted laterally around low-permeability horizons, particularly where there is perched water, to fault zones. Diffusion, sorption, and dispersion processes would retard the movement of radionuclides. Each of these processes potentially affects the distribution and concentration of radionuclide particles at the water table.

The transport of aqueous and colloidal radionuclide species can occur in both fracture and matrix continua, with exchange between continua (fracture/matrix interaction) resulting from advective and(or) diffusive processes, as well as sorption in the matrix. The flow pathways are determined by the characteristics of hydrogeologic units, faults, and perched water.

These characteristics control the extent of downward compared to lateral flow, fracture/matrix interaction, and the partitioning of flow between fractures and rock matrix. Fractures and faults can be fast flow paths, with diffusion into the matrix and sorption to the rock being the important processes for radionuclide retardation.

The concentrations of radionuclides and their daughter products are diminished according to their radioactive decay rates, the extent of sorption onto the solid phase, and dilution as a result of mixing and dispersion. The effects of advective flow processes, sorption of solutes or filtration of colloids, matrix diffusion, hydrodynamic dispersion, and radioactive decay are factors with varying degrees of importance in slowing the movement of radionuclides through the unsaturated zone.

An ideal analogue site for the evaluation of flow in the unsaturated zone is in fractured rock with low matrix permeability, having heterogeneity in some horizons where some portion of flow may be lateral. The analogue would contain a perched-water zone, and some portion of flow would occur along preferentially fast pathways.

\section{Unsaturated-Zone Transport Studies}

In this section, the following unsaturated-zone analogues are considered: (1) fracture/matrix interaction at Rainier Mesa, Nevada; (2) transport at the Subsurface Disposal Area (SDA) of the Idaho National Laboratory (INL); (3) transport at the Nopal I uranium deposit at Peña Blanca, Chihuahua, Mexico; (4) the collective northwestern Nevada-southeastern Oregon uranium deposits; and (5) the trace-element migration study at Santorini, Greece. Additional insight is derived from a tracer test at Busted Butte, Nevada, and from natural analogues in Steenkampskraal, South Africa, and Koongarra, Australia, on colloid transport in the unsaturated zone.

\section{Limited Fracture/Matrix Interaction at Rainier Mesa, Nevada}

Although not an ideal analogue, Rainier Mesa does provide insights that support the concept of limited fracture/ matrix interaction. Rainier Mesa is located approximately $32 \mathrm{~km}$ to the northeast of Yucca Mountain. The stratigraphy of both Rainier Mesa and Yucca Mountain consists of alternating welded and nonwelded tuffs. The zeolitic Tunnel Bed tuffs at Rainier Mesa show a range of mineral compositions similar to those in the Calico Hills Formation nonwelded tuff at Yucca Mountain.

Rainier Mesa is situated at a higher elevation than Yucca Mountain and has a mean annual precipitation of about 320 $\mathrm{mm} / \mathrm{yr}$, approximately double the Yucca Mountain mean (Wang and others, 1993). About 8 percent of the measured Rainier Mesa mean precipitation was observed to be infiltrating into one of the tunnels constructed in zeolitic tuffs at Rainier Mesa, which illustrates the point made previously that only a small percentage of infiltration becomes seepage. The seepage was associated with a small number of faults and fractures that are thought to be a flow pathway for perched water above the zeolitic horizon (Wang, 1991). The seepage is geochemically similar to meteoric water (Wang and others, 1993). Tracer tests and tritium samples indicate that the fast pathway flow takes from 1 to 6 years to reach from the land surface to the water table at a depth of $1,000 \mathrm{~m}$. The traveltime is orders of magnitude less than the matrix traveltime calculated using measured matrix sample conductivities. This is supported by measurements of "bomb-pulse" ${ }^{36} \mathrm{Cl}$ in several samples from one of the tunnels (Wang and others, 1993).

The calculated rate and amount of radionuclides that could be transported away from a repository is, in part, dependent upon the interaction between fracture flow and pore water in the matrix. The amount of naturally occurring fracture water at Yucca Mountain is too small to allow direct observations of these important processes. However, with the matrix close to saturation at Rainier Mesa, there should be limited fracture/ matrix interaction. Thordarson (1965) noted that only portions of fractures at Rainier Mesa typically carried water, and that the chemical composition of water obtained from fractures was substantially different from water samples extracted from the nearby rock matrix at the site, which supports the concept of limited fracture/matrix interaction under conditions of near saturation. Further support for this concept is at a field site in the Negev Desert in Israel, where manmade tracers were observed to migrate with velocities of several meters per year across a 20- to 60-m thickness of fractured chalk (Nativ and others, 1995). Such high velocities could occur only for conditions of limited fracture/matrix interaction. 


\section{The Subsurface Disposal Area at the Idaho National Laboratory as a Potential Analogue for Radionuclide Transport at Yucca Mountain}

Between 1952 and 1986, approximately $180,000 \mathrm{~m}^{3}$ of transuranic and low-level radioactive mixed wastes, containing about 9.5 million curies of radioactivity, was buried in unlined trenches and pits in shallow sediment above basalt flows at INL in the $144,100-\mathrm{m}^{2}$ subsurface disposal area (SDA) of the Radioactive Waste Management Complex (RWMC) (Cecil and others, 1992; Lockheed Idaho Technologies Company, 1995). Included with these buried wastes were approximately 334,000 L of transuranic-contaminated mixed-waste sludges that were adsorbed on calcium silicate and placed in 55-gallon steel drums (Rawson and others, 1991). Since 1970, transuranic wastes have been stored in containers placed above ground on asphalt pads in the SDA. Environmental monitoring beneath the SDA in both the unsaturated and saturated zones has resulted in detections as deep as $43 \mathrm{~m}$ of americium, plutonium, and other waste products that migrated below the SDA (Dames and Moore, 1992; Becker and others, 1998), thereby raising concerns about the long-term water quality of the Snake River Plain aquifer, the principal source of potable groundwater in the area.

The motivation for evaluating the potential use of the SDA as an analogue for radionuclide migration from a proposed repository at Yucca Mountain was to examine modeling approaches and transport through the unsaturated zone. The study of unsaturated flow and transport at the RWMC was chosen because INL is somewhat analogous to Yucca Mountain hydrogeologically. Average precipitation is similar at both sites, as is infiltration. Perched water is located in the unsaturated zone at both sites, and rocks at both sites consist of a fractured porous media - basalt at INL and rhyolitic ash-flow tuff at Yucca Mountain. At both sites, lateral flow is a factor in diverting flow, whereas the dominant flow paths are along fracture pathways. Fracture-filling minerals consist of clays and calcite at both sites (Rawson and others, 1991; Rightmire and Lewis, 1987a; Montazer and Wilson, 1984; U.S. Geological Survey, 2000a; Flint and others, 2002; Day and others, 1998). These similarities made it worthwhile to test modeling approaches of flow and radionuclide transport in the unsaturated zone at Yucca Mountain by using INL data, even though the two sites are not perfectly analogous.

Dissimilarities in fracture patterns, local recharge, the amount of organic matter, and fracture-filling materials that influence the type of fracture flow exist between the hydrogeologic settings at the SDA and Yucca Mountain (Barraclough and others, 1976; Martian, 1995; Magnuson and Sondrup, 1998; Knutson and others, 1990). These dissimilarities need to be taken into account when radionuclide migration in the unsaturated zone at the SDA is used as an analogue for how radionuclides could migrate in the unsaturated zone at Yucca Mountain. In addition to these dissimilarities, several other challenges exist if the SDA is to be used as an analogue to unsaturated-zone transport at Yucca Mountain. These challenges include (1) uncertain source terms for various radionuclides, (2) absence of a well-defined distribution or plume of radionuclides in the deep subsurface that can be used to calibrate geochemical transport models of radionuclides at the field scale, and (3) the hydrogeological complexity of the SDA.

\section{Geologic and Hydrologic Setting}

The top of the surficial sediment in which the transuranic wastes are buried at the SDA is approximately $175-180 \mathrm{~m}$ above the regional water table (Rightmire and Lewis, 1987a, b). The thick unsaturated zone beneath the SDA contains 13 individual basalt flows ranging in thickness from less than $1 \mathrm{~m}$ to $17 \mathrm{~m}$ and averaging about $5 \mathrm{~m}$ in thickness (Knutson and others, 1990). Three sedimentary interbeds at $9 \mathrm{~m}, 34 \mathrm{~m}$, and $73 \mathrm{~m}$ subdivide the basalts into A-, B-, C-, and D-group basalts; correspondingly, the 9-m, 34-m, and 73-m interbeds are known as the $\mathrm{A}-\mathrm{B}, \mathrm{B}-\mathrm{C}$, and $\mathrm{C}-\mathrm{D}$ sediment layers.

Annual precipitation at INL averages $20 \mathrm{~cm} / \mathrm{yr}$. Infiltration rates within the SDA have been estimated to be higher than the background infiltration rates because of accumulation of snow within the SDA. Infiltration rates within the SDA have averaged between 6 and $10 \mathrm{~cm} / \mathrm{yr}$ since 1952 (Martian, 1995). Perched water has been contacted by boreholes within the SDA at depths that correspond roughly to the tops of the sedimentary interbeds (Rightmire and Lewis, 1987b). At least some of the perched water actually was infiltration from surficial regions informally known as spreading areas (fig. 64). The spreading areas are located about $1.7 \mathrm{~km}$ to the southwest of the SDA and are used to divert water from the Big Lost River into these areas during periods of high flow (more than 14 $\mathrm{m}^{3} / \mathrm{s}$ ) to minimize flooding to downstream areas. Water from these areas may have migrated laterally in the unsaturated zone along and across the interbeds (Rightmire and Lewis, 1987b).

\section{Modeling the Large-Scale Aquifer Pumping and Infiltration Test at the Idaho National Laboratory}

A location map of the RWMC and SDA sites within INL is shown in figure 64. The migration pathway at the SDA is suspected to be vertically downward through the unsaturated basaltic lava flows and then laterally on the low-permeability (silt, clay) interbeds as ponded-water conditions develop. Lateral transport of the radionuclides is suspected to have been enhanced by water infiltrating from the spreading areas (as noted in the previous section), causing ponded-water conditions in an area substantially larger than the SDA. The fate and transport of radionuclides at the regional scale involve the RWMC, the spreading areas, and the inferred saturatedzone pathway that radionuclides would take from beneath the RWMC to the INL boundary (Magnuson and Sondrup, 1998).

Migration of radionuclides from the RWMC is dependent upon the mechanisms controlling unsaturated flow of infiltrating water. It is dependent also upon the fate and transport of 


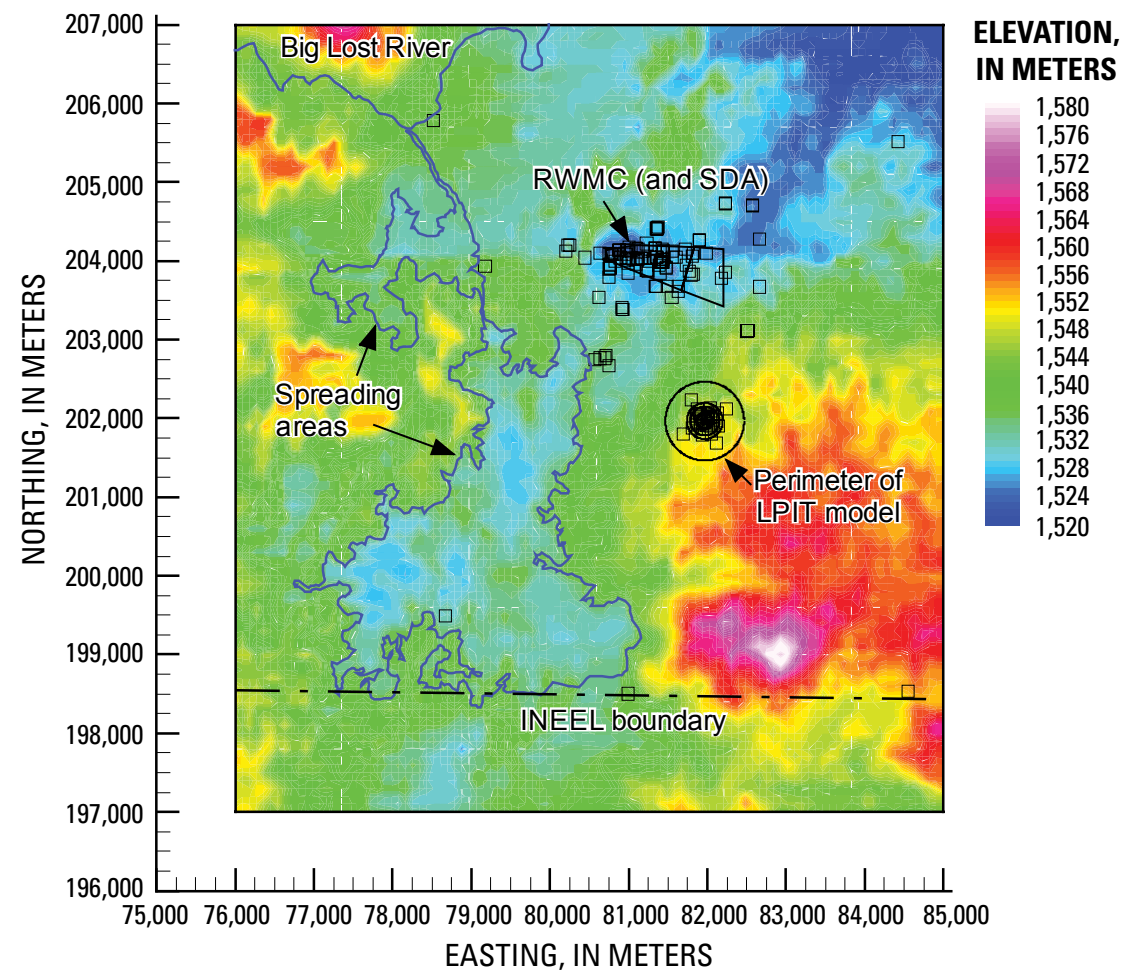

NOTE: RWMC, Radioactive Waste Management Complex; LPIT, Large-Scale Aquifer Pumping and Infiltration Test; SDA, Subsurface Disposal Area; INEEL, Idaho National Engineering and Environmental Laboratory, now known as INL.

Figure 64. Plan view of the regional model at the Idaho National Laboratory with shading to illustrate ground surface elevation (A.M. Simmons, Los Alamos National Laboratory, written commun., 2002).

radionuclides within the infiltrating water as it flows through the undulating, fractured, basaltic lava flows and sedimentary interbeds beneath the SDA. To address these issues, the Large-Scale Aquifer Pumping and Infiltration Test (LPIT) was conducted in the summer of 1994 to mimic the intermittent floods observed at the SDA (Starr and Rohe, 1995; Dunnivant and others, 1998). The LPIT took place at a 183 -m-diameter infiltration pond. The test was located $1.43 \mathrm{~km}$ south of the RWMC within the same geological units (fig. 64). ${ }^{75} \mathrm{Se}$ tracer was used in the test to track the infiltration.

One modeling study was conducted to build confidence in the modeling approach used for unsaturated-zone process modeling at Yucca Mountain by comparing simulations to results of the LPIT. The numerical model involved determining parameters controlling unsaturated and saturated flow and transport in fractured basalt by using a dual-permeability modeling approach that has been extensively used to simulate flow and transport at Yucca Mountain. Both regional- and local-scale LPIT models were developed, based upon the work of Magnuson (1995) and Magnuson and Sondrup (1998). The sequence of model development was first to use a local-scale LPIT model (fig. 64) to determine a set of hydrologic parameters by simultaneous calibration to multiple hydrographs, while using a dual-permeability representation of the basalt fracture and matrix continua. These parameters would represent the large-scale properties of the lithologic units affected by the field-scale LPIT as used in the dual-permeability approach rather than local-scale heterogeneities influencing individual hydrographs. The model was calibrated to the LPIT hydrographs and ${ }^{75} \mathrm{Se}$ breakthrough curves. Next, hydrologic parameters obtained from the LPIT calibration were used to simulate the transport of radionuclides from the SDA in the regional model. The dimensions of the regional model are shown in figure 64. Results presented here are limited to the LPIT analysis.

Hydrographs of ponded water (Burgess, 1995) and ${ }^{75}$ Se breakthrough curves measured during the LPIT conducted at INL were analyzed to determine parameters controlling unsaturated flow and transport. Unsaturated flow and ${ }^{75} \mathrm{Se}$ transport were simulated using the code ITOUGH2 (Finsterle, 1999). The mesh was constructed using a dual-permeability representation for the basalt fracture and matrix continua, while the surficial sediments and $\mathrm{B}-\mathrm{C}$ interbed were simulated as a single matrix continuum.

The LPIT modeling study produced simultaneous calibration to hydrographs using ITOUGH2 (Finsterle, 1999), which yielded parameters that were consistent with the range of data values obtained from cores drilled near the LPIT site. The dual-permeability approach provided conservative estimates of peak concentrations and arrival times by underpredicting the mass transfer of conservative (nonsorbing) tracers from the fracture to the matrix continua. Results indicated that, although the dual-permeability conceptual model could be used to simulate unsaturated flow, it may not have adequately captured the physics of conservative transport in fractured basalt.

\section{The Subsurface Disposal Area Transport Modeling Study}

This section presents a preliminary hydrologic and geochemical transport model for $\mathrm{Am}, \mathrm{Cs}, \mathrm{Np}, \mathrm{Pu}, \mathrm{Sr}$, and $\mathrm{U}$ in the unsaturated zone beneath the SDA. A conceptual model of flow and transport beneath the SDA was developed. Next, a series of numerical models was developed that tested various aspects of the conceptual model. In this case, the computer codes FLOTRAN (Lichtner, 2003) and FEHM (Zyvoloski and others, 1997) were used to develop models for flow and radionuclide movement in the surficial sediments in and beneath the waste pits. Measurements of radionuclide concentrations made during the drilling of shallow monitoring holes in and near the 
waste trenches (Humphrey and Tingey, 1978; Rightmire and Lewis, 1988) provided a basis for evaluating the model. Flow and radionuclide transport in the unsaturated zone beneath the SDA were simulated, and the results were compared to available field data.

The SDA transport modeling study used data results from column experiments and associated batch tests that measured values of the equilibrium distribution coefficients $\left(K_{\mathrm{d}}\right)$ and the reaction-rate coefficients for the sorption of ${ }^{241} \mathrm{Am},{ }^{137} \mathrm{Cs}$, ${ }^{60} \mathrm{Co},{ }^{90} \mathrm{Sr},{ }^{233} \mathrm{U}$, and ${ }^{239} \mathrm{Pu}$ (Newman, 1996). The experiments included columns of crushed basalt (greater than $0.25-\mathrm{mm}$ size fraction), mixed interbed sediments (less than $0.25-\mathrm{mm}$ size fraction), and intact basalt cores taken from the same boulder that provided the crushed basalt. In the first phase of the experiments, the steady, saturated flow of synthetic water with a composition similar to groundwater at INL was established in the columns (table 9).

Results for the columns containing crushed basalt showed that most of the radionuclide mass (except for ${ }^{233} \mathrm{U}$ ) was substantially retarded compared to the water. Results from column studies of the interbed material indicated much higher sorption of all radionuclides in the interbed material compared to the crushed basalt. The percent recovery for ${ }^{233} \mathrm{U}$ was more than 90 percent but was less than 4 percent for all other radionuclides (Newman, 1996, Table 7, Appendix F).

Several radionuclides, including ${ }^{238} \mathrm{Pu},{ }^{239,240} \mathrm{Pu},{ }^{241} \mathrm{Am}$, ${ }^{60} \mathrm{Co},{ }^{137} \mathrm{Cs}$, and ${ }^{90} \mathrm{Sr}$, are sorbed to rocks and interbed sediments beneath the surficial sediments at the SDA. The locations where radionuclide activities were at least three times greater than the detection limits are noted on maps showing the locations of all deep wells (on the order of $30 \mathrm{~m}$ or greater) in figures 65 to 67 . These maps are based on data compilation by the USGS (U.S. Geological Survey, 2000a, tables 3-10a, b, and c). Each map shows the radionuclides present in different depth intervals, either the 9-m, 34-m, or 73-m interbed (figs. 65-67, respectively). Note that not all of the wells shown in figures 65 to 67 have been sampled, so that well locations with no indicated radionuclides are a mixture of true nondetections and unsampled wells.

The maps in figures 65 through 67 locally show some lateral and vertical consistency with regard to radionuclide distributions. Elsewhere, however, different radionuclides are present at different depths in a given borehole or different radionuclides are present at the same depths in nearby boreholes, making simple interpretations of these radionuclide distributions difficult. The erratic distribution of these radionuclides may be related to complex flow and transport behavior, including preferential and lateral flow, or to cross contamination during drilling (U.S. Geological Survey, 2000a).

Results of tracer tests have indicated that percolation from the infiltration ponds can reach the water table in less than 9 days, at an average rate of at least $22 \mathrm{~m} / \mathrm{d}$, and that water from this source can move horizontally in the unsaturated zone at an average rate of at least $14 \mathrm{~m} / \mathrm{d}$ (Nimmo and others, 2001). The tracer tests showed that at least under ponded filtration, the interbeds and dense basalt layers do not prevent rapid, high-volume vertical flow through fractured basalt. However, some impediments to flow were sufficient to cause substantial perching and horizontal diversion of flow. Perched water has been observed at many locations within the SDA: (1) along the surficial sediment/basalt interface, showing strong seasonal effects; and (2) in a number of wells within the SDA (Hubbell, 1993, 1995). Observations summarized in figure 68 suggest that the topography (fig. 64), the orientation of the surficial sediment/basalt interface, and, possibly, the absence of the A-B interbed may determine where perched water is located at the SDA. The fact that horizontal flow moves quickly over considerable distances indicates that there also must be layers of high horizontal permeability in the zone of perching above the impeding layers. Having a low permeability layer directly overlain by a fractured or rubbly layer through which the transport could occur, such as conditions existing at the RWMC, might cause the observed detections.

In view of the uncertainties in the hydrologic system, the radionuclide source term, and even in the distribution of radionuclides in the field environment at the SDA, two radionuclide transport models were developed: (1) a shallow, one-dimensional model extending a few meters from the waste burial pits to the top of the underlying basalt, and (2) a deeper two-dimensional model extending from the ground surface to the water table beneath the SDA. The purpose of the shallow model was to identify the transport parameters of the sediments through trial-and-error matches of the model to the measured radionuclide concentrations beneath the waste burial pits. The effects of assumptions regarding source-term inventory and of hydrologic property contrasts were explored in this group of simulations.

The deeper, two-dimensional model was restricted to the transport of a single tracer. The results of the model were qualitatively compared to measurements of matric potential, observations of perched water, and the distributions of radionuclides and other contaminants in the interbed sediments, the perched water, and the Snake River Plain aquifer. The overall purpose of the two-dimensional model was to identify combinations of rock hydrologic and geochemical properties that could have allowed the deep migration of radionuclides through the basalt layers and interbedded sediments. The fully coupled, nonisothermal, two-phase flow and reactive transport computer codes FLOTRAN (Lichtner, 2003) and FEHM (Zyvoloski and others, 1997) were used for these modeling studies.

Single- and dual-permeability models of water flow and conservative tracer transport were based on a highly schematic representation of the unsaturated zone beneath the SDA. The purpose of these schematic models was to investigate the conditions under which radionuclides might have reached the $\mathrm{B}-\mathrm{C}$ and $\mathrm{C}-\mathrm{D}$ interbeds at depths of approximately 34 and $73 \mathrm{~m}$, respectively. The flow domain for these models extends $60 \mathrm{~m}$ in the horizontal direction and from land surface to slightly below the water table at a depth of approximately $180 \mathrm{~m}$. A background infiltration rate of $1 \mathrm{~cm} / \mathrm{yr}$ (Cecil and others, 1992) was used to establish steady-flow conditions in these models and was maintained at land surface outside the 
Table 9. Chemical characteristics of selected samples of pore water, perched water, and groundwater from Yucca Mountain and the Subsurface Disposal Area of the Idaho National Laboratory (INL).

[Temp., temperature; ${ }^{\circ} \mathrm{C}$, degrees Celsius; $\mathrm{mg} / \mathrm{L}$, milligrams per liter; *, estimated temperature; - , no data]

\begin{tabular}{|c|c|c|c|c|c|c|c|c|c|c|c|c|c|c|}
\hline & Location & $\begin{array}{l}\text { Temp. } \\
\left({ }^{\circ} \mathrm{C}\right)\end{array}$ & $\mathbf{p H}$ & $\underset{(\mathrm{mg} / \mathrm{L})}{\mathrm{Ca}}$ & $\underset{(\mathrm{mg} / \mathrm{L})}{\mathrm{Mg}}$ & $\begin{array}{c}\mathrm{Na} \\
(\mathrm{mg} / \mathrm{L})\end{array}$ & $\begin{array}{c}\mathrm{K} \\
(\mathrm{mg} / \mathrm{L})\end{array}$ & $\begin{array}{c}\mathrm{Cl} \\
(\mathrm{mg} / \mathrm{L})\end{array}$ & $\begin{array}{c}\mathrm{SO}_{4} \\
(\mathrm{mg} / \mathrm{L})\end{array}$ & $\begin{array}{l}\mathrm{HCO}_{3} \\
\text { (mg/L) }\end{array}$ & $\underset{(\mathrm{mg} / \mathrm{L})}{\mathrm{SiO}_{2}}$ & $\begin{array}{c}F \\
(\mathrm{mg} / \mathrm{L})\end{array}$ & $\begin{array}{c}\mathrm{NO}_{3} \\
\text { (mg/L) }\end{array}$ & $\begin{array}{c}\text { Data } \\
\text { source }\end{array}$ \\
\hline \multirow{3}{*}{$\begin{array}{l}\text { Yucca } \\
\text { Mountain }\end{array}$} & $\mathrm{UZ}-14$ pore water $(\mathrm{CHn})$ & $28 *$ & 8.7 & 1.2 & 0.2 & 155 & - & 16 & 14 & 160 & 72.0 & - & 4 & A \\
\hline & UZ-14 perched water & $25^{*}$ & 7.8 & 31 & 2.5 & 35 & 4.1 & 7.0 & 24.2 & 146.4 & 40.7 & - & 17.1 & $\mathrm{~B}$ \\
\hline & WT-3 saturated zone & 31.8 & 7.6 & 11.2 & 1.0 & 49.0 & 3.9 & 6.0 & 18.3 & 138.5 & 56.0 & 2.3 & 5.7 & $\mathrm{C}$ \\
\hline \multirow[t]{3}{*}{ INL } & $\begin{array}{l}\text { Borehole W02 Lysimeter } \\
\text { W0L01 }\end{array}$ & 5 to $10^{*}$ & 8.1 & 46.1 & 15 & 188 & 15 & 27 & 133 & 508 & - & 0.2 & - & $\mathrm{D}$ \\
\hline & $\begin{array}{l}\text { Well } 92 \text { perched water } \\
\quad(10 / 29 / 76)\end{array}$ & 13.5 & 8.4 & 29 & 17 & 120 & 12 & 81 & 64 & 290 & 22 & 0.4 & - & $\mathrm{E}$ \\
\hline & $\begin{array}{l}\text { RWMC production well, } \\
\text { saturated zone }\end{array}$ & 13 & 8.1 & 45 & 15 & 9.0 & 2.8 & 13 & 27 & 180.4 & 28 & 0.2 & 3.0 & $\mathrm{~F}$ \\
\hline
\end{tabular}

a Data source: A = Yang and others (1996, table 3, sample UZ-14/1563.6-1563.8/up1,2,3); B = Yang and others (1996, table 6, sample UZ-14D); C = U.S. Department of Energy unpublished Yucca Mountain Project data (internal data base Data Tracking Number GS980908312322.008); D = Dicke (1997, table 5); E = Rightmire and Lewis (1987b, table 13, sample of 10/29/1976); F = U.S. Geological Survey (2000a, table 4-2). 


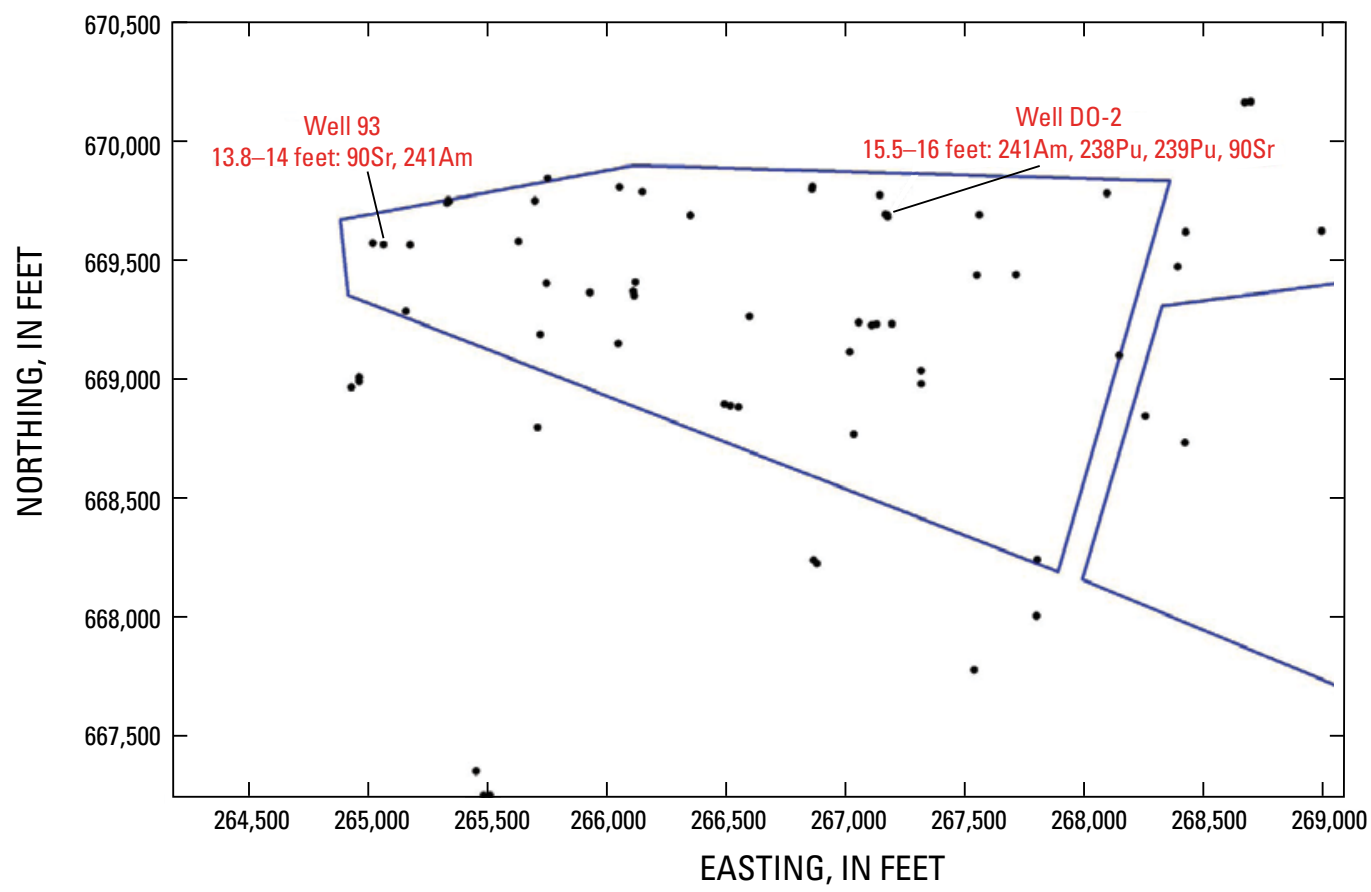

Figure 65. Map of the Subsurface Disposal Area, Idaho National Laboratory, and deep wells showing location of radionuclide concentrations greater than three times detection for depth intervals to the 9-meter interbed (A.M. Simmons, Los Alamos National Laboratory, written commun., 2002).

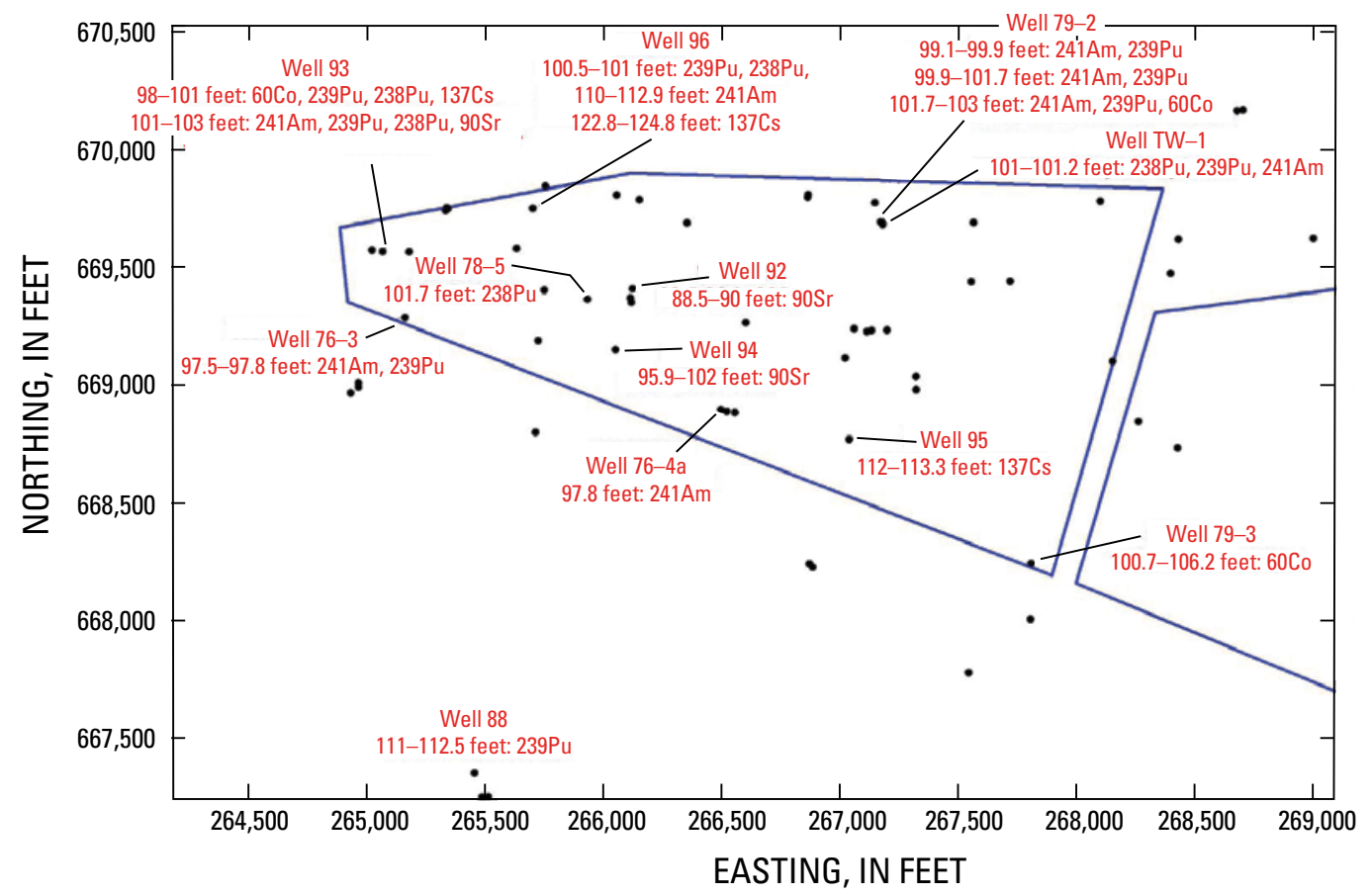

Figure 66. Map of the Subsurface Disposal Area, Idaho National Laboratory, and deep wells showing location of radionuclide concentrations greater than three times detection for depth intervals to the 34-meter interbed (A.M. Simmons, Los Alamos National Laboratory, written commun., 2002). 


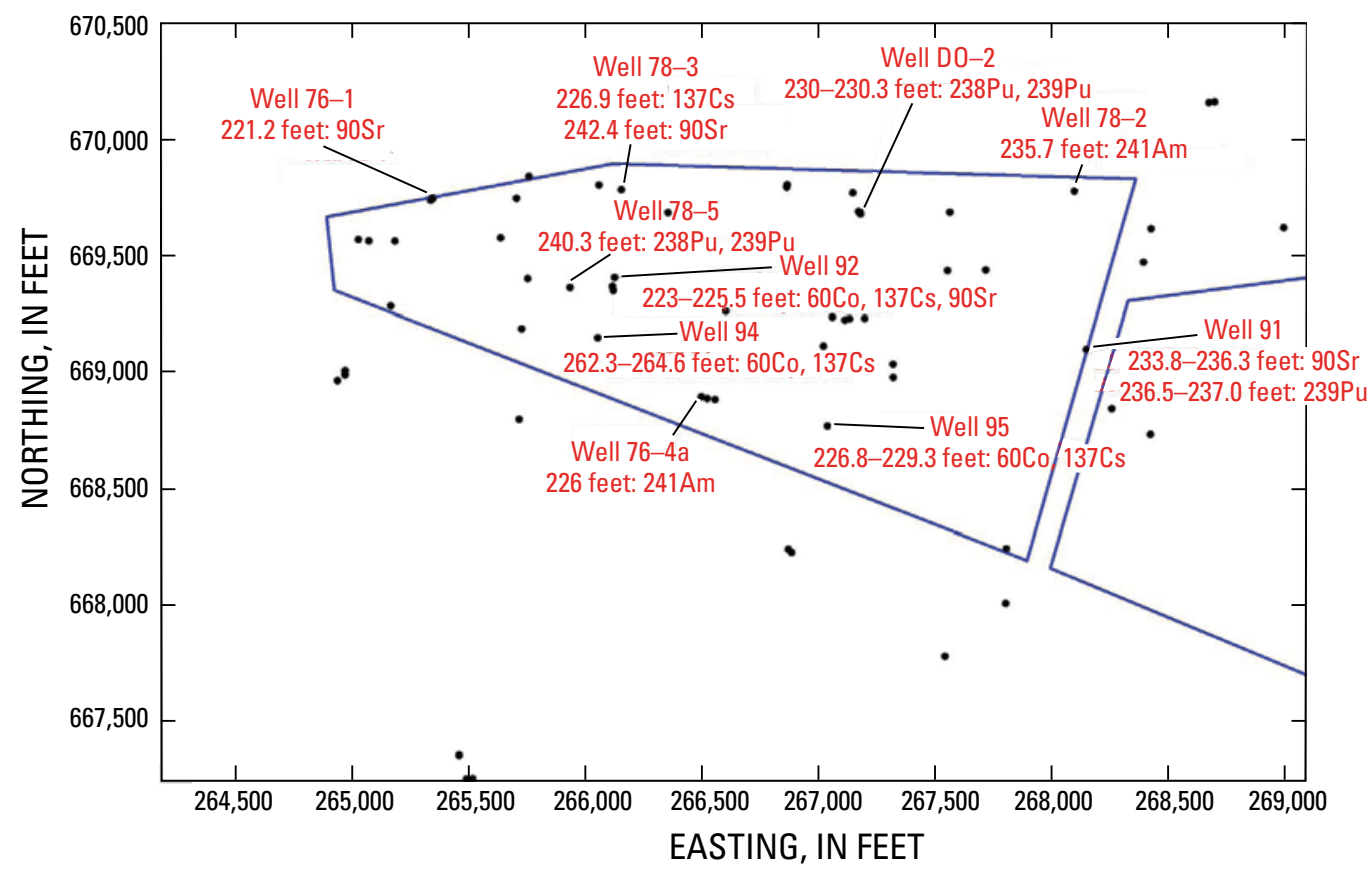

Figure 67. Map of the Subsurface Disposal Area, Idaho National Laboratory, and deep wells showing location of radionuclide concentrations greater than three times detection for depth intervals to the 73-meter interbed (A.M. Simmons, Los Alamos National Laboratory, written commun., 2002).

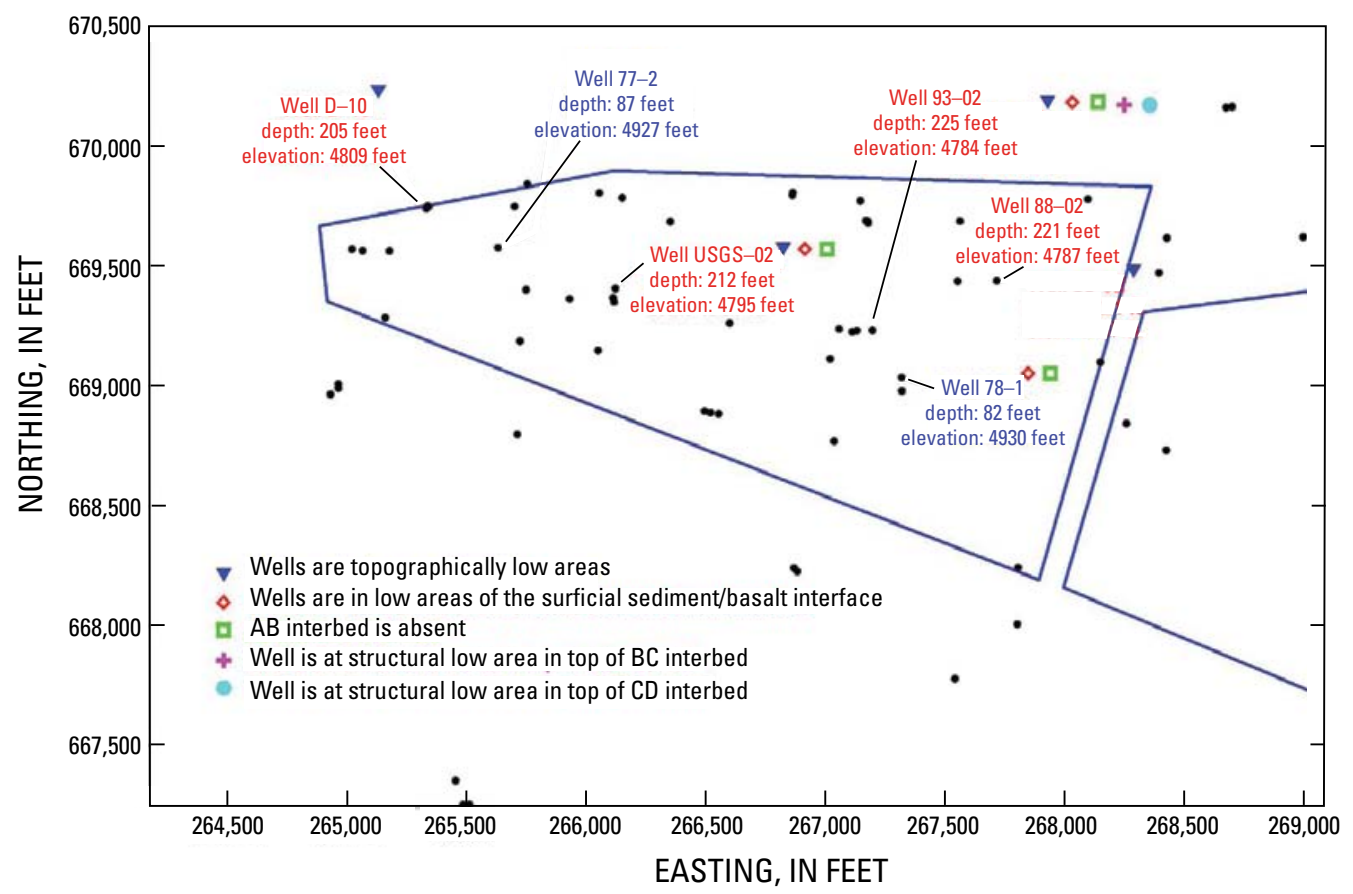

Figure 68. Depths and elevations of perched water in the vicinity of the Subsurface Disposal Area, Idaho National Laboratory (A.M. Simmons, Los Alamos National Laboratory, written commun., 2002). 
waste-disposal area throughout the transient period, spanning the last 50 years. Within the 12-m-wide waste-disposal area, the flux was increased to $8 \mathrm{~cm} / \mathrm{yr}$ at the start of the transient part of the simulations, reflecting the increase in infiltration rates that is estimated to have occurred at the SDA because of disturbances to the natural conditions following construction of the SDA in 1952 (Magnuson and Sondrup, 1998). Additional amounts of water (table 10) were applied over 10-day periods 10,17 , and 30 years into the transient part to represent floods that occurred at the SDA in 1962, 1969, and 1982 (Magnuson and Sondrup, 1998, Table 2-3).

In the single-continuum models, only the fracturecontinuum properties of the basalts and the matrix-continuum properties of the surficial sediments and sedimentary interbeds are represented. The normalized tracer concentrations (concentration relative to input concentration) at the end of the 50-year transient period are shown for the upper $80 \mathrm{~m}$ of the model domain in figure 69 for constant and pulse infiltration, the latter representing the flooding events listed in table 10. Shown in figure 69 is the tracer concentration for both FLOTRAN and FEHM for constant infiltration and pulsed infiltration using FLOTRAN along the centerline of the computation domain. The tracer is applied with unit concentration within the wastedisposal area in the central part of the model domain. Outside this region, a concentration of $10^{-3}$ units is applied. An initial

Table 10. Additional water inputs to the Idaho National Laboratory Subsurface Disposal Area due to flooding used in the single- and dual-permeability models (Magnuson and Sondrup,1998, table 2-3).

[m, meters; d, day]

\begin{tabular}{ccc}
\hline Year & $\begin{array}{c}\text { Infiltration rate } \\
(\mathbf{m} / \mathbf{d})\end{array}$ & $\begin{array}{c}\text { Total equivalent depth of } \\
\text { infiltrating water }(\mathbf{m})\end{array}$ \\
\hline 1962 & $1.66 \times 10-2$ & 0.166 \\
1969 & $1.24 \times 10-2$ & 0.124 \\
1982 & $7.49 \times 10-3$ & 0.075 \\
\hline
\end{tabular}

concentration of $10^{-8}$ units is assumed. The model results indicate that a small fraction of a conservative solute could migrate from shallow waste-disposal pits to the 73-m (C-D) interbed within 50 years, given the infiltration rates and rock properties assumed in this model. The pulse release leads to a somewhat greater penetration depth.

In the dual-permeability models, the basalt fracturecontinuum properties and the sediment matrix-continuum properties are the same as in the single-continuum models and, additionally, the basalt matrix-continuum properties and sediment fracture-continuum properties are included. The simulated saturation profiles for the fracture and matrix continua of the dual-permeability model are shown in figures 70 and 71 , respectively, after an elapsed time of 50 years for constant infiltration. Matrix saturations in the basalts are much higher than fracture saturations throughout the model domain because the assumed moisture-retention characteristics allow the matrix to retain more water at high capillary pressures than the fractures. The fracture and matrix continua are in approximate capillary pressure equilibrium above the $73-\mathrm{m}(\mathrm{C}-\mathrm{D})$ interbed; but, similar to the results of the one-dimensional steady-state dual-permeability model (fig. 72), the matrix capillary pressures just below the 73-m interbed correspond to drier conditions (have higher capillary pressures) than in the adjacent fractures. Gradually, as water flows from the fractures into the matrix, capillary-pressure equilibrium between the two continua is reestablished with increasing depth below the $73-\mathrm{m}$ interbed. Also shown in figure 72 is the numerical solution to the Richards equation obtained using the software code Mathematica (Wolfram, 1991) for the single-continuum case.

The normalized tracer concentrations at the end of the 50 -year transient period are shown for the upper $180 \mathrm{~m}$ of the fracture and matrix continua, respectively, in figures 73 and 74 for the case of constant infiltration. The fracture-continuum normalized concentrations in the dual-continuum model (fig. 73) are slightly less than the concentrations of the singlecontinuum model at the same location (fig. 75) because some of the tracer has moved into the basalt matrix in the dualpermeability model. The additional storage provided by the basalt matrix prevents the tracer from arriving at the $73-\mathrm{m}$ interbed in the dual-permeability model. However, tracer is present in the 9-m interbed at a normalized concentration of 0.06 and in the $34-\mathrm{m}$ interbed at a normalized concentration of 0.03 , despite the much lower concentrations or absence of the tracer in the overlying basalt matrix (fig. 74). Clearly, the tracer distribution in the matrix continuum of the $\mathrm{A}-\mathrm{B}$ and $\mathrm{B}-\mathrm{C}$ interbeds reflects the transport of tracer almost exclusively through the fractures of the basalt units.

The previous simulations considered an idealized hydrostratigraphy for the SDA in which layers are horizontal and of uniform thickness. In contrast, structural contour and isopach maps indicate that the SDA is located in an area where the surficial-sediment/basalt interface is relatively low and where the interbeds have variable thicknesses and dips. To examine the effect that departures from the idealized stratigraphy of the previous case might have on flow and transport beneath the SDA, investigators created a model with the computer code FEHM (Zyvoloski and others, 1997) that considers the structural depression in the A-basalt beneath the SDA and treats the 9-m and 34-m interbeds as dipping, discontinuous layers (fig. 76). The $\mathrm{C}-\mathrm{D}$ interbed is horizontal with uniform thickness, as in the previous calculations.

For a steady-state uniform infiltration rate of $1 \mathrm{~cm} / \mathrm{yr}$, flow lines calculated by particle tracking in FEHM indicate that the clay layer at the base of the surficial sediment strongly focuses flow toward low areas in this layer beneath the hypothetical SDA, at the center of the model domain (fig. 77). The interbeds also divert water laterally along their upper surface, but the amount of offset for the flow lines is less than $5 \mathrm{~m}$ at any interbed. Because water flow is focused by the slope of these layers, wetter conditions exist at low points in the clay 


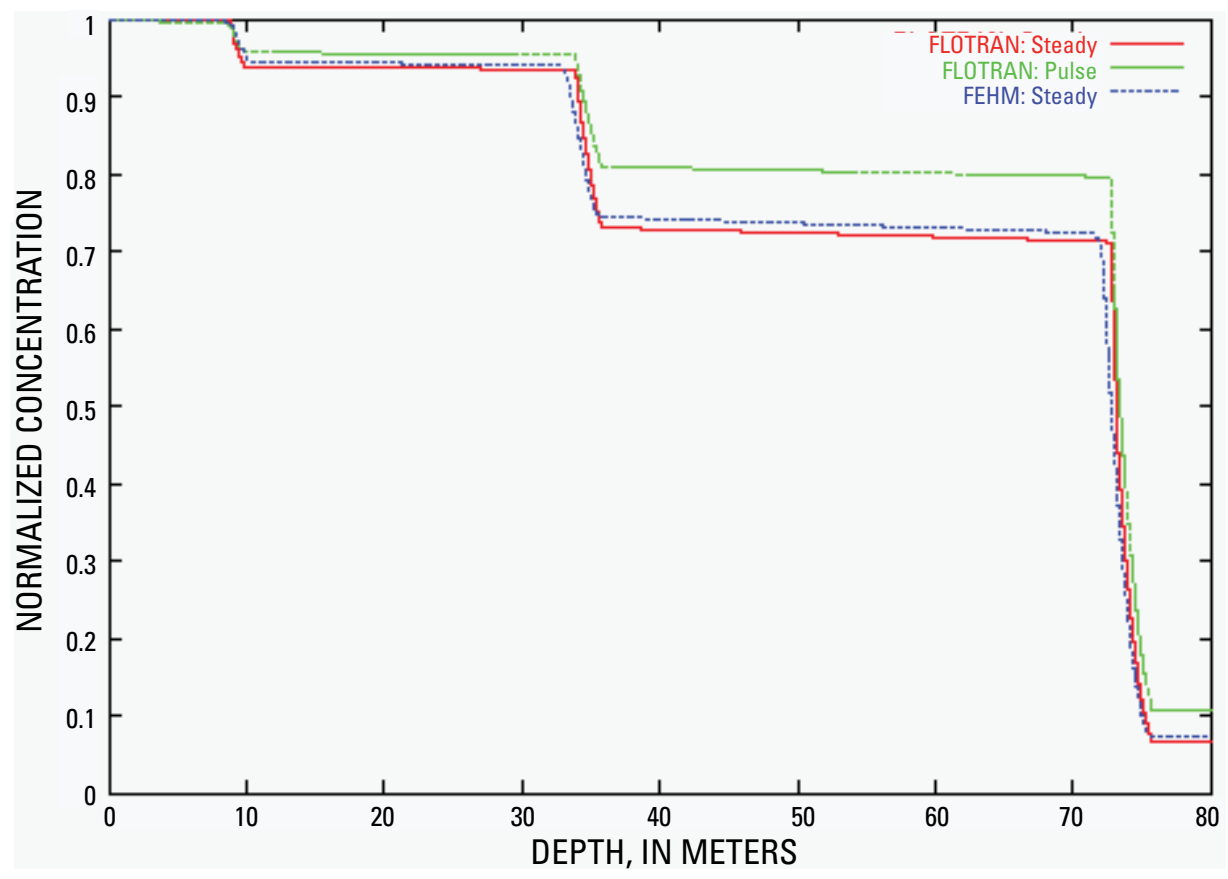

NOTE: Also shown is the pulse release using FLOTRAN.

Figure 69. Comparison of FEHM and FLOTRAN for normalized tracer concentration after 50 years for the single-continuum model of the Subsurface Disposal Area, Idaho National Laboratory, with steady release at the center of the injection region (P.C. Lichtner, Los Alamos National Laboratory, written commun., 2002).

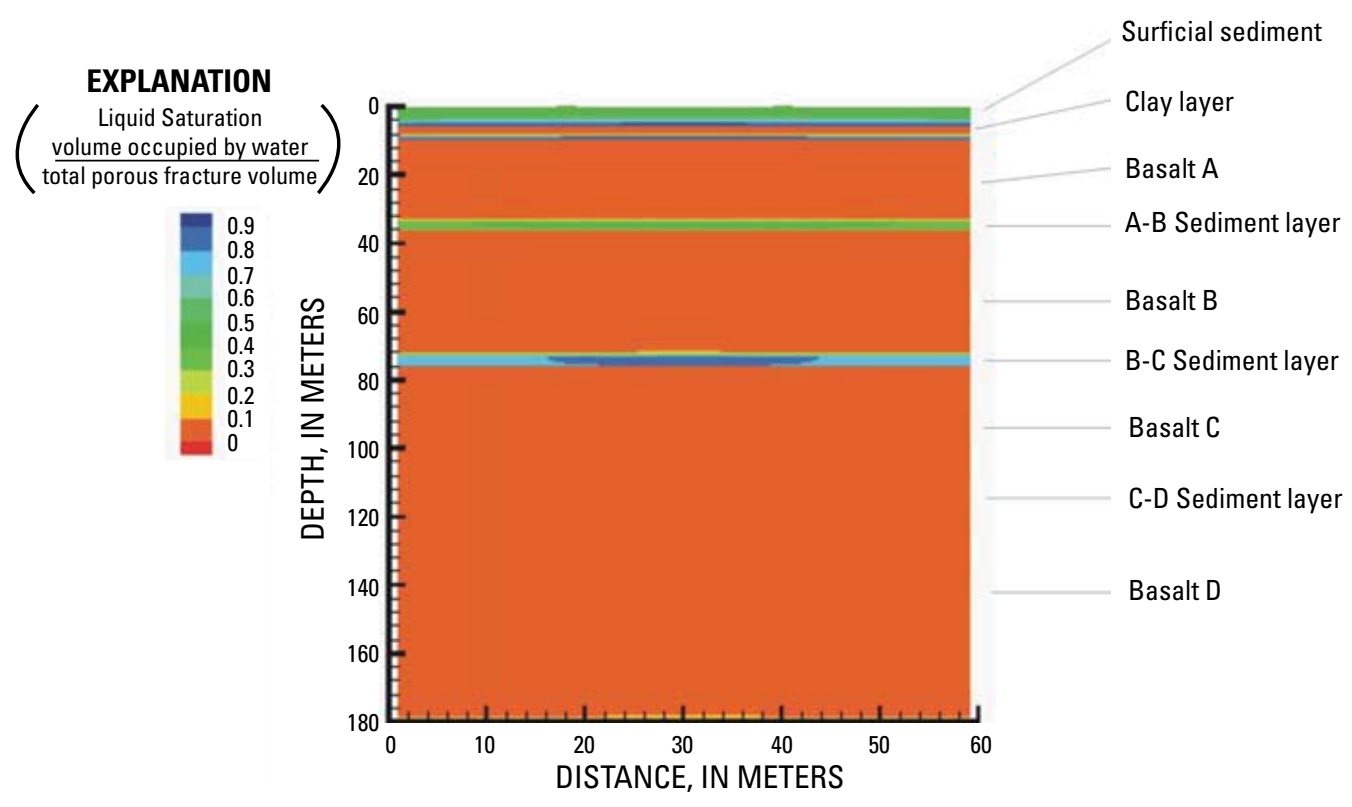

Figure 70. Liquid saturation for fracture continuum in model of the Subsurface Disposal Area, Idaho National Laboratory (P.C. Lichtner, Los Alamos National Laboratory, written commun., 2002). 


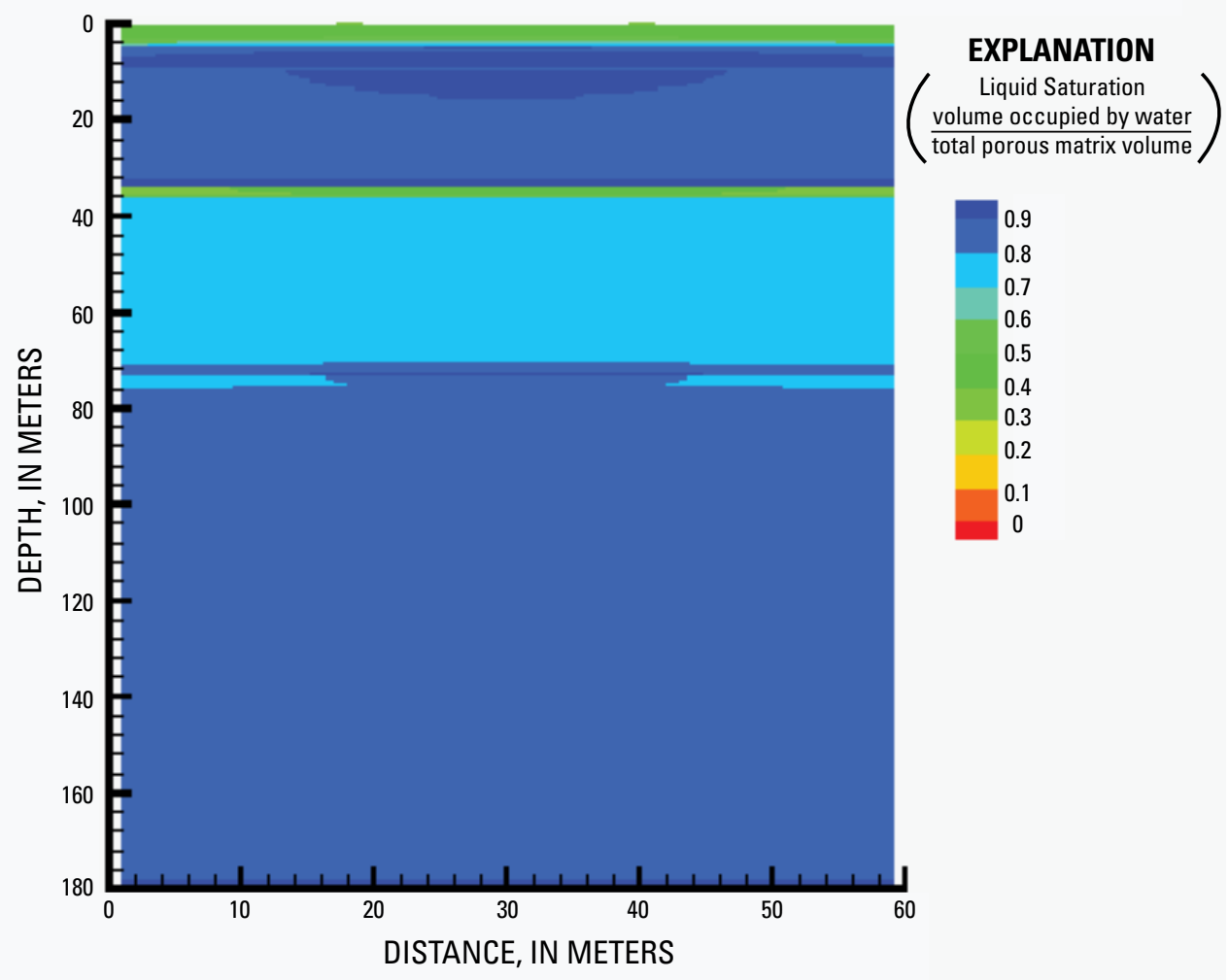

Figure 71. Liquid saturation for matrix continuum in model of the Subsurface Disposal Area, Idaho National Laboratory (P.C. Lichtner, Los Alamos National Laboratory, written commun., 2002).

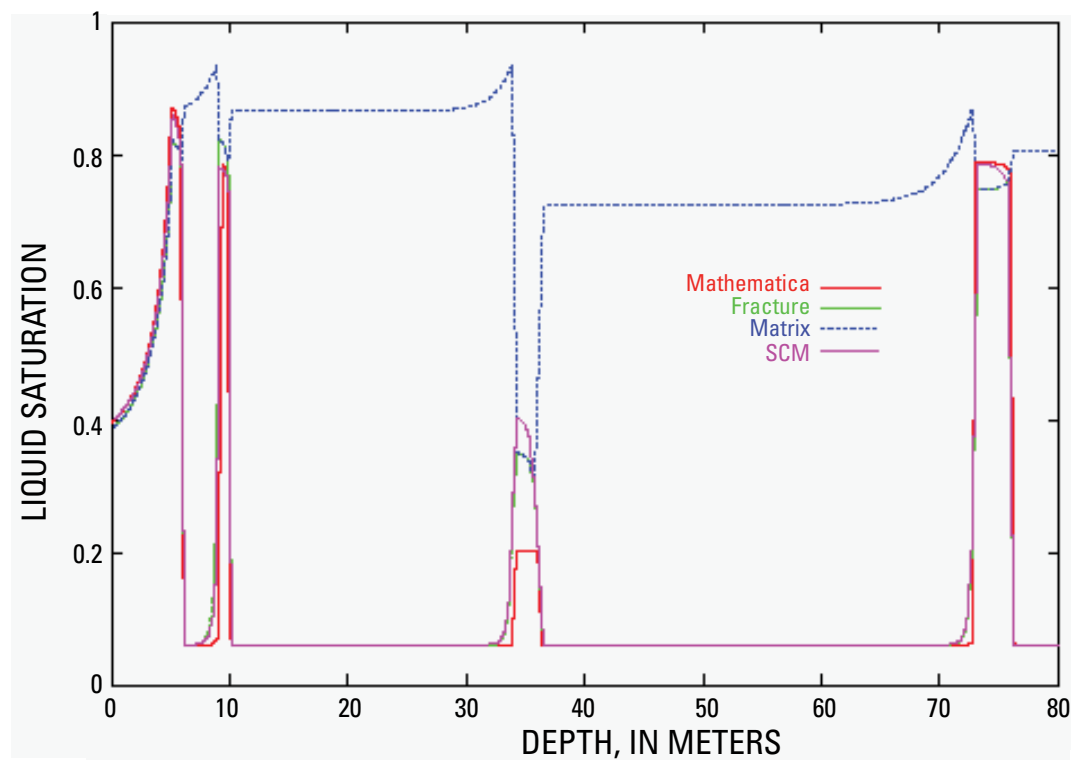

Figure 72. Comparison of steady-state saturation profiles for single- and dual-continuum simulations in model of the Subsurface Disposal Area, Idaho National Laboratory (P.C. Lichtner, Los Alamos National Laboratory, written commun., 2002). 


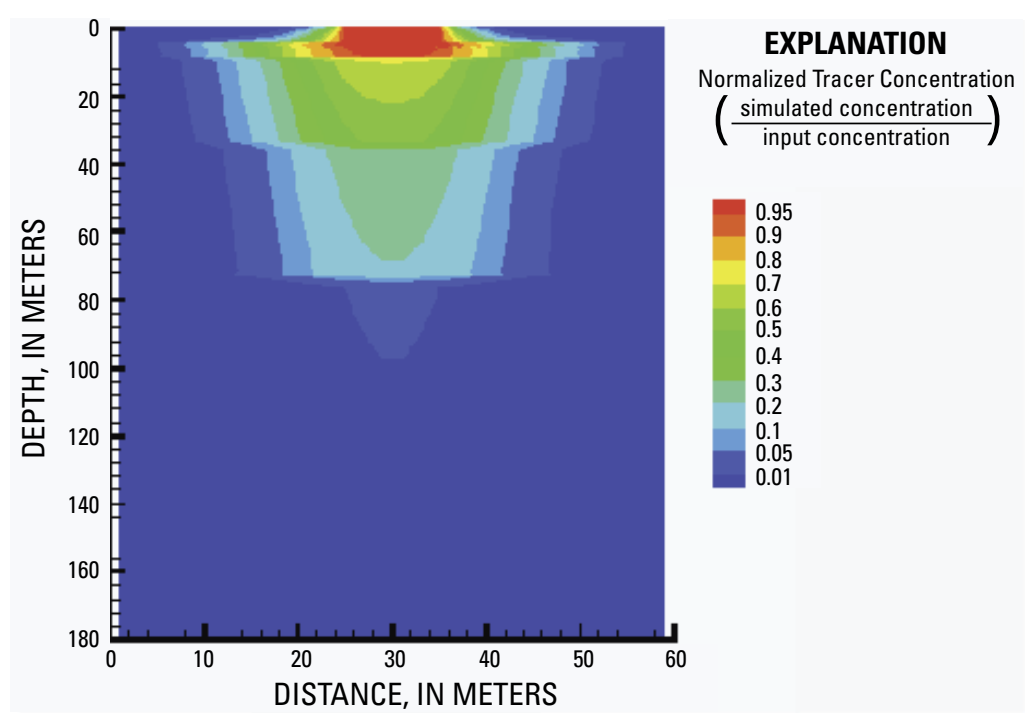

Figure 73. Normalized tracer concentration for fracture continuum in dual-continuum transport model of the Subsurface Disposal Area, Idaho National Laboratory (P.C. Lichtner, Los Alamos National Laboratory, written commun., 2002).

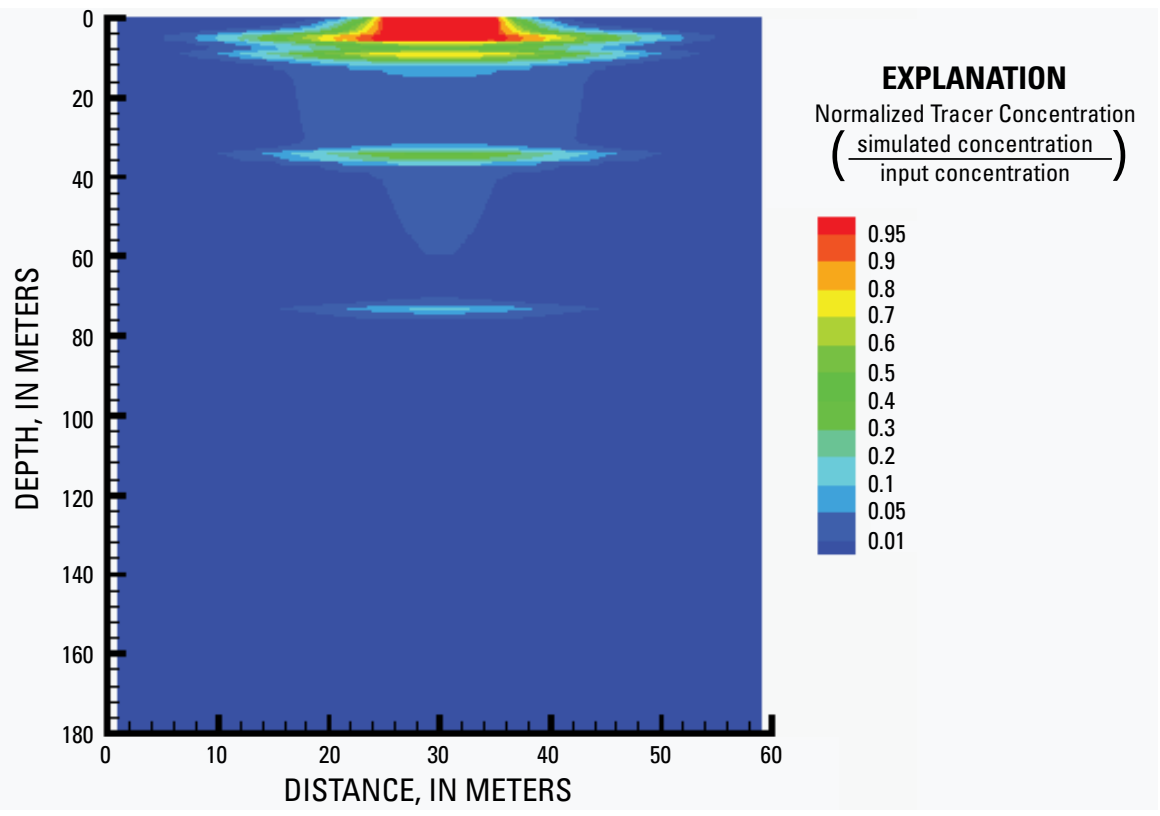

Figure 74. Normalized tracer concentration for matrix continuum in dual-continuum transport model of the Subsurface Disposal Area, Idaho National Laboratory (P.C. Lichtner, Los Alamos National Laboratory, written commun., 2002). 


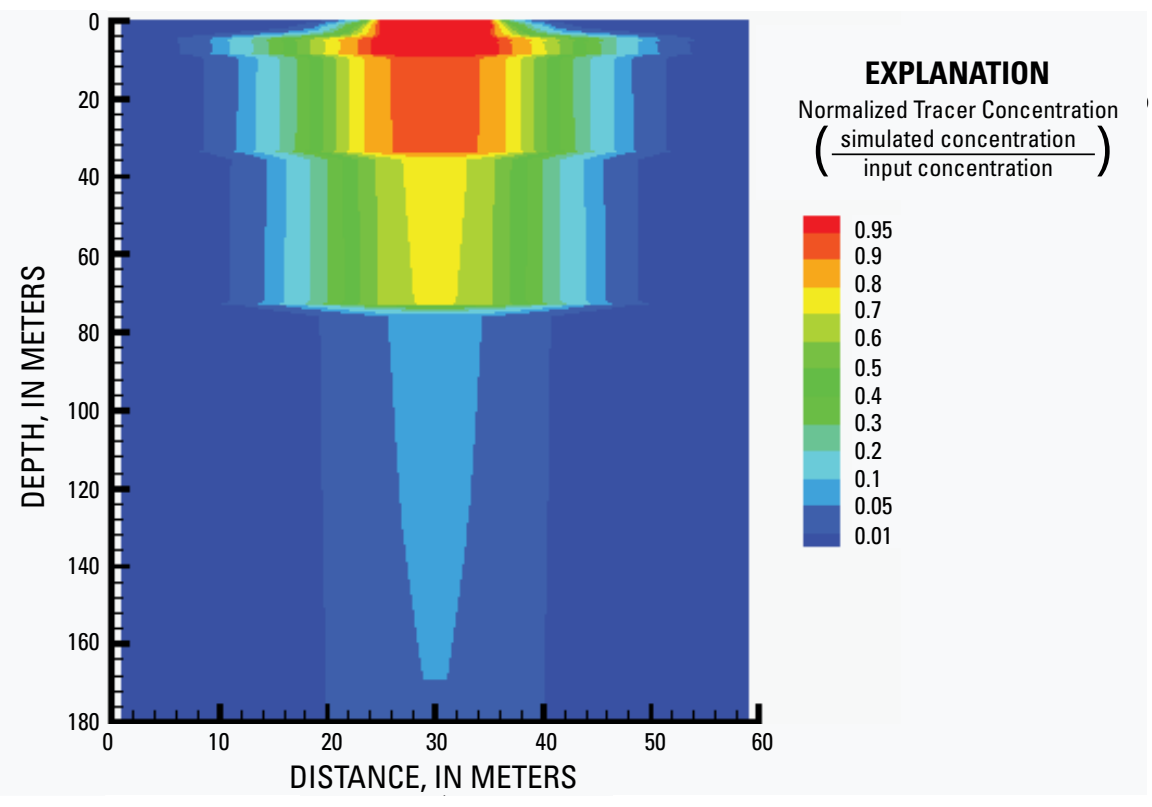

Figure 75. Normalized tracer concentration after 50 years for the singlecontinuum model of the Subsurface Disposal Area, Idaho National Laboratory, with constant release (P.C. Lichtner, Los Alamos National Laboratory, written commun., 2002).

layers and where the interbeds terminate, even when infiltration rates are uniform. Peak normalized tracer concentrations at the water table near the $\mathrm{B}-\mathrm{C}$ interbed are about 0.12 compared to peak concentrations of about 0.05 for the case with uniform, horizontal layers. Although slightly more water was applied in the case with discontinuous layers, the patterns of saturation (fig. 78) and normalized tracer concentrations (fig. 79) indicate that part of the early breakthrough is caused by some water flowing around rather than through the highporosity interbeds. Also, flow rates are relatively high where flow is focused by the dipping, discontinuous layers.

In the reactive transport calculations, vertical radionuclide transport through the surficial sediment zone in the SDA was investigated. Using representative soil-zone water and $P_{\mathrm{CO} 2}$, along with surface site density, cation exchange capacity, and mineralogy of the soil zone, sorption profiles for ${ }^{241} \mathrm{Am}$, ${ }^{238} \mathrm{Pu},{ }^{137} \mathrm{Cs}$, and ${ }^{90} \mathrm{Sr}$ were calculated and compared with field observations. The resulting model calibration predicts a high retardation factor for neptunium and essentially no retardation for uranium.

Calculations were performed in one dimension with a constant infiltration darcy flow rate of $10 \mathrm{~cm} / \mathrm{yr}$, a porosity of 50 percent, and an average saturation of 0.58 (Magnuson and Sondrup, 1998). Radioactive decay was not included in the simulations. An aqueous diffusion coefficient of $10^{-5} \mathrm{~cm}^{2} / \mathrm{s}$ with a tortuosity of 0.294 taken from Magnuson and Sondrup (1998) for the surficial sediment layer was used in the simulations.
The injection fluid composition is listed in table 11. The fluid composition is taken from Well 92 corresponding to perched water, as listed in table 9 . The $\mathrm{pH}$ was adjusted to give equilibrium with calcite, which otherwise would have been supersaturated by one log unit. This adjustment resulted in a reduction in the reported $\mathrm{pH}$ from 8.4 to 7.59 . The redox state of the fluid is not given in table 9. As discussed in the following paragraph, to obtain a simultaneous fit to the concentration profiles for plutonium and americium, it was necessary to invoke reducing conditions. The initial fluid composition was set to be the same as the injection fluid, with the exception of the radionuclide concentrations: plutonium, americium, cesium, uranium, and neptunium, which were set to small values $\left(10^{-20} \mathrm{~mol} / \mathrm{L}\right)$, and strontium, which was given the value of $5 \times 10^{-16} \mathrm{~mol} / \mathrm{L}$ to fit the minimum observed strontium value. It was not determined how much of the strontium profile resulted from nonradioactive strontium that was naturally occurring. The calculated $\log P_{\mathrm{CO} 2}=-2.18$, which is relatively high, presumably resulted from decomposition of organic matter in the waste and soil zones. As can be seen by inspection of table 11, carbonate complexes are an important factor in speciation of uranium and are less important for neptunium. Plutonium exists primarily in the IV oxidation state in the form of the complex $\mathrm{Pu}(\mathrm{OH})_{4}$.

The observed sorbed concentration profiles were fit by adjusting the surface site densities and the injected radionuclide concentrations. An entirely different result is obtained under oxidizing conditions. In this case, both plutonium and americium are strongly sorbed to $\alpha \mathrm{FeOH}$, with americium 


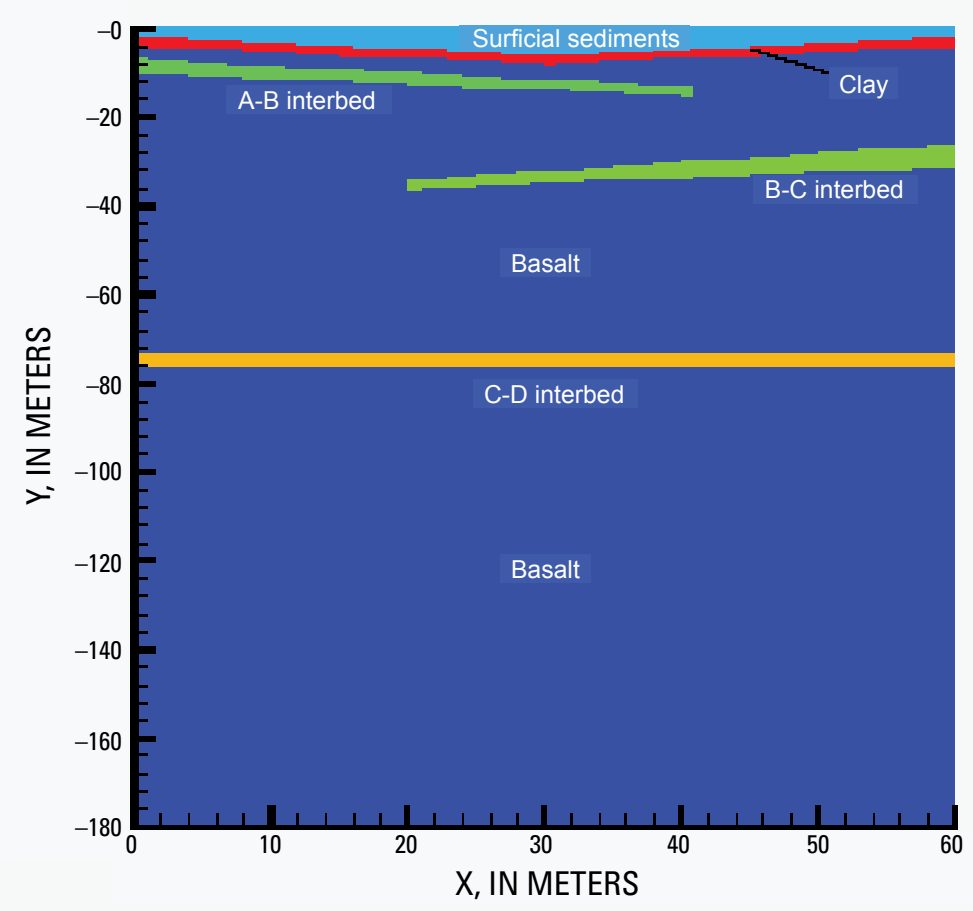

Figure 76. Hydrostratigraphy of the Subsurface Disposal Area, Idaho National Laboratory (P.C. Lichtner, Los Alamos National Laboratory, written commun., 2002).

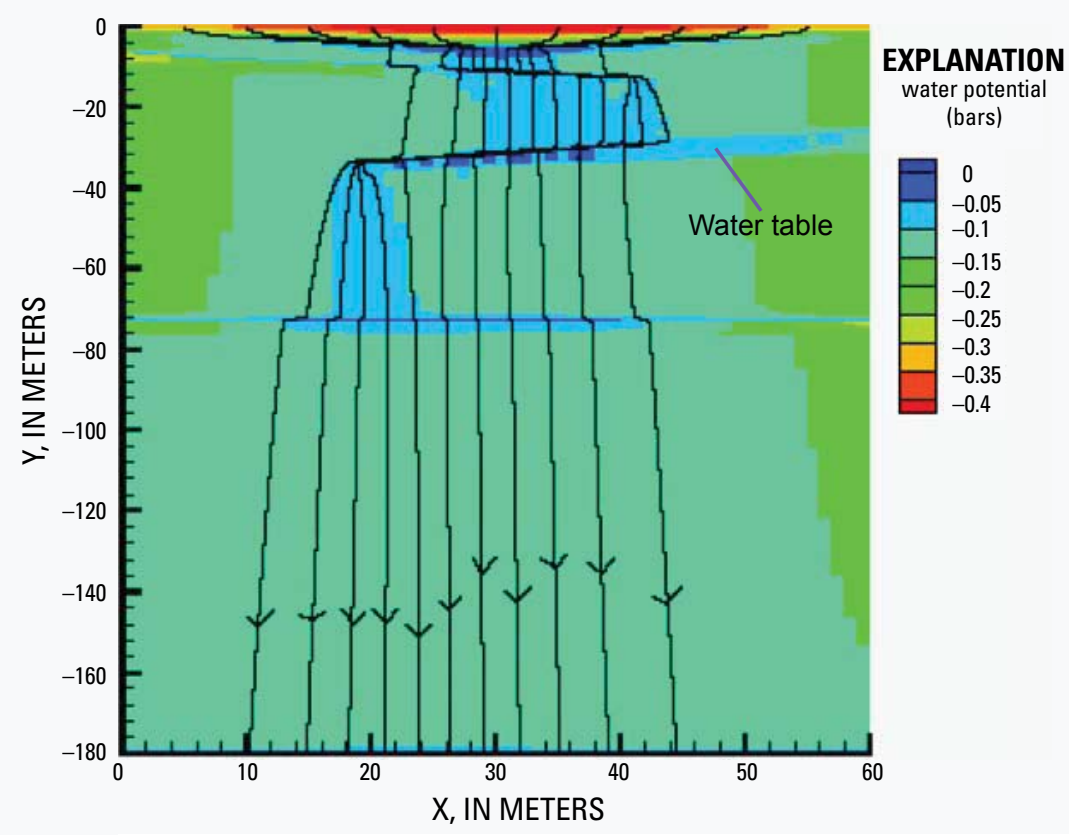

NOTE: Arrows indicate particle-tracking flow lines.

Figure 77. Steady-state water potentials at the Subsurface Disposal Area, Idaho National Laboratory (P.C. Lichtner, Los Alamos National Laboratory, written commun., 2002). 


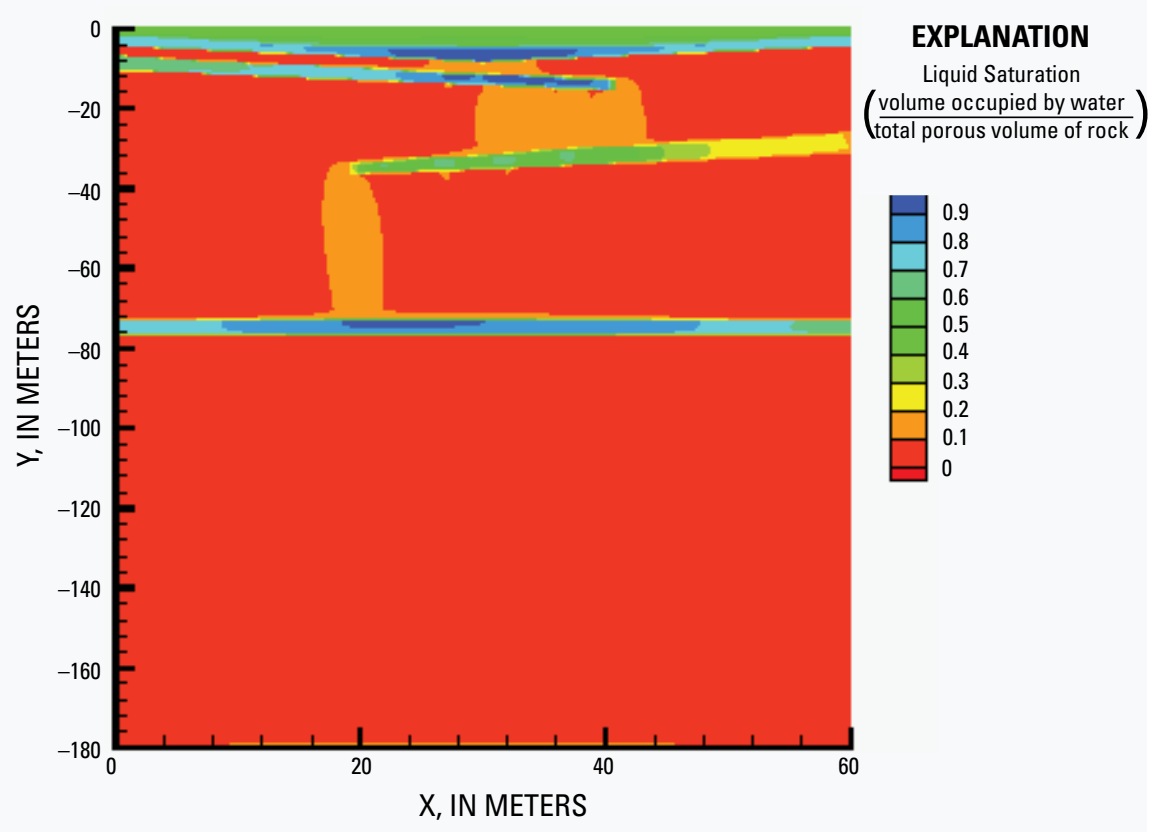

Figure 78. Liquid saturation at 50 years in the dipping, continuous layer transport model of the Subsurface Disposal Area, Idaho National Laboratory (P.C. Lichtner, Los Alamos National Laboratory, written commun., 2002).

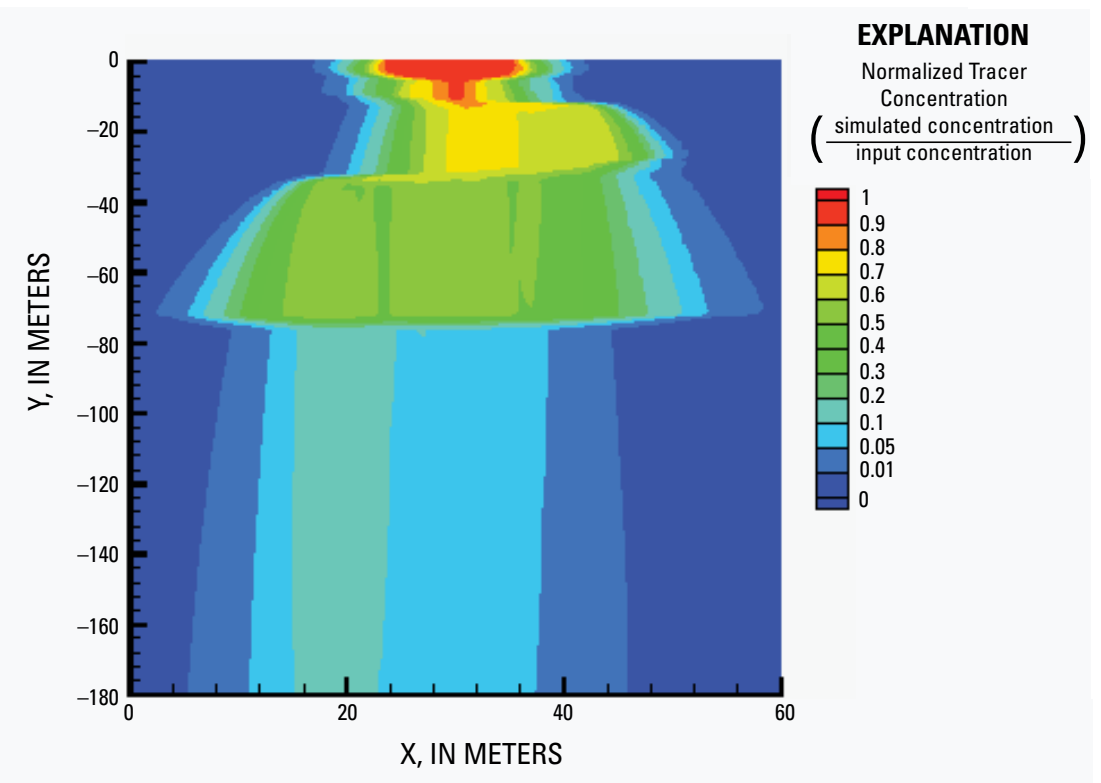

Figure 79. Normalized tracer concentration at 50 years in the dipping, continuous layer transport model of the Subsurface Disposal Area, Idaho National Laboratory (P.C. Lichtner, Los Alamos National Laboratory, written commun., 2002). 
Table 11. Composition of injected fluid used in model of Subsurface Disposal Area transport (P.C. Lichtner, Los Alamos National Laboratory, written commun., 2002).

[Solution conditions: temperature: $25.0^{\circ} \mathrm{Celsius}$, ionic strength: $1.0087 \times 10-2$, solution density: 0.99780 grams per cubic centimeter, pH: 7.5936, pe: 1.931 , Eh: $1.1430 \times 10-1$ volts, charge balance: $-6.3071 \times 10-16$; aq, aqueous; $\mathrm{K}$, potassium; $\log K, \log$ of equilibrium constant]

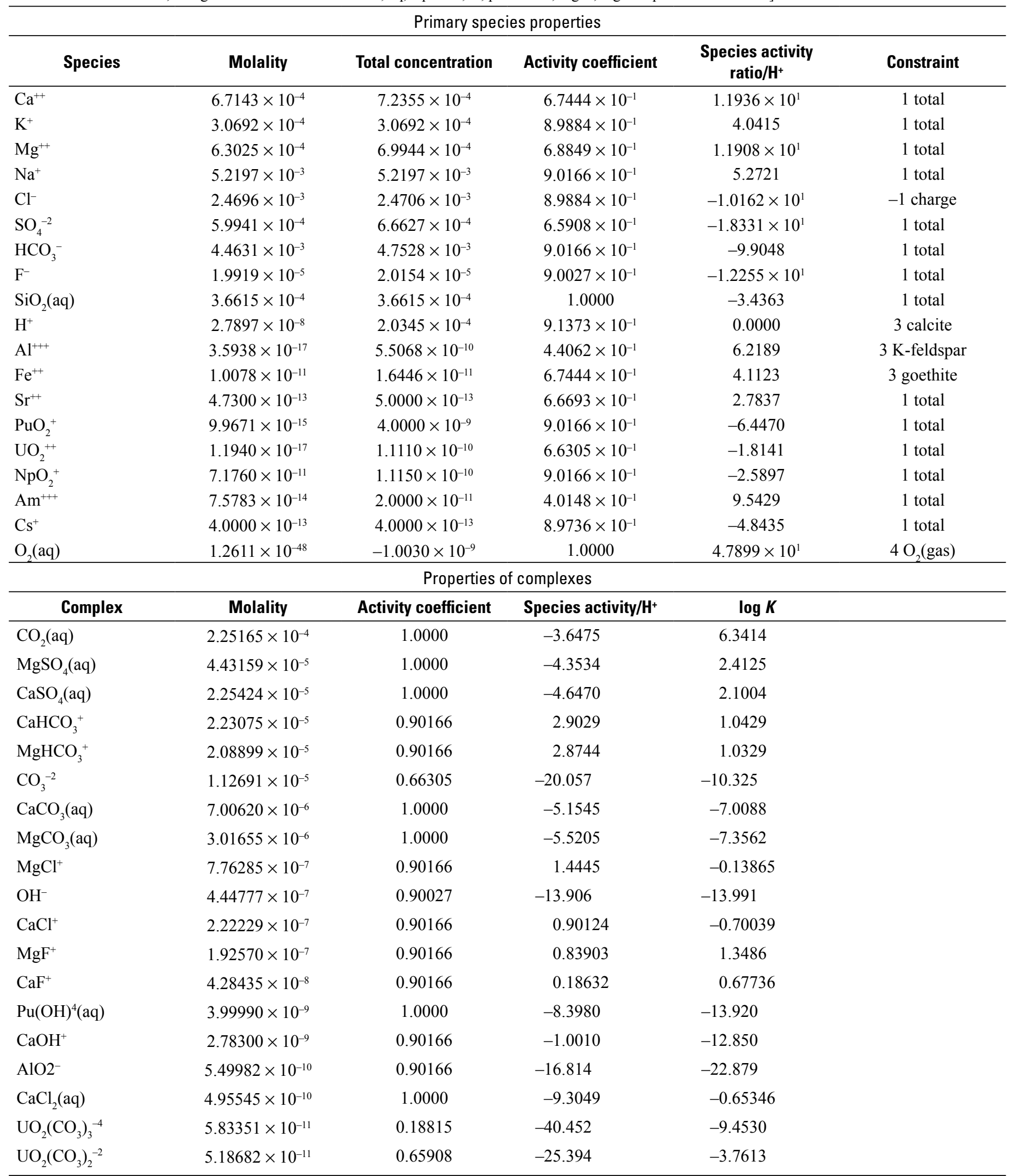


Table 11. Composition of injected fluid used in model of Subsurface Disposal Area transport.-Continued

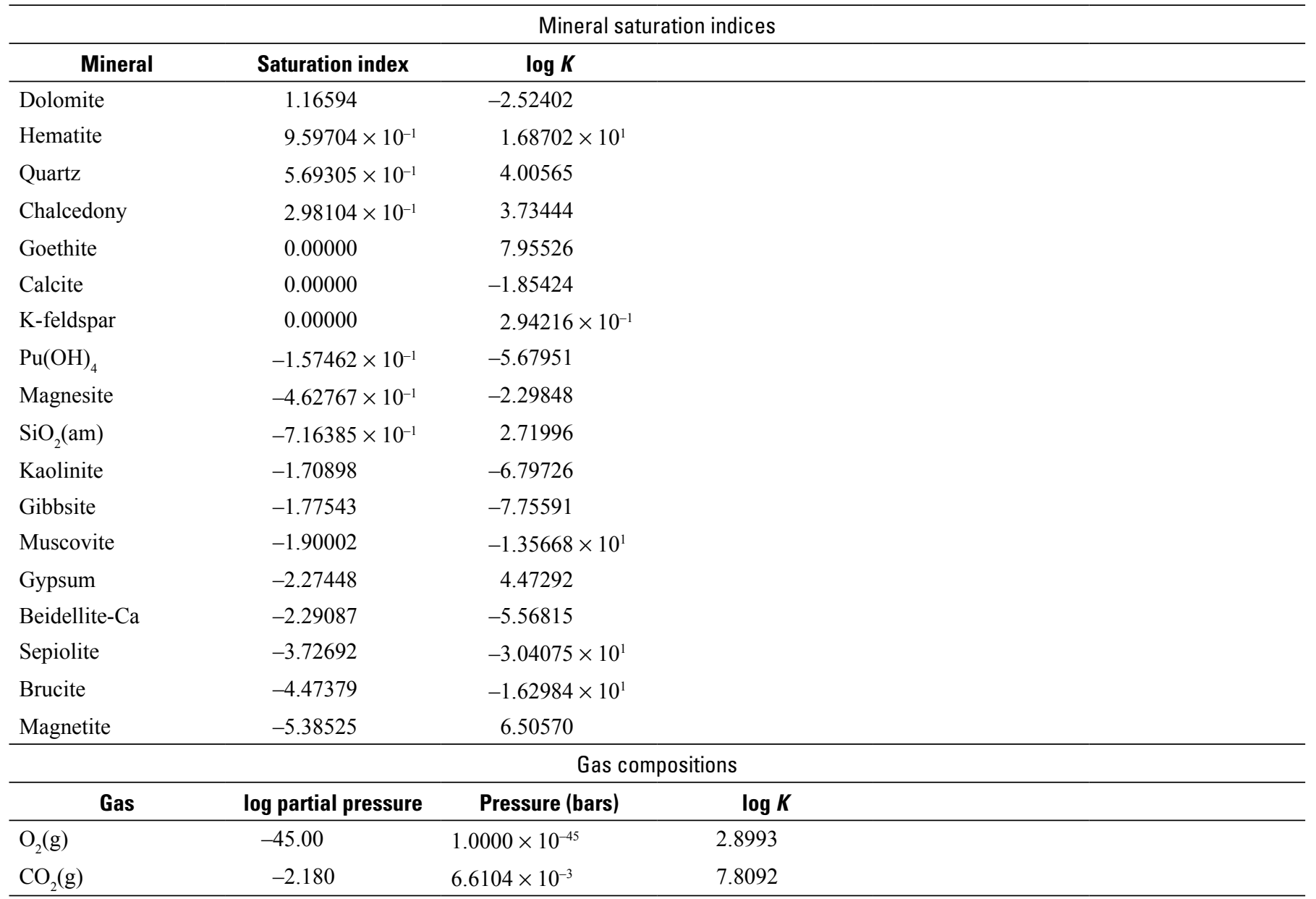

several orders of magnitude greater compared to plutonium. Because under oxidizing conditions plutonium is not sorbed to any other sites, it is not possible to fit the plutonium and americium profiles simultaneously under these conditions.

The resulting fit to the data is shown in figure 80. The obtained fit does not capture the observed decrease in plutonium concentration at a depth of approximately $1 \mathrm{~m}$. This discrepancy could be a result of several factors, including heterogeneity, lateral flow, and the possibility of the presence of the contact between the clay and basalt layer that occurs at this depth. Other species also indicate a slight increase in concentration at this depth.

\section{Discussion of the Subsurface Disposal Area Modeling Study}

Several interpretations of radionuclide transport in the surficial sediment zone are possible. One is that lateral flow occurred, sweeping out part of the radionuclide plume. The thickness of the stratigraphic layers is highly irregular, and the possibility exists that flow occurred along the interface between the clay layer and the surficial sediment layer.
Another possibility is that a sudden release of a pulse of fluid, caused by floods, released a pulse of radionuclides that propagated downward with reduced retardation, due to kinetic effects caused by fast flow rates. In this scenario, the lower portion of the profile, where the concentration is increasing, was the result of a sudden flow event. Presumably, according to this interpretation, the peak lies at a still greater depth below that at which the data were collected.

The model calculations predict retardation factors for neptunium and uranium that are orders of magnitude higher compared to the other radionuclides. This result would indicate that little movement of neptunium and uranium should be observed. No values for these radionuclides were reported that could be taken as consistent with their predicted high retardation. However, a potential effect that was not considered in the model was the manner in which differing redox conditions with depth might have affected episodic compared to nominal flow conditions. The INL has a wetter environment than that of Yucca Mountain. This increase in infiltration is manifested in higher infiltration at the SDA and flooding events that could have resulted in enhanced radionuclide migration beneath the SDA. Focused flow resulting from the undulating topography 


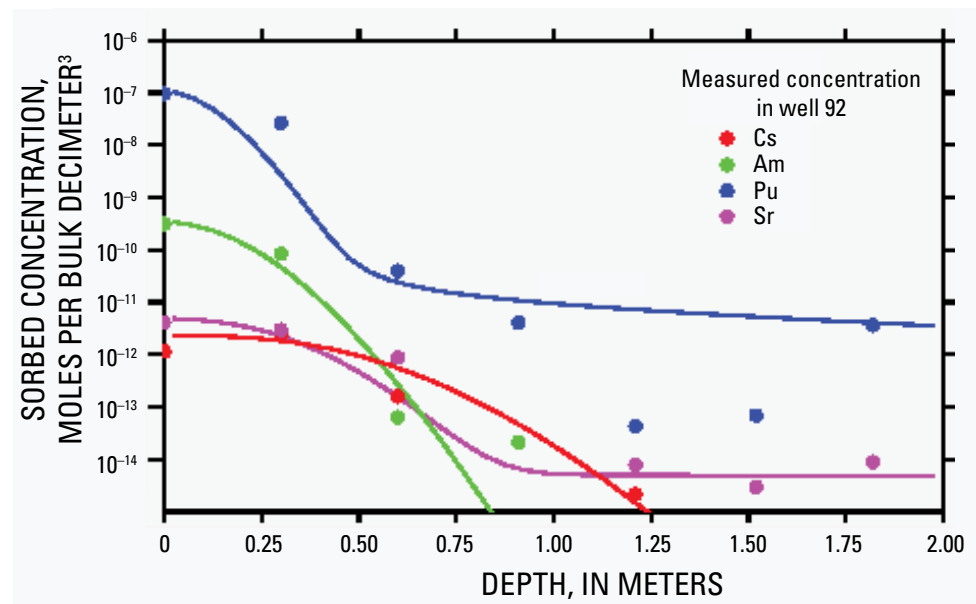

Figure 80. Comparison of field data to model for sorption of cesium, plutonium, americium, and strontium for a flow velocity of 0.1 meter per year through the surficial sediment at the Subsurface Disposal Area, Idaho National Laboratory (P.C. Lichtner, Los Alamos National Laboratory, written commun., 2002).

of the basalt flows and sedimentary interbeds would be expected to exacerbate the situation, leading to even greater distances of radionuclide migration, as demonstrated in the modeling exercises.

To fit observed radionuclide concentrations in the surficial sediment layer, reducing conditions were required. Otherwise, it was not possible to fit the observed profiles of both americium and plutonium simultaneously. Note that although detailed waste compositions are not currently known, there is significant organic matter in the waste that is not inconsistent with the assumption of reducing conditions. However, such conditions are not expected to prevail at greater depths, where the system would be expected to be oxidizing. The calculated profiles did not capture the increase in concentration observed at greater depth near the base of the surficial sediment layer. To further test and validate model predictions, continuity of data at greater depths beneath the SDA would be needed along with site-specific data for surface complexation site densities.

\section{Radionuclide Flow and Transport Studies at Nopal I, Peña Blanca, Chihuahua, Mexico}

Studies of uranium-series disequilibria within and around uranium deposits can provide valuable information on the timing of actinide mobility, and hence the undisturbed stability of a potential repository over the geologic time scales associated with the required lifetime of the facility. The objective of the Peña Blanca natural analogue studies of the Yucca Mountain Project was to construct a three-dimensional conceptual model of the transport of uranium and radiogenic daughter products at Peña Blanca, Mexico.

\section{Background}

The Peña Blanca uranium district is located in the northern part of the Sierra Peña Blanca, in central Chihuahua, Mexico (fig. 81), approximately $50 \mathrm{~km}$ north of Chihuahua City. The region is part of the Chihuahua tectonic belt, which is characterized by northwesterly vergent folds and thrust faults in Mesozoic and lower Tertiary rocks. A regionally extensive sequence of Tertiary volcanic rock unconformably overlies the older units. The region was affected by north-south-trending normal faulting, which is thought to be the southern manifestation of the Rio Grande Rift tectonism. North-south-oriented basin-and-range topography now characterizes the region (Goodell, 1985).

In the 1970s, the Peña Blanca region was a major target of uranium exploration and mining by the Mexican Government because the region contains numerous uranium deposits. Since that time, the Nopal I uranium deposit has been studied extensively because it is a good analogue for evaluating the fate of spent fuel, associated actinides, and fission products at a geologic repository in fractured, unsaturated volcanic tuff (Murphy, 1995). Briefly, the Nopal I uranium deposit at Peña Blanca represents an environment that closely approximates that of the proposed Yucca Mountain high-level radioactive waste repository in the following ways:

- Climatologically: both are located in semiarid to arid regions. 


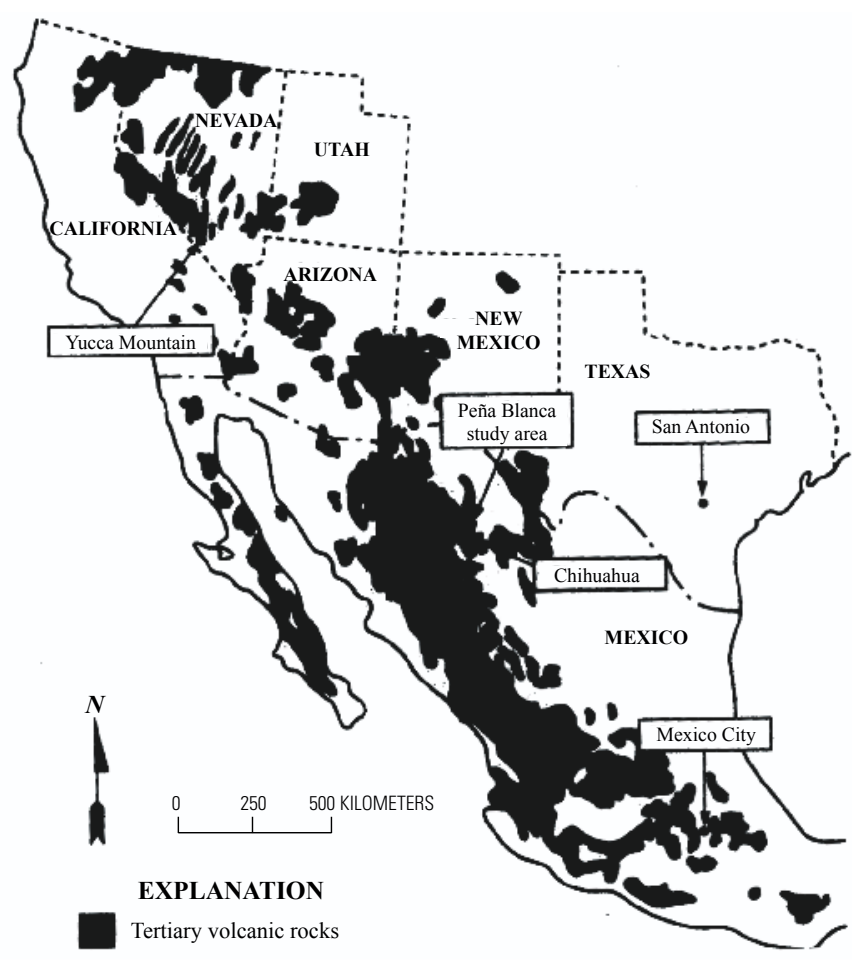

NOTE: The Yucca Mountain potential repository site is located northwest of the Peña Blanca district along a general trend of Tertiary volcanic rocks in the Basin and Range Province.

Figure 81. Nopal I uranium deposit in the Peña Blanca Mining District, Chihuahua, Mexico (Pearcy and others, 1994).

- Structurally: both are parts of a basin-and-range horst structure composed of Tertiary rhyolitic tuffs overlying carbonate rocks.

- Hydrologically: both are located in a chemically oxidizing environment within an unsaturated zone, $200 \mathrm{~m}$ or more above the water table, and have broadly similar water chemistries.

- Chemically: the alteration of primary uraninite (Pearcy and others, 1994) to secondary uranium minerals at Nopal I may be similar to the eventual fate of uranium fuel rods in a potential geologic repository such as Yucca Mountain, according to results of spent-fuel alteration experiments (Wronkiewicz and others, 1996).

The Peña Blanca uranium district consisted of three exploration camps: El Nopal, Margaritas, and El Cuervo. Many of the uranium deposits in the district were drilled or developed by underground or open-pit mining, but there has been no mining activity at Peña Blanca since 1985. Combined, these deposits contained more than 2,000 metric tons of $\mathrm{U}_{3} \mathrm{O}_{8}$ and constitute the bulk of Mexican uranium sources. The deposits lie close to the eastern edge of the Sierra Peña Blanca range and are generally concentrated in the lower part of the Tertiary volcanic section. Uranium mineralization locally extends downward into the upper part of the Cretaceous limestone (just below the Pozos Formation in figure 82).

The oldest rocks in the vicinity of the Peña Blanca district are Early to Late Cretaceous reef, back-reef, and basinal, thinly bedded to massive limestones. The limestone is unconformably overlain by a sequence of Tertiary volcanic and lesser sedimentary rocks. From older to younger, these Tertiary units are the Pozos conglomerate and rhyolitic ignimbrite of the Corrales, Coloradas, Nopal, and Escuadra Formations (Reyes-Cortés, 2002). Locally, the Piloncillos fanglomerate separates the Nopal and Escuadra Formations. The Nopal Formation was dated at $44 \mathrm{Ma}$ (K-Ar age) (Alba and Chavez, 1974; Pearcy and others, 1994).

Nopal I at the Nopal camp was a major focus of some of the studies. Nopal I is a small, high-grade uranium deposit located in a highly brecciated zone that lies at the intersection of two steep faults (fig. 82). The Nopal I deposit is interpreted to have formed by hydrothermal solutions that precipitated uraninite as they moved through a subvertical, highly fractured zone within welded silicic tuff (Pearcy and others, 1994). This deposit is approximately cylindrical, with horizontal dimensions of about $18 \mathrm{~m}$ by $30 \mathrm{~m}$, with a nominal ore zone extending approximately $100 \mathrm{~m}$ vertically (Pearcy and others, 1995) (fig. 82). The upper, highest-grade portion of the deposit is hosted by heavily fractured, silicic tuffs of the Nopal and Coloradas Formations. The deposit extends into the underlying Pozos Formation, although the grade decreases significantly. In the vicinity of the orebody, the Nopal Formation is a densely welded, crystal-lithic rhyolitic tuff, with phenocrysts of quartz, sanidine, and biotite. A highly altered vitrophyre is at the base of the formation. The Coloradas Formation is a lithic-crystal, densely welded tuff, with phenocrysts of quartz, sanidine, plagioclase, and biotite.

Uraninite is only present in highly silicified pods near the center of the orebody and $100 \mathrm{~m}$ deeper in the uraniferous Pozos conglomerate. Uranium-lead dating of uraninite from the main orebody gives an age of $32 \pm 8 \mathrm{Ma}$, and uraninite from the Pozos conglomerate gives an age of less than $1 \mathrm{Ma}$ (Fayek and others, 2005). The uraninite is interpreted to be part of a relict ore assemblage that was altered by oxidizing fluids that produced the secondary suite of uranyl oxyhydroxides (schoepite) and uranyl silicates (uranophane) (Pearcy and others, 1993) (fig. 83). Uranophane is the primary ore mineral, but at least seven other uranium-bearing minerals have been identified (Pearcy and others, 1994; Fayek and others, 2006). Uranophane occurs as euhedral needles and granular masses in highly oxidized zones that also are enriched in kaolinite, limonite, and chalcedony. The Pozos conglomerate contains disseminated grains of anatase $\left(\mathrm{TiO}_{2}\right)$ and uraninite. Preliminary results from back-scattered electron imaging and high-resolution transmission electron microscopy indicate that anatase is actively sequestering the uranium from the fluids that have interacted with the conglomerate (Fayek and others, 


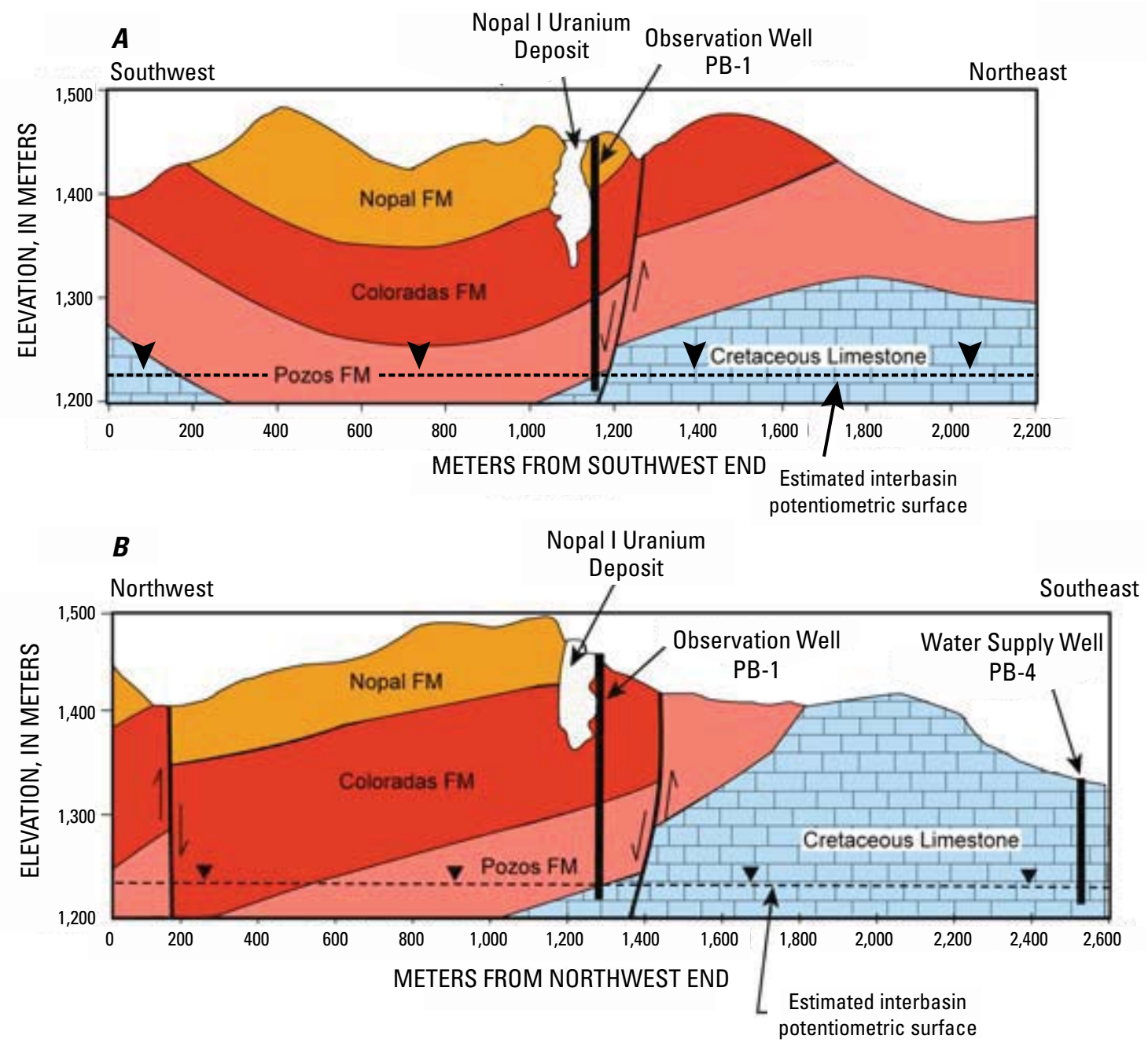

NOTE: Figure illustrates location above the water table and within silicic tuffs of the Nopal and Coloradas Formations and the basal conglomerate of the Pozos Formation.

Figure 82. Orthogonal, vertical cross sections through observation well PB 1 of the Nopal I deposit, Chihuahua, Mexico (modified from Pearcy and others, 1994).

2006). This observation has a bearing on the sequestration of uranium by secondary minerals, as discussed in the section "Analogue Studies Related to Immobilization by Secondary Minerals."

As previously noted, the sequence of uranium-bearing oxidation products observed at Nopal I is closely similar to those produced in laboratory experiments of uranium oxide exposed to oxidizing conditions in the presence of simulated groundwater (Wronkiewicz and others, 1996). Updated thermodynamic property data of uranyl minerals permit evaluations of their stabilities in relation to variations in groundwater chemistry and temperature. The observed parageneses are consistent with increasing aqueous concentrations of environmental components, which are dominated by silica and calcium at Nopal I. The uranyl mineralogy at Nopal I is also consistent with a prograde hydrothermal paragenesis corresponding to the retrograde solubilities of schoepite, soddyite, and uranophane (Murphy and others, 2005).

\section{Early Characterization of Radionuclide Transport Using Uranium-Series Disequilibria}

Uranium-series activity ratios can be used to determine the apparent age of samples based on isotopic disequilibria (Ivanovich and Harmon, 1992). Both fracture and groundwater samples from Peña Blanca have been analyzed to estimate mobility in an environment similar to that of Yucca Mountain.

Two dominant fault and fracture systems bound the western and eastern margins of the Nopal I deposit (fig. 84). The western fault is nearly vertical. The fracture system that bounds the eastern margin of the deposit shows little vertical or horizontal movement (Saucedo and others, 2005). A third, 


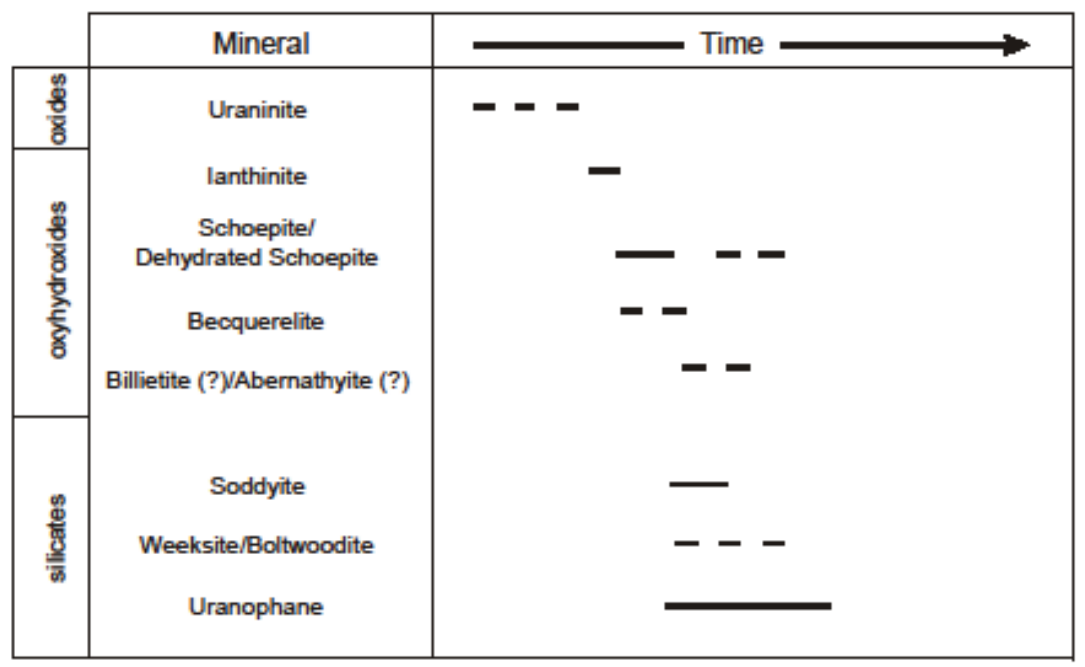

EXPLANATION
Abundant
Figure 83. Relative sequence of formation and abundance of uranium minerals at the Nopal I deposit, Chihuahua, Mexico (Pearcy and others, 1993). nearly horizontal, fault system is exposed along the +10 level of the deposit. The west- and east-bounding fault and fracture systems occur throughout the Nopal I deposit and appear to have channeled subsequent hydrothermal flow, which resulted in formation of the breccia pipe that hosts the uranium ore (Saucedo and others, 2005).

To determine the relative mobility of uranium along fractures and in the rock matrix, Pearcy and others (1993, 1995) mapped and sampled portions of the Nopal I deposit at the $+10 \mathrm{~m}$ level (surface level) of the deposit. Fracture mapping, carried out at a scale of 1:25, included 11,374 individual fractures. Distribution of uranium in the host tuff, examined at scales ranging from $10^{-6}$ to $10 \mathrm{~m}$, indicated that it occurs outside the primary deposit, mainly along fractures in secondary minerals (iron hydroxides, oxides, and silicates) (Pearcy, 1994; Pearcy and others, 1994). Uranium-rich caliche, located about $3 \mathrm{~m}$ outside the limit of uranium mineral occurrence, was dated by U-series isochron techniques at $53.6 \pm 0.8 \mathrm{ka}$, indicating that weathering of the deposit has been the dominant mode of alteration for at least that period (Pearcy and others, 1994).

Major conclusions from this work (Pearcy and others, 1995), based on both field study and ${ }^{234} U$ analyses, include the following:

- Transport of uranium away from the deposit occurred mainly along fracture paths.

- Transport along mesofractures (aperture greater than $1 \mathrm{~mm}$ and trace length greater than $10 \mathrm{~m}$ ) (Pearcy and others, 1995) occurred at 20 times greater distance (up to $30 \mathrm{~m}$ ) than along microfractures (aperture less than $1 \mathrm{~mm}$ ).
- Mobilization of uranium from the deposit occurred within the last $1 \mathrm{~m} . \mathrm{y}$.

- Matrix transport was limited to distances of less than $1 \mathrm{~mm}$.

Prikryl and others (1997) reported electron microprobe analyses of the uranium concentration in fracture-filling minerals, as well as ${ }^{238} \mathrm{U}^{234} \mathrm{U}_{-}{ }^{230} \mathrm{Th}$ alpha spectrometry data on bulk-fracture samples from the major east-west-trending fracture at $13.5 \mathrm{~m}$ north (fracture of Pearcy in figure 84). Their work demonstrated that uranium concentrations in bulk-fracture materials and in goethite and hematite show a downward trend away from the orebody. This trend indicates that uranium was mobilized and transported away from the deposit, most likely by episodic infiltration of meteoric water. Uranium and thorium isotopic data on the $13.5-\mathrm{m}$ north fracture also revealed $\mathrm{a}^{234} \mathrm{U} /{ }^{238} \mathrm{U}$ activity ratio ${ }^{1}$ greater than unity, both within and outside the deposit. This indicates that uranium mobilization was relatively recent (less than $1 \mathrm{Ma}$ ) and is related to uptake of uranium from fracture fluids that carried excess ${ }^{234} \mathrm{U}$. Variations in ${ }^{234} \mathrm{U} /{ }^{238} \mathrm{U}$ were interpreted as resulting from a multistage mobilization process.

${ }^{1} \mathrm{The}{ }^{234} \mathrm{U} /{ }^{238} \mathrm{U}$ activity ratio is the rate of decay of the daughter isotope divided by the rate of decay of the parent isotope. At secular equilibrium, both rates are equal and the ratio is 1 . The two isotopes do not fractionate the way light-stable isotopes do because that type of fractionation is dependent upon the percent difference in the atomic masses, which for uranium isotopes is too small to cause fractionation. However, the two isotopes do fractionate because of the Szilard-Chalmers effect. The alpha decay of ${ }^{238} \mathrm{U}$ followed by the two beta decays leaves the lattice around the ${ }^{234} \mathrm{U}$ atom damaged, and as such, the ${ }^{234} \mathrm{U}$ atom is more susceptible to leaching; therefore, the leachate can have an activity ratio greater than 1 . If a ${ }^{238} \mathrm{U}$ atom is on the surface of a solid and in contact with water, the recoil from an alpha decay can eject the ${ }^{234} \mathrm{U}$ atom into the water. 


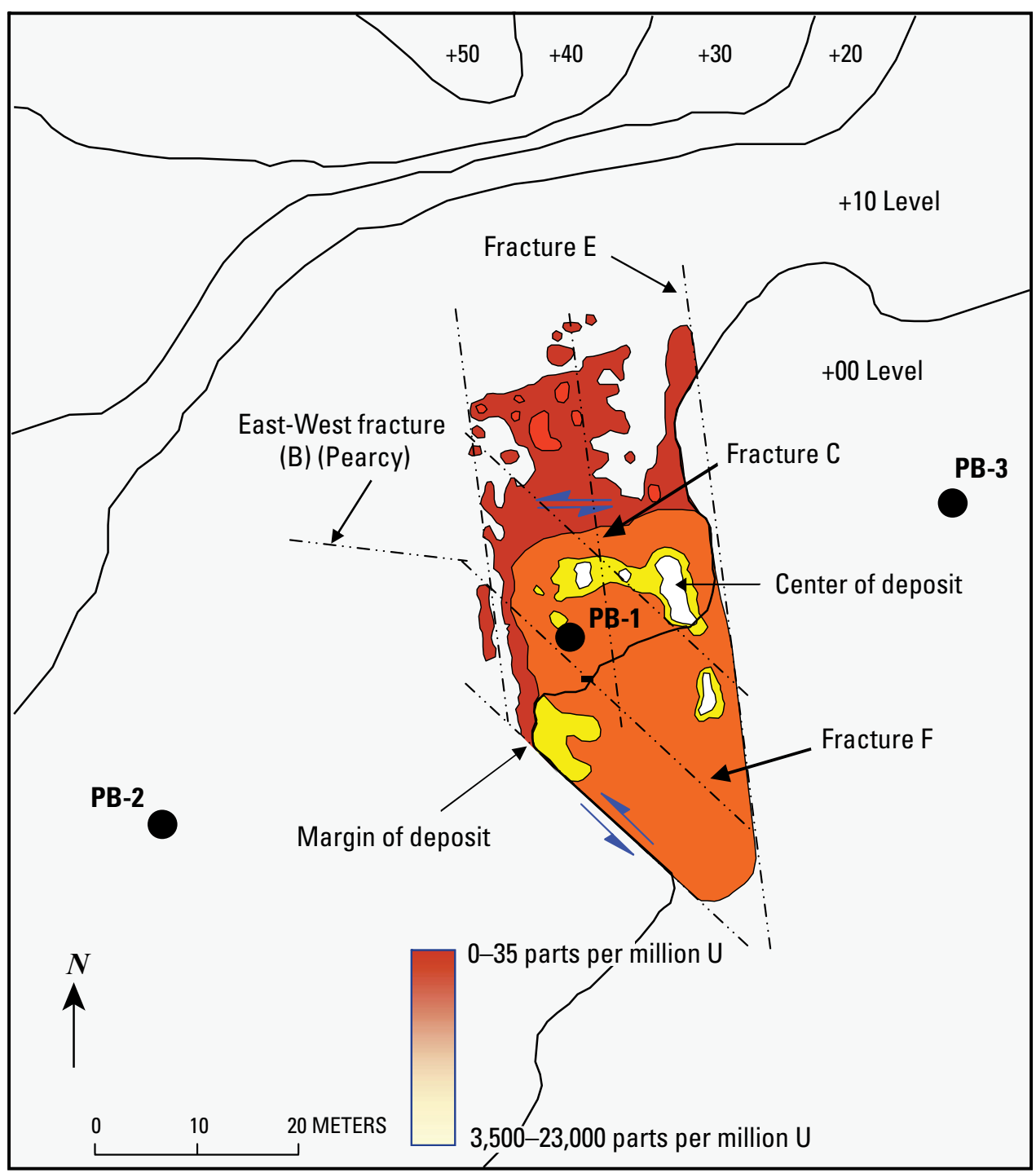

Figure 84. Plan view of the Nopal I deposit (Fayek and others, 2006). Map shows topography, uranium-rich zones, the location of Wells PB-1, PB-2, and PB-3, and the major fracture/fault systems that define the margins of the deposit (dot-dashed lines). Also shown is the major east-west fracture system (Fracture B of Pearcy and others [1994]) along which most of the samples reported in CRWMS M\&O (2000b) were collected.

In further work, Pickett and others (1996) and Pickett and Murphy (1997) obtained additional ${ }^{238} \mathrm{U}_{-}{ }^{234} \mathrm{U}-{ }^{230} \mathrm{Th}$ data for other fractures at Nopal I. Most of their data for fracture-filling materials plots in the "forbidden zone" (for example, fig. 85), which is the region on a Concordia diagram where there is no finite single-stage age solution.

Figure 85 has been modified from Pickett and Murphy (1997) by the addition of typical error bars and data (shown as orange dots) from Murrell and others (1997). Pickett and Murphy (1997) used decay-counting methods whereas Murrell and others (1997) used more precise TIMS. These values led Pickett and Murphy (1997) and Wong (1998) to invoke multiple uranium-mobilization events involving both uranium enrichment and removal over the past few hundred thousand years to explain their data. The values that fall in the forbidden zone are a consequence of their higher ${ }^{230} \mathrm{Th} /{ }^{234} \mathrm{U}$ and variable ${ }^{226} \mathrm{Ra} /{ }^{230} \mathrm{Th}$ measurements, which cannot be explained by a simple model of closed system evolution. The ${ }^{230} \mathrm{Th} /{ }^{234} \mathrm{U}$ activity ratios measured by Murrell and others (1997) are generally close to 1 and fall along the curved time arrow in figure 85, indicating closed-system behavior in Nopal I fracture-filling material for uranium for the last 100,000-400,000 years (Murrell and others, 1997). 


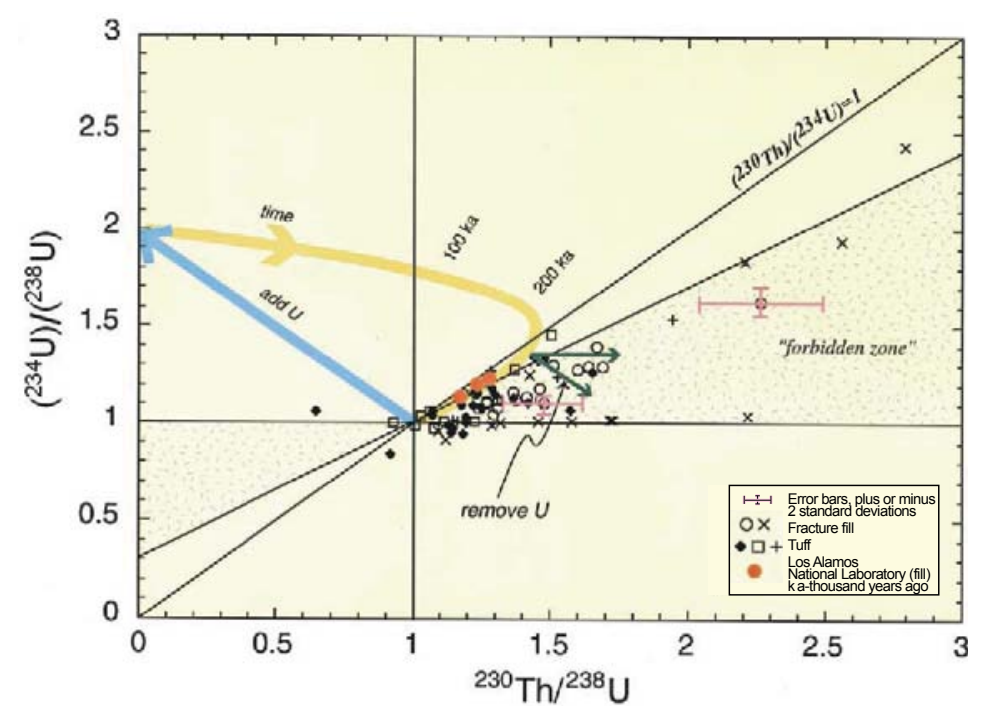

Figure 85. Plot of measurements of ${ }^{234} \mathrm{U} /{ }^{238} \mathrm{U}$ compared to ${ }^{230} \mathrm{Th} /{ }^{238} \mathrm{U}$ for fracture-filling materials, Nopal I area, Chihuahua, Mexico, obtained by the Center for Nuclear Waste Regulatory Analyses (Pickett and Murphy, 1997, with added data identified as Los Alamos National Laboratory [LANL] from Murrell and others, 1997).

In an effort to learn the extent of uranium mobility at Peña Blanca, 18 additional samples were analyzed by TIMS from four prominent uranium-mineralized fractures $(\mathrm{B}, \mathrm{C}, \mathrm{E}$, and $\mathrm{F}$ in figure 84) emanating into surrounding silicic tuff. Results for uranium and thorium isotopes for the samples and standards are provided in table 12. Many of the sampling locations referred to in this section came from the east-west fracture shown in figure 84. Uranium concentrations for the samples generally decrease from the outer margin of the deposit to the far end of the fractures, in general agreement with previous studies (Pearcy and others, 1995; Wong, 1998). The absolute concentrations for the samples agreed well with the results obtained by Pickett and Murphy (1997).

Three samples of uranophane gave ${ }^{238} \mathrm{U} /{ }^{206} \mathrm{~Pb}$ and ${ }^{235} \mathrm{U} /{ }^{207} \mathrm{~Pb}$ internal and external isochron ages of 3.4 and 3.2 m.y., respectively (Pickett and Murphy, 1997). Collectively, their isotopic and chemical data indicate the following history:

- Primary uraninite mineralization occurred approximately 8 Ma.

- Deposition of uranyl silicates occurred during a single period around $3 \mathrm{Ma}$.

- Complex episodic uranium mobilization and remobilization, including dispersion of uranium through aqueous transport into the surrounding fractured tuff, took place over the past few hundred thousand years.

Complementary to their earlier studies of fracture-filling materials, Pickett and Murphy (1999) presented measurements of uranium-thorium isotope composition and concentration in samples from perched water, seep water, and groundwater collected near the Nopal I uranium deposit (see 1995 collections in table 12). The uranium and thorium concentrations generally correlate with concentrations of major cations and anions and total conductivity, which may reflect evaporation followed by dilution or rock-dissolution effects on all of these species. Thorium and uranium concentrations also correlate strongly with each other, which is surprising given the expected differences in solution chemistry and potential solubility controls for these two elements. Pickett and Murphy (1999) interpreted these concentrations in the context of solubility control by various uranium silicate minerals (haiweeite, soddyite) and thorianite.

They observed that the perched water is close to the solubility limit for haiweeite, a calcium uranyl silicate mineral. All of the other waters are undersaturated with respect to uranium mineral phases. However, all of the waters are supersaturated with respect to thorianite, which is attributed to the presence of colloidal thorium in the $<0.2-\mu \mathrm{m}$ fraction of these samples. The occurrence of undersaturation for uranium and supersaturation for thorium indicates that radionuclide transport in the unsaturated zone may be controlled by kinetic factors such as evaporation, rock dissolution, and colloid formation, which complicate the interpretations based on thermodynamic (solubility) considerations.

French and others (2006) investigated a cleared area where ore had previously been stored, known as the Prior High-Grade Stockpile area. They collected soil samples from alluvium surrounding and underlying a boulder that had rolled downhill from the area when it was cleared and a bulk sample of the boulder. Gamma-ray spectroscopy of uranium-series disequilibria determined that the boulder was close to secular equilibrium; however some daughter/parent pairs in the soils were in disequilibrium. Namely, ${ }^{230} \mathrm{Th} /{ }^{234} \mathrm{U}>1$, ${ }^{226} \mathrm{Ra} /{ }^{230} \mathrm{Th}>1$, and ${ }^{210} \mathrm{~Pb} /{ }^{214} \mathrm{Bi}<1$. As with Pickett and Murphy's (1999) and Wong's (1998) work, French and others' (2006) results require a multistage history of mobilization of uranium-series radionuclides. The short residence time of the ore at the Prior High-Grade Stockpile requires a time span for mobilization of 20-30 years (French and others, 2006), but the radionuclides have not traveled far from the source boulder.

Using an entirely different approach that employed electron paramagnetic resonance, Allard and Muller (1998) tested the potential use of point-defect centers (essentially, radiation damage from absorbed dose) in kaolinite to detect uranium mobilization. They compared integrated defects to current uranium distribution to infer the past distributions of uranium at Peña Blanca. This investigation indicated two major migration events: (1) past accumulation of uranium outside the mineralized zone, followed by leaching; and (2) a late-stage accumulation of uranium in the area of the primary uranium deposit. 
Table 12. Measurements of concentration and isotopic composition in water samples collected near the Nopal I uranium deposit, Peña Blanca, Mexico.

[ID, identifier; collect., collection; conc., concentration; ppb, parts per billion; ppq, parts per quadrillion; AR, radioactivity ratio; mg/L, milligrams per liter; m, meter; na, not analyzed; $8.5 \mathrm{~m}$ into north part of adit at +00 level is location $\mathrm{E}$ in figure $89 ; 23 \mathrm{~m}$ from adit entrance is location $\mathrm{D}$ in figure $89 ; 15 \mathrm{~m}$ from adit entrance is location $\mathrm{C}$ in figure $89 ; 12 \mathrm{~m}$ from adit entrance is location $\mathrm{B}$ in figure 89; $5 \mathrm{~m}$ from adit entrance is location A in figure 89; 1995 samples from Pickett and Murphy (1999, Table II); 2000 and 2001 samples from A.M. Simmons, Los Alamos National Laboratory, written commun. (2002); 2003 samples from BSC (2004)]

\begin{tabular}{|c|c|c|c|c|c|c|c|c|c|c|c|c|c|c|c|c|c|c|c|c|c|}
\hline \multicolumn{3}{|c|}{ Sample information } & \multicolumn{4}{|c|}{ Uranium } & \multicolumn{4}{|c|}{ Thorium } & \multicolumn{6}{|c|}{ Radium } & \multicolumn{3}{|c|}{ Strontium } & \multicolumn{2}{|c|}{$\begin{array}{c}\text { Stable } \\
\text { isotopes }\end{array}$} \\
\hline $\begin{array}{c}\text { Sampling } \\
\text { location }\end{array}$ & Sample ID & $\begin{array}{l}\text { Collect. } \\
\text { Date }\end{array}$ & $\begin{array}{c}U \\
(\mathbf{p p b})\end{array}$ & $\begin{array}{c} \pm \\
(\%)\end{array}$ & $\begin{array}{c}{ }^{234} U /^{238} U \\
\left(\times 10^{-6}\right)\end{array}$ & $\begin{array}{c} \pm \\
(\%)\end{array}$ & $\begin{array}{l}{ }^{232} \mathrm{Th} \\
\text { (ppb) }\end{array}$ & $\begin{array}{l} \pm \\
(\%)\end{array}$ & \begin{tabular}{|l|}
${ }^{230} \mathrm{Th}$ \\
(ppq)
\end{tabular} & $\begin{array}{c} \pm \\
(\%)\end{array}$ & $\begin{array}{l}{ }^{226} \mathrm{Ra} \\
\text { (ppq) }\end{array}$ & \begin{tabular}{c|} 
\pm \\
$(\%)$
\end{tabular} & ${ }_{\mathrm{AR}}^{{ }^{226} \mathrm{Ra} /{ }^{230} \mathrm{Th}}$ & $\begin{array}{l}+/- \\
(\%)\end{array}$ & $\begin{array}{c}{ }^{226} \mathrm{Ra} /{ }^{238} \mathrm{U} \\
\mathrm{AR}\end{array}$ & \begin{tabular}{c|} 
\pm \\
$(\%)$
\end{tabular} & ${ }^{87} \mathrm{Sr} /{ }^{86} \mathrm{Sr}$ & \pm & $\begin{array}{l}\sim \mathrm{Sr} \\
\text { Conc. } \\
\text { (mg/L) }\end{array}$ & $\begin{array}{l}\delta \mathrm{D} \\
(\% \circ)\end{array}$ & $\begin{array}{l}\delta^{18} \mathrm{O} \\
(\% \circ)\end{array}$ \\
\hline \multirow{4}{*}{$\begin{array}{c}\text { Perched } \\
\text { water from } \\
\text { borehole at } \\
+10 \text { level }\end{array}$} & BH12W95-5 & $8 / 95$ & 4.79 & 0.20 & 119.7 & 0.18 & na & na & na & na & na & na & na & na & na & na & na & na & na & na & na \\
\hline & BH12W95-11 & 9/95 & 5.77 & 0.25 & 120.9 & 0.14 & na & na & na & na & na & na & na & na & na & na & na & na & na & na & na \\
\hline & AS-5 & $2 / 25 / 00$ & 5.73 & 0.19 & 156.8 & 0.10 & na & na & na & na & na & na & na & na & na & na & 0.70781 & 0.00001 & 0.3 & -64 & -9.3 \\
\hline & 030701-0 & $3 / 7 / 01$ & 10.4 & 0.19 & 112.6 & 0.11 & na & na & na & na & 0.02 & 4 & na & na & 0.01 & 4 & 0.70781 & 0.00001 & 0.3 & na & na \\
\hline \multirow{3}{*}{$\begin{array}{c}8.5 \mathrm{~m} \text { into } \\
\text { north part of } \\
\text { adit at }+00 \\
\text { level }\end{array}$} & ADIT95-6 & 9/95 & 0.20 & 2.4 & 278.4 & 0.16 & na & na & na & na & na & na & na & na & na & na & na & na & na & na & na \\
\hline & AS-4 & $2 / 25 / 00$ & 2.87 & 0.30 & 121.2 & 0.25 & na & na & na & na & 5.51 & 0.8 & na & na & 5.68 & 0.83 & \begin{tabular}{|l|}
0.70801 \\
\end{tabular} & 0.00004 & 0.01 & -1 & -2.8 \\
\hline & 030701-02 & $3 / 7 / 01$ & 1.20 & 0.24 & 142.1 & 0.20 & na & na & na & na & 46.0 & 1.3 & na & na & 113 & 1.4 & 0.70792 & 0.00001 & 0.03 & na & na \\
\hline \multirow{3}{*}{$\begin{array}{c}23 \mathrm{~m} \text { from } \\
\text { adit } \\
\text { entrance }\end{array}$} & ADIT95-9 & $9 / 95$ & 0.89 & 0.54 & 156.2 & 0.11 & na & na & na & na & na & na & na & na & na & na & na & na & na & na & na \\
\hline & AS-3 & $2 / 25 / 00$ & 4.03 & 0.19 & 64.61 & 0.18 & 0.0012 & 3.0 & 0.88 & 5.0 & 76 & 8 & 4165 & 9.5 & 56 & 10 & 0.70789 & 0.00003 & 0.03 & -7 & -3.6 \\
\hline & 030701-03 & $3 / 7 / 01$ & 27.0 & 0.18 & 64.36 & 0.10 & na & na & na & na & 472 & \begin{tabular}{|l|} 
\\
lower \\
limit
\end{tabular} & na & na & 52 & \begin{tabular}{|c|}
$\begin{array}{l}\text { lower } \\
\text { limit }\end{array}$ \\
\end{tabular} & 0.70786 & 0.00002 & 0.05 & na & na \\
\hline \multirow{2}{*}{$\begin{array}{c}15 \mathrm{~m} \text { from } \\
\text { adit } \\
\text { entrance }\end{array}$} & AS-2 & $2 / 25 / 00$ & 36.9 & 0.19 & 51.53 & 0.16 & 0.0102 & 0.44 & 7.88 & 0.58 & 202 & 0.42 & 1234 & 0.72 & 16.2 & 0.46 & 0.70790 & 0.00001 & 0.03 & -7 & -3.4 \\
\hline & 030701-04 & $3 / 7 / 01$ & 16.5 & 0.28 & 50.51 & 0.40 & na & na & na & na & 21 & \begin{tabular}{|c|} 
lower \\
limit \\
\end{tabular} & na & na & 4 & $\begin{array}{c}\text { lower } \\
\text { limit } \\
\end{array}$ & 0.70786 & 0.00002 & 0.10 & na & na \\
\hline $\begin{array}{c}12 \mathrm{~m} \text { from } \\
\text { adit } \\
\text { entrance }\end{array}$ & AS-1 & $2 / 25 / 00$ & 68.5 & 0.19 & 58.21 & 0.14 & 0.0095 & 0.54 & 93.8 & 0.58 & 194 & 2 & 99.37 & 2.35 & 8.4 & 2 & 0.70783 & 0.00002 & 0.02 & -11 & -2.5 \\
\hline $\begin{array}{c}5 \mathrm{~m} \text { from } \\
\text { adit } \\
\text { entrance }\end{array}$ & 030701-05 & $3 / 7 / 01$ & 13.0 & 0.23 & 56.14 & 0.20 & na & na & na & na & 54.3 & 0.53 & na & na & 12.4 & 0.57 & 0.70778 & 0.00001 & 0.05 & na & na \\
\hline \multirow{7}{*}{$\begin{array}{c}\text { Abandoned } \\
\text { mining } \\
\text { camp } \\
\text { supply well } \\
\text { (PB-4) }\end{array}$} & WVW95-03 & $9 / 95$ & 0.17 & 2.8 & 76.02 & 0.22 & na & na & na & na & na & na & na & na & na & na & na & na & na & na & na \\
\hline & AS-6 & $2 / 25 / 00$ & 2.53 & 0.25 & 64.93 & 0.30 & na & na & na & na & na & na & na & na & na & na & na & na & na & na & na \\
\hline & 032703-1 & $3 / 27 / 03$ & 0.16 & 0.27 & 78.07 & 0.80 & & na & na & na & na & na & na & na & na & na & na & na & na & na & na \\
\hline & $\begin{array}{c}\text { SPC1025020- } \\
\text { SJG2 }\end{array}$ & $5 / 7 / 03$ & 0.48 & 0.20 & 93.98 & 0.39 & na & na & na & na & na & na & na & na & na & na & na & na & na & na & na \\
\hline & $\begin{array}{c}\text { SPC1025025 } \\
\text { MTM-4A }\end{array}$ & $8 / 6 / 03$ & 2.39 & 0.19 & 82.03 & 0.12 & na & na & na & na & na & na & na & na & na & na & na & na & na & na & na \\
\hline & $\begin{array}{c}\text { SPC1025031 } \\
\text { MTM-4 }\end{array}$ & $8 / 29 / 03$ & 1.11 & 0.22 & 89.53 & 0.18 & na & na & na & na & na & na & na & na & na & na & na & na & na & na & na \\
\hline & $\begin{array}{c}\text { SPC } 1025048 \\
\text { MTM-2 }\end{array}$ & $12 / 12 / 03$ & 0.09 & 0.25 & 80.69 & 0.70 & na & na & na & na & na & na & na & na & na & na & na & na & na & na & na \\
\hline
\end{tabular}


Table 12. Measurements of concentration and isotopic composition in water samples collected near the Nopal I uranium deposit, Peña Blanca, Mexico.-Continued

[ID, identifier; collect., collection; conc., concentration; ppb, parts per billion; ppq, parts per quadrillion; AR, radioactivity ratio; mg/L, milligrams per liter; $\mathrm{m}$, meter; na, not analyzed; $8.5 \mathrm{~m}$ into north part of adit at +00 level is location $\mathrm{E}$ in figure $89 ; 23 \mathrm{~m}$ from adit entrance is location $\mathrm{D}$ in figure $89 ; 15 \mathrm{~m}$ from adit entrance is location C in figure $89 ; 12 \mathrm{~m}$ from adit entrance is location $\mathrm{B}$ in figure 89; $5 \mathrm{~m}$ from adit entrance is location A in figure 89; 1995 samples from Pickett and Murphy (1999, Table II); 2000 and 2001 samples from A.M. Simmons, Los Alamos National Laboratory, written commun. (2002); 2003 samples from BSC (2004)]

\begin{tabular}{|c|c|c|c|c|c|c|c|c|c|c|c|c|c|c|c|c|c|c|c|c|c|}
\hline \multicolumn{3}{|c|}{ Sample Information } & \multicolumn{4}{|c|}{ Uranium } & \multicolumn{4}{|c|}{ Thorium } & \multicolumn{6}{|c|}{ Radium } & \multicolumn{3}{|c|}{ Strontium } & \multicolumn{2}{|c|}{$\begin{array}{c}\text { Stable } \\
\text { Isotopes }\end{array}$} \\
\hline $\begin{array}{l}\text { Sampling } \\
\text { Location }\end{array}$ & Sample ID & $\begin{array}{l}\text { Collect. } \\
\text { Date }\end{array}$ & $\underset{(p p b)}{U}$ & $\underset{(\%)}{ \pm}$ & $\begin{array}{c}{ }^{234} U /^{238} U \\
\left(e^{-6}\right)\end{array}$ & $\stackrel{ \pm}{(\%)}$ & $\begin{array}{l}{ }^{232} \mathrm{Th} \\
(\mathrm{ppb})\end{array}$ & $\stackrel{ \pm}{(\%)}$ & \begin{tabular}{|l|}
${ }^{230} \mathrm{Th}$ \\
$(\mathrm{ppq})$
\end{tabular} & $\stackrel{ \pm}{(\%)}$ & $\begin{array}{l}{ }^{226} \mathrm{Ra} \\
\text { (ppq) }\end{array}$ & $\stackrel{ \pm}{ \pm}$ & $\begin{array}{c}{ }^{226} \mathrm{Ra} /{ }^{230} \mathrm{Th} \\
\mathrm{AR}\end{array}$ & $\stackrel{ \pm}{(\%)}$ & $\begin{array}{c}{ }^{226} \mathrm{Ra} /{ }^{238} \mathrm{U} \\
\mathrm{AR}\end{array}$ & $\begin{array}{l} \pm \\
(\%)\end{array}$ & ${ }^{87} \mathrm{Sr} l^{86} \mathrm{Sr}$ & \pm & $\begin{array}{l}\sim \mathrm{Sr} \\
\text { Conc. } \\
\text { (mg/L) }\end{array}$ & $\begin{array}{l}\delta \mathrm{D} \\
(\% \circ)\end{array}$ & $\begin{array}{l}\delta^{18} \mathrm{O} \\
(\%)\end{array}$ \\
\hline \multirow{5}{*}{$\begin{array}{l}\text { Pozos } \\
\text { Ranch }\end{array}$} & AS-7 & $2 / 25 / 00$ & 0.27 & 0.18 & 140.0 & 0.50 & na & na & na & na & 0.086 & 9 & na & na & 0.96 & 9 & 0.70769 & 0.00002 & 0.02 & -61 & -8.7 \\
\hline & 030701-06 & $3 / 7 / 01$ & 5.71 & 0.19 & 111.7 & 0.10 & na & na & na & na & 0.124 & 2 & na & na & 0.06 & 2 & 0.70774 & 0.00001 & 0.5 & na & na \\
\hline & 020403-1 & $2 / 4 / 03$ & 5.02 & 0.19 & 118.3 & 0.08 & na & na & na & na & na & na & na & na & na & na & na & na & na & na & na \\
\hline & \begin{tabular}{|c|} 
SPC1025021- \\
SJG2
\end{tabular} & $5 / 7 / 03$ & 5.29 & 0.19 & 117.9 & 0.09 & na & na & na & na & na & na & na & na & na & na & na & na & na & -60 & -9.5 \\
\hline & $\begin{array}{l}\text { SPC1025039 } \\
\text { MTM-92603-5a }\end{array}$ & 9/26/03 & 5.10 & 0.20 & 118.0 & 0.18 & na & na & na & na & na & na & na & na & na & na & na & na & na & na & na \\
\hline $\begin{array}{c}\text { Spring N } \\
\text { Ranch }\end{array}$ & $\begin{array}{c}\text { SPC1025038 } \\
\text { MTM-92603-4 } \\
\end{array}$ & 9/26/03 & 9.69 & 0.21 & 124.4 & 0.15 & na & na & na & na & na & na & na & na & na & na & na & na & na & na & na \\
\hline \multirow{2}{*}{$\begin{array}{c}\text { NW Ranch } \\
\text { (Peña } \\
\text { Blanca) }\end{array}$} & 020403-3 & $2 / 4 / 03$ & 10.0 & 0.19 & 252.7 & 0.05 & na & na & na & na & na & na & na & na & na & na & na & na & na & -55 & -8.7 \\
\hline & \begin{tabular}{|c|} 
SPC1025037 \\
MTM-92603-3a \\
\end{tabular} & 9/26/03 & 9.94 & 0.20 & 252.6 & 0.09 & na & na & na & na & na & na & na & na & na & na & na & na & na & na & na \\
\hline \multirow{5}{*}{ PB-1 } & $\begin{array}{c}\text { SPC1025022 } \\
\text { MTM-1A }\end{array}$ & $8 / 6 / 03$ & 328 & 0.24 & 58.09 & 0.15 & na & na & na & na & na & na & na & na & na & na & na & na & na & na & na \\
\hline & $\begin{array}{c}\text { SPC1025028 } \\
\text { MTM-3A }\end{array}$ & $7 / 1 / 03$ & 802 & 0.32 & 56.48 & 0.09 & na & na & na & na & na & na & na & na & na & na & na & na & na & na & na \\
\hline & $\begin{array}{c}\text { SPC1025029 } \\
\text { MTM-1 }\end{array}$ & 8/29/03 & 166 & 0.19 & 56.03 & 0.10 & na & na & na & na & na & na & na & na & na & na & na & na & na & na & na \\
\hline & $\begin{array}{c}\text { SPC1025044 } \\
\text { MTM-2 }\end{array}$ & $12 / 9 / 03$ & 241 & 0.24 & 55.51 & 0.16 & na & na & na & na & na & na & na & na & na & na & na & na & na & na & na \\
\hline & $\begin{array}{c}\text { SPC1025047 } \\
\text { MTM-2 }\end{array}$ & $12 / 9 / 03$ & 195 & 0.26 & 56.45 & 0.24 & na & na & na & na & na & na & na & na & na & na & na & na & na & na & na \\
\hline \multirow{5}{*}{ PB-2 } & $\begin{array}{c}\text { SPC1025017- } \\
\text { SJG2 }\end{array}$ & $5 / 6 / 03$ & 137 & 0.19 & 55.18 & 0.08 & na & na & na & na & na & na & na & na & na & na & na & na & na & na & na \\
\hline & $\begin{array}{c}\text { SPC1025023 } \\
\text { MTM-2A }\end{array}$ & 8/6/03 & 12.7 & 0.24 & 56.24 & 0.15 & na & na & na & na & na & na & na & na & na & na & na & na & na & na & na \\
\hline & $\begin{array}{l}\text { SPC1025026 } \\
\text { MTM-1A }\end{array}$ & 7/1/03 & 87.3 & 0.19 & 55.91 & 0.11 & na & na & na & na & na & na & na & na & na & na & na & na & na & na & na \\
\hline & $\begin{array}{c}\text { SPC1025030 } \\
\text { MTM-2 }\end{array}$ & 8/29/03 & 16.9 & 0.19 & 55.91 & 0.10 & na & na & na & na & na & na & na & na & na & na & na & na & na & na & na \\
\hline & $\begin{array}{l}\text { SPC1025043 } \\
\text { MTM-2 }\end{array}$ & $12 / 8 / 03$ & 124 & 0.24 & 59.25 & 0.18 & na & na & na & na & na & na & na & na & na & na & na & na & na & na & na \\
\hline
\end{tabular}


Table 12. Measurements of concentration and isotopic composition in water samples collected near the Nopal I uranium deposit, Peña Blanca, Mexico.—Continued

[ID, identifier; collect., collection; conc., concentration; ppb, parts per billion; ppq, parts per quadrillion; AR, radioactivity ratio; mg/L, milligrams per liter; $\mathrm{m}$, meter; na, not analyzed; $8.5 \mathrm{~m}$ into north part of adit at +00 level is location $\mathrm{E}$ in figure $89 ; 23 \mathrm{~m}$ from adit entrance is location $\mathrm{D}$ in figure $89 ; 15 \mathrm{~m}$ from adit entrance is location $\mathrm{C}$ in figure $89 ; 12 \mathrm{~m}$ from adit entrance is location $\mathrm{B}$ in figure 89; $5 \mathrm{~m}$ from adit entrance is location A in figure 89; 1995 samples from Pickett and Murphy (1999, Table II); 2000 and 2001 samples from A.M. Simmons, Los Alamos National Laboratory, written commun. (2002); 2003 samples from BSC (2004)]

\begin{tabular}{|c|c|c|c|c|c|c|c|c|c|c|c|c|c|c|c|c|c|c|c|c|c|}
\hline \multicolumn{3}{|c|}{ Sample Information } & \multicolumn{4}{|c|}{ Uranium } & \multicolumn{4}{|c|}{ Thorium } & \multicolumn{6}{|c|}{ Radium } & \multicolumn{3}{|c|}{ Strontium } & \multicolumn{2}{|c|}{$\begin{array}{c}\text { Stable } \\
\text { Isotopes }\end{array}$} \\
\hline $\begin{array}{l}\text { Sampling } \\
\text { Location }\end{array}$ & Sample ID & $\begin{array}{c}\text { Collect. } \\
\text { Date }\end{array}$ & $\underset{(p p b)}{U}$ & $\stackrel{ \pm}{ \pm}$ & $\begin{array}{c}{ }^{234} U /^{238} U \\
\left(e^{-6}\right)\end{array}$ & $\stackrel{ \pm}{ \pm}$ & $\begin{array}{l}{ }^{232} \mathrm{Th} \\
\text { (ppb) }\end{array}$ & $\stackrel{ \pm}{ \pm}$ & $\begin{array}{l}{ }^{230} \mathrm{Th} \\
\text { (ppq) }\end{array}$ & $\stackrel{ \pm}{(\%)}$ & $\begin{array}{l}{ }^{226} \mathrm{Ra} \\
\text { (ppq) }\end{array}$ & $\stackrel{ \pm}{ \pm}$ & ${ }_{\mathrm{AR}}^{226} \mathrm{Ra} /{ }^{230} \mathrm{Th}$ & $\stackrel{ \pm}{ \pm}$ & $\begin{array}{c}{ }^{226} \mathrm{Ra} /{ }^{238} \mathrm{U} \\
\mathrm{AR}\end{array}$ & $\underset{(\%)}{ \pm}$ & ${ }^{87} \mathrm{Sr} /{ }^{86} \mathrm{Sr}$ & \pm & $\begin{array}{l}\sim \mathrm{Sr} \\
\text { Conc. } \\
\text { (mg/L) }\end{array}$ & $\begin{array}{l}\delta D \\
(\%)\end{array}$ & $\begin{array}{l}\delta^{18} \mathrm{O} \\
(\% \circ)\end{array}$ \\
\hline \multirow{4}{*}{ PB-3 } & $\begin{array}{c}\text { SPC1025019- } \\
\text { SJG2 }\end{array}$ & $5 / 7 / 03$ & 18204 & 1.21 & 98.50 & 0.06 & na & na & na & na & na & na & na & na & na & na & na & na & na & na & na \\
\hline & $\begin{array}{c}\text { SPC1025024 } \\
\text { MTM-3A }\end{array}$ & $8 / 6 / 03$ & 5343 & 0.40 & 83.24 & 0.10 & na & na & na & na & na & na & na & na & na & na & na & na & na & na & na \\
\hline & $\begin{array}{c}\text { SPC1025027 } \\
\text { MTM-2A }\end{array}$ & $7 / 1 / 03$ & 3596 & 0.27 & 74.83 & 0.10 & na & na & na & na & na & na & na & na & na & na & na & na & na & na & na \\
\hline & $\begin{array}{c}\text { SPC1025046 } \\
\text { MTM-2 }\end{array}$ & $12 / 10 / 03$ & 967 & 0.28 & 100.7 & 0.11 & na & na & na & na & na & na & na & na & na & na & na & na & na & na & na \\
\hline \multirow{3}{*}{$\begin{array}{c}\text { Back of } \\
\text { Adit }\end{array}$} & $\begin{array}{l}\text { SPC1025034 } \\
\text { MTM-Mina } 3\end{array}$ & $7 / 1 / 03$ & 0.25 & 0.24 & 267.8 & 0.54 & na & na & na & na & na & na & na & na & na & na & na & na & na & na & na \\
\hline & $\begin{array}{l}\text { SPC1025035 } \\
\text { MTM-92603-1 }\end{array}$ & 9/26/03 & 4.50 & 0.23 & 82.55 & 0.22 & na & na & na & na & na & na & na & na & na & na & na & na & na & na & na \\
\hline & $\begin{array}{c}\text { SPC1025042 } \\
\text { MTM-3 }\end{array}$ & $10 / 15 / 03$ & 29.4 & 0.20 & 125.7 & 0.09 & na & na & na & na & na & na & na & na & na & na & na & na & na & na & na \\
\hline \multirow{3}{*}{$\begin{array}{l}\text { Back of } \\
\text { Adit }\end{array}$} & $\begin{array}{l}\text { SPC1025033 } \\
\text { MTM-Mina } 2\end{array}$ & 7/1/03 & 0.36 & 0.30 & 141.1 & 1.0 & na & na & na & na & na & na & na & na & na & na & na & na & na & na & na \\
\hline & $\begin{array}{l}\text { SPC1025036 } \\
\text { MTM-92603-2 }\end{array}$ & 9/26/03 & 2.82 & 0.20 & 230.4 & 0.24 & na & na & na & na & na & na & na & na & na & na & na & na & na & na & na \\
\hline & $\begin{array}{c}\text { SPC1025041 } \\
\text { MTM-2a }\end{array}$ & $\mid 10 / 15 / 03$ & 0.44 & 0.22 & 284.4 & 0.22 & na & na & na & na & na & na & na & na & na & na & na & na & na & na & na \\
\hline \multirow{2}{*}{$\begin{array}{c}\text { Back of } \\
\text { Adit }\end{array}$} & $\begin{array}{l}\text { SPC1025032 } \\
\text { MTM-Mina } 1 \\
\end{array}$ & 7/1/03 & 2.84 & 0.19 & 199.0 & 0.09 & na & na & na & na & na & na & na & na & na & na & na & na & na & na & na \\
\hline & $\begin{array}{c}\text { SPC1025040 } \\
\text { MTM-1 }\end{array}$ & $10 / 15 / 03$ & 4.52 & 0.20 & 243.2 & 0.09 & na & na & na & na & na & na & na & na & na & na & na & na & na & na & na \\
\hline
\end{tabular}


The ${ }^{234} \mathrm{U} /{ }^{238} \mathrm{U}$ activity ratios for the Nopal I deposit determined by the Yucca Mountain Project (Murrell and others, 1997) are shown in figure 86 and range from 0.94 to 1.49 , with a mean of about 1.2. There is no obvious systematic spatial trend for these data within the fractures. These results also are similar to values reported by Pickett and Murphy (1997). The ${ }^{234} U{ }^{238} U$ results are generally consistent with an old ${ }^{234} \mathrm{U}$ enrichment (approximately 100-1,000 ka) (Ivanovich and Harmon, 1992), produced during dissolution processes and preserved in precipitated minerals. However, as can be seen from figure 86, there appears to be a small-scale, postdepositional loss and gain of ${ }^{234} \mathrm{U}$ to the fracture materials that have spread the distribution about the mean.

Because the fracture minerals were deposited by aqueous solutions, the ages of the fracture mineral phases are related to the timing of the primary fluid flow. Subsequent alteration of these mineral phases during more recent fluid movement also can be evaluated using uranium-series disequilibria data. As shown in figure 87 , the majority of the uranium-thorium data provide finite solutions to the age equation, and, although most points plot very near the forbidden zone, only two points actually fall in this area. The data for these two samples are consistent with the small amounts of ${ }^{234} \mathrm{U}$ loss. Model uranium-thorium ages for the other samples indicate ages of greater than 300 k.y., with the exception of discordant sample NOPI 320, with a uranium-thorium model age of 88 k.y., which also indicated ${ }^{234} \mathrm{U}$ loss.

The ${ }^{231} \mathrm{~Pa} /{ }^{235} \mathrm{U}$ activity ratios are either at, or very near, secular equilibrium (sample mean $=0.996 \pm 0.007$ [CRWMS M\&O, 2000b]). Analytical errors are smaller than the data points and are typically less than 1 percent. This means that ${ }^{231} \mathrm{~Pa}^{235} \mathrm{U}$ (and ${ }^{238} \mathrm{U}$ because the 238/235 ratios are natural) have behaved as a closed system in the fractures over the last 200 k.y. From these observations, it can be concluded that uranium $(235,238)$ has remained in the fractures over the last 200 k.y., and the

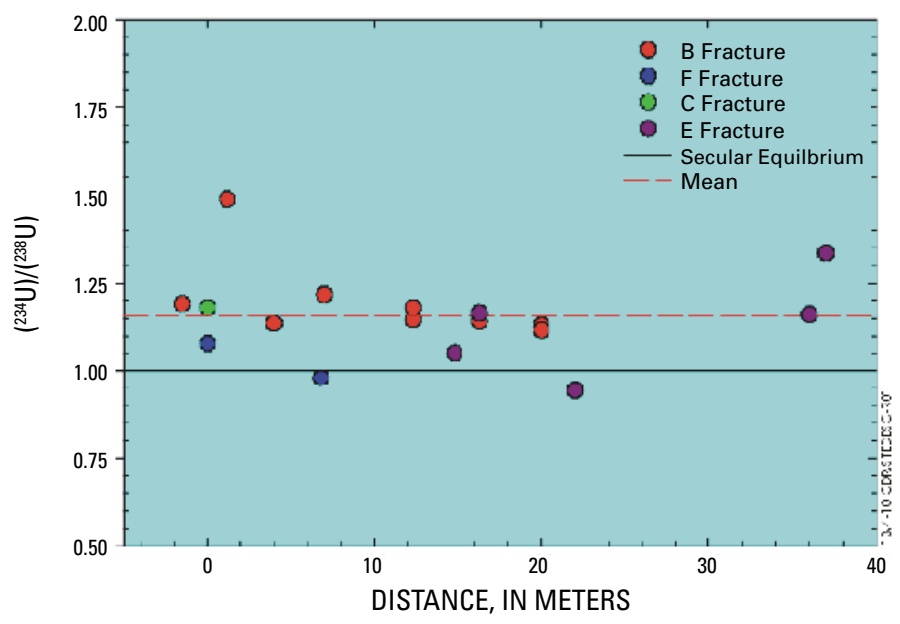

Figure 86. ${ }^{234} \mathrm{U} /{ }^{238} \mathrm{U}$ activity ratios at distances from edge of the Nopal I deposit, Chihuahua, Mexico, for the fracture samples (CRWMS M\&0, 2000b, fig. 13.4-10). mobility of uranium discussed above seems limited to ${ }^{234} \mathrm{U}$ (the only one of the three isotopes subject to the alpharecoil effects).

One sample (NOPI-320) is younger than all the others, with a uranium-protactinium model age of $47 \pm 2$ k.y. This sample also has an anomalously low uranium-thorium model age of $88 \pm 4 \mathrm{k} . \mathrm{y}$. The uranium-protactinium model age is similar to uranium-thorium ages for caliche (Pearcy and others, 1995) and opal of about 50 k.y. This event caused a resetting of sample NOPI-320 but had no measurable effect on ${ }^{235} \mathrm{U}$ or ${ }^{238} \mathrm{U}$, thorium, or protactinium mobility in the vast majority of fracture samples.

The ${ }^{226} \mathrm{Ra} /{ }^{230} \mathrm{Th}$ activity ratios range from 0.7 to 1.1 (CRWMS M\&O, 2000b). These results are similar to values reported by Wong (1998). The ${ }^{226} \mathrm{Ra} /{ }^{230} \mathrm{Th}$ results are consistent with open-system radium behavior and demonstrate that fluids have occupied the fractures over the last 5,000 years, which implies that uranium has had ample opportunity for fluid interactions. Furthermore, a variety of plant (Phacelia robusta) growing in the vicinity has a high radium content (Leslie and others, 1999).

The early uranium-series work showed that transport of uranium-series nuclides at Peña Blanca has occurred over a range of time scales. From the uranium-thorium age data, it appears that the primary transport of uranium to the fractures occurred more than $300 \mathrm{ka}$. Subsequently, there has not been significant ${ }^{238} \mathrm{U}$ or ${ }^{235} \mathrm{U}$ redistribution along the fractures, but there has been limited redistribution of ${ }^{234} \mathrm{U}$ along fractures associated with fluids. Presumably, this reflects the preferential mobility of ${ }^{234} \mathrm{U}$ resulting from selective leaching and direct-recoil effects. Such effects are well documented in rock/water systems (for example, Ivanovich and Harmon, 1992). The ${ }^{231} \mathrm{~Pa}{ }^{235} \mathrm{U}$ activity ratios for the fracture samples support this conclusion. Results for one anomalous sample, along with uranium-thorium ages for opal and caliche, indicate enhanced aqueous fluxes at approximately 50-90 ka and local uranium mobility. The enhanced flux had no effect on ${ }^{235} \mathrm{U}$ or ${ }^{238} \mathrm{U}$, thorium, or protactinium distribution in the remainder of the fracture samples. Closed system behavior was observed for uranium-protactinium over the last 200,000 years. In contrast, the ${ }^{226} \mathrm{Ra}{ }^{230} \mathrm{Th}$ activity ratios indicate redistribution of radium within the last 5,000 years as a result of secondary fluid events, resulting in a loss of radium from the fractures (fig. 88) (Murrell and others, 2002).

The $300-k . y$. stability of ${ }^{235} \mathrm{U},{ }^{238} \mathrm{U}$, thorium, and protactinium in the fracture-filling minerals has apparently survived even recent hydrologic disturbances from surface-water infiltration of the fracture because of mining activities, as well as the infiltration of rainwater, since the fractured rock was uplifted above the water table (Pearcy and others, 1994). Hence, uranium, thorium, and protactinium in secondary fracture materials appear to be unaffected by surface-water infiltration and, perhaps, saturated groundwater flow over approximately 100-k.y. time scales. 


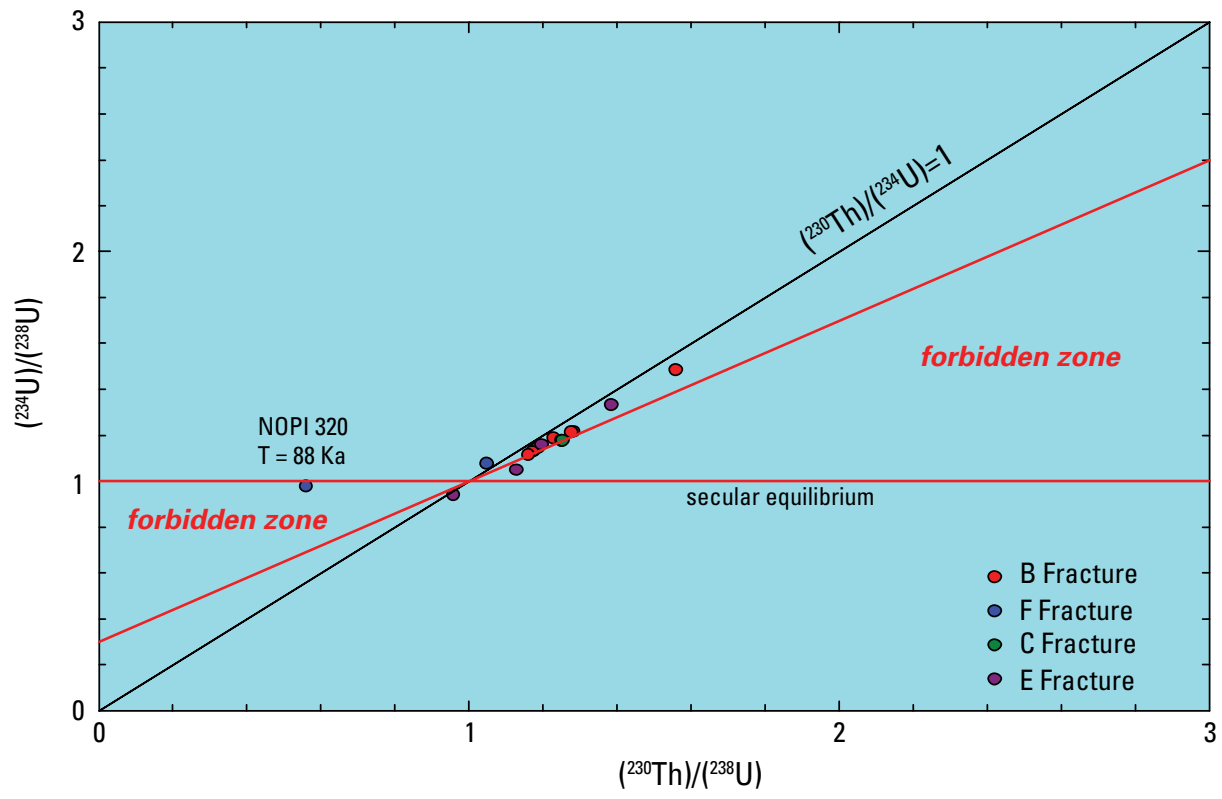

NOTE: Plotted as activity ratio. Most of the samples yield whole rock ages (T) of more than 300 ka.

Figure 87. ${ }^{238} \mathrm{U}-{ }^{234} \mathrm{U}-230$ Th systematics for fracture-filling materials at Peña Blanca, Chihuahua, Mexico (CRWMS M\&0, 2000b, fig. 13.4-11).

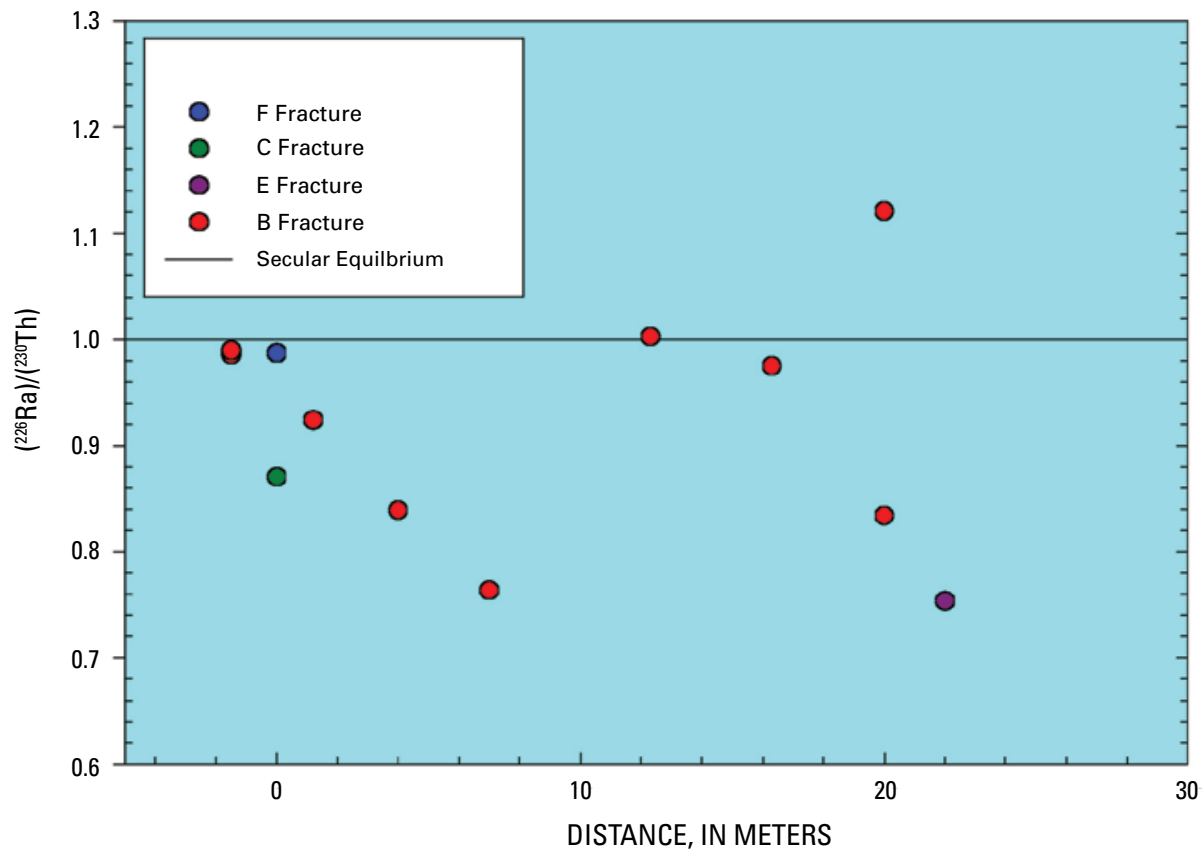

NOTE: Generally indicates ${ }^{226}$ Ra loss from the fractures during the past 8,000 years. Distance refers to distance from orebody at +10-meter level.

Figure 88. ${ }^{230} \mathrm{Th}-{ }^{226} \mathrm{Ra}$ systematics (plotted as activity ratio) for fracture-filling materials at Peña Blanca, Chihuahua, Mexico (BSC, 2004, fig. 10.4-2). 


\section{Seasonal Variability at Nopal I}

Because the net uranium flux offsite is not well constrained other than by the $8 \pm 5$-m.y. age of the primary uranium mineralization at Nopal I (Pearcy and others, 1994), the work of Pickett and Murphy (1999) under relatively wet conditions was extended to include water samples collected at Nopal I during the dry (spring) season to provide information on temporal and seasonal variations at the site (Simmons and others, 2002). As with the previous work, samples were of three different types: (1) perched water trapped in an old borehole about $20 \mathrm{~m}$ outside the deposit, (2) seep water obtained from an old adit approximately $8 \mathrm{~m}$ below the +10 -m surface (see fig. 89), and (3) a groundwater sample located in the regional carbonate aquifer $1.3 \mathrm{~km}$ southeast of the deposit. In addition, data have been collected from an old mining camp well (PB4) located about $0.6 \mathrm{~km}$ southeast of the deposit.

These data, along with the 1995 data of Pickett and Murphy (1999), are detailed in table 12. In many cases, the 2002 data show higher uranium concentrations than the results from Pickett and Murphy for samples collected during the wet season. This could result from longer fluid/rock interaction times or from greater evaporation. A portion of the collection system is shown in figure 90 . The water was collected in plastic sheets, in which it remains until sampled. Although the adit is comparatively cool and damp, evaporation could greatly affect the uranium concentrations.

Stable isotope data were obtained for some of these adit samples to evaluate the effects of evaporation on the uranium concentrations. These data are shown in figure 91 . When water evaporates, the isotopic composition of the resulting vapor will be shifted to lower values of $\delta^{18} \mathrm{O}$, and the residual water will be shifted to higher values on a plot of $\delta \mathrm{D}$ compared to $\delta^{18} \mathrm{O}$. The stable isotope data for AS-7 (from a water well) and AS-5 (from a drill hole into a perched-water horizon) have substantially lower values than other samples. They fall on the Global Meteoric Water Line (GMWL) and probably represent the average composition for the precipitation at the site. The adit samples all lie much higher on this plot. Of these, AS-2, AS -3 , and AS-4 all fall substantially to the left of the GMWL and may represent atmospheric water vapor that has diffused into the adit and condensed in the cooler underground environment, followed by some period of evaporation in the collection system. AS-1 lies on the GMWL but probably does not represent a rainwater sample because it is relatively high for meteoric water at the latitude of Peña Blanca; it is closer to the opening of the adit and may represent a more evaporated version of cluster AS-2, AS-3, and AS-4. The evolution of stable isotopes for the adit samples appears to have at least three

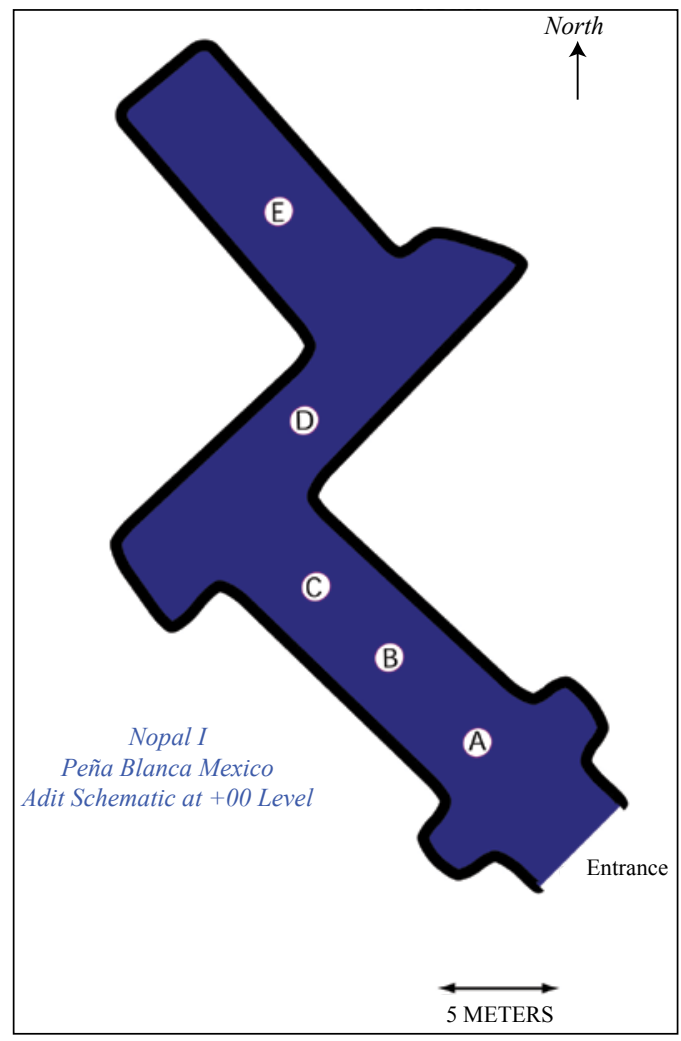

Figure 89. Schematic of Nopal I Level +00 Adit sampling locations, Chihuahua, Mexico (BSC, 2004, fig. 10.4-3).

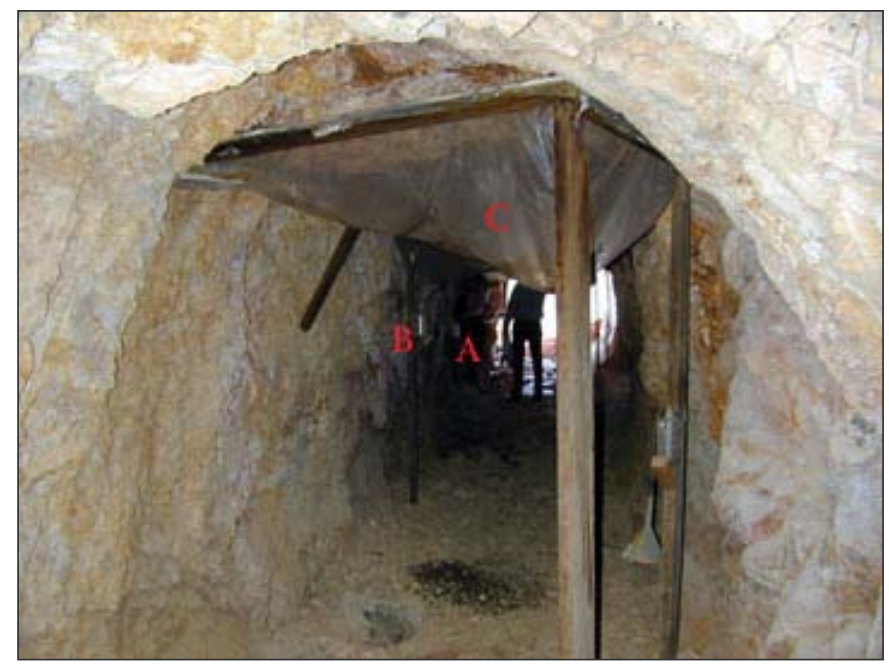

Figure 90. Photograph of sampling locations $A, B$, and $C$ in the Nopal I +00 Adit, Chihuahua, Mexico (BSC, 2004, fig. 10.4-5). 


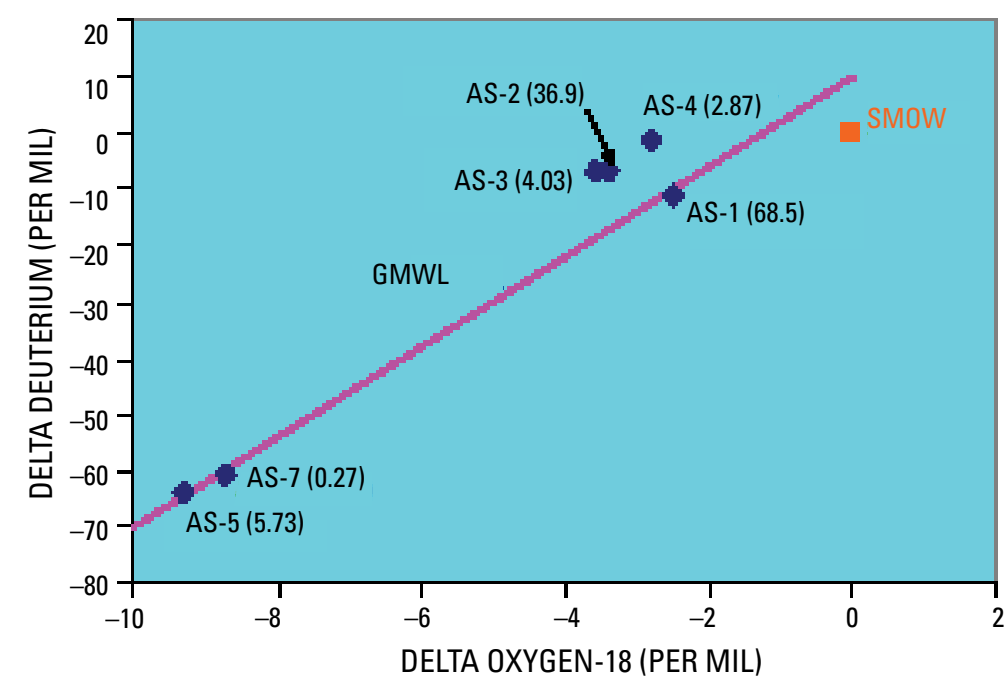

NOTE: SMOW, Standard Mean Ocean Water; GMWL, Global Meteoric Water Line, Uranium concentration values shown in parentheses.

Figure 91. Plot showing stable isotope ratios for waters collected from the Nopal I adit, Peña Blanca, Chihuahua, Mexico (BSC, 2004, fig. 10.4-6).

components: (1) evolution of vapor from GMWL, (2) modification by water/rock interaction, and (3) evaporation in the adit collection system.

Fayek and others $(2005,2006)$ measured the oxygen isotope composition of uraninite from the orebody and the Pozos conglomerate. The orebody uraninite has a $\delta^{18} \mathrm{O}=-10.8$ per mil, whereas uraninite within the Pozos conglomerate has a $\delta^{18} \mathrm{O}=+1.5$ per mil. For the most part, the $\delta^{18} \mathrm{O}$ of the collected water samples falls between these two values.

\section{Continued Uranium-Series Analyses}

Three additional boreholes were drilled at Peña Blanca in 2003 to provide subsurface data (figs. 92 and 93). A borehole with continuous core was drilled near the Nopal I deposit (PB-1) and two additional boreholes were drilled about $50 \mathrm{~m}$ uphill (PB-2) and downhill (PB-3) from PB-1. These boreholes were drilled out and completed to depths of approximately $20 \mathrm{~m}$ below the observed water table (total well depths of about 243-255 m). These wells facilitated direct sampling of the groundwater to determine water chemistry, including the concentration of radionuclides possibly leached from the Nopal I uranium deposit. In addition, the collection of cuttings and core samples provided the opportunity to characterize the lithologic and hydrogeologic properties of this system, as well as to conduct uranium-series studies of fracture-filling materials.

In addition to the drilled wells, a mining-camp well (PB-4) about $1.3 \mathrm{~km}$ southeast of the deposit was reconditioned (fig. 92). A portable pump was used to condition the wells, collect samples, and conduct drawdown tests. Also, an existing water-collection system within a series of interconnected adits at the $+00-\mathrm{m}$ level was refurbished to allow for systematic collection of rainfall seepage into the adit network (fig. 90).

After well-drilling and seepage-collection system improvement, uranium-series work focused on uranium, radium, and thorium isotopic analyses for adit water samples from the unsaturated zone and well waters from the saturated zone. These water analyses provide complementary information to the fractures by revealing a more recent/instantaneous picture of uranium-series transport. Measurements of uranium, thorium, and radium isotopes in nearfield unsaturated-zone waters to date have largely confirmed predictions of low uranium, thorium, and protactinium concentrations and high radium concentrations in water samples from the unsaturated zone (table 12) (Pickett and Murphy, 1999, table 2; Simmons and others, 2002; Goldstein and others, 2003).

As is common for many groundwater systems, a roughly inverse correlation between the ${ }^{234} \mathrm{U} / 238 \mathrm{U}$ activity ratio and uranium concentrations is evident for unsaturated-zone waters near the deposit (fig. 94A). This indicates either variable residence times or mixing between two end members: one with high recoil-related ${ }^{234} \mathrm{U}$ and low uranium concentration and another with low recoil-related ${ }^{234} \mathrm{U}$ and high uranium concentration. This relation is illustrated by the red inverse correlation line in figure $94 A$. Such end members can result from short compared to long water/rock interaction times, respectively. Data from adit water samples collected postdrilling in 2003 reveal substantially more scatter, which may reflect the presence of additional components due to drilling operations (for example, lost drilling fluids from PB-1). This is because long interaction times result in more bulk-rock dissolution, which results in relatively more total uranium dissolution. The ${ }^{234} \mathrm{U} /{ }^{238} \mathrm{U}$ then reflects the bulkrock value and is closer to secular equilibrium (that is, lower). For short interaction times, more of a flushing effect is expected in which mobile fluids that have been in contact with the rock in fractures and pores are flushed out. These fluids would have more of the recoil-enhanced ${ }^{234} \mathrm{U}$ and would result in higher ${ }^{234} \mathrm{U} /{ }^{238} \mathrm{U}$, but overall less total uranium, because little of the rock is dissolved in a short time.

The saturated-zone waters, including those from the newly drilled wells, show a more complicated relationship between ${ }^{234} \mathrm{U} /{ }^{238} \mathrm{U}$ and $1 / \mathrm{U}$ (fig. 94B) and appear to show mixing of three or more components. High uranium concentrations (up to $18 \mathrm{ppm}$ ) in the newly drilled wells generally decreased over about a 4-month time postdrilling, but still remained higher (124-967 ppb uranium) 


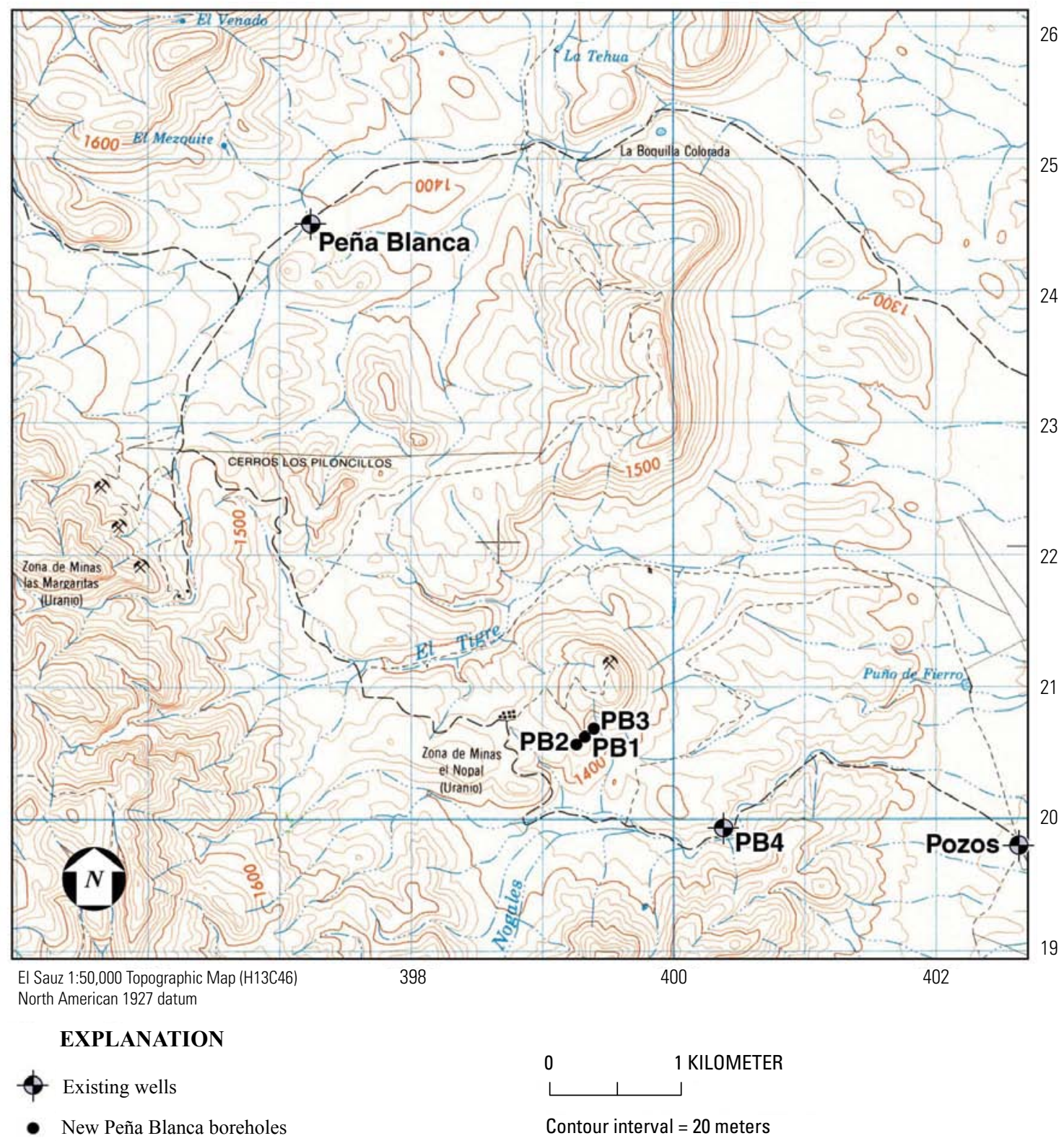

Figure 92. Portion of topographic map showing locations of Nopal I ore deposit and Peña Blanca wells, Peña Blanca, Chihuahua, Mexico (BSC, 2004, fig. 10.4-4). 


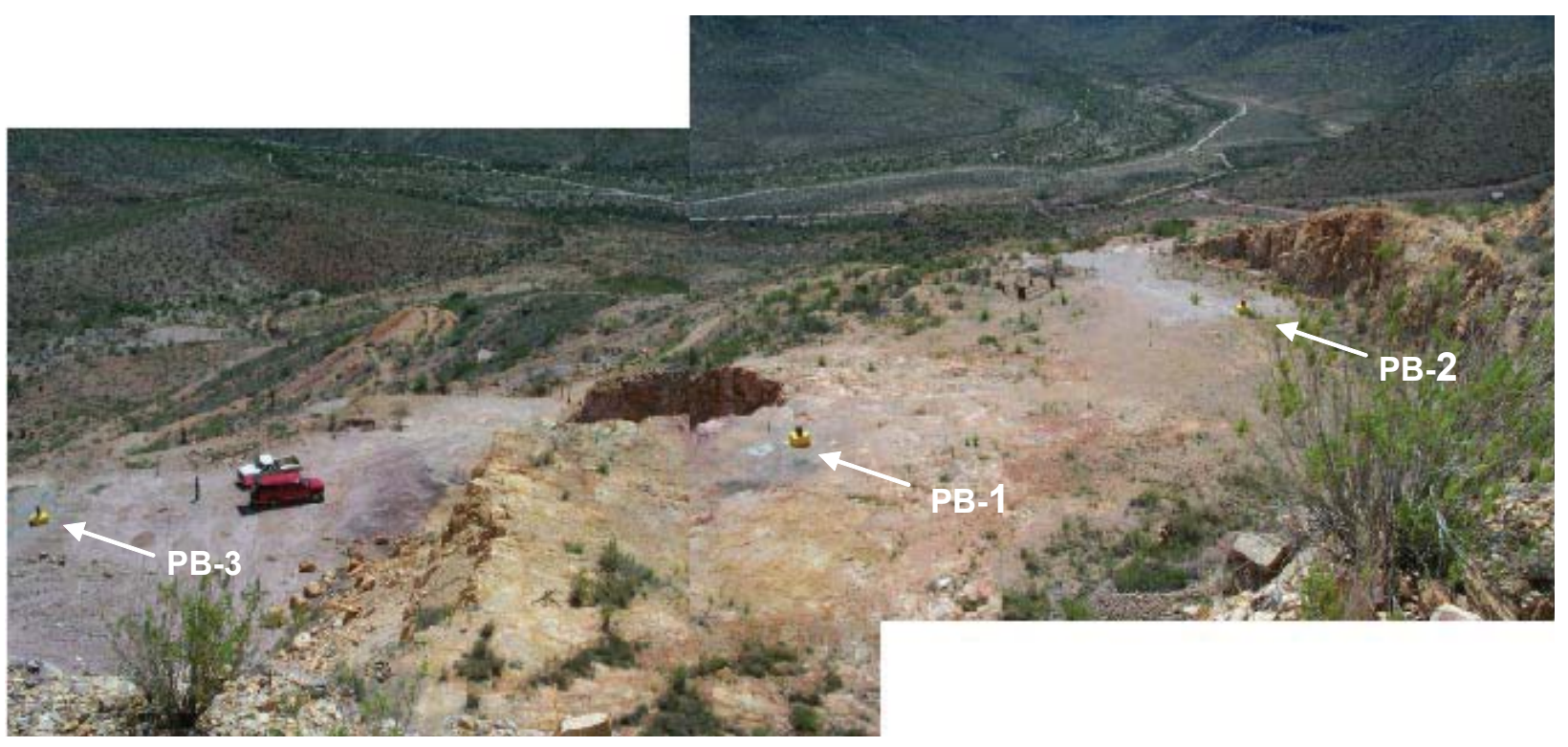

Figure 93. Panoramic view of the wells drilled in 2003, Peña Blanca, Chihuahua, Mexico (BSC, 2004, fig. 10.4-9).
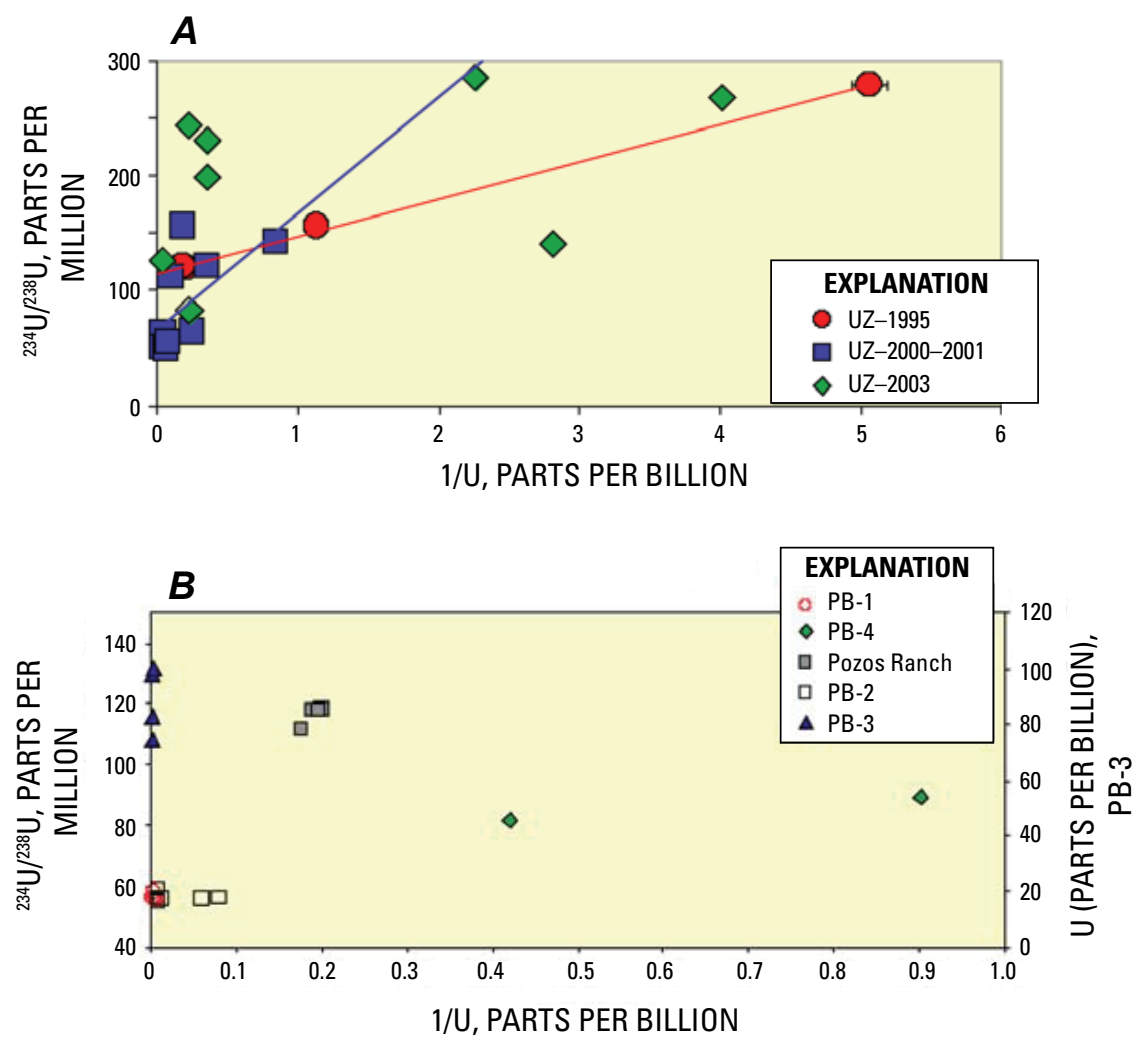

Figure 94. Uranium isotope systematics and mixing lines for $(A)$ unsaturatedzone and $(B)$ saturated-zone waters, Peña Blanca, Chihuahua, Mexico (BSC, 2004, fig. 10.4-14). 
than regional saturated-zone waters (0.1-10 ppb uranium) after well conditioning and pumping (fig. 95). The samples shown in figure 95 were collected by bailer with the exception of the last point in the time series (December 2003) when well pumping and conditioning took place. Low ${ }^{234} \mathrm{U}$ excesses for some of the samples (PB-1 and PB-2) may indicate that their high concentrations result from drilling activities, namely, bulk dissolution of uranium-containing minerals by drilling fluids. The well conditioning and pump testing, along with uranium concentration and isotopic data, indicate hydraulic connectivity between the $50-\mathrm{m}$-spaced wells $\mathrm{PB}-1$ and $\mathrm{PB}-2$ (giving ${ }^{234} \mathrm{U} /{ }^{238} \mathrm{U}=1.005-1.079$; Goldstein and others, 2005). Well PB-3, with an order of magnitude higher uranium concentration, appears to be more distinct in terms of uranium concentration and isotopics $\left({ }^{234} \mathrm{U} /{ }^{238} \mathrm{U}=1.36-1.83\right)$ after pumping and may be hydraulically isolated from PB-1 and PB-2 (Goldstein and others, 2005).

The high levels of uranium observed in wells PB-1, PB-2, and PB-3 (fig. 95) are likely the result of mineral dissolution during drilling, as the uranium levels observed in these wells are higher than any of the unsaturated-zone waters or other sampled well waters. The initially high $\mathrm{pH}$ values and high levels of carbonate and bicarbonate in these samples (table 13) would help maintain high concentrations of uranium. Also shown in figure 95 are uranium concentrations in two wells near Nopal I (PB-4 and Pozos Ranch). No transport of uranium from the deposit into these more regional carbonate aquifer locales is observed before, during, or after drilling.

A 1-D (one-dimensional) advection-dispersion model was constructed to model the decreasing uranium concentration in the wells (Goldstein and others, 2005, 2010). Using typical relations between velocity and dispersion along with the relation observed from the uranium data, estimates of velocity $(1-10 \mathrm{~m} / \mathrm{yr})$ and dispersion coefficient $\left(1 \times 10^{-5}\right.$ to $1 \times 10^{-2} \mathrm{~cm}^{2} / \mathrm{s}$ ) were obtained (Goldstein and others, 2005,
2010). These results and the limited productivity of the wells indicate limited groundwater flow and mixing.

Thorium isotope $\left({ }^{232} \mathrm{Th},{ }^{230} \mathrm{Th}\right)$ measurements for three adit water samples from the unsaturated zone indicate low thorium concentrations $(0.001-0.010 \mathrm{ppb})$ and variable ${ }^{230} \mathrm{Th} /{ }^{232} \mathrm{Th}$ activity ratios $(130-1,900)$. Prior thorium isotope data (Pickett and Murphy, 1999) for primarily unsaturatedzone water samples indicated a much larger range in thorium concentrations $(0.1-270 \mathrm{ppt})$ and lower ${ }^{230} \mathrm{Th} /{ }^{232} \mathrm{Th}$ activity ratios $(0.2-65)$. For both data sets, ${ }^{230} \mathrm{Th} /{ }^{234} \mathrm{U}$ activity ratios are quite low (0.001-0.08), indicating low thorium mobility in the unsaturated zone. Because thorium is so insoluble and particle-reactive, particle abundance in the samples (colloid concentrations) probably exerts a major influence on overall thorium concentrations.

Unsaturated-zone water ${ }^{226} \mathrm{Ra}$ concentrations near the deposit correspond to large activity excesses relative to ${ }^{238} \mathrm{U}$ $\left({ }^{226} \mathrm{Ra} /{ }^{238} \mathrm{U}\right.$ activity ratio $\left.[\mathrm{AR}]=4-113\right),{ }^{234} \mathrm{U}$, and ${ }^{230} \mathrm{Th}$, with a relative order of mobility of $\mathrm{Ra}>>\mathrm{U}>>\mathrm{Th}$ (Goldstein and others, 2003). Large ${ }^{226} \mathrm{Ra}$ excesses are also observed in vegetation samples from this site (Leslie and others, 1999); hence, the oxidized ore deposit (Wong and others, 1996), fracture, water, and vegetation data all point to preferential radium mobility near the surface of the deposit. A rough correlation between ${ }^{234} \mathrm{U}$ excess and ${ }^{226} \mathrm{Ra}$ excess indicates that the large ${ }^{226} \mathrm{Ra}$ mobility in unsaturated-zone waters may be recoil related. In contrast, the few radium data for saturatedzone waters from the Pozos Ranch area indicate that ${ }^{226} \mathrm{Ra} /{ }^{238} \mathrm{U}$ activity ratios in regional groundwaters are much less than 1 , whereas ${ }^{234} U / 238 \mathrm{U}$ activity ratios are approximately greater than 1. Short-lived nuclide data for the groundwater wells were used to calculate retardation factors on the order of 1,000 for radium and $1 \times 10^{4}-1 \times 10^{7}$ for lead and polonium (Goldstein and others, 2006; Luo and others, 2005). This observation suggests a relative order of mobility in the saturated environment of $U>\operatorname{Ra}>>T h$, in contrast to the order of mobility in

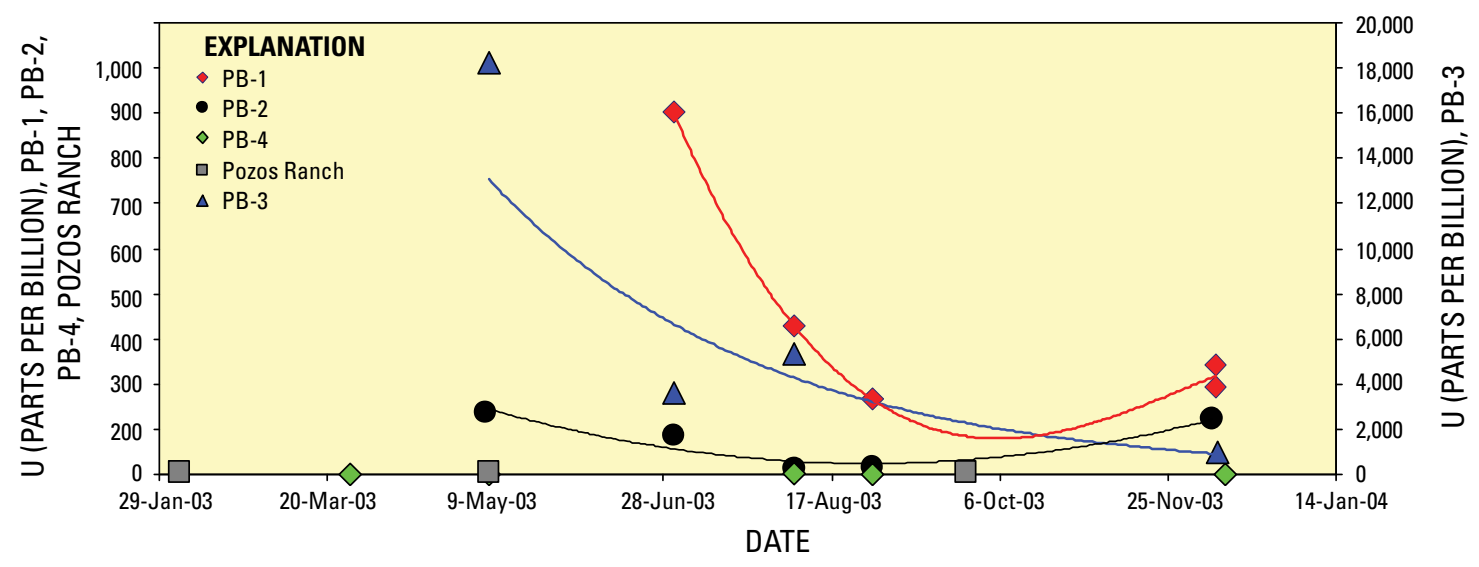

Figure 95. Decrease in uranium (U) concentrations in 2003-drilled well waters and well development over time, Peña Blanca, Chihuahua, Mexico (BSC, 2004, fig. 10.4-15). 
Table 13. Comparison of Peña Blanca (PB) and Yucca Mountain (YM) water samples.

[Benson and others (1983); Pickett and Murphy (1999); A.M. Simmons, Los Alamos National Laboratory, written commun. (2004). Type: YM, Yucca Mountain; SZ, saturated zone; UZ, unsaturated zone; NF, near field (PB-1, PB-2, PB-3); FF, far field (PB-4, ranch waters); lab, laboratory; Temp., temperature; ${ }^{\circ} \mathrm{C}$, degrees Celsius; ppm, parts per million; ppb, parts per billion; Std. Dev., standard deviation; - , not calculated or measured]

\begin{tabular}{|c|c|c|c|c|c|c|c|c|c|c|c|c|c|c|c|c|c|}
\hline Type & $\begin{array}{l}\text { Para- } \\
\text { meter }\end{array}$ & $\underset{\text { (field) }}{\mathrm{pH}}$ & $\underset{\text { (lab) }}{\mathrm{pH}}$ & $\begin{array}{c}\text { Temp. } \\
\left({ }^{\circ} \mathrm{C}\right)\end{array}$ & $\begin{array}{c}\mathrm{Ca} \\
(\mathrm{ppm})\end{array}$ & $\underset{(p p m)}{\mathbf{M g}}$ & $\begin{array}{c}\mathrm{Na} \\
(\mathrm{ppm})\end{array}$ & $\begin{array}{c}K \\
\text { (ppm) }\end{array}$ & $\begin{array}{c}\mathrm{HCO}_{3} \\
\text { field } \\
\text { (ppm) }\end{array}$ & $\begin{array}{c}\mathrm{HCO}_{3} \\
\text { lab } \\
\text { (ppm) }\end{array}$ & $\begin{array}{c}\text { CI } \\
(\mathrm{ppm})\end{array}$ & $\begin{array}{c}\mathrm{SO}_{4} \\
\text { (ppm) }\end{array}$ & $\begin{array}{c}F \\
\text { (ppm) }\end{array}$ & $\underset{(p p m)}{S i}$ & $\begin{array}{c}\mathbf{L i} \\
\text { (ppm) }\end{array}$ & $\begin{array}{c}\mathrm{Sr} \\
(\mathrm{ppm})\end{array}$ & $\underset{(p p b)}{U}$ \\
\hline \multicolumn{18}{|l|}{ YM-SZ } \\
\hline & Mean & 7.5 & 7.7 & 33.5 & 10.6 & 0.85 & 58.1 & 2.5 & 146.2 & 138.6 & 8.1 & 25.0 & 2.1 & 22.7 & 0.14 & 0.03 & $0.34-25.2$ \\
\hline & $\begin{array}{l}\text { Std. } \\
\text { Dev. }\end{array}$ & 0.33 & 0.36 & 4.4 & 5.5 & 0.75 & 15.4 & 1.2 & 25.6 & 22.9 & 2.2 & 9.8 & 1.1 & 2.0 & 0.21 & 0.02 & - \\
\hline \multicolumn{18}{|c|}{$\begin{array}{l}\text { PB-SZ NF- } \\
\text { Pump }\end{array}$} \\
\hline & Mean & 7.4 & 7.9 & 27.4 & 49.2 & 12.3 & 102.9 & 5.9 & - & 278.8 & 8.1 & 131.4 & 2.8 & 9.7 & 0.17 & 1.0 & 381.7 \\
\hline & $\begin{array}{l}\text { Std. } \\
\text { Dev. }\end{array}$ & 0.4 & 0.1 & 1.5 & 21.1 & 1.2 & 25.6 & 4.2 & - & 21.9 & 0.1 & 41.7 & 0.3 & 1.5 & 0.05 & 0.3 & 392.9 \\
\hline \multicolumn{18}{|c|}{$\begin{array}{l}\text { PB-SZ NF- } \\
\text { Bailer }\end{array}$} \\
\hline & Mean & 9.9 & 9.8 & 33.1 & 31.8 & 5.2 & 160.1 & 28.6 & - & 283.0 & 9.3 & 191.8 & 2.7 & 15.4 & 0.16 & 0.7 & 2869.3 \\
\hline & $\begin{array}{l}\text { Std. } \\
\text { Dev. }\end{array}$ & 2.0 & 2.4 & 2.3 & 27.6 & 4.4 & 107.4 & 29.4 & - & - & 3.6 & 121.3 & 0.4 & 8.0 & 0.06 & 0.4 & 5689.4 \\
\hline \multicolumn{18}{|c|}{ PB-SZ FF } \\
\hline & Mean & 8.4 & 8.0 & 30.6 & 34.2 & 4.5 & 23.2 & 3.6 & 152.5 & 89.9 & 6.6 & 12.0 & 1.1 & 10.3 & 0.02 & 0.3 & 3.9 \\
\hline & $\begin{array}{l}\text { Std. } \\
\text { Dev. }\end{array}$ & 1.5 & 1.1 & 1.6 & 17.3 & 3.2 & 23.4 & 2.3 & - & 103.6 & 5.1 & 0.7 & 0.9 & 7.8 & 0.02 & 0.2 & 4.0 \\
\hline \multicolumn{18}{|l|}{$\begin{array}{c}\text { PB-UZ- } \\
\text { Adit }\end{array}$} \\
\hline & Mean & - & - & - & 38.1 & 1.0 & 10.3 & 5.5 & - & 30.5 & 7.6 & 95.7 & 1.3 & 5.9 & 0.03 & 0.3 & 11.2 \\
\hline & $\begin{array}{l}\text { Std. } \\
\text { Dev. }\end{array}$ & - & - & - & 44.0 & 1.7 & 14.6 & 6.0 & - & 25.9 & 8.4 & 137.3 & 1.4 & 6.1 & - & 0.3 & 12.9 \\
\hline \multicolumn{18}{|c|}{$\begin{array}{l}\text { PB-UZ- } \\
\text { Borehole }\end{array}$} \\
\hline & Mean & 7.3 & - & 26.0 & 98.3 & 5.2 & 18.5 & 5.4 & 347.7 & - & 7.6 & 29.7 & 1.1 & 18.3 & 0.03 & 0.3 & 7.0 \\
\hline & $\begin{array}{l}\text { Std. } \\
\text { Dev. }\end{array}$ & 0.0 & - & 0.4 & 11.8 & 0.9 & 1.7 & 1.2 & - & - & 1.7 & 45.0 & 0.4 & 0.8 & - & - & 3.0 \\
\hline
\end{tabular}


the unsaturated environment. Although radium has enhanced mobility in adit water and fractures near the deposit, this indicates that other factors limit radium mobility over long transport distances, such as sorption onto mineral surfaces, coprecipitation with calcium fluoride or carbonate minerals, or colloid filtration in fractures (Luo and others, 2005).

In comparing major-element chemistry for saturatedzone waters from Peña Blanca to saturated-zone waters at Yucca Mountain (table 13), similarities and differences both are apparent. Components that are nearly identical include $\mathrm{pH}$, silicon, potassium, and fluoride. Both water types are broadly similar in that the principal cations are sodium and calcium, and the principal anions are bicarbonate and sulfate. However, saturated-zone waters at Peña Blanca are roughly two times as concentrated for both calcium and bicarbonate and show much larger ranges for sodium and sulfate. Alkalinity (as indicated by $\mathrm{HCO}_{3}$ on table 13) is twice as high in Peña Blanca carbonate groundwaters as in the tuff aquifer at Yucca Mountain. The higher alkalinity in Peña Blanca groundwaters provides a greater solubility for uranium and its daughter products and, thus, would provide more favorable conditions for transport than would Yucca Mountain groundwaters.

Both saturated- and unsaturated-zone waters are characterized by a very narrow range in ${ }^{87} \mathrm{Sr} /{ }^{86} \mathrm{Sr}$ ratios $(0.7077-$ 0.7080), which hinders the application of this tracer to fingerprint the different source rocks for strontium in the water. Strontium concentrations typically range from 0.1 to $1.4 \mathrm{ppm}$ and may be largely controlled by solubility with respect to strontium-calcium carbonate minerals (saturation index for strontianite, about 1; A.M. Simmons, Los Alamos National Laboratory, written commun., 2004). There is a rough correlation between ${ }^{87} \mathrm{Sr} /{ }^{86} \mathrm{Sr}$ and $1 / \mathrm{Sr}$ for the unsaturated-zone waters, while saturated-zone ranch waters tend to lie below this two-component mixing trend (fig. 96). There is no evidence from strontium isotopes for recharge through tuffs with compositions of those at Peña Blanca.

\section{Conceptual Model of Transport}

Data for the long-lived uranium-series members indicate limited mobility of uranium and its daughters over 100-k.y. time scales (CRWMS M\&O, 2000b). Transport from the uranium deposit to fractures has occurred in the past. However, the main transport activity currently observed is elevated ${ }^{226} \mathrm{Ra}$ in water samples in proximity to the deposit. The large depletions of ${ }^{226} \mathrm{Ra}$ seen in the fractures point to ${ }^{226} \mathrm{Ra}$ mobilization by way of recoil from fine-grained (submicron) uraniumbearing materials in the fracture coatings. The ${ }^{226} \mathrm{Ra}$ concentrations in waters sampled away from the deposit are low, which is typical for surface waters around the world (Porcelli and Swarzenski, 2003). Hence, the mobilization of radium is a near-field event resulting from recoil of the ${ }^{226} \mathrm{Ra}$ from highuranium regions into fluids. This mode of radionuclide mobilization would have a bearing on transport of uranium and its daughters from breached canisters at a high-level geologic storage system but would not have a bearing on transport of fission products such as ${ }^{133} \mathrm{Ba},{ }^{135} \mathrm{Cs},{ }^{137} \mathrm{Cs}$, and ${ }^{90} \mathrm{Sr}$. By analogy to the Peña Blanca observations, one would expect to see any mobilized uranium transported locally to fracture-filling materials. Recoil effects would raise local concentrations of daughters in the fluids to be redeposited/sorbed at some moderate distance away from the recoil site.

\section{Conclusions of Peña Blanca Studies}

Some of the conclusions thus far include:

1. The Nopal I uranium deposit remained largely in place prior to mining operations, indicating limited uranium transport (CRWMS M\&O, 2000b).

2. Some of the uranium was remobilized during 2003 drilling operations. The gradual approach of uranium concentrations in the drilled wells to background conditions over several months indicates that the uranium deposit is not being actively leached into the underlying groundwater.

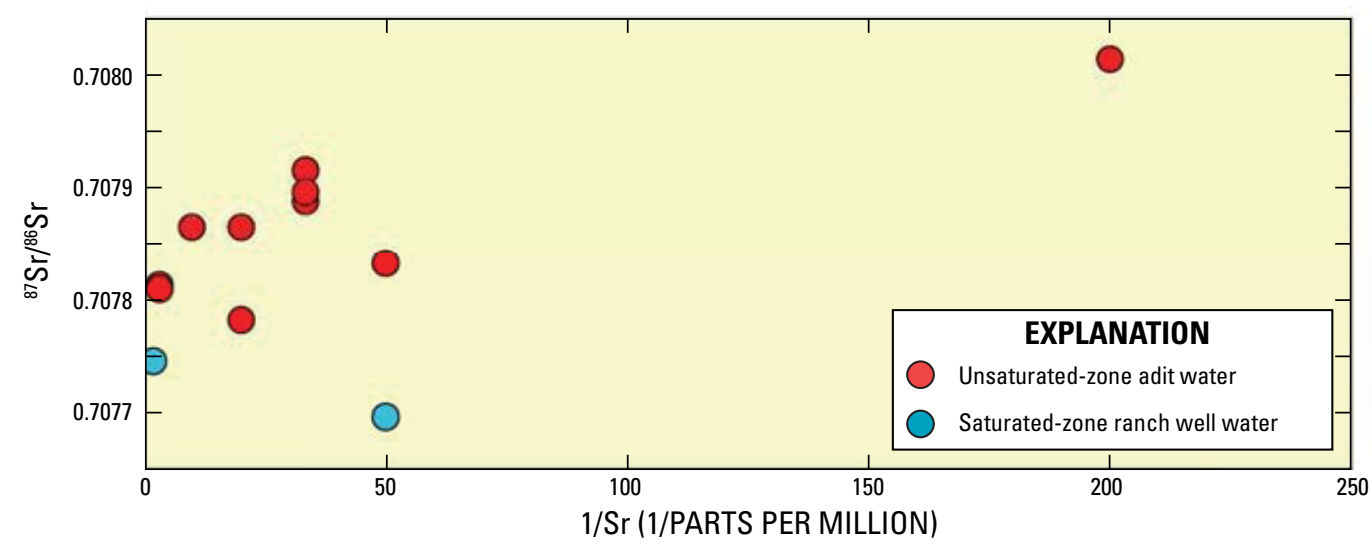

Figure 96. Strontium $(\mathrm{Sr})$ isotope mixing diagram for unsaturated-zone adit waters and saturated-zone ranch well waters, Peña Blanca, Chihuahua, Mexico (BSC, 2004, fig. 10.4-16). 
3. A conceptual model of transport has been developed that describes the timing of uranium transport from the deposit into near-field fractures, where it largely remains (CRWMS M\&O, 2000b).

4. High radium mobility is observed near the surface of the deposit. This mobility appears to be related to alpha-recoil from fine-grained, uranium-rich, fracture-filling phases. It is a near-field effect resulting from the high uranium contents in fractures.

5. Away from the deposit, low radium concentrations are observed in the waters. This indicates that other factors limit radium mobility over long distances, such as sorption onto mineral surfaces or coprecipitation with calcium fluoride or carbonate minerals (Porcelli and Swarzenski, 2003). By analogy, it would be expected that similar limits apply to the transport of fission products such as ${ }^{133} \mathrm{Ba},{ }^{135} \mathrm{Cs}$, ${ }^{137} \mathrm{Cs}$, and ${ }^{90} \mathrm{Sr}$.

\section{Uranium Deposits in Northwestern Nevada/ Southeastern Oregon}

The McDermitt caldera uranium deposits and other uranium deposits in northwestern Nevada and southeastern Oregon have been suggested as possible analogues to potential radionuclide transport processes at Yucca Mountain (Alexander and Van Luik, 1991). Castor and others (1996) compared features of 16 of the deposits, 5 of which are located in settings having a thin unsaturated zone. These are the Moonlight, Bretz, and Opalite uranium mines of the McDermitt caldera, Virgin Valley deposits of northwestern Nevada, and Painted Hills deposits near Reno, Nevada. The age of tuffs in the McDermitt caldera and Virgin Valley is 15.7-16.5 Ma (Castor and others, 1996). Depth to the water table is $38-50 \mathrm{~m}$. At the Moonlight mine, uranium deposition has occurred along faults. The host rocks are dacite flows, rhyolite ash-flow tuffs, and rhyolite breccias (Wallace and Roper, 1981).

Uranium deposition in Virgin Valley is associated with airfall and minor ash-flow tuffs and lacustrine sediments, including diatomite and lignite. Stratiform opal deposits contain uranium, and uranium also is found along fractures in rhyolitic breccia. In the Painted Hills district, notable uranium is concentrated at the contact between rhyolitic ash-flow tuff and a basalt dike, and as fracture filling in the tuffs. In all of the deposits mentioned, uranium is present as $\mathrm{U}(\mathrm{VI})$; only at the Moonlight mine is it also U(IV) in association with zircon. At the Painted Hills deposits and at Virgin Valley, evidence indicates remobilization and redeposition of uranyl minerals to account for local enrichment. The northern Nevada uranium deposits require additional characterization before data can be used in any real sense for building confidence in flow and transport process models.

\section{Akrotiri, Santorini}

Murphy and others (1998) conducted a study of traceelement transport at the Akrotiri archeological site on the island of Santorini, Greece, to evaluate the use of natural analogue data in support of long-term performance-predictive modeling for a proposed Yucca Mountain repository. Akrotiri is similar to Yucca Mountain in its silicic volcanic rocks, dry climate, and oxidizing, hydrologically unsaturated subsurface conditions. At Akrotiri, bronze and lead artifacts were buried under 1.5-2.0 m of volcanic ash 3,600 years ago (1645 B.C.; Murphy and others, 1998) by the Minoan eruption.

The Minoan eruption buried settlements under $30 \mathrm{~m}$ of volcanic sediment. Evidence for a plume of copper, zinc, and lead was found through selective leaching of packed earth and bedrock samples collected directly beneath the site where bronze and lead artifacts had been excavated. Field data indicated that little of the bronze material had been transported away from its primary location. Original textures and patterns were preserved in fine detail even on artifacts that were apparently crushed by compacting volcanic ash. The total amount of copper estimated to have been removed from the artifacts was approximately $38 \mathrm{~cm}^{3}$, roughly three orders of magnitude smaller than the volume of the artifacts (Murphy and others, 1998). Neither copper nor lead was detected below a depth of $45 \mathrm{~cm}$.

A numerical model of elemental transport was developed using geological characteristics and hydraulic properties of the enclosing tuff (Murphy and others, 1998). The well-constrained location of the contaminant source, well-constrained time scale for transport processes, and relatively well known physical characteristics of the site facilitated development of the transport model. Some of the model results were qualitatively consistent with the field data, including the small amount of material transported, limited amounts of sorbed material, and relatively elevated sorption on a packed earth layer. System heterogeneity and complexity also were integral factors in the distribution of contaminants on solids in the excavated area. The Akrotiri study shows preservation of artifacts for a long period of time in an oxidizing environment.

Data on the spatial distribution of metals derived from archeological artifacts at Akrotiri were then used to evaluate PA model assumptions of radionuclide transport through unsaturated volcanic tuffs at Yucca Mountain (Hughson and others, 2000). Despite the temporal and spatial source constraints of the Akrotiri data and characterization of the site, the data were open to different interpretations because of uncertainties in the extent of the plume, transport pathways, parameter heterogeneities, and boundary conditions. Rather than validating a particular conceptual model of flow and transport, the Akrotiri data indicate that 1-D models of aqueous-phase transport in the unsaturated zone with high infiltration and no retardation are conservative. Alternatively, a nonconservative bound to the calculations would indicate that very little transport has occurred (Hughson and others, 2000). 


\section{Koongarra Uranium Deposit, Alligator Rivers, Northern Territory, Australia}

The Alligator Rivers Analogue Project (ARAP) was a multinational investigation of the Koongarra secondary enricheduranium deposit in the Northern Territory of Australia (fig. 97). Numerous reports and papers discussing the analogue characteristics and project goals have been published (for example, Duerden and others, 1987; Hardy and Duerden, 1989; Airey and Ivanovich, 1985; Airey and others, 1987; Airey, 1986; von Maravic and Smellie, 1994). Investigations at Alligator Rivers were designed to study the decomposition and leaching of primary uraninite and pitchblende and the migration of radionuclides away from a uranium deposit as an analogue to migration from a waste repository. ARAP focused on the Koongarra deposit because it contains high uranium concentrations, its hydrology has been undisturbed by mining, and elemental migration has taken place.

Like other Alligator Rivers uranium deposits, the Koongarra deposit is located at a basal unconformity with a genesis similar to unconformity-type uranium deposits in the Athabasca Basin

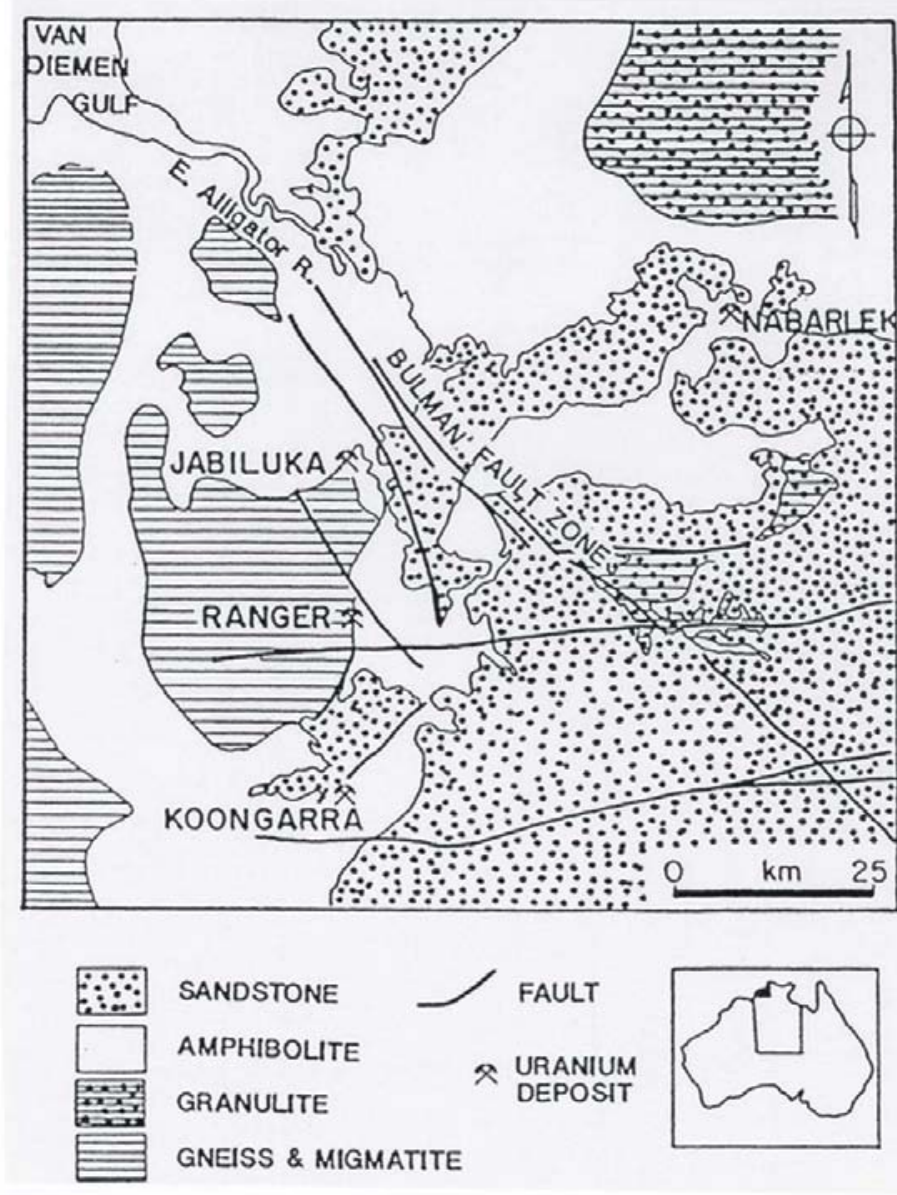

Figure 97. Location of the uranium orebodies in the Alligator Rivers region, Northern Territory, Australia; the Koongarra deposit was the focus of the Alligator Rivers natural analogue study (Airey, 1987). in northern Saskatchewan, Canada (for example, Cigar Lake). However, Koongarra has been exposed to strongly oxidizing conditions near the surface.

The Koongarra orebody lies in two distinct parts separated by a barren zone. The two parts are composed of uraninite and pitchblende-bearing veins within a zone of steeply dipping, sheared quartz-chlorite schists and a reverse fault that brings the orebody in contact with the overlying Kambolgie sandstone (fig. 98). The primary ore at depth is being leached by groundwater to form secondary mineralization (Isobe and others, 1992) that extends from the ground surface to the base of the weathered zone at about $30 \mathrm{~m}$. This leaching process has resulted in the orebody, and the region above it, forming four mineral zones: (1) the primary ore of uraninite and pitchblende, (2) a uranium silicate zone formed by in-situ alteration of the primary ore, (3) a zone of secondary uranyl phosphate minerals that are currently being leached by the groundwater, and (4) a shallow, dispersed uranium zone with the uranium in association with clays and iron oxyhydroxides (Snelling, 1980, 1992; Isobe and others, 1992, 1994; and Murakami and others, 1997).

Akin to the mineralized zones, four distinctive zones of weathering are apparent at Koongarra, differing in the relative intensity of weathering. As a result of the weathering front, a dispersion fan has developed in the weathering zone, where uranium has been mobilized. Secondary minerals are present as far as $50 \mathrm{~m}$ downgradient from the orebody, with detectable concentrations of uranium-series nuclides for about $300 \mathrm{~m}$ downgradient in the dispersion fan (Golian and Lever, 1992).

The uppermost of the four weathering zones (above about $20 \mathrm{~m}$ ) is the most weathered. Weathering of the quartz-chlorite schist produces different mineral assemblages according to the degree of alteration. The migration behavior of nuclides at each depth is thought to be related to the chlorite alteration mineral assemblage (Ohnuki and others, 1990). The zone of lowest uranium concentration corresponds to the chlorite-rich zone; that of intermediate uranium concentration to the vermiculite-rich zone, and that of greatest uranium concentration to the kaolinite-rich zone. The highest uranium concentrations in the dispersion fan are associated with the lower part of the kaoliniteweathered zone, which is closest to the surface (Ohnuki and others, 1990; Isobe and others, 1992; Murakami and others, 1997). Water from the weathered zone is undersaturated with respect to a number of uranium-bearing minerals. This is consistent with the concept that the present groundwater may be dissolving and dispersing the uranium in the deposit's phosphate zone (Sverjensky and others, 1992).

Koongarra may represent a worst-case scenario for transport, with its near-surface exposure to oxidizing weathering conditions and monsoonal climate. The dissolution and reprecipitation of uranium in the dispersion fan is especially notable. 


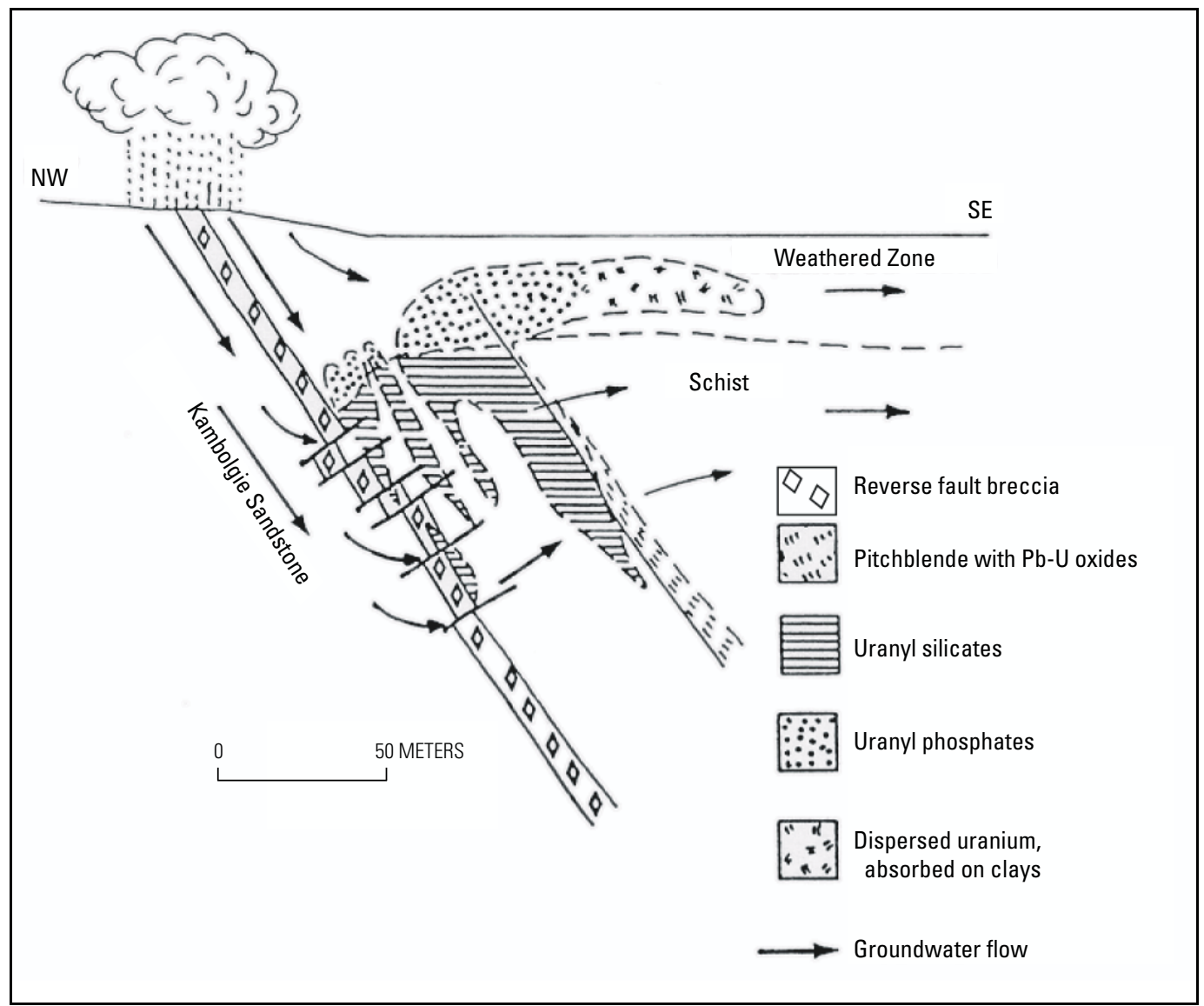

Figure 98. Cross section through the Koongarra, Alligator Rivers, Australia, orebody showing the distribution of the major rock types and uranium-bearing minerals (Miller and others, 1994).

\section{Busted Butte, Nevada, Tracer Test}

Radionuclide migration experiments under unsaturated conditions were conducted in a $30-\mathrm{cm}$ cubic block of Calico Hills nonwelded tuff from the Busted Butte test facility near Yucca Mountain. This type of study could be thought of as a self-analogue to migration in the Calico Hills nonwelded unit under Yucca Mountain. Elution profiles showed that, relative to an ideal conservative tracer (tritiated water), transport of $\mathrm{TcO}_{4}^{-}$was approximately 15 percent faster, but that $\mathrm{NpO}_{2}^{+}$ was retarded by a factor of 3 (Vandergraaf and others, 2001). These findings fall within the range of retardation coefficients determined from tuff column experiments (Triay and others, 1996, Appendix table). Retardation of ${ }^{22} \mathrm{Na},{ }^{60} \mathrm{Co}$, and ${ }^{137} \mathrm{Cs}$ was higher than for neptunium in the Calico Hills block experiments, and this agreed qualitatively with experimentally determined batch sorption coefficients for these isotopes (BSC, 2001a).

\section{Evidence for Colloidal Transport in the Unsaturated Zone}

The Steenkampskraal monazite mine, located north of Cape Town, South Africa, provides an example of colloidal transport of radionuclides in the unsaturated zone (fig. 99). Results of a study by Jarvis and others (1997) indicate that the monazite deposit behaves as a partly open system, especially where monazite disseminated in its silicate matrix is exposed to oxidizing surface and groundwaters along fractures and stratigraphic discontinuities, such as the contact between overburden and bedrock. Under these conditions, there is evidence that colloids in the infiltrating water are agents for the transport of thorium, uranium, and REE. This evidence includes the high contents of uranium and thorium and the fractionation between the heavy and light REE in samples collected from boreholes. 


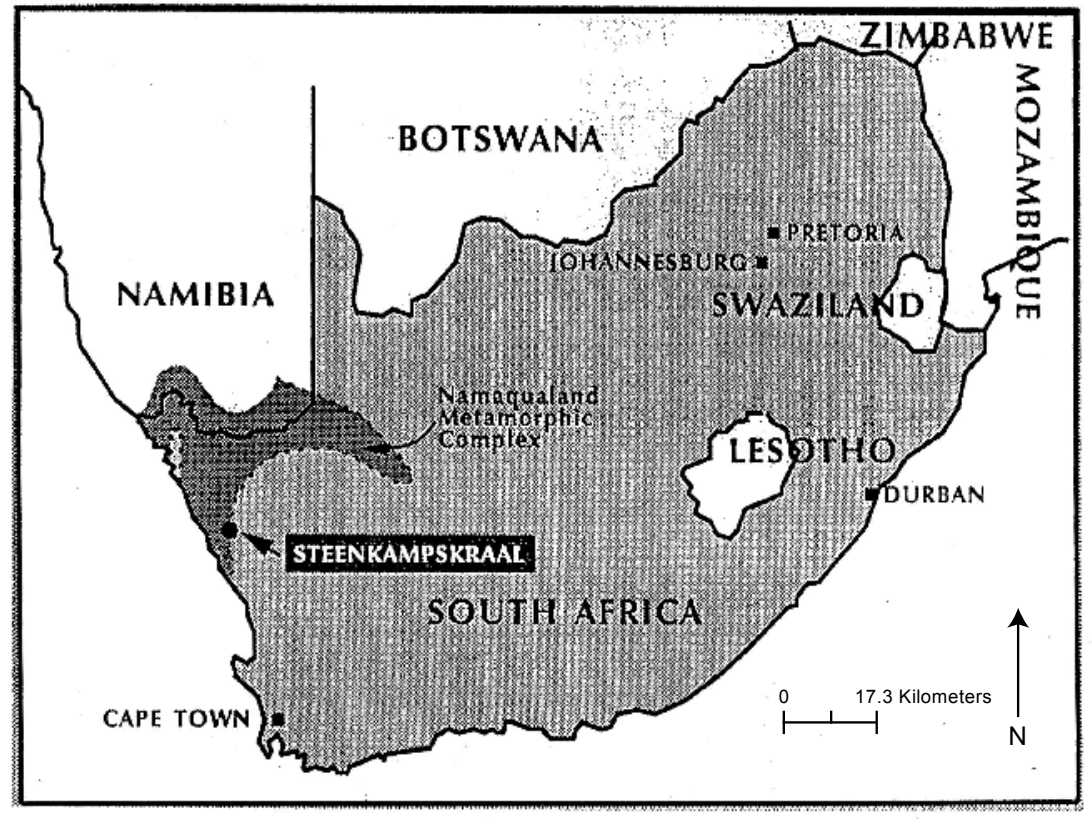

Figure 99. Location of Steenkampskraal, South Africa (Jarvis and others, 1997, fig. 1).
The Koongarra uranium deposit at Alligator Rivers, Australia, is located in a shallow, unsaturated environment that is subject to seasonal fluctuations of monsoons. Payne and others (1992) investigated the function of colloids in transport of uranium in the dispersion fan of the weathered zone above the orebody. The colloids and particles included clay minerals, particularly kaolinite and chlorite, along with fine quartz grains. Iron was present as particle coatings and in a separate colloidal form. The amount of ${ }^{238} \mathrm{U}$ associated with colloids ranged up to 6.5 percent, whereas the amount of ${ }^{230} \mathrm{Th}$ associated with colloids ranged from 10 to 85 percent. However, ${ }^{230} \mathrm{Th}$ was associated to a much greater extent with larger particles, which are unlikely to be mobile in natural groundwaters. The ${ }^{227} \mathrm{Th} /{ }^{230} \mathrm{Th}$ ratio was high in some fractions, indicating that ${ }^{227} \mathrm{Ac}$ could be present as colloids. Overall, however, there was little colloidal material in these groundwaters, with only iron, uranium, thorium, and actinium showing a significant association with colloids (Payne and others, 1992).

Groundwater samples collected from drill holes at Koongarra also were studied with respect to their colloidal contents (Airey, 1986; Ivanovich and others, 1987; Edghill and Davey, 1988). Drill holes closest to faults have the greatest variety of colloids (Ivanovich and others, 1987). The colloids identified include particles of iron, kaolinite, chlorite, silica, lead, uranium, and titanium. All colloid samples were dominated by iron-rich particles, and uranium was only observed in iron-rich species (Ivanovich and others, 1987). Low colloid concentrations (about 106 particles/L or less) and the absence of radionuclides in colloids outside the center of the orebody indicated that colloidal transport of radionuclides is minor at Koongarra (Edghill and Davey, 1988; Payne and others, 1992).

\section{Conclusions of Unsaturated-Flow and Transport Analogues}

The hydrogeologic and geochemical setting at Peña Blanca is closely analogous to that at Yucca Mountain. Although the hydrogeologic and geochemical features at the INL are less similar to Yucca Mountain, of the contaminated anthropogenic sites initially considered for study, the INL site was the most similar in that it is in a fractured porous medium with perched-water zones and units of varying permeability. It provided the additional advantage of datasets that included radionuclides, which strengthen model-testing aspects of the analogue study.

Hydrographs of ponded water and ${ }^{75} \mathrm{Se}$ breakthrough curves measured during the LPIT test conducted at the INL were analyzed to determine parameters controlling unsaturated flow and transport. Analysis of these data involved building a numerical model using TOUGH2 in a dual-permeability modeling approach that has been extensively used to simulate flow and transport at Yucca Mountain. The transport model calculations predicted retardation factors for neptunium and uranium that are orders of magnitude higher than retardation factors for the other radionuclides at the RWMC. This result would indicate that little movement of neptunium and uranium should be observed. However, detection of these radionuclides at depth was inconsistent with their predicted high retardation. Because the PTn hydrogeologic unit at Yucca Mountain has a damping effect on downward flow to the TSw hydrogeologic unit, and a similar damping effect has not been observed in the sedimentary interbeds at the RWMC, the enhanced transport scenario proposed in the INL modeling study is not expected to occur at Yucca Mountain. 
Fractures act as both transport pathways and places of retardation at a number of analogue sites, including INL; Peña Blanca, Mexico; Akrotiri, Greece; and volcanic tuffhosted uranium deposits in northern Nevada. At Nopal I (Peña Blanca), uranium and its daughters have been transported relatively short distances, essentially completely along fractures, and have been sorbed or precipitated onto fracture-coating iron-oxides and calcites. Matrix diffusion appears to have been inconsequential at Nopal I. Advective transport along fractures has been identified as a more significant transport mechanism than matrix diffusion in all of the unsaturated-zone analogue sites. In the Yucca Mountain Project TSPA, transport models are not sensitive to fracture sorption, but analogues indicate that fracture sorption enhances radionuclide retardation substantially.

Data indicate that the geochemical system at Nopal I restricted actinide mobility in the unsaturated zone and that by analogy the tuffs at Yucca Mountain should have similar retentive properties and impede the mobility of oxidized uranium. Additionally, clays in fractures and vitrophyres at Yucca Mountain may be effective in physically impeding flow, blocking movement of colloids, slowing movement of dissolved species, and retarding migration of radionuclides. This conclusion can be drawn from examination of the clay haloes (5-30 cm thick) surrounding ore deposits at Oklo, Gabon, and Cigar Lake, Canada, which have been shown to be effective in largely preventing the migration of uranium away from these deposits (CRWMS M\&O, 2000b).

The Nopal I uranium deposit remained largely in place prior to mining operations, indicating limited uranium transport. Some of the uranium was remobilized during 2003 drilling operations; however, uranium and thorium concentrations in groundwaters away from the drilling operations are low. High radium mobility is observed near the surface of the deposit. This mobility appears to be related to alpha-recoil from fine-grained, uranium-rich, fracture-filling phases. It is a near-field effect resulting from the high uranium contents in fractures. Away from the deposit, low radium concentrations are present in the waters. This indicates that other factors limit radium mobility over long distances, such as sorption onto mineral surfaces or coprecipitation with calcium fluoride or carbonate minerals. By analogy, it would be expected that similar limits apply to the transport of fission products such as ${ }^{133} \mathrm{Ba},{ }^{135} \mathrm{Cs},{ }^{137} \mathrm{Cs}$, and ${ }^{90} \mathrm{Sr}$.

As a final point, colloid transport appears to be an important factor for migration of thorium in one open unsaturated system, Steenkampskraal, but not in another, Nopal I. Colloidal transport of uranium was shown to be minimal at the analogue site in Koongarra, Australia, where filtration of colloids appears to be effective. The Yucca Mountain Project TSPA assumes no colloid filtration, an assumption that may be unnecessarily conservative (CRWMS M\&O, 2000a).

\section{Coupled Processes Analogues}

\section{Introduction}

The emplacement of heat-generating waste in a geologic repository located in the unsaturated zone will cause perturbations to the natural environment through heat transfer, resulting from convection and conduction, as well as by associated geochemical and geomechanical changes taking place in the repository near-field and altered rock zones (Apps, 1995; Hardin and Chesnut, 1997; Hardin, 1998). Although data collected from heater tests have significantly advanced understanding of thermohydrologic processes and coupled behavior, it will be difficult to measure thermohydrologic behavior deterministically because the experiments are too limited for the timeframe over which the processes take place and thus cannot represent time and rate scales. Natural analogues, on the other hand, provide opportunities for testing models and building understanding of thermally coupled processes by providing data from fossil hydrothermal systems, by observations from ongoing processes in geothermal fields, and by using data from geothermal systems to test and build confidence in numerical modeling codes and in thermodynamic and kinetic databases.

Geothermal systems provide an ideal opportunity for examining the long-term effects of coupled thermal-hydrologic-chemical (THC) processes expected for the proposed nuclear waste repository at Yucca Mountain, Nevada. Active and fossil geothermal systems provide important insights into the consequences of processes such as boiling, condensation, fluid mixing, and water/rock interaction associated with fluid flow in matrix and fractures, and can be used to test coupled process models. Geothermal systems also allow observation of the effects of processes over much larger volumes and longer time scales than would be possible in laboratory or field experiments. Characterization of the effects of water/rock interaction, such as mineral precipitation and dissolution, on matrix and fracture permeability in geothermal systems can eventually be used to estimate potential changes in fluid flow resulting from the thermal effects of storing high-level nuclear wastes in fractured ash-flow tuffs.

There are many similarities between geothermal systems and an anthropogenic hydrothermal system that would be created by the emplacement of high-level nuclear waste. For most geothermal systems, intrusion of magma at shallow crustal levels results in high heat flow and the formation of a convective hydrothermal system with associated water/ rock interaction. In the anthropogenic system, heat-generating nuclear waste is the agent that would induce changes in the ambient system. Both types of systems are subjected to coupled THC processes such as conductive and advective heating, fluid flow and chemical transport through matrix and fractures, boiling and condensation, and mineral dissolution and precipitation (fig. 100). These processes can result 

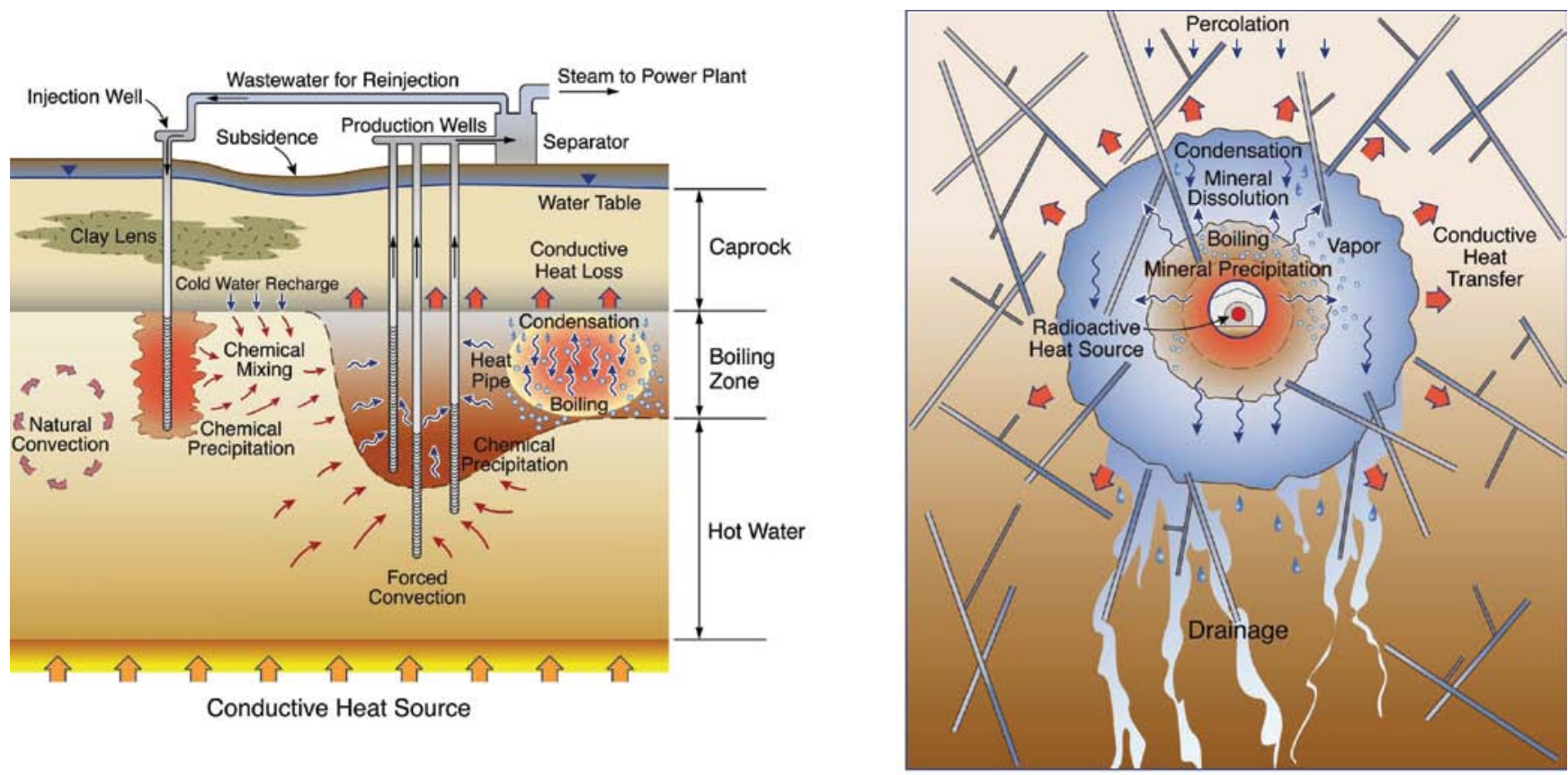

NOTE: Similar processes include boiling and condensation, advective liquid flow, mineral dissolution and precipitation, mixing, recharge (percolation), and heat conduction. A heat pipe is depicted on the right side of the geothermal system, showing countercurrent liquid and vapor flow resulting from boiling and condensation.

Figure 100. Comparison of processes in geothermal (left) and anthropogenic (right) thermal systems created by emplacing heat-generating nuclear waste in an unsaturated fractured rock mass (adapted from Bodvarsson and Witherspoon, 1989, and CRWMS M\&0, 2000b).

in important changes in the fluid-flow properties of the rocks surrounding the heat source over time.

The magnitude of the effects of many THC processes (such as boiling, condensation, mineral dissolution, and precipitation) is envisioned to be substantially reduced at Yucca Mountain as a result of the much lower anticipated fluid and thermal flux rates than those observed in active geothermal systems. However, geothermal systems provide well-constrained examples of how THC processes can modify important hydrogeologic properties (such as porosity, permeability, and sorptive capacity) that would affect the total system performance of a geologic high-level radioactive waste repository. Examples of active (Yellowstone) and fossil (Yucca Mountain, Paiute Ridge, and others) geothermal systems and their use as analogues for THC processes are presented herein.

\section{Yellowstone as a Natural Analogue for Thermal- Hydrologic-Chemical Processes}

The volcanic stratigraphy of the Yellowstone system, which consists primarily of variably welded rhyolitic ash-flow tuffs, is closely similar to the geology of the unsaturated zone at Yucca Mountain, thus making Yellowstone an appropriate analogue for coupled THC processes (Meijer, 1987). The Yellowstone volcanic center is the site of one of the largest active geothermal systems in the world, with hundreds of thermal features located both within and outside of the 0.6-Ma Yellowstone caldera (Fournier, 1989). Although the most recent volcanic activity at Yellowstone occurred about $70 \mathrm{ka}$, the high heat flow indicates that magma currently underlies much of the Yellowstone caldera.

\section{Hydrothermal Sealing}

Numerous studies at Yellowstone have focused on hydrothermal silica sealing and its effect on permeability (Keith and others, 1978; Keith and Muffler, 1978; Sturchio and others, 1986; Fournier and others, 1991; Dobson and others, 2001a, b; Dobson, Kneafsey, Hulen, and Simmons, 2003; Dobson, Kneafsey, Sonnenthal, and others, 2003). Mechanisms for silica precipitation include (1) cooling of silica-saturated waters, (2) mixing of fluids with different chemistries and temperatures, and (3) boiling. Silica sinter is a commonly observed trait of many of the thermal features at Yellowstone National Park, and several features of silica deposition have been observed over a period of decades at Porkchop Geyser (fig. 101), making it an ideal site for documenting evolution of geothermal processes.

Porkchop Geyser has evolved from a quiescent hot spring (1960-71) to an infrequently geysering pool (1971-85) to a 


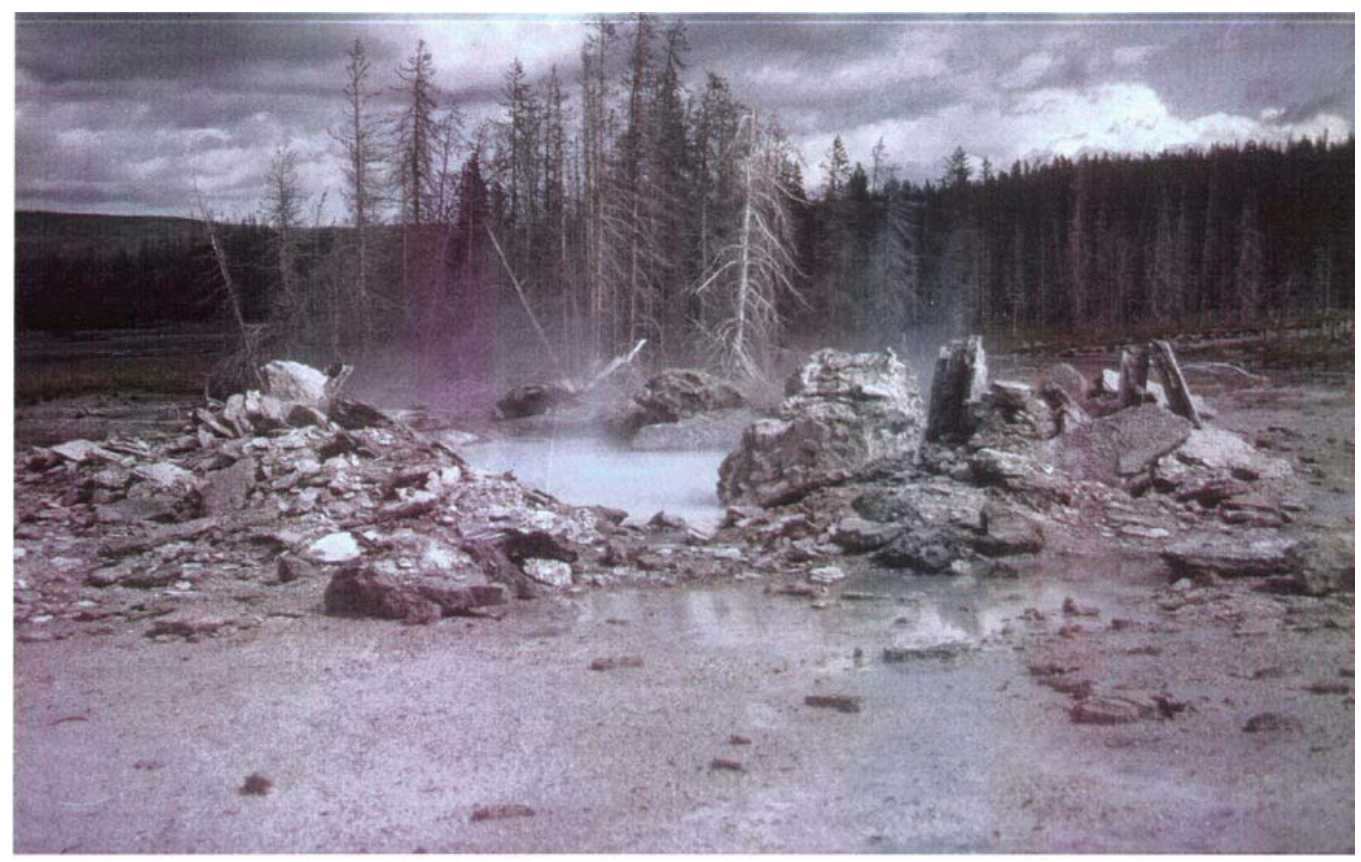

NOTE: Large sinter blocks were ejected by 1989 explosion. The pool has an opalescent color, indicating presence of colloidal silica (photograph by R. Fournier, USGS).

Figure 101. Porkchop Geyser, Yellowstone National Park, Wyoming (July 1991).

perpetually spouting geyser (1985-89), culminating in a small hydrothermal eruption on September 5, 1989 (Fournier and others, 1991). These changes were accompanied by increases in sodium-potassium-calcium (NKC) geothermometry temperatures and silica concentrations (fig. 102) from $214^{\circ} \mathrm{C}$ and $420 \mathrm{ppm} \mathrm{SiO}_{2}$ in 1961 to $273^{\circ} \mathrm{C}$ and $741 \mathrm{ppm} \mathrm{SiO}_{2}$ in 1989 (Fournier and others, 1991, 1992). Some of the sinter blocks ejected during the hydrothermal eruption had coatings of botryoidal silica, indicating that amorphous silica formed as a colloidal coating just prior to eruption.

Fournier and others (1991) interpreted the changes at Porkchop Geyser as an indication that the waters were derived from an increasingly hotter source over time, with more boiling occurring during upflow. Deposition of amorphous silica triggered by the increased silica concentrations would result in decreased permeability within the flow channels and contribute to increased pressures below constrictions present in the fluid pathways. Fluid overpressures probably led to the rupturing of the sinter throttle at the mouth of the geyser, resulting in a rapid depressurization of the shallow part of the geyser plumbing, causing immediate boiling that triggered the hydrothermal explosion.

Numerous hydrothermal explosion craters have been identified at Yellowstone (Muffler and others, 1971), indicating that the self-sealing process that leads to these eruptions is common. Hydrothermal breccias within the densely welded tuff in the subsurface (Dobson and others, 2001b) represent transient conduits of high fluid flow that were formed by the explosive release of overpressure in the underlying geothermal reservoir and were subsequently sealed by supersaturated geothermal fluids (Grindley and Browne, 1976).

Hydrothermal self-sealing appears to have generated the existing permeability barrier that caps the convecting geothermal system at Yellowstone. A sharp increase in wellhead pressure observed in the $\mathrm{Y}-8$ well indicates that a major low-permeability zone is located within a silicified interval of volcaniclastic rocks (White and others, 1975; Dobson and others, 2001a). This interval also marks the transition between a steep conductive thermal gradient observed above and a near-isothermal section that extends to the well bottom. The presence of bladed calcite and elevated $\delta^{18} \mathrm{O}$ values of hydrothermal quartz indicate that the silica seal may have formed in response to transient boiling events associated with depressurization (Sturchio and others, 1990).

Hydrothermal sealing can occur fairly rapidly. Most of the USGS core holes at Yellowstone were partially or completely plugged by mineral precipitation within 25 years of having been drilled (Fournier and others, 1993; Bargar and Beeson, 1984, 1985; Bargar and others, 1981). A radium disequilibrium study of hot-spring waters at Yellowstone (Clark and Turekian, 1990) indicates that the mean water/rock reaction time (involving congruent rock dissolution and release of radium) in the high-temperature reservoir is 540 years, with a maximum calculated reaction time of 1,150 years. 


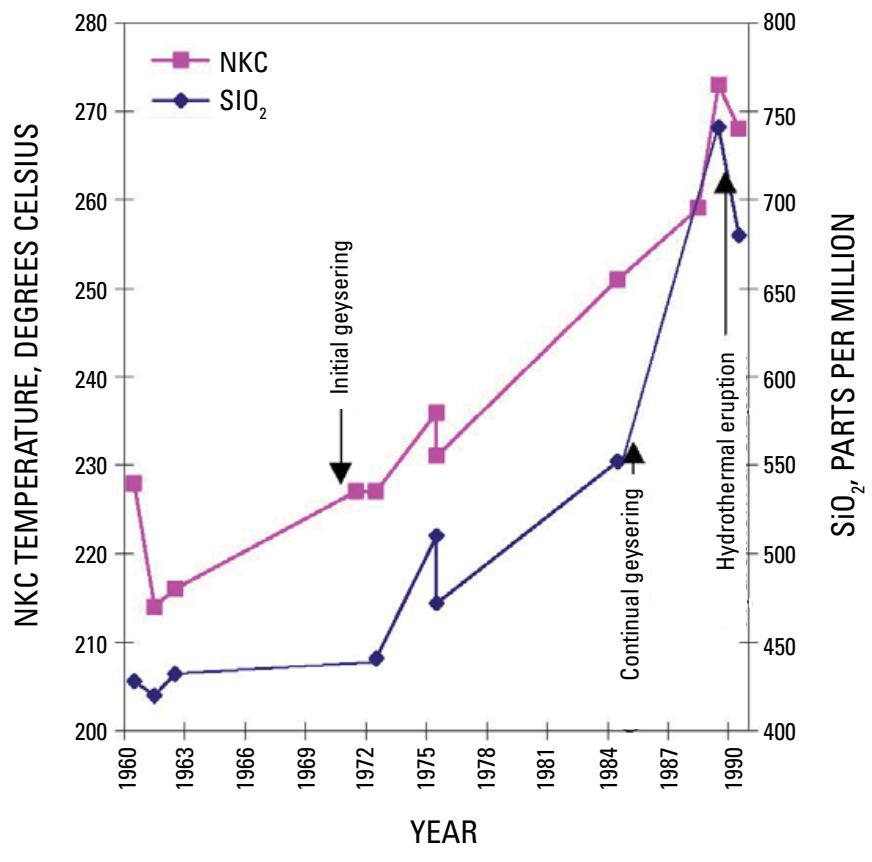

Figure 102. Calculated changes in sodium-potassiumcalcium (NKC) reservoir temperatures and silica (SiO2) concentrations for waters sampled from Porkchop Geyser, Yellowstone National Park, Wyoming (Fournier, 1991).

Silicification is not the only type of hydrothermal alteration that has affected fluid flow in the Yellowstone geothermal system. The presence of abundant clay minerals and zeolites as replacement minerals and in void spaces also probably reduced the matrix permeability for all of the rock units studied. Dissolution of volcanic glass likely led to localized increases in porosity and permeability. The presence of multiphase veining in the Yellowstone cores indicates that there have been multiple episodes of fluid flow and self-sealing. A commonly observed vein assemblage for rhyolitic lava in the well $\mathrm{Y}-8$ core is an outer band of celadonite, followed by chalcedony, and with most recent precipitation of mordenite. The sequential deposition of these phases indicates that there were progressive changes in fluid chemistry and(or) temperature with time that resulted in this paragenetic sequence.

Meijer (1987) used Yellowstone fluid compositions and the EQ3/6 geochemical codes (Wolery, 1979) to calculate mineral assemblages for a fixed temperature, with the goal of validating these geochemical codes for evaluating the effects of water/rock interaction at Yucca Mountain. Meijer (1987) predicted mineral assemblages that included silica polymorphs (chalcedony or cristobalite), zeolites (leonhardite or $\mathrm{K}$-clinoptilolite), clays (Ca-nontronite, Ca-saponite) \pm calcite and talc. These modeled assemblages are similar to those in the Yellowstone cores, thus validating the use of geochemical modeling to predict changes in fluid and rock chemistry resulting from water/rock interaction. Meijer (1987) concluded that the effects of hydrothermal alteration on welded devitrified tuffs for temperatures below $170^{\circ} \mathrm{C}$ were generally relatively minor; thus, the thermal pulse at Yucca Mountain would have only minor effects on the host rocks, limited to transport and redeposition of silica and precipitation of clays and zeolites in fractures, cavities, and the groundmass.

\section{Comparison with Yucca Mountain}

The dissolution, transport, and precipitation of silica are highly dependent on system temperature, mineralogy, and liquid flux rate, as well as on whether boiling occurs (Chigira and others, 1995). Although the amount of fluid flow at Yellowstone is orders of magnitude greater than that expected for the potential Yucca Mountain repository system, the link between boiling, increased silica concentrations, and resulting precipitation of amorphous silica can still be applied to the Yucca Mountain system. Under the high-temperature operating mode, where boiling temperatures are predicted to persist in the near-drift environment for 1,000-2,000 years, dissolved solids will precipitate as dryout occurs (Sonnenthal and Spycher, 2001). The amount and composition of minerals precipitated by dryout depend in part on the flux of fluids into the dryout front and the composition of these fluids (Kneafsey and others, 2001). Development of a heat pipe above the proposed emplacement drifts at Yucca Mountain could lead to increased fluid flow and chemical transport into the dryout area.

Measured concentrations of dissolved silica in heated waters $\left(26.5-51.7^{\circ} \mathrm{C}\right)$ collected from hydrology boreholes around the Yucca Mountain drift-scale test (DST) are as much as two times higher than those of unheated pore-water compositions (Sonnenthal and Spycher, 2001). Although the DST fluid concentrations (as much as 139 ppm $\mathrm{SiO}_{2}$ ) are still substantially lower than those observed in downhole water samples from the Yellowstone Y-7 and Y-8 wells (364 and $290 \mathrm{mg} / \mathrm{L}$, respectively; Sturchio and others, 1989) and surface samples from Porkchop Geyser (as much as 741 ppm; Fournier and others, 1991), they demonstrate how heating can lead to increased silica concentration that ultimately results in the precipitation of amorphous silica. Sustained reflux of silica-bearing fluids into fractures within the dryout zone at Yucca Mountain could lead to plugging of flow channels in the near-drift area. These changes could persist with time so that when the near-drift area cools below boiling temperatures, seepage into the drifts may be restricted to flow along unsealed fractures with larger apertures. The presence of discrete zones of silicification at Yellowstone indicates that the processes controlling mineralization are restricted both spatially and temporally. Because of the unsaturated nature of the Yucca Mountain system, fluid overpressures will not develop, and thus hydrothermal explosions need not be considered for Yucca Mountain.

Geochemical modeling for the Yucca Mountain system (Sonnenthal and Spycher, 2001) used a more dynamic approach that couples heat and fluid flow with geochemical transport and reactions and resulting changes in porosity and 
permeability. The TOUGHREACT simulators (for example, Xu and Pruess, 2001a, b) incorporate reactive chemistry and transport into the framework of the TOUGH2 code, which simulates multiphase flow of gas and fluids together with tracer and heat transport through porous and fractured geologic media (Pruess, 1991; Pruess and Narasimhan, 1985). The TOUGHREACT code allows for the selection of kinetic or equilibrium thermodynamics for mineral dissolution and precipitation and has several permeability law options available to relate porosity changes to changes in permeability. Simulations of fluid and heat flow and changes in permeability and porosity resulting from water/rock interaction were conducted for the neardrift region of the proposed Yucca Mountain repository (Sonnenthal and Spycher, 2001). The results of these simulations (conducted for thermal loads where boiling conditions persist for 1,000-2,000 years) indicate that only small reductions in fracture porosity (1-3 percent) and permeability (less than 1 order of magnitude) will occur in the near field as a result of amorphous silica and calcite precipitation, and that these changes will not significantly affect repository performance. The approach used for these simulations was validated through the modeling of the results of the DST conducted at Yucca Mountain (Sonnenthal and Spycher, 2001) and by simulating a series of dissolution and precipitation experiments conducted using Topopah Spring Tuff samples (Sonnenthal and Spycher, 2001). These simulations successfully predicted observed changes in fluid and gas chemistry, mineral precipitation, and associated changes in porosity and permeability over the duration of these experiments.

\section{Other Examples of Fossil Hydrothermal Systems}

Fossil hydrothermal systems record the integrated long-term effects of THC processes. Portions of fossil systems that were located above the paleowater table provide a direct analogue to the conditions expected for the proposed repository at Yucca Mountain. The presence of unsaturated conditions results in much less extensive water/rock interaction than is observed in actively convecting geothermal systems. Examples of fossil hydrothermal systems with unsaturated portions, including Paiute Ridge in Nevada, Banco Bonito and Grants Ridge in New Mexico, and Yucca Mountain itself, are discussed in the following paragraphs.

\section{Yucca Mountain as a Self-Analogue}

As described in the "Introduction" section, the proposed repository at Yucca Mountain would be sited within devitrified, moderately to densely welded rhyolitic ashflow tuff that is part of a thick sequence of Miocene volcanic rocks. The repository horizon is located within the unsaturated zone, more than $300 \mathrm{~m}$ above the regional water table. The volcanic rock units have varying hydrologic properties, with the nonwelded vitric tuffs having few fractures and moderate matrix permeability, whereas welded tuffs have lower porosities, more fractures, and very low matrix permeabilities. The volcanic rocks at Yucca Mountain can serve as a self-analogue, where the integrated effects of coupled processes observed in the geologic record can be used to predict future changes induced by the storage of heat-generating nuclear waste. Two main alteration features are present in the unsaturated zone at Yucca Mountain: (1) hydrothermal alteration of volcanic glass to clays and zeolites, and (2) calcite and opal mineralization in fractures and cavities.

Bish and Aronson (1993) interpreted the formation of clays and zeolites in the matrix and fractures of formerly vitric, nonwelded tuffs to have resulted from low-temperature hydrothermal activity associated with the Timber Mountain caldera complex between 10 and $11 \mathrm{Ma}$. Low-temperature zeolites (clinoptilolite and mordenite) occur at shallower depths, with analcime (a less hydrous, higher temperature zeolite) found in deeper altered tuffs (Broxton and Carlos, 1986). Cation exchange between percolating waters and zeolites has resulted in increases in calcium, magnesium, and strontium (and decreases in sodium and potassium) in the altered tuffs, with corresponding water-chemistry changes (Vaniman and others, 2001).

Information on the long-term thermal, fluid flow, and reactive transport history at Yucca Mountain can be elucidated from secondary minerals (calcite and opal) precipitated within fractures and lithophysal cavities. The presence of these deposits along the footwalls of fractures and along the floors of lithophysal cavities indicates that they precipitated from fluids flowing through the fracture network under unsaturated conditions (Whelan and others, 2002). Fluid inclusions trapped within these secondary minerals and oxygen stable isotope compositions of calcite were used to estimate temperature at the time of entrapment (Whelan and others, 2001, 2002). Radiogenic dating of the opal layers (Neymark and others, 2001) was combined with this information to derive a postemplacement thermal history for the volcanic sequence at Yucca Mountain. These data indicate a gradual cooling trend from about $70^{\circ} \mathrm{C}$ at around $10 \mathrm{Ma}$ to near ambient temperatures starting around $5 \mathrm{Ma}$, which has been interpreted by Marshall and Whelan (2001) as resulting from crystallization and cooling of a large magma body associated with the Timber Mountain caldera complex to the north of Yucca Mountain. The presence of both mineralized and nonmineralized fractures and cavities indicates that fluid flow and transport occurred preferentially along a limited set of fracture pathways.

\section{Paiute Ridge, Banco Bonito, and Grants Ridge}

The Paiute Ridge intrusive complex (Matyskiela, 1997; Lichtner and others, 1999) is located about $40 \mathrm{~km}$ northeast of Yucca Mountain. At Paiute Ridge, basaltic dikes were intruded 
along normal faults, and a series of domed lopoliths was emplaced at shallow depths (above the paleowater table) along contacts between the Paintbrush and Timber Mountain tuffs. Alteration, as defined by the presence of secondary minerals and variations in tuff chemistry, appears to be concentrated near the intrusive contacts.

Lichtner and others (1999) noted that the tuff is fused into a gray to black vitrophyre within $0.5-1 \mathrm{~m}$ of the intrusive contact and that the degree of contact welding decreases within 1-3 $\mathrm{m}$ from the contact. Devitrification and partial alteration of volcanic glass to clay begins at about $2 \mathrm{~m}$ from the contact, with higher-temperature illite closer to the contact and lower-temperature montmorillonite present at distances of 3-5 m. The zone of devitrification extends up to $15 \mathrm{~m}$ from the contact. Localized chemical variations (fig. 103) were also noted in the host Rainier Mesa Tuff adjacent to basaltic sills (BSC, 2004). For less mobile components such as $\mathrm{TiO}_{2}$, $\mathrm{Al}_{2} \mathrm{O}_{3}$, total iron, niobium, and zirconium, little variation is observed throughout the suite of samples, with most variability occurring within a zone that extends about $10 \mathrm{~m}$ from the sill contact. Although silica appears to be mobile (as observed by the presence of opal veins), the actual range of observed silica concentrations for all of the analyzed tuff samples is fairly small (74-81 percent $\mathrm{SiO}_{2}$, normalized to anhydrous compositions). Substantially more variability is observed for the more mobile alkali and alkaline-earth elements $(\mathrm{Na}, \mathrm{K}$, $\mathrm{Rb}, \mathrm{Ca}, \mathrm{Sr}$ ). Most of the variability for sodium, potassium, and rubidium occurs within $10 \mathrm{~m}$ of the sill contact, indicating that the original tuff compositions were modified by hydrothermal alteration resulting from the sill intrusion.

Matyskiela (1997) studied the alteration mineralogy associated with the Papoose Lake basalt sill, one of the Paiute Ridge intrusions. According to Matyskiela, all tuffs within $50 \mathrm{~m}$ of the sill contact have been altered to some extent, and alteration decreases with distance from the intrusive contact.

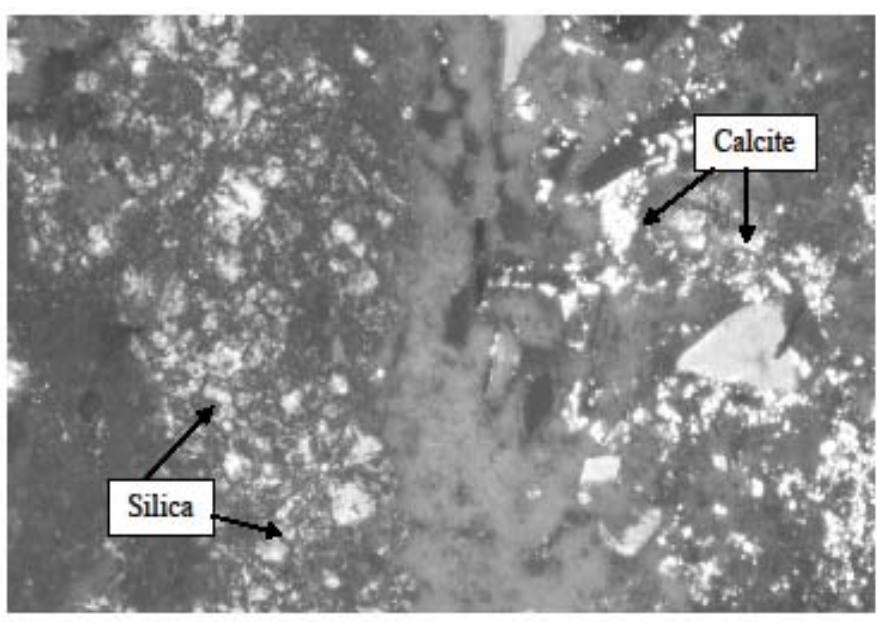

Figure 103. Photomicrograph of altered Rainier Mesa Tuff, Nevada (BSC, 2004, fig. 11.4-4).
The most intense alteration appears to be focused along the margins of widespread near-vertical fractures (1-15 per m) that parallel extensional faults in the area. The tuff matrix glass and pores within $1 \mathrm{~cm}$ of the fractures have been completely replaced by an impermeable and nonporous zone of clinoptilolite and cristobalite. Later-formed chalcedony and rare calcite fill most fractures. Matyskiela interpreted that the reduced matrix permeability and the sealing of fracture margins caused by this alteration event would result in enhanced fluid flow through the fractures.

The effect of a basaltic intrusion on alteration of the host rock in which it is emplaced and alteration of the intrusion itself was modeled using the computer code FLOTRAN (Lichtner, 2003). Preliminary results were presented for a onedimensional THC dual-continuum model of the interaction of country rock with heat released from an intrusive complex emplaced above the water table (BSC, 2004). Simulations conducted using a simplified chemical system demonstrated the possibility of forming opal-filled veins with the source of silica derived from the matrix of the host rock.

The effects of shallow (less than $500 \mathrm{~m}$ deep) magmatic intrusions into unsaturated host rocks can be quite different from the effects associated with deeper hydrothermal systems, which have been studied more extensively. One site in an unsaturated environment is the contact between the Banco Bonito obsidian flow and the underlying Battleship Rock Tuff in a steep-walled canyon on the southwest rim of the Valles caldera in New Mexico. This has been the focus of a number of analogue studies (Krumhansl and Stockman, 1988; Stockman and others, 1994). The Banco Bonito flow filled a steepwalled canyon cut in the Battleship Rock Tuff about $400 \mathrm{ka}$. The obsidian, initially at temperatures of $850^{\circ} \mathrm{C}$, heated the porous tuff in the canyon walls to $150^{\circ}-350^{\circ} \mathrm{C}$ for decades, and, according to models, vaporized much of the pore water, causing refluxing of water. Contact effects include a reddish baked zone extending tens of feet into the tuffs. No evidence of hydrothermal alteration was noted, indicating that the area was unsaturated at the time of contact.

Based on a detailed mineralogical, chemical, and isotopic study, Stockman and others (1994) concluded that the overall effects of heating in this unsaturated environment appeared to have been slight and were limited to the tuff nearest the contact. Some evidence existed for devitrification and migration of volatiles in the tuff within $10 \mathrm{~m}$ of the contact, but variations in major- and trace-element chemistry were small and difficult to distinguish from the natural variability of these elements in the rock. Apart from devitrification, the principal mineralogic change in tuff near the contact was the development of feldspar-silica linings on voids in the pumiceous-tuff matrix. No significant development of zeolites was observed.

The influence of a shallow, basaltic intrusion into pyroclastic deposits at Grants Ridge in New Mexico was studied by WoldeGabriel and others (1999). At Grants Ridge, a 2.6-Ma basalt plug intruded into 3.3-Ma nonwelded, pumice-rich, compositionally homogeneous rhyolitic tuff and volcaniclastic 
sediments. A 10-m-wide aureole, characterized by color variation, contact welding, brecciation, partial melting, and stoping, developed around the 150-m-wide basalt plug. Despite the high-temperature basaltic intrusion, there was no evidence of pervasive hydrothermal circulation and consequent alteration of the country rock that could have occurred had there been extensive, fluid-driven, convective heat transfer. WoldeGabriel and others (1999) observed that the proportion of volcanic glass, volatile species, iron, and some trace-element and REE contents in the host rocks were somewhat depleted at the contact of the intrusion. In contrast, the degree of devitrification and the potassium content were higher along the contact. The authors postulated that vapor-phase expulsion of elemental species could have been responsible for the minor depletion of elements during devitrification of the silicic glass at nearsolidus temperature related to the basaltic intrusion.

The WoldeGabriel and others (1999) study performed finite-difference numerical modeling to simulate the Grants Ridge intrusion as a dry, conduction-dominated system. Model results were compared to an analytical solution and to results using the heat and mass transport code FEHM (Zyvoloski and others, 1992, 1997). Modeling results, which agreed well with geochemical and mineralogical data, indicated that contact welding of the host rocks apparently occurred at temperatures greater than $700^{\circ} \mathrm{C}$ and under a lateral load of approximately 1 megapascal (MPa), corresponding to the observed depth below the former land surface of approximately $100 \mathrm{~m}$ (WoldeGabriel and others, 1999). Because devitrification is generally enhanced by the presence of aqueous fluids, the abundance of volcanic glass within a short distance (about $10 \mathrm{~m}$ ) from the plug is consistent with the inference that the plug intruded into an unsaturated environment. Although no apparent hydrothermal alteration was recognized in the contact zone, this field study and others like it provide an upper-temperature-bound natural analogue to evaluate the effects of heat from decay of radioactive waste. In fact, the temperatures in these studies far exceed the highest temperatures anticipated in a repository. Field and laboratory data from this analogue study also can be used to build confidence and to calibrate models of such processes within similar physical and chemical environments.

The ideal intrusion to serve as a natural analogue to THC processes anticipated at a Yucca Mountain repository would be emplaced above the water table in host rock of similar composition and characteristics to the Topopah Spring Tuff and would be of sufficient size to produce enough heat to sustain boiling conditions for times on the order of several thousand years (about $30 \mathrm{~m}$ wide). The Paiute Ridge intrusive complex does not fit all of these criteria-its host rock is a nonwelded vitric tuff-but this does not exclude it as a meaningful analogue. In both the Banco Bonito study and the Grants Ridge basalt-intrusion study, the effects of high-temperature intrusions into unsaturated environments appear to have been slight, to have been limited to within approximately $10 \mathrm{~m}$ of the contact, and to show no evidence of fluid-driven convec- tive heat transfer or pervasive hydrothermal alteration of the country rock.

\section{Comparison with Yucca Mountain}

The fossil hydrothermal systems described previously in this section illustrate some important effects of THC-coupled processes that would be expected for the proposed Yucca Mountain repository. The intensity and extent of alteration is much more limited for the unsaturated-zone environment than what is observed in typical geothermal systems such as Yellowstone. Alteration is more intense near the heat source, indicating that most changes would occur in the near-field environment for the proposed Yucca Mountain repository. Secondary mineralization appears to be concentrated along fractures, which likely serve as the primary conduits for episodic fluid flow within these systems. The addition of heat and hydrothermal fluids could hasten the alteration of volcanic glass to clays and zeolites, which would retard radionuclide transport as a result of enhanced sorption and ion-exchange capacity, thus improving performance of the geological repository.

\section{Numerical Tools}

Because many of the same thermohydrologic processes operating in geothermal systems are applicable to behavior of a nuclear waste repository, the same numerical tools may be used to study thermohydrologic evolution in both environments. Geothermal reservoir simulators have been used to model laboratory experiments, to study fundamental aspects of geothermal reservoir dynamics, and to perform simulation studies, such as parameter matching and field history studies in their various natural, exploited, and predicted states for dozens of specific geothermal fields. For all of these applications, it is essential that users have a high level of confidence in the ability of their numerical tools to simulate processes and predict thermohydrologic conditions over extended time periods.

Numerical simulators in geothermal studies are used to determine the characteristic parameters of reservoirs, especially the reserves of heat and fluid, and to simulate the performance of reservoirs upon production and injection. To produce an adequate model, numerical codes must be able to handle processes of heat transfer, two-phased flow under nonisothermal conditions in one, two, and three dimensions with varying degrees of nonlinearity, coupling of fluid and heat flow, and complex boundary conditions. Solution of twophase fluid-flow problems with heat transport in a fractured porous medium is a challenging task that adds complexity when modeling in three dimensions, as was done for the Yucca Mountain PA. Modeling of geothermal systems has provided major advances toward this goal, which adds confidence to numerical models of Yucca Mountain.

Table 14 compares issues important to assessing coupled processes that may occur at Yucca Mountain and processes 
that take place in geothermal reservoir systems. Some issues that are important for assessing Yucca Mountain (that is, water saturation near the heated, localized seepage) have been omitted from the list because they are not of concern in geothermal reservoir engineering. Table 14 shows geothermal fields that could be used as potential analogues to study THC processes. Corresponding to each issue, geothermal sites are listed that may, upon further evaluation, provide added confidence in modeling thermally coupled processes at Yucca Mountain by using approaches suggested in column 4 of the table.

The capabilities and limitations of geochemical modeling codes, such as the solubility, speciation, and reaction-path code EQ3/6 (Wolery and Daveler, 1992), and thermodynamic databases have been tested by analyzing natural hydrothermal systems with mineralogical and environmental similarities to Yucca Mountain. One example is at the Yellowstone caldera, as discussed previously in the "Yellowstone as a Natural Analogue for Thermal-Hydrologic-Chemical Processes" section (Meijer, 1987). Results of the Carey and others' (1997) model of mineral evolution at Yucca Mountain compared favorably with earlier simulations by Meijer (1987).

In another study, Bruton and others (1995) cataloged a survey of literature and data for many geothermal fields as a means of selecting a field-analogue site for THC studies. The sites in their survey included many of the better-known geothermal fields: The Geysers in California; Krafla (and other geothermal areas) in Iceland; Cerro Prieto in Mexico; Valles caldera in New Mexico; Larderello, Italy; Long Valley caldera in California; Yellowstone in Wyoming; and the Wairakei and Ohaaki-Broadlands fields of New Zealand. Some fields were considered unsuitable because they are in rock types dissimilar to those at Yucca Mountain, lack sufficient data, have access problems, or are entirely liquid- or vapor-dominated fields. The geothermal system at Wairakei was endorsed by the Yucca Mountain Project as the site most amenable to the study of THC processes because it had the greatest number of features similar to Yucca Mountain (Bruton and others, 1995), possessed logistic practicalities, and had the potential for collaborative research.

EQ3/6 was used to simulate mineral/fluid relations in Wairakei and other New Zealand geothermal fields (Glassley and Christensen, 1992; Bruton and others, 1993; Bruton, 1995). Comparisons between observed mineral assemblages and model simulations of equilibria were used to evaluate the thermodynamic database for various environmental conditions encompassing the possible range of temperatures and water conditions anticipated in a Yucca Mountain repository system. The results of these modeling studies are generally consistent with observed vein and matrix mineral equilibria at Wairakei for fluids at temperatures above $240^{\circ} \mathrm{C}$. Field data and model results both indicate that stable mineral assemblages can be significantly affected by small differences in fluid chemistry, temperature, or pressure. Comparison of laboratory data with field data from natural hydrothermal waters at Wairakei for amorphous silica precipitation has shown that significant discrepancies exist between results obtained with different test conditions (Carroll and others, 1995, 1998). Rates measured in the field were 400 times faster than those obtained in laboratory measurements. Silica precipitation under repository conditions at Yucca Mountain could exhibit rate behavior somewhere in the range between the laboratory and field experiments.

The results of these studies emphasize two points necessary for use of geothermal systems in model validation. First, the natural systems need to be thoroughly understood and quantitatively characterized if rigorous testing of simulations is to be completed. Second, simulations need to be capable of providing predictive results that can be tested in an active field setting. Thus, the chemical and hydrological features associated with actively evolving systems need to be amenable to measurement and study if kinetically controlled systems are to be rigorously simulated.

\section{Summary of Coupled Processes Analogues}

Geothermal systems illustrate a variety of THC processes that are relevant to Yucca Mountain. Yellowstone and other geothermal systems in welded ash-flow tuffs or other low-permeability rocks indicate that fluid flow is controlled by interconnected fractures. Alteration in low-permeability rocks is typically focused along fracture flow pathways. Only a small portion of the fracture volume needs to be sealed by precipitated minerals to retard fluid flow effectively. The main minerals predicted to precipitate in the near field of the proposed Yucca Mountain repository are amorphous silica and calcite, which also commonly form as sealing minerals in geothermal systems. Sealing in geothermal fields can occur over a relatively short timeframe (days to years). The unsaturated conditions, lower temperatures, and much lower fluid-flow rates predicted for the Yucca Mountain system, in comparison to geothermal systems, should result in less extensive water/ rock interaction than is observed in geothermal systems. Fracturing and sealing occur episodically in geothermal systems. Most mineralization at Yucca Mountain is predicted to occur soon after waste emplacement (1,000-2,000 years) when temperatures would reach boiling (for the higher-temperature operating mode) above the emplacement drifts.

As discussed, THC processes are expected to have a much smaller effect on hydrogeological properties at Yucca Mountain than what is observed at Yellowstone. However, development of a heat pipe above emplacement drifts at Yucca Mountain under a higher-temperature operating mode could lead to increased chemical reaction and transport in the near field. Reflux and boiling of silica-bearing fluids within the near field at Yucca Mountain could cause fracture plugging, thus changing fluid flow paths.

Geochemical modeling of fluid compositions has been used to successfully predict observed alteration mineral assemblages at Yellowstone. THC simulations conducted to date for the proposed Yucca Mountain repository indicate that only small reductions in fracture porosity (4-7 percent) 
Table 14. Application of geothermal field information as analogues to coupled processes anticipated at the proposed Yucca Mountain, Nevada, repository.

[The following sites have (a) similar water chemistry to Yucca Mountain, (b) similar geology to Yucca Mountain, and (or) (c) similar alteration mineralogy to Yucca Mountain: Larderello (Italy)—b, possibly c; Yellowstone (Wyoming)—a,b,c; Fenton Hill (New Mexico)—b; Dixie Valley (Nevada) — c; Wairakei (New Zealand)—a,b,c; Broadlands (New Zealand)—a,b,c; Long Valley (California)—a,b, possibly c]

\begin{tabular}{|c|c|c|c|}
\hline Yucca Mountain issue & Geothermal analogue & Potential sites & Possible approach \\
\hline $\begin{array}{l}\text { Multiphase flow (liquid, vapor, } \\
\text { gas) }\end{array}$ & $\begin{array}{l}\text { Multiphase flow } \\
\text { (liquid, vapor, gas) }\end{array}$ & All & $\begin{array}{l}\text { Numerical modeling, conducing } \\
\text { and reviewing geothermal } \\
\text { postaudits }\end{array}$ \\
\hline Hydrologic properties & Hydrologic properties & $\begin{array}{l}\text { Kamojang (Indonesia), Tianjin (China), } \\
\text { Wairakei (New Zealand), Oguni } \\
\text { (Japan), Sumikawa (Japan) }\end{array}$ & Numerical modeling \\
\hline $\begin{array}{l}\text { Fracture network } \\
\text { permeability }\end{array}$ & $\begin{array}{l}\text { Fracture network } \\
\text { permeability }\end{array}$ & $\begin{array}{l}\text { All modeled fractured sites (for example, } \\
\text { Cerro Prieto [Mexico], Krafla [Iceland], } \\
\text { Matsukawa [Japan], Sumikawa [Japan], } \\
\text { Olkaria [Kenya], Wairakei [New } \\
\text { Zealand], The Geysers [California], } \\
\text { Kamojang [Indonesia], Larderello } \\
\text { [Italy]) }\end{array}$ & Use of reservoir model calibrations \\
\hline Fracture/matrix interaction & $\begin{array}{l}\text { Fracture-matrix } \\
\text { interaction }\end{array}$ & $\begin{array}{l}\text { Yellowstone (Wyoming), Long Valley } \\
\text { (California), Olkaria (Kenya), Dixie } \\
\text { Valley (Nevada) }\end{array}$ & $\begin{array}{l}\text { Field and laboratory experiments, } \\
\text { evaluating geothermal tracer- } \\
\text { study results evaluations }\end{array}$ \\
\hline $\begin{array}{l}\text { Heat pipes, boiling, and } \\
\text { condensation }\end{array}$ & $\begin{array}{l}\text { Heat pipes, boiling, } \\
\text { and condensation }\end{array}$ & $\begin{array}{l}\text { The Geysers (California), Kamojang } \\
\text { (Indonesia), Matsukawa (Japan), } \\
\text { Larderello (Italy) }\end{array}$ & $\begin{array}{l}\text { Numerical modeling to extend } \\
\text { measurements }\end{array}$ \\
\hline $\begin{array}{l}\text { Mineral precipitation and } \\
\text { dissolution }\end{array}$ & $\begin{array}{l}\text { Mineral precipitation } \\
\text { and dissolution }\end{array}$ & $\begin{array}{l}\text { Larderello (Italy), Fenton Hill (New } \\
\text { Mexico), Dixie Valley (Nevada), } \\
\text { Wairakei (New Zealand), Broadlands } \\
\text { (New Zealand), Long Valley } \\
\text { (California) }\end{array}$ & $\begin{array}{l}\text { Laboratory experiments, analogue } \\
\text { site investigation, numerical } \\
\text { modeling }\end{array}$ \\
\hline $\begin{array}{l}\text { Thermal-hydro-mechanical } \\
\text { effects }\end{array}$ & $\begin{array}{l}\text { Subsidence, flow } \\
\text { changes }\end{array}$ & $\begin{array}{l}\text { Wairakei (New Zealand) Bulalo } \\
\text { (Philippines), Krafla (Iceland) }\end{array}$ & Numerical modeling \\
\hline
\end{tabular}


and permeability (less than 1 order of magnitude) will occur in the near field as a result of amorphous silica and calcite precipitation. Changes in permeability, porosity, and sorptive capacity are expected to be relatively minor at the mountain scale, where thermal perturbations will be reduced. This THC result applies to both the higher and lower temperature (subboiling) operating modes. These predicted changes in hydrogeological properties should not significantly affect repository performance.

At the Paiute Ridge intrusive complex, the Papoose Lake Sill intruded into Rainier Mesa Tuff, and the resulting hydrothermal effects were characterized by low-temperature alteration of glass to clinoptilolite and opal, similar to the alteration assemblage present at Yucca Mountain. Hydrothermal alteration was confined to a narrow zone close to the sill/ host-rock contact. The pervasive opal veins and associated secondary minerals (for example, clinoptilolite, calcite, cristobalite) appear to have reduced matrix or fracture permeability in the immediate vicinity of the basaltic intrusion. In another study, no evidence of alteration was observed at the contact between the Banco Bonito obsidian flow and underlying tuff. Similarly, no alteration was noted at the contact between the Grants Ridge basalt intrusion and surrounding host rock. Both of these locations are in unsaturated environments.

Preliminary results of a one-dimensional THC dualcontinuum model of the interaction of country rock with heat released from an intrusive complex emplaced above the water table demonstrated the possibility of forming opal-filled veins with the source of silica derived from the matrix of the host rock. However, because of the irregularities caused by kinetic barrier effects associated with reaction of glass, it is important to compare and contrast a number of different sites to be able to derive general conclusions regarding mineral alteration.

\section{Analogues to Saturated-Zone Transport}

This section discusses analogues to transport in a saturated environment under oxidizing conditions, such as those at Yucca Mountain. Most of the analogue sites studied to date in saturated environments are present in rock types dissimilar to the saturated zone at Yucca Mountain; for example, fractured crystalline granite or gneiss, or sandstone. All are in uranium ore deposits and REE deposits. The sites are relevant to the degree that they demonstrate something about the potential transport of radionuclides in particular environments. Sites in strongly reducing environments, such as that at Tono, Japan, have little relevance to groundwater conditions at Yucca Mountain, although the Tono site provides insights about uranium retention at the edge of a fault zone. The uranium deposits that display a redox front (for example, Poços de Caldas, Brazil, and Palmottu, Finland), provide insights into matrix diffusion (El Berrocal, Spain), or that are subject to weathering and periodic influx of water (for example, Alligator Rivers in Australia, discussed previously in the "Koongarra Uranium
Deposit, Alligator Rivers, Northern Territory, Australia" section, and Bangombé, Gabon) are somewhat more relevant. The saturated-zone transport analogues that may be most relevant to Yucca Mountain are the anthropogenic analogues discussed later in this section that include uranium mill tailing sites in Colorado, colloidal transport at the NTS, and retardation of radionuclides at INL.

\section{Conceptual Model of Saturated-Zone Flow and Transport}

The water table near the proposed Yucca Mountain repository block has an elevation of about $730 \mathrm{~m}$, more than $300 \mathrm{~m}$ below the proposed repository horizon. Water infiltrating the unsaturated zone becomes recharge to the regional flow system. Water moves generally southeast beneath the site before flowing south out of the volcanic rocks and into the thick valley fill of the Amargosa Valley. The hydraulic gradient is extremely low (about 0.0001; Fridrich and others, 1994) downgradient from Yucca Mountain, so that traveltime of groundwater may be long. This is supported by isotopic data that indicate a Pleistocene age for Yucca Mountain groundwaters (Benson and McKinley, 1985). Near Yucca Mountain, volcanic rocks as much as several thousand meters thick overlie the Paleozoic and older rocks of the region. Their hydrologic properties change substantially over short distances, producing a complex hydrogeology. The volcanic-rock section becomes thinner to the south and is a lesser component of the saturated-zone flow system in Amargosa Valley, where the major aquifer consists of Quaternary-Tertiary heterogeneous valley-fill deposits.

The dominant regional aquifer is the Paleozoic carbonate aquifer, consisting of marine limestones, dolomites, and minor clastic sediments thousands of meters thick, which directly underlie the volcanic rocks at Yucca Mountain. Fractures enlarged by dissolution provide the large permeability associated with this aquifer, which underlies most of the Ash Meadows and part of the Alkali Flat-Furnace Creek subbasins that make up the regional saturated-zone flow system. In the vicinity of Yucca Mountain, the carbonate aquifer is not tapped as a source of groundwater because of its great depth. The hydraulic head in the carbonate aquifer is approximately $20 \mathrm{~m}$ greater than that in the overlying volcanic rocks (Luckey and others, 1996), and there is some evidence for upward leaking along block-bounding faults (Stuckless and others, 1991; Bredehoeft, 1997). Luckey and others (1996) divided the volcanic rocks below the water table into four hydrogeologic units. From top to bottom, these are the upper volcanic aquifer, the upper volcanic confining unit, the lower volcanic aquifer, and the lower volcanic confining unit. The upper volcanic aquifer is composed of the Topopah Spring Tuff, which occupies the unsaturated zone near the proposed repository but is present beneath the water table to the east and south of the proposed repository and in Crater Flat. The upper volcanic 
confining unit includes the Calico Hills Formation and the uppermost, unfractured part of the Prow Pass Tuff in areas where they are saturated (see fig. 2 for stratigraphic units).

The lower volcanic aquifer includes most of the Crater Flat Group (Luckey and others, 1996), and the lower volcanic confining unit includes the lowermost Crater Flat Group and deeper tuffs, lavas, and flow breccias. The upper volcanic aquifer underlying Yucca Mountain is generally productive and provides groundwater for the site. The main distinction between saturated zone volcanic aquifers and confining units is that the aquifers tend to be more welded and contain more permeable fractures than the confining units. However, alteration of the nonwelded tuffs to zeolites and clays, which reduces permeability, is more pronounced at depth. The increase of pressure with depth also reduces fracture permeability, such that the overall tendency is toward decreased permeability with depth, even in aquifers.

The chemistry of saturated-zone waters beneath Yucca Mountain (Oliver and Root, 1997) reflects processes that affected these waters as they flowed to the Yucca Mountain area from recharge areas to the north (McKinley and others, 1991). In general, they are dilute sodium bicarbonate waters that are neutral to mildly alkaline and mildly oxidizing. Similarities between the composition of saturated-zone waters in the recharge areas north of Yucca Mountain and those beneath Yucca Mountain indicate that water compositions primarily reflect water/rock interactions in the recharge areas. After reaching the water table, flow continues generally to the southeast away from the proposed repository area. Most of the saturated flow is in zones with enhanced permeabilities caused by fractures.

Retardation processes such as sorption, matrix diffusion, and dispersion also function in the saturated zone. Water may contact sorbing zeolites in the Calico Hills Formation and Prow Pass Tuff, and, as in the unsaturated zone, fracture minerals may have a significant effect on both flow and transport. Fracture-filling minerals in the saturated zone include smectite clay, manganese oxide minerals, hematite, quartz, opal-CT (cristobalite-tridymite), calcite, and clinoptilolite and mordenite, the same zeolites that characterize the altered rock matrix below the water table (Carlos and others, 1995; Carey and others, 1997). Laboratory experiments have shown that fractures containing smectite, manganese oxides, and calcite have particular affinity for plutonium retention (U.S. Department of Energy, 1998a, section 2.2.5.2). Thus, analogues related to transport through saturated, oxidizing environments need to consider the function of fracture-filling minerals such as these in retarding the migration of radionuclides.

\section{Performance Assessment Insights from Poços de Caldas, Brazil}

The Poços de Caldas plateau, located in the state of Minas Gerais in Brazil, has been investigated for about 20 years because of its high levels of natural radiation. The Morro do Ferro site, in particular, has been identified as among the most naturally radioactive places on Earth (Miller and others, 1994). The area was identified as a promising site for a natural analogue study, and a 3-year, multinational project was undertaken (1986-89). The project generated a series of technical reports that were published in 15 volumes and summarized by Chapman and others $(1991,1992)$. The project aims were focused on PA requirements for a geological nuclear-waste repository, specifically requirements to understand groundwater interactions with colloids and radionuclides, solubility and speciation of elements, and validation of equilibrium thermodynamic codes and databases used to evaluate water/rock interactions and to model the migration of radionuclides under hydrothermal conditions (Smellie and others, 1989).

The Poços de Caldas caldera is a ring structure approximately $53 \mathrm{~km}$ in diameter (fig. 104), composed of alkaline volcanic and plutonic rocks, mainly phonolites, carbonatites, and nepheline syenites of Cretaceous age (Schorscher and Shea, 1991; Miller and others, 1994). Two major hydrothermal events that affected the caldera led to widespread argillization (alteration to clay minerals) and zeolite formation. Local magmatic brecciation occurred in association with intense hydrothermal potassium- and sulfur-rich alteration (Schorscher and Shea, 1991). The second hydrothermal event was more localized than the first and is believed to be responsible for the formation of the numerous orebodies within the caldera complex. The mineralizing events ended about $76 \mathrm{Ma}$ (Schorscher and Shea, 1991).

Two of these orebodies were the focus of the Poços de Caldas natural analogue study: (1) the Osamu Utsumi Mine, which is a uranium orebody with subsidiary thorium, zirconium, and lanthanide enrichment; and (2) Morro do Ferro, which, in contrast, is a thorium and lanthanide element orebody, with subsidiary uranium. The Osamu Utsumi uranium mine is known for its well-developed redox front within the uranium ore (Smellie and others, 1989). At Osamu Utsumi, research was directed toward understanding the behavior of natural decay-series nuclides at the redox front, whereas at Morro do Ferro, attempts were made to relate the distributions of thorium, uranium, and light REEs to the groundwater flow patterns in order to evaluate the extent of mobilization of these elements (MacKenzie and others, 1991). In addition to the analytical aspects of the study, much attention was paid to testing thermodynamic solubility and speciation codes and databases in blind predictions at both sites.

Groundwaters in the Poços de Caldas area typically have low concentrations (less than $1 \mathrm{mg} / \mathrm{L}$ ) of colloids (Miekeley and others, 1989, 1991a). Most of the colloids consist of iron and organic species. Only minor amounts of uranium are associated with colloids, but greater amounts of thorium and REEs are transported in the colloidal fraction. The suspended particle concentration is 5-10 times greater at Morro do Ferro than at Osamu Utsumi, but there appears to be little thorium transport at Morro do Ferro, either by colloids or true solution. Filtration of particulate material, even in the highly fractured and porous rocks of the Poços de Caldas plateau, seems to be 


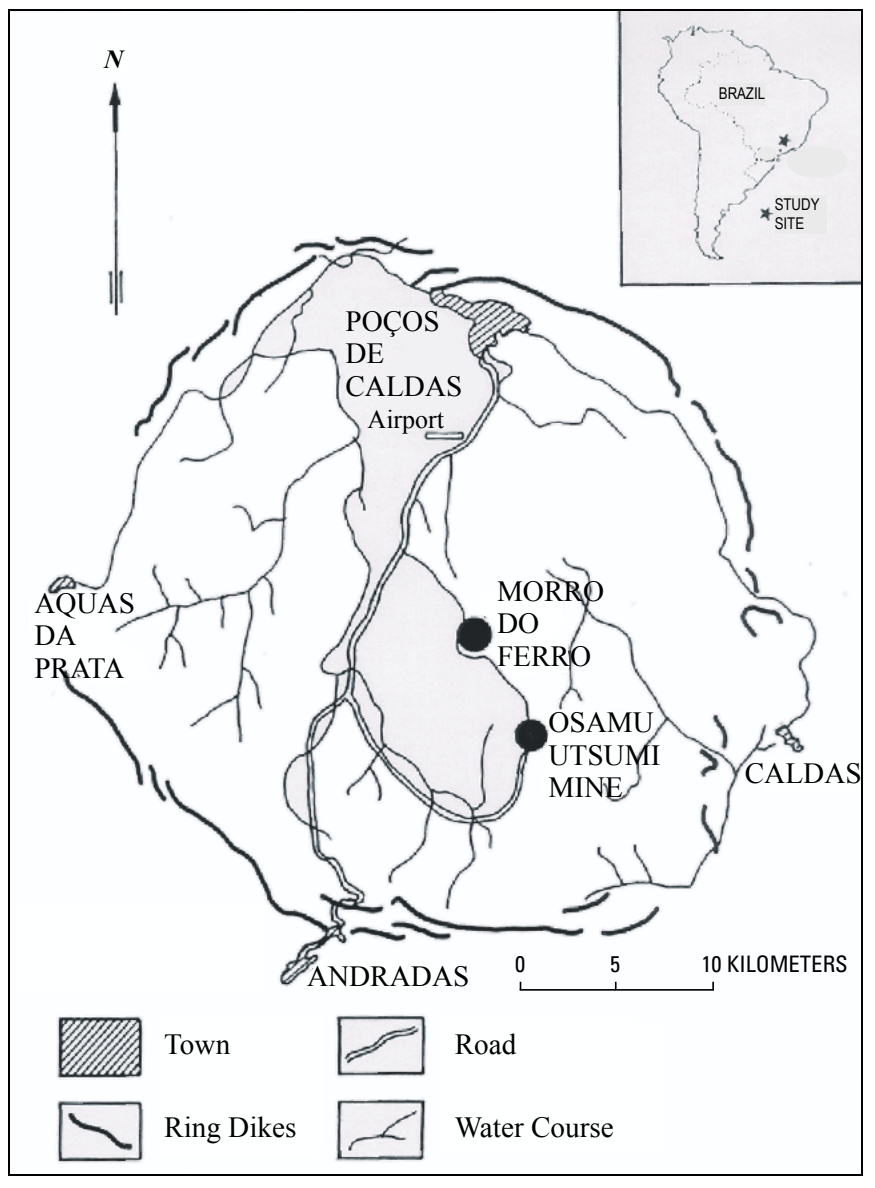

Figure 104. Location map of the Osamu Utsumi Mine and Morro do Ferro study sites at Poços de Caldas, Minas Gerais, Brazil (Chapman and others, 1991).

an efficient process (Smellie and others, 1989). The colloidal material acts as a largely irreversible sink for many elements (especially as they are immobile).

Microbial activity is important for the pyrite oxidation at Osamu Utsumi and may be responsible for uraninite mobilization and reprecipitation at the redox front. At Poços de Caldas, microbes were observed in all core and groundwater samples, independent of depth (West and others, 1989, 1990). West and others (1989) reported that microbes are enhancing the supply of oxidants from the rock mass, thereby accelerating the rate of advance of the redox front. This could explain the observation that the redox front is moving faster than would be expected, simply on the basis of dissolved oxygen concentration.

The Poços de Caldas project, in common with other natural analogue studies, illustrates the complexity of natural groundwater systems. In particular, it highlighted the importance of amorphous phases in suspension, or as coatings on rock, as the principal reactive surfaces for many trace elements in solution. The presence of amorphous phases tends to reduce the concentration and mobility of trace elements in solution. Some of the fixing processes appear to be irreversible over long time scales, which tends to make these models conservative compared to reversible sorption used in PA models (Chapman and others, 1991).

Study of the redox front provided direct evidence of the operation of flow channeling in fractures and solute transport in the rock matrix as the key controls on the shape and movement of these fronts. A consistent picture emerged of slow front movement and solute transport over the front dominated by diffusion. The front is active in retarding a wide spectrum of trace elements.

\section{Uranium Retardation under Oxidizing Conditions at Coles Hill, Virginia}

Studies of the weathered zone overlying the Coles Hill, Virginia, uranium deposit indicate that the natural attenuation of uranium in oxidizing environments may take place in groundwaters with low dissolved carbonate/phosphate ratios (Jerden and Sinha, 2001). At this site, uranium concentrations are buffered to values less than $20 \mathrm{ppb}$ due to the precipitation of low-solubility U(VI) phases. The attenuation mechanism involves the transformation of U(IV) coffinite, the primary ore, to U(VI) phosphate minerals. Above the water table in the soil zone, where phosphate minerals are rare, uranium is primarily associated with an aluminum phosphate of the crandallite mineral group and with phosphorus sorbed to ferric hydroxide mineral coatings. Experiments demonstrated that the transformation of U(IV) to U(VI) assemblages could occur in less than 2 months, given high enough phosphate levels. Model predictions agreed with the field observations: for oxidizing systems with relatively low dissolved carbonate/ phosphate ratios, uranium may be immobilized by secondary uranium phosphate precipitation and sorption processes. It is unlikely that low dissolved carbonate/phosphate ratios would occur in bedrock aquifers at Yucca Mountain, but if use of phosphate-containing fertilizer contaminates the alluvial aquifer in Amargosa Valley, the carbonate/phosphate ratio could be lowered, making this a more analogous situation for Yucca Mountain.

\section{Matrix Diffusion Analogues: El Berrocal in Spain, Palmottu in Finland, and Others}

El Berrocal is an area about $100 \mathrm{~km}$ southwest of Madrid, Spain. The El Berrocal granite forms a large hill and contains a number of small, vein-hosted uranium orebodies, one of which was the focus of analogue investigations (fig. 105). The El Berrocal granite has a uranium content that averages $16 \mathrm{mg} / \mathrm{kg}$, with primary uranium occurring as accessory uraninite dispersed in the granite matrix (De la Cruz and others, 1997). Postemplacement hydrothermal alteration mobilized some of the uranium, thorium, and REEs from the granite and 
redeposited them in a 2-m-wide, steeply dipping quartz vein more than $1 \mathrm{Ma}$ (Rivas and others, 1998). Erosion and weathering exposed the vein-hosted mineralization, causing further elemental mobilization and transport. The groundwaters contain moderate to low concentrations of uranium $\left(4 \times 10^{-9}\right.$ to $8 \times 10^{-6}$ Molar) (De la Cruz and others, 1997; this converts to $9.52 \times 10^{-4}$ to $1.9 \mathrm{mg} / \mathrm{L}$ ). Uranium carbonate complexes are the dominant species in oxidized zones, whereas U(IV) hydroxides dominate in reduced zones.

The multinational El Berrocal project had the objective of investigating these present-day, low-temperature processes, as well as the processes causing elemental retardation in the granite, to provide field-derived evidence for radionuclide behavior in the geosphere that could be used to constrain transport models for radionuclide release from a geological radioactive waste repository. Considerable effort was made to understand coprecipitation processes in order to improve thermodynamic models and databases for PA. The results of the project indicated that mobilized uranium and thorium tended to be associated by sorption and coprecipitation with certain fracture-coating minerals, notably iron oxyhydroxides and calcite. Enrichment of uranium by a factor of as much as 6 was observed, and as much as 3 for thorium, relative to the unaltered granite (Miller and others, 2000).

The Palmottu, Finland, uranium-thorium deposit in saturated, fractured gneisses and migmatites was the location of a multinational matrix diffusion study (Valkiainen, 1989). The deposit is as much as $15 \mathrm{~m}$ thick, $400 \mathrm{~m}$ long, and $300 \mathrm{~m}$ deep, but it is discontinuous in the form of uraniferous pegmatites and veins (fig. 106). The principal ore mineral is disseminated grains of uraninite, thinly coated with coffinite. The purpose of the study was to improve the scientific basis of PA in fractured, crystalline bedrock under groundwater-saturated conditions. Primary results of the Palmottu natural analogue study are given in project reports by Blomqvist and others (1987, 1991, 1998) and Jaakkola and others (1989). Summaries of the results from the radionuclide migration investigations are given in papers by Ruskeeniemi and others (1989), Suutarinen and others (1991), and Suksi and others (1991).

Radionuclide concentration profiles from a fracture in the rock matrix at Palmottu were examined in three cores collected from holes 304, 346, and 356 drilled perpendicular to strike of the orebody (Blomqvist and others, 1995). Alpha autoradiography showed the distribution of radionuclides decreasing from the fracture surface into the rock matrix. Based on the findings of the three core samples, the profile of decreasing radioactive content could be traced more than $100 \mathrm{~mm}$ into the rock (Blomqvist and others, 1995). The radionuclides were associated with clay particles and iron oxyhydroxides that had formed from alteration of feldspar and biotite grains. Selective leaching experiments showed that most of the radionuclides that had diffused into the rock matrix were only loosely bound to the iron-rich phases. In some samples, activity correlated to microfractures indicated that fluid flow was channeled even at the microscopic level, whereas in another sample, diffusion was predominantly along grain boundaries. This supports the hypothesis that physical disruption around a fracture may enhance transport into the rock matrix (Blomqvist and others, 1995).

Sorption onto fracture coatings, particularly calcite, efficiently retards uranium transport in fractures at Palmottu. Uranium concentrations in calcite as much as $1,600 \mathrm{ppm}$ were measured (Rasilainen and others, 1991). The long retention time of uranium in calcite, determined by $\mathrm{U}$-series disequilibrium measurements, was also recognized. Uranium-234/ uranium-238 in the dissolved fraction increases with depth from a value of nearly 1.0 , whereas ${ }^{234} \mathrm{U} /{ }^{238} \mathrm{U}$ in the particulate fraction shows a slight (though less substantial) decrease with depth. The ${ }^{234} \mathrm{U} /{ }^{238} \mathrm{U}$ ratios of extracted phases indicate limited mixing of groundwaters in the study area (Blomqvist and others, 1995).

A comprehensive investigation of matrix diffusion processes compared granite samples from a number of locations: the El Berrocal natural analogue site in Spain, the Stripa test mine in Sweden, the Whiteshell Underground Research Laboratory (URL) in Canada, and the Grimsel Test Site in Switzerland (Heath, 1995). Each sample was collected from close to a hydraulically active fracture, cut to provide a series of slices parallel to the fracture, and characterized in detail. For all samples, the region of enhanced uranium mobility correlated with the zone of microstructural alteration in the rock adjacent to the fractures. The actual depth of enhanced uranium mobility varied from site to site; for example, enhanced uranium mobility extended $35 \mathrm{~mm}$ in the shallow El Berrocal granite but extended $50 \mathrm{~mm}$ in both the altered and unaltered URL granite. Interpretation of the El Berrocal core sample data indicated that not only was matrix diffusion limited to the first few tens of millimeters of rock adjacent to the fracture surface, but that, also within the rock matrix, the mobilized uranium was associated with secondary phases and located in microfissures along grain boundaries (Heath, 1995). There was a close correlation between the distribution of the mobilized uranium, the redox conditions, and the isotopic disequilibrium.

Heath (1995) concluded from the combined data that a complex combination of matrix diffusion and chemical interaction had occurred between the rock and the mobile phases rather than matrix diffusion alone. From this conclusion, Heath suggested the possibility that retardation processes that rely on matrix diffusion mechanisms may make little overall contribution to performance in a crystalline rock mass. However, the data from El Berrocal provide good evidence that, once radionuclides migrate into the rock matrix from the flowing fracture, they are effectively immobilized irrespective of the process involved.

\section{Uranium Retention Under Variable Redox Conditions: Bangombé in Gabon, and Olden Granite in Sweden}

The Bangombé uranium deposit is located approximately $25 \mathrm{~km}$ west-northwest of Franceville, Gabon, and is near the 


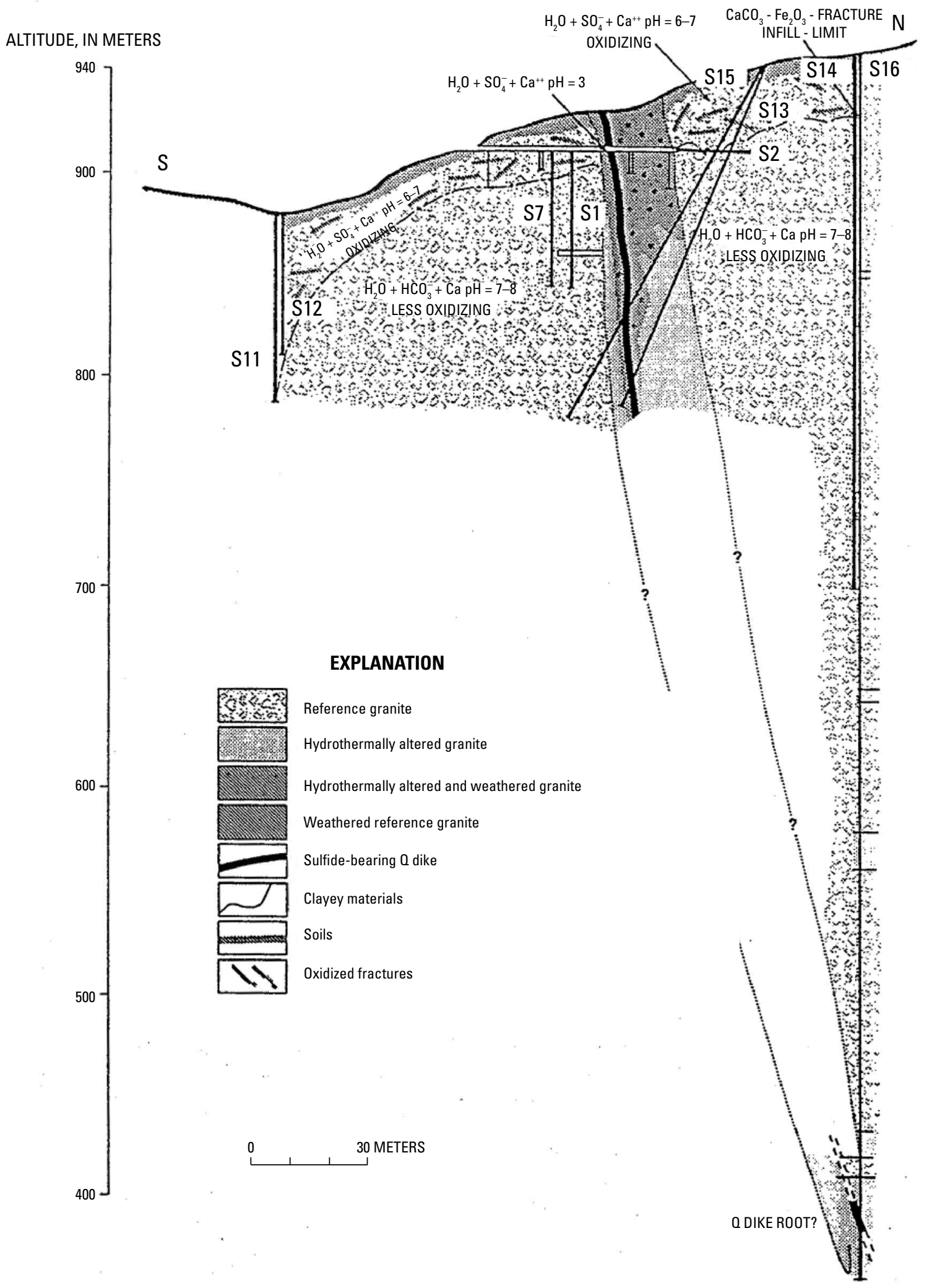

Figure 105. North-south cross section of the El Berrocal, Spain, granite-uranium-quartz vein system and location of selected boreholes (Rivas and others, 1998). 


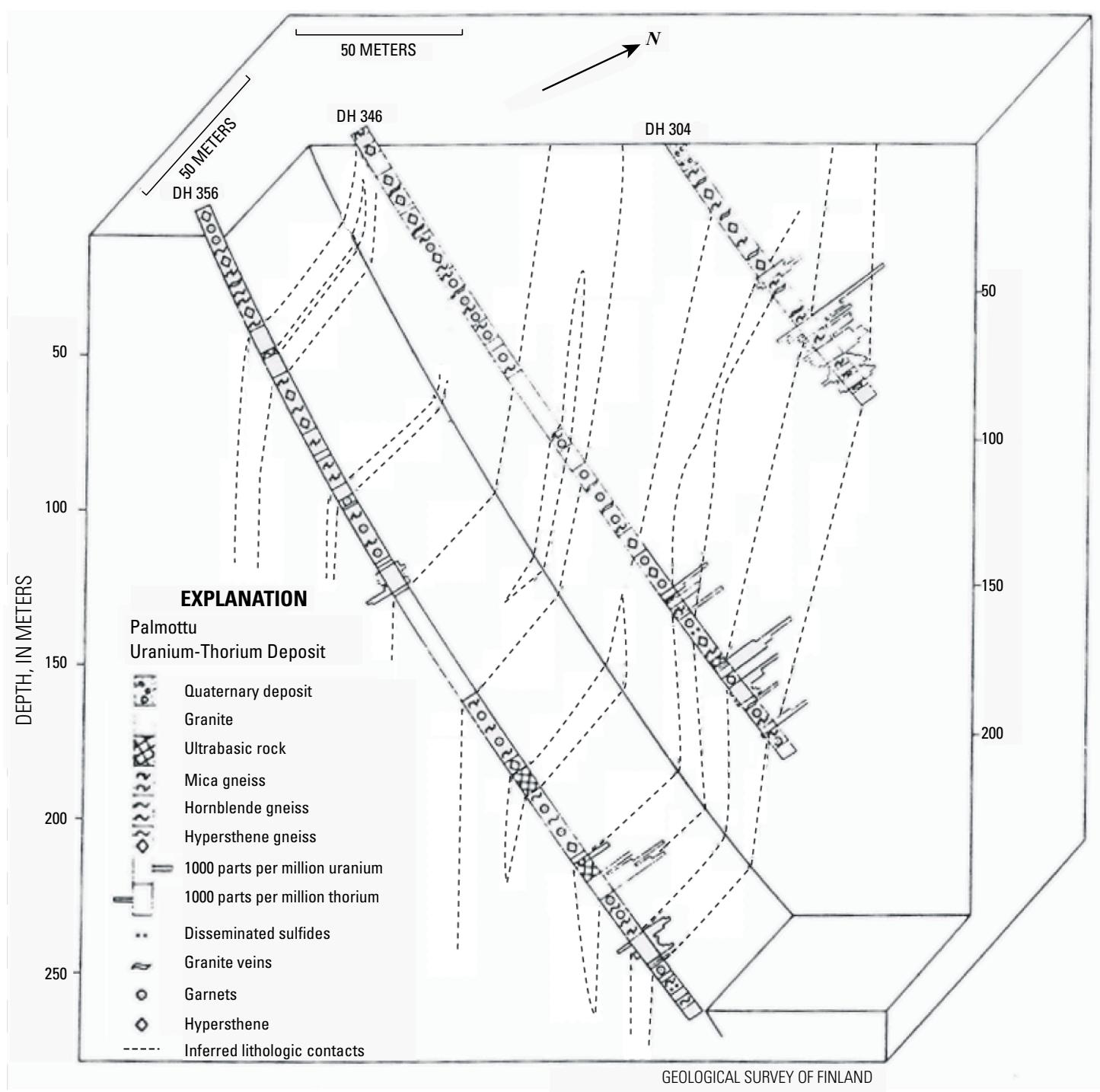

NOTE: Compiled from drillholes (DH) 304, 346, and 356.

Figure 106. Lithology at Palmottu, Finland, with respective uranium and thorium contents (Rasilainen and others, 1991).

Oklo uranium deposits. Like the Oklo deposits, the Bangombé deposit also experienced natural fission. It differs from the Oklo deposits, however, in that it is strongly affected by near-surface ferralitic (iron-rich) weathering (Bros and others, 1998). The Bangombé reactor zone consists of an approximately 5 -cm-thick reactor core, overlain by as much as a 0.3-m-thick hydrothermal clay mantle (Bros and others, 1993; Gauthier-Lafaye and Weber, 1989). Immediately above this mantle lie black shales and green pelites of the FB-formation (fig. 107).
The Bangombé uranium deposit is located within the saturated zone (groundwater is within 4-6 m of the land surface in the vicinity of the reactor zone). Smellie and others (1993) and Gauthier-Lafaye and others (1996) interpreted the deposit as being located in a groundwater discharge area (fig. 108). These authors concluded that preservation of the Bangombé mineralization is attributable to the discharging groundwater that is less oxidizing than surface waters and that the green pelites act not only as a potential hydraulic barrier, preventing large-scale penetration of surface and near-surface oxidizing waters from reaching the mineralization, but also as 


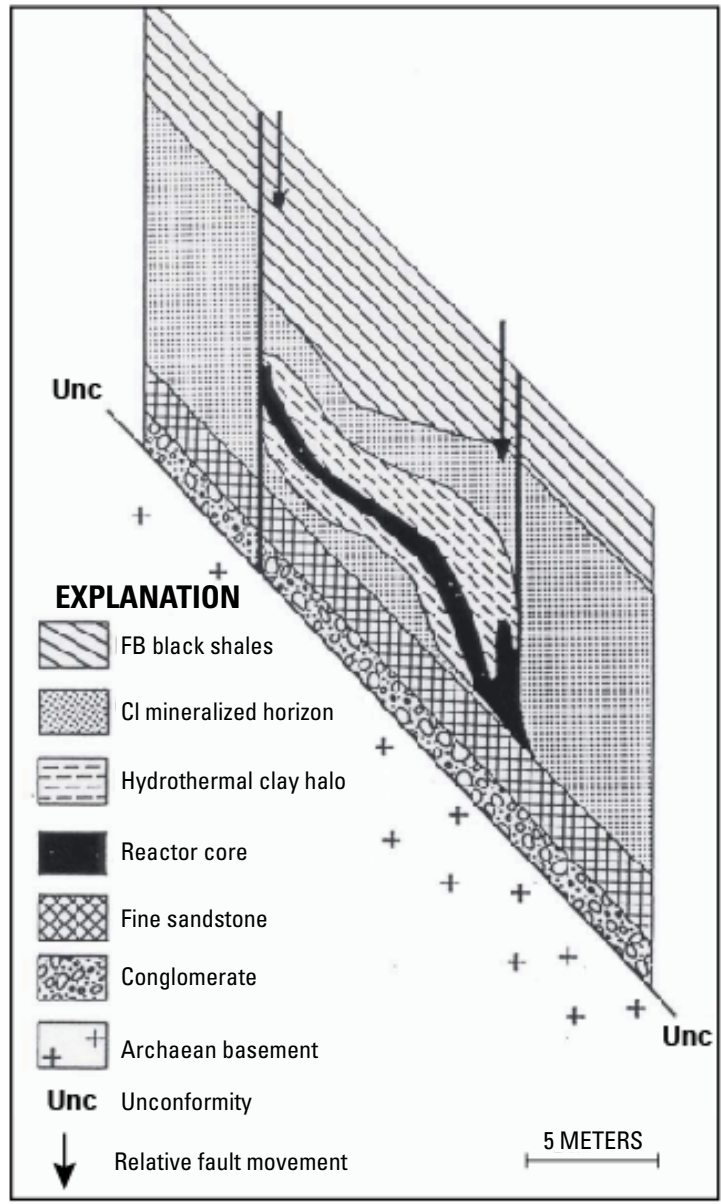

Figure 107. Idealized cross section of a fossil reactor zone at Oklo and Bangombé, Gabon (Smellie, 1995).

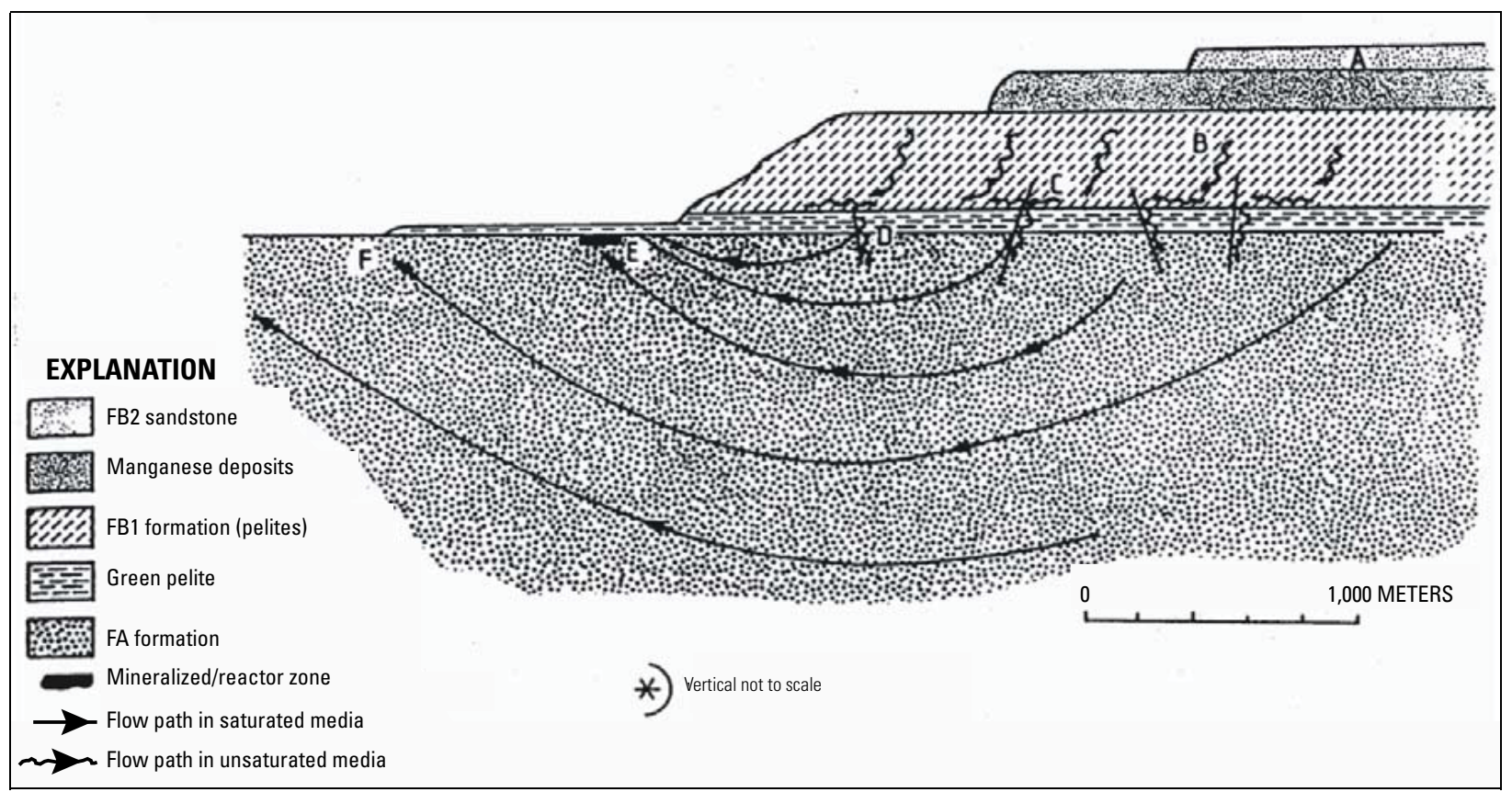

Figure 108. Schematic representation of groundwater flow paths in the Bangombé area, Gabon (Smellie and others, 1993). Letters A-F refer to points along flow path. Arrows along curved lines refer to flow paths in saturated media. Arrows along wavy lines refer to flow paths in unsaturated media. 
a trap for the uranium-rich solutions reaching the surface. In short, at the Oklo and Bangombé uranium deposits, retention of uranium and fission products in the reactor zone appears to rely on reducing conditions in groundwater, sequestration within small uraninite grains, and hydraulic barrier properties of the green pelite.

The Olden Granite, located in central Sweden on the Norway border, was intruded as a high-uranium granite approximately 1,650 Ma (Stuckless and Troeng, 1984). Caledonian thrusting created fracture zones, which subsequently were mineralized with uraninite and minor coffinite. A lead-lead isochron utilizing both mineralized and unmineralized wholerock samples yields an age of $420 \pm 1 \mathrm{Ma}$. The lack of scatter about the isochron indicates that lead was well homogenized during the Caledonian event and that little, if any, mobility of lead has occurred since. Microprobe analyses of the uraninite show some areas of incipient alteration, which is reflected in a small amount of scatter about a chord on Concordia. The chord has intercepts of approximately 1,650 and $420 \mathrm{Ma}$, with samples plotting both above and below Concordia. The Caledonian event apparently caused uranium loss from some samples of 30-70 percent and uranium gain in the mineralized samples of 300-50,000 percent. For most of its history, the granite must have behaved as a closed system, probably because of deep burial. Within the last few million years (Stuckless and Troeng, 1984), exposure to oxidizing conditions caused some visible alteration of uraninite. In addition, some secondary uranium minerals formed, and there is commonly pronounced disequilibrium within the uranium decay chain for both mineralized and unmineralized samples, as indicated by the difference between uranium content and radium equvalent uranium (Stuckless and Ferreira, 1976).

\section{Retention of Uranium Along a Fault: Tono Mine, Japan}

The Tono region, located about $350 \mathrm{~km}$ southwest of Tokyo, is the site of Japan's most extensive uranium deposits. The largest, the Tsukiyoshi uranium orebody, has been the focus of most of the natural analogue studies in the area. This orebody has not been commercially exploited, and only one gallery, at a depth of $150 \mathrm{~m}$ below the ground surface, has been constructed. Thus, the orebody can be examined in a relatively undisturbed state. The Tsukiyoshi orebody is about $3.4 \mathrm{~km}$ long, between $300-700 \mathrm{~m}$ wide, and is $1-3 \mathrm{~m}$ thick (Ochiai and others, 1989). The primary, unoxidized uranium ore is composed of accumulations of coffinite and pitchblende, closely associated with pyrite, altered biotite, or bituminous plant materials, in fractured quartz grains, or on mineral grain boundaries (Yoshida, 1994). These associations indicate that uranium concentrations and fixation processes have a close relation to mineralogical phases controlling redox conditions. The secondary, oxidized uranium mineralization is composed of uranium-bearing autunite, zippeite, and uranocircite, in association with montmorillonite, limonite, and other minerals in oxidized zones. Rocks with a high uranium content have a higher permeability and sorption capacity than low uranium zones within the rock mass (Yoshida, Kodama, and Ota, 1994).

The orebodies at Tono lie in paleochannels in the unconformity between Cretaceous granitic basement rocks (the Toki Granite) and overlying Miocene lacustrine sediments of the Mizunami Group (fig. 109). The basement granitic rocks contain about $6 \mathrm{ppm}$ of uranium and are considered to be the source of the Tono uranium mineralization. The sandstones and mudstones at the unconformity (the Toki Lignite-bearing Formation) contain significant quantities of carbonaceous material and pyrite in a strongly reducing environment. The uranium mineralization itself is in conglomerate, sandstone, and the lignite-bearing formation. The uranium deposit, which is disseminated in the lowermost part of the Mizunami Group, is considered to have formed when uranium in the granite was dissolved into migrating pore fluids and then deposited under more reducing conditions in the lignite-bearing strata (Katayama and others, 1974).

Fission-track dating indicates that the ore deposit is about $10 \mathrm{Ma}$ (Ochiai and others, 1989). It was split into two sections, about 5-10 Ma, by the Tsukiyoshi fault, which has a vertical displacement of $30 \mathrm{~m}$ and does not continue upward into the youngest sedimentary rocks in the region, the Plio-Pleistocene Seto Group. Consequently, the Tsukiyoshi uranium deposit has been preserved despite fault movement, uplift, subsidence, denudation, deposition, and climatic and sea-level changes since its formation about $10 \mathrm{Ma}$.

Uranium-series nuclides $\left({ }^{238} \mathrm{U},{ }^{234} \mathrm{U}\right.$, and $\left.{ }^{230} \mathrm{Th}\right)$ in rock samples collected from different locations in the deposit were in nearly equilibrium states (Yusa and Yoshida, 1993). This indicates that these nuclides have been maintained in a closed system over a long time. It is considered that movement of uranium and thorium was confined within a range of a few centimeters (migrated from sediments into the fault gouge) for at least 1 m.y. (Yoshida,Yui, and Shibutani, 1994). However, it is possible that uranium was transported along the fault by oxidizing groundwater at a sufficiently rapid rate to prevent the development of ${ }^{234} \mathrm{U} /{ }^{238} \mathrm{U}$ disequilibrium. It can be inferred that the uranium ore deposit was preserved because a deep, chemically reducing geological environment with a minimal flow of groundwater was maintained for thousands of years (Iwatsuki and others, 1995; Shikazono and Utada, 1997).

The natural analogue studies at Tono are described by Yusa and Yamakawa (1992), Nohara and others (1992), Seo and Yoshida (1994), and Arthur and others (2006). Results of uranium-series disequilibrium studies (Nohara and others, 1992) indicate the following:

1. Reducing conditions were maintained for at least the last 1 m.y.

2. Although limited uranium migration has occurred along the fault, the greatest uranium migration occurred in the ore matrix, but this was limited to less than $1 \mathrm{~m}$ over the $1 \mathrm{~m} . \mathrm{y}$. 
A
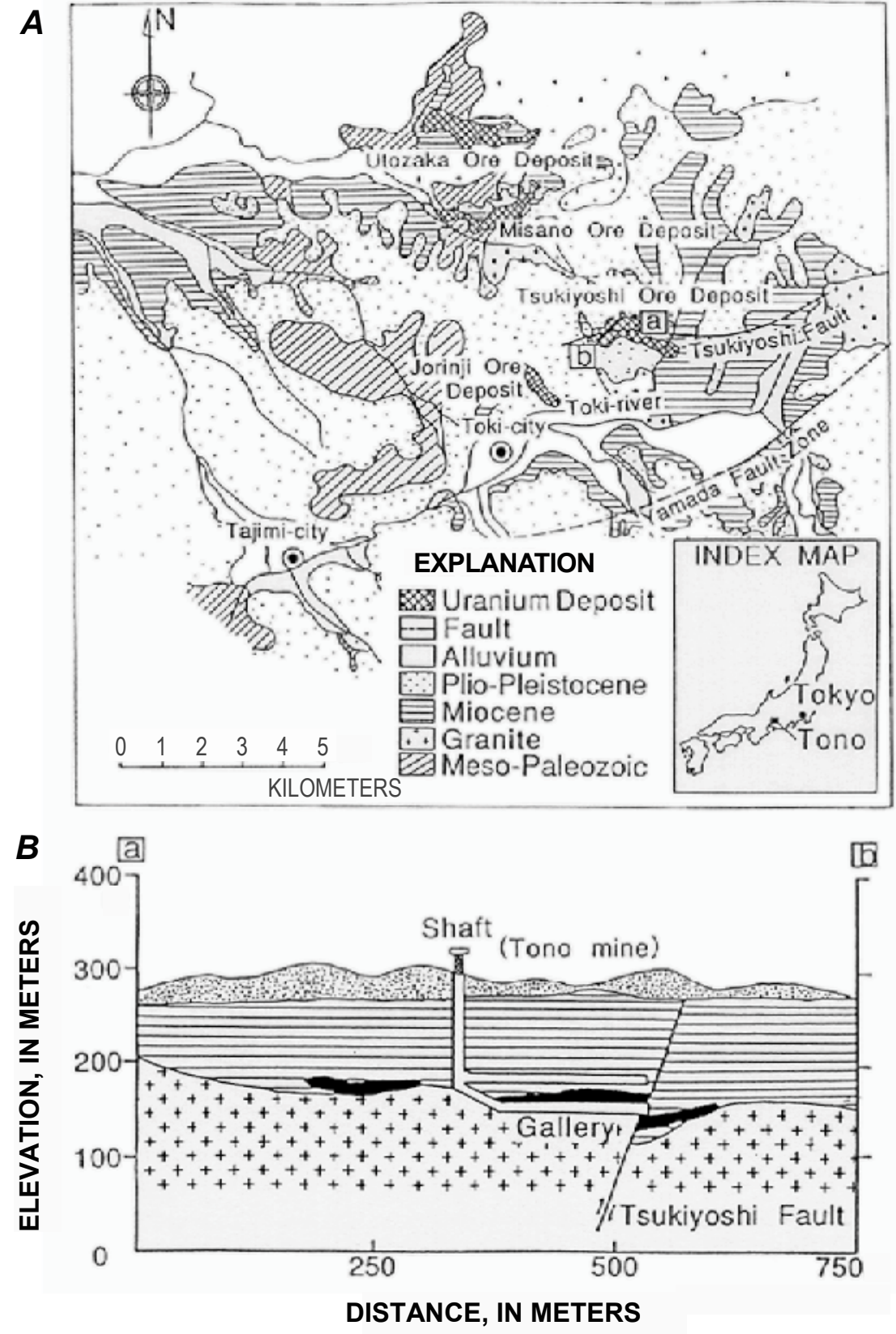

Figure 109. Geology of the Tono, Japan, natural analogue study site. (A) Tono mine site, including regional geology. $(B)$ Cross section through the Tsukiyoshi orebody (black) showing its faulted nature (Yusa and Yamakawa, 1992). 
3. Radium has been mobilized during the last several thousand years. The relative mobility of radium, as compared to uranium, and the limited migration along faults or fractures are similar to the situation at Nopal I, although Nopal I is in an unsaturated, oxidizing environment.

\section{Colloidal Transport in the Saturated Zone}

Colloids are ubiquitous in all groundwaters (McCarthy, 1996). However, in deep crystalline rocks with a stable geochemical system, the colloid concentrations are low (about $25 \mu \mathrm{g} / \mathrm{L}$ ). In contrast, shallow aquifer systems generally appear to have the largest colloid concentrations, even in the presence of geochemical stability. Enhanced colloid concentrations occur in all rock types where there is some hydrogeochemical perturbation to the system. For example, in fractured granitic systems, colloid concentrations are 20-1,000 times higher in groundwaters affected by inputs of surface water or in hydrothermal zones with large temperature and pressure gradients, compared to stable hydrogeochemical systems (Degueldre, 1994).

The uptake and transport of radionuclides by colloids has been investigated in several analogue studies of natural systems with enhanced radionuclide content: Cigar Lake, Canada (Vilks and others, 1993, 1988); Alligator Rivers, Australia (Seo and others, 1994); El Berrocal, Spain (Rivas and others, 1998); and Poços de Caldas (Morro de Ferro), Brazil (Miekeley and others, 1992). In most of these studies, it was concluded that some proportion of the total uranium, thorium, and REEs in the groundwater was associated with the colloids. This proportion was higher for thorium than for uranium because of thorium's lower solubility in most groundwaters. The REEs generally show an affinity for colloids intermediate between uranium and thorium (Miekeley and others, 1992).

Unambiguous evidence from natural systems indicating colloid transport over long distances is rare. The only known example indicating transport on the kilometer scale is at the Krunkelbach Mine in Menzenschwand, Germany, where the Ti:Mg ratio and REE composition of the natural colloids differed from that of the host granite but were similar to that of a neighboring gneiss several kilometers away and upgradient (Hofmann, 1989; Dearlove and others, 1989). However, the flow system at Menzenschwand is not representative of a natural system because it is perturbed by the presence of a uranium mine with associated fast flow.

Many analogue studies indicate that colloid transport in natural systems is substantially restricted. For instance, at Cigar Lake, the uranium and radium contents of colloids in the ore and the surrounding clay zones are substantially higher than in colloids from the sandstone host rock, indicating that the clay is an effective barrier to colloid migration (Vilks and others, 1993). Similar results at Alligator Rivers and Morro de Ferro also indicate that colloids have a limited capacity for migration because the concentrations of colloid-bound radionuclides outside the orebodies are relatively low (Miekeley and others, 1992).

Colloid concentrations of $0.8-6.9 \mathrm{mg} / \mathrm{L}$ for particles larger than $30 \mathrm{~nm}$ were observed in two wells on Pahute Mesa at the NTS (Buddemeier and Hunt, 1988). One well was inside the Cheshire UNE (underground nuclear explosion) site and the second, a water well, was $300 \mathrm{~m}$ away. Tritium, $\mathrm{Kr}$, Sr, Cs, $\mathrm{Sb}, \mathrm{Co}, \mathrm{Ce}$, and $\mathrm{Eu}$ were detected in pumped water from the water well. All of the cobalt, cesium, and europium was associated with colloids in samples from both wells. Buddemeier and Hunt (1988) maintained that the presence of colloidal radionuclides outside the test cavity indicates radionuclide transport as colloids.

In another study at the NTS (Kersting and others, 1999), isotopic ratios of plutonium were used to fingerprint the source of plutonium detected in monitoring wells for the Benham underground nuclear test, and results indicated that the plutonium had migrated a distance of $1.3 \mathrm{~km}$ since the test that was done 28 years before the study. Plutonium has a tendency to strongly sorb to tuff minerals, which would retard its transport. Thus, the observed presence of colloids in waters at the NTS and the observed association of plutonium with colloids were interpreted to indicate that radionuclide transport was expedited by colloids. However, the plutonium colloid concentration in the monitoring wells was low. A similar conclusion was reported by Triay and others (1997) to explain the transport of plutonium and americium away from a low-level waste site in alluvial sediments at Mortandad Canyon at Los Alamos, New Mexico. These radionuclides were detected at a depth of $30 \mathrm{~m}$ in monitoring wells in unsaturated tuff as much as $3.4 \mathrm{~km}$ downgradient from the waste disposal site. The migration reportedly took place over a period of 30 years (Buddemeier and Hunt, 1988). Because sorption studies involving the alluvial sediments indicated that plutonium and americium should be relatively immobile, the observed movement of radionuclides was interpreted by Triay and others (1997) as an indication that the transport of plutonium and americium through alluvium resulted from association with highly mobile colloids.

These observations lend support to the concept that radionuclide transport in the far field can be facilitated by colloids, but so far no natural analogue studies have been able to quantify the importance of this process over long distances. The analogue evidence indicates that colloids have a limited capacity for migration because the concentrations of colloidbound radionuclides away from the source are relatively low.

Overall, the sites described in this section contribute to understanding migration processes at a detailed scale in a variety of different settings. These sites provide a better understanding of the stability of radionuclides over long timeframes, allowing the placement of broad bounds on processes such as colloid transport. In addition, they confirm the importance of fracture flow and sorption onto fracture-coating minerals, such as calcite and iron oxyhydroxides. As discussed in the following section, although anthropogenic analogues have operated over a time period orders of magnitude shorter than the natural 
analogues discussed, anthropogenic analogues also may enhance knowledge of radionuclide transport.

\section{Anthropogenic Analogues of Saturated-Zone Flow and Transport}

The purpose of investigating anthropogenic analogues is to obtain a better understanding of the migration of shorterlived transuranic elements than is amenable to study by natural analogues. Through natural analogues it is possible to observe processes that began thousands to millions of years ago. A disadvantage of the natural analogues is that over such long time periods a number of the shorter-lived radioelements of concern at a high-level radioactive waste repository, such as ${ }^{237} \mathrm{~Np}$ (half-life $2.14 \times 10^{6}$ years), have decayed to small quantities or are nonexistent. To gain a better understanding of the transport of radionuclides over shorter timeframes and, in many cases, of the distinct migration pathways that are amenable to quantitative modeling, anthropogenic analogues are examined. In this section, saturated-zone radionuclide transport relative to uranium mill tailing sites, the INL, and the NTS is reviewed in varying degrees of detail.

\section{Saturated-Zone Transport at Uranium Mill Tailings Sites}

This section is limited to a review of the subsurface transport behavior of uranium and other constituents of interest at Uranium Mill Tailings Recovery Act (UMTRA) sites. All UMTRA sites were evaluated to identify those sites appropriate for more detailed analysis. The emphasis here is on the transport behavior of uranium and other constituents in alluvial deposits because the potential transport pathways from Yucca Mountain to the accessible environment pass through alluvium and because there are no UMTRA sites with bedrock similar to the volcanic rocks at Yucca Mountain. The approach evaluated the UMTRA sites in terms of aquifer materials, hydrologic characteristics, and groundwater chemistry. Those sites closest in hydrologic and chemical characteristics to the alluvium downgradient from Yucca Mountain and for which sufficient data were available for detailed transport analysis were considered in more detail.

The UMTRA Project was authorized by Congress in 1978 to clean up 23 inactive uranium ore-processing sites, located mostly in the Western States (U.S. Department of Energy, 1996). Most of the sites consisted of a uranium-processing mill with associated waste streams and ore and tailings piles, the piles being situated directly on surface soils. Rain and snowmelt percolated through the piles, leaching uranium and other constituents before entering the underlying shallow groundwater systems. The UMTRA Project has monitored the concentrations of radionuclides and other contaminants in shallow groundwaters beneath and downgradient from these sites for 15-20 years. The information obtained provides useful insight on the fate and transport of uranium and related ore constituents in shallow aquifers. The information obtained on transport in alluvial aquifers could be particularly useful in the development of models and calculations for radionuclide transport in shallow alluvial aquifers downgradient from Yucca Mountain.

The magnitude of operations at the various UMTRA sites was variable. The scope of the site-characterization activities undertaken by the UMTRA Project was generally proportional to the size of the operation at a given site. To be useful for the Yucca Mountain site, detailed site-characterization data are required on the flow and transport systems at these sites. Only a small number of such sites have been investigated in sufficient detail to be of use as analogues to the transport of uranium and other constituents of interest in the alluvial part of the Yucca Mountain flow system.

The history of operations at the various sites also varied. Most of the sites started operation in the mid- to late 1950s and ended operations in the early 1960s to early 1970s. During the 1980s and 1990s, the tailings piles located at the sites were either capped in place or removed to another location and encapsulated. Therefore, the tailings piles were sources of contaminants for subsurface transport for, at most, 30-60 years.

The ores processed at the various locations contained other chemical elements besides uranium and its daughter products, including V, As, Se, Mn, Mo, Ba, and other trace elements. Most of these ore "byproducts" ended up in the tailings piles. In addition, chemicals used in processing the ore were also dumped on the tailings piles. Important among the latter were sulfuric acid, nitric acid, ammonium hydroxide, and organic complexing agents. While the mills were in operation, rain and melted snow infiltrated into the uncovered tailings piles and leached constituents from the tailings. Liquid spills or leaks from site operations also infiltrated into the subsurface. These spill, leak, and leach solutions have since percolated downward through the subsoils and sediments beneath the sites and reached groundwater, forming plumes of contaminants in shallow aquifers. Low-pH groundwaters resulting from addition of contaminants could have facilitated transport of uranium. In contrast, acidic groundwaters are not expected to be found at Yucca Mountain.

Those UMTRA sites where the most extensive subsurface characterization and groundwater monitoring activities were performed are of the most use for the Yucca Mountain site. The transport of contaminants in groundwater is controlled by numerous site-specific factors. Part of the value of UMTRA sites as analogues, therefore, is the site-specific information they can provide on the factors that control the transport behavior of important constituents such as uranium. The intent was to select sites with alluvial aquifers and low-ionic-strength groundwaters. The sites chosen for detailed discussion are the Gunnison and New Rifle sites in Colorado.

\section{Gunnison, Colorado, UMTRA Site}

The following discussion is based primarily on information presented in the "Final Site Observational Work Plan 
for the Gunnison, Colorado, UMTRA Project Site" (U.S. Department of Energy, 2001b) and "Groundwater Hydrology Report," Attachment 3 of "Remedial Action Plan and Site Design for Stabilization of the Inactive Uranium Mill Tailings Site at Gunnison, Colorado, Final" (U.S. Department of Energy, 1992). The Gunnison processing site is located adjacent to the city of Gunnison in Gunnison County, Colorado, on a drainage divide between the Gunnison River and Tomichi Creek in the Gunnison River valley (figs. 110 and 111). Uranium was processed at the site from 1958 to 1962. Approximately $550,000 \mathrm{~m}^{3}$ of contaminated material including tailings was originally present on 68 acres. Between 1992 and 1995, the contaminated material was moved to the Gunnison disposal site, approximately $6 \mathrm{mi}$ from the processing site. The processing site was located on flood-plain alluvium, about $0.6 \mathrm{~km}$ east of the Gunnison River and $0.6 \mathrm{~km}$ west of Tomichi Creek (figs. 110 and 111). It is bounded on the west by small storm drainage ditches and on the south and west by irrigation ditches.

The climate at the site is semiarid, with an average annual precipitation of $26.7 \mathrm{~cm}$, of which approximately one-half is contributed by snowfall. The average depth to groundwater beneath the site is $1.5 \mathrm{~m}$. The uppermost (unconfined) aquifer is in the flood-plain alluvium of the Gunnison River and Tomichi Creek (fig. 111). These alluvial deposits extend to a depth of at least $33.5 \mathrm{~m}$ beneath the processing site. The aquifer is recharged from rain, snowmelt, the Gunnison River, Tomichi Creek, and seasonal irrigation ditches around the site.

The groundwater flows southwest at an average velocity of $82 \mathrm{~m} / \mathrm{yr}$, and beneath the site the groundwater discharges into the Gunnison River and Tomichi Creek (fig. 111). Tailings seepage has contaminated the alluvial groundwater beneath and downgradient from the processing site. Sulfuric acid was used extensively in ore processing at the site (U.S. Department of Energy, 1992). Because sulfate is a conservative constituent (that is, is not retarded) in oxidizing groundwater, it can be used to delineate the maximum extent of movement of siterelated contaminants in groundwater. A sulfate plume has been delineated that originates at the site and extends about 2,000 m in a southwesterly direction (fig. 111). Even though the plume intersects, and possibly flows beneath, the Gunnison River, sulfate is conservative relative to uranium at this site. The inferred areal shape of the sulfate plume indicates only limited lateral dispersion over most of the length of the plume. A lateral pinching of the plume also is inferred by its shape.

Borehole lithology logs show a local variation in unit thicknesses close to the narrowing of the plume. Here, the uppermost sand and gravel unit is about twice its thickness in adjacent boreholes and appears to fill a paleochannel cut into the underlying clayey sand and gravel unit. The highest concentration contours of both the sulfate and uranium plumes (U.S. Department of Energy, 1992; figs. 111 and 112) are tied to a water analysis from this location. Therefore, the widths of the plumes may be locally constrained by geohydrologic variations in the subsurface alluvial deposits. Interpretations of plume shape are tempered by the small number of sampling points available to construct the plume map. The maximum concentrations of sulfate in groundwaters along the length of the plume show only limited variation $(715-378 \mathrm{mg} / \mathrm{L})$. This indicates that downgradient dilution of contaminants originating at the processing site is limited.

A uranium plume has also been delineated in association with the Gunnison site (fig. 112). The inferred plume has a shape and lateral extent closely similar to the inferred sulfate plume (fig. 111). The similar shapes of the two inferred plume maps support the concept that the narrow shape of the uranium plume is locally controlled by geohydrologic variations in the alluvium, described previously, and not directly related to chemical conditions in the alluvial aquifer. For example, the possibility that lower uranium concentrations outside the inferred plume could simply reflect more reducing conditions that lead to the removal of uranium from groundwater is not supported by the data. The similarity in the lengths of the inferred uranium and sulfate plumes indicates that at least some of the uranium originating from the site may have been transported with little or no retardation. The groundwater concentrations of uranium, however, decrease more rapidly with distance from the site than the sulfate concentrations. One possible explanation for the different concentration gradients is that the source terms increased with time. Another possible explanation is that the traveltime for uranium was longer than the traveltime for sulfate (that is, that uranium was retarded to some degree). Laboratory data on sorption coefficients for uranium on alluvium from this area support the latter interpretation. The uranium sorption coefficient values obtained for two alluvium samples were 1.70 and $5.24 \mathrm{~mL} / \mathrm{g}$ (U.S. Department of Energy, 2000). Note that dilution alone is not a likely explanation for the decreasing uranium concentrations downgradient because sulfate concentrations do not decrease proportionately downgradient.

In summary, the groundwater data for the Gunnison saturated site yield several conclusions that may be significant with regard to radionuclide transport in alluvium at the Yucca Mountain site. To the extent that the hydrology of the alluvial aquifers at the Gunnison site and Yucca Mountain are comparable, the Gunnison data indicate that (1) lateral dispersion may be limited downgradient, (2) dilution may not be a significant process over the transport distance in alluvium, and (3) uranium may be only slightly retarded by interaction with aquifer materials.

\section{New Rifle UMTRA Site, Rifle, Colorado}

The Rifle UMTRA site is located along the Colorado River about $144 \mathrm{~km}$ east of Grand Junction, Colorado. The Rifle site actually consists of two separate sites, known as "Old Rifle" and "New Rifle." The Old Rifle site is located about $3.7 \mathrm{~km}$ ( 2.3 miles) northeast of the New Rifle site (fig. 113). The New Rifle site has been studied in greater detail and is the subject of this summary, which is based primarily on the "Final Site Observational Work Plan for the UMTRA 

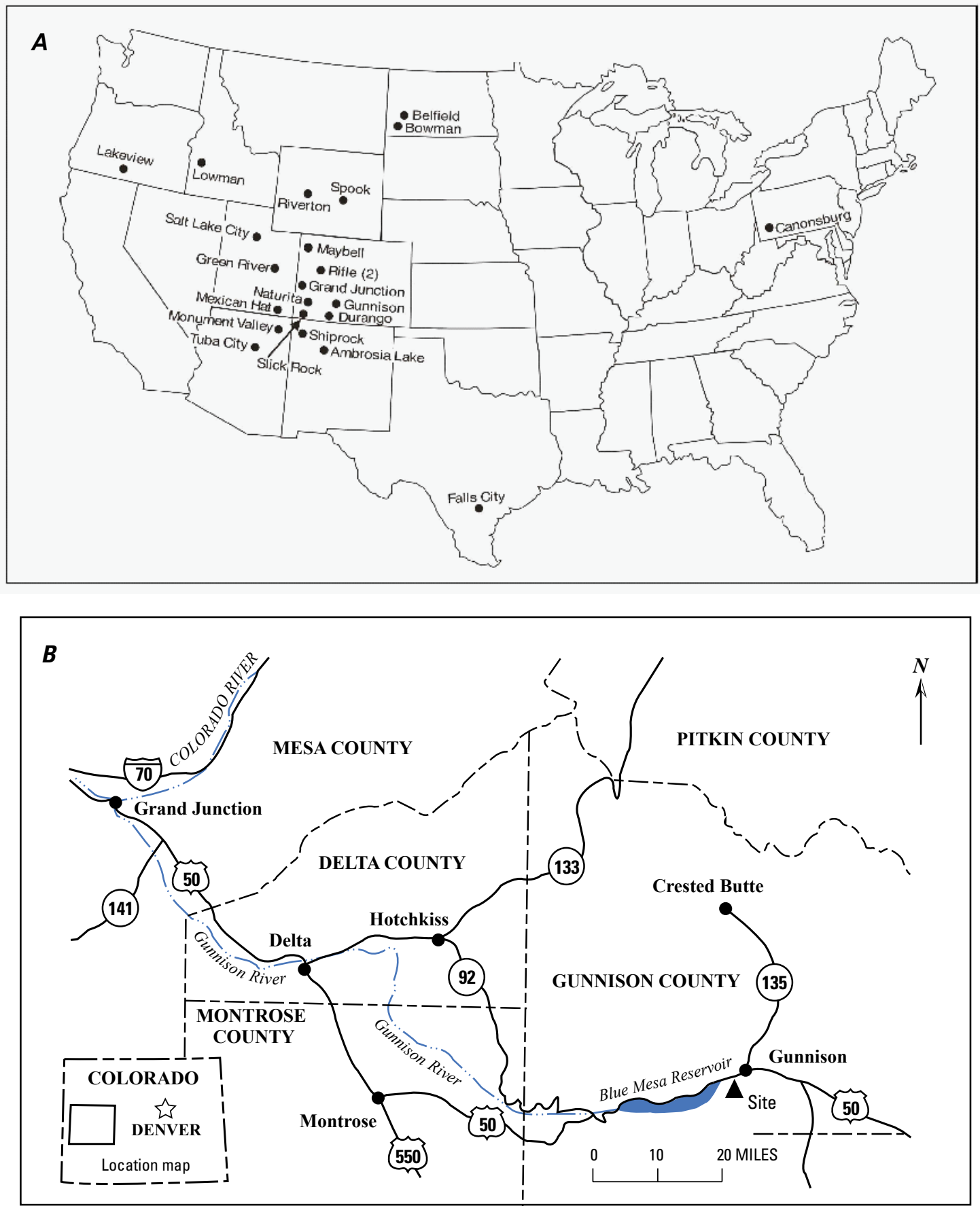

Figure 110. (A) Locations of the Uranium Mill Tailings Recovery Act groundwater project sites (modified from U.S. Department of Energy, 2000). (B) Location map for the Gunnison, Colorado, Uranium Mill Tailings Recovery Act site (U.S. Department of Energy, 2001b, fig. 1-1). 


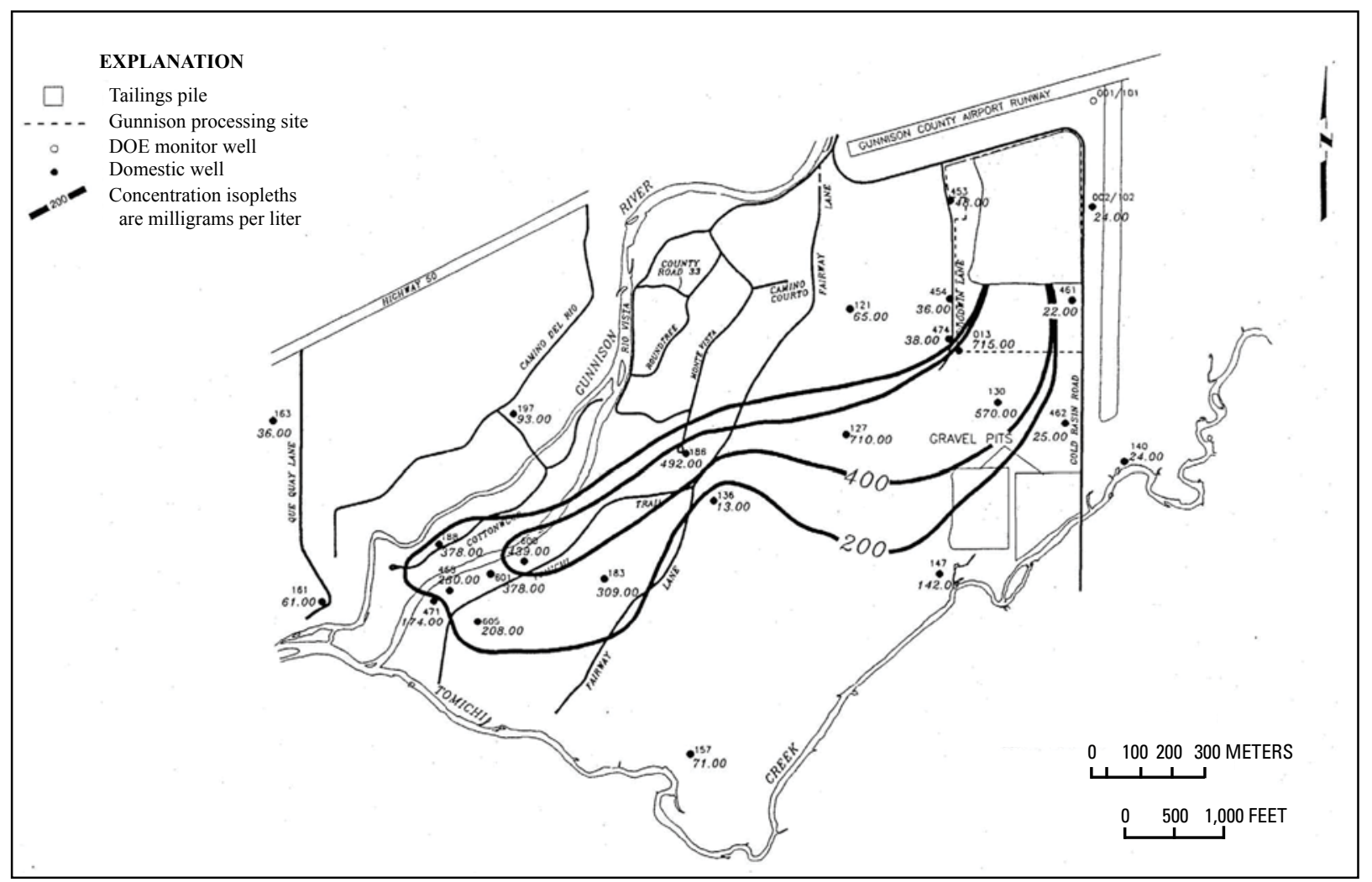

Figure 111. Plume map of sulfate concentrations, in milligrams per liter, in alluvial groundwater at the Gunnison, Colorado, Uranium Mill Tailings Recovery Act site (U.S. Department of Energy, 1992).

Project New Rifle Site, Volumes 1 and 2" (U.S. Department of Energy, 1999).

The New Rifle site processed uranium and vanadium ores from 1958 to 1984; it is located within the broad alluvial flood plain of the Colorado River (fig. 114). The site occupied much of the width of the Colorado River flood plain in a north-south direction (about $910 \mathrm{~m}$ ) with the river located on the southern portion of the flood plain. The ore storage areas were located in the easternmost (upgradient) portion of the site, whereas the tailings pile was located in the western portion of the site. The mill and other buildings were located between the tailings pile and the ore storage areas. Approximately 2.7 million $\mathrm{m}^{3}$ of contaminated material was present on 238 acres at the site. The transfer of this contaminated material to a disposal cell was completed in 1996.

The climate in the Rifle region is semiarid, with an average total annual precipitation of $28 \mathrm{~cm}$, of which approximately one-third is contributed by snowfall (U.S. Department of Energy, 1999, section 3.2). The New Rifle site is underlain by 6-9 $\mathrm{m}$ of alluvium deposited by the Colorado River (U.S. Department of Energy, 1999). Unconfined groundwater is present at the base of the alluvium at a depth of 1.5-3 $\mathrm{m}$ below the ground surface. In general, groundwater flows westsouthwest in the alluvium and in the underlying bedrock (U.S. Department of Energy, 1999). The alluvial deposits north of the river pinch out about $5.9 \mathrm{~km}$ to the southwest of the site (fig. 113). The alluvium is underlain by the Eocene Wasatch Formation. The weathered upper few feet of the Wasatch Formation also contain unconfined groundwater. Semiconfined and confined groundwater is present in interlayered sandstone, siltstone, and claystone beds deeper in the Wasatch Formation. The hydraulic gradient in the deeper Wasatch Formation is upward (U.S. Department of Energy, 1999).

The major-ion composition of waters in the unconfined aquifer varies, largely because of seepage of contaminants from site operations. The downgradient groundwaters in the alluvial aquifer are primarily sodium-calcium sulfate waters. Upgradient (background) groundwaters tend to be of the sodium-calcium bicarbonate-sulfate-chloride type, similar to river waters and of much lower ionic strength than downgradient groundwaters (U.S. Department of Energy, 1999). Processing operations at various locations on the site have resulted in the seepage of contaminants into the alluvial aquifer and the upper Wasatch Formation. The major sources of contaminated 


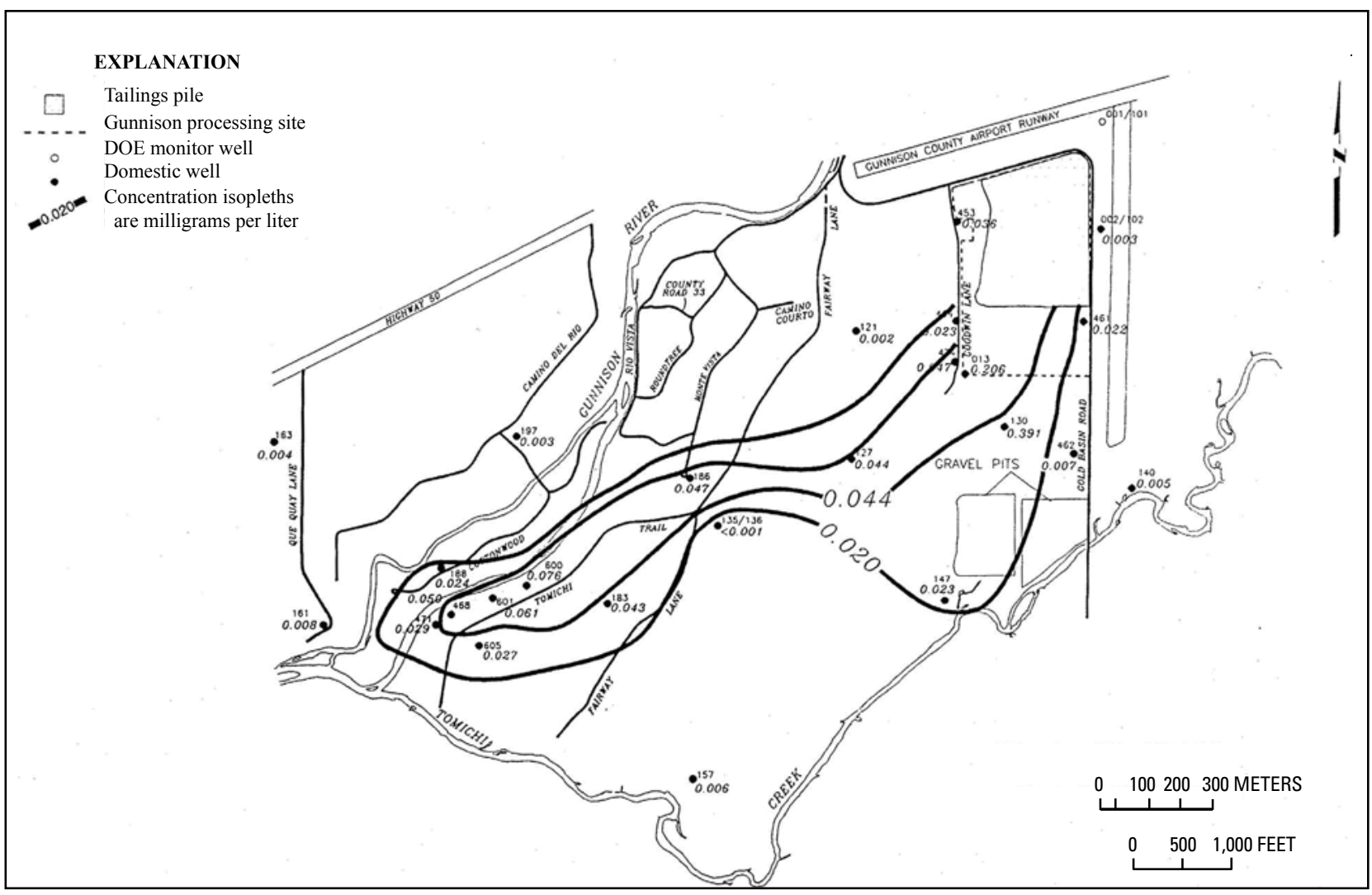

Figure 112. Plume map of uranium concentrations, in milligrams per liter, in alluvial groundwater at the Gunnison, Colorado, Uranium Mill Tailings Recovery Act site (U.S. Department of Energy, 1992).

seepage were the mill and other processing buildings and vats, vanadium and gypsum ponds, evaporation ponds, and the tailings pile (fig. 113). The degree to which contaminants have migrated from various source areas on the site has been investigated with an extensive monitoring program that began in 1985. Monitoring wells were used to obtain water levels and water samples from the alluvial aquifer and from the Wasatch Formation. Monitoring wells that intersect the Wasatch Formation are located within about $0.4 \mathrm{~km}$ of the operations area. The proximity of the uranium source to the underlying bedrock aquifer and the disturbed nature of the UMTRA sites are two conditions that would not be analogous to transport at Yucca Mountain.

The locations of the New Rifle monitoring wells are shown in fig. 115. The site-related inorganic constituents most prevalent in the alluvial aquifer include ammonia, calcium, nitrate, molybdenum, selenium, sulfate, and uranium. Of these constituents, the transport behavior of uranium and selenium are of interest for the Yucca Mountain site. Nitrate and sulfate are potentially of interest as conservative constituents to trace the maximum extent of movement of contaminants from the site. However, the existence of somewhat reducing conditions in various wells downgradient from the site calls into question the use of nitrate as a conservative constituent. Organic constituents such as kerosene were also released to the alluvial aquifer, particularly in and around the processing buildings and vats.

An estimate of the average extent of movement of contaminants from the site, without accounting for dispersion, can be obtained by calculating the distance groundwater could have traveled from the site since operations were initiated in 1958. The estimate is obtained using the following equation for the average linear groundwater velocity, $V_{x}$ (Fetter, 2001):

$$
V_{x}=-K / n_{e}(d h / d l)
$$

where $K$ is the hydraulic conductivity, $n_{e}$ is the effective porosity, and $d h / d l$ is the head gradient.

The average hydraulic conductivity for the New Rifle site is reported as $34.7 \mathrm{~m} / \mathrm{d}$ (U.S. Department of Energy, 1999), and was derived for the alluvial aquifer on the basis of pumping tests. The effective porosity was specified as 0.27 . Based on water-level measurements made in 1998, the average gradient was 0.0030. Substituting these values into the equation 


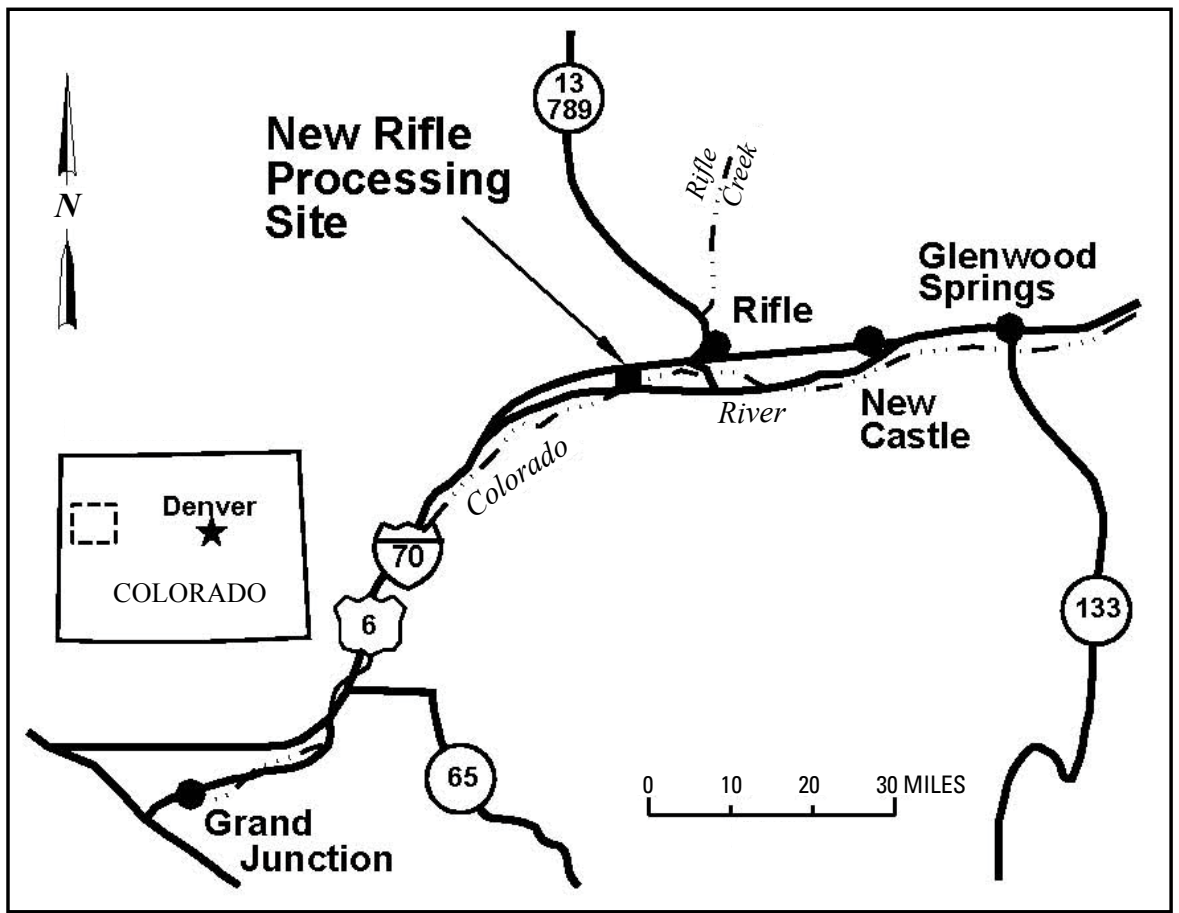

Figure 113. Location map for the New Rifle, Colorado, Uranium Mill Tailings Recovery Act site (U.S. Department of Energy, 1999).

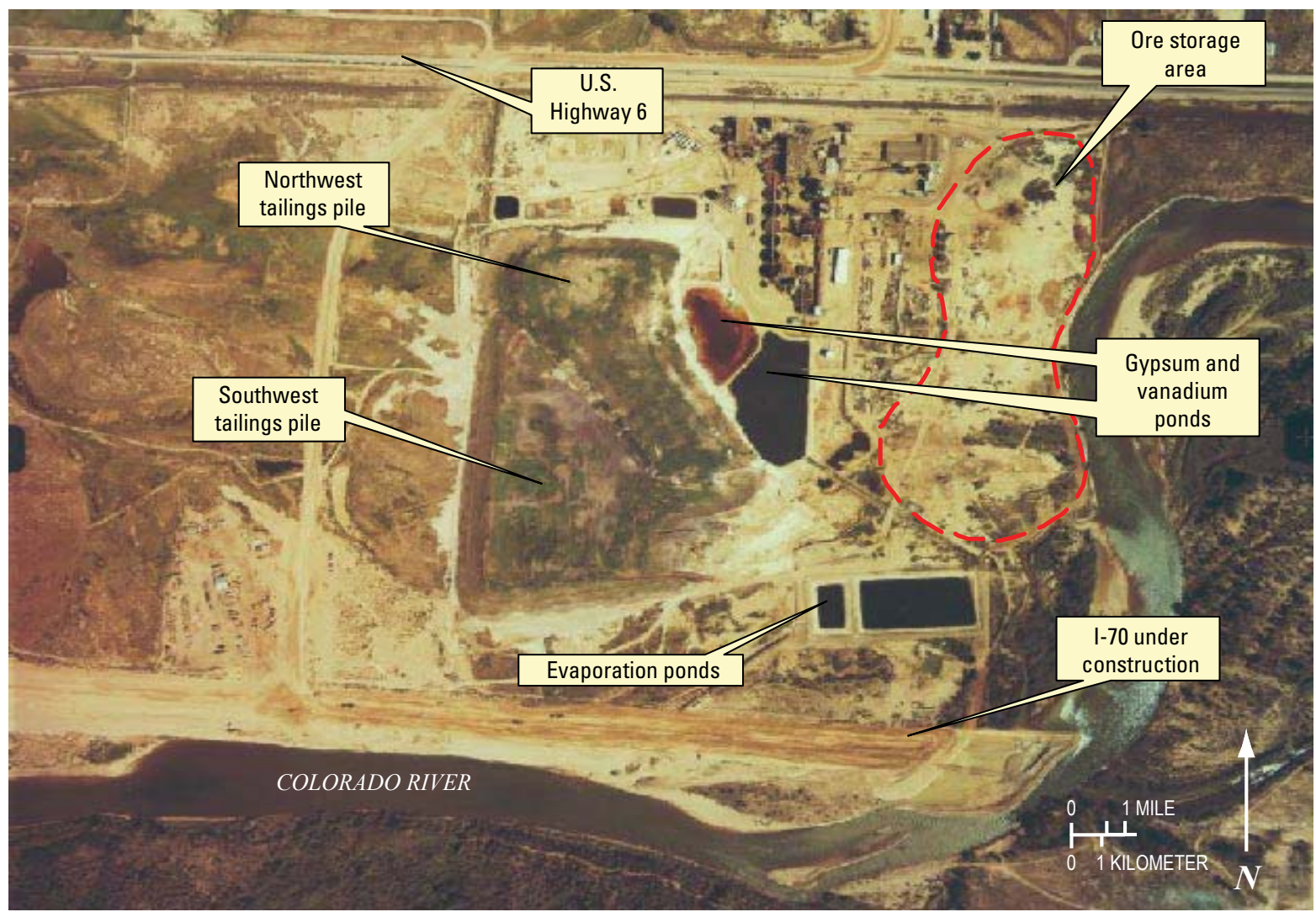

Figure 114. Aerial photograph of the New Rifle, Colorado, Uranium Mill Tailings Recovery Act site, showing location of tailings piles in August 1974 (U.S. Department of Energy, 1999). 


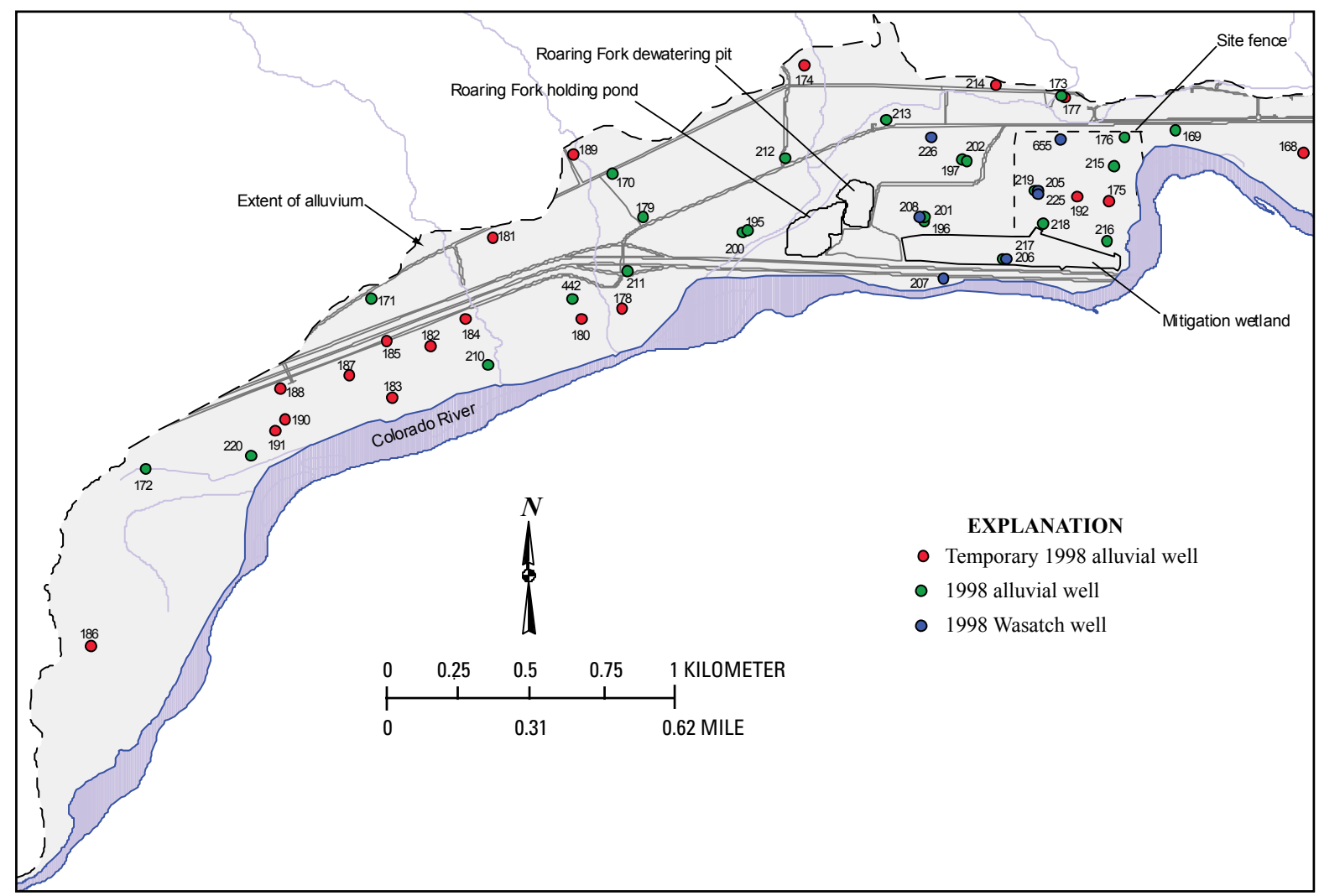

Figure 115. Map showing locations of wells screened in the alluvial aquifer at the New Rifle, Colorado, Uranium Mill Tailings Recovery Act site (U.S. Department of Energy, 1999).

yields the following linear groundwater velocity:

$$
V_{x}=(34.7 \mathrm{~m} / \mathrm{d}) / 0.27(0.0030)=0.39 \mathrm{~m} / \mathrm{d} \text {. }
$$

A linear groundwater velocity of $0.39 \mathrm{~m} / \mathrm{d}$ over a period of 40 years (1958-98) leads to an estimated travel distance of $5.64 \mathrm{~km}$. Because the site operations covered most of the alluvial terrace in a north-south direction, and because most of the contamination is in the alluvial aquifer, significant lateral dispersion of contaminated groundwater is precluded by the decreasing width of the alluvial deposits in the downgradient direction. However, the magnitude of the source term for different contaminants may have varied over the site. For example, uranium processing facilities were located in the northern portion of the site. Therefore, uranium concentrations might be expected to be highest in groundwater beneath this portion of the site. In fact, well 655 , located near the northern end of the site fence shown in fig. 115, has the highest uranium concentrations in any of the wells sampled in the 1998 and 1999 sampling rounds (U.S. Department of Energy, 1999). The absence of similarly high concentrations in downgradient wells indicates the operation of some dispersive process. In addition to lateral dispersion, vertical advective dispersion of contaminants in the alluvial aquifer may also occur. However, the saturated thickness of the alluvial deposits is only 3-6 m
(U.S. Department of Energy, 1999). Furthermore, the hydraulic gradient in the underlying Wasatch Formation is upward. These observations indicate that vertical advective dispersion of contaminants in the alluvial aquifer would be limited, but dilution may be an active process.

The use of sulfuric acid in processing ores at the site, which is inferred to be common practice (Merritt, 1971), would have resulted in seepage to the unsaturated zone with high concentrations of sulfate and may have resulted in low$\mathrm{pH}$ waters that would have facilitated uranium transport. The highest measured concentrations were obtained in samples collected in the first 2 years of the monitoring program. The available data indicate that sulfate concentrations in groundwater beneath and downgradient from the site have generally been decreasing since approximately 1986, consistent with the fact that processing operations at the site ended in 1984. Analyses of groundwater samples from background wells in the Wasatch Formation located across the Colorado River and upgradient from the site indicate that these waters have lower sulfate concentrations than waters from the alluvial aquifer but substantially higher chloride concentrations. This indicates that the $\mathrm{SO}_{4}{ }^{2-} / \mathrm{Cl}^{-}$ratio may be useful in identifying groundwater contaminated by site operations. Groundwater from wells at background locations (U.S. Department of Energy, 1999, Appendix C) shows that $\mathrm{SO}_{4}{ }^{2-} / \mathrm{Cl}^{-}$ratios in the Wasatch 
Formation are less than 2.0, with most being less than 0.5 . Water samples from the Colorado River have $\mathrm{SO}_{4}^{2} / \mathrm{Cl}^{-}$ratios in the range of $0.75-0.85$. As shown in fig. 116 , most water samples from wells located on the site have $\mathrm{SO}_{4}{ }^{2-} / \mathrm{Cl}^{-}$ratios in the range of 10-20. This ratio decreases with distance downgradient. The $\mathrm{SO}_{4}^{2-} / \mathrm{Cl}^{-}$ratio returns to near-background values at wells 220 and 172, the wells farthest downgradient that were sampled. Thus, the maximum distance contaminants appear to have traveled from the site, based on the $\mathrm{SO}_{4}{ }^{2-} / \mathrm{Cl}^{-}$ ratio of alluvial groundwater samples, is approximately $5.8 \mathrm{~km}$ $(19,000 \mathrm{ft})$. This is similar to the maximum travel distance of $5.64 \mathrm{~km}(18,506 \mathrm{ft})$ calculated for groundwater based on hydraulic parameters.

The observed decreases in the $\mathrm{SO}_{4}{ }^{2-} / \mathrm{Cl}^{-}$ratios (fig. 116) and $\mathrm{SO}_{4}{ }^{2-}$ concentrations $(6,000-2,000 \mathrm{mg} / \mathrm{L})$ in alluvial groundwater with increasing distance downgradient indicates that these waters are progressively diluted with waters that have low $\mathrm{SO}_{4}{ }^{2-} / \mathrm{Cl}^{-}$ratios and low $\mathrm{SO}_{4}{ }^{2-}$ concentrations. Because there is an upward hydraulic gradient in the Wasatch Formation (U.S. Department of Energy, 1999) and because Wasatch Formation groundwaters from upgradient wells have low $\mathrm{SO}_{4}{ }^{2-} / \mathrm{Cl}^{-}$ratios (less than 0.5 ) and low sulfate concentra- tions (less than $500 \mathrm{mg} / \mathrm{L}$ ), the diluting waters most likely come from the Wasatch Formation.

Measured uranium concentrations show a pattern similar to that observed in the $\mathrm{SO}_{4}^{2-} / \mathrm{Cl}^{-}$ratio data. Upgradient alluvial wells located on the eastern portion of the site have uranium concentrations between zero and $0.05 \mathrm{mg} / \mathrm{L}$ (fig. 117). Wells located near the former uranium processing buildings onsite have the highest uranium concentrations of all water samples $(0.4-0.5 \mathrm{mg} / \mathrm{L})$. Note that waters with these uranium concentrations are undersaturated with respect to solid uranyl phases, as calculated by Jove Colon and others (2001), for groundwater compositions typical of the New Rifle site. Uranium concentrations in alluvial groundwaters decrease downgradient and reach the $0.05 \mathrm{mg} / \mathrm{L}$ (background) level between 3,040 and 4,560 m (10,000 and 20,000 ft) downgradient (fig. 117). Thus, it appears uranium has not traveled downgradient as far as sulfate, although the exact travel distance is difficult to quantify because background values show such a large range $(0-0.05 \mathrm{mg} / \mathrm{L})$. The uranium "plume length" based on the 1998 sampling data is considerably greater than the 1-km length proposed by Jove Colon and others (2001) as the "steady-state" length for uranium plumes in groundwater systems (that is, the length at which uranium concentration in
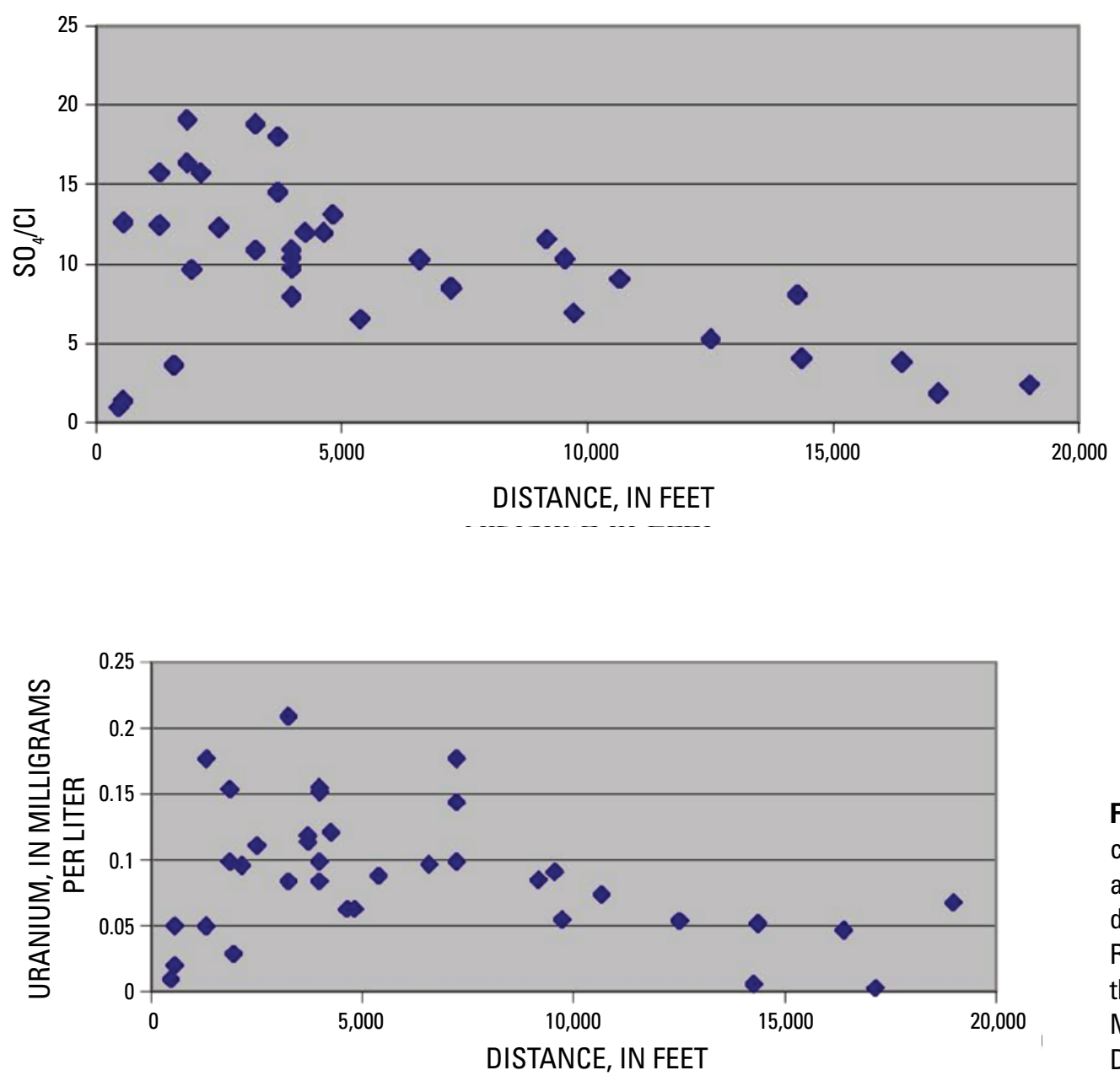

Figure 116. Sulfatechloride $\left(\mathrm{SO}_{4} / \mathrm{Cl}\right)$ ratios in downgradient alluvial groundwater relative to distance in feet from the Colorado River bank on the eastern edge of the New Rifle, Colorado, Uranium Mill Tailings Recovery Act site (U.S Department of Energy, 1999).
Figure 117. Uranium concentration in downgradient alluvial groundwater relative to distance in feet from the Colorado River bank on the eastern edge of the New Rifle, Colorado, Uranium Mill Tailings Recovery Act site (U.S. Department of Energy, 1999). 
monitoring wells remains fairly constant). In fact, there is no evidence in the New Rifle data (U.S. Department of Energy, 1999) that the uranium migration rate has decreased substantially with time, contrary to the conclusions reached by Jove Colon and others (2001).

Taking the maximum distance traveled by uranium as $3.96 \mathrm{~km}(13,000 \mathrm{ft})$ (fig. 117) and the maximum distance traveled by sulfate as $5.49 \mathrm{~km}(18,000 \mathrm{ft})$ (fig. 116), an estimated retardation factor $\left(R_{t}\right)$ for uranium of 1.38 (that is, 5.49/3.96) is obtained. Using the retardation equation (Freeze and Cherry, 1979, their Equation 9.14)

$$
R_{t}=\left(1+\frac{\rho_{b} K_{d}}{\phi}\right)
$$

where $\rho_{b}$ is the dry bulk density in $\mathrm{g} / \mathrm{cm}^{3}$ and $\phi$ is the porosity, we can solve for the sorption coefficient $\left(K_{d}\right)$,

$$
K_{d}=\frac{\left(R_{t}-1\right) \phi}{\rho}
$$

Using values for the dry bulk density $\left(\rho_{b}\right)$ and porosity given for the alluvial aquifer in U.S. Department of Energy (1999), we obtain the following result for the uranium sorption coefficient $\left(K_{d}\right)$ :

$$
K_{d}=(1.38-1) 0.25 / 1.52=0.06 \mathrm{~mL} / \mathrm{g}
$$

Batch-sorption coefficient measurements for uranium using alluvial materials from the New Rifle site and a synthetic groundwater show a range of coefficients from -0.3 to 1.4 $\mathrm{mL} / \mathrm{g}$, with an average value of $1.0 \mathrm{~mL} / \mathrm{g}$ (U.S. Department of Energy, 1999, Table 4-6). The $K_{d}$ calculated here falls within that range but is lower than the mean average value. This difference may be partly accounted for by the fact that the calculated $R_{t}$ is based on what may be closer to the maximum, rather than the average, distance traveled by uranium; therefore, the calculation yields a lower $K_{d}$.

It is possible also that some uranium could have been transported downgradient as part of a colloidal phase (including microbes). Such colloidal transport could carry the uranium at essentially the velocity of groundwater. Selenium has been detected only in groundwaters from wells located within the boundaries of the original New Rifle site. There is no evidence of substantial downgradient transport (U.S. Department of Energy, 1999). This is probably a result of the combined effects of a smaller source term and higher sorption coefficients measured for selenium in contact with sediments from the alluvial aquifer (U.S. Department of Energy, 1999).

In summary, the data available on uranium transport at the New Rifle UMTRA site indicate that dilution in the alluvial aquifer is an important process downgradient from the site and that the sorption of uranium on alluvial sediments also occurs.

\section{Summary and Conclusions of the UMTRA Study}

The conclusions derived from an analysis of the Gunnison site are (1) that a fraction of the uranium originating at the site is transported in the alluvial aquifer at a rate similar to the rate at which a conservative constituent is transported, and (2) little evidence exists for dispersion of contaminants in the downgradient direction. For the New Rifle site, the main conclusions are that (1) dilution is a significant process in the downgradient direction, and (2) uranium is transported at a slower rate than conservative constituents, although a fraction of the uranium traveled almost as far. The conclusions regarding uranium transport distances relative to conservative constituents are tempered somewhat by uncertainties regarding the potential presence of unidentified complexing agents, such as organic materials, that could form colloids and enhance uranium transport. An additional note of caution attaches to the use of laboratory batch-derived $K_{d}$ values for the prediction of large-scale field transport because the two parameters are conceptually and numerically different.

\section{Saturated-Zone Transport at the Idaho National Laboratory}

The Idaho Chemical Processing Plant (ICPP) at the INL was designed principally to recover highly enriched uranium (93 percent or more ${ }^{235} \mathrm{U}$ ) from different fuel types used in naval propulsion, research, and test reactors. From 1952 until 1984, low-level radioactive waste was discharged from the ICPP directly to the Snake River Plain by means of an injection well and seepage ponds. Over time, a suite of radionuclides has been measured in the underlying aquifer, including ${ }^{3} \mathrm{H},{ }^{36} \mathrm{Cl},{ }^{90} \mathrm{Sr},{ }^{137} \mathrm{Cs},{ }^{129} \mathrm{I}$, and Pu isotopes. Beasley and others (1998) reported the first measurement of the longlived radionuclides ${ }^{99} \mathrm{Tc},{ }^{236} \mathrm{U}$, and ${ }^{237} \mathrm{~Np}$ in the aquifer and their downgradient concentration changes during aqueous transport through fractured basalt.

The Snake River Plain aquifer is unconfined, with the highly fractured tops of basalt flows leading to high hydraulic conductivities. Beasley and others (1998) reported that the average hydraulic gradient across the INL is approximately $2 \mathrm{~m} / \mathrm{km}$, and water traveltimes between the ICPP and the southern site boundary have been estimated at $2 \mathrm{~m} / \mathrm{d}$.

Eight to 23 groundwater monitoring wells at the INL were sampled for radionuclide measurements in 1991, 1992, and 1994. Activity concentrations were measured for ${ }^{36} \mathrm{Cl}$, ${ }^{99} \mathrm{Tc},{ }^{129} \mathrm{I},{ }^{236} \mathrm{U}$, and ${ }^{237} \mathrm{~Np}$. To determine the relative mobilities of these radionuclides, individual radionuclide activities in wells near the ICPP were normalized to those at a distance. Figure 118 shows a best-fit plot of these normalizations for each radionuclide. The close correspondence in the decrease of ${ }^{36} \mathrm{Cl}$ and ${ }^{99} \mathrm{Tc}$ with distance from the ICPP indicates that ${ }^{99} \mathrm{Tc}$, like ${ }^{36} \mathrm{Cl}$, behaves conservatively in the fractured basalt and that observed concentration decreases result from dilution 


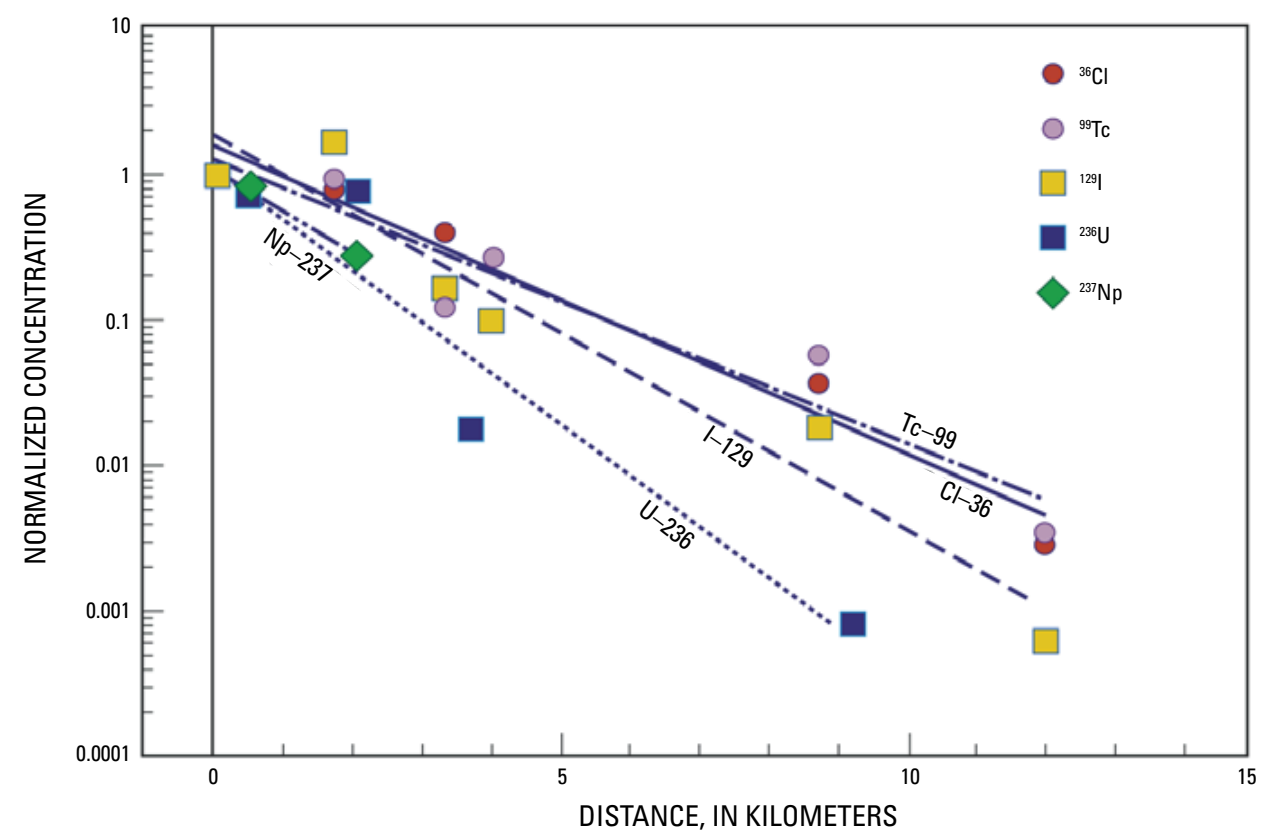

NOTE: For chlorine-36, technetium-99, and iodine-129, the values are normalized to their concentrations in Well 57, whereas uranium-236 and neptunium-237 concentrations are normalized to Well 123.

Figure 118. Decrease in normalized concentrations of selected radionuclides in the Snake River Plain aquifer with distance from the Idaho Chemical Processing Plant, Idaho (Beasley and others, 1998).

or dispersion (Beasley and others, 1998). Iodine-129 is attenuated and ${ }^{237} \mathrm{~Np}$ and ${ }^{236} \mathrm{U}$ are even more attenuated. Because none of the radionuclides discussed were routinely monitored in low-level waste streams discharged from the ICPP, a possibility exists that the relation shown in figure 118 could have arisen from variable discharge rates over time for the radionuclides shown. However, the authors point out that, even though the absolute amounts of radioactivity most likely varied over time, the ratios of radionuclides in the discharges probably were consistent and, therefore, did not affect the composition of radioactivity in the waste streams.

Although this study is only one, its application of radionuclide wastes as tracers in fractured, saturated basalt under oxidizing conditions showed that ${ }^{36} \mathrm{Cl}$ and ${ }^{99} \mathrm{Tc}$ behaved conservatively during transport, whereas ${ }^{129} \mathrm{I},{ }^{236} \mathrm{U}$, and ${ }^{237} \mathrm{~Np}$ were retarded.

\section{Saturated-Zone Transport at the Nevada Test Site}

The 0.75-kiloton underground nuclear test, Cambric, was conducted at the NTS in 1965 in tuffaceous alluvium 73 $\mathrm{m}$ below the water table (Hoffman and Daniels, 1981). Data from a field experiment initiated in 1974 at the Cambric site have provided direct information on the transport rates of radionuclides through alluvium. Tests began after the cavity and chimney were predicted to be filled with groundwater to the preshot static water level. It was assumed that tritium, plutonium, and uranium fission products would be present in the cavity (and in the groundwater within the cavity) and could be used to study possible migration from the cavity (Hoffman and Daniels, 1981).

The field study began with the completion of a satellite well $91 \mathrm{~m}$ from the Cambric cavity, followed by drilling of a reentry well into the cavity itself. Both solid and liquid samples were collected from the reentry well to determine the radionuclide distribution between the solid material and the groundwater. Water was then pumped from the satellite well to induce an artificial gradient sufficient to draw water from the Cambric cavity through the surrounding rocks.

Approximately 2 years after pumping began, substantial volumes of tritiated water were observed in water samples from the satellite well, signaling the arrival of water from the Cambric cavity region. After almost 6 years of pumping, the tritium concentration in the pumped water reached a maximum (Hoffman and Daniels, 1981). By the end of September 1984 , about 60 percent of the initial tritium inventory had been pumped out through the satellite well (Thompson, 1986).

Other radionuclides were also measured in water from the satellite well, including ${ }^{36} \mathrm{Cl},{ }^{85} \mathrm{Kr},{ }^{106} \mathrm{Ru}$, and ${ }^{129} \mathrm{I}$. During the 10 -year experiment ${ }^{90} \mathrm{Sr}$ and ${ }^{137} \mathrm{Cs}$ were not detected in water from the satellite well (Thompson, 1986). The ${ }^{36} \mathrm{Cl}$ pulse and ${ }^{129} \mathrm{I}$ preceded the tritium pulse in the satellite well. Krypton was shown to be correlated with tritium but more strongly sorbed onto alluvium than tritium (Thompson, 1986). Ruthenium-106 was detected in water from the satellite well and was unretarded in the alluvium. 


\section{Summary of Saturated-Zone Analogues} herein:

The following points apply to the analogues discussed

1. Filtration of particulate matter is an efficient process at Poços de Caldas, Brazil. The colloidal material acts as largely irreversible sinks for many immobile elements, such as thorium and REEs.

2. The redox front at Poços de Caldas provided direct evidence of the operation of flow channeling in fractures and solute transport in the rock matrix as the key controls on the shape and movement of the redox front. The very slow, diffusion-dominated movement of the redox front performs an important function in retarding many trace elements (Romero and others, 1992). Redox fronts also retard migration of uranium at Tono, Japan, and Bangombé, Gabon. At these analogue sites, matrix diffusion was important. Matrix diffusion in crystalline rock is generally limited to only a small volume of rock close to fractures, but even a small volume can make a significant difference in radionuclide retardation, particularly when enhanced by secondary mineral sequestration in microfissures. Poços de Caldas also highlighted the importance of amorphous phases in suspension or as coatings on rock as the principal sorptive surfaces for many trace elements in solution. Some of the fixing processes appeared to be irreversible over long time scales compared to reversible sorption used in PA models.

3. Sorption onto fracture coatings, particularly calcite, efficiently retards uranium transport in fractures at Palmottu. Selective leaching experiments at Palmottu showed that, of the radionuclides that had diffused into the rock matrix, most were only loosely bound to iron-rich phases. Comparison of the results from a number of analogue study sites shows that sorption onto fractures is seen at many locations in crystalline rocks. For example, the El Berrocal project indicated that mobilized uranium and thorium tended to be associated by sorption and coprecipitation with fracture-coating minerals and had not diffused substantially into the granite matrix.

4. Investigation of two UMTRA sites discovered that some fraction of the total inventory of uranium mill tailings appears to be transported as a nonsorbing to weakly sorbing species under oxidizing conditions. This supports the treatment of uranium in PA models as weakly sorbing (BSC, 2001a, section 12.4.2).

5. The study of radionuclide wastes as tracers in fractured, saturated basalt at the INL under oxidizing conditions showed that ${ }^{36} \mathrm{Cl}$ and ${ }^{99} \mathrm{Tc}$ behave conservatively during transport, whereas ${ }^{129} \mathrm{I},{ }^{236} \mathrm{U}$, and ${ }^{237} \mathrm{~Np}$ were retarded. In a study of radionuclide migration from a nuclear test cavity at NTS, ${ }^{129} \mathrm{I}$ was not retarded.

6. Although several natural analogue studies have demonstrated the effect of sorption and precipitation processes on fracture surfaces, none has been able to distinguish clearly between these processes or to provide quantitative data on retardation with respect to transport of trace elements in natural waters. However, these studies do highlight which phases are most active and provide useful information on the effect of interaction between solutes and the rock surface. In most studies of natural systems, a proportion of the total uranium, thorium, and REEs in the groundwater was associated with colloids. Colloids can serve as sorbers of radionuclides and may be agents either of retardation or of fast transport. Unambiguous evidence from natural systems indicating colloidal transport over kilometer-scale distances is limited to a few reports. Observations at Los Alamos National Laboratory in New Mexico and at the NTS lend support to the concept that radionuclide transport in the saturated far field can be facilitated by colloids, but so far no natural analogue studies have been able to quantify the importance of this process over long distances. The analogue evidence indicates that colloids have a limited capacity for migration because the concentrations of colloid-bound radionuclides away from the source are relatively low.

\section{Applications and Conclusions}

Natural analogues may be applied in a quantitative or a qualitative manner, depending upon the purpose to which they are applied and upon the specific analogue. They can provide descriptive information about the occurrence of various processes, or they may be able to constrain the bounds of those processes. Natural analogues allow testing of the pertinence of individual processes over geologic time and space scales, assessing the relative importance of various processes, and gaging the effects of process coupling. For some processes (for example, those that are thermally coupled), natural analogues may be the only means of providing the required understanding of long-term and large-scale behavior needed to provide scientific confidence in process models for input to TSPA. Analogue investigations may determine the conditions under which the processes occur, the effects of the processes, and the magnitude and duration of the processes.

Analogue information may also provide a body of data for testing codes and for validation of conceptual and numerical models. Natural analogue information may also be used to build confidence in databases themselves. Because natural analogues can be used to evaluate the validity of extrapolating 
from temporally limited field-scale experiments to longer time scales, or to add confidence when extrapolating from laboratory and intermediate-scale experiments to tests at larger spatial scales, they are uniquely suited to building confidence in process models. In this manner, they are used as a means of model validation, or confidence-building. For this reason, process models developed for the Yucca Mountain Project have included natural analogue information in model validation.

Less commonly, natural analogues may be used to assist and support the selection of scenarios and to establish the probability of occurrence of selected scenarios. Natural analogues do not reduce uncertainty per se; that is, the uncertainty bounds on a given parameter value may remain unchanged. However, natural analogues can build confidence that the bounds are set appropriately. Because some uncertainties are greater in natural analogues than at the site being characterized, information from natural analogues needs to be used only in conjunction with other information to evaluate consistency with laboratory and field data.

Figure 119 illustrates the flow of information from natural analogues and other site-characterization data into PA models. The figure indicates that natural analogues provide both qualitative and quantitative information, as this report has demonstrated through many examples in the preceding sections. Stated in words, the stages or components in the development of a PA code (shown in figure 119) are the following:

1. Construction of a conceptual model that describes the system and includes all of the important processes and their interactions.

2. Translation of conceptual models into mathematical assessment models and encoding those models in the form of a numerical code.

3. Acquisition of input data for all the variable and constant parameter values included in the numerical code.

4. Verification of the numerical correctness of the computer code.

5. Validation of the code's applicability to the repository system in assessing its ability to predict future conditions.

The ways in which analogues can be or have been used to assist in steps 1, 3, 4, and 5 above are discussed in the following list.

Conceptual model construction: In the stage of model construction, natural analogues can be used to tell the PA modeler:

- Which processes and process interactions to include,

- Which processes are likely to be dominant and which are of secondary importance,

- The spatial and temporal scales over which the model should perform, and(or)
- Whether the basic premises of the model hold up under extrapolation to long time periods.

Some of the analogues discussed for the waste form and engineered barrier systems, for transport of radionuclides in the unsaturated and saturated zones, and for coupled processes relate to identification of processes that are or may be included in models.

The IAEA (1999) report correctly claims, as can be judged by the "Natural Analogue Synthesis Report" (BSC, 2004), that the use of analogue information in the Yucca Mountain Project has been dominantly to inform the content of conceptual models in terms of processes that need to be incorporated. The IAEA report also discusses the anthropogenic analogues provided by the NTS where radionuclides from nuclear bomb tests are detected in rock and water. It was a result of water testing for radioactivity that indicated transport by colloid-sized mineral fragments was possible. That in turn led to the introduction of a colloid transport model into the Yucca Mountain unsaturated- and saturated-zone transport models. Thus, an analogue was used to add a process to a model but did not provide data to help define and constrain the model. Additional testing was needed to provide data for use in the modeling of this transport process.

Data acquisition: Information derived from natural analogue studies is generally semiquantitative and cannot, in many cases, directly satisfy the parameter value requirements of a PA code. However, laboratory data have uncertainty related to the lack of similarity between the laboratory and repository systems. Therefore, analogues in data acquisition can provide a measure of validation for the laboratory data. Even though the analogue data may be imprecise, they can be used to give confidence in the reliability of the laboratory data. An example of this application was given, describing the similarity between uraninite alteration phases produced in laboratory dissolution experiments and those uraninite alteration phases identified in rock samples at the Nopal I, Peña Blanca, analogue site.

Mathematical model validation: Thermodynamic solubility and speciation codes and databases have been extensively applied in a number of natural analogue studies (for example, Maqarin, Poços de Caldas, Koongarra). Natural analogues can help determine whether the solubility-controlling mineral species and complexes in solution (generally specified by hydrochemical databases or from theoretical or laboratory experiments) are appropriate to the site-specific conditions being modeled and whether or not mineral phases and(or) ionic species in solution indicate chemical equilibrium has been achieved or whether the system is controlled by kinetics.

A subcategory of modeling studies is database evaluation. One application of natural analogues in this category is the evaluation of geochemical models and numerical tools used in describing the predicted migration of radionuclides in a repository system. Blind predictive modeling comparisons are a means of evaluating geochemical databases. For instance, Bruno and others (2001) reviewed and compared the results obtained from the blind prediction modeling exercise 


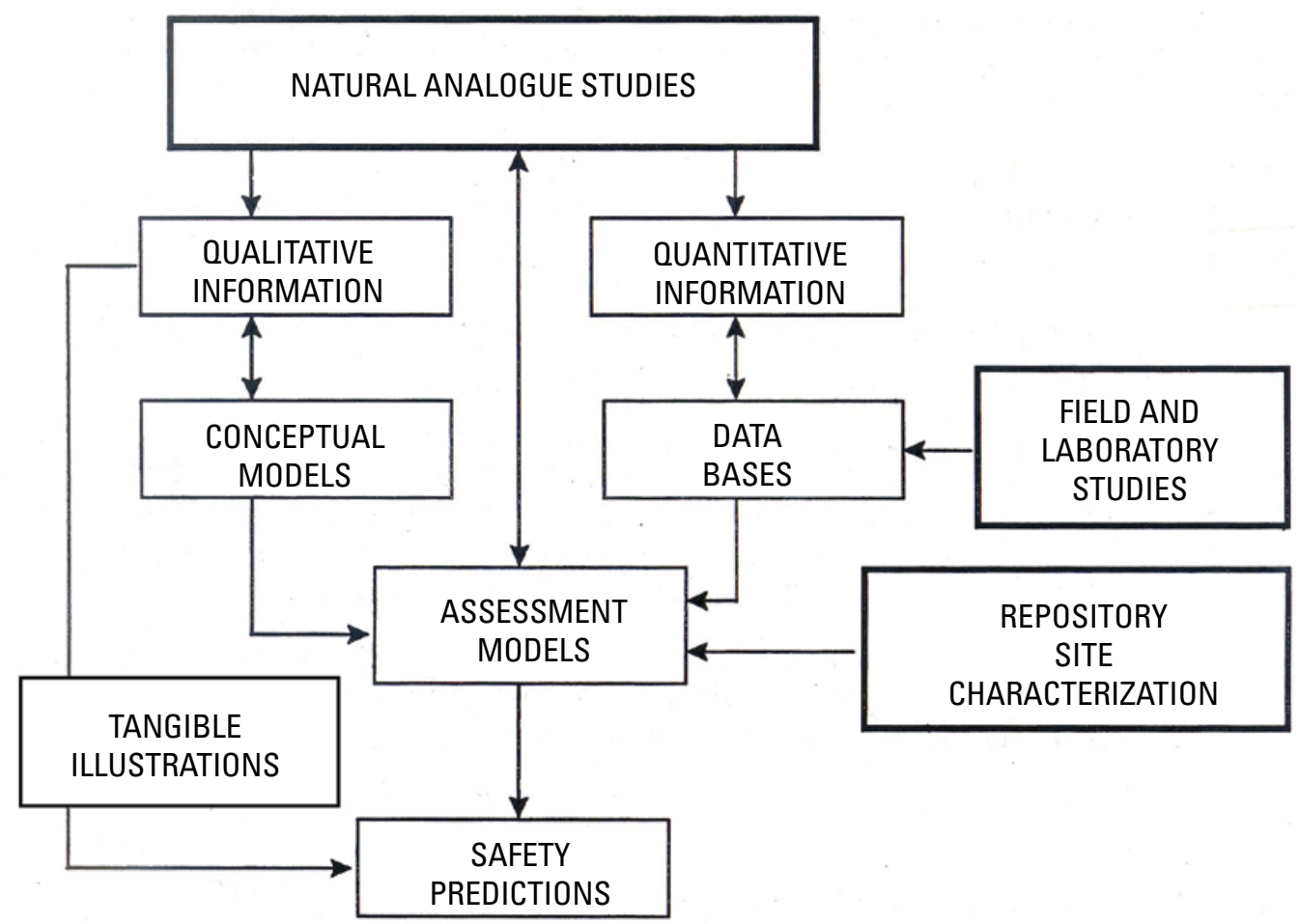

Figure 119. The function of natural analogues and site characterization in performance assessment (International Atomic Energy Agency, 1999).

carried out for seven natural analogue studies relevant to European repository concepts: Oman; Poços de Caldas, Brazil; Cigar Lake, Canada; Maqarin, Jordan; El Berrocal, Spain; Oklo, Gabon; and Palmottu, Finland. The blind predictive model exercise (Bruno and others, 2001) was able to improve conceptual and numerical models to identify relevant radionuclides to major component phases in the rock/water systems of interest. The modeling group achieved a consensus concerning the most appropriate methodology for approaching solubilitylimited calculations and identified the main requirements for acquiring improved site-characterization data to describe radionuclide mobility.

Tangible illustrations: Natural analogues also have an important function, beyond their application to PA, in providing illustrative information to a broad range of audiences, including the general public. Comparisons with natural systems are frequently mentioned as important components of the process of evaluation and acceptance of disposal concepts. In quoting the IAEA (1999), Miller and others (2000, section 6.1) stated, "Among all levels of reviewer, from technical peer review panels to nontechnical audiences, there is a clear belief that PAs are only credible if shown to have strong natural parallels." Recognition of the important processes and events that control the repository behavior can be demonstrated from illustrative geological analogues. Natural analogues assist in the public understanding of timescales applicable to radioactive decay. These real-world examples are important because the extended time periods of interest to disposal are generally longer than those in the normal range of experience. Dozens of tangible illustrations have been provided in sections of this report describing seepage analogues and analogues demonstrating the efficacy of preservation in an arid environment.

\section{Performance Assessment Applications of Analogues in Geologic Disposal Programs Worldwide}

Several reviews have examined the level of direct and acknowledged use of natural analogues in published PA documents of geologic repository programs worldwide (for example, McKinley and Alexander, 1996; IAEA, 1999). Results of these reviews indicated that few TSPA documents provided detailed discussion of how analogues were used to support specific aspects of the assessments, and some PA reports did not discuss how natural analogues support geological disposal in even a general way.

An indirect use of analogues in PA in some programs is in the development of scenarios, where identification of features, events, and processes (FEPs) of importance to repository evolution are required (Chapman and others, 1995). The contribution of analogue information in this case is to provide supplemental evidence to support the inclusion or exclusion of different FEPs in scenarios to be analyzed for PA. An example of this application of analogues is the scenario case for criticality in a waste repository. This scenario was screened 
out using, in part, understanding of processes that occurred at Oklo.

Miller and others (2000), referring to IAEA (1999), summarized the use of analogues for model development, data provision, and model validation in 10 PAs over the past two decades. These are KBS-3 (Sweden in 1983); Projekt Gewähr (Switzerland in 1985); SKB-91 (Sweden in 1991); TVO (Finland in 1991); AECL EIS (Canada in 1994); Kristallin-I (Switzerland in 1993); NRC IPA (United States of America in 1995); TILA-99 (Finland in 1999); SR-97 (Sweden in 1999); and SFR (Sweden in 1999). All but one of these PAs used analogues in conceptual model development or scenario development. All of the PAs used data from analogues, either as bounding conditions or as direct parameter values. Seven of the 10 PAs used analogues for blind predictive modeling or for the evaluation of models and databases as part of model validation. The NRC, for instance, used natural analogues in the following ways:

- In scenario development for volcanism, as an alternative source-term conceptual model using Peña Blanca data (Murphy and Codell, 1999).

- To establish relative importance of microfractures and matrix transport at Peña Blanca in Mexico.

- As backup for vapor-phase transport at the Valles caldera in New Mexico.

- To identify secondary phases for long-term release at Peña Blanca.

- For model testing of elemental transport in unsaturated media at Akrotiri, Greece (Murphy, 2000; Hughson and others, 2000).

Miller and others (2000, their Table 6.1.1) noted that few of the analogue applications were explicitly mentioned in the top-level documents associated with these PAs. The lack of acknowledgment of these applications of analogues by PAs is evident from a disconnect between the examples of uses shown in the IAEA (1999) report and the applications noted in the report's conclusions. Thus, it appears that the contribution of natural analogues in providing a general conceptual basis for the geological disposal of radioactive waste and for specific waste-isolation mechanisms is largely unacknowledged.

Only a few clear examples of parameter values are provided by natural analogues that may be directly input to a PA model, such as measured matrix diffusion and metal corrosion rates. A semiquantitative use of natural analogues has been to provide bounding limits to the ranges of parameter values obtained from laboratory studies. The most valuable quantitative contribution of natural analogues, which cannot be replicated in laboratory systems, is to provide bounding estimates for validation of PA models. So far, this has only been seriously attempted for equilibrium geochemical modeling (for example, at Poços de Caldas, Oman, Maqarin, and El Berrocal).

\section{Yucca Mountain Project Incorporation of Natural Analogues}

Process modelers, as users of analogue information, have participated in determining how analogues can best be used to support PA and design groups by reducing uncertainties in the long-term behavior of natural and engineered systems. In the past, the Yucca Mountain Project has used analogues for testing and building confidence in conceptual and numerical process models in a number of ways:

1. Yucca Mountain as a self analogue: Mineral alteration zones that formed during cooling of Timber Mountain ash-flow tuffs were shown to be the same as those expected to form under the thermal conditions predicted by numerical codes (Bish and Aronson, 1993).

2. Thermochemical data: Data from the Wairakai, New Zealand, geothermal field were used to build confidence in thermodynamic parameters for silica minerals in databases used in geochemical modeling (Carroll and others, 1995).

3. Spent fuel alteration parageneses: Mineral phases determined in laboratory experiments were compared to those of Nopal I, at Peña Blanca. The results of these studies have increased the confidence in models describing spent-fuel alteration.

4. Future climate boundary conditions: The Yucca Mountain Project has relied heavily on natural analogue data to set bounds on future climate (for example, Sharpe, 2007) and the consequent response of the water table. Stable isotope data from continuously deposited calcite at Devils Hole (about $50 \mathrm{~km}$ south of Yucca Mountain) have provided a proxy for climate data for the last 500,000 year. (Winograd and others, 1992, 2006; Coplen and others, 1994). Species of ostracodes have been identified in lacustrine and paludal deposits and then matched to modern assemblages elsewhere to delimit past climates (Forester and Smith, 1994). Finally, the elevation of past groundwater discharge deposits relative to the elevation of the modern water table have been used to define groundwater response to past (and, by analogy, future) climates (Paces and Whelan, 2001).

5. Saturated-zone transport: Scoping calculations were conducted for the Peña Blanca site using the same numerical model that was used to assess total system performance of the proposed Yucca Mountain repository. The model attempted to predict the transport of ${ }^{99} \mathrm{Tc}$, which is expected to be a conservative ion that would be released from the waste inventory. Results of the modeling indicated that both ${ }^{99} \mathrm{Tc}$ and some forms of uranium may be detected in groundwater close to the Nopal I mine at Peña Blanca (CRWMS 
M\&O, 2000a, Appendix C, Figure C-12). The scoping predictions were sensitive to the surface area assumed for the inventory of leachable mineral species because a reduction of mineral surface area led to a reduction in both uranium and ${ }^{99} \mathrm{Tc}$ concentrations (CRWMS M\&O, 2000a, Appendix C). Results of the scoping study predictions differ from analytical results of groundwater samples collected in the 1980s from a monitoring well 1,300 m downgradient from the Nopal I mine where low concentrations of uranium were detected.

To corroborate the model results for uranium and technetium, the scoping simulations were rerun in a PA model, using additional data from analyses of water and rock samples collected from wells at and immediately downgradient from the Nopal I ore deposit (Saulnier and Statham, 2006). Results of the PA model indicated that picogram quantities of ${ }^{99} \mathrm{Tc}$ generated by spontaneous fission of ${ }^{238} \mathrm{U}$ may be detectable at $50 \mathrm{~m}$ and $1,300 \mathrm{~m}$ from the Nopal I ore deposit. In addition, the model shows uranium to be transported in limited quantities. However, released uranium is exchanging with uranium minerals that precipitate in fractures around the ore deposit. Despite this precipitation, much of the deposit remains in place (Saulnier and Statham, 2006).

6. Multiple lines of evidence in the "FY 01 Supplemental Science and Performance Analyses, Volume 1: Scientific Bases and Analyses" (BSC, 2001a). To a large degree, these analogues have been referenced in this report. Analogues have also been used to provide multiple lines of evidence in support of both analysis and model reports, in screening arguments for inclusion or exclusion of FEPs in TSPAs, and in the quantification of uncertainties (BSC, 2001b). Several expert elicitations have made use of natural analogues, for example the "Probabilistic Volcanic Hazard Analysis for Yucca Mountain, Nevada" (CRWMS M\&O, 1996); "Probabilistic Seismic Hazard Analyses for Fault Displacement and Vibratory Ground Motion at Yucca Mountain, Nevada" (U.S. Geological Survey, 1998; CRWMS M\&O, 1998a); and "An International Peer Review of the Biosphere Modelling Programme of the U.S. Department of Energy's Yucca Mountain Site Characterization Project, Report of the IAEA International Review Team" (IAEA, 2001).

\section{Yucca Mountain Project Identified Needs and Applications from this Report}

The TSPA Viability Assessment (TSPA-VA) was an interim PA (U.S. Department of Energy, 1998b) that raised questions that afforded exploration through natural analogues.
Areas identified by the TSPA-VA in which analogue studies might contribute to evaluating and building confidence in PA models include:

- Seepage threshold and the fraction of waste packages contacted by seeps (including seepage enhanced by thermally induced drift collapse)

- Alteration of hydrologic properties by mineral precipitation or dissolution

- Sorption onto fractures

- The action of colloid filtration in reducing radionuclide migration

- Alloy 22 corrosion

- Neptunium solubility

- Saturated-zone dilution

Table 15 is a compilation of the ways in which analogues have been used in this report. The analogues are categorized as to their use in building conceptual models or understanding of processes, development of data parameters and their use in TSPA, or use for model validation. It is evident that the majority of uses of analogues for the Yucca Mountain Project has been in the understanding of which processes to model and how to incorporate them into PA. Less frequent has been their use in model validation, and even more infrequently is their use directly in PA. The categorization on this table should not be surprising because it corresponds to the frequency of application of analogues to these steps in TSPA in the international community, as stated in the previous section and in IAEA (1999).

A number of processes amenable to study through natural analogues have not been discussed in this report. These processes include biosphere analogies, microbially induced corrosion, efficacy of a clay buffer in backfill, the contribution of organic materials and microbes in enhancing or preventing radionuclide migration, and analogues to disruptive events such as volcanism and seismicity. The introductory discussion in this report presents the reasons for this omission.

\section{Remaining Areas for Increased Process Understanding through Analogue Studies}

The analogue examples and studies presented in this report provide varying degrees of confidence in the processes they are intended to support. The investigation of these analogues has helped to indicate the directions along which further analogue studies can best be focused to address processes that are not fully understood. Key areas where analogues may assist in building more confident assessments of processes are the following:

1. Irreversible sorption: TSPA makes the conservative assumption that sorption is reversible because 
no useful data exist that show it to be irreversible. If analogues could demonstrate convincingly the conditions under which sorption could be irreversible, they would contribute greatly to the realism of models.

2. Plume dispersion: Following the UMTRA study, modeling of different types of plumes in alluvium could build confidence in the way plume dispersion is modeled for the Yucca Mountain Project TSPA. Examples could be toxic spills or natural analogues such as Koongarra. One such study was conducted by Kelkar and others (2006) who investigated plumes at the INL in Idaho, at Hanford, Washington, and at Oak Ridge, Tennessee.

3. Geosphere/biosphere interface: Radionuclide behavior at the geosphere/biosphere interface could be investigated by natural analogue studies on the migration of radionuclides released from spills, leaks, and underground bomb tests and accidents. Some sites in Russia (for example, Mayak) may yield these types of data.

4. Colloids: Analogue studies indicate that colloids provide an inefficient mechanism for transport because of low populations, limited radionuclide uptake, and filtration by the rock. However, to conclude that colloids are an unimportant factor for repository safety would require information from larger-scale natural studies in relevant geological environments, which would allow study of the efficacy of buffering reactions for oxidation-reduction potential and $\mathrm{pH}$ and evidence for long-distance (kilometer-scale) transport in relevant geologic formations.

5. Transport in unsaturated ash-flow tuffs: Peña Blanca is probably the closest overall analogue with conditions similar to Yucca Mountain. Nopal I is a natural environment where groundwater chemistry is somewhat analogous to groundwaters in the Yucca Mountain system, and groundwaters contain elevated concentrations of radionuclides and other trace elements from a known source. Nopal I also displays discrete zones in fractured rocks intersected by potentially identifiable preferential groundwater flow paths. Such flow paths would allow definition of a source region and transport pathway, as well as a study of sorption processes on fracture surface minerals.
In conclusion, natural and anthropogenic analogues have provided and can continue to provide value in understanding features and processes of importance across a wide range of topics in addressing the challenges of geologic isolation of radioactive waste.

\section{Acknowledgments}

This report has benefited by help from numerous contributors over a span of several years. The initial concept of evaluating radioactive waste disposal using analogue information was espoused by Isaac Winograd (U.S. Geological Survey, retired). Many helpful discussions were provided by Eugene Roseboom, William Dudley, and Zell Peterman (all U.S. Geological Survey, retired). James Goodbar (Bureau of Land Management) provided field assistance to both authors as well as an introduction to karst literature. Amy Dansie (Nevada Museum of Natural History, retired) assisted with archeology of the Western United States. Robert Levich and Abraham Van Luik (both U.S. Department of Energy, the former now retired) provided continued encouragement, assistance with field visits, and helpful suggestions.

Contributions to the report content also were provided by Los Alamos National Laboratory staff, including Edward Kwicklis, Peter Lichtner, James (Bill) Carey, Michael Murrell, and Arend Meijer (retired). Patrick Dobson (Lawrence Berkeley National Laboratory) contributed to the discussion of coupled processes analogues. Abraham Van Luik, William Halsey (Lawrence Livermore National Laboratory), and William Keefer (U.S. Geological Survey, retired) provided reviews that greatly improved the original manuscript. Mary Kidd (U.S. Geological Survey) thoroughly edited the report and Randi Moore (Los Alamos National Laboratory) was instrumental in assistance with figures and compositing. 
Table 15. Natural analogues discussed in this report and their potential application to Yucca Mountain performance assessment.

[TSPA, total system performance assessment; ITOUGH2, model code for unsaturated zone transport; LPIT, large-scale aquifer pumping and infiltration tests; SDA, subsurface disposal area; NTS, Nevada Test Site; TOUGH2, model code for unsaturated zone transport; UMTRA, Uranium Mill Tailings Recovery Act]

\begin{tabular}{|c|c|c|}
\hline $\begin{array}{l}\text { Conceptual model development (applied } \\
\text { processes from natural analogues) }\end{array}$ & $\begin{array}{c}\text { Use of specific parameters in Yucca } \\
\text { Mountain TSPA model }\end{array}$ & $\begin{array}{l}\text { Use for model validation of Yucca } \\
\text { Mountain characterization }\end{array}$ \\
\hline & & $\begin{array}{l}\text { Dimensions of caves and underground } \\
\text { openings that have stood open for } \\
\text { thousands of years }\end{array}$ \\
\hline & & $\begin{array}{l}\text { Stability of natural and manmade under- } \\
\text { ground openings for thousands of years, } \\
\text { even withstanding seismic effects }\end{array}$ \\
\hline \multicolumn{3}{|l|}{$\begin{array}{l}\text { Variables that determine structural stability } \\
\text { of underground openings }\end{array}$} \\
\hline & & $\begin{array}{l}\text { Nopal I validated spent fuel dissolution } \\
\text { experiments where uranium silicates are } \\
\text { long-term solubility-limiting phases and } \\
\text { sequence of formation of secondary } \\
\text { minerals is similar }\end{array}$ \\
\hline \multicolumn{3}{|l|}{$\begin{array}{l}\text { Importance of secondary phases at } \\
\text { Shinkolobwe and Okélobondo in } \\
\text { retaining uranium }\end{array}$} \\
\hline & & $\begin{array}{l}\text { Chemical and physical conditions required to } \\
\text { reach criticality at Oklo used to estimate } \\
\text { amount of spent fuel needed to create criti- } \\
\text { cal conditions at a repository }\end{array}$ \\
\hline & & $\begin{array}{l}\text { Qualitative validation that natural glass alter- } \\
\text { ation studies indicate nuclear waste glass } \\
\text { will be stable in a repository environment }\end{array}$ \\
\hline \multicolumn{3}{|l|}{$\begin{array}{l}\text { Formation of protective passive film around } \\
\text { metals, as observed in Delhi iron pillar } \\
\text { (India) }\end{array}$} \\
\hline $\begin{array}{l}\text { Long-term stability of nickel-iron metals, as } \\
\text { evidenced by occurrence of josephinite } \\
\text { in } 150 \text {-million-year-old ultramafic rocks, } \\
\text { Oregon }\end{array}$ & & \\
\hline
\end{tabular}


Table 15. Natural analogues discussed in this report and their potential application to Yucca Mountain performance assessment.-Continued

[TSPA, total system performance assessment; ITOUGH2, model code for unsaturated zone transport; LPIT, large-scale aquifer pumping and infiltration tests; SDA, subsurface disposal area; NTS, Nevada Test Site; TOUGH2, model code for unsaturated zone transport; UMTRA, Uranium Mill Tailings Recovery Act]

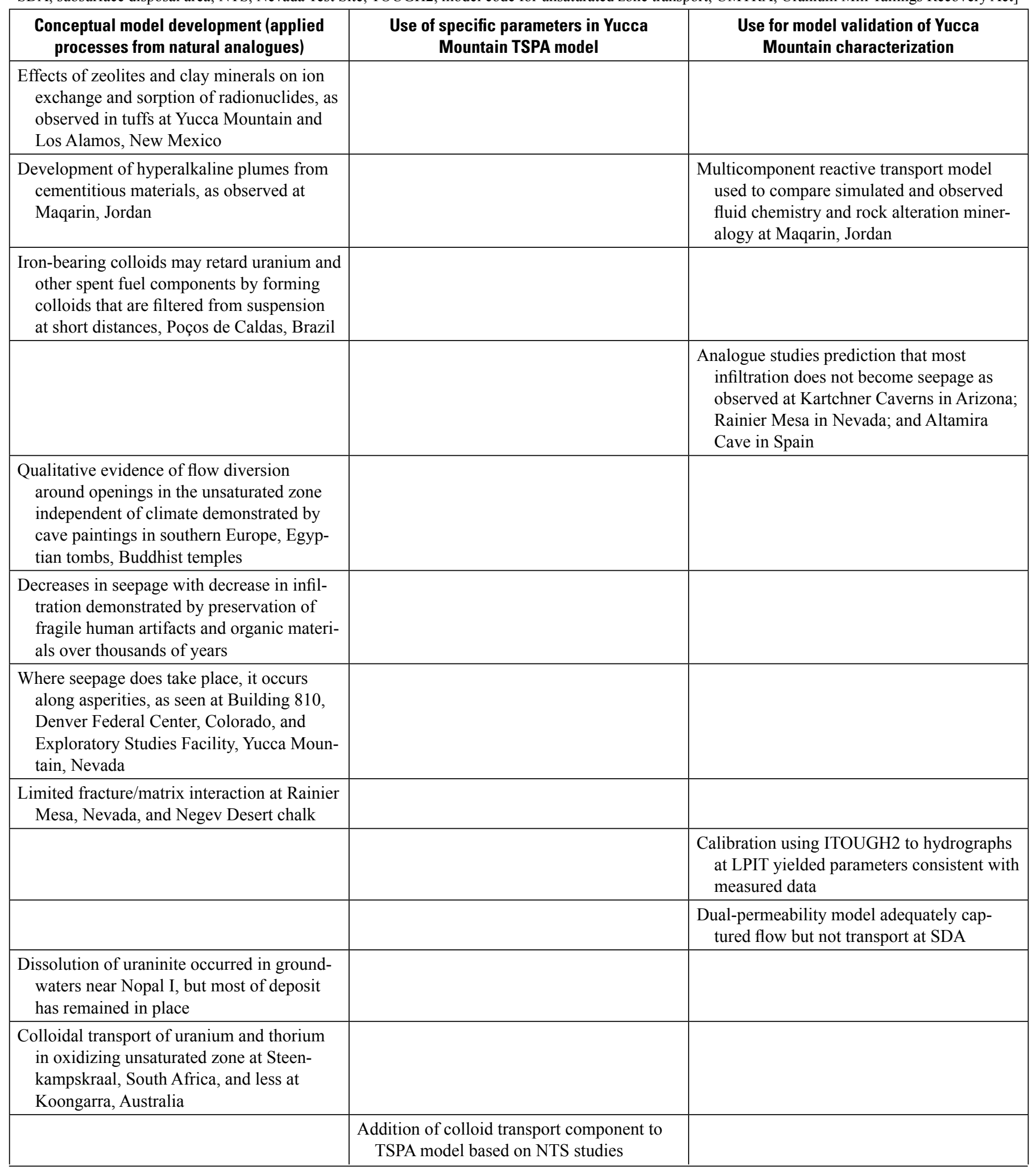


Table 15. Natural analogues discussed in this report and their potential application to Yucca Mountain performance assessment.-Continued

[TSPA, total system performance assessment; ITOUGH2, model code for unsaturated zone transport; LPIT, large-scale aquifer pumping and infiltration tests; SDA, subsurface disposal area; NTS, Nevada Test Site; TOUGH2, model code for unsaturated zone transport; UMTRA, Uranium Mill Tailings Recovery Act]

\begin{tabular}{|c|c|c|}
\hline $\begin{array}{c}\text { Conceptual model development (applied } \\
\text { processes from natural analogues) }\end{array}$ & $\begin{array}{c}\text { Use of specific parameters in Yucca } \\
\text { Mountain TSPA model }\end{array}$ & $\begin{array}{l}\text { Use for model validation of Yucca } \\
\text { Mountain characterization }\end{array}$ \\
\hline $\begin{array}{l}\text { Numerical simulation of heat and fluid } \\
\text { flow in numerous developed geothermal } \\
\text { systems }\end{array}$ & & $\begin{array}{l}\text { Confirmation of TOUGH2-based thermal- } \\
\text { hydrological reservoir simulations through } \\
\text { postaudit history matching of Olkaria } \\
\text { (Kenya) and Nesjavellir (Iceland) geother- } \\
\text { mal fields }\end{array}$ \\
\hline \multicolumn{3}{|l|}{$\begin{array}{l}\text { Reduction in porosity and permeability due } \\
\text { to silica precipitation, as observed at } \\
\text { Yellowstone, Wyoming, and in reinjection } \\
\text { wells at Wairakei (New Zealand) geother- } \\
\text { mal field }\end{array}$} \\
\hline $\begin{array}{l}\text { Use of thermodynamic models to predict } \\
\text { fluid-mineral reactions at geothermal } \\
\text { reservoir conditions }\end{array}$ & & $\begin{array}{l}\text { Modeled possibility of forming opal-filled } \\
\text { veins with source of silica derived from } \\
\text { host rock at Paiute Ridge, Nevada }\end{array}$ \\
\hline \multicolumn{3}{|l|}{$\begin{array}{l}\text { Limited fracture-filling and secondary } \\
\text { mineral alteration at Paiute Ridge (Ne- } \\
\text { vada); no alteration at Grants Ridge (New } \\
\text { Mexico) and Banco Bonito (New Mexico) }\end{array}$} \\
\hline \multicolumn{3}{|l|}{$\begin{array}{l}\text { Advective fracture transport at Nopal I } \\
\text { (unsaturated) and Palmottu, Poços de } \\
\text { Caldas, and El Berrocal, Spain (all } \\
\text { saturated) }\end{array}$} \\
\hline \multicolumn{3}{|l|}{$\begin{array}{l}\text { Matrix diffusion for short distances at Poços } \\
\text { de Caldas, Brazil and Oklo, Gabon }\end{array}$} \\
\hline & $\begin{array}{l}\text { Future climate conditions bounded by data } \\
\text { from Devils Hole, Nevada }\end{array}$ & \\
\hline & $\begin{array}{l}\text { A complete TSPA based on Peña Blanca } \\
\text { parameters (Saulnier and Statham, 2006) }\end{array}$ & \\
\hline & & $\begin{array}{l}\text { Dispersion of plume in Yucca Mountain } \\
\text { model based on examples from anthropo- } \\
\text { genic sites (Kelkar and others, 2006) }\end{array}$ \\
\hline
\end{tabular}




\section{References}

Ahn, T.M., and Soo, P., 1995, Corrosion of low-carbon cast steel in concentrated synthetic groundwater at 80 to $150^{\circ} \mathrm{C}$ : Waste Management, New York, Elsevier, v. 15, no. 7, p. 471-476.

Airey, P.L., 1986, Radionuclide migration around uranium ore bodies in the Alligator Rivers region of the Northern Territory of Australia-Analogue of radioactive waste repositories-A review: Chemical Geology, v. 55, no. 3/4, p. $255-268$.

Airey, P.L., 1987, Application of natural analogue studies to the long-term prediction of far field migration at repository sites, in Côme, B., and Chapman, N.A., eds., Natural analogues in radioactive waste disposal symposium, Brussels, April 28-30, 1987: Radioactive Waste Management Serial, EUR 11037 EN, p. 32-41.

Airey, P.L., and Ivanovich, M., 1985, Geochemical analogues of high level radioactive waste repositories, appendix 2, in Côme, B., and Chapman, N., eds., First Natural Analogue Working Group, Brussels, November 5-7, 1985: Commission of the European Communities Nuclear Science and Technology Report, EUR 10315, p. 57-75.

Airey, P.L., Duerden, P., Roman, D., Golian, C., Nightingale, T., Payne, T., Davey, B.G., Gray, D., Snelling, A., and Lever, D., 1987, The prediction of the long-term migration of radionuclides in the far field of high-level waste repositories, in Brookins, D.G., ed., Results from the Alligator Rivers natural analogue study - The geological disposal of high level radioactive wastes: Athens, Greece, Theophrastus Publications, p. 507-524.

Alba, L.A., and Chavez, R., 1974, K-Ar ages of volcanic rocks from the central Sierra Peña Blanca, Chihuahua, Mexico: Isochron/West, v. 10, p. 21-23.

Alexander, D.H., and Van Luik, A.E., 1991, Natural analogue studies useful in validating regulatory compliance analyses in safety assessment of radioactive waste repositories, GEOVAL-1990, Symposium on Validation of Geosphere Flow and Transport Models, Stockholm, Sweden, May 14-17, 1990: Organisation for Economic Co-operation and Development, p. 589-597.

Allard, Thierry, and Muller, J.P., 1998, Kaolinite as an in situ dosimeter for past radionuclide migration at the earth's surface: Applied Geochemistry, v. 13, no. 6, p. 751-765.

Allison, M.J., 1985, Chile's ancient mummies: Natural History, v. 94 , no, 10, p. 74-81.

Andrews, E.W., IV, 1970, Balankanche, throne of the tiger priest: Tulane University, New Orleans, Middle American Research Institute, publication 32, $182 \mathrm{p}$.
Anna, L.O., and Wallman, P., 1997, Characterizing the fracture network at Yucca Mountain, Nevada, part 2-Numerical simulation of flow in a three-dimensional discrete fracture network, in Hoak, T.E., Klawitter, A.L., and Blomquist, P.K., eds., Fractured reservoirs - Characterization and modeling Guidebook 1997: Rocky Mountain Association of Geologists, p. 199-207.

Anthony, D.M., and Granger, D.E., 2004, A later Tertiary origin for multilevel caves along the western escarpment of the Cumberland Plateau, Tennessee and Kentucky, established by cosmogenic ${ }^{26} \mathrm{Al}$ and ${ }^{10} \mathrm{Be}$ : Journal of Caves and Karst Studies, v. 66, p. 46-55.

Apostol, T.M., 2004, The tunnel of Samos: Engineering and Science, v. 1, p. 30-40.

Apps, J.A., 1995, Natural geochemical analogues of the near field of high-level nuclear waste repositories, in Kovach, L.A., and Murphy, W.M., eds., Proceedings of the workshop on the role of natural analogs in geologic disposal of highlevel nuclear waste, San Antonio, Texas, July 22-25 1991: U.S. Nuclear Regulatory Commission, NUREG/CP-0147, p. 75-99.

Arai, T., Yusa, Y., Sasaki, N., Tsunoda, N., and Takano, H., 1989, Natural analogue study of volcanic glass - A case study of basaltic glasses in pyroclastic fall deposits of Fuji Volcano, Japan, in Lutze, W., and Ewing, R.C., eds., Scientific basis for nuclear waste management XII, Berlin, Germany, October 10-13 1988 Symposium: Materials Research Society, v. 127, p. 73-80.

Arizona Conservation Projects, Inc., 1992, Environmental studies for Kartchner Caverns State Park-Final report: Arizona State Parks Department, 328 p.

Arriaza, B.T., and Ferorelli, 1995, Chile's Chinchorro mummies: National Geographic, v. 187, no. 3, p. 68-89.

Arriaza, B.T., Hapke, R.A., and Standen, V.G., 1998, Making the dead beautiful-Mummies as art: Archaeology, www. archaeology.org/online/features/chinchorro/index.html (last accessed May 4, 2010).

Arroyo-Cabrales, Joaquin, and Polaco, O.J., 2003, Caves and Pleistocene vertebrate paleontology of Mexico, in Schubert, B.W., Mead, J.I., and Graham, R.W., eds., Ice age cave faunas of North America: Bloomington, Indiana University Press, p. 273-299.

Arthur, R.C., Iwatsuki, T., Sasao, E., Metcalfe, R., Amano, K., and Ota, K., 2006, Geochemical constraints on the origin and stability of the Tono uranium deposit, JapanGeochemistry: Exploration, Environment, Analysis, v. 6, p. 33-48. 
Atkinson, Anne, Griffin, T.J., and Stephenson, P.J., 1975, A major lava tube system from Undara Volcano, North Queensland: Bulletin Volcanologique, v. 39, p. 266-293.

Bakalowicz, M.J., Ford, D.C., Miller, T.E., Palmer, A.N., and Palmer, M.V., 1987, Thermal genesis of dissolution caves in the Black Hills, South Dakota: Geological Society of America Bulletin, v. 99, p. 729-738.

Balasubramaniam, R., 2000, On the corrosion resistance of the Delhi iron pillar: Corrosion Science, v. 42 , no. 12 , p. 2103-2129.

Bargar, K.E., and Beeson, M.H., 1984, Hydrothermal alteration in research drill hole Y-6, upper Firehole River, Yellowstone National Park, Wyoming: U.S. Geological Survey Professional Paper 1054-B, 40 p.

Bargar, K.E., and Beeson, M.H., 1985, Hydrothermal alteration in research drill hole Y-3, lower Geyser Basin, Yellowstone National Park, Wyoming: U.S. Geological Survey Professional Paper 1054-C, 23 p.

Bargar, K.E., Beeson, M.H., and Keith, T.E.C., 1981, Zeolites in Yellowstone National Park: The Mineralogical Record, v. 12 , p. 29-38.

Barraclough, J.T., Robertson, J.B., and Janzer, V.J., 1976, Hydrology of the solid waste burial ground as related to the potential migration of radionuclides, Idaho National Engineering Laboratory, with a section on Drilling and sample analyses by L.G. Saindon: U.S. Geological Survey OpenFile Report 76-471, 199 p.

Barton, R.N.E., Currant, A.P., Fernandez-Jalvo, Y., Finlayson, J.C., Goldbert, P., MacPhail, R., Pettitt, P.B., and Stinger, C.B., 1999, Gibraltar Neanderthals and Gorham's, Vanguard, and Ibex caves: Antiquity, v. 73, p. 13-23.

Bar-Yosef, O., Arnold, M., Mercier, N., Belfer-Cohen, A., Goldberg, P., Housley, R., Laville, H., Meignen, L., Vogel, J.C., and Vandermeersch, B., 1996, The dating of the Upper Paleolithic layers in Kebara Cave, Mt. Carmel: Journal of Archaeological Science, v. 23, p. 297-306.

Bassett, W.A., Bird, J.M., Weathers, M.S., and Kohlstedt, D.L., 1980, Josephinite, crystal structures and phase relations of the metals: Physics of the Earth and Planetary Interiors, v. 23, p. 255-261.

Bath, A.H., Berner, U., Cave, M., McKinley, I.G., and Neal, C., 1987a, Testing geochemical models in a hyperalkaline environment, in Côme, B., and Chapman, N.A., eds., Natural analogues in radioactive waste disposal, Brussels, April 28-30, 1987, Symposium: Radioactive Waste Management Series, EUR 11037 EN, p. 167-178.
Bath, A.H., Christofi, N., Neal, C., Philp, J.C., Cave, M.R., McKinley, I.G., and Berner, U., 1987b, Trace element and microbiological studies of alkaline groundwaters in Oman, Arabian Gulf, in A natural analogue for cement pore-waters: Technical Report 87-16, Switzerland, Nationale Genossenschaft für die Lagerung Radioaktiver Abfalle (NAGRA), $65 \mathrm{p}$.

Beasley, T.M., Dixon, P.R., and Mann, L.J., 1998, ${ }^{99} \mathrm{Tc},{ }^{236} \mathrm{U}$, and ${ }^{237} \mathrm{~Np}$ in the Snake River Plain aquifer at the Idaho National Engineering and Environmental Laboratory, Idaho Falls, Idaho: Environmental Science \& Technology, v. 32, no. 24 , p. $3875-3881$.

Becker, B.H., Burgess, J.D., Holdren, K.J., Jorgensen, D.K., Magnuson, S.O., and Sondrup, A.J., 1998, Interim risk assessment and contaminant screening for the Waste Area Group 7 remedial investigation: Lockheed Martin Idaho Technologies Company, Idaho Falls, Idaho, DOE/ ID-10569, $712 \mathrm{p}$.

Behl, B.K., 1998, The Ajanta Caves-Artistic wonder of ancient Buddhist India: New York, Harry N. Abrams, Inc., $256 \mathrm{p}$.

Bell, C.J., and Glennon, J., 2003, Arvicoline rodents from Screaming Neotoma Cave, southern Colorado Plateau, Apache County, Arizona, with comments on the Pleistocene biogeography of Lemmiscus curtatus, in Schubert, B.W., Meads, J.I., and Graham, R.W., eds., Ice age cave faunas of North America, Bloomington, Indiana University Press, p. 54-63.

Benson, L.V., Robison, J.H., Blankennagel, R.K., and Ogard, A.E., 1983, Chemical composition of ground water and the locations of permeable zones in the Yucca Mountain area, Nevada: U.S. Geological Survey Open-File Report 83-854, $123 \mathrm{p}$.

Benson, L.V., and McKinley, P.W., 1985, Chemical composition of ground water in the Yucca Mountain area, Nevada, 1971-84: U.S. Geological Survey Open-File Report 85-484, 10 p.

Bini, Alfredo, Quinif, Yves, Sules, Oscar, and Uggeri, Allessandro, 1992, Les mouvements tectoniques recent dan les grottes du Monte Campo Dei Fiori (Lombardie, Italie): Karstologia, no. 19, p. 23-30.

Bird, J.M., 2001, “John M. Bird”: Ithaca, New York, Cornell University. Accessed January 30, 2002, http://www.geo. cornell.edu/geology/faculty/Bird.html.

Bird, J.M., and Ringwood, A.E., 1980, Container for radioactive nuclear waste materials, U.S. Patent Number: U.S. Patent Office, v. 4, no. 192, p. 765. 
Bird, J.M., and Ringwood, A.E., 1982, Container for radioactive nuclear waste materials, U.S. Patent Number: U.S. Patent Office, v. 4, no. 337, p. 167.

Bird, J.M., and Ringwood, A.E., 1984, Container for radioactive nuclear waste materials, U.S. Patent Number: U.S. Patent Office, v. 4, no. 474, p. 689.

Birkholzer, Jens, Li, G., Tsang, C-F., and Tsang, Y., 1999, Modeling studies and analysis of seepage into drifts at Yucca Mountain: Journal of Contaminant Hydrology, v. 38, no. $1-3$, p. 349-384.

Bish, D.L., and Aronson, J.L., 1993, Paleogeothermal and paleohydrologic conditions in silicic tuff from Yucca Mountain, Nevada: Clays and Clay Minerals, v. 41, no. 2, p. 148-161.

Blanc, P.L., 1996, Acquirements of the project_-Volume 1 of Oklo-Natural analogue for a radioactive waste repository (phase 1): Luxembourg, Commission of the European Communities, v. 1, EUR 16857/1 EN, 123 p..

Blomqvist, Runar, Jaakkola, T., Niini, H., and Ahonen, L., eds., 1991, The Palmottu analogue project, progress report, 1990 - The behaviour of natural radionuclides in and around uranium deposits, Nr. 4: Geological Survey of Finland, YST-73, 147 p.

Blomqvist, Runar, Kaija, J., Lampinen, P., Paananen, M., Ruskeeniemi, T., Korkealaakso, J., Pitkanen, P., Ludvigson, J.-E., Smellie, J., Koskinen, L., Floria, E., Turrero, M.J., Galarza, G., Jakobsson, K., Laaksoharju, M., Casanova, J., Grundfelt, B., and Hernan, P., 1998, The Palmottu natural analogue project phase I-Hydrogeological evaluation of the site: Luxembourg, Commission of the European Communities, Nuclear Science and Technology Report, EUR $18202 \mathrm{EN}$, variously paginated, 7 sections.

Blomqvist, Runar, Lindberg, A., Raisanen, E., Suutarinen, R., Jaakkola, T., and Suksi, J., 1987, The occurrence and migration of natural radionuclides in groundwater, 1, in Preliminary results of investigations in the Palmottu U-Th deposit, Nummi-Pusula, SW Finland: Geological Survey of Finland, YST-60, 23 p.

Blomqvist, Runar, Suksi, J., Ruskeeniemi, T., Ahonen, L., Niini, H., Vuorinen, U., and Jakobsson, K., 1995, The Palmottu natural analogue project, summary report, 1992-1994, in The behaviour of natural radionuclides in and around uranium deposits, Nr. 8: Geological Survey of Finland, YST-88, 82 p.

Bodvarsson, G.S., Boyle, W., Patterson, R., and Williams, D., 1999, Overview of scientific investigations at Yucca Mountain - The potential repository for high-level nuclear waste: Journal of Contaminant Hydrology, v. 38, no. 1-3, p. 3-24.
Bodvarsson, G.S., and Witherspoon, P.A., 1989, Geothermal reservoir engineering, part 1: Geothermal Science and Technology, v. 2, no. 1, p. 1-68.

Boles, J.R., 1999, Calcite precipitates in the Mission Tunnel-A 90-year record of groundwater seeps in fractured sandstone: EOS, Transactions (Supplement), v. 80, no. 46, p. F423.

Botto, R.I., and Morrison, G.H., 1976, Josephinite-A unique nickel-iron: American Journal of Science, v. 276, no. 3, p. 241-274.

Bredehoeft, J.D., 1997, Fault permeability near Yucca Mountain: Water Resources Research, v. 33, p. 2459-2463.

Breeden, Stanley, and Wright, B., 1988, The first Australians: National Geographic, v. 174, p. 266-289.

Breisch, R.L., 1987, The conservation of European cave art: National Speleological Society News, v. 45, p. 285-291.

Brookins, D.G., 1978, Retention of transuranic and actinide elements and bismuth at the Oklo natural reactor, GabonApplication of Eh-pH diagrams: Chemical Geology, v. 23, p. 309-323.

Brookins, D.G., 1990, Radionuclide behavior at the Oklo nuclear reactor, Gabon: Waste Management, Amsterdam, The Netherlands, Pergamon Press, v. 10, p. 285-296.

Bros, Regis, Andersson, P., Roos, P., Claesson, S., Holm, E., and Smellie, J., 1998, Swedish investigations on the Bangombé reactor zone U-series disequilibrium and timescale of radionuclide mobilization processes, in Louvat, D., and Davies, C., eds., Oklo working group-Proceedings of the First Joint EC-CEA Workshop on the Oklo-Natural Analogue Phase II Project, June 18-20 1997, Sitjes, Spain: Commission of the European Communities Nuclear Science and Technology Series, Luxembourg, EUR 18314 EN, p. 187-195.

Bros, Regis, Turpin, L., Gauthier-Lafaye, F., Holliger, PH., and Stille, P., 1993, Occurrence of naturally enriched ${ }^{235} \mathrm{U}$-Implications for plutonium behaviour in natural environments: Geochimica et Cosmochimica Acta, v. 57, no. 6, p. 1351-1356.

Brown, Ian, Brekke, T., and Korbin, G., 1981, Behavior of the Bay Area Rapid Transit tunnels through the Hayward fault: Report for USDOT, UMTA Report no. CA-06-0120-81-1, 208 p.

Broxton, D.E., and Carlos, B.A., 1986, Zeolitic alteration and fracture fillings in silicic tuffs at a potential nuclear waste repository, Yucca Mtn., Nevada, USA: Fifth International Symposium on Water-Rock Interaction, Reykjavik, Iceland, August 8-17,1986, Rotterdam, A.A. Balkema, p. 88-91. 
Bruno, Jordi, Duro, L., and Grivé, M., 2001, The applicability and limitations of the geochemical models and tools used in simulating radionuclide behaviour in natural watersLessons learned from the blind predictive modelling exercises performed in conjunction with natural analogue studies: Swedish Nuclear Fuel and Waste Management Company, SKB TR-01-20, 65 p.

Bruton, C.J., 1995, Testing EQ3/6 and GEMBOCHS using fluid-mineral equilibria in the Wairakei geothermal system: Letter Report MOL206, Livermore, Calif., Lawrence Livermore National Laboratory, $23 \mathrm{p}$.

Bruton, C.J., Glassley, W.E., and Bourcier, W.L., 1993, Testing geochemical modeling codes using New Zealand hydrothermal systems, in Proceedings of the Topical Meeting on Site Characterization and Model Validation, FOCUS '93, Las Vegas, Nevada, September 26-29 1993: American Nuclear Society, p. 240-245.

Bruton, C.J., Glassley, W.E., and Meike, A., 1995, Geothermal areas as analogues to chemical processes in the near-field and altered zone of the potential Yucca Mountain, Nevada repository: Livermore, Calif., Lawrence Livermore National Laboratory, UCRL-ID-119842, 24 p.

BSC, 2001a, FY 01 supplemental science and performance analyses, scientific bases and analyses: Bechtel SAIC Company, TDR-MGR-MD-000007 REV 00 ICN 01, Las Vegas, Nevada, 2 volumes, variously paginated.

BSC, 2001b, Drift degradation analysis: Bechtel SAIC Company, ANL-EBS-MD-000027 REV 01 ICN 01, Las Vegas, Nevada, variously paginated.

BSC, 2004, Natural analogues synthesis report, rev. 1: Bechtel SAIC Company, TDR-NBS-GS-000027, REV 01, Las Vegas, Nevada,, variously paginated.

Buck, P.E., and DuBarton, A., 1994, Archaeological investigations at Pintwater Cave, Nevada, during the 1963-64 field season: Journal of California and Great Basin Anthropology, v. 16 , no. 2 , p. $221-242$.

Buddemeier, R.W., and Hunt, J.R., 1988, Transport of colloidal contaminants in groundwater, radionuclide migration at the Nevada Test Site: Applied Geochemistry, v. 3, p. 535-548.

Buecher, R.H., 1999, Microclimate study of Kartchner Caverns, Arizona: Journal of Cave and Karst Studies, v. 61, no. 2 , p. $108-120$.

Burgess, J.D., 1995, Results of the neutron and natural gamma logging, stratigraphy, and perched water data collected during a large-scale infiltration test: Lockheed Martin Idaho Technologies, INEL-95/062, EDF-ER-WAG7-60.
Byers, C.D., Jercinovic, M.J., and Ewing, R.C., 1987, A study of natural glass analogues as applied to alteration of nuclear waste glass: U.S. Nuclear Regulatory Commission, no. NUREG/CR-4842, 150 .

Cadorin, J.F., Jongmans, D., Plumier, A., Camelbeeck, T., Delaby, S., and Quinin, Y., 2001, Modelling of speleothems failure in Hotton Cave (Belgium) - Is the failure earthquake induced?: Netherlands Journal of Geosciences/Geologie en Mijbouw, v. 80, no. 3-4, p. 315-321.

Carey, J.W., Chipera, S.J., Vaniman, D.T., and Bish, D.L., 1997, Three-dimensional mineralogic model of Yucca Mountain, Nevada: Milestone SP32B5M4, rev. 1.1, Los Alamos, New Mexico, Los Alamos National Laboratory, $12 \mathrm{p}$.

Carlos, B.A., Chipera, S.J., and Bish, D.L., 1995, Distribution and chemistry of fracture-lining minerals at Yucca Mountain, Nevada: Los Alamos, New Mexico, Los Alamos National Laboratory, no. LA-12977-MS, 94 p.

Carpenter, D.W., and Chung, D.H., 1986, Effects of earthquakes on underground facilities-Literature review and discussion: U.S. Nuclear Regulatory Commission, NUREG/ CR-4609, 53 p.

Carracedo, J.C., and Day, S., 2002, Classical geology in Europe 4-Canary Islands: Harpenden, England, Terra Publishing, 294 p.

Carracedo, J.C., Paterne, M., Guillou, H., Pérez Torrado, F.J., Paris, R., Rodríguez Badiola, E., and Hansen, A., 2003, Dataciones radiométricas $\left({ }^{14} \mathrm{C}\right.$ y K/Ar) del Teide y el rift noroeste, Tenerife, Islas Canarias: Estudios Geológicos, v. 59, p. $15-29$.

Carracedo, J.C., Singer, B., Jicha, B., Guillou, H., Rodríguez Badiola, E., Meco, J., Pérez Torrado, F.J., Gimeno, D., Socorro, S., and Láinez, A., 2003, La erupción y el tubo volcánico del volcán Corona (Lanzarote, Islas Canarias): Estudios Geológicos, v. 59, p. 277-302.

Carroll, Susan, Mroczek, E., Alai, M., and Ebert, M., 1998, Amorphous silica precipitation $\left(60\right.$ to $\left.120^{\circ} \mathrm{C}\right)$-Comparison of laboratory and field rates: Geochimica et Cosmochimica Acta, v. 62, no. 8, p. 1379-1396.

Carroll, Susan, Mroczek, E., Bourcier, B., Alai, M., and Ebert, M., 1995, Comparison of field and laboratory precipitation rates of amorphous silica from geothermal waters at $100^{\circ} \mathrm{C}$ : Letter Report MOL207, Livermore, Calif., Lawrence Livermore National Laboratory, $48 \mathrm{p}$.

Cascadden, T.E., Kudo, A.M., and Laughlin, W., 1997, El Calderon cinder cone and associated basalt flows: New Mexico Bureau of Geology \& Mineral Resources, Bulletin 156, p. 41-51. 
Castellani, Vittorio, and Dragoni, Walter, 1997, Ancient tunnels - From Roman outlets back to early Greek civilization: Proceedings from the 12th International Congress of Speleology, La Chau-de-fonds, Switzerland, August 10-17, 1997, v. 3, p. 265-268.

Castor, S.B., Henry, C.D., and Shevenell, L.A., 1996, Volcanic rock-hosted uranium deposits in northwestern Nevada and southeastern Oregon-Possible sites for studies of natural analogues for the potential high-level nuclear waste repository at Yucca Mountain, Nevada: Nevada Bureau of Mines and Geology Open-File Report 96-3, 81 p.

Cecil, L.D., Pittman, J.R., Beasley, T.M., Michel, R.L., Kubik, P.W., Sharma, P., Fen, U., and Gove, H.E., 1992, Water infiltration rates in the unsaturated zone at the Idaho National Engineering Laboratory estimated from chlorine-36 and tritium profiles, and neutron logging, in Kharaka, Y.K., and Maest, A.S., eds.,Water-Rock Interaction, Proceedings of the 7th International Symposium on Water-Rock Interaction-WRI-7, Park City, Utah, July 13-18, 1992: A.A. Balkema, v. 1, p. 709-718.

Chambers, A.V., Haworth, A., Ilett, D., Linklater, C.M., and Tweed, C.J., 1998, Geochemical modelling of hyperalkaline water/rock interactions, in Smellie, J.A.T., ed., MAQARIN natural analogue study, phase III, volume I: Svensk Kärnbränsleförsörjning A.B., v. 1, SKB TR-98-04, 401 p.

Chapman, Neil, Dansie, A., and McCombie, C., 2006, Preservation of archaeological material in arid environments relevant to Yucca Mountain, in Proceedings of the 11th International High-Level Radioactive Waste Management Conference, Las Vegas, Nevada, April 30-May 4, 2006 : American Nuclear Society, La Grange Park, Illinois, p. 691-697.

Chapman, N.A., Andersson, J., Robinson, P., Skagius, K., Wene, C-O., Wiborgh, M., and Wingefors, S., 1995, Systems analysis, scenario construction and consequence analysis definition for SITE-94: Swedish Nuclear Power Inspectorate, SKI Report 95, 26 p.

Chapman, N.A., McKinley, I.G., and Smellie, J.A.T., 1984, The potential of natural analogues in assessing systems for deep disposal of high-level radioactive waste: Swedish Nuclear Fuel and Waste Management Company, SKB Technical Report 84-16 103 p.

Chapman, N.A., McKinley, I.G., Shea, M.E., and Smellie, J.A.T., 1991, The Poços de Caldas Project—Summary and implications for radioactive waste management: Swedish Nuclear Fuel and Management Company, SKB Technical Report 90-24, 147 p.
Chapman, N.A., McKinley, I.G., Shea, M.E., and Smellie, J.A.T., eds., 1992, The Poços de Caldas Project-Natural analogues of processes in a radioactive waste repository, part I: Journal of Geochemical Exploration (Special Issue), v. 45 , no. $1-3$, p. $1-603$.

Chapman, N.A., and Smellie, J.A.T., 1986, Introduction and summary of the workshop: Chemical Geology, v. 55, p.167-173.

Chapuis, A.M., and Blanc, P.L., 1993, Oklo-Natural analogue for transfer processes in a geological repository-Present status of the programme, in von Maravic, H., and Moreno, J., eds., Migration of radionuclides in the geosphere, Proceedings of a Progress Meeting (Work Period 1991), Brussels, Belgium, April 9-10, 1992: Luxembourg, Commission of the European Communities, EUR 14690 EN, p. 135-142.

Chauvet, J-M., Deschamps, E.B., and Hillaire, C., 1996, Dawn of art-The Chauvet Cave: New York, Harry N. Abrams, Inc., $135 \mathrm{p}$.

Chenoweth, W.L., 1986, The Orphan lode mine, Grand Canyon, Arizona - A case history of a mineralized collapsebreccia pipe: U.S. Geological Survey Open-File Report 86-510, $125 \mathrm{p}$.

Chenoweth, W.L., 1988, The production history and geology of the Hacks, Ridenour, and Chapel breccia pipes, northwestern Arizona: U.S. Geological Survey Open-File Report 88-648, 60 p.

Chigira, Masahiro, Nakata, E., and Watanabe, M., 1995, Selfsealing of rock-water systems by silica precipitation, in Kharaka, Y.K., and Chudeav, O.V., eds, Proceedings of the 8th International Symposium on Water-Rock Interaction, WRI-8, Vladivostok, Russia, August 15-19, 1995: Rotterdam, The Netherlands, A.A. Balkema, p. 73-77.

Clark, J.F., and Turekian, K.K., 1990, Time scale of hydrothermal water-rock reactions in Yellowstone National Park based on radium isotopes and radon: Journal of Volcanology and Geothermal Research, v. 40, p. 169-180.

Clottes, Jean, and Courtin, J., 1996, The cave beneath the sea-Paleolithic images at Cosquer: New York, Harry N. Abrams, Inc., 200 p.

Conca, J.L., Apted, M.J., Zhou, W., Arthur, R.C., and Kessler, J.H., 1998, Flow barrier system for the long-term high-level-waste isolation-Experimental results: Nuclear Technology, v. 1124, p. 88-100.

Coplen, T.B., Winograd, I.J., Landwehr, J.M., and Riggs, A.C., 1994, 500,000-year stable carbon isotopic record from Devils Hole, Nevada: Science v. 263, p. 361-365. 
Corchon, M.S., Valladas, H., Becares, J., Arnold, M., Tisnerat, N., and Cachier, H., 1996, Datación de las pinturas y revision del arte Paleolitico de cueva Palomera (Ojo Guarena, Burgos, Espana): Zephyrus, v. XLIV, p. 37-60.

Coulson, David, 1999, Ancient art of the Sahara: National Geographic, v. 195, no. 6, p. 98-119.

Coulson, David, and Campbell, Alec, 2001, African rock art: New York, Harry N. Abrams, Inc., 256 p.

Covelli, Stefano, Cucchi, F., and Mosca, R., 1998, Monitoring of percolation water to discriminate surficial inputs in a karst aquifer: Environmental Geology: v. 36, no. 3-4, p. 296-304.

Cowan, G.A., 1976, A natural fission reactor: Scientific American, v. 235, no. 1, p. 36-47.

Cowan, Rachel, and Ewing, R.C., 1989, Freshwater alteration of basaltic glass, Hanauma Bay, Oahu, Hawaii-A natural analogue for the alteration of borosilicate glass in freshwater, in Lutze, W., and Ewing, R.C., eds., Scientific basis for nuclear waste management XII, Symposium, Berlin, Germany, October 10-13, 1988: Materials Research Society, v. 127, p. 49-56.

Cramer, J.J., 1986, Sandstone-hosted uranium deposits in northern Saskatchewan as natural analogs to nuclear fuel waste disposal vaults: Chemical Geology, v. 55, p. 269-279.

Cramer, J.J., 1989, Natural analogue studies on the Cigar Lake uranium deposit-An update, in Côme, B., and Chapman, N.A., eds., Commission of the European Communities natural analogue working group, Third Meeting, Snowbird, near Salt Lake City, USA, June 15-17, 1988: Commission of the European Communities Nuclear Science and Technology Series, Luxembourg, EUR 11725 EN, p. 50-56.

Cramer, J.J., 1994, Natural analogs in support of the Canadian concept for nuclear fuel waste disposal: Atomic Energy Canada Limited, AECL-10291, 109 p.

Cramer, J.J., 1995a, The Cigar Lake uranium deposit-Analog information for Canada's nuclear fuel waste disposal concept: Atomic Energy Canada Limited, AECL-11204, 32 p.

Cramer, J., 1995b, Cigar Lake-A natural example of longterm isolation of uranium: Radwaste Magazine, v. 2, no. 3, p. $36-40$.

Cramer, J.J., and Sargent, F.P., 1994, The Cigar Lake analog study-An international R\&D project: Proceedings of the High-Level Radioactive Waste Management Fifth Annual International Conference, Las Vegas, Nevada, May 22-26, 1994: American Nuclear Society, La Grange Park, Illinois, v. 4, p. 2237-2242.
Cramer, J.J., and Smellie, J.A.T., 1994, Final report of the AECL/SKB Cigar Lake analog study: Atomic Energy of Canada Limited, AECL-10851, 393 p.

Cramer, J.J., Vilks, P., and Larocque, J.P. A., 1987, Near-field analog features from the Cigar Lake uranium deposit, in Côme, B., and Chapman, N.A., eds., Natural analogues in radioactive waste disposal, Symposium, Brussels, April 28-30 1987: Radioactive Waste Management Series, EUR 11037 EN, p. 59-72.

Crawford, Harriet, 1979, Subterranean Britain-Aspects of underground archaeology: New York, St. Martin's Press, $201 \mathrm{p}$.

Crosby, H.W., 1997, The cave paintings of Baja California: San Diego, California, Sunbelt Publications, 246 p.

CRWMS (Civilian Radioactive Waste Management System) M\&O (Management and Operating Contractor), 1996, Probabilistic volcanic hazard analysis for Yucca Mountain, Nevada: BA0000000-0 17 17-2200-00082 REV 0, Las Vegas, Nevada, variously paginated, five sections, eight appendices.

CRWMS (Civilian Radioactive Waste Management System) M\&O (Management and Operating Contractor), 1998a, Probabilistic seismic hazard analyses for fault displacement and vibratory ground motion at Yucca Mountain, Nevada: Milestone SP321M3, three volumes, Las Vegas, Nevada, variously paginated.

CRWMS (Civilian Radioactive Waste Management System) M\&O (Management and Operating Contractor), 1998b, Waste form degradation, radionuclide mobilization, and transport through the engineered barrier system: Chapter 6 of Total System Performance Assessment-Viability Assessment (TSPA-VA) Analyses Technical Basis Document: B00000000-01717-4301-00006 Rev. 1, Las Vegas, Nevada, variously paginated.

CRWMS (Civilian Radioactive Waste Management System) M\&O (Management and Operating Contractor), 1999, License application design selection report: B0000000001717-4600-00123 REV 01, CRWMS M\&O, Las Vegas, Nevada variously paginated.

CRWMS (Civilian Radioactive Waste Management System) M\&O (Management and Operating Contractor), 2000a, Total system performance assessment for the site recommendation: TDR-WIS-PA-000001 REV 00 ICN 01, CRWMS M\&O, Las Vegas, Nevada, variously paginated.

CRWMS (Civilian Radioactive Waste Management System) M\&O (Management and Operating Contractor), 2000b, Yucca Mountain site description: TDR-CRW-GS-000001 REV 01 ICN 01, CRWMS M\&O, Las Vegas, Nevada, variously paginated, 13 sections, 3 volumes. 
Cucchi, Franco, Forti, F., Stefanini, S., and Ulcigrai, F., 1985, Mesures de degradation de roche carbonates et d'accroissement de stalagmites, in Collin, G. and Drouin, P., eds., Spelunca memories: Acta XVI Congres National de Speleologie, Nancy-Metz Universite, France, p. 87-90.

Culver, D.C., Hobbs III, H.H., Christman, M.C., and Master, L.L., 1999, Distribution map of caves and cave animals in the United States: Journal of Cave and Karst Studies, v. 61, no. 3 , p. 139-140.

Curtis, D., Benjamin, T., Gancarz, A., Loss, R., Rosman, K., De Laeter, J.R., Delmore, J.E., and Maeck, W.J., 1989, Fission product retention in the Oklo natural fission reactors: Applied Geochemistry, v. 4, p. 49-62.

Curtis, D., Fabryka-Martin, J., Dixon, P., and Cramer, J., 1999, Nature's uncommon elements, plutonium and technetium: Geochimica et Cosmochimica Acta, v. 63, no. 2, p. $275-285$.

Curtis, D.B., 1986, Geochemical controls on ${ }^{99} \mathrm{Tc}$ transport and retention: Chemical Geology, v. 55, p. 227-231.

Curtis, D.B., 1996, Radionuclide release rates from spent fuel for performance assessment modeling, in von Maravic, H., and Smellie, J., eds., Sixth EC Natural Analogue Working Group Meeting, Proceedings of an International Workshop, Santa Fe, New Mexico, USA, September 12-16, 1994: Luxembourg, Commission of the European Communities, EUR 16761 EN, p. 145-153.

Curtis, D.B., Benjamin, T.M., and Gancarz, A.J., 1981, The Oklo reactors-Natural analogs to nuclear waste repositories, in Hofmann, P.L., and Breslin, J.J., eds., The technology of high-level nuclear waste disposal: U.S. Department of Energy, Technical Information Center, DOE/TIC-4621, v. 1, p. $255-286$.

Curtis, D.B., Fabryka-Martin, J., Dixon, P., Aguilar, R., and Cramer, J., 1994, Radionuclide release rates from natural analogues of spent nuclear fuel in high-level radioactive waste management, Proceedings of the Fifth Annual International High Level Radioactive Waste Management Conference, Las Vegas, Nevada, May 22-26, 1994: American Nuclear Society, La Grange Park, Illinois, v. 4, p. 2228-2236.

Curtis, D.B., and Gancarz, A.J., 1983, Radiolysis in natureEvidence from the Oklo natural reactors: Swedish Nuclear Fuel and Waste Management Company, SKB Technical Report 83-10, $60 \mathrm{p}$.

Dabous, A.A., and Osmond, J.K., 2000, U/Th isotopic study of speleothems from Wadi Sannur Cavern, eastern desert of Egypt: Carbonates and Evaporites, v. 15, p. 1-6.
Dames and Moore, 1992, Compilation and summarization of the Subsurface Disposal Area radionuclide transport data at the Radioactive Waste Management Complex: Washington, D.C., U.S. Department of the Interior, Bureau of Mines, EGG-ER-10546, 242 p.

Dansie, Amy, 1997, Early Holocene burials in Nevada — Overview of localities, research and legal issues: Nevada Historical Society Quarterly, Reno, Nevada, Nevada Historical Society, v. 40, no. 1, p. 4-14.

Davies, Oliver, 1935, Roman mines in Europe: Oxford, England, Clarendon Press, 291 p.

Davis, O.K., 1990, Caves as sources of biotic remains in arid western North America: Palaeogeography, Palaeoclimatology, Palaeoecology, v. 76 , no. 3/4, p. 331-348.

Davis, R.A., Jr., Welty, A.T., Borrego, J., Morales, J.A., Pendon, J.G., and Ryan, J.G., 2000, Rio Tinto estuary (Spain) - 5000 years of pollution: Environmental Geology, v. 10 , no. 10 , p. $1107-1116$.

Day, Michael, 2001, Sandstone caves of Wisconsin: 13th International Congress of Speleology, Brasilia, Brazil, v. 1, p. 89-92.

Day, W.C., Potter, C.J., Sweetkind, D.S., Dickerson, R.P., and San Juan, C.A., 1998, Bedrock geologic map of the central block area, Yucca Mountain, Nye County, Nevada: U.S. Geological Survey Miscellaneous Investigations Series Map I-2601, scale 1:24,000, $15 \mathrm{p}$.

De la Cruz, Breta, Hernán, P., and Astudillo, J., 1997, The El Berrocal Project, in von Maravic, H., and Smellie, J., eds., Seventh EC Natural Analogue Working Group Meeting, Proceedings of an International Workshop, Stein am Rhein, Switzerland, October 28-30, 1996: Luxembourg, Commission of the European Communities, EUR 17851 EN., p. $79-103$.

Dearlove, J.P. L., Green, D.C., and Ivanovich, M., 1989, Uranium transport and the partitioning of $\mathrm{U}, \mathrm{Th}$, and $\mathrm{Ra}$ isotopes between solid and aqueous phases in the Krunkelbach Mine, Federal Republic of Germany, in Lutze, W., and Ewing, R.C., eds., Scientific basis for nuclear waste management XII, Symposium, Berlin, Germany, October 10-13, 1988: Materials Research Society, v. 127, p. 927-932.

Degueldre, C.A., 1994, Colloid properties in groundwaters from crystalline formations: Paul Scherrer Institut, PSI Bericht Nr. 94-21, 96 p.

De Laeter, J.R., Rosman, J.K.R., and Smith, C.L., 1980, The Oklo natural reactor - Cumulative fission yields and retentivity of the symmetric mass region fission products: Earth and Planetary Science Letters, v. 50, p. 238-246. 
Dick, H.J.B., 1974, Terrestrial nickel-iron from the Josephine peridotite-Its geologic occurrence, associations, and origin: Earth and Planetary Science Letters, v. 24, no. 2, p. 291-298.

Dicke, C.A., 1997, Distribution coefficients and contaminant solubilities for the Waste Area Group 7 Baseline Risk Assessment: Idaho Falls, Idaho, Lockheed Martin Idaho Technologies Company, INEL/EXT-97-00201, 143 p.

Dobson, Patrick, Hulen, J., Kneafsey, T.J., and Simmons, A., 2001a, Permeability at Yellowstone-A natural analog for Yucca Mountain processes, in Back to the future-Managing the back end of the nuclear fuel cycle to create a more secure energy future, Proceedings of the 9th International High-Level Radioactive Waste Management Conference, Las Vegas, Nevada, April 29-May 3, 2001: American Nuclear Society, La Grange Park, Illinois, 4 p.

Dobson, Patrick, Hulen, J., Kneafsey, T.J., and Simmons, A., $2001 \mathrm{~b}$, The role of lithology and alteration on permeability and fluid flow in the Yellowstone geothermal system, Wyoming, in Proceedings of the Twenty-Sixth Workshop on Geothermal Reservoir Engineering, Palo Alto, California, January 29-31 2001: Workshop Report SGP-TR-168, Stanford University, CD-ROM, 8 p.

Dobson, P.F., Kneafsey, T.J., Hulen, J., and Simmons, A., 2003, Porosity, permeability, and fluid flow in the Yellowstone geothermal system, Wyoming: Journal of Volcanology and Geothermal Research, v. 123, no. 3-4, p. 313-324.

Dobson, P.F., Kneafsey, T.J., Sonnenthal, E.L., Spycher, N., and Apps, J.A., 2003, Experimental and numerical simulation of dissolution and precipitation-Implications for fracture sealing at Yucca Mountain, Nevada: Journal of Contaminant Hydrology, v. 62-63, p. 459-476.

Dom, J.E., and Wicks, C.M., 2003, Morphology of the caves of Missouri: Journal of Caves and Karst Studies, v. 66, p. 155-159.

Donnelly-Nolan, J.M., and Lanphere, M.A., 2005, Argon dating at and near Medicine Lake Volcano, CaliforniaResults and data: U.S. Geological Survey Open-File Report 2005-1416, $37 \mathrm{p}$.

Dorale, J.A., Edwards, R.L., Ito, E., and Gonzalez, L.A., 1998, Climate and vegetation history of the mid-continent from 75 to $25 \mathrm{ka}-\mathrm{A}$ speleothem record from Crevice Cave, Missouri, USA: Science, v. 282, p. 1871-1874.

Dowding, C.H., and Rozen, A., 1978, Damage to rock tunnels from seismic shaking: Journal of the Geotechnical Engineering Division, v. 104, no. GT2, p. 175-191.
Duerden, Peter, Golian, C., Hardy, C.J., Nightingale, T., and Payne, T., 1987, Alligator Rivers Analogue ProjectReview of research and its implications for model validation, in Côme, B. and Chapman, N.A., eds., Natural analogues in radioactive waste disposal: Symposium, Brussels, April 28-30, 1987: Radioactive Waste Management Series, EUR 11037 EN, p. 82-91.

Dunbar, N.W., and Phillips, F.M., 2004, Cosmogenic ${ }^{36} \mathrm{Cl}$ ages of lava flows in the Zuni-Bandera volcanic field, north-central New Mexico, U.S.A.: New Mexico Bureau of Geology \& Mineral Resources, Bulletin 160, p. 309-317.

Dunnivant, F.M., Newman, M.E., Bishop, C.W., Burgess, D., Giles, J.R., Higgs, B.D., Hubbell, J.M., Neher, E., Norrell, G.T., Pfiefer, M.C., Porro, I., Starr, R.C., and Wylie, A.H., 1998, Water and radioactive tracer flow in a heterogeneous field-scale system: Ground Water, v. 36, no. 6, p. 949-958.

Eckel, E.B., 1970, The Alaska earthquake, March 27, 1964, lessons and conclusions: U.S. Geological Survey Professional Paper 546, 57 p.

Edghill, R.B., and Davey, B.G., 1988, Colloids in Koongarra groundwater, in Duerden, P., ed., Alligator Rivers Analogue Project—Progress report May 1988-August 1988: Australian Nuclear Science and Technology Organization, p. $147-156$.

Ericson, J.E., 1981, Durability of rhyolitic obsidian glass inferred from hydration dating research, in Moore, J.G., ed., Scientific basis for nuclear waste management: Proceedings of the Third International Symposium, Boston, Massachusetts, November 17-20, 1980, Materials Research Society, v. 3, p. 283-290.

Euler, R.C., ed., 1984, The archaeology, geology, and paleobiology of Stanton's Cave, Grand Canyon National Park, Arizona: Grand Canyon Natural History Association, Prescott, Arizona, 141 p.

Faulkner, C.H., 1997, Four thousand years of Native American cave art in the southern Appalachians: Journal of Caves and Karst Studies, v. 59, p. 148-153.

Fayek, Mostafa, Goodell, P., Ren, M., and Simmons, A., 2005, Geochronology and fluid-rock interaction associated with the Nopal I uranium deposit, Peña Blanca, Mexico: Geological Society of America Abstracts with Programs, v. 37, no. 7, p. 197.

Fayek, Mostafa, Ren, M., Goodell, P., Dobson, P., Saucedo, A., Kelts, A., Utsunomiya, S., Ewing, R.C., Riciputi, L.R., and Reyes, I., 2006, Paragenesis and geochronology of the Nopal I uranium deposit, Mexico, Proceedings of the 2006 International High-Level Radioactive Waste Management Conference, April 30-May 4, 2006, Las Vegas, Nevada: American Nuclear Society, La Grange Park, Illinois, p. 55-63. 
Fetter, C.W., 2001, Applied hydrogeology, 4th ed.: Englewood Cliffs, New Jersey, Prentice-Hall, 598 p.

Finch, R.J., and Ewing, R.C., 1991, Alteration of natural $\mathrm{UO}_{2}$ under oxidizing conditions from Shinkolobwe, Katanga, Zaire-A natural analogue for the corrosion of spent fuel: Radiochimica Acta, v. 52/53, p. 395-401.

Finch, R.J., and Ewing, R.C., 1992a, The corrosion of uraninite under oxidizing conditions: Journal of Nuclear Materials, v. 190, p.133-156.

Finch, R.J., and Ewing, R.C., 1992b, Alteration of natural uranyl oxide hydrates in Si-rich groundwatersImplications for uranium solubility, in Sombret, C.G., ed., Scientific basis for nuclear waste management XV, Symposium, Strasbourg, France, November 4-7, 1991: Materials Research Society, v. 257, p. 465-472.

Finsterle, Stefan, 1999, ITOUGH2 user's guide: Lawrence Berkeley National Laboratory, LBNL-40040, 140 p.

Flint, A.L., Flint, L.E., Kwicklis, E.M., Fabryka-Martin, J.T., and Bodvarsson, G.S., 2002, Estimating recharge at Yucca Mountain, Nevada - Comparison of methods: Hydrogeology Journal, v. 10, no. 1, p. 180-204.

Ford, D.C., 1989, Features of the genesis of Jewel Cave and Wind Cave, Black Hills, South Dakota: National Speleological Society Bulletin, v. 51, p. 100-110.

Ford, D.C., and Hill, C.A., 1999, Dating of speleothems in Kartchner Caverns, Arizona: Journal of Caves and Karst Studies, v. 61, p. 84-88.

Forester, R.M., and Smith, A.J., 1994, Late glacial climate estimates for southern Nevada-The ostracode fossil record, Proceedings of the Fifth International High-Level Radioactive Waste Management Conference, Las Vegas, Nevada, May 22-26, 1994: American Nuclear Society, La Grange Park, Illinois, p. 2553-2561.

Fournier, R.O., 1989, Geochemistry and dynamics of the Yellowstone National Park hydrothermal system: Annual Review of Earth and Planetary Sciences, v. 17, p. 13-53.

Fournier, R.O., 1991, Water geothermometers applied to geothermal energy, in D'Amore, F., ed., Application of geochemistry in geothermal reservoir development: UNITAR/UNDP Rome, Italy, p. 37-69.

Fournier, R.O., Pisto, L.M., Howell, B.B., and Hutchinson, R.A., 1993, Taming a wild geothermal research well in Yellowstone National Park: Geothermal Resources Council Transactions, v. 17, p. 33-36.
Fournier, R.O., Thompson, J.M., and Hutchinson, R.A., 1992, The geochemistry of hot spring waters at Norris geyser basin, Yellowstone National Park, USA, in Kharaka, Y.K., and Maest, A.S., eds., Water-Rock Interaction, Proceedings of the 7th International Symposium on Water-Rock Interaction-WRI-7, Park City, Utah, July 13-18, 1992: A.A. Balkema, v. 2, p. 1289-1292.

Fournier, R.O., Thompson, J.M., Cunningham, C.G., and Huchinson, R.A., 1991, Conditions leading to a recent small hydrothermal explosion at Yellowstone National Park: Geological Society of America Bulletin, v. 103, no. 8, p. 1114-1120.

Fowler, C.S., and Hattori, E.M., 2000, Early textile complexes in the western Great Basin, in Program and Abstracts, 27th Great Basin Anthropological Conference, Ogden, Utah, October 5-7: Great Basin Anthropological Association, p. 45 .

Freestone, I.C., and Gorin-Rosen, Y., 1999, The great glass slab of Bet She'arim, Israel_-An early Islamic glassmaking experiment?: Journal of Glass Studies, v. 41, p. 105-116.

Freeze, R.A., and Cherry, J.A., 1979, Groundwater: Englewood Cliffs, New Jersey, Prentice-Hall, 604 p.

French, Diana, Anthony, E., and Goodell, P., 2006, U-series disequilibria in soils, Peña Blanca natural analog, Chihuahua, Mexico: Proceedings of the 2006 International HighLevel Radioactive Waste Management Conference, Las Vegas, Nevada, April 30-May 4, 2006: American Nuclear Society, La Grange Park, Illinois, p. 63-69.

Fridrich, C.J., Dudley, W.W., Jr., and Stuckless, J.S., 1994, Hydrogeologic analysis of the saturated-zone ground-water system under Yucca Mountain, Nevada: Journal of Hydrology, v. 154, p. 133-168.

Galdenzi, Sandro, and Maruoka, T., 2003, Gypsum deposits in the Frasassi Caves, central Italy: Journal of Caves and Karst Studies, v. 65, p. 111-125.

Gambogi, Joseph, 2009, Titanium, in 2007 Minerals Yearbook (volume I-Minerals and metals): U.S. Geological Survey, p. 78.1-78.15.

Gancarz, Alexander, Cowan, G., Curtis, D., and Maeck, W., $1980,{ }^{99} \mathrm{Tc}, \mathrm{Pb}$ and $\mathrm{Ru}$ migration around the Oklo natural fission reactors, in Northrup, C.J..M., Jr., ed., Scientific basis for nuclear waste management, Proceedings of the International Symposium, Boston, Massachusetts, November 27-30, 1979: Materials Research Society, v. 2, p. 601-608.

Garfunkel, Zvi, Zak, I., and Freund, R., 1981, Active faulting in the Dead Sea Rift: Tectonophysics, v. 80, p. 1-26. 
Garvin, P.L., 1995, Paleokarst and associated mineralization at the Linwood Mine, Scott County, Iowa: Journal of the Iowa Academy of Sciences, v. 102, p. 1-21.

Gascoyne, Melvyn, Lantham, A.G., Harmon, R.S., and Ford, D.C., 1983, The antiquity of Castleguard Cave, Columbia Icefields, Alberta, Canada: Arctic and Alpine Research, v. 15 , p. 463-470.

Gascoyne, Melvyn, and Schwarcz, H.P., 1982, Carbonate and sulfate precipitates, in Ivanovich, M., and Harmon, R.S., eds., Uranium-series disequilibrium-Application to environmental problems: London, U.K., Clarendon Press, p. 268-301.

Gauthier-Lafaye, François, and Weber, F., 1989, The Francevillian (Lower Proterozoic) uranium ore deposits of Gabon: Economic Geology, v. 84, no. 8, p. 2267-2285.

Gauthier-Lafaye, François, 1996, Introduction to the Oklo problematic, in Blanc, P.L., and von Maravic, H., eds., Oklo Working Group, Proceedings of the Fourth Joint EC-CEA Progress and Final Meeting, Saclay, France, June 22-23 1995: Luxembourg, Commission of the European Communities, EUR 16704 EN, p. 5-16.

Gauthier-Lafaye, François, Holliger, P., and Blanc, P.-L., 1996, Natural fission reactors in the Franceville Basin, Gabon-A review of the conditions and results of a 'Critical Event' in a geologic system: Geochimica et Cosmochimica Acta, v. 60, no. 23 , p. $4831-4852$.

Gauthier-Lafaye, François, Ledoux, E., Smellie, J., Louvat, D., Michaud, V., Pérez del Villar, L., Oversby, V., and Bruno, J., 2000, Oklo natural analogue phase II—Behavior of nuclear reaction products in a natural environment: Luxembourg, Commission of the European Communities, EUR 19139 EN, $116 \mathrm{p}$.

Gauthier-Lafaye, François, Weber, F., and Ohmoto, H., 1989, Natural fission reactors of Oklo: Economic Geology, v. 84, no. 8, p. 2286-2295.

Gill, David, 2001, The art and archaeology of Attica-The interior of Mine 3, adjacent to the theatre: Swansea, Wales, David Gill. Accessed January 30, 2002, http://www.davidgill.co.uk/attica/thorikos $947 . h \mathrm{tm}$

Gilli, Eric, 1996, Effets des seismes dans l'endokarstApplication aus etudes de sismicite historic: Revue d'analyse spatiale quantitative et appliqué, no. 38 and 39, p. 121-132.

Gilli, Eric, 1999, Evidence of paleoseismicity in a flowstone of the Observatoire Cave (Monaco): Geodinamica Acta, v. 12 , p. $159-168$.
Gilli, Eric, Levret, A., Sollogoug, P., and Delange, P., 1999, Research on the February 18, 1996 earthquake in the caves of Saint-Paul-de-Fenouillet area, (eastern Pyrenees, France): Geodinamica Acta, v. 12, p. 143-158.

Gilli, Eric, and Serface, Roberta, 1999, Evidence of paleoseismicity in the caves of Arizona and New Mexico (USA): Paris, France, Academy of Sciences, v. 329, p. 31-37.

Glassley, W.E., and Christensen, B.W., 1992, Water-rock interaction in New Zealand hydrothermal systems - Comparison of some simulated and observed geochemical processes, in High-Level Radioactive Waste Management, Proceedings of the Third International Conference, Las Vegas, Nevada, April 12-16 1992: American Nuclear Society, La Grange Park, Illinois, v. 1, p. 352-356.

Golany, G.S., 1983, Earth-sheltered habitat, history, architecture and urban design: New York, Van Nostrand Reinhold Co., $240 \mathrm{p}$.

Golany, G.S., 1989, Urban underground space design in China—Vernacular and modern practice: Newark, New Jersey, University of Delaware Press, $160 \mathrm{p}$.

Goldstein, S.J., Abdel-Fattah, A.I., Murrell, M.T., Dobson, P.F., Norman, D.E., Amato, R.S., and Nunn, A.J., 2010, Uranium-series constraints on radionuclide transport and groundwater flow at the Nopal I uranium deposit, Sierra Peña Blanca, Mexico: Environmental Science and Technology, v. 44, p. 1579-1586.

Goldstein, S.J., Murrell, M.T., Simmons, A.M., Oliver, R.D., Dobson, P.F., Reyes, I.A., and de la Garza, R., 2003, Evidence for radium mobility at the Nopal I uranium deposit, Peña Blanca, Mexico: Geological Society of America Abstracts with Programs, v. 35, no. 6, p. 436.

Goldstein, S.J., Murrell, M.T., and Simmons, A.M., 2005, Uranium elemental and isotopic constraints on groundwater flow beneath the Nopal I uranium deposit, Peña Blanca, Mexico: Geological Society of America Abstracts with Programs, v. 37, no. 7, p. 197-198.

Goldstein, S.J., Luo, S., Ku, T.L., and Murrell, M.T., 2006, Uranium-series constraints on radionuclide transport and groundwater flow at the Nopal I uranium deposit, Sierra Peña Blanca, Mexico, Proceedings of the 2006 International High-Level Radioactive Waste Management Conference, Las Vegas, Nevada, April 30-May 4, 2006: American Nuclear Society, La Grange Park, Illinois, p. 215-222.

Golian, C., and Lever, D.A., 1992, Radionuclide transportAlligator Rivers Analogue Project, Menai: Australian Nuclear Science and Technology Organisation, v. 14, DOE/HMIP/RR/92/084, 272 p. 
Goodell, Phillip, 1985, Chihuahua City uranium province, Chihuahua, Mexico, in Uranium deposits in volcanic rocks, Proceedings of a technical committee meeting, El Paso, Texas, April 2-5, 1984: International Atomic Energy Agency, IAEA-TC-490/19, p. 97-124.

Goodwin, B.W., Cramer, J.J., and McConnell, D.B., 1988, The Cigar Lake uranium deposit-An analogue for nuclear fuel waste disposal, in Côme, B., and Chapman, N., eds., Commission of the European Communities natural analogue working group, Third Meeting, Snowbird, near Salt Lake City, USA, June 15-17, 1988: Nuclear Science and Technology Series, Luxembourg, Commission of the European Communities, EUR 11725 EN, p. 180-189.

Gore, Rick, Gurney, J.M., and Mazzatenta, O.L., 1988, The eternal Etruscans: National Geographic, v. 173, no. 6, p. 696-743.

Grady, Frederick, 1988, A Preliminary account of the Pleistocene mammals from Patton Cave, Monroe County, West Virginia: National Speleological Society Bulletin, v. 50, p. 9-16.

Graham, W.W., 2003, Pleistocene tapir from Hill Top Cave, Trigg County, Kentucky, and a review of Plio-Pleistocene tapirs of North America and their paleoecology, in Schubert, B.W., Mead, J.I., and Graham, R.W., eds., Ice age cave faunas of North America: Bloomington, Indiana University Press, p. 87-118.

Grambow, Bernd, Jercinovic, M.J., Ewing, R.C., and Byers, C.D., 1986, Weathered basalt glass - A natural analogue for the effects of reaction progress on nuclear waste glass alteration, in Werme, L.O., ed., Scientific basis for nuclear waste management IX, Symposium, Stockholm, Sweden, September 9-11, 1985: Materials Research Society, v. 50, p. 263-272.

Grand, P.M., 1967, Prehistoric art, paleolithic painting and sculpture: Greenwich, Connecticut, New York Graphic Society, $103 \mathrm{p}$.

Granger, D.E., Kircher, J.W., and Finkel, R.C., 1997, Quaternary downcutting rate of the New River, Virginia, measured from differential decay of cosmogenic ${ }^{26} \mathrm{Al}$ and ${ }^{10} \mathrm{Be}$ in cavedeposited alluvium: Geology, v. 25, p. 107-110.

Granger, D.F., Fabel, D., and Palmer, A.N., 2001, PliocenePleistocene incision of the Green River, Kentucky, determined from radioactive decay of cosmogenic ${ }^{26} \mathrm{Al}$ and ${ }^{10} \mathrm{Be}$ in Mammoth Cave sediments: Geological Society of America Bulletin, v. 113, p. 825-836.

Griffin, T.J., and McDougall, I., 1975, Geochronology of the Cainozoic McBride volcanic province, Queensland: Journal of the Geological Society of Australia, v. 22, no. 4, p. 387-396.
Grindley, G.W., and Browne, P.R.L., 1976, Structural and hydrological factors controlling the permeabilities of some hot-water geothermal fields, in Proceedings, Second United Nations Symposium on the Development and Use of Geothermal Resources, San Francisco, California, May 20-29, 1975, v. 1, p. 377-386.

Gulden, Bob, 2009, The NSS Geo2 long \& deep caves Web site is at $h t t p: / / w w w . c a v e r b o b . c o m$, last accessed January $10,2010$.

Gurban, Ioana, Laaksoharju, M., Ledoux, E., Made, B., and Salignac, A.L., 1998, Indications of uranium transport around the reactor zone at Bangombé (Oklo): Swedish Nuclear Fuel and Waste Management Company, SKB Technical Report 98-06, 30 p., 1 appendix.

Hardin, E.L., 1998, Near-field/altered-zone models report: Livermore, Calif., Lawrence Livermore National Laboratory, UCRL-ID-129179 DR, 873 p.

Hardin, E.L., and Chesnut, D.A., 1997, Synthesis report on thermally driven coupled processes: Livermore, Calif., Lawrence Livermore National Laboratory, UCRLID-128495, $238 \mathrm{p}$.

Hardy, C.J., and Duerden, P., 1989, Progress in the Alligator Rivers Analogue Project, in Côme, B. and Chapman, N.A., eds., Commission of the European Communities natural analogue working group, Third Meeting, Snowbird, near Salt Lake City, USA, June 15-17, 1988: Nuclear Science and Technology Series, Luxembourg, Commission of the European Communities, EUR 11725 EN, p. 43-49.

Harrell, J.A., 2004, Archaeological geology of the world's first emerald mine: Geoscience Canada, v. 31, no. 2, p. 69-76.

Heath, M.J., 1995, Rock matrix diffusion as a mechanism for radionuclide retardation-Natural radioelement migration in relation to the microfractography and petrophysics of fractured crystalline rock: Luxembourg, Commission of the European Communities, EUR 15977 EN, 128 p.

Heaton, T.H., and Grady, F., 2003, The late Wisconsin vertebrate history of Prince of Wales Island, southeast Alaska, in Schubert, B.W., Mead, J.I., and Graham, R.W., eds., Ice age cave faunas of North America: Bloomington, Indiana University Press, p. 17-53.

Heylmun, E.B., 2001, Breccia pipes: ICMJ's Prospecting and Mining Journal, v. 71, p. 13-14.

Hockett, B.S., 2000, Paleobiogeographic changes at the Pleistocene-Holocene boundary near Pintwater Cave, southern Nevada: Quaternary Research, v. 53, p. 263-269.

Hoffman, D.C., and Daniels, W.R., 1981, Assessment of the potential for radionuclide migration from a nuclear explosion cavity: Los Alamos, New Mexico, Los Alamos National Laboratory, LA-UR-81-3181, p. 139-146. 
Hofmann, B.A., 1989, Geochemical analogue study in the Krunkelbach Mine, Menzenschwand, southern GermanyGeology and water-rock interaction, in Lutze, W., and Ewing, R.C., eds., Scientific basis for nuclear waste management XII, Symposium, Berlin, Germany, October 10-13, 1988: Materials Research Society, v. 127, p. 921-926.

Hofstadter, Dan, 2004, What lies beneath: Smithsonian, v. 35, no. 8 , p. 100-108.

Holliger, Phillippe, 1993, Geochemical and isotopic characterization of the reaction zones (uranium, transuranium, lead and fission products), in von Maravic, H., ed., Oklo Working Group Meeting, Proceedings of the 2nd Joint CEC-CEA Progress Meeting, Brussels, April 6-7, 1992: Luxembourg, Commission of the European Communities, EUR 14877 EN, p. 25-35.

Hourani, Albert, 1997, History of the Arab people: New York, New York, MJF Books, 576 p.

Hubbell, J.M., 1993, Perched water monitoring in the Subsurface Disposal Area of the Radioactive Waste Disposal Complex, FY-93: EDF Serial Number ER\&WM-EDF-002293, EG\&G Idaho.

Hubbell, J.M., 1995, Perched water monitoring in the Subsurface Disposal Area of the Radioactive Waste Management Complex, Idaho, FY-94: EDF Serial Number INEL-95/14, EG\&G Idaho, 285 p.

Hughson, D.L, Browning, L., Murphy, W.M., and Green, R.T., 2000, An archeological site at Akrotiri, Greece, as a natural analog for radionuclide transport-Implications for validity of performance assessments, in Smith, R.W., and Shoesmith, D.W., eds., Scientific basis for nuclear waste management XXIII, Symposium Proceedings, Boston, Mass., November 30-December 4, 1999: Materials Research Society, v. 608 , p. 557-562.

Humphrey, T.G., and Tingey, F.H., 1978, The subsurface migration of radionuclides at the Radioactive Waste Management Complex, 1976-1977: U.S. Department of Energy, Idaho Operations Office Publication, TREE 1171, 98 p.

IAEA (International Atomic Energy Agency), 1975, The Oklo phenomenon: Proceedings of a Symposium, Libreville, Gabon, June 23-27, 1975: International Atomic Energy Agency Symposium 204, 646 p.

IAEA (International Atomic Energy Agency), 1978, Les reacteurs de fission naturels, natural fission reactors, in Proceedings of a meeting on the technical committee on natural fission reactors, Paris, December 19-21, 1977: International Atomic Energy Agency, STI/PUB/475, 753 p.
IAEA (International Atomic Energy Agency), 1989, Natural analogues in performance assessment for the disposal of radioactive waste: IAEA Technical Report 304, variously paginated, six sections, two appendices.

IAEA (International Atomic Energy Agency), 1999, Use of natural analogs to support radionuclide transport models for deep geological repositories for long-lived radioactive wastes: IAEA-TECDOC-1109, $56 \mathrm{p}$.

IAEA (International Atomic Energy Agency), 2001, An international peer review of the biosphere modelling programme of the U.S. Department of Energy's Yucca Mountain Site Characterization Project: Report of the IAEA International Review Team, variously paginated, seven sections, three appendices.

Isobe, Hiroshi, Ewing, R.C., and Murakami, T., 1994, Formation of secondary uranium minerals in the Koongarra deposit, Australia, in Barkatt, A., and Van Konynenburg, R.A., eds., Scientific basis for nuclear waste management XVII, Symposium, Boston, Massachusetts, November 29-December 3, 1993: Materials Research Society, v. 333, p. 635-650.

Isobe, Hiroshi, Murakami, T., and Ewing, R.C., 1992, Alteration of uranium minerals in the Koongarra deposit, Australia, unweathered zone: Journal of Nuclear Materials, v. 190, p. 174-187.

Ivanovich, Miro, and Harmon, R.S., eds., 1992, Uraniumseries disequilibrium-Applications to earth, marine, and environmental sciences: New York, Oxford University Press, $571 \mathrm{p}$.

Ivanovich, Miro, Duerden, P., Payne, T., Nightingale, T., Longworth, G., Wilkins, M.A., Edghill, R.B., Cockayne, D.J., and Davey, B.G., 1987, Natural analogue study of the distribution of uranium series radionuclides between the colloid and solute phases in the hydrogeological system of the Koongarra uranium deposit, N.T., Australia, in Côme, B. and Chapman, N.A., eds., Natural analogues in radioactive waste disposal, Symposium, Brussels, April 28-30, 1987: Radioactive Waste Management Series, EUR 11037 EN, p. 300-313.

Iwatsuki, Teruki, Sato, K., Seo, T., and Hama, K., 1995, Hydrogeochemical investigation of groundwater in the Tono area, Japan, in Murakami, T. and Ewing, R.C., eds., Scientific basis for nuclear waste management XVIII, Symposium, Kyoto, Japan, October 23-27, 1994: Materials Research Society, v. 353, part 2, p. 1251-1257.

Jaakkola, Tommi, Suksi, J., Suutarinen, R., Niini, H., Ruskeeniemi, T., Söderholm, B., Vesterinen, M., Blomqvist, R., Halonen, S., and Lindberg, A., 1989, The behaviour of radionuclides in and around uranium deposits, II, Results of investigations at the Palmottu analogue study site, SW Finland: Geological Survey of Finland, YST-64, 60 p. 
Jagnow, D.H., 1999, Geology of Kartchner Caverns State Park, Arizona: Journal of Cave and Karst Studies, v. 61, no. 2, p. 49-58.

Jakubick, A.T., and Church, W., 1986, Oklo natural reactors, geological and geochemical conditions-A review: Atomic Energy Board of Canada, INFO-0179, 53 p.

Janeczek, Janusz, and Ewing, R.C., 1992, Dissolution and alteration of uraninite under reducing conditions: Journal of Nuclear Materials, v. 190, p. 157-173.

Jans-Langel, C.M., and Semken, A.A., Jr., 2003, Paleoecological interpretations of Late Holocene and Late Pleistocene micromammal faunules from Duhme Cave, eastern Iowa, in Schubert, B.W., Mead, J.I., and Graham, R.W., eds., Ice age cave faunas of North America: Bloomington, Indiana University Press, p. 119-148.

Jarvis, N.V., Andreoli, M.A.G., and Read, D., 1997, The Steenkampskraal natural analogue study and nuclear waste disposal in South Africa, in von Maravic, H., and Smellie, J., eds., Seventh CEC natural analogue working group meeting, Proceedings of an International Workshop, Stein am Rhein, Switzerland, October 28-30, 1996: Luxembourg, Commission of the European Communities, EUR 17851 EN, p. 9-26.

Jen, C-P., and Li, S-H., 2001, Effects of hydrodynamic chromatography on colloid-facilitated migration of radionuclides in the fractured rock: Waste Management, v. 21, no. 6 , p. 499-509.

Jensen, K.A., Ewing, R.C., and Gauthier-Lafaye, F., 1997, Uraninite, a 2-Ga spent nuclear fuel from the natural fission reactor at Bangombé in Gabon, West Africa, in Gray, W.J., and Triay, I.R., eds., Scientific basis for nuclear waste management XX, Symposium, Boston, Massachusetts, December 2-6, 1996: Materials Research Society, v. 465, p. $1209-1218$.

Jensen, K.A. and Ewing, R.C., 2001, The Okélobondo natural fission reactor, southeast Gabon-Geology, mineralogy, and retardation of nuclear-reaction products: Geological Society of America Bulletin, 113, no. 1, p. 32-62.

Jercinovic, M.J., and Ewing, R.C., 1987, Basaltic glasses from Iceland and the deep sea-Natural analogues to borosilicate nuclear waste-form glass: JSS Project Technical Report 88-01, Swedish Nuclear Fuel and Waste Management Company, 211 p. and appendices.

Jercinovic, M.J., Ewing, R.C., and Byers, C.D., 1986, Alteration products of basalt glass from Frenchman Springs flow, Wanapum Basalts, Hanford, Washington, in Clark, D.E., White, W.B., and Machiels, A.J., eds., Nuclear Waste Management II, Third Annual Symposium on Ceramics in Nuclear Waste Management, Chicago, Illinois, April 28-30, 1986: Advances in Ceramics, v. 20, p. 671-679.
Jerden, J.L., Jr., and Sinha, A.K., 2001, Natural attenuation of uranium in an oxidizing rock-soil-groundwater system, Coles Hill uranium deposit, Virginia: Geological Society of America Abstracts with Programs, v. 33, p. A364.

Johnson, A.B., Jr., and Francis, B., 1980, Durability of metals from archaeological objects, metal meteorites, and native metals: Pacific Northwest Laboratory, PNL-3198, variously paginated, 7 sections.

Josephs, R.L., 2002, A Late Pleistocene ceiling collapse in Bogus Cave, Jones County, Iowa-A potential relationship to coeval accelerated mass wasting events across the central Midwest: Journal of Caves and Karst Studies, v. 64, p. $175-179$.

Jove Colon, C.F., Brady, P.V., Siegel, M.D., and Lindgren, E.R., 2001, Historical case analysis of uranium plume attenuation: U.S. Nuclear Regulatory Commission, NUREG/ CR-6705, $40 \mathrm{p}$.

Jull, A.J.T., Donahue, D.J., Carmi, I., and Segal, D., 1998, Radiocarbon datings of finds, in Schick, Tamar, ed., The Cave of the Warrior-A fourth millennium burial in the Judean Desert: Israel Antiquities Authority Report, no. 5, p. $110-112$.

Kagan, E.J., Agnon, Amotz, Barmatthews, Miryam, and Ayalon, Avner, 2005, Dating large infrequent earthquakes by damaged cave deposits: Geology, v. 33, no. 4, p. 261-264.

Kaplan, M.F., 1980, Characterization of weathered glass by analyzing ancient artifacts, in Northrup, C.J.M., Jr., ed., Scientific basis for nuclear waste management: Proceedings of the International Symposium, Boston, Massachusetts, November 27-30, 1979: Materials Research Society, v. 2, p. 85-92.

Kaplan, M.F., and Mendel, J.E., 1982, Ancient glass and the safe disposal of nuclear waste: Archaeology, v. 35, no. 4, p. 22-29.

Katayama, Norio, Kubo, K., and Hirono, S., 1974, Genesis of uranium deposits of the Tono Mine, Japan, in Formation of uranium ore deposits, Proceedings of a symposium on the formation of uranium ore deposits, Athens, Greece, May 6-10, 1974: IAEA-SM-183/11, p. 437-452.

Keefer, W.R., Whitney, J.W., and Buesch, D.C., 2007, Geology of the Yucca Mountain site area, in Stuckless, J.S., and Levich, R.A. eds., The geology and climatology of Yucca Mountain and vicinity, southern Nevada and California: Geological Society of America Memoir, v. 199, p. 53-103.

Keith, T.E.C., and Muffler, L.J.P., 1978, Minerals produced during cooling and hydrothermal alteration of ash flow tuff from Yellowstone drill hole Y-5: Journal of Volcanology and Geothermal Research, v. 3, p. 373-402. 
Keith, T.E.C., White, D.E., and Beeson, M.H., 1978, Hydrothermal alteration and self-sealing in $\mathrm{Y}-7$ and $\mathrm{Y}-8$ drill holes in the northern part of upper Geyser Basin, Yellowstone National Park, Wyoming: U.S. Geological Survey Professional Paper 1054-A, p. A1-A26.

Kelkar, Sharad, Roback, R., Robinson, B., Srinivasan, G., Jones, C., and Reimus, P., 2006, Saturated zone plumes in volcanic rock-Implications for Yucca Mountain, Proceeedings of the 2006 International High-Level Radioactive Waste Management Conference, Las Vegas, Nevada, April 30-May 4, 2006: American Nuclear Society, La Grange Park, Illinois, p. 97-104.

Kersting, A.B., Efurd, D.W., Finnegan, D.L., Rokop, D.J., Smith, D.K., and Thompson, J.L., 1999, Migration of plutonium in ground water at the Nevada Test Site: Nature, v. 397 , p. $56-59$.

Khoury, H.N., Salameh, E., Clark, I.D., Fritz, P., Milodowski, A.E., Cave, M.R., Bajjali, W., and Alexander, W.R., 1992, A natural analogue of high $\mathrm{pH}$ cement pore waters from the Maqarin area of northern Jordan-I, Introduction to the site: Journal of Geochemical Exploration, v. 46, no. 1, p. 117-132.

Kingston, W.L., and Whitbeck, M., 1991, Characterization of colloids found in various groundwater environments in central and southern Nevada: DOE/NV/10384-36, Las Vegas, Nevada, Desert Research Institute, Water Resources Center, $136 \mathrm{p}$.

Kislev, M.E., 1985, Early Neolithic horsebean from Yiftah'el, Israel: Science, v. 228, p. 319-320.

Kneafsey, T.J., Apps, J.A., and Sonnenthal, E.L., 2001, Tuff dissolution and precipitation in a boiling, unsaturated fracture, in Back to the future-Managing the back end of the nuclear fuel cycle to create a more secure energy future, Proceedings of the 9th International High-Level Radioactive Waste Management Conference, Las Vegas, Nevada, April 29-May 3, 2001: American Nuclear Society, La Grange Park, Illinois, $4 \mathrm{p}$.

Knutson, C.F., McCormick, K.A., Smith, R.P., Hackett, W.R., O’Brien, J.P., and Crocker, J.C., 1990, FY 89 Report, RWMC vadose zone basalt characterization: EGGWM-8949, EG\&G Idaho, 426 p.

Kovach, L.A., and Murphy, W.M., eds., 1995, Proceedings of the Workshop on the Role of Natural Analogs in Geologic Disposal of High-Level Nuclear Waste, San Antonio, Texas, July 22-25, 1991: U.S. Nuclear Regulatory Commission, NUREG/CP-0147, 120 p.
Krumhansl, J.L., and Stockman, H.W., 1988, Site selection criteria and preliminary results from the Valles Caldera natural analog study, in Proceedings of Workshop IV on Flow and Transport Through Unsaturated Fractured Rock-Related to High-Level Radioactive Waste Disposal, Tucson, Arizona, December 12-15, 1998: Tucson, University of Arizona, p. 249-276.

Kuntz, M.A., Skipp, B., Lanphere, M.A., Scott, W.E., Pierce, K.L., Dalrymple, G.B., Champion, D.E., Embree, G.F., Page, W.R., Morgan, L.A., Smith, R.P., Hackett, W.R., and Rogers, D.W., 1994, Geologic map of the Idaho National Engineering Laboratory and adjoining areas, eastern Idaho: U.S. Geological Survey Miscellaneous Investigation Series 2330, scale 1:100,000.

Kuttruff, J.T., DeHart, S.G., and O’Brien. M.J., 1998, 7500 year old prehistoric footwear from Arnold Research Cave, Missouri: Science, v. 281, p. 72-75.

Laughlin, A.W., Poths, J., Healey, H.A., Reneau, S., and WoldeGabriel, G., 1994, Dating of Quaternary basalts using the cosmogenic ${ }^{3} \mathrm{He}$ and ${ }^{14} \mathrm{C}$ with implications for excess ${ }^{40} \mathrm{Ar}$ : Geology, v. 22, p. 135-138.

Laughlin, A.W., and WoldeGabriel, G., 1997, Dating the ZuniBandera volcanic field: New Mexico Bureau of Geology \& Mineral Resources, Bulletin 156, p. 25-29.

Lauritzen, S.E., and Mylroie, J.E., 2000, Results of a speleothem U/Th dating reconnaissance from the Helderberg Plateau, New York: Journal of Caves and Karst Studies, v. 62 , p. $20-26$.

Lauritzen, S.E., and Onac, B.P., 1999, Isotopic stratigraphy of a last interglacial stalagmite from northwestern RomaniaCorrelation with the deep-sea record and northern-latitude speleothem: Journal of Caves and Karst Studies, v. 61, p. $22-30$.

LeCain, G.D., 1997, Air-injection testing in vertical boreholes in welded and nonwelded tuff, Yucca Mountain, Nevada: U.S. Geological Survey Water-Resources Investigations Report 96-4262, $33 \mathrm{p}$.

Lee, J.H., 2001, Median lead concentration in groundwater samples cited in section 7.3.1.3.4 of the SSPA Report: Memorandum from J.H. Lee (BSC) to P. Pasupathi, June 20, 2001, Proj.06/01.049, with enclosure, v. 1.

Lena, Kim, ed., 2004, Koguryo tomb murals: Seoul, ICOMOS-Korea \& Cultural Properties Administration, 108 p.

Leroi-Gourhan, André, 1982, The archaeology of Lascaux Cave: Scientific American, v. 246, no. 6, p. 104-112. 
Leslie, B.W., Pearcy, E.C., and Prikryl, J.D., 1993, Oxidative alteration of uraninite at the Nopal I deposit, MexicoPossible contaminant transport and source term constraints for the proposed repository at Yucca Mountain, in Interrante, C.G., and Pabalan, R.T., eds., Scientific basis for nuclear waste management XVI, Symposium, Boston, Massachusetts, November 30-December 4, 1992: Materials Research Society, v. 294, p. 505-512.

Leslie, B.W., Pickett, D.A., and Pearcy, E.C., 1999, Vegetation-derived insights on the mobilization and potential transport of radionuclides from the Nopal I natural analog site, Mexico, in Wronkiewicz, D.J., and Lee, J.H., eds., Scientific basis for nuclear waste management XXII, Symposium, Boston, Massachusetts, November 30-December 4, 1998: Materials Research Society, v. 556, p. 833-842.

Lichtner, P.C., 2003, FLOTRAN user's manual, two-phase nonisothermal coupled thermal-hydrologic-chemical (THC) reactive flow and transport code: Los Alamos, New Mexico, Los Alamos National Laboratory, version 1.0, LA-UR-01-2349, $42 \mathrm{p}$.

Lichtner, P.C., Keating, G., and Carey, B., 1999, A natural analogue for thermal-hydrological-chemical coupled processes at the proposed nuclear waste repository at Yucca Mountain, Nevada: Los Alamos, New Mexico, Los Alamos National Laboratory, LA-13610-MS, $34 \mathrm{p}$.

Lichty, R.W., and McKinley, P.W., 1995, Estimates of groundwater recharge rates for two small basins in central Nevada: U.S. Geological Survey Water-Resources Investigations Report 94-4104, 31 p.

Linklater, C.M., Albinsson, Y., Alexander, W.R., Casas, I., McKinley, I.G., and Sellin, P., 1996, A natural analogue of high-pH cement pore waters from the Maqarin area of northern Jordan-Comparison of predicted and observed trace-element chemistry of uranium and selenium: Journal of Contaminant Hydrology, v. 21, no. 1-4, p. 59-69.

Lockheed Idaho Technologies Company, 1995, A comprehensive inventory of radiological and nonradiological contaminants in waste buried or projected to be buried in the Subsurface Disposal Area of the INEL RWMC during the years 1984-2003: INEL/95-0135, v. 1, Idaho National Engineering Laboratory, Lockheed Idaho Technologies Company, variously paginated, 7 sections, 7 appendices.

Lopez, C.R., Rodriguez, J., Recreo, F., Ruiz, C., Prado, P., Gimeno, M.J., Auque, L.F., Gomez, J., Acero, P., Gonzalez, A., Samper, J., Montenegro, L., Molinero, J., Delgato, J., Criado, A., Martinez, J.A., and Ruiz, S., 2004, Analogue application to safety assessment and communication of radioactive waste geologic disposal-Illustrative synthesis: Consejo Seguridad Nuclear, $167 \mathrm{p}$.
Loss, R.D., Rosman, K.J.R., De Laeter, J.R., Curtis, D.B., Benjamin, T.M., Gancarz, A.J., Maeck, W.J., and Delmore, J.E., 1989, Fission-product retentivity in peripheral rocks at the Oklo natural fission reactors, Gabon: Chemical Geology, v. 76 , no. $1 / 2$, p. $71-84$.

Louvat, Didier, and Davies, C., eds., 1998, Oklo Working Group, in Proceedings of the First Joint EC-CEA Workshop on the Oklo Natural Analogue Phase II Project, Sitjes, Spain, June 18-20, 1997: Luxembourg, Commission of European Communities, EUR 18314 EN, 328 p.

Luckey, R.R., Tucci, P., Faunt, C.C., Ervin, E.M., Steinkampf, W.C., D’Agnese, F.A., and Patterson, G.L., 1996, Status of understanding of the saturated-zone ground-water flow system at Yucca Mountain, Nevada, as of 1995: U.S. Geological Survey Water-Resources Investigations Report 96-4077, $71 \mathrm{p}$.

Lundberg, Joyce, Ford, D.C., and Hill, C.A., 2000, A preliminary $\mathrm{U}-\mathrm{Pb}$ date on cave spar-Big Canyon, Guadalupe Mountains, New Mexico, USA: Journal of Cave and Karst Studies, v. 62, p. 144-146.

Lundelius, E.L., Jr., 2003, A history of paleontological investigations of Quaternary cave deposits on the Edwards Plateau, central Texas, in Schubert, B.W., Mead, J.I., and Graham, R.W., eds., Ice age cave faunas of North America: Bloomington, Indiana University Press, p. 201-214.

Luo, Shangde, Ku, T.-L., Todd, V., Murrell, M.T., Rodriguez, J.A., Dinsmoor, J.C., and Mitchell, A.J., 2005, In-situ radionuclide transport near the Nopal I uranium deposit at Peña Blanca, Mexico - Constraints from short-lived decay-series nuclides: Geological Society of America Abstracts with Programs, v. 37, no. 7, Geological Society of America, Boulder, Colo., p. 198.

Lutze, Werner, Grambow, B., Ewing, R.C., and Jercinovic, M.J., 1987, The use of natural analogues in the long-term extrapolation of glass corrosion processes, in Côme, B., and Chapman, N.A., eds., Natural analogues in radioactive waste disposal-Symposium, Brussels, April 28-30, 1987: Radioactive Waste Management Series, EUR 11037 EN, p. $142-152$.

Lynch, T.F., Gillespie, R., Gowlett, J.A.J., and Hedges, R.E.M., 1985, Chronology of Guitarrero Cave, Peru: Science, v. 229, p. 864-867.

Macdonald, D.D., 1992, The point defect model for the passive state: Journal of the Electrochemical Society, v. 139, no. 12 , p. 3434-3449. 
MacKenzie, A.B., Scott, R.D., Linsalata, P., Miekeley, N., Osmond, J.K., and Curtis, D.B., 1991, Natural radionuclide and stable element studies of rock samples from the Osamu Utsumi Mine and Morro do Ferro analogue study sites, Poços de Caldas, Brazil: Swedish Nuclear Fuel and Waste Management Company, SKB Technical Report 90-16, $164 \mathrm{p}$.

Magaloni-Kerpel, D.I., 1994, Metodología para el análisis de la técnica pictórica mural prehispánica-El Templo Rojo de Cacaxtla: Serie Arqueología, Colección Cientifica no. 280, Instituto Nacional de Antropología e Historia, Mexico, D.F., $86 \mathrm{p}$.

Magnuson, S.O., 1995, Inverse modeling for field-scale hydrologic and transport parameters of fractured basalt: Idaho National Engineering Laboratory, Lockheed Martin Idaho Technologies, INEL-95/0637, $230 \mathrm{p}$.

Magnuson, S.O., and Sondrup, A.J., 1998, Development, calibration, and predictive results of a simulator for subsurface pathway fate and transport of aqueous- and gaseousphase contaminants in the Subsurface Disposal Area at the Idaho National Engineering and Environmental Laboratory: INEEL/EXT-97-00609, Idaho National Engineering Laboratory, Lockheed Idaho Technologies Company, variously paginated.

Malow, Günter, and Ewing, R.C., 1981, Nuclear waste glasses and volcanic glasses-A comparison of their stabilities, in Moore, J.G., ed., Scientific basis for nuclear waste management: Proceedings of the Third International Symposium, Boston, Massachusetts, November 17-20, 1980: Materials Research Society, v. 3, p. 315-322.

Mannell, Robert, 1973, Nangwarry sandstone caves: Institute of Technology Speleological Society, v. 3, p. 10-20.

Maqarin Natural Analogue Site Study Group, 1992, A natural analogue study of the Maqarin hyperalkaline groundwaters-I. Source term description and thermodynamic database testing: NAGRA Technical Report 91-10, National Cooperative for the Disposal of Radioactive Waste, $149 \mathrm{p}$.

Marcus, Phillippe, and Maurice, V., 2000, Passivity of metals and alloys, chapter 3, in Schütze, M., ed., Corrosion and environmental degradation, volume I: Materials Science and Technology, v. 19, p. 131-169.

Marshall, B.D., Neymark, L.A., Paces, J.B., Peterman, Z.E., and Whelan, J.F., 2000, Seepage flux conceptualized from secondary calcite in lithophysal cavities in the Topopah Spring Tuff, Yucca Mountain, Nevada: Society for Mining, Metallurgy, and Exploration Annual Meeting, February 28-March 1, 2000, Salt Lake City, Utah: Preprint 00-12, Society for Mining, Metallurgy, and Exploration, 6 p.
Marshall, B.D., Neymark, L.A., and Peterman, Z.E., 2003, Estimation of past seepage volumes from calcite distribution in the Topopah Spring Tuff, Yucca Mountain, Nevada: Journal of Contaminant Hydrology, v. 62-63, p. 237-247.

Marshall, B.D., and Whelan, J.F., 2001, Simulating the thermal history of the unsaturated zone at Yucca Mountain, Nevada: Geological Society of America, Abstracts with Programs, v. 33, no. 6, p. A-375.

Martian, P., 1995, UNSAT-H infiltration model calibration at the Subsurface Disposal Area, Idaho Falls, Idaho National Engineering Laboratory: Lockheed Idaho Technologies Company, INEL-95/0596, 38 p. and 4 appendices.

Martin, Kyle, 1990, Paleomagnetism of speleothems in Gardner Cave, Washington: National Speleological Society Bulletin, v. 52, p. 87-94.

Mathpal, Yashodhar, 1996, Indian rock art today, in Bahn, P.G., and Fossati, A., eds., Rock art studies-News of the World I: Acts of symposium 14D at the NEWS95 World Rock Art Congress, Turin and Pinerolo, Italy, August 30-September 6, 1995: Oxbow Monograph 72, p. 133-140.

Matyskiela, Walter, 1997, Silica redistribution and hydrologic changes in heated fractured tuff: Geology, v. 25, no. 12, p. $1115-1118$.

Mazzatenta, O.L., 1992, A Chinese emperor's army for eternity: National Geographic, v. 182, no. 2, p. 114-130.

Mazzatenta, O.L., 1996, China's warriors rise from the earth: National Geographic, v. 190 , no. 4, p. 68-85.

McCarthy, J.F., 1996, Natural analogue studies of the role of colloids, natural organics and microorganisms on radionuclide transport, in von Maravic, H., and Smellie, J., eds., Sixth EC Natural Analogue Working Group MeetingProceedings of an International Workshop, Santa Fe, New Mexico, USA, September 12-16, 1994: Luxembourg, Commission of the European Communities, EUR 16761 EN, p. 195-210.

McCright, R.D., 1998, Corrosion data and modeling-Update for viability assessment, volume 3 of Engineered materials characterization report: UCRL-ID-119564, Rev. 1.1, Livermore, California, Lawrence Livermore National Laboratory, $360 \mathrm{p}$.

McCright, R.D., Frey, W.F., and Tardiff, G.E., 1980, Localized corrosion of steels in geothermal steam/brine mixtures: Geothermal Resources Council Transactions, v. 4, p. 645-648.

McDonald, H.G., 2003, Sloth remains from North American caves and associated karst features, in Schubert, B.W., Mead, J.I., and Graham, R.W., eds., Ice age cave faunas of North America: Bloomington, Indiana University Press, p. 1-16. 
McFarlane, D.A., Lundberg, J., and Fincham, A.G., 2002, A Late Quaternary paleoecological record from caves of southern Jamaica, West Indies: Journal of Caves and Karst Studies, v. 64, p.117-125.

McKinley, I.G., and Alexander, W.R., 1996, The uses of natural analogue input in repository performance assessment—An overview, in von Maravic, H., and Smellie, J., eds., Sixth EC Natural Analogue Working Group Meeting, Proceedings of an International Workshop, Santa Fe, New Mexico, USA, September 12-16, 1994: Luxembourg, Commission of the European Communities, EUR 16761 EN, p. $273-282$.

McKinley, I.G., Bath, A.H., Berner, U., Cave, M., and Neal, C., 1988, Results of the Oman analogue study: Radiochimica Acta, v. 44/45, no. II, p. 311-316.

McKinley, P.W., Long, M.P., and Benson, L.V., 1991, Chemical analyses of water from selected wells and springs in the Yucca Mountain area, Nevada, and southeastern California: U.S. Geological Survey Open-File Report 90-355, 47 p.

McLean, J.S., 1976, Factors altering the microclimate in Carlsbad Caverns, New Mexico: U.S. Geological Survey Open-File Report 76-171, 56 p.

Mead, J.I., Coats, L.L., and Schubert, B.W., 2003, Late Pleistocene fauna from caves in the eastern Grand Canyon, Arizona, in Schubert, B.W., Mead, J.I., and Graham, R.W., eds., Ice age cave faunas of North America: Indiana University Press, p. 64-86.

Meijer, A., 1987, Investigations of natural geologic and geochemical analogs in relation to a potential nuclear waste repository at Yucca Mountain, Nevada: Milestone R398, Los Alamos, New Mexico, Los Alamos National Laboratory, $62 \mathrm{p}$.

Merritt, R.C., 1971, The extractive metallurgy of uranium: Colorado School of Mines Research Center, Boulder, Colorado, Johnson Publishing Company, 576 p.

Miekeley, Norbert, Couthinho de Jesus, H., Porto da Silveira, C.L., and Degueldre, C., 1992, Chemical and physical characterization of suspended particles and colloids in waters from the Osamu Utsumi Mine and Morro do Ferro analogue study sites, Poços de Caldas, Brazil: Journal of Geochemical Exploration, v. 45, p. 409-437.

Miekeley, Norbert, Coutinho de Jesus, H., Porto da Silveira, C.L., Linsalata, P., Morse, R., and Osmond, J.K., 1991a, Natural series radionuclide and rare-earth element geochemistry of waters from the Osamu Utsumi Mine and Morro do Ferro analogue study sites, Poços de Caldas, Brazil: Stockholm, Sweden, Swedish Nuclear Fuel and Waste Management Company, SKB Technical Report 90-17, 70 p., 1 appendix.
Miekeley, Norbert, Coutinho de Jesus, H., Porto da Silveira, C.L., and Degueldre, C., 1991b, Chemical and physical characterisation of suspended particles and colloids in waters from the Osamu Utsumi Mine and Morro do Ferro analogue study sites, Poços de Caldas, Brazil: SKB Technical Report 90-18, Stockholm, Sweden, Swedish Nuclear Fuel and Waste Management Company, 78 p.

Miekeley, Norbert, Coutinho de Jesus, H., Porto da Silveira, C.L., and Kuechler, I.L., 1989, Colloid investigations in the Poços de Caldas natural analogue project, in Lutze, W., and Ewing, R.C., eds., Scientific basis for nuclear waste management XII, Symposium, Berlin, Germany, October 10-13, 1988: Materials Research Society, v. 127, p. 831-842.

Miller, Bill, and Chapman, N., 1995, Postcards from the past - Archaeological and industrial analogs for deep repository materials: Radwaste Magazine, v. 2, no. 1, p. 32-42.

Miller, D.M., Miller, R.J., Nielson, J.E., Wilshire, H.G., Howard, K.A., and Stone, P., 1993, Preliminary geologic map of the East Mojave National Scenic Area, California: U.S. Geological Survey Open-File Report 91-435, 8 p.

Miller, T.E., 1989, Evidence of Quaternary tectonic activity and for regional aquifer flow at Wind Cave, South Dakota: National Speleological Society Bulletin, v. 51, p. 111-119.

Miller, William, Alexander, R., Chapman, N., McKinley, I., and Smellie, J., 1994, Natural analogue studies in the geological disposal of radioactive wastes - Studies in environmental science, 57: New York, Elsevier, 395 p.

Miller, William, Alexander, R., Chapman, N., McKinley, I., and Smellie, J., 2000, Geologic disposal of radioactive wastes \& natural analogues-Lessons from nature and archaeology: Waste Management Series, New York, Pergamon, v. 2, $316 \mathrm{p}$.

Miller, William, Hooker, P., Smellie, J.A.T., Dalton, J., Degnan, P., Knight, P., Nosek, U., Ahonen, L., Laciok, A., Trotignon, L., Wouter, L., Hernan, P., and Vela, A.L., 2006, NAnet Project (Network to review natural analogue studies and their application to repository safety assessment and public communication) Synthesis Report: European Community contract no. FIKW-CT-2002-20204, 67 p.

Milske, J.A., Alexander, C.E., Jr., and Lively, R.S., 1983, Clastic sediments in Mystery Cave, southeastern Minnesota: National Speleological Society Bulletin, v. 45, p. 55-75.

Montazer, Parviz, and Wilson, W.E., 1984, Conceptual hydrologic model of flow in the unsaturated zone, Yucca Mountain, Nevada: U.S. Geological Survey Water-Resources Investigations Report 84-4345, 55 p. 
Muffler, L.J.P., White, D.E., and Truesdell, A.H., 1971, Hydrothermal explosion craters in Yellowstone National Park: Geological Society of America Bulletin, v. 82, no. 3, p. $723-740$.

Mumme, I.A., 1991, The effect of earthquakes on underground openings, Twenty-fifth Newcastle Symposium on Advances in the Study of the Sydney Basin, Newcastle, New South Wales, Australia, April 12-14, 1991: University of Newcastle, Department of Geology Publication No. 413, p. 75-79.

Murakami, Takashi, Ohnuki, T., Isobe, H., and Sato, T., 1997, Mobility of uranium during weathering: American Mineralogist, v. 82 , p. 888-899.

Murphy, W.M., 1995, Natural analogs for Yucca Mountain: Radwaste Magazine, American Nuclear Society, v. 2, no. 6, p. $44-50$.

Murphy, W.M., 2000, Natural analogs and performance assessment for geologic disposal of nuclear waste, in Smith, R.W., and Shoesmith, D.W., eds., Scientific basis for nuclear waste management XXIII, Symposium, Boston, Massachusetts, November 29-December 2, 1999: Materials Research Society, v. 608, p. 533-544.

Murphy, W.M., and Codell, R.B., 1999, Alternate source term models for Yucca Mountain performance assessment based on natural analog data and secondary mineral solubility, in Wronkiewicz, D.J., and Lee, J.H., eds., Scientific basis for nuclear waste management XXII, Symposium, Boston, Massachusetts, November 30-December 4, 1998: Materials Research Society, v. 556, p. 551-558.

Murphy, W.M., Pearcy, E.C., Green, R.T., Prikryl, J.D., Mohanty, S., Leslie, B.W., and Nedungadi, A., 1998, A test of long-term, predictive, geochemical transport modeling at the Akrotiri archaeological site: Journal of Contaminant Hydrology, v. 29, p. 245-279.

Murphy, W.M., Prikryl, J., and Pickett, D.A., 2005, Thermodynamics of hydrothermal uranyl mineral formation at Nopal I: Geological Society of America Abstracts with Programs, v. 37, no. 7, p. 197.

Murrell, M.T., Goldstein, S.J., and Dixon, P.R., 1997, Uranium decay series mobility from a uranium ore deposit-Implications for nuclear repository stability: Eos, v. 78 , no. 46 , p. F788.

Murrell, M.T., Goldstein, S.J., and Dixon, P.R., 2002, Uranium decay series mobility at Peña Blanca, Mexico-Implications for nuclear repository stability, in von Maravic, H., and Alexander, W.R., eds., Nuclear Science and Technology, 8th EC Natural Analogue Working Group Meeting, Strasbourg, France, March 23-25, 1999: Luxembourg, Office for Official Publications of the European Communities, EUR 19118, p. 339-347.
National Research Council, 1990, Rethinking high-level radioactive waste disposal-A position statement of the Board on Radioactive Waste Management: National Academy Press, $38 \mathrm{p}$.

Nativ, Ronit, Adar, E., Hahan, O., and Geyh, M., 1995, Water recharge and solute transport through the vadose zone of fractured chalk under desert conditions: Water Resources Research, v. 31, p. 253-261.

Naudet, Roger, 1978, Etude Parametrique de la Criticite des Reacteurs Naturels in Les Reacteurs de Fission Naturels, Natural Fission Reactors-Proceedings of a Meeting on the Technical Committee on Natural Fission Reactors, Paris, December 19-21, 1977: International Atomic Energy Agency, p. 589-599.

Neretnieks, Ivars, 1986, Investigations on old bronze cannons, in Côme, B., and Chapman, N.A., eds., Commission of European Communities natural analogue working group, Second Meeting, Interlaken, Switzerland, June 17-19, 1986: Luxembourg, Commission of the European Communities, EUR 10671 EN, p. 191-197.

Neumayer, Erwin, 1983, Prehistoric Indian rock paintings: Bombay, India, Oxford University Press, 304 p.

Newman, M.E., 1996, Evaluation of the mobility of Am, $\mathrm{Cs}, \mathrm{Co}, \mathrm{Pu}, \mathrm{Sr}$, and $\mathrm{U}$ through INEL basalts and interbed materials - Summary report of the INEL/Clemson University Laboratory Studies: WAG7-82, INEL-95/282, Idaho National Engineering Laboratory, Lockheed Idaho Technologies Company.

Neymark, L.A., Amelin, Y.V., Paces, J.B., Peterman, Z.E., and Whelan, J.F., 2001, Age constraints on fluid inclusions in calcite at Yucca Mountain, Proceedings of the 9th International High-Level Radioactive Waste Management Conference, Las Vegas, Nevada, April 29-May 3, 2001: American Nuclear Society, La Grange Park, Illinois, 4 p.

Nimmo, J.R., Perkins, K.S., Rose, P.E., Rousseau, J.P., Orr, B.R., Twining, B.V., and Anderson, S.R., 2001, Kilometerscale rapid flow in a fractured-basalt unsaturated zone at the Idaho National Engineering and Environmental Laboratory, in Kueper, B.H., Novakowski, K.S., and Reynolds, D.A., eds., Fractured rock, 2001: An international conference addressing groundwater flow, solute transport, multiphase flow, and remediation in fractured rock, International Groundwater Association, Toronto, Ontario, Canada, March 26-28, 2001: Smithville Phase IV, CD-ROM, 4 p.

Noblecourt, C.D., and Kenett, F.L., 1963, Tutankhamun's golden trove: National Geographic, v. 124, no. 4, p. 625-646. 
Nohara, Takahiro, Ochiai, Y., Seo, T., and Yoshida, H., 1992, Uranium-series disequilibrium studies in the Tono uranium deposit, Japan: Radiochimica Acta, v. 58/59, no. 2, p. 409-413.

Norris, R.M., 1999, Geologic setting of Mitchell Caverns: California State Parks Bulletin, p. 3-14.

Nuclear Waste Technical Review Board, 1990, Second report to the U.S. Congress and the U.S. Secretary of Energy: Washington, D.C., Nuclear Waste Technical Review Board, 34 p. with appendices.

Nuclear Waste Technical Review Board, 2000, Report to the U.S. Congress and the Secretary of Energy, January to December, 1999: U.S. Nuclear Waste Technical Review Board, $30 \mathrm{p}$.

Ochiai, Yasuhiro, Yamakawa, M., Takeda, S., and Harashima, F., 1989, Natural analogue study of the Tono uranium deposit in Japan, in Côme, B., and Chapman, N.A., eds., Commission of the European Communities natural analogue working group, Third Meeting, Snowbird, near Salt Lake City, USA, June 15-17, 1988: Nuclear Science and Technology Series, Luxembourg, Commission of the European Communities, EUR 11725 EN, p. 126-138.

Ohnuki, Toshihiko, Murakami, T., Sekine, K., Yanase, N., Isobe, H., and Kobayashi, Y., 1990, Migration behavior of uranium series nuclides in altered quartz-chlorite schist, in Oversby, V.M., and Brown, P.W., eds., Scientific basis for nuclear waste management XIII, Symposium, Boston, Massachusetts, November 27-30, 1989: Materials Research Society, v. 176, p. 607-614.

Oliver, Thomas, and Root, T., 1997, Hydrochemical database for the Yucca Mountain area, Nye County, Nevada: Denver, Colorado, U.S. Geological Survey, Database and memorandum to the Technical Project Officer, $16 \mathrm{p}$.

Olsen, Rick, 1996, This old cave-The ecological restoration of the historic entrance ecotone of Mammoth Cave and mitigation of visitor impact, in Proceedings of the Fifth Annual Mammoth Cave National Park Science Conference: U.S. National Park Service, p. 87-95.

Onac, B.P., 2000, Mineralogical studies and uranium-series dating of speleothems from Scarisoara Glacier Cave (Bihor Mountains, Romania): Theoretical and Applied Karstology, v. 13 , p. $33-38$.

Osborne, R.A.L., 2005, Dating ancient caves and related paleokarst: Acta Carsologia, v. 34, p. 51-72.

Osborne, R.A.L., Zwingmann, H., Pogson, R.E., and Colchester, D.D.M., 2006, Carboniferous clay deposits from Jenolan Caves, New South Wales-Implications for timing of speleogenesis and regional geology: Australian Journal of Earth Science, v. 5, p. 377-405.
Oversby, V.M., 1996, Criticality in a high-level waste repository-A review of some important factors and an assessment of the lessons that can be learned from the Oklo reactors: Svensk Kärnbränsleförsörjning A.B., SKB TR-96-07, $41 \mathrm{p}$.

Ozment, Katherine, 1999, Journey to the copper age: National Geographic, v. 195, no. 4, p. 70-79.

Paces, J.B., Neymark, L.A., Marshall, B.D., Whelan, J.F., and Peterman, Z.E., 1998, Inferences for Yucca Mountain unsaturated-zone hydrology from secondary minerals, Proceedings of the Eighth International High-Level Radioactive Waste Management Conference, Las Vegas, Nevada, May 11-14, 1998: American Nuclear Society, La Grange Park, Illinois, p. 36-39.

Paces, J.B., and Whelan, J.F., 2001, Water-table fluctuations in the Amargosa Desert, Nye County, Nevada, Proceedings of the Ninth International High-Level Radioactive Waste Management Conference, Las Vegas, Nevada, April 29-May 3, 2001: American Nuclear Society, La Grange Park, Illinois, $4 \mathrm{p}$.

Parizek, K.A., 2006, Importance of zones of fracture concentrations and tombs within the Valley of the Kings: Geological Society of America Abstracts with Program, v. 38, no. 7, p. 23.

Payne, T.E., Edis, R., and Seo, T., 1992, Radionuclide transport by groundwater colloids at the Koongarra uranium deposit, in Sombret, C.G., ed., Scientific basis for nuclear waste management XV, Symposium, Strasbourg, France, November 4-7, 1991: Materials Research Society, v. 257, p. 481-488.

Pearcy, E.C., 1994, Fracture transport of uranium at the Nopal I natural analog site: Center for Nuclear Waste Regulatory Analyses, CNWRA 94-011, 50 p.

Pearcy, E.C., and Murphy, W.M., 1991, Geochemical natural analogs, chapter 7, in Patrick, W.C., ed., Report on research activities for calendar year 1990: U.S. Nuclear Regulatory Commission, NUREG/CR-5817, p. 7-1 to 7-7.

Pearcy, E.C., Prikryl, J.D., and Leslie, B.W., 1995, Uranium transport through fractured silicic tuff and relative retention in areas with distinct fracture characteristics: Applied Geochemistry, v. 10, p. 685-704.

Pearcy, E.C., Prikryl, J.D., Murphy, W.M., and Leslie, B.W., 1993, Uranium mineralogy of the Nopal I natural analog site, Chihuahua, Mexico: Center for Nuclear Waste Regulatory Analyses, CNWRA 93-012, variously paginated, 6 sections. 
Pearcy, E.C., Prikryl, J.D., Murphy, W.M., and Leslie, B.W., 1994, Alteration of uraninite from the Nopal I deposit, Peña Blanca District, Chihuahua, Mexico, compared to degradation of spent nuclear fuel in the proposed U.S. high-level nuclear waste repository at Yucca Mountain, Nevada: Applied Geochemistry, v. 9, p. 713-732.

Perfect, D.L., Faunt, C.C., Steinkampf, W.C., and Turner, A.K., 1995, Hydrochemical data base for the Death Valley region, California and Nevada: U.S. Geological Survey Open-File Report 94-305, 10 p.

Petit, J.C., 1990, Migration of radionuclides in the geosphere-What can we learn from natural analogues?: Radiochimica Acta, v. 51, no. 4, p. 181-188.

Petit, J.C., Della Mea, G., Dran, J.C., Magonthier, M.C., Mando, P.A., and Paccagnella, A., 1990, Hydrated-layer formation during dissolution of complex silicate glasses and minerals: Geochimica et Cosmochimica Acta, v. 54, no. 7, p. 1941-1955.

Phillips, F.M., Dunbar, N.W., and Zreda, M., 1997, A test of chlorine-36 for dating of late Quaternary basaltic volcanos: EOS, Transactions of the American Geophysical Union, v. 78 , p. F760.

Phillips, J.S., and Luke, S.A., 1991, Tunnel damage resulting from seismic loading, Proceedings of the Second International Conference on Recent Advances in Geotechnical Earthquake Engineering \& Soil Dynamics: American Society of Civil Engineers, St. Louis, Missouri, March 11-15, v. 1, p. $207-217$.

Pickett, D.A., and Murphy, W.M., 1999, Unsaturated zone waters from the Nopal I natural analog, Chihuahua, Mexico-Implications for radionuclide mobility at Yucca Mountain, in Wronkiewicz, D.J., and Lee, J.H., eds., Scientific basis for nuclear waste management XXII, Symposium, Boston, Massachusetts, U.S.A., November 30-December 4, 1998: Warrendale, Pennsylvania, Materials Research Society, v. 556, p. 809-816.

Pickett, D.A., and Murphy, W.M., 1997, Isotopic constraints on radionuclide transport at Peña Blanca, in von Maravic, H., and Smellie, J., eds., Seventh EC Natural Analogue Working Group Meeting, Proceedings of an International Workshop, Stein am Rhein, Switzerland, October 28-30, 1996: Luxembourg, Commission of European Communities, EUR 17851 EN, p. 113-122.

Pickett, D.A., Prikryl, J.D., Murphy, W.M., and Pearcy, E.C., 1996, Uranium-series disequilibrium investigation of radionuclide mobility at the Nopal I uranium deposit, Peña Blanca district, Mexico-Implications for episodic radionuclide transport at a geologic repository for high-level nuclear waste: Eos, Transactions, Supplement 77, p. S94.
Pinto, D.G., 1989, The archeology of Mitchell Caverns: California Archeological Reports, Sacramento, California, State of California Department of Parks and Recreation, no. 25, p. 1-110.

Polyak, V.J., and Asmerom, Y., 2001, Late Holocene climate and cultural changes in the southwestern United States: Science, v. 294, p. 148-151.

Polyak, V.J., Hill, C., and Asmerom, Y., 2008, Age and evolution of the Grand Canyon revealed by U-Pb dating of watertype speleothems: Science, v. 319, p. 1377-1380.

Polyak, V.J., McIntosh, W.C., Guven, N., and Provencio, P., 1998, Age and origin of the Carlsbad Cavern and related caves from ${ }^{40} \mathrm{Ar} /{ }^{39} \mathrm{Ar}$ of alunite: Science, v. 279 , p. 1919-1922.

Polyak, V.J., and Provencio, P., 2000, Summary of the timing of sulfuric-acid speleogenesis for the Guadalupe caves based on ages of alunite: Journal of Caves and Karst Studies, v. 62 , no. 2 , p. $72-74$.

Polyak, V.J., Rasmussen, J.B.T., and Asmerom, Y., 2004, Prolonged wet period in the southwestern United States through the Younger Dryas: Geology, v. 32, p. 5-8.

Porcelli, Donald, and Swarzenski, P.W., 2003, The behavior of $\mathrm{U}$ - and Th-series nuclides in groundwater: Reviews in Mineralogy and Geochemistry, v. 52, p. 317-361.

Postpischl, Daniele, Agostini, S., Forti, P., and Quinif, Y, 1991, Palaeoseismicity from karst sediments-The Grotta del Cervo cave case study (central Italy): Tectonophysics, v. 193, p. 33-44.

Power, M.S., Rosidi, D., and Kaneshiro, J.Y., 1998, Seismic vulnerability of tunnels and underground structures revisited, in North American Tunneling '98: Proceedings of the North American Tunneling '98 Conference, Newport Beach, California, USA, February 21-25, 1998: Rotterdam, A.A. Balkema, p, 243-250.

Prasad, K.N., 1996, Pleistocene cave fauna from peninsular India: Journal of Caves and Karst Studies, v. 58, p. 30-34.

Pratt, H.R., Hustrulid, W.A., and Stephenson, D.E., 1978, Earthquake damage to underground facilities: DP-1513, Aiken, South Carolina, E.I. du Pont de Nemours and Company, Savannah River Laboratory, $84 \mathrm{p}$.

Prikryl, J.D., Pickett, D.A., Murphy W.M., and Pearcy, E.C., 1997, Migration behavior of naturally occurring radionuclides at the Nopal I uranium deposit, Chihuahua, Mexico: Journal of Contaminant Hydrology, v. 26, p. 61-69.

Pruess, Karsten, 1991, TOUGH2-A general-purpose numerical simulator for multiphase fluid and heat flow: Berkeley, Calif., Lawrence Berkeley Laboratory, LBL-29400, 102 p. 
Pruess, Karsten, and Narasimhan, T.N., 1985, A practical method for modeling fluid and heat flow in fractured porous media: Society of Petroleum Engineers Journal, v. 25, no. 1, p. 14-26.

Putman, J.J., 1988, The search for modern humans: National Geographic, v. 174, no. 4, p. 439-477.

Pye, D.S., Holligan, D., Cron, C.J., and Love, W.W., 1989, The use of beta-C titanium for downhole production casing in geothermal wells: Geothermics, v. 18 , no. 1/2, p. 259-267.

Quindos, L.S., Bonet, A., Diaz-Caneja, N., Fernandez, P.L., Gutierrez, I., Solana, J.R., Soto, J., and Villar, E., 1987, Study of the environmental variables affecting the natural preservation of the Altamira cave paintings located at Santillana Del Mar, Spain: Atmospheric Environment, v. 21, no. 3, p. 551-560.

Raney, R.G., 1988, Reported effects of selected earthquakes in the western North America intermountain region, 1852-1983, on underground workings and local and regional hydrology - A summary: U.S. Nuclear Regulatory Commission Report NNI-1988-3143, 114 p.

Rasilainen, Kari, Suksi, J., Blomqvist, R., Valkiainen, M., and Ruskeeniemi, T., 1991, Natural analogue studies and performance assessments in Finland, in Côme, B., and Chapman, N.A., eds., Fourth Natural Analogue Working Group Meeting and Poços de Caldas Project Final Workshop, Pitlochry, Scotland, June 18-22, 1990: Luxembourg, Commission of the European Communities, EUR 13014 EN, p. 193-210.

Rawson, S.A., Walton, J.C., and Baca, R.G., 1991, Migration of actinides from a transuranic waste disposal site in the vadose zone: Radiochimica Acta, v. 52/53, no. 2, p. $477-486$.

Reyes-Cortés, I.A., 2002, Geologic setting and mineralisation, Sierra Peña Blanca, Chihuahua, México, in von Maravic, H., and Alexander, W.R., eds., Eighth EC Natural Analogue Working Group Meeting, Proceedings of an International Workshop, Strasbourg, France, March 23-25, 1999: Luxembourg, Commission of European Communities, EUR 19118 EN, p. 321-331.

Rightmire, C.T., and Lewis, B.D., 1987a, Geologic data collected and analytical procedures used during a geochemical investigation of the unsaturated zone, Radioactive Waste Management Complex, Idaho National Engineering Laboratory, Idaho: U.S. Geological Survey Open-File Report $87-246,83 \mathrm{p}$.

Rightmire, C.T., and Lewis, B.D., 1987b, Hydrogeology and geochemistry of the unsaturated zone, Radioactive Waste Management Complex, Idaho National Engineering Laboratory, Idaho: U.S. Geological Survey Water-Resources Investigations Report 87-4198, 89 p.
Rightmire, C.T., and Lewis, B.D., 1988, Influence of the geochemical environment on radionuclide migration in the unsaturated zone, Radioactive Waste Management Complex, Idaho National Engineering Laboratory, Idaho: U.S. Geological Survey Open-File Report 87-246, 83 p.

Ring, Uwe, Laws, Susanne, and Bernet, Matthias, 1999, Structural analysis of a complex nappe sequence and late orogenic basins from the Aegean island of Samos, Greece: Journal of Structural Geology, v. 21 p. 1575-1601.

Rivas, P., Hernán, P., Astudillo, J., Bruno, J., Carrerra, J., De la Cruz, B., Guimerà, J., Gomez, P., Ivanovich, M., Marín, C., Miller, W., and Pèrez del Villar, L., 1998, Nuclear science and technology: El Berrocal Project, Luxembourg, Commission of European Communities, EUR 17830 EN, 70 p.

Robles-Camacho, Jasinto, and Armienta, M.A., 2000, Natural chromium contamination of groundwater at León Valley, México: Journal of Geochemical Exploration, v. 68, no. 3, p. $167-181$.

Rogers, K.L., Repenning, C.A., Luiszer, F.G., and Benson, R.D., 2000, Geologic history, stratigraphy, and paleontology of SAM Cave, north-central New Mexico: New Mexico Geology, New Mexico Bureau of Mines and Mineral Resources, v. 22, no. 4, p. 89-100.

Romero, Librado, Neretnieks, I., and Moreno, L., 1992, Movement of the redox front at the Osamu Utsumi uranium mine, Poços de Caldas, Brazil: Journal of Geochemical Exploration, v. 45 , no. $1-3$, p. $471-502$.

Roseboom, E.H., Jr., 1983, Disposal of high-level nuclear waste above the water table in arid regions: U.S. Geological Survey Circular 903, 21 p.

Rosenberg, N.D., Gdowski, G.E., and Knauss, K.G., 2001, Evaporative chemical evolution of natural waters at Yucca Mountain, Nevada: Applied Geochemistry, v. 16, no. 9-10, p. 1231-1240.

Ruskeeniemi, Timo, Niini, H., Söderholm, B., Vesterinen, M., Blomqvist, R., Halonen, S., Lindberg, A., Jaakkola, T., Suksi, J., and Suutarinen, R., 1989, The Palmottu U-Th deposit in SW Finland as a natural analogue to the behaviour of spent nuclear fuel in bedrock-A preliminary report, in Miles, D.L., ed., Proceedings of the 6th International Symposium on Water-Rock Interaction, WRI-6, Malvern, August 3-8, 1989: Brookfield, Massachusetts, A.A. Balkema, p. 601-604.

Ruspoli, Mario, 1986, The cave of Lascaux, the final photographs: New York, Harry N. Abrams, Inc., 206 p.

Russell, Kenneth W., 1982, The earthquake chronology of Palestine and northwest Arabia from the 2nd through the mid-8th century A.D.: Bulletin of the American Schools of Oriental Research, No. 260, p. 37-53. 
Sánchez-Moral, Sergio, Soler, V., Cañaveras, J.C., SanzRubio, E., Van Grieken, R., and Gysels, K., 1999, Inorganic deterioration affecting the Altamira Cave, northern SpainQuantitative approach to wall-corrosion (solutional etching) processes induced by visitors: The Science of the Total Environment, v. 243/244, p. 67-84.

Sandia National Laboratories, 2008, Probabilistic volcanic hazards analysis update (PVHA-U) for Yucca Mountain, Nevada: TDR-MGR-PO-000001, Rev. 0, OCRWM Lead Laboratory for Repository Systems, Las Vegas, Nevada, variously paginated.

Sargent, F.P., and Cramer, J.J., 1986, Cigar Lake Project, A U-deposit natural analogue, in Côme, B., and Chapman, N.A., eds., Commission of European Communities Natural Analogue Working Group, Second Meeting, Interlaken, Switzerland, June 17-19, 1986: Luxembourg, Commission of the European Communities, EUR 10671 EN, p. 93-100.

Saucedo, Alba Luz, Fayek, M., Reyes, I.A., Dobson, P.F., and Goodell, P.C., 2005, Structural analysis of the Nopal I uranium deposit, Peña Blanca, Mexico: Geological Society of America Abstracts with Programs, v. 37, no. 7, p. 197.

Saulnier, G.J., Jr., and Statham, W., 2006, The Peña Blanca natural analogue performance assessment model, Proceedings of the International High-Level Radioactive Waste Management Conference 2006, Las Vegas, Nevada, April 30-May 4, 2006: American Nuclear Society, La Grange Park, Illinois, p. 228-235.

Saura Ramos, P.A., 1998, The cave of Altamira: New York, Harry N. Abrams, Inc., 180 p.

Savannah Guides, 2009, Undara experience, Australia's accessible outback: Queensland, Australia, Undara Experience, http://www.savannah-guides.com.au/page3-1.html, last accessed December 30, 2009.

Savino, J.M., Smith, K.D., Biasi, G., Sullivan, T., and Cline, M., 1999, Earthquake ground motion effects on underground structures/tunnels: Eos, Transactions (Supplement, American Geophysical Union), v. 80, no. 17, p. S10.

Sawyer, D.A., Fleck, R.J., Lanphere, M.A., Warren, R.G., Broxton, D.E., and Hudson, M.R., 1994, Episodic caldera volcanism in the Miocene southwestern Nevada volcanic field-Revised stratigraphic framework, ${ }^{40} \mathrm{Ar} /{ }^{39} \mathrm{Ar}$ geochronology, and implications for magmatism and extension: Geological Society of America Bulletin, v. 106, no. 10, p. 1304-1318.

Schick, Tamar, 1998, The Cave of the Warrior-A fourth millennium burial in the Judean Desert: IAA Reports, no. 5, Jerusalem, Israel Antiquities Authority, $137 \mathrm{p}$.
Schorscher, H.D., and Shea, M.E., 1991, The regional geology, mineralogy and geochemistry of the Poços de Caldas alkaline caldera complex, Minas Gerais, Brazil: Swedish Nuclear Fuel and Waste Management Company, SKB Technical Report 90-10, 36 p.

Seo, Toshi, Edis, R., and Payne, T.E., 1994, A study of colloids in groundwaters at the Koongarra uranium deposit, in von Maravic, H., and Smellie, J., eds., Fifth CEC Natural Analogue Working Group Meeting and Alligator Rivers Analogue Project (ARAP) final workshop-Proceedings of an International Workshop, Toledo, Spain, October 5-9, 1992: Luxembourg, Commission of the European Communities, EUR 15176 EN, p. 71-76.

Seo, Toshi, and Yoshida, H., 1994, Natural analogue studies of the Tono uranium deposit in Japan, in von Maravic, $\mathrm{H}$. and Smellie, J., eds., Fifth CEC Natural Analogue Working Group Meeting and Alligator Rivers Analogue Project (ARAP) final workshop-Proceedings of an international workshop, Toledo, Spain, October 5-9, 1992: Luxembourg, Commission of the European Communities, EUR 15176 EN, p. 179-184.

Sharma, Sunil, and Judd, W.R., 1991, Underground opening damage from earthquakes: Engineering Geology, v. 30, no. $3 / 4$, p. $263-276$.

Sharpe, S.E., 2007, Using modern through mid-Pleistocene climate to bound future variations in infiltration at Yucca Mountain, Nevada, in Stuckless, J.S., and Levich, R.A., eds., The geology and climatology of Yucca Mountain and vicinity, southern Nevada and California: Geological Society of America Memoir 199, p. 155-205.

Shepherd, Robert, 1993, Ancient mining: New York, Elsevier Applied Science, 494 p.

Shikazono, Naotatsu, and Utada, M., 1997, Stable isotope geochemistry and diagenetic mineralization associated with the Tono Sandstone-type uranium deposit in Japan: Mineralium Deposita, v. 32, no. 6, p. 596-606.

Siliotti, Alberto, 1996, Guide to the Valley of the Kings and to the Theban necropolises and temples: White Star S.r.l., Vercille, Italy, $168 \mathrm{p}$.

Simmons, A.M., and Bodvarsson, G.S., 1997, Building confidence in thermohydrologic models of Yucca Mountain using geothermal analogues: Milestone SPLE1M4, Berkeley, California, Lawrence Berkeley National Laboratory, 64 p.

Simmons, A.M., Murrell, M.T., and Goldstein, S.J., 2002, Seasonal fluctuation in uranium decay-series composition of waters at Peña Blanca, Mexico: Geological Society of America Abstracts with Programs, v. 34, no. 6, p. 235.

Smellie, John, 1995, The fossil nuclear reactors of Oklo, Gabon: Radwaste Magazine, v. 2, no. 2, p. 18-20, 22-27. 
Smellie, J.A.T., ed., 1998, MAQARIN natural analogue study, phase III: SKB Technical Report 98-04, two volumes, Stockholm, Sweden, Swedish Nuclear Fuel and Waste Management Company, variously paginated.

Smellie, John, Chapman, N., McKinley, I., Penna Franca, E., and Shea, M., 1989, Testing safety assessment models using natural analogues in high natural-series groundwaters, in Lutze, W., and Ewing, R.C., eds., The second year of the Poços de Caldas Project, Scientific basis for nuclear waste management XII, Symposium, Berlin, Germany, October 10-13, 1988: Materials Research Society, v. 127, p. $863-870$.

Smellie, J.A.T., and Stuckless, J.S., 1985, Element mobility studies of two drill cores from the Gotemar Granite (Krakemala Test Site), southeast Sweden: Chemical Geology, v. 51, p. $55-78$.

Smellie, J.A.T., Winberg, A., and Karlsson, F., 1993, Swedish activities in the Oklo natural analogue project, in von Maravic, H., ed., 2nd Joint CEC-CEA Progress Meeting of the Oklo Working Group, Brussels, Belgium, April 6-7, 1992: Luxembourg, Commission of the European Communities, EUR 14877 EN, p. 131-142.

Smith, F.H., Trinkaus, E., Pettitt, P.B., Karavanic, I., and Paucvic, M., 1999, Direct radiocarbon dates for Vindija G1 and Velika Pecina Late Pleistocene hominid remains: Proceedings of the National Academy of Sciences of the United States of America, v. 96, p. 12281-12286.

Snelling, A.A., 1980, Uraninite and its alteration products, Koongarra uranium deposit, in Ferguson, J., and Goleby, A.B., eds., Proceedings of International Uranium Symposium on the Pine Creek Geosyncline, 1980: International Atomic Energy Agency, p. 487-498.

Snelling, A.A., 1992, Geologic setting-Volume 2 of Alligator Rivers Analogue Project: SKI TR 92,20-2, Australian Nuclear Science and Technology Organisation, $118 \mathrm{p}$.

Sonnenthal, E.L., and Spycher, N., 2001, Drift-scale coupled processes (DST and THC seepage) models: Las Vegas, Nevada, Bechtel SAIC Company, Report MDL-NBSHS-000001 REV01, variously paginated.

Spengler, R.W., and Fox, K.F., Jr., 1989, Stratigraphic and structural framework of Yucca Mountain, Nevada: Radioactive Waste Management and Nuclear Fuels Cycle, v. 13, p. 21-36.

Starr, R.C., and Rohe, M.J., 1995, Large-scale aquifer stress test and infiltration test: Water Management System Operation and Results, Idaho National Engineering Laboratory, INEL-95/059.
Steefel, C.I., and Lichtner, P.C., 1998, Multicomponent reactive transport in discrete fractures II-Infiltration of hyperalkaline groundwater at Maqarin, Jordan, a natural analogue site: Journal of Hydrology, v. 209, no. 1-4, p. 200-224.

Steelman, K.L., Rowe, M.W., Boszhardt, R.F., and Southon, J.R., 2001, Radiocarbon age determination of a rock painting at Arnold/Tainter Cave, Wisconsin: Midcontinental Journal of Archeology, v. 26, p. 121-131.

Stein, B.A., and Warrick, S.F., 1979, Granite Mountains resource survey - Natural and cultural values of the Granite Mountains, Eastern Mojave Desert, California: Publication no. 1, University of California, Santa Cruz, Environmental Field Program, 363 p.

Stevens, P.R., 1977, A review of the effects of earthquakes on underground mines: U.S. Geological Survey Open-File Report 77-313, $47 \mathrm{p}$.

Stock, G.M., Anderson, R.S., and Kinkel, R.C., 2004, Pace of landscape evolution in the Sierra Nevada, California, revealed by cosmogenic dating of cave sediment: Geology, v. 32, p. 193-196.

Stock, G.M., Granger, D.E., Sasowsky, I.D., Anderson, R.S., and Finkel, R.C., 2005, Comparison of U-Th, paleomagnetism, and cosmogenic burial methods for dating cavesImplications for landscape evolution studies: Earth and Planetary Science Letters, v. 236, p. 388-403.

Stock, G. M., Riihimaki, C.A., and Anderson, R.S., 2006, Age constraints on cave development and landscape evolution in the Bighorn Basin of Wyoming, USA: Journal of Caves and Karst Studies, v. 68, p. 76-84.

Stockman, Harlan, Krumhansl, J., Ho, C., and McConnell, V., 1994, The Valles Natural Analogue Project: Washington, D.C., U.S. Nuclear Regulatory Commission, NUREG/ CR-6221, $112 \mathrm{p}$.

Stout, R.B., and Leider, H.R., eds., 1997, Waste form characteristics report, revision 1: Livermore, Calif., Lawrence Livermore National Laboratory, UCRL-ID-108314, Version $1.2,850 \mathrm{p}$.

Stover, C.W., and Coffman, J.L., 1993, Seismicity of the United States, 1568-1989 (revised): U.S. Geological Survey Professional Paper 1527, 418 p.

Stuckless, J.S., 2000, Archaeological analogues for assessing the long-term performance of a mined geologic repository for high-level radioactive waste: U.S. Geological Survey Open-File Report 2000-181, 27 p.

Stuckless, J.S., 2002, Natural analogues - One way to help build public confidence in the predicted performance of a mined geologic repository for nuclear waste: Proceedings of the Waste Management 2002 Conference, Tucson, Arizona, February 24-28, 2002, v. 2002 symposium, 15 p. 
Stuckless, J.S., 2003, The use of qualitative analogues to help build confidence in predictive models for subsystems at Yucca Mountain, Nevada: Geological Society of America Abstracts with Programs, v. 35, no. 6, p. 436.

Stuckless, J.S., 2006, Analogues as a means of facilitating communication with the public: Geological Society of America Abstracts with Programs, v. 38, no. 7, p. 516.

Stuckless, J.S., and Dudley, W.W., 2002, The geohydrologic setting of Yucca Mountain, Nevada: Applied Geochemistry, v. 17 , p. 659-682.

Stuckless, J.S., and Ferreira, C.P., 1976, Labile uranium in granitic rocks, in Exploration for uranium ore deposits: Vienna, International Atomic Energy Agency, p. 717-730.

Stuckless, J.S., and Nkomo, I.T., 1978, Uranium-lead isotope systematics in a uraniferous, alkali-rich granite from the Granite Mountains, Wyoming-Implications for uranium source rocks: Economic Geology, v. 73, p. 427-441.

Stuckless, J.S., and Nkomo, I.T., 1980, Preliminary investigations of U-Th-Pb systematics in uranium-bearing minerals from two granitic rocks from the Granite Mountains, Wyoming: Economic Geology, v. 75, no. 2, p. 289-295.

Stuckless, J.S., Nkomo, I.T., and Butt, K. K., 1986, U-Th$\mathrm{Pb}$ systematics of an Archean granite from the Owl Creek Mountains, Wyoming: U.S. Geological Survey Professional Paper 1388-C, p. 34-48.

Stuckless, J.S., Nkomo, I.T., Wenner, D.B., and VanTrump, G., Jr., 1983, Geochemistry and uranium favorability of the post-orogenic granites of the northeastern Arabian Shield, Kingdom of Saudi Arabia: Proceedings of the 1st Symposium of IGCP 164, Bulletin Faculty Earth Sciences, King Abdul-Aziz University, v. 6, p.195-209.

Stuckless, J.S., and Toomey, R.S. III, 2003, A case of longterm passive ventilation for the proposed repository at Yucca Mountain, Nevada-Evidence from natural analogues, Proceedings of the 10th International High-Level Radioactive Waste Management Conference, Las Vegas, Nevada, March 30-April 2, 2003: American Nuclear Society, La Grange Park, Illinois, p. 267-278.

Stuckless, J.S., and Troeng, B., 1984, Uranium mineralization in response to regional metamorphism at Lilljuthatten, Sweden: Economic Geology, v. 79, p. 509-528.

Stuckless, J.S., Whelan, J.F., and Steinkampf, W.C., 1991, Isotopic discontinuities in ground water beneath Yucca Mountain, Nevada - Proceedings of the Second Annual International High-Level Radioactive Waste Management Conference, Las Vegas, Nevada, April 28-May3, 1991: American Nuclear Society, La Grange Park, Illinois, p. $1410-1415$.
Sturchio, N.C., Böhlke, J.K., and Binz, C.M., 1989, Radiumthorium disequilibrium and zeolite-water ion exchange in a Yellowstone hydrothermal environment: Geochimica et Cosmochimica Acta, v. 53, p. 1025-1034.

Sturchio, N.C., Keith, T.E.C., and Muehlenbachs, K., 1990, Oxygen and carbon isotope ratios of hydrothermal minerals from Yellowstone drill cores: Journal of Volcanology and Geothermal Research, v. 40, p. 23-37.

Sturchio, N.C., Muehlenbachs, K., and Seitz, M.G., 1986, Element redistribution during hydrothermal alteration of rhyolite in an active geothermal system-Yellowstone drill cores $\mathrm{Y}-7$ and $\mathrm{Y}-8$ : Geochimica et Cosmochimica Acta, v. 50, no. 8 , p. 1619-1631.

Suksi, Johani, Ruskeeniemi, T., Lindberg, A., and Jaakkola, T., 1991, The distribution of natural radionuclides on fracture surfaces in Palmottu analogue study site in SW Finland: Radiochimica Acta, v. 52/53, no. 2, p. 367-372.

Suutarinen, R., Blomqvist, R., Halonen, S., and Jaakkola, T., 1991, Uranium in groundwater in Palmottu analogue study site in Finland: Radiochimica Acta, v. 52/53, no. 2, p. $373-380$.

Sverjensky, Dimitri, Bennett, D.G., and Read, D., 1992, Geochemical modelling of secondary uranium ore formationAlligator Rivers Analogue Project: Australian Nuclear Science and Technology Organisation, v. 11, DOE/HMIP/ $\mathrm{RR} / 92 / 081,51 \mathrm{p}$.

Sweetkind, D.S., Anna, L.O., Williams-Stroud, S.C., and Coe, J.A., 1997, Characterizing the fracture network at Yucca Mountain, Nevada, part 1, Integration of field data for numerical simulations, in Hoak, T.E., Klawitter, A.L., and Blomquist, P.K.. eds., Fractured reservoirs, characterization and modeling guidebook, 1997: Rocky Mountain Association of Geologists, p. 185-197.

Thomassin, J.H., and Rassineux, F., 1992, Ancient analogues of cement-based materials - Stability of calcium silicate hydrates: Applied Geochemistry, Supplemental Issue, no. 1, p. $137-142$.

Thompson, J.L., ed., 1986, Laboratory and field studies related to the radionuclide migration October 1, 1984-September 30, 1985: Los Alamos, New Mexico, Los Alamos National Laboratory, LA-10644-PR, 24 p.

Thordarson, William, 1965, Perched ground water in zeolitized bedded tuff, Rainier Mesa and vicinity, Nevada Test Site, Nevada: U.S. Geological Survey Trace Elements Investigations Report 862, prepared for the Atomic Energy Commission, p. 86-90.

Tolman, C.F., 1937, Ground water: New York, McGraw-Hill Book Company, 593 p. 
Toprak, Vedat, Keller, J., and Schumacher, R., 1994, Volcanotectonic features of the Cappadocian volcanic province, Ankara, Turkey: 1994 International Volcanology Congress of the International Association of Volcanology and Chemistry of the Earth's Interior, Amsterdam, The Netherlands, Elsevier, 58 p.

Triay, I.R., Furlano, A.C., Weaver, S.C., Chipera, S.J., and Bish, D.L., 1996, Comparison of neptunium sorption results using batch and column techniques: Los Alamos, New Mexico, Los Alamos National Laboratory, LA-12958-MS, $30 \mathrm{p}$.

Triay, I.R., Meijer, A., Conca, J.L., Kung, K.S., Rundberg, R.S., Strietelmeier, B.A., and Tait, C.D., 1997, Summary and synthesis report on radionuclide retardation for the Yucca Mountain Site Characterization Project, Eckhardt, R.C., ed.: Los Alamos, New Mexico, Los Alamos National Laboratory, LA-13262-MS, 286 p.

Tuohy, D.R., and Dansie, A.J., 1997, New information regarding early Holocene manifestations in the western Great Basin: Nevada Historical Society Quarterly, v. 40, no. 1, p. 24-53.

Turgeon, Steven, and Lundberg, J., 2001, Chronology of discontinuities and petrology of speleothems as paleoclimatic indicators of the Klamath Mountains, southwest Oregon, USA: Carbonates and Evaporites, v. 16, p. 153-167.

Tweed, C.J., and Milodowski, A.E., 1994, An overview of the Maqarin natural analogue project-A natural analogue study of a hyperalkaline cement groundwater system, in von Maravic, H., and Smellie, J., eds., Fifth CEC Natural Analogue Working Group Meeting and Alligator Rivers Analogue Project (ARAP) Final Workshop: Proceedings of an International Workshop, Toledo, Spain, October 5-9, 1992, Luxembourg, Commission of the European Communities, EUR 15176 EN, p. 203-209.

Tylecote, R.F., 1977, Durable materials for seawater-The archaeological evidence: The International Journal of Nautical Archaeology and Underwater Exploration, v. 6, no. 4, p. 269-283.

Tylecote, R.F., 1979, The effect of soil conditions on the longterm corrosion of buried tin-bronzes and copper: Journal of Archeological Science, v. 6, p. 345-368.

U.S. Department of Energy, 1992, Groundwater hydrology report, Attachment 3 of Remedial action plan and site design for stabilization of the inactive uranium mill tailings site at Gunnison, Colorado, Final: Albuquerque, New Mexico, U.S. Department of Energy, UMTRA project office, UMTRADOE/ AL-050508,0000, 60 p.
U.S. Department of Energy, 1995, Applications of natural analogue studies to Yucca Mountain as a potential high-level radioactive waste repository: U.S. Department of Energy, DOE/YMSCO-002, 29 p.

U.S. Department of Energy, 1996, Final programmatic environmental impact statement for the uranium mill tailings remedial action ground water project: Grand Junction, Colorado, U.S. Department of Energy, Grand Junction Project Office, DOE/EIS-0198, 1999?, two volumes, variously paginated.

U.S. Department of Energy, 1998a, Viability assessment of a repository at Yucca Mountain - Overview and five volumes: Washington, D.C., U.S. Department of Energy, Office of Civilian Radioactive Waste Management, DOE/RW-0508, variously paginated.

U.S. Department of Energy, 1998b, Total system performance assessment, volume 3 of Viability Assessment of a repository at Yucca Mountain: Washington, D.C., U.S. Department of Energy, Office of Civilian Radioactive Waste Management, DOE/RW-0508, variously paginated.

U.S. Department of Energy, 1999, Final site observational work plan for the UMTRA Project, New Rifle Site: Grand Junction, Colorado, U.S. Department of Energy, Grand Junction Office, GJO-99-112-TAR, Rev. 1, 2 volumes, variously paginated.

U.S. Department of Energy, 2000, Sites-UMTRA ground water project, Grand Junction, Colorado: U.S. Department of Energy, Grand Junction Office, accessed February 13, 2002 at http://www.doegjpo.com/ugw/sites/sites.htm.

U.S. Department of Energy, 2001a, Yucca Mountain science and engineering report: Washington, D.C., U.S. Department of Energy, Office of Civilian Radioactive Waste Management, DOE/RW-0539, DOE/YMSCO-002, variously paginated.

U.S. Department of Energy, 2001b, Final site observational work plan for the Gunnison, Colorado, UMTRA project site: Grand Junction, Colorado, U.S. Department of Energy, Grand Junction Office, GJO-2001-214-TAR, variously paginated.

U.S. Department of Energy, 2002, Final environmental impact statement for a geologic repository for the disposal of spent nuclear fuel and high-level radioactive waste at Yucca Mountain, Nye County, Nevada: U.S. Department of Energy, Office of Civilian Radioactive Waste Management, DOE/EIS-0250, variously paginated.

U.S. Department of Energy, 2008, Yucca Mountain repository license application, general information and safety analysis report: Washington, D.C., Office of Civilian Radioactive Waste Management, DOE/RW/-0573, rev. 0, variously paginated. 
U.S. Geological Survey, 1998, Probabilistic seismic hazard analyses for fault displacement and vibratory ground motion at Yucca Mountain, Nevada: U.S. Geological Survey Milestone SP32IM3, June 15, 1998, three volumes, variously paginated.

U.S. Geological Survey, 2000a, Review of the transport of selected radionuclides in the Interim Risk Assessment for the Radioactive Waste Management Complex, Waste Area Group 7 Operable Unit 7-13/14, Administrative Report, Idaho, vol. 2: Idaho National Engineering and Environmental Laboratory, $25 \mathrm{p}$.

U.S. Geological Survey, 2000b, Lava tube-Photo glossary of volcano terms: Menlo Park, California, U.S. Geological Survey, accessed January 30, 2002. http://volcanoes.usgs. gov/images/pglossary/LavaTube.php.

U.S. Nuclear Regulatory Commission, 2003, Yucca Mountain Review Plan, Final Report: U.S. Nuclear Regulatory Commission, Office of Nuclear Material Safety and Safeguards, NUREG-1804, Rev. 2, variously paginated.

Valkiainen, Mati, 1989, Finnish natural analogue research, in Côme, B., and Chapman, N.A., eds., Commission of the European Communities natural analogue working group, Third Meeting, Snowbird, near Salt Lake City, USA, June 15-17, 1988, Nuclear Science and Technology Series: Luxembourg, Commission of the European Communities, EUR 11725 EN, p. 110-118.

Valladas, Helene, Cachier, H., Maurice, P., Bernaldo de Quiros, F., Clottes, J., Cabrera Valdes, V., Uzquiano, P., and Arnold, M., 1992, Direct radiocarbon dates for prehistoric paintings at the Altamira, El Castillo and Niaux caves: Nature, v. 357, p. 68-70.

Vandergraaf, T.T., Drew, D.J., Ticknor, K.V., and Seddon, W.A., 2001, Radionuclide migration in tuff under unsaturated conditions, in Back to the future-Managing the back end of the nuclear fuel cycle to create a more secure energy future, in Proceedings of the 9th International High-Level Radioactive Waste Management Conference, Las Vegas, Nevada, April 29-May 3, 2001: American Nuclear Society, La Grange Park, Ill., 4 p.

Vaniman, D.T., Chipera, S.J., Bish, D.L., Carey, J.W., and Levy, S.S., 2001, Quantification of unsaturated-zone alteration and cation exchange in zeolitized tuffs at Yucca Mountain, Nevada, USA: Geochimica et Cosmochimica Acta, v. 65 , no. 20 , p. $3409-3433$.

Vilks, Peter, Cramer, J.J., Bachinski, D.B., Doern, D.C., and Miller, H.G., 1993, Studies of colloids and suspended particles, Cigar Lake uranium deposit, Saskatchewan, Canada: Applied Geochemistry, v. 8, no. 6, p. 605-616.
Vilks, Peter, Cramer, J.J., Shewchuk, T.A., and Larocque, J.P.A., 1988, Colloid and particulate matter studies in the Cigar Lake natural analog program: Radiochimica Acta, v. $44 / 45$, no. 2 , p. $305-310$.

Villar, Eugenio, Bonet, A., Diaz-Caneja, B., Fernandez, P.L., Gutierrez, I., Quindos, L.S., Solana, J.R., and Soto, J., 1985, Natural evolution of percolation water in Altamira cave: Cave Science, British Cave Research Association, v. 12, no. 1, p. 21-24.

von Maravic, Henning, and Smellie, J.A.T., eds., 1994, Fifth CEC Natural Analogue Working Group Meeting and Alligator Rivers Analogue Project (ARAP) final workshop, in Proceedings of an international workshop, Toledo, Spain, October 5-9,1992: Luxembourg, Commission of the European Communities, EUR 15176 EN, 397 p.

Wallace, A.B., and Roper, M.W., 1981, Geology and uranium deposits along the northeastern margin, McDermitt caldera complex, Oregon, in Goodell, P.C., and Waters, A.C., eds., Uranium in volcanic and volcaniclastic rocks, Symposium held in El Paso, Texas, February 25-27, 1980: American Association of Petroleum Geologists Studies in Geology no. 13 , p. $73-80$.

Waltham, A.C., and Park, D.H., 2002, Roads over lava tubes in Cheju Island, South Korea: Engineering Geology, v. 66, p. 53-64.

Walton, J.C., 1994, Influence of evaporation on waste package environment and radionuclide release from a tuff repository: Water Resources Research, v. 30, no. 12, p. 3479-3487.

Wang, J.S.Y., 1991, Fracture flow and matrix flow in the unsaturated zone at Yucca Mountain and at Rainier MesaAppendix B of A review of Rainier Mesa tunnel and borehole data and their possible implications to Yucca Mountain site study plans: Berkeley, Calif., Lawrence Berkeley Laboratory report LBL-32068, variously paginated.

Wang, J.S.Y., Cook, N.G.W., Wollenberg, H.A., Carnahan, C.L., Javandel, I., and Tsang, C.F., 1993, Geohydrologic data and models of Rainier Mesa and their implications to Yucca Mountain, in Proceedings of the Fourth Annual International High Level Radioactive Waste Management Conference, Las Vegas, Nevada, April 26-30, 1993: American Nuclear Society, La Grange Park, Illinois, v. 1, p. 675-681.

Wang, J-M., 1985, The distribution of earthquake damage to underground facilities during the 1976 Tang-Shan earthquake: Earthquake Spectra, v. 1, no. 4, p. 741-757.

Watanabe, Kazumasa, 1989, Archaeological evidence supports a preferred soil cap for LLRW disposal, in Proceedings of the 1989 Joint International Waste Management Conference, Kyoto, Japan, low and intermediate-level radiactive waste management: American Society of Mechanical Engineers, p. 567-571. 
Weeks, K.R., 1998, Valley of the Kings: National Geographic, v. 194 , no. 3 , p. $5-33$.

Wenbin, Zhang, 2000, Dunhuang-A centennial commemoration of the discovery of the cave library: Beijing, China, Morning Glory Publishers, 188 p.

West, J.M., McKinley, I.G., and Vialta, A., 1989, The influence of microbial activity on the movement of uranium at Osamu Utsumi Mine, Poços de Caldas, Brazil, in Lutze, W., and Ewing, R.C., eds., Scientific basis for nuclear waste management XII, Symposium, Berlin, Germany, October 10-13, 1988: Materials Research Society, v. 127, p. $771-777$.

West, J.M., Vialta, A., and McKinley, I.G., 1990, Poços de Caldas report number 10, Microbiological analysis at the Osamu Utsumi and Morro do Ferro analogue study sites, Poços de Caldas, Brazil: NAGRA NTB 90-28, Baden, Switzerland, Nationale Genossenschaft für die Lagerung Radioaktiver Abfalle, 32 p.

Wheeler, S.M., 1973, The archeology of Etna Cave, Lincoln County, Nevada, in a reprint, Fowler, D.D., ed.: Desert Research Institute, Publications in Social Sciences no. 7, $56 \mathrm{p}$.

Wheeler, S.M., 1997, Cave burials near Fallon, Nevada: Nevada Historical Society Quarterly, v. 40, no. 1, p. 15-23.

Whelan, J.F., Paces, J.B., and Peterman, Z.E., 2002, Physical and stable-isotope evidence for formation of secondary calcite and silica in the unsaturated zone, Yucca Mountain, Nevada: Applied Geochemistry, v. 17, p. 735-750.

Whelan, J.F., Roedder, E., and Paces, J.B., 2001, Evidence for an unsaturated-zone origin of secondary minerals in Yucca Mountain, Nevada, in Back to the future-Managing the back end of the nuclear fuel cycle to create a more secure energy future: Proceedings of the 9th International HighLevel Radioactive Waste Management Conference, Las Vegas, Nevada, April 29-May 3, 2001: American Nuclear Society, La Grange Park, Illinois, 4 p.

White, D.E., Fournier, R.O., Muffler, L.J.P., and Truesdell, A.H., 1975, Physical results of research drilling in thermal areas of Yellowstone National Park, Wyoming: U.S. Geological Survey Professional Paper 892, 70 p.

Whitfield, Roderick, and Otsuka, Seigo, 1996, DunhuangCaves of the Singing Sands, Buddhist art from the Silk Road: London, U.K., Textile and Art Publications Ltd., $356 \mathrm{p}$.

Wieland, Eric, and Spieler, P., 2001, Colloids in the mortar backfill of a cementitious repository for radioactive waste: Waste Management, v. 21, no. 6, p. 511-523.
Willey, P.S., Stolen, J., Crothers, G., and Watson, P.J., 2005, Preservation of prehistoric footprints in Jaguar Cave, Tennessee: Journal of Caves and Karst Studies, v. 67, p. 61-68.

Winkler, A.J., and Gose, W., 2003, Mammalian fauna and paleomagnetics of the Middle Irvingtonian (Early Pleistocene) Fyllan Cave and Kitchen Door localities, Travis County, Texas, in Schubert, B.W., Mead, J.I., and Graham, R.W., eds., Ice age cave faunas of North America: Bloomington, Indiana University Press, p. 215-261.

Winograd, I.J., 1986, Archaeology and public perception of a transscientific problem-Disposal of toxic wastes in the unsaturated zone: U.S. Geological Survey Circular 990, 9 p.

Winograd, I.J., Coplen, T.B., Landwehr, J.M., Riggs, A.C., Ludwig, K.R., Szabo, B. J., Kolesar, P.T., and Revesz, K.M., 1992, Continuous 500,000-year climate record from vein calcite in Devils Hole, Nevada: Science, v. 258, p. $255-260$.

Winograd, I.J., Landwehr, J.D., Coplen, T.B., Sharpe, W.D., Riggs, A.C., Ludwig, K.R., and Kolesar, P.T., 2006, Devils Hole, Nevada, ${ }^{18} \mathrm{O}$ record extended to the mid-Holocene: Quaternary Research v. 66, p. 202-212.

WoldeGabriel, Giday, Keating, G.N., and Valentine, G.A., 1999, Effects of shallow basaltic intrusion into pyroclastic deposits, Grants Ridge, New Mexico, USA: Journal of Volcanology and Geothermal Research, v. 92, p. 389-411.

Wolery, T.J. and Daveler, S.A., 1992, EQ6, A computer program for reaction path modeling of aqueous geochemical systems, theoretical manual, user's guide, and related documentation (version 7.0): UCRL-MA-110662 PT IV, Livermore, Calif., Lawrence Livermore National Laboratory, 243 p., 6 appendices.

Wolery, T.J., 1979, Calculation of chemical equilibrium between aqueous solution and minerals - The EQ3/6 software package: UCRL-52658, Livermore, Calif., Lawrence Livermore National Laboratory, 41 p.

Wolfram, Stefan, 1991, Mathematica, a system for doing mathematics by computer, $2 \mathrm{~d}$ ed.: Redwood City, Calif., Addison-Wesley, $354 \mathrm{p}$.

Wong, Virginia, 1998, Gamma-ray characterization of uranium-series nuclides and its application to the study of the Peña Blanca natural analogue site, Chihuahua, Mexico: University of Texas at El Paso, Ph.D. dissertation.

Wong, Virginia, Anthony, E., and Goodell, P., 1996, Nopal I uranium deposit - A study of radionuclide migration, in Proceedings of the Seventh Annual International HighLevel Radioactive Waste Management Conference, Las Vegas, Nevada, April 29-May 3, 1996: American Nuclear Society, La Grange Park, Illinois, p. 43-45. 
Woo, K.S., Hong, G.H., Choi, D.W., Jo, K.N., Bskaran, M., and Lee, H.M., 2005, A reconnaissance on the use of the speleothems in Korean limestone caves to retrospective study on the regional climate change for the recent and geologic past: Geosciences Journal, v. 9, p. 243-247.

Woo, K.S., Hong, G.H., Choi, D.W., and Lee, H.M., 2007, Silicification of cave corals from some lava tube caves in the Jeju Island, Korea-Implications for speleogenesis and a proxy for paleoenvironmental change during the Late Quaternary: Quaternary International, v. 176-177, p. 82-95.

Wronkiewicz, D.J., Bates, J.K., Wolf, S.F., and Buck, E.C., 1996, Ten-year results from unsaturated drip tests with $\mathrm{UO}_{2}$ at $90^{\circ} \mathrm{C}$ - Implications for the corrosion of spent nuclear fuel: Journal of Nuclear Materials, v. 238, no. 1, p. 78-95.

Wulff, H.E., 1968, The qanats of Iran: Scientific American, v. 218 , no. 4 , p. $94-105$.

Xu, Tienfu, and Pruess, K., 2001a, Modeling multiphase nonisothermal fluid flow and reactive geochemical transport in variably saturated fractured rocks, 1, Methodology: American Journal of Science, v. 301, p. 16-33.

Xu, Tienfu, and Pruess, K., 2001b, On fluid flow and mineral alteration in fractured caprock of magmatic hydrothermal systems: Journal of Geophysical Research, v. 106, no. B2, p. 2121-2138.

Yamato, Aiji., Masuda, S., and Sakuma, H., 1992, The highlevel radioactive waste management program in Japan, in Proceedings of the Third International High-Level Radioactive Waste Management Conference, Las Vegas, Nevada, April 12-16, 1992: American Nuclear Society, La Grange Park, Illinois, v. 1, p. 41-48.

Yang, I.C., Rattray, G.W., and Yu, P., 1996, Interpretation of chemical and isotopic data from boreholes in the unsaturated zone at Yucca Mountain, Nevada: U.S. Geological Survey Water-Resources Investigations Report 96-4058, $57 \mathrm{p}$.

Yoshida, Hidekasu, 1994, Relation between U-series nuclide migration and microstructural properties of sedimentary rocks: Applied Geochemistry, v. 9, no. 5, p. 479-490.

Yoshida, Hidekasu, Kodama, K., and Ota, K., 1994, Role of microscopic flowpaths on nuclide migration in sedimentary rocks - A case study from the Tono uranium deposit, central Japan: Radiochimica Acta, v. 66/67, p. 505-511.

Yoshida, Hidekasu, Yui, M., and Shibutani, T., 1994, Flow path structure in relation to nuclide migration in sedimentary rocks - An approach with field investigations and experiments for uranium migration at Tono uranium deposit, central Japan: Journal of Nuclear Science and Technology, Atomic Energy Society of Japan, v. 31, no. 8, p. 803-812.
Yusa, Yasuhisa, and Yamakawa, M., 1992, Tono in-situ research facilities for studies of the geological environment, in Kato, H. and Noro, H., eds., Environmental geology and the Late Quaternary of Japan, 29th International Geological Congress Field Trip Guide Book: Geological Survey of Japan, v. 3, p. 145-153.

Yusa, Yasuhisa, and Yoshida, H., 1993, Migration behaviour of natural radionuclides in geological formation-A case study of the Tono uranium deposits, Japan: Hoshasen (Japan), Tokyo, Japan, Power Reactor and Nuclear Fuel Development Corporation (PNC), Chubu Works, p. 20, no. 1, p. 29-39.

Zetterström, Lena, 2000, Oklo-A review and critical evaluation of literature: Svensk Kärnbränsleförsörjning A.B., Stockholm, Sweden, SKB TR 00-17, 37 p.

Zhang, Juzhong, Harbottle, Garman, Wang, Changsui, and Kong, Zhaochen, 1999, Oldest playable musical instruments found at Jiahu early Neolithic site in China: Nature, v. 401, p. 366-368.

Zhang, Meiliang, Yuan, D., Lin, Y., Qin, J., Bin, I., Cheng, H., and Edwards, R.L., 2004, A 6000-year high-resolution climatic record from a stalagmite in Xiangshui Cave Guilin, China: The Holocene, v. 14, p. 697-702.

Zielinski, R.A., 1980, Stability of glass in the geologic environment-Some evidence from studies of natural silicate glasses: Nuclear Technology, v. 51, no. 2, p. 197-200.

Zielinski, R.A., Peterman, Z.E., Stuckless, J.S., Rosholt, J.N., and Nkomo, I.T., 1981, The chemical and isotopic record of rock-water interactions in the Sherman Granite, Wyoming and Colorado: Contributions to Mineralogy and Petrology, v. 78, p. 209-219.

Zyvoloski, George, Dash, Z., and Kelkar, S., 1992, FEHMN 1.0, finite element heat and mass transfer code: LA12062-MS, Rev. 1, Los Alamos, New Mexico, Los Alamos National Laboratory, 113 p.

Zyvoloski, G.A., Robinson, B.A., Dash, Z.V., and Trease, L.L., 1997, User's manual for the FEHM application-A finite element heat and mass transfer code: Los Alamos National Laboratory, Los Alamos, New Mexico, LA13306-M, 146 p. 


\section{Appendix-Known Caves with Assigned Ages and the Methods of Age Determination}


Appendix table. Known caves with assigned ages and the methods of age determination.

[ $>$, greater than; <, less than; North American Land Mammal ages used are: Irvingtonian $=1.806 \pm 0.0005$ to $0.3 \mathrm{Ma}$, and Rancholabrean $=0.3$ to $0.01143 \pm 0.00013 \mathrm{Ma}$. Wisconsinan is 30 to $20 \mathrm{ka}$; Illinoian is 200 to $125 \mathrm{ka}$; Late Pleistocene is $500 \mathrm{ka}$ to 11,700 years ago; Pleisto-Holocene is 15,000 to 10,000 years ago, Holocene is 11,700 years to present. , approximately; Ma (mega-annum, million years ago; ka, thousand years ago; SAM, San Antonio Mountain; mtns, mountains; Co., county; n, number of samples; USGS, U.S. Geological Survey; \#, number]

\begin{tabular}{|c|c|c|c|c|}
\hline Name & Location & Age & Method & Reference \\
\hline Unnamed cave & Linwood, Iowa & $>360 \mathrm{Ma}$ & Pre-Pennsylvanian karst & Garvin (1995) \\
\hline Jenolan Caves & New South Wales, Australia & $342-335 \mathrm{Ma}$ & K-Ar authigenic clays & Osborne and others (2006) \\
\hline Unnamed cave & Guadalupe Mtns, N. Mex. & $90.7 \pm 2.8 \mathrm{Ma}$ & U-Pb calcite & Lundberg and others (2000) \\
\hline Grand Canyon Caverns & Grand Canyon, Ariz. & $16.96 \pm 0.83 \mathrm{Ma}$ & $\mathrm{U}-\mathrm{Pb}$ concordia & Polyak and others (2008) \\
\hline Cottonwood Cave & Guadalupe Mtns, N. Mex. & $12.26 \pm 0.16 \mathrm{Ma}$ & $\mathrm{Ar} / \mathrm{Ar}$ authigenic alunite & Polyak and others (1998) \\
\hline Virgin Cave & Guadalupe Mtns, N. Mex. & $11.30 \pm 0.17 \mathrm{Ma}$ & $\mathrm{Ar} / \mathrm{Ar}$ authigenic alunite & Polyak and others (1998) \\
\hline Grand Wash Cliffs Cave & Grand Canyon, Ariz. & $7.55 \pm 0.34 \mathrm{Ma}$ & $\mathrm{U}-\mathrm{Pb}$ concordia & Polyak and others (2008) \\
\hline Endless Cave & Guadalupe Mtns, N. Mex. & $6.02 \pm 0.05 \mathrm{Ma}$ & $\mathrm{Ar} / \mathrm{Ar}$ authigenic alunite & Polyak and others (1998) \\
\hline Lechuguilla Cave & Guadalupe Mtns, N. Mex. & $5.72 \pm 0.08 \mathrm{Ma}$ & $\mathrm{Ar} / \mathrm{Ar}$ authigenic alunite & Polyak and others (1998) \\
\hline Bone Cave & Cumberland Plateau, Tenn. & $5.68 \pm 1.09 \mathrm{Ma}$ & $\mathrm{Al} / \mathrm{Be}$ cave sediments & Anthony and Granger (2004) \\
\hline Carlsbad Caverns & Guadalupe Mtns, N. Mex. & $3.94 \pm 0.13 \mathrm{Ma}$ & $\mathrm{Ar} / \mathrm{Ar}$ authigenic alunite & Polyak and others (1998) \\
\hline Cave B & Grand Canyon, Ariz. & $3.87 \pm 0.10 \mathrm{Ma}$ & $\mathrm{U}-\mathrm{Pb}$ concordia & Polyak and others (2008) \\
\hline Shinumo Creek Cave & Grand Canyon, Ariz. & $3.72 \pm 0.80 \mathrm{Ma}$ & U-Pb concordia & Polyak and others (2008) \\
\hline Cumberland Caverns & Cumberland Plateau, Tenn. & $3.52 \pm 0.42 \mathrm{Ma}$ & $\mathrm{Al} / \mathrm{Be}$ cave sediments & Anthony and Granger (2004) \\
\hline Tsean Bida Cave & Grand Canyon, Ariz. & $3.43 \pm 0.43 \mathrm{Ma}$ & $\mathrm{U}-\mathrm{Pb}$ concordia & Polyak and others (2008) \\
\hline SAM cave (lava tube) & Northern New Mexico & $3.4-3.9 \mathrm{Ma}$ & K-Ar host basalt & Rogers and others (2000) \\
\hline Mammoth Cave (level B) & Mammoth Cave, Ky. & $3.36 \pm 0.42 \mathrm{Ma}$ & $\mathrm{Al} / \mathrm{Be}$ cave sediments & Granger and others (2001) \\
\hline Mammoth Cave (level B) & Mammoth Cave, Ky. & $3.20 \pm 0.29 \mathrm{Ma}$ & $\mathrm{Al} / \mathrm{Be}$ cave sediments & Granger and others (2001) \\
\hline Bat Cave & Sierra Nevada, Calif. & $2.70 \pm 0.21 \mathrm{Ma}$ & $\mathrm{Al} / \mathrm{Be}$ cave sediments & Stock and others (2004) \\
\hline Butte Fault Cave & Grand Canyon, Ariz. & $2.68 \pm 0.49 \mathrm{Ma}$ & $\mathrm{U}-\mathrm{Pb}$ concordia & Polyak and others (2008) \\
\hline Mammoth Cave (level B) & Mammoth Cave, Ky. & $2.65 \pm 0.28 \mathrm{Ma}$ & $\mathrm{Al} / \mathrm{Be}$ cave sediments & Granger and others (2001) \\
\hline Mammoth Cave (level B) & Mammoth Cave, Ky. & $2.62 \pm 0.27 \mathrm{Ma}$ & $\mathrm{Al} / \mathrm{Be}$ cave sediments & Granger and others (2001) \\
\hline Mammoth Cave (level B) & Mammoth Cave, Ky. & $2.50 \pm 0.13 \mathrm{Ma}$ & $\mathrm{Al} / \mathrm{Be}$ cave sediments & Granger and others (2001) \\
\hline Weiss Cave & Sierra Nevada, Calif. & $2.42 \pm 0.16 \mathrm{Ma}$ & $\mathrm{Al} / \mathrm{Be}$ cave sediments & Stock and others (2004) \\
\hline Mammoth Cave (level A) & Mammoth Cave, Ky. & $2.28 \pm 0.15 \mathrm{Ma}$ & $\mathrm{Al} / \mathrm{Be}$ cave sediments & Granger and others (2001) \\
\hline Mammoth Cave (level B) & Mammoth Cave, Ky. & $2.27 \pm 0.13 \mathrm{Ma}$ & $\mathrm{Al} / \mathrm{Be}$ cave sediments & Granger and others (2001) \\
\hline Mammoth Cave (level B) & Mammoth Cave, Ky. & $2.22 \pm 0.10 \mathrm{Ma}$ & $\mathrm{Al} / \mathrm{Be}$ cave sediments & Granger and others (2001) \\
\hline Gavain Abyss & Grand Canyon, Ariz. & $2.19 \pm 0.47 \mathrm{Ma}$ & $\mathrm{U}-\mathrm{Pb}$ concordia & Polyak and others (2008) \\
\hline Mammoth Cave (level B) & Mammoth Cave, Ky. & $2.19 \pm 0.11 \mathrm{Ma}$ & $\mathrm{Al} / \mathrm{Be}$ cave sediments & Granger and others (2001) \\
\hline Dry Canyon & Grand Canyon, Ariz. & $2.17 \pm 0.34 \mathrm{Ma}$ & $\mathrm{U}-\mathrm{Pb}$ concordia & Polyak and others (2008) \\
\hline Wolf River Cave & Cumberland Plateau, Ky. & $2.15 \pm 0.47 \mathrm{Ma}$ & $\mathrm{Al} / \mathrm{Be}$ cave sediments & Anthony and Granger (2004) \\
\hline Mammoth Cave (level B) & Mammoth Cave, Ky. & $2.00 \pm 0.11 \mathrm{Ma}$ & $\mathrm{Al} / \mathrm{Be}$ cave sediments & Granger and others (2001) \\
\hline Foxhole Cave & Cumberland Plateau, Tenn. & $1.97 \pm 0.10 \mathrm{Ma}$ & $\mathrm{Al} / \mathrm{Be}$ cave sediments & Anthony and Granger (2004) \\
\hline Mammoth Cave (level B) & Mammoth Cave, Ky. & $1.95 \pm 0.10 \mathrm{Ma}$ & $\mathrm{Al} / \mathrm{Be}$ cave sediments & Granger and others (2001) \\
\hline Mammoth Cave (level B) & Mammoth Cave, Ky. & $1.87 \pm 0.13 \mathrm{Ma}$ & $\mathrm{Al} / \mathrm{Be}$ cave sediments & Granger and others (2001) \\
\hline
\end{tabular}


[ $>$, greater than; <, less than; North American Land Mammal ages used are: Irvingtonian $=1.806 \pm 0.0005$ to $0.3 \mathrm{Ma}$, and Rancholabrean $=0.3$ to $0.01143 \pm 0.00013 \mathrm{Ma}$. Wisconsinan is 30 to $20 \mathrm{ka}$; Illinoian is 200 to $125 \mathrm{ka}$; Late Pleistocene is $500 \mathrm{ka}$ to 11,700 years ago; Pleisto-Holocene is 15,000 to 10,000 years ago, Holocene is 11,700 years to present. , approximately; Ma (mega-annum, million years ago; ka, thousand years ago; SAM, San Antonio Mountain; mtns, mountains; Co., county; n, number of samples; USGS, U.S. Geological Survey; \#, number]

\begin{tabular}{|c|c|c|c|c|}
\hline Name & Location & Age & Method & Reference \\
\hline Coleman 2a Cave & Sumter Co., Fla. & Irvingtonian & Fossil age & McDonald (2003) \\
\hline Cumberland Cave & Allegheny Co., Md. & Irvingtonian & Fossil age & McDonald (2003) \\
\hline Porcupine Cave & Park Co., Colo. & Irvingtonian & Fossil age & McDonald (2003) \\
\hline Port Kennedy Cave & Montgomery Co., Pa. & Irvingtonian & Fossil age & McDonald (2003) \\
\hline Scott Hollow Cave & Monroe Co., W. Va. & Irvingtonian & Fossil age & McDonald (2003) \\
\hline Zarathustra's Cave & Cumberland Plateau, Ky. & $1.80 \pm 0.31 \mathrm{Ma}$ & $\mathrm{Al} / \mathrm{Be}$ cave sediments & Anthony and Granger (2004) \\
\hline Mammoth Cave (level B) & Mammoth Cave, Ky. & $1.78 \pm 0.17 \mathrm{Ma}$ & $\mathrm{Al} / \mathrm{Be}$ cave sediments & Granger and others (2001) \\
\hline Mammoth Cave (level B) & Mammoth Cave, Ky. & $1.67 \pm 0.20 \mathrm{Ma}$ & $\mathrm{Al} / \mathrm{Be}$ cave sediments & Granger and others (2001) \\
\hline Blue Spring Cave & Cumberland Plateau, Tenn. & $1.66 \pm 0.23 \mathrm{Ma}$ & $\mathrm{Al} / \mathrm{Be}$ cave sediments & Anthony and Granger (2004) \\
\hline Xanadu Cave & Cumberland Plateau, Ky. & $1.64 \pm 0.46 \mathrm{Ma}$ & $\mathrm{Al} / \mathrm{Be}$ cave sediments & Anthony and Granger (2004) \\
\hline Crystal Stanislaus Cave & Sierra Nevada, Calif. & $1.63 \pm 0.08 \mathrm{Ma}$ & $\mathrm{Al} / \mathrm{Be}$ cave sediments & Stock and others (2004) \\
\hline Mother Cave & Grand Canyon, Ariz. & $1.6 \pm 0.5 \mathrm{Ma}$ & $\mathrm{U}-234$ & Polyak and others (2008) \\
\hline Mammoth Cave (level B) & Mammoth Cave, Ky. & $1.50 \pm 0.09 \mathrm{Ma}$ & $\mathrm{Al} / \mathrm{Be}$ cave sediments & Granger and others (2001) \\
\hline Mammoth Cave (level C) & Mammoth Cave, Ky. & $1.50 \pm 0.08 \mathrm{Ma}$ & $\mathrm{Al} / \mathrm{Be}$ cave sediments & Granger and others (2001) \\
\hline Eggleston Cave & Western Kentucky & $1.47 \pm 0.22 \mathrm{Ma}$ & $\mathrm{Al} / \mathrm{Be}$ cave sediments & Granger and others (1997) \\
\hline Mammoth Cave (level B) & Mammoth Cave, Ky. & $1.47 \pm 0.09 \mathrm{Ma}$ & $\mathrm{Al} / \mathrm{Be}$ cave sediments & Granger and others (2001) \\
\hline Mammoth Cave (level C) & Mammoth Cave, Ky. & $1.46 \pm 0.09 \mathrm{Ma}$ & $\mathrm{Al} / \mathrm{Be}$ cave sediments & Granger and others (2001) \\
\hline Buffalo Cave & Cumberland Plateau, Ky. & $1.45 \pm 0.42 \mathrm{Ma}$ & $\mathrm{Al} / \mathrm{Be}$ cave sediments & Anthony and Granger (2004) \\
\hline Boyden Cave & Sierra Nevada, Calif. & $1.40 \pm 0.08 \mathrm{Ma}$ & $\mathrm{Al} / \mathrm{Be}$ cave sediments & Stock and others (2004) \\
\hline Mammoth Cave (level D) & Mammoth Cave, Ky. & $1.38 \pm 0.10 \mathrm{Ma}$ & $\mathrm{Al} / \mathrm{Be}$ cave sediments & Granger and others (2001) \\
\hline Mammoth Cave (level C) & Mammoth Cave, Ky. & $1.34 \pm 0.15 \mathrm{Ma}$ & $\mathrm{Al} / \mathrm{Be}$ cave sediments & Granger and others (2001) \\
\hline Mammoth Cave (level D) & Mammoth Cave, Ky. & $1.34 \pm 0.09 \mathrm{Ma}$ & $\mathrm{Al} / \mathrm{Be}$ cave sediments & Granger and others (2001) \\
\hline Mammoth Cave (level D) & Mammoth Cave, Ky. & $1.28 \pm 0.10 \mathrm{Ma}$ & $\mathrm{Al} / \mathrm{Be}$ cave sediments & Granger and others (2001) \\
\hline Pearisburg Caves (Cliff 3) & Western Kentucky & $1.25 \pm 0.50 \mathrm{Ma}$ & $\mathrm{Al} / \mathrm{Be}$ cave sediments & Granger and others (1997) \\
\hline Soldiers Cave (upper level) & Sierra Nevada, Calif. & $1.25 \pm 0.13 \mathrm{Ma}$ & $\mathrm{Al} / \mathrm{Be}$ cave sediments & Stock and others (2004) \\
\hline Mammoth Cave (level C) & Mammoth Cave, Ky. & $1.23 \pm 0.09 \mathrm{Ma}$ & $\mathrm{Al} / \mathrm{Be}$ cave sediments & Granger and others (2001) \\
\hline Mammoth Cave (level C-D) & Mammoth Cave, Ky. & $1.21 \pm 0.12 \mathrm{Ma}$ & $\mathrm{Al} / \mathrm{Be}$ cave sediments & Granger and others (2001) \\
\hline Mammoth Cave (level C) & Mammoth Cave, Ky. & $1.21 \pm 0.09 \mathrm{Ma}$ & $\mathrm{Al} / \mathrm{Be}$ cave sediments & Granger and others (2001) \\
\hline Crystal (Bear Den) Cave & Sierra Nevada, Calif. & $1.17 \pm 0.09 \mathrm{Ma}$ & $\mathrm{Al} / \mathrm{Be}$ cave sediments & Stock and others (2004) \\
\hline Mammoth Cave (level C) & Mammoth Cave, Ky. & $1.13 \pm 0.09 \mathrm{Ma}$ & $\mathrm{Al} / \mathrm{Be}$ cave sediments & Granger and others (2001) \\
\hline Pearisburg Caves (Klotz Quarry) & Western Kentucky & $1.09 \pm 0.19 \mathrm{Ma}$ & $\mathrm{Al} / \mathrm{Be}$ cave sediments & Granger and others (1997) \\
\hline Clough Cave & Sierra Nevada, Calif. & $1.06 \pm 0.17 \mathrm{Ma}$ & $\mathrm{Al} / \mathrm{Be}$ cave sediments & Stock and others (2004) \\
\hline Crystal (Marble Hall) Cave & Sierra Nevada, Calif. & $1.05 \pm 0.08 \mathrm{Ma}$ & $\mathrm{Al} / \mathrm{Be}$ cave sediments & Stock and others (2004) \\
\hline Pearisburg Caves (Quartz & Western Kentucky & $1.02 \pm 0.19 \mathrm{Ma}$ & $\mathrm{Al} / \mathrm{Be}$ cave sediments & Granger and others (1997) \\
\hline
\end{tabular}


Appendix table. Known caves with assigned ages and the methods of age determination.-Continued

[ $>$, greater than; <, less than; North American Land Mammal ages used are: Irvingtonian $=1.806 \pm 0.0005$ to $0.3 \mathrm{Ma}$, and Rancholabrean $=0.3$ to $0.01143 \pm 0.00013 \mathrm{Ma}$. Wisconsinan is 30 to $20 \mathrm{ka}$; Illinoian is 200 to $125 \mathrm{ka}$; Late Pleistocene is $500 \mathrm{ka}$ to 11,700 years ago; Pleisto-Holocene is 15,000 to 10,000 years ago, Holocene is 11,700 years to present. , approximately; Ma (mega-annum, million years ago; ka, thousand years ago; SAM, San Antonio Mountain; mtns, mountains; Co., county; n, number of samples; USGS, U.S. Geological Survey; \#, number]

\begin{tabular}{|c|c|c|c|c|}
\hline Name & Location & Age & Method & Reference \\
\hline Jewel Cave & Black Hills, S. Dak. & $>1.0 \mathrm{Ma}$ & U-series spar sheet & Bakalowicz and others (1987) \\
\hline Great Saltpeter Cave & Cumberland Plateau, Ky. & $0.95 \pm 0.29 \mathrm{Ma}$ & $\mathrm{Al} / \mathrm{Be}$ cave sediments & Anthony and Granger (2004) \\
\hline Sloan's Valley Cave & Cumberland Plateau, Ky. & $0.89 \pm 0.31 \mathrm{Ma}$ & $\mathrm{Al} / \mathrm{Be}$ cave sediments & Anthony and Granger (2004) \\
\hline Skagnasty Cave & Cumberland Plateau, Tenn. & $0.89 \pm 0.21 \mathrm{Ma}$ & $\mathrm{Al} / \mathrm{Be}$ cave sediments & Anthony and Granger (2004) \\
\hline Zarathustra's Cave & Cumberland Plateau, Ky. & $0.86 \pm 0.17 \mathrm{Ma}$ & $\mathrm{Al} / \mathrm{Be}$ cave sediments & Anthony and Granger (2004) \\
\hline Xanadu Cave & Cumberland Plateau, Ky. & $0.85 \pm 0.37 \mathrm{Ma}$ & $\mathrm{Al} / \mathrm{Be}$ cave sediments & Anthony and Granger (2004) \\
\hline Fyllan Cave & Travis Co., Texas & $>0.83 \mathrm{Ma}$ & Paleomagnetics & Winkler and Gose (2003) \\
\hline Zarathustra's Cave & Cumberland Plateau, Ky. & $0.83 \pm 0.21 \mathrm{Ma}$ & $\mathrm{Al} / \mathrm{Be}$ cave sediments & Anthony and Granger (2004) \\
\hline Kitchen Door & Travis Co., Texas & $>0.83 \mathrm{Ma}$ & Paleomagnetics & Winkler and Gose (2003) \\
\hline New Cave & Sierra Nevada, Calif. & $0.83 \pm 0.10 \mathrm{Ma}$ & $\mathrm{Al} / \mathrm{Be}$ cave sediments & Stock and others (2004) \\
\hline Bedrock Cave & Grand Canyon, Ariz. & $0.83 \pm 0.05 \mathrm{Ma}$ & $\mathrm{U}-\mathrm{Pb}$ concordia & Polyak and others (2008) \\
\hline Mammoth Cave (level D) & Mammoth Cave, Ky. & $0.80 \pm 0.09 \mathrm{Ma}$ & $\mathrm{Al} / \mathrm{Be}$ cave sediments & Granger and others (2001) \\
\hline Mammoth Cave (level D) & Mammoth Cave, Ky. & $0.70 \pm 0.08 \mathrm{Ma}$ & $\mathrm{Al} / \mathrm{Be}$ cave sediments & Granger and others (2001) \\
\hline Crystal (Junction Room) Cave & Sierra Nevada, Calif. & $0.56 \pm 0.08 \mathrm{Ma}$ & $\mathrm{Al} / \mathrm{Be}$ cave sediments & Stock and others (2004) \\
\hline Soldiers Cave (lower level) & Sierra Nevada, Calif. & $0.40 \pm 0.17 \mathrm{Ma}$ & $\mathrm{Al} / \mathrm{Be}$ cave sediments & Stock and others (2004) \\
\hline Autolite Cave & Perry Co., Mo. & Rancholabrean & Fossil age & McDonald (2003) \\
\hline Axtun Spukil Cave & Yucatan, Mexico & Rancholabrean & Fossil age & McDonald (2003) \\
\hline Baker Bluff Cave & Sullivan Co., Tenn. & Rancholabrean & Fossil age & Graham (2003) \\
\hline Bell Cave & Colbert Co., Ala. & Rancholabrean & Fossil age & McDonald (2003) \\
\hline Big Bone Cave & Van Buren Co., Tenn. & Rancholabrean & Fossil age & McDonald (2003) \\
\hline Bowden Cave System & Randolph Co., W. Va. & Rancholabrean & Fossil age & Graham (2003) \\
\hline Brynjulfson Cave & Boone Co., Mo. & Rancholabrean & Fossil age & McDonald (2003) \\
\hline Buckeye Creek Cave & Greenbriar Co., W.Va. & Rancholabrean & Fossil age & Graham (2003) \\
\hline Claiborne Cave & Campbell Co., Tenn. & Rancholabrean & Fossil age & Graham (2003) \\
\hline Coconino Caverns & Coconino Co., Ariz. & Rancholabrean & Fossil age & McDonald (2003) \\
\hline Conkling Cave & Dona Ana Co., N. Mex. & Rancholabrean & Fossil age & McDonald (2003) \\
\hline Crankshaft Cavern & Jefferson Co., Mo. & Rancholabrean & Fossil age & McDonald (2003) \\
\hline Cromer Cave & Greenbriar Co., W. Va. & Rancholabrean & Fossil age & McDonald (2003) \\
\hline Devil's Den & Levy Co., Fla. & Rancholabrean & Fossil age & McDonald (2003) \\
\hline Eichelberger Cave & Marion Co., Fla. & Rancholabrean & Fossil age & Graham (2003) \\
\hline Frankstown Cave & Blair Co., Pa. & Rancholabrean & Fossil age & McDonald (2003) \\
\hline Freeman Cox Cave & Sullivan Co., Tenn. & Rancholabrean & Fossil age & Graham (2003) \\
\hline Gebhard's Cave & Schoharie Co., N.Y. & Rancholabrean & Fossil age & Graham (2003) \\
\hline Gillanwater Cave & Barren Co., Ky. & Rancholabrean & Fossil age & McDonald (2003) \\
\hline Glass Cave & Franklin Co., Ky. & Rancholabrean & Fossil age & McDonald (2003) \\
\hline
\end{tabular}


[ $>$, greater than; <, less than; North American Land Mammal ages used are: Irvingtonian $=1.806 \pm 0.0005$ to $0.3 \mathrm{Ma}$, and Rancholabrean $=0.3$ to $0.01143 \pm 0.00013 \mathrm{Ma}$. Wisconsinan is 30 to $20 \mathrm{ka}$; Illinoian is 200 to $125 \mathrm{ka}$; Late Pleistocene is $500 \mathrm{ka}$ to 11,700 years ago; Pleisto-Holocene is 15,000 to 10,000 years ago, Holocene is 11,700 years to present. , approximately; Ma (mega-annum, million years ago; ka, thousand years ago; SAM, San Antonio Mountain; mtns, mountains; Co., county; n, number of samples; USGS, U.S. Geological Survey; \#, number]

\begin{tabular}{|c|c|c|c|c|}
\hline Name & Location & Age & Method & Reference \\
\hline Guy Wilson Cave & Sullivan Co., Tenn. & Rancholabrean & Fossil age & Graham (2003) \\
\hline Hawver Cave & El Dorado Co., Calif. & Rancholabrean & Fossil age & McDonald (2003) \\
\hline Hill Cave & Anderson Co., Tenn. & Rancholabrean & Fossil age & Graham (2003) \\
\hline Jaguar Cave & Fentress Co., Tenn. & Rancholabrean & Fossil age & Graham (2003) \\
\hline Lane Cave & Scott Co., Va. & Rancholabrean & Fossil age & McDonald (2003) \\
\hline Laubach Cave \#3 & Williamson Co., Texas & Rancholabrean & Fossil age & McDonald (2003) \\
\hline Lecanto 1 Cave & Citrus Co., Fla. & Rancholabrean & Fossil age & McDonald (2003) \\
\hline Little Bear Cave \#2 & Colbert Co., Ala. & Rancholabrean & Fossil age & McDonald (2003) \\
\hline Little Salt River Cave & Franklin Co., Tenn. & Rancholabrean & Fossil age & McDonald (2003) \\
\hline Lookout Mountain Caverns & Hamilton Co., Tenn. & Rancholabrean & Fossil age & McDonald (2003) \\
\hline Mefford Cave 1 & Marion Co., Fla. & Rancholabrean & Fossil age & McDonald (2003) \\
\hline Mercers Cave & Calaveras Co., Calif. & Rancholabrean & Fossil age & McDonald (2003) \\
\hline New Trout Cave & Pendleton Co., W. Va. & Rancholabrean & Fossil age & McDonald (2003) \\
\hline Potter Creek Cave & Shasta Co., Calif. & Rancholabrean & Fossil age & McDonald (2003) \\
\hline Reddick 1 Cave & Marion Co., Fla. & Rancholabrean & Fossil age & McDonald (2003) \\
\hline Robinson Cave & Overton Co., Tenn. & Rancholabrean & Fossil age & McDonald (2003) \\
\hline Sabertooth Cave & Citrus Co., Fla. & Rancholabrean & Fossil age & McDonald (2003) \\
\hline San Josecito Cave & Nuevo Leon, Mexico & Rancholabrean & Fossil age & McDonald (2003) \\
\hline Stamwell Cave & Shasta Co., Calif. & Rancholabrean & Fossil age & McDonald (2003) \\
\hline Stone Gulch Cave & Shasta Co., Calif. & Rancholabrean & Fossil age & Graham (2003) \\
\hline Tuscumbia Cave & Colbert Co., Ala. & Rancholabrean & Fossil age & McDonald (2003) \\
\hline West Cave & Pulaski Co., Mo. & Rancholabrean & Fossil age & McDonald (2003) \\
\hline Will Farley's Cave & Washington Co., Va. & Rancholabrean & Fossil age & Graham (2003) \\
\hline Worm Hole Cave & Pendleton Co., W. Va. & Rancholabrean & Fossil age & Graham (2003) \\
\hline Pearisburg Caves (Cliff 1) & Western Kentucky & $0.29 \pm 0.18 \mathrm{Ma}$ & $\mathrm{Al} / \mathrm{Be}$ cave sediments & Granger and others (1997) \\
\hline River Bluff Cave & Missouri & $0.097 \pm 0.05 \mathrm{Ma}$ & $\mathrm{Al} / \mathrm{Be}$ cave sediments & $\begin{array}{l}\text { C.W. Rovey, Missouri State } \\
\text { University, written commun. } \\
\text { (2007) }\end{array}$ \\
\hline Horsethief Cave & Northern Wyoming & $639 \pm 2 \mathrm{ka}$ & $\begin{array}{l}\text { Lava Creek B ash age in cave } \\
\text { based on tephrachronology }\end{array}$ & Stock and others (2006) \\
\hline Jewel Cave & Black Hills, S. Dak. & $>350 \mathrm{ka}$ & U-series speleothem & Ford (1989) \\
\hline Sarisoara Cave $(\mathrm{n}=3)$ & Romania & $>350 \mathrm{ka}$ & U-series flowstone & Onac (2000) \\
\hline Schoharic Cave $(n=6)$ & Helderberg Plateau, N. Y. & $>350 \mathrm{ka}$ & U-series speleothem & Lauritzen and Mylroie (2000) \\
\hline Wind Cave & Black Hills, S. Dak. & $>350 \mathrm{ka}$ & U-series, flowstone & Miller (1989) \\
\hline Lost Cave & Idaho National Laboratory & $350 \pm 40 \mathrm{ka}$ & $\mathrm{K}$-Ar overlying lava & Kuntz and others (1994) \\
\hline
\end{tabular}


Appendix table. Known caves with assigned ages and the methods of age determination.-Continued

[ $>$, greater than; <, less than; North American Land Mammal ages used are: Irvingtonian $=1.806 \pm 0.0005$ to $0.3 \mathrm{Ma}$, and Rancholabrean $=0.3$ to $0.01143 \pm 0.00013 \mathrm{Ma}$. Wisconsinan is 30 to $20 \mathrm{ka}$; Illinoian is 200 to $125 \mathrm{ka}$; Late Pleistocene is $500 \mathrm{ka}$ to 11,700 years ago; Pleisto-Holocene is 15,000 to 10,000 years ago, Holocene is 11,700 years to present. , approximately; Ma (mega-annum, million years ago; ka, thousand years ago; SAM, San Antonio Mountain; mtns, mountains; Co., county; n, number of samples; USGS, U.S. Geological Survey; \#, number]

\begin{tabular}{|c|c|c|c|c|}
\hline Name & Location & Age & Method & Reference \\
\hline Middle Butte Cave & Idaho National Laboratory & $350 \pm 40 \mathrm{ka}$ & K-Ar overlying lava & Kuntz and others (1994) \\
\hline Moonshiner Cave & Idaho National Laboratory & $350 \pm 40 \mathrm{ka}$ & K-Ar overlying lava & Kuntz and others (1994) \\
\hline North Tower Cave & Idaho National Laboratory & $350 \pm 40 \mathrm{ka}$ & K-Ar overlying lava & Kuntz and others (1994) \\
\hline Rattlesnake Caves & Idaho National Laboratory & $350 \pm 40 \mathrm{ka}$ & K-Ar overlying lava & Kuntz and others (1994) \\
\hline Spence Cave & Northern Wyoming & $310 \pm 200 \mathrm{ka}$ & $\mathrm{Al} / \mathrm{Be}$ cave sediments & Stock and others (2006) \\
\hline Cattleguard Cave & Alta, B.C., Canada & $277.8 \pm 23.9 \mathrm{ka}$ & U-series speleothem & Gascoyne and Schwarcz (1982) \\
\hline New Cave $(n=4)$ & Southern Jamaica & $202 \pm 16 \mathrm{ka}$ & U-series flowstone & McFarlane and others (2002) \\
\hline Wadi Sannur Cavern $(n=17)$ & Eastern Egypt & $<200 \mathrm{ka}$ & U-series stalagmite & Dabous and Osmond (2000) \\
\hline Frasassi Caves & Central Italy & As much as $200 \mathrm{ka}$ & U-series speleothem & Galdenzi and Maruoka (2003) \\
\hline Kartchner Caverns & Southern Arizona & $194 \pm 50 \mathrm{ka}$ & U-series stalactite & Ford and Hill (1999) \\
\hline Undara Lava Tube & North Queensland, Australia & $191 \pm 30 \mathrm{ka}$ & $\mathrm{K}-\mathrm{Ar}$ & Griffin and McDougal (1975) \\
\hline Kartchner Caverns & Southern Arizona & $176 \pm 62 \mathrm{ka}$ & U-series flowstone & Ford and Hill (1999) \\
\hline Winnat's Head Cave & Derbyshire, England & $175.5 \pm 7.3 \mathrm{ka}$ & U-series speleothem & Gascoyne and Schwarcz (1982) \\
\hline Kartchner Caverns & Southern Arizona & $166 \pm 38 \mathrm{ka}$ & U-series stalactite & Ford and Hill (1999) \\
\hline Mystery Cave (n=1) & Southeastern Minnesota & $161 \pm 14 \mathrm{ka}$ & U-series speleothem & Milske and others (1983) \\
\hline Kartchner Caverns & Southern Arizona & $129 \pm 25 \mathrm{ka}$ & U-series stalactite & Ford and Hill (1999) \\
\hline Bahama Blue Hole & San Salvador Island, Bahamas & $128.8 \pm 11.6 \mathrm{ka}$ & U-series speleothem & Gascoyne and Schwarcz (1982) \\
\hline Junction Cave & Malpais, N. Mex. & $115-120 \mathrm{ka}$ & Paleomagnetics & Cascadden and others (1997) \\
\hline Neptune's Grotto $(n=7)$ & Oregon Caves National Monument, Ore. & $122-360 \mathrm{ka}$ & U-series flowstone & Turgeon and Lundberg (2001) \\
\hline Sarisoara Cave $(\mathrm{n}=4)$ & Romania & $96.4-126 \mathrm{ka}$ & U-series speleothem & Onac (2000) \\
\hline Lost John's Cave (n=3) & England & $92-112 \mathrm{ka}$ & U-series speleothem & Gascoyne and Schwarcz (1982) \\
\hline Gorham's Cave & Gibraltar, Spain & $80-100 \mathrm{ka}$ & U-series & Barton and others (1999) \\
\hline Barrack Zouric Cave $(n=5)$ & Helderberg Plateau, N. Y. & $60.7-161.7 \mathrm{ka}$ & U-series speleothem & Lauritzen and Mylroie (2000) \\
\hline Caboose Cave $(\mathrm{n}=13)$ & Helderberg Plateau, N. Y. & $56.4-209.9 \mathrm{ka}$ & U-series speleothem & Lauritzen and Mylroie (2000) \\
\hline Lithphagus Cave ( $\mathrm{n}=11)$ & Northwestern Romania & $55-132 \mathrm{ka}$ & U-series stalagmite & Lauritzen and Onac (1999) \\
\hline Peak Cavern & Derbyshire, England & $51.2 \pm 1.6 \mathrm{ka}$ & U-series speleothem & Gascoyne and Schwarcz (1982) \\
\hline Vindija Cave & Croatia & $51.0 \pm 8 \mathrm{ka}$ & U-series bone & Smith and others (1999) \\
\hline Nurnoor Cave & Southern India & $>50 \mathrm{ka}$ & ${ }^{14} \mathrm{C}$ charcoal & Prasad (1996) \\
\hline Ibex Cave & Gibraltar, Spain & $\sim 49 \mathrm{ka}$ & ${ }^{14} \mathrm{C}$ charcoal & Barton and others (1999) \\
\hline On Your Knees Cave & Prince of Wales Island, Alaska & $>44.94-1.99 \mathrm{ka}$ & ${ }^{14} \mathrm{C}$ bone collagen & Heaton and Grady (2003) \\
\hline Devil's Canopy Cave & Prince of Wales Island, Alaska & $>44.5 \mathrm{ka}$ & ${ }^{14} \mathrm{C}$ bone collagen & Heaton and Grady (2003) \\
\hline Bacho Kiro Cave & Bulgaria & $>43 \mathrm{ka}$ & ${ }^{14} \mathrm{C}$ bone collagen & Smith and others (1999) \\
\hline Vanguard Cave $(\mathrm{n}=6)$ & Gibraltar, Spain & $41.1-54.0 \mathrm{ka}$ & ${ }^{14} \mathrm{C}$ charcoal & Barton and others (1999) \\
\hline CC:5:3 Cave & Grand Canyon, Ariz. & $39.2 \pm 1.6 \mathrm{ka}$ & ${ }^{14} \mathrm{C}$ packrat midden & Mead and others (2003) \\
\hline CC:5:2 Cave $(n=3)$ & Grand Canyon, Ariz. & $39.1-42.9 \mathrm{ka}$ & ${ }^{14} \mathrm{C}$ packrat midden & Mead and others (2003) \\
\hline
\end{tabular}


[ $>$, greater than; <, less than; North American Land Mammal ages used are: Irvingtonian $=1.806 \pm 0.0005$ to $0.3 \mathrm{Ma}$, and Rancholabrean $=0.3$ to $0.01143 \pm 0.00013 \mathrm{Ma}$. Wisconsinan is 30 to $20 \mathrm{ka}$; Illinoian is 200 to $125 \mathrm{ka}$; Late Pleistocene is $500 \mathrm{ka}$ to 11,700 years ago; Pleisto-Holocene is 15,000 to 10,000 years ago, Holocene is 11,700 years to present. , approximately; Ma (mega-annum, million years ago; ka, thousand years ago; SAM, San Antonio Mountain; mtns, mountains; Co., county; n, number of samples; USGS, U.S. Geological Survey; \#, number]

\begin{tabular}{|c|c|c|c|c|}
\hline Name & Location & Age & Method & Reference \\
\hline Lancaster-Easegill Cave $(\mathrm{n}=4)$ & England & $38-225 \mathrm{ka}$ & U-series speleothem & Gascoyne and Schwarcz (1982) \\
\hline Mystery Cave $(n=18)$ & Southeastern Minnesota & $36-158 \mathrm{ka}$ & U-series speleothem & Milske and others (1983) \\
\hline 500 lava tubes & Lava Beds National Monument, Ore. & $36 \pm 16 \mathrm{ka}$ & $\operatorname{Ar} / \operatorname{Ar}$ (total fusion) & $\begin{array}{l}\text { Donnelly-Nolan and Lanphere } \\
\text { (2005) }\end{array}$ \\
\hline Crevice Cave $(n=6)$ & Southeastern Missouri & $35.7-68.1 \mathrm{ka}$ & U-series stalagmite & Dorale and others (1998) \\
\hline Hollyhock Hollow Cave $(n=7)$ & Helderberg Plateau, N. Y. & $34.7-67.3 \mathrm{ka}$ & U-series speleothem & Lauritzen and Mylroie (2000) \\
\hline Velika Pecina Cave & Croatia & $33.85 \pm 0.52 \mathrm{ka}$ & ${ }^{14} \mathrm{C}$ "nonhuman material" & Smith and others (1999) \\
\hline Chauvet Cave & Ardeche, France & $32.41 \pm 0.72 \mathrm{ka}$ & ${ }^{14} \mathrm{C}$ charcoal & Chauvet and others (1996) \\
\hline Chauvet Cave & Ardeche, France & $30.94 \pm 0.57 \mathrm{ka}$ & ${ }^{14} \mathrm{C}$ charcoal & Chauvet and others (1996) \\
\hline Kent's Cavern & Devonshire, England & $30.9 \pm 0.6 \mathrm{ka}$ & ${ }^{14} \mathrm{C}$ bone collagen & Smith and others (1999) \\
\hline CC:5:6 Cave $(\mathrm{n}=2)$ & Grand Canyon, Ariz. & $>29.9$ and $>33.1 \mathrm{ka}$ & ${ }^{14} \mathrm{C}$ packrat midden & Mead and others (2003) \\
\hline Screaming Neotoma Cave & Apache Co., Ariz. & $29.65 \pm 0.25 \mathrm{ka}$ & ${ }^{14} \mathrm{C}$ bone collagen & Bell and Glennon (2003) \\
\hline Crevice Cave $(n=10)$ & Southeastern Missouri & $28.9-64.7 \mathrm{ka}$ & U-series stalagmite & Dorale and others (1998) \\
\hline Gruta de Loltun & Southeastern Yucatan, Mexico & $28.4 \mathrm{ka}$ & Volcanic ash correlation & $\begin{array}{l}\text { Arroyo-Cabrales and Polaco } \\
\text { (2003) }\end{array}$ \\
\hline Cosquer Cave & Bouch-de-Rhone, France & $27.11 \pm 0.39 \mathrm{ka}$ & ${ }^{14} \mathrm{C}$ charcoal & Chauvet and others (1996) \\
\hline Crevice Cave $(n=11)$ & Southeastern Missouri & $26.9-65.6 \mathrm{ka}$ & U-series stalagmite & Dorale and others (1998) \\
\hline Gorham's Cave $(\mathrm{n}=8)$ & Gibraltar, Spain & $25.6-51.7 \mathrm{ka}$ & ${ }^{14} \mathrm{C}$ charcoal & Barton and others (1999) \\
\hline Cougnac Cave & Lot, France & $25.12 \pm 0.39 \mathrm{ka}$ & ${ }^{14} \mathrm{C}$ charcoal & Chauvet and others (1996) \\
\hline Pech-Merle Cave & Lot, France & $24.64 \pm 0.39 \mathrm{ka}$ & ${ }^{14} \mathrm{C}$ charcoal & Chauvet and others (1996) \\
\hline Cougnac Cave & Lot, France & $23.61 \pm 0.35 \mathrm{ka}$ & ${ }^{14} \mathrm{C}$ charcoal & Chauvet and others (1996) \\
\hline Laubach III Cave & Williamson Co., Texas & $23.25 \mathrm{ka}$ & ${ }^{14} \mathrm{C}$ & Lundelius (2003) \\
\hline Patton Cave & Monroe Co., W. Va. & $22.26 \pm 0.24 \mathrm{ka}$ & ${ }^{14} \mathrm{C}$ bone collagen & Grady (1988) \\
\hline Crevice Cave $(\mathrm{n}=11)$ & Southeastern Missouri & $21.9-74.1 \mathrm{ka}$ & U-series stalagmite & Dorale and others (1998) \\
\hline Duhme Cave & Jackson Co., Iowa & $21.8 \pm 0.24 \mathrm{ka}$ & ${ }^{14} \mathrm{C}$ bone collagen & Jans-Langel and Semken (2003) \\
\hline Tubo Volcánico Corona & Lanzarote, Canary Islands & $21 \pm 6.5 \mathrm{ka}$ & $\mathrm{Ar} / \mathrm{Ar}$ & $\begin{array}{l}\text { Carracedo, Singer, and others } \\
\text { (2003) }\end{array}$ \\
\hline Algerita Bloom Cave & Eddy Co., N. Mex. & Wisconsinan & Fossil age & McDonald (2003) \\
\hline Bustamente Cave & Nuevo Leon, Mexico & Wisconsinan & Fossil age & McDonald (2003) \\
\hline Cowboy Cave & Wayne Co., Utah & Wisconsinan & Fossil age & McDonald (2003) \\
\hline Deadman Cave & Pima Co., Ariz. & Wisconsinan & Fossil age & McDonald (2003) \\
\hline Dry Cave & Eddy Co., N. Mex. & Wisconsinan & Fossil age & McDonald (2003) \\
\hline Dust Cave & Culbertson Co., Texas & Wisconsinan & Fossil age & McDonald (2003) \\
\hline Gypsum Cave & Clark Co., Nev. & Wisconsinan & Fossil age & McDonald (2003) \\
\hline La Presita Cave & San Luis Potosi, Mexico & Wisconsinan & Fossil age & McDonald (2003) \\
\hline
\end{tabular}


Appendix table. Known caves with assigned ages and the methods of age determination.-Continued

[ $>$, greater than; <, less than; North American Land Mammal ages used are: Irvingtonian $=1.806 \pm 0.0005$ to $0.3 \mathrm{Ma}$, and Rancholabrean $=0.3$ to $0.01143 \pm 0.00013 \mathrm{Ma}$. Wisconsinan is 30 to $20 \mathrm{ka}$; Illinoian is 200 to $125 \mathrm{ka}$; Late Pleistocene is $500 \mathrm{ka}$ to 11,700 years ago; Pleisto-Holocene is 15,000 to 10,000 years ago, Holocene is 11,700 years to present. , approximately; Ma (mega-annum, million years ago; ka, thousand years ago; SAM, San Antonio Mountain; mtns, mountains; Co., county; n, number of samples; USGS, U.S. Geological Survey; \#, number]

\begin{tabular}{|c|c|c|c|c|}
\hline Name & Location & Age & Method & Reference \\
\hline Lower Sloth Cave & Culbertson Co., Texas & Wisconsinan & Fossil age & McDonald (2003) \\
\hline Ludlow Cave & San Bernardino Co., Calif. & Wisconsinan & Fossil age & McDonald (2003) \\
\hline Mitchell Caverns & San Bernardino Co., Calif. & Wisconsinan & Fossil age & McDonald (2003) \\
\hline Muav Cave & Mohave Co., Ariz. & Wisconsinan & Fossil age & McDonald (2003) \\
\hline Newbury Cave & San Bernardino Co., Calif. & Wisconsinan & Fossil age & McDonald (2003) \\
\hline Pyeatt Cave & Cochise Co., Ariz. & Wisconsinan & Fossil age & McDonald (2003) \\
\hline Rampart Cave & Mohave Co., Ariz. & Wisconsinan & Fossil age & McDonald (2003) \\
\hline Shelter Cave & Dona Ana Co., N. Mex. & Wisconsinan & Fossil age & McDonald (2003) \\
\hline U-Bar Cave & Hidalgo Co., N. Mex. & Wisconsinan & Fossil age & McDonald (2003) \\
\hline Upper Sloth Cave & Culbertson Co., Texas & Wisconsinan & Fossil age & McDonald (2003) \\
\hline Ventana Cave & Pima Co., Ariz. & Wisconsinan & Fossil age & McDonald (2003) \\
\hline Williams Cave & Culbertson Co., Texas & Wisconsinan & Fossil age & McDonald (2003) \\
\hline Cosquer Cave & Bouch-de-Rhone, France & $19.50 \pm 0.27 \mathrm{ka}$ & ${ }^{14} \mathrm{C}$ charcoal & Chauvet and others (1996) \\
\hline Cougnac Cave & Lot, France & $19.50 \pm 0.27 \mathrm{ka}$ & ${ }^{14} \mathrm{C}$ charcoal & Chauvet and others (1996) \\
\hline Cosquer Cave & Bouch-de-Rhone, France & $18.84 \pm 0.24 \mathrm{ka}$ & ${ }^{14} \mathrm{C}$ charcoal & Chauvet and others (1996) \\
\hline Cosquer Cave & Bouch-de-Rhone, France & $18.53 \pm 0.18 \mathrm{ka}$ & ${ }^{14} \mathrm{C}$ charcoal & Chauvet and others (1996) \\
\hline Cueva del Viento & Tenerife, Canary Islands & $17.57 \pm 0.15 \mathrm{ka}$ & ${ }^{14} \mathrm{C}$ carbonized root & $\begin{array}{l}\text { Carracedo, Paterne, and others } \\
\text { (2003) }\end{array}$ \\
\hline Bogus Cave & Jones Co., Iowa & $17.26 \pm 0.12 \mathrm{ka}$ & ${ }^{14} \mathrm{C}$ tooth & Josephs (2002) \\
\hline Lloyd's Cave & Southern Jamaica & $16.4 \pm 0.11 \mathrm{ka}$ & ${ }^{14} \mathrm{C}$ guano & McFarlane and others (2002) \\
\hline Laubach I Cave & Williamson Co., Texas & $15.85 \mathrm{ka}$ & ${ }^{14} \mathrm{C}$ & Lundelius (2003) \\
\hline Gimnyeongsa lava tube & Jeju, South Korea & $15.25 \pm 0.25 \mathrm{ka}$ & ${ }^{14} \mathrm{C}$ organic-rich soil & $\begin{array}{l}\text { M.A. Clynne, USGS, written } \\
\text { commun. (2007) }\end{array}$ \\
\hline Kimnyonga lava tube & Jeju, South Korea & $15.25 \pm 0.25 \mathrm{ka}$ & ${ }^{14} \mathrm{C}$ organic-rich soil & $\begin{array}{l}\text { M.A. Clynne, USGS, written } \\
\text { commun. (2007) }\end{array}$ \\
\hline Hall's Cave & Kerr Co., Texas & $15.0 \mathrm{ka}$ & ${ }^{14} \mathrm{C}$ & Lundelius (2003) \\
\hline Altamira Cave & Santander, Spain & $14.33 \pm 0.19 \mathrm{ka}$ & ${ }^{14} \mathrm{C}$ charcoal & Chauvet and others (1996) \\
\hline Cougnac Cave & Lot, France & $14.29 \pm 0.18 \mathrm{ka}$ & ${ }^{14} \mathrm{C}$ charcoal & Chauvet and others (1996) \\
\hline La Covaciella Cave & Asturias, Spain & $14.26 \pm 0.14 \mathrm{ka}$ & ${ }^{14} \mathrm{C}$ charcoal & Chauvet and others (1996) \\
\hline CC:5:5 Cave $(\mathrm{n}=8)$ & Grand Canyon, Ariz. & $14.0-46.4 \mathrm{ka}$ & ${ }^{14} \mathrm{C}$ packrat midden & Mead and others (2003) \\
\hline Cheek Bend Cave & Maury Co., Tenn. & $14.0-14.5 \mathrm{ka}$ & ${ }^{14} \mathrm{C}$ bone collagen & Graham (2003) \\
\hline Laubach II Cave & Williamson Co., Texas & $13.97 \mathrm{ka}$ & ${ }^{14} \mathrm{C}$ & Lundelius (2003) \\
\hline La Covaciella Cave & Asturias, Spain & $13.94 \pm 0.17 \mathrm{ka}$ & ${ }^{14} \mathrm{C}$ charcoal & Chauvet and others (1996) \\
\hline Altamira Cave & Santander, Spain & $13.94 \pm 0.15 \mathrm{ka}$ & ${ }^{14} \mathrm{C}$ charcoal & Chauvet and others (1996) \\
\hline Niaux Cave & Ariege, France & $13.85 \pm 0.15 \mathrm{ka}$ & ${ }^{14} \mathrm{C}$ charcoal & Chauvet and others (1996) \\
\hline
\end{tabular}


[>, greater than; <, less than; North American Land Mammal ages used are: Irvingtonian $=1.806 \pm 0.0005$ to $0.3 \mathrm{Ma}$, and Rancholabrean $=0.3$ to $0.01143 \pm 0.00013 \mathrm{Ma}$. Wisconsinan is 30 to $20 \mathrm{ka}$; Illinoian is 200 to $125 \mathrm{ka}$; Late Pleistocene is $500 \mathrm{ka}$ to 11,700 years ago; Pleisto-Holocene is 15,000 to 10,000 years ago, Holocene is 11,700 years to present. , approximately; Ma (mega-annum, million years ago; ka, thousand years ago; SAM, San Antonio Mountain; mtns, mountains; Co., county; n, number of samples; USGS, U.S. Geological Survey; \#, number]

\begin{tabular}{|c|c|c|c|c|}
\hline Name & Location & Age & Method & Reference \\
\hline Cougnac Cave & Lot, France & $13.81 \pm 0.21 \mathrm{ka}$ & ${ }^{14} \mathrm{C}$ charcoal & Chauvet and others (1996) \\
\hline Altamira Cave & Santander, Spain & $13.57 \pm 0.19 \mathrm{ka}$ & ${ }^{14} \mathrm{C}$ charcoal & Chauvet and others (1996) \\
\hline Boney Spring Cave & Missouri & $13.5-16.6 \mathrm{ka}$ & ${ }^{14} \mathrm{C}$ bone collagen & Graham (2003) \\
\hline Patton Cave & Monroe Co., W. Va. & $13.35 \pm 0.12 \mathrm{ka}$ & ${ }^{14} \mathrm{C}$ bone collagen & Grady (1988) \\
\hline Drum Cave & Southern Jamaica & $13.22 \pm 0.15 \mathrm{ka}$ & ${ }^{14} \mathrm{C}$ gastropod & McFarlane and others (2002) \\
\hline El Castillo Cave & Santander, Spain & $13.1 \pm 0.20 \mathrm{ka}$ & ${ }^{14} \mathrm{C}$ charcoal & Chauvet and others (1996) \\
\hline Niaux Cave & Ariege, France & $13.06 \pm 0.20 \mathrm{ka}$ & ${ }^{14} \mathrm{C}$ charcoal & Chauvet and others (1996) \\
\hline El Castillo Cave & Santander, Spain & $12.9 \pm 0.18 \mathrm{ka}$ & ${ }^{14} \mathrm{C}$ charcoal & Chauvet and others (1996) \\
\hline Niaux Cave & Ariege, France & $12.89 \pm 0.16 \mathrm{ka}$ & ${ }^{14} \mathrm{C}$ charcoal & Chauvet and others (1996) \\
\hline Warm Mineral Spring & Florida & 12.6 and $14.4 \mathrm{ka}$ & U-series speleothem & Gascoyne and Schwarcz (1982) \\
\hline Guitarrero Cave & Peru & $12.56 \pm 0.36 \mathrm{ka}$ & ${ }^{14} \mathrm{C}$ charcoal & Lynch and others (1985) \\
\hline CC:5:4 Cave & Grand Canyon, Ariz. & $12.4 \pm 0.7 \mathrm{ka}$ & ${ }^{14} \mathrm{C}$ packrat midden & Mead and others (2003) \\
\hline El Capitan Cave & Prince of Wales Island, Alaska & $12.295-5.77 \mathrm{ka}$ & ${ }^{14} \mathrm{C}$ bone collagen & Heaton and Grady (2003) \\
\hline Le Portel Cave & Ariege, France & $12.18 \pm 0.13 \mathrm{ka}$ & ${ }^{14} \mathrm{C}$ charcoal & Chauvet and others (1996) \\
\hline Exit Tunnel Cave $(\mathrm{n}=5)$ & Oregon Caves National Monument, Ore. & $12.0-119.3 \mathrm{ka}$ & U-series flowstone & Turgeon and Lundberg (2001) \\
\hline Peccary Cave & Northwestern Arkansas & $12-17 \mathrm{ka}$ & ${ }^{14} \mathrm{C}$ bone collagen & Graham (2003) \\
\hline Cueva Quebrada & Val Verde Co., Texas & $12.0-14.0 \mathrm{ka}$ & ${ }^{14} \mathrm{C}$ & Lundelius (2003) \\
\hline Drum Cave & Southern Jamaica & $11.98 \pm 0.08 \mathrm{ka}$ & ${ }^{14} \mathrm{C}$ guano & McFarlane and others (2002) \\
\hline Bumper Cave & Prince of Wales Island, Alaska & $11.725-7.205 \mathrm{ka}$ & ${ }^{14} \mathrm{C}$ bone collagen & Heaton and Grady (2003) \\
\hline Enigma Cave & Prince of Wales Island, Alaska & $11.715 \mathrm{ka}$ & ${ }^{14} \mathrm{C}$ bone collagen & Heaton and Grady (2003) \\
\hline Cave \#10 Carlsbad (n=4) & Guadalupe Mtns, N. Mex. & $11.7-14.3 \mathrm{ka}$ & U-series stalagmite & Polyak and others (2004) \\
\hline Colander Cave & Prince of Wales Island, Alaska & $11.63-3.31 \mathrm{ka}$ & ${ }^{14} \mathrm{C}$ bone collagen & Heaton and Grady (2003) \\
\hline Candelaria Cave & El Malpais, N. Mex. & $11.6 \pm 0.6 \mathrm{ka}$ & ${ }^{36} \mathrm{Cl}$ & Dunbar and Phillips (2004) \\
\hline Le Portel Cave & Ariege, France & $11.60 \pm 0.15 \mathrm{ka}$ & ${ }^{14} \mathrm{C}$ charcoal & Chauvet and others (1996) \\
\hline Hole 52 Cave & Prince of Wales Island, Alaska & $11.46-4.395 \mathrm{ka}$ & ${ }^{14} \mathrm{C}$ bone collagen & Heaton and Grady (2003) \\
\hline Cave \#10 Carlsbad (n=9) & Guadalupe Mtns, N. Mex. & $11.3-19.9 \mathrm{ka}$ & U-series stalagmite & Polyak and others (2004) \\
\hline Bat Cave Carlsbad (n=7) & Guadalupe Mtns, N. Mex. & $11.0-11.4 \mathrm{ka}$ & U-series stalagmite & Polyak and others (2004) \\
\hline Horn 2 Cave & McLennan Co., Texas & $11.0 \mathrm{ka}$ & ${ }^{14} \mathrm{C}$ & Lundelius (2003) \\
\hline Tlacatzinacantli Cave & Prince of Wales Island, Alaska & $10.97-5.235 \mathrm{ka}$ & ${ }^{14} \mathrm{C}$ bone collagen & Heaton and Grady (2003) \\
\hline CC:5:1 Cave $(\mathrm{n}=5)$ & Grand Canyon, Ariz. & $10.9-44.5 \mathrm{ka}$ & ${ }^{14} \mathrm{C}$ packrat midden & Mead and others (2003) \\
\hline Cave without a name & Kendall Co., Texas & $10.9 \mathrm{ka}$ & ${ }^{14} \mathrm{C}$ & Lundelius (2003) \\
\hline High Dome Cave & Southern Jamaica & $10.9 \pm 0.01 \mathrm{ka}$ & ${ }^{14} \mathrm{C}$ guano & McFarlane and others (2002) \\
\hline Cave \#10 Carlsbad $(n=14)$ & Guadalupe Mtns, N. Mex. & $10.8-12.6 \mathrm{ka}$ & U-series stalagmite & Polyak and others (2004) \\
\hline Sarisoara Cave $(\mathrm{n}=6)$ & Romania & $10.7-51.4 \mathrm{ka}$ & U-series speleothem & Onac (2000) \\
\hline
\end{tabular}


Appendix table. Known caves with assigned ages and the methods of age determination.-Continued

[ $>$, greater than; <, less than; North American Land Mammal ages used are: Irvingtonian $=1.806 \pm 0.0005$ to $0.3 \mathrm{Ma}$, and Rancholabrean $=0.3$ to $0.01143 \pm 0.00013 \mathrm{Ma}$. Wisconsinan is 30 to $20 \mathrm{ka}$; Illinoian is 200 to $125 \mathrm{ka}$; Late Pleistocene is $500 \mathrm{ka}$ to 11,700 years ago; Pleisto-Holocene is 15,000 to 10,000 years ago, Holocene is 11,700 years to present. , approximately; Ma (mega-annum, million years ago; ka, thousand years ago; SAM, San Antonio Mountain; mtns, mountains; Co., county; n, number of samples; USGS, U.S. Geological Survey; \#, number]

\begin{tabular}{|c|c|c|c|c|}
\hline Name & Location & Age & Method & Reference \\
\hline Hidden Cave Carlsbad & Guadalupe Mtns, N. Mex. & $10.6 \pm 0.5 \mathrm{ka}$ & U-series stalagmite & Polyak and others (2004) \\
\hline Hidden Cave Carlsbad & Guadalupe Mtns, N. Mex. & $10.6 \pm 0.19 \mathrm{ka}$ & U-series stalagmite & Polyak and others (2004) \\
\hline Cueva de San Josecito & Zaragoza, Mexico & 10.5 and $44.0 \mathrm{ka}$ & ${ }^{14} \mathrm{C}$ bone & $\begin{array}{l}\text { Arroyo-Cabrales and Polaco } \\
\text { (2003) }\end{array}$ \\
\hline Carrizozo lava tube & Western New Mexico & $10.06 \pm 0.01 \mathrm{ka}$ & ${ }^{14} \mathrm{C}$ charcoal & Laughlin and others (1994) \\
\hline Candelaria Cave & El Malpais, N. Mex. & $10.02-10.05 \mathrm{ka}$ & ${ }^{14} \mathrm{C}$ charcoal & $\begin{array}{l}\text { Laughlin and WoldeGabriel } \\
\text { (1997) }\end{array}$ \\
\hline Blowing in the Wind Cave & Prince of Wales Island, Alaska & $9.995 \mathrm{ka}$ & ${ }^{14} \mathrm{C}$ bone collagen & Heaton and Grady (2003) \\
\hline Friesenhahn Cave & Bexar Co., Texas & 9.2 and $19.0 \mathrm{ka}$ & ${ }^{14} \mathrm{C}$ & Lundelius (2003) \\
\hline Felton Cave & Sutton Co., Texas & $7.7 \mathrm{ka}$ & ${ }^{14} \mathrm{C}$ & Lundelius (2003) \\
\hline Levi Shelter & Travis Co., Texas & $6.5-10.0 \mathrm{ka}$ & ${ }^{14} \mathrm{C}$ & Lundelius (2003) \\
\hline Skeleton Cave & Southern Jamaica & $6.41 \pm 0.11 \mathrm{ka}$ & ${ }^{14} \mathrm{C}$ gastropod & McFarlane and others (2002) \\
\hline Carrizozo lava tube & Western New Mexico & $5.2 \pm 0.7 \mathrm{ka}$ & ${ }^{36} \mathrm{Cl}$ & Phillips and others (1997) \\
\hline Puffin Gratti & Prince of Wales Island, Alaska & $5.115 \mathrm{ka}$ & ${ }^{14} \mathrm{C}$ bone collagen & Heaton and Grady (2003) \\
\hline Montell Shelter & Uvalde Co., Texas & $5.0-10.0 \mathrm{ka}$ & ${ }^{14} \mathrm{C}$ & Lundelius (2003) \\
\hline Jaguar Cave $(n=3)$ & Tennessee & $4.87-5.575 \mathrm{ka}$ & ${ }^{14} \mathrm{C}$ & Willey and others (2005) \\
\hline Wunderlich Site & Comal Co., Texas & $4.1-5.4 \mathrm{ka}$ & ${ }^{14} \mathrm{C}$ & Lundelius (2003) \\
\hline Gardner Cave & Northeastern Washington & 4 and $20 \mathrm{ka}$ & U-series stalagmite & Martin (1990) \\
\hline Seminole Sink & Val Verde Co., Texas & $4.0-19.0 \mathrm{ka}$ & ${ }^{14} \mathrm{C}$ & Lundelius (2003) \\
\hline Unknown Cave & Kentucky & $3.84-4.15 \mathrm{ka}$ & ${ }^{14} \mathrm{C}$ & Willey and others (2005) \\
\hline Schultze Cave & Edwards Co., Texas & $\begin{array}{l}3.8-5.0 \text { and } 8.0- \\
\quad 11.0 \mathrm{ka}\end{array}$ & ${ }^{14} \mathrm{C}$ & Lundelius (2003) \\
\hline Adair Glyph Cave & Central Kentucky & $3.6 \pm .1 \mathrm{ka}$ & ${ }^{14} \mathrm{C}$ & Faulkner (1997) \\
\hline Onesquethaw Cave $(n=5)$ & Helderberg Plateau, N. Y. & $3.1-12.5 \mathrm{ka}$ & U-series speleothem & Lauritzen and Mylroie (2000) \\
\hline Lawyers' Cave & Prince of Wales Island, Alaska & $3.05-8.88 \mathrm{ka}$ & ${ }^{14} \mathrm{C}$ bone collagen & Heaton and Grady (2003) \\
\hline Coontail Spin Cave & Val Verde Co., Texas & $3.0-10.0 \mathrm{ka}$ & ${ }^{14} \mathrm{C}$ & Lundelius (2003) \\
\hline Miller's Cave & Llano Co., Texas & 3.0 and $7.3 \mathrm{ka}$ & ${ }^{14} \mathrm{C}$ & Lundelius (2003) \\
\hline Kushtaka Cave & Prince of Wales Island, Alaska & $2.82-9.33 \mathrm{ka}$ & ${ }^{14} \mathrm{C}$ bone collagen & Heaton and Grady (2003) \\
\hline Fisher Ridge Cave ( $\mathrm{n}=2$ ) & Kentucky & $2.75-3.63 \mathrm{ka}$ & ${ }^{14} \mathrm{C}$ & Willey and others (2005) \\
\hline Broken Promise Cave & Prince of Wales Island, Alaska & $2.23 \mathrm{ka}$ & ${ }^{14} \mathrm{C}$ bone collagen & Heaton and Grady (2003) \\
\hline White Formation Passage Cave & Oregon Caves National Monument, Ore. & 2.2 and $3.9 \mathrm{ka}$ & U-series stalagmite & Turgeon and Lundberg (2001) \\
\hline $3^{\text {rd }}$ unnamed cave $(n=14)$ & Tennessee & $1.83-5.21 \mathrm{ka}$ & ${ }^{14} \mathrm{C}$ & Willey and others (2005) \\
\hline Nautilus Cave & Prince of Wales Island, Alaska & $1.58-8.18 \mathrm{ka}$ & ${ }^{14} \mathrm{C}$ bone collagen & Heaton and Grady (2003) \\
\hline Bonfire Shelter & Val Verde Co., Texas & $1.4-10.2 \mathrm{ka}$ & ${ }^{14} \mathrm{C}$ & Lundelius (2003) \\
\hline
\end{tabular}


[>, greater than; <, less than; North American Land Mammal ages used are: Irvingtonian $=1.806 \pm 0.0005$ to $0.3 \mathrm{Ma}$, and Rancholabrean $=0.3$ to $0.01143 \pm 0.00013 \mathrm{Ma}$. Wisconsinan is 30 to $20 \mathrm{ka}$; Illinoian is 200 to $125 \mathrm{ka}$; Late Pleistocene is $500 \mathrm{ka}$ to 11,700 years ago; Pleisto-Holocene is 15,000 to 10,000 years ago, Holocene is 11,700 years to present. , approximately; Ma (mega-annum, million years ago; ka, thousand years ago; SAM, San Antonio Mountain; mtns, mountains; Co., county; n, number of samples; USGS, U.S. Geological Survey; \#, number]

\begin{tabular}{|c|c|c|c|c|}
\hline Name & Location & Age & Method & Reference \\
\hline Barton Rd Site & Travis Co., Texas & 1.02 and $3.45 \mathrm{ka}$ & ${ }^{14} \mathrm{C}$ & Lundelius (2003) \\
\hline Baker Cave & Val Verde Co., Texas & $1.0-10.0 \mathrm{ka}$ & ${ }^{14} \mathrm{C}$ & Lundelius (2003) \\
\hline Eagle Cave & Val Verde Co., Texas & $1.0-9.0 \mathrm{ka}$ & ${ }^{14} \mathrm{C}$ & Lundelius (2003) \\
\hline Mosquito Cave & Val Verde Co., Texas & $1.0-9.0 \mathrm{ka}$ & ${ }^{14} \mathrm{C}$ & Lundelius (2003) \\
\hline Damp Cave & Val Verde Co., Texas & $1.0-8.0 \mathrm{ka}$ & ${ }^{14} \mathrm{C}$ & Lundelius (2003) \\
\hline Bering's Sinkhole & Kerr Co., Texas & $1.0-7.9 \mathrm{ka}$ & ${ }^{14} \mathrm{C}$ & Lundelius (2003) \\
\hline Fate Bell Shelter & Val Verde Co., Texas & $1.0-6.0 \mathrm{ka}$ & ${ }^{14} \mathrm{C}$ & Lundelius (2003) \\
\hline Centipede Cave & Val Verde Co., Texas & $1.0-5.0 \mathrm{ka}$ & ${ }^{14} \mathrm{C}$ & Lundelius (2003) \\
\hline Murrah Cave & Val Verde Co., Texas & $1.0-5.0 \mathrm{ka}$ & ${ }^{14} \mathrm{C}$ & Lundelius (2003) \\
\hline Parida Cave & Val Verde Co., Texas & $1.0-2.0 \mathrm{ka}$ & ${ }^{14} \mathrm{C}$ & Lundelius (2003) \\
\hline Potoo Hole & Southern Jamaica & $0.95 \pm 0.05 \mathrm{ka}$ & ${ }^{14} \mathrm{C}$ top of guano deposit & McFarlane and others (2002) \\
\hline Castleguard Cave & Alberta, Canada & $>0.78 \mathrm{Ma}$ & Paleomagnetics & Gascoyne and others (1983) \\
\hline Conejo Shelter & Val Verde Co., Texas & $0.5-5.0 \mathrm{ka}$ & ${ }^{14} \mathrm{C}$ & Lundelius (2003) \\
\hline Mystery Cave ( $\mathrm{n}=13$ ) & Southeastern Minnesota & $0.5-13.0 \mathrm{ka}$ & U-series speleothem & Milske and others (1983) \\
\hline Arenosa Shelter & Val Verde Co., Texas & $0.5-9.8 \mathrm{ka}$ & ${ }^{14} \mathrm{C}$ & Lundelius (2003) \\
\hline Oblate Site & Comal Co., Texas & $0.5-4.0 \mathrm{ka}$ & ${ }^{14} \mathrm{C}$ & Lundelius (2003) \\
\hline Squoyah Cave & Alabama & $0.5-0.64 \mathrm{ka}$ & ${ }^{14} \mathrm{C}$ & Willey and others (2005) \\
\hline Hiangshui Cave & Guilin, China & $0.49-6.0 \mathrm{ka}$ & U-series stalagmite & Zhang and others (2004) \\
\hline Footprint Cave $(\mathrm{n}=2)$ & Virginia & $0.32-0.55 \mathrm{ka}$ & ${ }^{14} \mathrm{C}$ & Willey and others (2005) \\
\hline Kincaid Shelter & Uvalde Co., Texas & $0.1-11.0 \mathrm{ka}$ & ${ }^{14} \mathrm{C}$ & Lundelius (2003) \\
\hline Stadium Cave & Prince of Wales Island, Alaska & $0.26 \mathrm{ka}$ & ${ }^{14} \mathrm{C}$ bone collagen & Heaton and Grady (2003) \\
\hline Zesch Cave & Mason Co., Texas & Late Pleistocene & Fossil age & Lundelius (2003) \\
\hline Longhorn Cavern & Burnet Co., Texas & Pleisto-Holocene & Fossil age & Lundelius (2003) \\
\hline Fern Cave & Val Verde Co., Texas & Holocene & Fossil age & Lundelius (2003) \\
\hline
\end{tabular}


Publishing support provided by:

Denver Publishing Service Center

For more information concerning this publication, contact: Chief, USGS Yucca Mountain Project Branch

Box 25046, Mail Stop 421

Denver Federal Center

Denver, C0 80225-0046

(303) 236-5050 


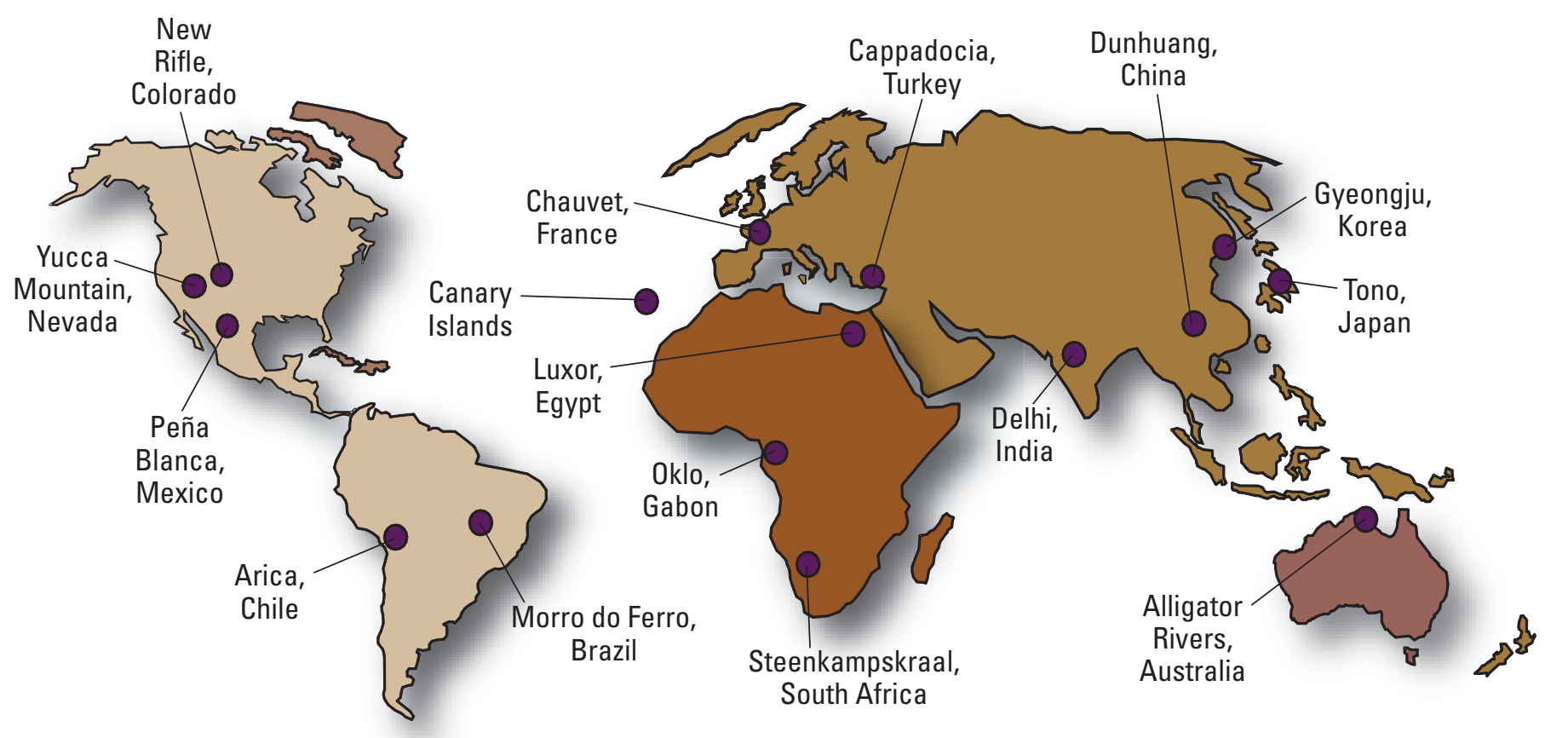

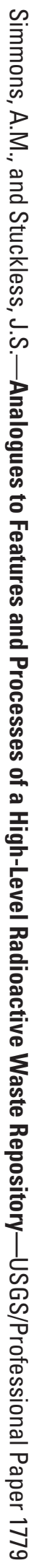

